\title{
O FINANCIAMENTO PÚBLICO FEDERAL DO SISTEMA ÚNICO DE SAÚDE 1988-2001
}

\author{
GILSON DE CÁSSIA MARQUES DE CARVALHO
}

Tese de Doutorado, apresentada ao Departamento de Saúde Materno-Infantil da Faculdade de Saúde Pública da Universidade de São Paulo para obtenção do Grau de Doutor em Saúde Pública.

\section{ORIENTADOR:}

PROF. DR. CORNÉLIO PEDROSO ROSENBURG

São Paulo

2002 


\section{DEDICATÓRIAS}

GUIDO, irmão no sangue e na alma.

Como imãa de sangue, dez anos nos separam entre os dezesseis irmãos que somos. Você, o mais velho de todos, e eu, o mais novo dos homens e o décimo entre todos. Os primeiros registros de relaf̧ão foi entre mim, criança e adolescente, e meu irmão mais velho, de temo de linfo: o líder estudantil da UME e da UNNE no Rio; o redator do Sine-Die, tablóide dos estudantes campanfienses ausentes; $o$ organizador de eventos culturais, como a conferência em Campanfa do grande orador Alcides Carneiro; o bem-sucedido estudante de Direito no Rio; o organizador do restaurante Calabouço, em nome e pelo movimento estudantil. Tudo motivo de glória e honra famifiar. Como irmão de alma três momentos decisivos de minha vida tiveram a sua mão e o carinho de seu apoio: a decisão final pelo estudo da medicina, minfia introdução na área de saúde pública e a apresentação da Emília, companheira, há mais de trinta anos. Mas, foi nas últimas décadas que nos fizemos parceiros inseparáveis na luta pelo direito à vida e saúde. No convívio, somaram-se e entraram em simbiose seus confecimentos juridicos com os meus de médico. A militância antiga, de cada um de nós, em seus campos, concentrou-se na defesa da saúde para todos.Discutíamos, debatíamos, como 6ons befigerantes romanos e nos uníamos, no mesmo momento, debaixo de uma única verdade em que acreditávamos e acreditamos. Dos embates empolgados saíamos mais fortalecidos para enfrentar os contrários. Os papos varavam noites e madrugadas e, nos dias subseqüentes, saíam textos subsidiários da construf̧ão do Sistema Único de Saúde. Para sua clareza de rumos e caminfios irritava a lentidão da implantafãa e implementação do SUS e nossos medos de gestores de construir o novo sem poder ruir de vez o velho. Para esta luta, você trouxe também a Lenir e, ao lado de inúmeros outros, fizemos parte da tropa de choque da inclusão prática da saúde nos direitos de cidadania. Sabíamos que lutávamos por todos, mas o desvelo era e é afimentado por reconfiecer entre todos os mais excluídos com pouca ou nenhuma força de luta ou vocalização de necessidades. Você, Guido, continua presente. Está ao nosso lado, por tudo o que foi e fez em sua vida. Intensa, profunda e apaixonadamente vivida. Nossa homenagem é mantê-lo vivo em seus escritos, permanentemente ajudando a muitos a garantir a vida e a saúde. E, também vivo, cá bem dentro de nós. 


\section{MILTON CARVALHO}

Pai desvelado, já beira um século de vida, que aconchega ao redor uma centena de filhos, noras, genros, netos e bisnetos. Exxemplo de uma constante dedicação voluntária às pessoas, com predileção devotada pelos excluídos.

\section{ANDRÉ, BEATRIZ, CRISTINA, CYNTHIA, DANIEL, EMÍLIA, ÉRIKA, FRANCISCO, IDALINA, MARCELO, LETÍCIA, VITOR}

Minha família. Todos e cada um, por si só, gratas razões do viver.

\section{CIDADÃO BRASILEIRO}

No Ser Humano, Cidadão e Politico, de cada um de nós, sintetizo a dedicatória a inúmeras pessoas, umas confrecidas, cujos nomes conservo "in pectore", outras, anônimas, immanadas na luta pela conquista do direito à vida e saúde para todos. 


\section{HOMENAGENS}

\section{KEIKO}

Mestra-madrinha que me incentivou na realização de um de meus sonfos que era voltar à academia. Primeiro o mestrado, depois o doutorado. Seu desvelo comigo, nesta trajetória de 15 anos foi permanente e essencial.

Homenageio sua presteza, sua paciência em estar ao lado. Seu dizer, com jeito, onde meThorar forma e conteúdo. Os elogios, como estimulante.

O grande destaque de sua vida e testemunho, foi o bíblico de ser a menor entre os menores. Pequena. Miúda. Mas, grande. Imensa em coração e alma. Um ser discreto à disposição de servir a quem quer que fosse. Uma predileção franciscana pelos mais carentes, com apoio e conforto permanente ou pontuah Era como que um atrativo. A aparente fragifidade, era o cartão de visita para que os mais fracos se aproximassem e pudessem beber de sua ajuda, a transbordar-the em essência.

Obrigado pela carinhosa presença permanente, não importa so6 que forma.

\section{PROF.ROSENBURG}

A sabedoria forjada na riqueza do espírito e na vivência dos vários janeiros. O homem forte. 
AGRADECIMENTOS

\section{EMILIA}

Companheira de caminhada. Obrigado pelo emocional, do estar ao lado nas horas duras do fazer constante. Obrigado pelo materiah das sugestões e idéias e das cansativas e repetidas revisões.

FUMIKA E NEIA

O obrigado pela amizade e o apoio estratégico no humano e no técnico.

ROSA, ZEZÉ, DANIEL AMARAL, TONINHO

O obrigado pelo carinho do apoio.

Em vocês sintetizo, meu carinho a todos quantos, física ou mentalmente, apoiaram esta "gravidez e parto" ou arcaram, com o que tem de ônus, conviver com alguém nessas circunstâncias. 
RESUMO

O Autor faz uma análise sobre o Financiamento Federal para a saúde no periodo de 1988 a 2001. A base da análise é a Legislação Federal sobre o Direito à Saúde e aos preceitos sobre o financiamento deste direito. Diante do prescrito analisa-se o ocorrido. Uma tentativa de estudo relacionando o diploma legal (virtual) e o diploma do acontecido (real). Historiam-se os documentos e o ocorrido neste período. No final as conclusões são tiradas orientadas por uma dezena de eixos. Desde a interpretação do conceito de saúde para efeito do financiamento, a gratuidade do direito, as fontes de recursos, a obrigatoriedade dos repasses, a administração dos recursos até outros aspectos mais genéricos. A partir da constatação de que neste período foram cometidas inúmeras ilegalidades são feitas recomendações relativas a cada uma delas com o intuito de corrigí-las ou compensá-las.

\section{SUMMARY}

The author performs an analysis concerning the Federal Budget for Health during the period from 1988 to 2001 . The analysis is based on the Federal Law for Health Rights and the precepts of the budget for these rights. The author attempts to compare the legal scenario with the real one through documentary evidences. Conclusions are drawn from different approaches, i.e., from an interpretation of the concept of Health for budget purposes, the free health care as a social right, the budget resources, the mandatory budget transferences, the resource management and other general aspects. Considering the illegality observed in this field during the concerned period, specific recommendations are made with the intention to correct or minimize them. 
ABREVIATURAS, SIGLAS E SÍMBOLOS

ABRAHUE - ASSOCIAÇÃO BRASILEIRA DE HOSPITAIS UNIVERSITÁRIOS E ESCOLA ABRES - ASSOCIAÇÃO BRASILEIRA DE ECONCOMIA EM SAÚDE ADCT - ATO DAS DISPOSIÇOES CONSTITUCIONAIS TRANSITÓRIAS AIH - AUTORIZAÇÃO DE INTERNAÇÃO HOSPITALAR AIS - AÇŐES INTEGRADAS DE SAUUDE AMACVS - AÇŐES DE MÉDIA E ALTA COMPLEXIDADE EM VIGILÂNCIA SANITÁRIA BID - BANCO INTERAMERICANO DE DESENVOLVIMENTO BIRD - BANCO INTERNACIONAL DE RECONSTRUÇÃO E DESENVOLVIMENTO (BANCO MUNDIAL)

BNDES - BANCO NACIONAL DE DESENVOLVIMENTO ECONÓMICO E SOCIAL CAUDI - CONTROLE E AUDITORIA (ÓRGÃO DO MS)

CEB - COMUNIDADE ECLESIAL DE BASE

CEBES - CENTRO BRASILEIRO DE ESTUDOS EM SAÚDE

CEME - CENTRAL DE MEDICAMENTOS

CEPAM - CENTRO DE ESTUDOS E PESQUISA DE ADMINISTRAÇÃO MUNICIPAL FUNDAÇÃO PREFEITO FARIA LIMA

CES - CONSELHO ESTADUAL DE SAÚDE

CF - CONSTITUIÇÃO FEDERAL

CIB - COMISSÃO INTERGESTORES BIPARTITE

CIMS - COMISSÃO INTERINSTITUCIONAL MUNICIPAL DE SAÚDE

CIPLAN - COMISSÃO INTERINSTITUCIONAL DE PLANEJAMENTO

CIS - COMISSÃO INTERINSTITUCIONAL DE SAÚDE

CISET - CONTROLE INTERNO SETORIAL

CIT - COMISSÃO INTERGESTORES TRIPARTITE

CLIS - COMISSÃO LOCAL INTERINSTITUCIONAL DE SAÚDE

CMS - CONSELHO MUNICIPAL SAÚDE

CNS - CONSELHO NACIONAL DE SAÚDE

CDEFAT - CONSELHO DE DESENVOLVIMENTO DO FUNDO DE AMPARO AO TRABALHADOR

COFINS - CONTRIBUIÇÃO DO FINANCIAMENTO SOCIAL

CONASEMS - CONSELHO NACIONAL DE SECRETARIOS MUNICIPAIS DE SAÚDE CONASP - COMISSÃO NACIONAL DE ASSISTENNCIA A SAÚDE DA PREVIDÊN CIA CONASS - CONSELHO NACIONAL DE SECRETARIOS DE SAÚDE (ESTADUAIS) CONFINS - CONTRIBUIÇĀO AO FINANCIAMENTO SOCIAL CPI - COMISSÃO PARLAMENTAR DE INQUÉRITO

CPMF - CONTRIBUIÇÃO PROVISÓRIA SOBRE A MOVIMENTAÇÃO FINANCEIRA

CRIS - COMISSÅO REGIONAL INTERINSTITUCIONAL DE SAÚDE

CSF - CONTRIBUIÇÃO SOBRE FOLHA

CSSF - CONTRIBUIÇĀO SOCIAL SOBRE A FOLHA

CSSLL - CONTRIBUIÇĀO SOCIAL SOBRE O LUCRO LIQUIDO

DATASUS - DEPARTAMENTO DE INFORMATICA DO SUS

DCAS - DEPARTAMENTO DE CONTROLE E AVALIAÇÃO

DCT - DISPOSIÇOES CONSTITUCIONAIS TRANSITORIAS

DOU - DIARIO ÓFICIAL DA UNIAOO

DPVAT -DOCUMENTO DE PROPRIEDADE DE VEICULO AUTOMOTOR TERRESTRE SEGURO OBRIGATORIO

DRU - DESVINCULAÇÃO DOS RECURSOS DA UNIÃO

DT - DISPOSIÇOES TRANSITORIAS

EC - EMENDA CONSTITUCIONAL 
EPU - ENCARGOS PREVIDENCIÁRIOS DA UNIÃO

FAE - FRAÇÃO ASSISTENCIAL ESPECIALIZADA

FAI-PAB - FATOR DE AJUSTE A IMPLEMENTAÇÃO DO PISO DA ATENÇÃO BÁSICA

FAS - FUNDO DE APOIO AO DESENVOLVIMENTO SOCIAL

FAT - FUNDO DE AMPARO AO TRABALHADOR

FBH - FEDERAÇÃO BRASILEIRA DE HOSPITAIS

FEF - FUNDO DE ESTABILIZAÇÃO FISCAL

FENAESS -FEDERAÇÃO NACIONAL DE ESTABELECIMENTOS E SERVIÇOS DE SAÚDE FHC - FERNANDO HENRIQUE CARDOSO

FIDEPS - FATOR DE INCENTIVO AO DESENVOLVIMENTO DE ENSINO E PESQUISA EM SAÚDE

FINAME - FINANCIADORA NACIONAL DE MAQUINAS E EQUIPAMENTOS

FINSOCIAL - CONTRIBUIÇÃO DO FINANCIAMENTO SOCIAL

FIOCRUZ - FUNDAÇÃO INSTITUTO OSWALDO CRUZ

FIPE - FUNDAÇÃO INSTITUTO DE PESQUISAS ECONOMICAS

FMI - FUNDO MONETARIO INTERNACIONAL

FPAS - FUNDO DE PREVIDÊNCIA E ASSISTÊNCIA SOCIAL

FPE - FUNDO DE PARTICIPAÇÃO DOS ESTADOS

FPM - FUNDO DE PARTICIPAÇÃO DOS MUNICIPIOS

FSE - FUNDO SOCIAL DE EMERGÉNCIA

FSP - FACULDADE DE SAÚDE PÚBLICA

FUNASA - FUNDAÇÃO NACIONAL DE SAÚDE

FUNDAÇÃO SESP - FUNDAÇÃO SERVIÇO ESPECIAL DE SAÚDE PÚBLICA

FUNDEF - FUNDO DE DESENVOLVIMENTO DO ENSINO FUNDAMENTAL

GDF - GOVERNO DO DISTRITO FEDERAL

GED - GRUPO ESPECIAL DE DESCENTRALIZAÇÃO

GIH - GUIA DE INTERNAÇÃO HOSPITALAR

GM - GABINETE DO MINISTRO

GPAB - GESTÃO PLENA DA ATENÇÃO BÁSICA

GPABA - GESTÃO PLENA DA ATENÇÃO BASSICA AMPLIADA

IBGE - INSTITUTO BRASILEIRO DE GEOGRAFIA E ESTATISTIICA

ICMS - IMPOSTO DE CIRCULAÇÃO DE MERCADORIAS E SERVIÇOS

INAMPS - INSTITUTO NACIONAL DE ASSISTÊNCIA MÉDICA DA PREVIDÊNCIA SOCIAL INAN - INSTITUTO NACIONAL DE ALIMENTAÇÃO E NUTRIÇÃO

INPC - INDICE NACIONAL DE PREÇOS AO CONSUMIDOR

INPS - INSTITUTO NACIONAL DE PREVIDENCIA SOCIAL

INSS - INSTITUTO NACIONAL DE SEGURIDADE SOCIAL

IPEA - INSTITUTO DE PESQUISA ECONOMICA APLICADA

IPI - IMPOSTO SOBRE PRODUTOS INDUSTRIALIZADOS

IPMF - IMPOSTO PROVISORIO SOBRE A MOVIMENTAÇÃO FINANCEIRA

IPTU - IMPOSTO PREDIAL TERRITORIAL URBANO

IPVA - IMPOSTO DE PROPRIEDADE DE VEICULOS AUTOMOTORES

IR - IMPOSTO DE RENDA

ISSQN - IMPOSTO SOBRE SERVICCOS DE QUALQUER NATUREZA

ITBVI - IMPOSTO DE TRANSMISSǍO DE BENS INTER VIVOS

ITCM - IMPOSTO DE TRANSMISSÃO CAUSA MORTIS

ITR - IMPOSTO TERRITORIAL RURAL

IVH - INDICE DE VALORIZAÇÃO HOSPITALAR

IVH-E - INDICE DE VALORIZAÇÃO HOSPITALAR DE EMERGÊNCIA

IVISA - INDICE DE VALORIZAÇĀO DE IMPACTO EM VIGILĀNCIA SANITARIA

IVR - INDICE DE VALORIZAÇÅO DE RESULTADO

LC - LEI COMPLEMENTAR

LDBE - LEI DE DIRETRIZES E BASES DA EDUCAÇÅO 
LDO - LEI DE DIRETRIZES ORÇAMENTÁRIAS

LO - LEI ORÇAMENTÁRIA

LOA - LEI ORÇAMENTARIA ANUAL

LOS - LEI ORGÂNICA DA SAÚDE

LRF - LEI DE RESPONSABILIDADE FISCAL

MDB - MOVIMENTO DEMOCRATICO BRASILEIRO

MDE - MANUTENÇÃO E DESENVOLVIMENTO DE ENSINO

MF - MINISTÉRIO DA FAZENDA

MPAS - MINISTÉRIO DE PREVIDÊNCIA E ASSISTÊNCIA SOCIAL

MPO - MINISTÉRIO DO PLANEJAMENTO E ORÇAMENTO

MS - MINISTÉRIO DA SAÚDE

MT - MINISTÉRIO DO TRABALHO

NF - NOVA FEDERAÇÃO

NOAS - NORMA OPERACIONAL DE ASSISTÊNCIA À SAÚDE

NOB - NORMA OPERACIONAL BÁSICA

OAB - ORDEM DOS ADVOGADOS DO BRASIL

OMS - ORGANIZAÇÃO MUNDIAL DA SAÚDE

OPAS - ORGANIZAÇÃO PAN-AMERICANA DE SAÚDE

OSS - ORÇAMENTO DA SEGURIDADE SOCIAL

PAB - PISO DA ATENÇÃO BÁSICA

PACS - PROGRAMA DE AGENTE COMUNITARIO DE SAÚDE

PAIS - PROGRAMA DE AÇOOES INTEGRADAS DE SAÚDE

PAM - POSTO DE ASSISTENNCIA MÉDICA

PASEP - PLANO DE ASSISTENNCIA DO SERVIDOR PÚBLICA

PC - PER CAPITA

PCCS - PLANO DE CARGOS, CARREIRA E SALARIOS

PDT - PARTIDO DEMOCRATA TRABALHISTA

PEA - POPULAÇÃO ECONOMICAMENTE ATIVA

PEC - PROPOSTA DE EMENDA CONSTITUCIONAL

PFL - PARTIDO DA FRENTE LIBERAL

PGR - PROCURADORIA GERAL DA REPÚBLICA

PIB - PRODUTO INTERNO BRUTO

PIS - PROGRAMA DE INTEGRAÇÃO SOCIAL

PISUS - PROGRAMA DE INTERIORIZAÇÃO DO SUS

PMDB - PARTIDO DO MOVIMENTO DEMOCRÁTICO BRASILEIRO

POI - PROGRAMAÇÃO E ORÇAMENTAÇÃO INTEGRADAS

PPA - PLANO DE PRONTA AÇÃO

PPA - PLANO PLURIANUAL

PPI - PROGRAMAÇÃO PACTUADA E INTEGRADA

PQS - PLANO QUINQUENAL DE SAÚDE

PREV-SAÚDE - PROGRAMA NACIONAL DE SERVIÇOS BÁSICOS DE SAÚDE

PROER - PROGRAMA DE ESTÍMULO A REFORMULAÇÃO DO SISTEMA FINANCEIRO

PRÓ-SAÚDE - PROGRAMA NACIONAL DE SERVIÇOS BÁSICOS DE SAÚDE

PSB - PARTIDO SOCIALISTA BRASILEIRO

PSDB - PARTIDO DA SOCIAL DEMOCRACIA BRASILEIRA

PSF - PROGRMA DE SAÚDE DA FAMILIA

RCA - RECURSOS DE COBERTURA ASSISTENCIAL

RH - RECURSOS HUMANOS

RSP - REMUNERAÇÃO DE SERVIÇOS PRESTADOS

SAB - SOCIEDADE AMIGOS DE BAIRRO

SAG - SECRETARIA DE ADMINISTRAÇÃO GERAL

SAS - SECRETARIA DE ASSISTÉNCIA A SAÚDE

SE - SECRETARIA EXECUTIVA 
SEPLAN - PR - SECRETARIA DE PLANEJAMENTO DA PRESIDÊNCIA DA REPÚBLICA SES - SECRETARIA ESTADUAL DE SAÚDE

SFH - SISTEMA FINANCEIRO DE HABITAÇÃO

SIA-SUS - SISTEMA DE INFORMAÇÃO AMBULATORIAL DO SUS

SIH-SUS - SISTEMA DE INTERNAÇÃO HOSPITALAR DO SUS

SIM - SISTEMA DE INFORMAÇÃO D MORTALIDADE

SINAN - SISTEMA DE INFORMAÇÃO DE ALIMENTAÇÃO E NUTRIÇÃO

SINASC - SISTEMA DE INFORMAÇÃO DE NASCIDOS VIVOS

SIOPS - SISTEMA DE INFORMAÇŐES DE GASTO PÚBLICO EM SAÚDE

SIS - DPI - DEPARTAMENTO DE PROJETOS E INVESTIMENTOS

SIS - SECRETARIA DE INVESTIMENTOS EM SAÚDE

SMS - SECRETARIA MUNICIPAL DE SAÚDE

SNA - SISTEMA NACIONAL DE AUDITORIA

SNA - SISTEMA NACIONAL DE AUDITORIA

SOF - SECRETARIA DE ORÇAMENTO E FINANÇAS

SPA - SECRETARIA DE PLANEJAMENTO E AVALIAÇÃO

SPS - SECRETARIA DE POLITICAS DE SAÚDE

SRF - SECRETARIA DE RECEITA FEDERAL

STN - SECRETARIA DO TESOURO NACIONAL

SUCAM - SUPERINTENDÉNCIA DE CAMPANHAS

SUDS - SISTEMA UNIFICADO E DESCENTRALIZADO DE SAÚDE

SUS - SISTEMA ÚNICO DE SAÚDE

SVS - SECRETARIA DE VIGILÅNCIA EPIDEMIOLOGICA

TCE - TRIBUNAL DE CONTAS DO ESTADO

TCU - TRIBUNAL DE CONTAS DA UNIĀO

TFAE - TETO DE FINANCIAMENTO DA ASSISTENNCIA DO ESTADO

TFAM - TETO DE FINANCIAMENTO DE ASSISTENNCIA DO MUNICIPIO

TFECD - TETO FINANCEIRO DE EPIDEMIOLOGIA E CONTROLE DE DOENÇAS

TFVS - TETO FINANCEIRO DE VIGILÁNCIA SANITÁRIA

TN - TESOURO NACIONAL

TPC - TRANSFERÊNCIA POR CONVÊNIO

TRAFF - TRANSFERÊNCIA REGULAR E AUTOMATICA FUNDO A FUNDO

UBS - UNIDADE BASICA DE SAÚDE

UCA - UNIDADE DE COBERTURA AMBULATORIAL

UNICAMP - UNIVERSIDADE DE CAMPINAS

US - UNIDADE DE SERVIÇO

VE - VIGILANCIA EPIDEMIOLOGICA

VS - VIGILANCIA SANITARIA 
ÍNDICE

I - INTRODUÇÃO

II - OBJETIVO

III - PROCESSO METODOLÓGICO

IV - DESENVOLVIMENTO DO TEMA

1. O FINANCIAMENTO FEDERAL PARA A SAÚDE - NO PERÍODO
PRÉ E PÓS-CONSTITUCIONAL IMEDIATO -1963 - 1990

2. O FINANCIAMENTO FEDERAL PARA A SAÚDE NO GOVERNO
COLLOR-PQS 1990-1995 E NOBS-1991 E 1992

3. O FINANCIAMENTO FEDERAL PARA A SAÚDE NO GOVERNO ITAMAR- A DEFESA DA DESCENTRALIZAÇÃO DA NOB-1993-

A OUSADIA DE CUMPRIR E FAZER CUMPRIR A LEI

4. O FINANCIAMENTO FEDERAL PARA A SAÚDE NO GOVERNO ITAMAR - A GRAVE CONVULSÃO DA SAÚDE EM 1993 -

A CRISE BRITTO

5. O FINANCIAMENTO FEDERAL PARA A SAÚDE NO GOVERNO ITAMAR- "NOB-1994"

6. O FINANCIAMENTO FEDERAL PARA A SAÚDE NO GOVERNO ITAMAR - CRISE DA CONVERSÃO DO REAL E SUAS REPERCUSSÕES ATÉ 2001

7. O FINANCIAMENTO FEDERAL PARA A SAÚDE NO GOVERNO ITAMAR - CRISES E AVANÇOS DE FINAL DE GOVERNO

8. O FINANCIAMENTO FEDERAL PARA A SAÚDE NO GOVERNO FHC - A BUSCA DE MAIS RECURSOS E A CPMF

9. O FINANCIAMENTO FEDERAL PARA A SAÚDE NO GOVERNO FHC - NOBS -96 \& “NOB-98” - INICIO DO PROCESSO RECENTRALIZADOR NA IMPLANTAÇÃO DO SUS

10. O FINANCIAMENTO FEDERAL PARA A SAÚDE NO GOVERNO FHC - A PEC-169 - EC-29, DE 13/9/2000

11. O FINANCIAMENTO FEDERAL PARA A SAÚDE NO GOVERNO FHC - NOB-2001 - DENOMINADA DE NOAS-2001

1. CONCEITO DE SAÚDE, PARA EFEITO DO FINANCIAMENTO 268

2. FONTE DOS RECURSOS PARA A SAÚDE 276

3. DISTRIBUIÇÃO DOS RECURSOS FEDERAIS DA SAÚDE PARA AS TRÊS ESFERAS DE GOVERNO

4. CRITÉRIOS DE RATEIO DOS RECURSOS FEDERAIS DA SAÚDE ENTRE AS TRÊS ESFERAS DE GOVERNO

5. REPASSE AUTOMÁTICO DA UNIĀO - DOS RECURSOS DO ORÇAMENTO FISCAL E DA SEGURIDADE SOCIAL - PARA O FUNDO NACIONAL DE SAÚDE 304

6. REPASSE AUTOMÁTICO DOS RECURSOS FEDERAIS DO MS FUNDO NACIONAL DE SAÚDE-PARA ESTADOS E MUNICÍPIOS

7. ADMINISTRAÇÃO DOS RECURSOS FINANCEIROS FEDERAIS, ESTADUAIS E MUNICIPAIS EM FUNDOS DE SAÚDE

8. FINANCIAMENTO DAS AÇŌES E SERVIÇOS COMPLEMENTARES DO SUS PRESTADOS PELO PRIVADO

9. A GRATUIDADE NO SUS

10. CONTROLE PÚBLICO INSTITUCIONAL E SOCIAL DOS RECURSOS FINANCEIROS DO SUS 
I - INTRODUÇÃO 


\section{INTRODUÇÃO}

Ao lerem meus textos de comentários, reflexões sobre os assuntos da saúde, da educação, da economia e da vida, algumas pessoas fazem uma observação sobre o caráter apaixonado e passional com que escrevo. Sem nenhum sentimento de menos-valia, mas por vezes constrangido, continuo falando e escrevendo com paixão. Noutro dia, casualmente, deparei com uma frase que passarei a utilizar para persistir na minha maneira de ser e escrever. Fiquei contente ao encontrar este dito emblemático e discreto do Milton Santos: "E o homem da universidade imagina que tem de reprimir a emoção para produzir..." Minha lide apenas tangenciou a universidade em algumas épocas, portanto me dou ao desfruto de continuar colocando emoção no que falo e escrevo. No que produzo. Agora com a benção de dois grandes homens: Milton Santos e Ladislau Dowbor que o lembra. Nas últimas décadas fui um ator privilegiado no sistema de saúde brasileiro. Fui de "operário de pronto-atendimento médico pediátrico" a gestor de saúde municipal e nacional. Estive em todas as posições, mas, sobretudo por cardiopatia familiar fui e sou usuário-paciente desde criança. Batalho, como outros, há décadas pelo direito à vida e saúde, hoje representado pelo Sistema Único de Saúde - SUS. Por poucas pessoas terem afinidade com orçamento e finanças públicos e conseqüentemente, encontrar poucas respostas a minhas indagações, acabei por me interessar pelos temas mais por necessidade que gosto. Participei intensamente na busca de mais recursos para a área de saúde. Estive presente nos embates gerais sobre a garantia mínima de seu financiamento. No periodo anterior à Constituinte, durante e depois, na aprovação das leis, decretos, portarias,normas e nas várias crises do sistema. Desde a concepção do Bloco de Constitucionalidade no que se refere à saúde, estive sempre participando como um ator privilegiado. De uma feita mais ativamente, como um dos seus responsáveis legais, por via de cargo ocupado à época no Ministério da Saúde. Outras acompanhei, bem de perto como dirigente municipal ou assessorando-os. Não posso negar este meu papel, ainda que possa contaminar minha análise pois, só a farei sempre "in processu". Aceitando este risco optei por uma metodologia simples de pesquisa entre o prescrito nas leis de financiamento da saúde e o acontecido. O "virtual" e o real, diria o Prof.Elias Jorge. É justamente com este olhar de sujeito e protagonista que ouso iniciar esta pesquisa de dados e fatos e tento fazer a sua análise. 


\section{O DIREITO À SAÚDE COMO DIREITO À VIDA NA CONSTITUIÇÃO FEDERAL DE 1988 E NA LEGISLAÇÃO INFRACONSTITUCIONAL}

Primeiramente um comentário sobre este título. Saúde é o campo destas reflexões. Dentro dela se aprofundará sobre o processo de financiamento das ações e dos serviços de saúde. Serão analisados com detalhes os avanços e os entraves neste processo.

Se se entender o financiamento da saúde como um instrumento, uma ferramenta em busca da eficiência e da eficácia, seria muito pouco fazer esta análise exclusivamente sob esse prisma. Preferiu-se tomar partido de analisar os avanços e entraves do processo de garantia do direito à saúde, como direito fundamental de cidadania, e que tem como uma de suas diretrizes constitucionais o financiamento tripartite das ações e serviços e da gestão destes.

O Brasil vive, desde 1988, sob a égide de uma nova regra: a Constituição Federal (CF) de 1988. Um novo paradigma foi posto depois do país ter saído de uma ditadura de mais de 20 anos. Esta foi uma Constituição que, em muitos capítulos incluindo-se o da saúde, nasceu da base, das entranhas da própria população e técnicos que discutiram e formularam premissas e propostas a serem incorporadas.

A CF em suas entranhas, intrinsecamente, caracteriza o Estado como "Servidor do Cidadão". Este Estado Servidor tem regras a seguir que, se cumpridas, mudam a sua ação. As políticas públicas, como forma de ação do Estado, passam a externar esta característica "servidora" em substituição à "usurpadora". É a proposta de um novo Estado. O "Estado Servidor" (CF de 1988) se contrapondo ao "Estado Usurpador" CF 1967-1999).

Os direitos individuais, sociais e politicos dos cidadãos estão claros, patentes. O Estado democrático e de direito está definido como aquele que tem como fundamentos a soberania, a cidadania, a dignidade da pessoa humana, os valores sociais do trabalho e da livre iniciativa, o pluralismo político. CF,1 (16)Os objetivos fundamentais são o de construir uma sociedade livre, justa e solidária, garantir o desenvolvimento nacional, erradicar a pobreza e a marginalização e reduzir as desigualdades sociais e regionais, promover o bem de todos, sem preconceitos de origem, raça, sexo, cor, idade e quaisquer outras formas de discriminação. CF art.3 (16) 
A base e linha estão lançados, o mais dificil está sendo fazer sair do papel, fazer acontecer esta caracteristica de Estado Servidor.

A CF, denominada Constituição Cidadã, não sem razão, coloca como centro os direitos do povo brasileiro. A maior das declarações é : "Todo o poder emana do povo que o exerce por meio de representantes eleitos (democracia representativa) ou diretamente (democracia participativa) nos termos desta Constituição Federal." CF,1 PU (16)

Nosso objetivo dentro deste novo conceito de Brasil é contextualizar a questão do direito à saúde com todos os princípios que o consagram e depois entrar na questão do financiamento deste direito à saúde.

Dentro dos objetivos gerais da sociedade brasileira, inscritos em nossa Constituição CF art. 3 (16) a questão saúde se coloca como um direito do povo e dever do Estado, a ser conquistada com a participação das pessoas, das familias, da sociedade e das empresas.

\section{A SAÚDE NA CONSTITUIÇÃO BRASILEIRA DE 1988}

A Constituição tem, pela primeira vez, entre seus artigos, toda uma seção referente à saúde. Além desta seção existem vários artigos que se referem à saúde e estão em outros locais da própria Constituição Federal. (16)

Art. $6-(\ldots)$ Saúde direito social.

Art. $10-E$ assegurada a participação dos trabalhadores e empregadores nos colegiados dor órgãos públicos, em que seus interesses profissionais ou previdenciários sejam objeto de discussão e deliberação.

Art. 21 - (....) compete à União instituir diretrizes para o saneamento básico.

Art. 22 - (....) compete privativamente à União legislar sobre seguridade social (previdência, saúde e assistência social).

Art. 23 - (....)compete à União, Estados e Municípios cuidar da saúde e assistência pública, da proteção e garantia das pessoas e portadores de deficiência.

Art. 24 - (....) compete à União, Estados e DF, legislar concorrentemente sobre previdência social, proteção e defesa à saúde.

Art. $30-(. .$.$) compete aos Municipios, prestar, com a cooperação técnica e financeira da União e$ dos Estados, serviços de atendimento à saúde da população.

Art. 37 § 3 - A lei disciplinará as formas de participação do usuário na administração pública direta e indireta (....)

Art. 129 - (....)são funções institucionais do Ministério Público, zelar pelo efetivo respeito, dos poderes públicos e dos serviços de relevância pública, aos direitos assegurados nesta constituição, promovendo as medidas necessánias à sua garantia.

Art.194 - A seguridade social (....) com base nos seguintes objetivos (....) universalidade do atendimento, uniformidade, seletividade e distributividade, irredutibilidade, equidade, diversidade na base de financiamento, caráter democrático e descentralizado da administração(....)

Art. $195-(. .$.$) a seguridade social será financiada(....) mediante recursos provenientes dos orçamen-$ tos da União, Estados, DF e dos Municípios e das seguintes contribuições sociais(....) \$10 - A lei definirá os critérios de transferência de recursos para o sistema único de saúde(....) 
Art.196,197,198,199,200 e, mais recentemente, o ART.77 do ADCT falam mais especificamnente da saúde, dos principios e competências das três esferas, do financiamento etc.

\section{A SAÚDE NAS LEIS ORGÂNICAS DA SAÚDE (8080 E 8142)}

A Constituição Federal coloca os fundamentos e os principios do Sistema Único de Saúde. Entretanto, estes principios precisavam de uma regulamentaçăo o que foi feito pelas leis $8080(27)$ e 8142 (28). Estas foram promulgadas em dezembro de 1990, dois anos após a da CF. Posteriormente outras leis vieram completar o que já estava ali consagrado.

A Lei 8080 (27) tem maior amplitude e regulamenta praticamente todo o sistema de saúde: disposições gerais e preliminares, objetivos e atribuições, principios e diretrizes, organização, direção e gestão, competências e atribuições, serviços privados de assistência à saúde (funcionamento e participação complementar), recursos humanos, financiamento (dos recursos, da gestão financeira, do planejamento e do orçamento) e finalmente das disposições transitórias.

A lei 8142 (28) é complementar, de menor tamanho e trata de dois assuntos não contemplados na 8080 (27), pois foram vetados pelo Presidente. Depois de um acordo chegou-se à conclusão de fazer uma outra lei completando a 8080 . Os dois temas são: participação da comunidade com a criação das Conferências de Saúde e dos Conselhos e o financiamento incluindo a transferência intergovernamental de recursos financeiros.

Existem outras que tratam da saúde e se somam a estas duas essenciais:

Lei 9782 (36) Trata da criação da Agência Nacional de Vigilância Sanitária.

Lei 9836 (38) Acrescenta dispositivos da 8080 instituindo o Subsistema de Atenção à Saúde Indígena.

Lei 8689 (33) Extingue o Inamps e cria o Sistema Nacional de Auditoria.

Lei 9961 (39) Cria a Agência Nacional de Saúde Suplementar - ANS e dá outras providências

Lei 9434 (35) Trata da remoção de órgãos.

Lei 9797 (37) Trata da Cirurgia Plástica Reparadora de Mama. 
A OPERACIONALIZAÇÃO DO SUS ATRAVÉS DE DECRETOS, PORTARIAS, NORMAS TÉCNICAS, INSTRUÇÕES NORMATIVAS, RESOLUÇÕES DO CONSELHO DE SAÚDE

Nem sempre as leis resolvem e explicam tudo. São os decretos, as portarias, as normas técnicas, as instruções normativas e as circulares que acabam detalhando aquilo que se deva fazer. Por vezes extrapolam e se colocam acima das leis. O SUS dispõe de todos esses mecanismos legais para que venha a funcionar bem.

Entre os decretos primeiros da nova ordenação jurídica destacam-se dois: são aqueles referentes à passagem dos recursos de saúde, Fundo a Fundo da União a Estados e Municípios (26) e o que cria o Sistema Nacional de Auditoria. (17)

As portarias são várias. Destacam-se, entre muitas, a que explicita o quanto cada esfera de governo deverá alocar para a área da saúde e aquelas que promulgaram as normas operacionais básicas de 1991, 1992, 1993 e de 1996. Outras portarias definem os tetos estaduais e a operacionalização do Piso de Atenção Básica (PAB) à saúde, o Programa de Saúde da Família, de Agentes Comunitários de Saúde, regulamentações sobre os vários programas de controle de doenças e inúmeros outros.

A operacionalização final, em aplicação hoje, é a NOB-93 (59) (ainda em vigor em quase sua integralidade) e a NOB-96 (68) que coloca os níveis de responsabilização a que estão submetidos estados e municípios de modo a que o processo de gestão possa atender às características peculiares a cada situação.

\section{DE QUE SAÚdE SE FALA ? O CONCEITO DE SAÚdE}

É interessante que, em momento algum, toda esta legislação da saúde com seu caráter inovador, traz uma definição explicita do que seja Saúde. O que se tem é a definição de uma série de atributos que tentam fechar o conceito de saúde de forma indireta.

Portanto, para atender a abrangência do termo saúde adotada hoje pela CF é imprescindivel conhecer os princípios fundamentais do Sistema Único de Saúde. Neles vai-se buscar muito mais a caracterização das "providências" que o governo irá to- 
mar para que seja promovida, preservada e recuperada a saúde, como expresso na Lei 8080 art. 5 e 6 (27).

Esta limitação e dificuldade em se definir o que seja saúde não é própria apenas de nosso arcabouço legal. Há uma dificuldade universal em se colocar saúde dentro de termos que a definam. Buscando no dicionário teremos a mesma dificuldade. O Dicionário Aurélio lembra a origem da palavra saúde do termo "salute" do latim e que significa a conservação da vida. Mais audazmente tenta caracterizar "a saúde como o estado do individuo cujas funções orgânicas, fisicas e mentais se acham em situação normal." As interrogações continuam muitas: o que é normal? Mais normal, menos normal?

A Organização Mundial de Saúde também tentou buscar uma definição, com intenção de aprofundá-la: "Saúde não é apenas a ausência de doenças mas um estado de completo bem estar físico, social e mental". Que estado é esse de plenitude? Qual a possibilidade de que as pessoas em geral consigam essa saúde tão idealizada?

Os princípios do Sistema Único de Saúde foram gerados nos últimos quarenta anos de discussão, em busca de um sistema de saúde que atingisse a todos como um direito de cidadania.

Como marco legal podemos citar alguns projetos dessas últimas décadas e que se constituíram em propostas do novo, da universalização e da equidade: Fundação SESP (53), PIASS - Programa de Interiorização das Ações de Saúde e Saneamento (55), PRÓ-SAÚdE, PREV-SAÚdE (45), Plano CONASP (43), AIS-AIH (72), SUDS Sistema Unificado e Descentralizado de Saúde $(6,20,21,22,23,19)$, SUS (27) Abaixo se faz uma abordagem sintética daquilo que, pela primeira vez, está numa Constituição Brasileira. Constitui-se no arcabouço de idéias que compõem o Sistema Único de Saúde - SUS.(27)

\subsection{PRINCÍPIOS TÉCNICO-ASSISTENCIAIS}

SAÚDE-FELICIDADE COMO DIREITO DE TODOS E DEVER DO ESTADO 
Destemida e persistentemente ousa-se buscar uma ligação essencial. $O$ direito à saúde tem como fundamento o direito à vida e à vida em sua plenitude e abundância. Direito ao bem-estar, ao estar bem, à felicidade individual e coletiva.

Todos que buscam a saúde, como seres humanos, e aqueles que socialmente desempenham a função de ajudar os outros a terem saúde, os provedores de saúde, públicos e privados, individual ou institucionalmente, deveriam ter sempre em vista o objetivo maior da conquista da saúde, qual seja, ajudar as pessoas a serem e estarem bem, a estarem felizes.

Se se colocarem todos, provedores e consumidores dos serviços de saúde, como artifices do bem-estar da saúde, os serviços de saúde jamais serão os mesmos. Terão um ganho em qualidade. Não se questionará que a relação entre provedores e consumidores está esgarçada, pois a relação passará pelo humano. Não se discutirá que nessa relação falta humanismo, atributo básico da espécie humana à qual pertencem. Carinho. Ternura na relação. Todos a reconhecerem a conquista a fazer. $O$ objetivo coletivo maior será a busca contínua da saúde-felicidade. A qualidade de vida e o bem-estar.

A Constituição Federal de 1988 consagrou os direitos e deveres de todos os cidadãos brasileiros (CF, 5-6 1). Foram as maiores conquistas de cidadania que um povo conseguiu incluir em sua Carta Magna. Muitos acusaram os constituintes de terem prodigalizado os direitos sem, contudo, pensarem em como garantí-los. Isto é um ledo engano, pois, para esses direitos foram colocados deveres a serem cumpridos por todos.

A SAÚDE está entre os direitos constitucionais inscritos no Capítulo II, que trata dos DIREITOS SOCIAIS: "SÃO DIREITOS SOCIAIS A EDUCAÇÃO, A SAÚDE, O TRABALHO, O LAZER A SEGURANÇA, A PREVIDÊNCIA SOCIAL, A PROTEÇÃO À MATERNIDADE E À INFÂNCIA, A ASSISTÊNCIA AOS DESAMPARADOS". CF,6 (16)

Já nos primeiros artigos, genericamente, está defendido o direito à saúde no momento em que se afirma que a República Federativa do Brasil tem como fundamento a cidadania, a dignidade da pessoa humana e outros. Entre os objetivos fundamentais do Brasil estão a construção de uma sociedade livre, justa e solidária com erradica- 
ção da pobreza e redução das desigualdades sociais e regionais, promovendo o bem de todos, sem preconceito algum.

A SAÚDE, como direito especifico, está bem clara nos direitos sociais. Nos enunciados gerais, acima, pressupõe-se que seja um dos condicionantes fundamentais de se garantir cidadania, dignidade etc...

Sonho ou realidade?!... Um sonho que deve tornar-se realidade, na medida em que os cidadãos cumpram as obrigações individuais e coletivas que possibilitarão usufruir de direitos, entre eles, o de ter e gozar saúde.

Entre esses deveres de cidadania são essenciais: contribuir com o fisco, sem sonegação; praticar a não corrupção passiva e ativa; proteger o patrimônio, bem e serviços públicos; exercer o controle da sociedade tanto do público como do privado para que ambos utilizem bem os recursos públicos.

SAÚDE é um direito essencial que na Constituição está colocado como DEVER do ESTADO, mas que só acontecerá se todos cumprirem os maiores e menores deveres cotidianos, exercendo a cidadania plena.

Na lei orgânica de Saúde está bem explicito: só se conseguirá saúde na medida em que houver a contribuição das pessoas, das familias, das empresas e da sociedade. Lei $8080,2, \S 2(27)$

O DIREITO À SAÚDE exige que cada um cumpra deveres. Entre o omitir-se e o compactuar-se existe uma terceira via: a participação e luta de cada um para que todos sejam cidadãos plenos, iguais em direitos e deveres. A conquista do DIREITO À SAÚDE figura como parte da transformação do país.

\section{AÇÕES E SERVIÇOS DE SAÚDE PARA SUA PROMOÇÃO, PROTEÇÃO E RE- CUPERAÇÃO}

O principio da integralidade das ações e serviços de saúde, sob o prisma da horizontalidade: não se deve separar ações de promoção, proteção e recuperação mas sim integrá-las e oferecê-las à população de forma igual e universal. CF 198 II (16) Atividades preventivas, sem prejuizo das assistenciais. Nesse item, rompe-se uma outra prática prejudicial ao sistema de saúde e que imperou durante décadas. A famosa 
dicotomia entre prevenção e assistência. Marcador teórico do sistema de saúde, sob gestão diversa, em que os serviços previdenciários de saúde se dedicavam mais às ações curativas e MS, Estados e Municípios, mais às ações preventivas. Lei 8080,5 III(27) A demanda da população geralmente é por serviços assistenciais que respondem às suas necessidades sentidas. Procedimentos de promoção e prevenção à saúde nem sempre são buscados. Vacinas e outros procedimentos preventivos, em menor volume, só são buscados atendendo a forte apelo promocional por se constituirem, na maioria das vezes, em necessidades não sentidas.

\section{UNIVERSALIDADE}

A todos é dado o direito, independente de poder aquisitivo, raça, cor, credo etc. O acesso universal e igualitário às ações e serviços de saúde, com igualdade e equidade, significa que todas as pessoas, por terem direito à saúde, têm direito à igualdade de acesso, de chegada e de ingresso às ações e serviços de saúde, próprios estatais, ou nos privados conveniados com o público.. "Universalidade da cobertura e do atendimento".CF 194, I (16) "Saúde direito de todos(....)"CF 196 (16) A universalidade da cobertura e do acesso não permite nem a discriminação dos que menos têm, nem daqueles que mais têm: todos são iguais perante a lei. CF 5 (16) "A universalidade de acesso aos serviços de saúde, em todos os niveis de assistência. A igualdade da assistência à saúde, sem preconceitos ou privilégios de qualquer espécie."Lei $8080,7, \mathrm{I}, \mathrm{IV}(16)$

\section{EQUIDADE}

Oferecer os recursos de saúde, de acordo com as necessidades de cada um, dar mais para quem mais precisa. Tratar diferentemente desiguais (equidade vertical) e, igualmente, os iguais (equidade horizontal). Existe igualdade no direito e equidade na execução do direito. É clara a prioridade do atendimento quando a necessidade for de tratamento. $\mathrm{O}$ entendimento da equidade, segundo o critério social, ainda que não definido legalmente, tem a prática aceita em determinadas áreas, principalmente quando os recursos são insuficientes diante de necessidades crescentes. A palavra equidade não consta, nem na CF nem nas Leis 8080 e 8142 , mas passou por toda a 
discussão prévia e posterior à Constituição. Juridicamente, a busca de definição passa pelo critério discricionário do juiz ou de quem está exercendo o poder de poder qualificar a igualdade, diante de situações especiais. "Equidade é assegurar ações e serviços de todos os niveis, de acordo com a complexidade que cada caso requeira, more o cidadão onde morar, sem privilégios e sem barreiras. Todo cidadão é igual perante o SUS e será atendido, conforme suas necessidades, até o limite do que o SUS poderá oferecer para todos."(100) O grande lutador pelo direito à saúde, Prof. Nelson Rodrigues dos Santos, dizia em suas palestras, citando Mooney. " Existem várias formas de equidade: a igualdade de gastos e de recursos e a igualdade de recursos, oportunidades de acesso e de utilização para necessidades iguais".

\section{INTEGRALIDADE}

As ações de saúde têm uma integralidade dita vertical, em que o indivíduo é visto em sua totalidade, com unicidade e não dissociado por doenças e aparelhos. Outra compreensão é a integralidade dita horizontal, em que se acabam com as várias abordagens fragmentadas de promoção, prevenção, tratamento e reabilitação. Buscase a integralidade dessas abordagens, que deixam de ter a contradição interna da dicotomia. A diretriz do "atendimento integral, é mais um preceito constitucional com prioridade para as atividades preventivas, sem prejuizo das assistenciais" CF 198, II. (16) "Princípios e Diretrizes do Sistema Único de Saúde:....integralidade de assistência, entendida como conjunto articulado e contínuo das ações e serviços preventivos e curativos, individuais e coletivos, exigidos para cada caso em todos os níveis de complexidade do sistema". "Entender que cada pessoa é um todo indivisível,o homem é um ser integral, bio-psico-social e deverá ser atendido com esta visão integral por um sistema de saúde também integral, voltado a promover, proteger e recuperar sua saúde". (100)

\section{INTERSETORIALIDADE}

Muito se fala da intersetorialidade, como elemento essencial ao abordar saúde. Isso acabou sendo consagrado na CF quanto à saúde, quando se coloca a interdependência da saúde com o econômico e social "A saúde é direito de todos e dever do 
Estado, garantido mediante politicas sociais e econômicas que visem a redução do risco de doença e de outros agravos..." CF 196 (16)

Na Lei 8080, a intersetorialidade fica explicita no momento em que se diz que "Saúde tem como fatores determinantes e condicionantes, entre outros, a alimentação, a moradia, o saneamento básico, o meio ambiente, o trabalho, a renda, a educação, o transporte, o lazer e acesso aos bens e serviços essenciais; os niveis de saúde da população expressam a organização social e econômica do País." Lei 8080,3. (27)

O artigo 193 da CF (16) está contido em uma única frase. Talvez seja o menor artigo. Pequeno em tamanho, funda a ordem social: "A ordem social tem como base o primado do trabalho e, como objetivo, o bem-estar e a justiça sociais". Aqui está sintetizada uma das maiores questões da intersetorialidade. Para que se consiga o bem estar e a justiça social, o primado é o trabalho. Falar e discutir saúde sem partir de seu alicerce econômico e social é praticamente impossivel. A relação é quase que linear: melhora a saúde, quando melhora o econômico e social de uma população.

\subsection{PRINCÍPIOS ORGANIZACIONAIS E GERENCIAIS}

\section{SAÚDE É DE RELEVÂNCIA PÚBLICA.}

Entre todos os setores de caráter público a saúde ganha uma posição privilegiada, que é ser mais que público: de relevância pública. Lembre-se que não é apenas o setor de saúde pública, mas todas as ações e serviços de saúde, tanto públicos como privados são públicos e relevantes CF 197.(16) Isso tem outra implicação, na medida em que o ministério público é responsável por zelar para que os serviços de relevância pública respeitem os direitos constitucionais, como o é o da saúde CF 129 II (16). Portanto, responsável pela saúde pública e privada. Poderia ser apenas a ênfase da qualificação mais forte da definição de saúde: relevância, destaque. Na própria CF, além dessa conotação, existe uma correlação com as funções do Ministério Público, entre as quais está a de zelar pelo efetivo respeito dos poderes públicos e dos serviços de relevância pública aos direitos assegurados na Constituição, promovendo as medidas necessárias à sua garantia. Portanto, o Ministério Público tem, como obrigação, zelar para que os serviços de saúde garantam o direito à saúde das pessoas. 


\section{GESTOR ÚNICO EM CADA ESFERA DE GOVERNO.}

É preceito constitucional que na área de saúde cada esfera de governo tenha um só gestor, isto é, direção única em cada esfera de governo. CF 198,I (16) Um só comando. Acaba com a tradição dos serviços, com vários gestores em cada municipio: o federal do MS-Inamps, ou Funasa; o estadual, do posto ou regional de saúde e o municipal com pronto-socorro elou unidades de saúde. Todos trabalhando sem coordenação inter e intra-institucional.

Gestor Municipal cuidando do Município, Gestor Estadual do Estado e Gestor Federal do âmbito Nacional. Princípio pétreo do SUS, com ameaças constantes de interferência de uma esfera de gestão sobre outra.

\section{REGULAÇÃO, FISCALIZAÇÃO E CONTROLE}

O poder público tem que exercer seu papel de regulação, fiscalização e controle sobre todos os serviços de saúde, tanto próprios como privados. Esta é uma das funções precipuas do Estado. CF 197 (16) É livre a iniciativa privada na assistência à saúde. CF 199,5 (16) Entretanto, essa liberdade constitucional é de existência e não total. A regulamentação, fiscalização e controle da iniciativa privada estão submetidos ao público estatal. São atividades que fazem parte das atribuições comuns da União, Estados, Distrito Federal e Municípios, que "exercerão, em seu âmbito administrativo(....) a definição das instâncias e mecanismos de controle, avaliação e de fiscalização das ações e serviços de saúde. Lei 8080 Art.15,I (27)

\section{EXECUÇÃO PÚBLICA ESTATAL E COMPLEMENTARIDADE DO PRIVADO}

No Sistema Único de Saúde, o Público é responsável pela garantia do Direito à Saúde, de todos os cidadãos visto como dever, obrigação do Estado. O Estado tem a obrigação de executar as ações e serviços de saúde e buscar a complementaridade no setor privado lucrativo ou filantrópico, dando-se preferência a este. As definições jurídicas do público e do privado passam por uma análise afeita às definiçōes clássi- 
cas de que o público é a ação do aparelho estatal e o privado é a ação dos indivíduos, isolada ou em sociedade.

Ao buscar as definições em dicionário, encontra-se no Aurélio uma dupla definição do público: a) relativo, pertencente ou destinado ao público b) relativo ou pertencente ao governo de um pais, aberto a quaisquer pessoas.

O Brasil, segundo a CF, está aberto à iniciativa privada. Portanto, na saúde, também, todos podem desenvolver livremente atividades de saúde de caráter privado. As pessoas físicas e jurídicas de direito privado podem executar as ações de saúde, sob a regulamentação, fiscalização e controle do público. CF 199 (16)

Além disso, podem participar complementarmente do SUS, mediante contrato de direito público com o privado lucrativo ou de convênios com o privado não lucrativo, dando-se preferência às entidades filantrópicas e às sem fins lucrativos. $\mathrm{O}$ caráter público do SUS não é estatal. As ações serão desenvolvidas por serviços públicos e, complementarmente, pelo setor privado, com preferência para o filantrópico e o sem fins lucrativos, mediante contrato administrativo ou convênio.

Muito se tem discutido sobre a relação público-privado dentro do Sistema Único de Saúde. A primeira coisa a fazer é definir esses dois pólos de análise. O que é público e o que é privado em relação à saúde? Definidos os pólos, explicitar em qual das concepções de público e privado vão estar estabelecidas essas relações.

$\mathrm{Na}$ busca da definição precisamos tomar da CF e nela entender a questão do SUS como o Sistema Único de Saúde do Brasil. Esse Sistema Único de Saúde deveria ser entendido como o Sistema Nacional de Saúde, que se subdivide em dois subsistemas: o público e o privado. Não foi assim explicitada, como seria esperada.

O sub-sistema privado pode desdobrar-se em dois. O primeiro, lucrativo, dentro do princípio constitucional de que é livre a propriedade privada no Brasil, sem se esquecer de que ela atenderá à sua função social.CF,.5. (16). O segundo, não-lucrativo ou filantrópico e que, ainda que privado, não tem lucro, apenas superávit. É mantido com reinvestimento de seu superávit, com isenções fiscais, com contribuições da comunidade, direta ou indiretamente, e com a possibilidade de venda de seus serviços. 
Vale a pena lembrar uma constatação que daria um outro estudo. No momento atual, no Brasil, ao se falar de setor privado lucrativo puro, a afirmação será que, na acepção prática do termo, não existe nenhum. O mais puro dos privados lucrativos, na pior das hipóteses, ainda goza de algum tipo de isenção fiscal, que é recurso público indireto do qual usufrui.

Portanto, segundo a legislação, há dois espaços abertos à iniciativa privada:

$1^{\circ}$ - a possibilidade de que exista, desde que cumpridas as exigências legais requeridas pela Vigilância Sanitária;

$2^{\circ}$ - a possibilidade de participar complementarmente do Sistema Único de Saúde, o que implica contratação ou conveniamento do privado pelo público, para desempenho de função de relevância pública, momento em que se publiciza.

Sob o comando de um GESTOR PÚBLICO, Federal, Estadual ou Municipal, estão os serviços públicos estatais e os conveniados, contratados.

Esse processo de relacionamento entre o público e o privado, respeitando-se a Constituição e a Lei Orgânica da Saúde, que garantem a livre iniciativa e sua participação em caráter complementar no SUS, é um novo aprendizado na garantia dos principios democráticos.

Os novos tempos de igualdade democrática entre todos os cidadãos vêm mostrar que é possivel buscar-se a imparcialidade e a garantia do direito de igualdade e de escolha daquele que for melhor, antes mesmo de ser dos meus ou de favorecer-me, agradecido. É um aprendizado difícil, mas tardiamente necessário. Esta relação ficou melhor explicitada em documento legal do Ministério da Saúde que desde outubro de 1993 regulamentou esta relação. (67)

\section{REGIONALIZAÇÃO E HIERARQUIZAÇÃO DAS AÇÕES E SERVIÇOS PÚBLICOS DE SAÚDE}

Os serviços de saúde devem estar dispostos de maneira regionalizada "e hierarquizada em niveis de complexidade crescente" Lei 8080,(27) A lei 9836 (38) que acrescenta à 8080 o Subsistema de Atenção à Saúde Indigena. 
Os municipios não poderão, todos e cada um deles, esgotar-se no oferecimento de tudo que a medicina dispõe. Regionalização é a organização dos serviços cobrindo determinada região, complementando-se.

Os serviços de saúde devem se organizar de maneira a obedecer a uma hierarquia entre eles, de tal modo que as questões menos complexas sejam atendidas em local de menos recursos. Esta hierarquia é feita desde as unidades básicas de saúde, passando pelas unidades especializadas, pelo hospital geral até o hospital especializado.

As ações e serviços públicos de saúde constituem o sistema único de saúde. Sua organização deve ser em forma de uma rede, com caracteristicas regionais e de forma hierarquizada, cuja ordem seja dos mais simples aos mais complexos. O primeiro atendimento deve ser feito ou por equipe profissional de trabalho externo ou em unidades básicas menores e, de lá, encaminhados aos serviços de maior complexidade. Um dos principios gerais que perpassa pela constituição em vários capitulos e artigos é o da descentralização. A descentralização tem a municipalização como caminho e expressão. CF, 30,VII(16)

"O sistema único de saúde tem que estar organizado de acordo com as seguintes diretrizes: descentralização com direção única em cada esfera" CF.198 (16) Há um movimento mundial visando fortalecer o poder local. Se se for buscar na história do homem, o início de todo o poder foi sempre ele, quando, individualmente, detinha-o todo. A origem do poder começou pelo chefe do pequeno: o chefe da familia, do clã, da horda, da tribo. Bem mais tarde o poder foi ligado a um povo, criandose a figura embrionária do Estado. Com o aumento da população no mundo, os Estados foram crescendo e o próprio homem acabou por entregar o poder a quem o representasse (ou devesse representar). Cada civilização fez a transformação do poder por caminhos próprios: uns, consentidos socialmente (democracia), outros, usurpados tragicamente e outros, ainda, deturpados.

"O Estado Moderno nasceu unitário, como decorrência da noção de soberania adequada às monarquias absolutas. Era indispensável que um só poder fosse soberano sobre todo o povo de determinado território. (....) O Estado unitário simples, onde, em tese, existe centralização pura, é aquele que possui tanto uma organização politica unitária como uma estrutura administrativa única. (....) O Estado Unitário Complexo, onde existe mais de um órgão não-central, encarregado de determinada atividade deve-se falar em desconcentração e não em descentralização. Desconcentração, segundo o ci- 
entista politico francês Maurice Duverger, "consiste em transferir o poder de decisão das autoridades centrais para os representantes locais por elas nomeados e que são dependentes das autoridades centrais"(....) Nas deliberações do Nono Congresso Internacional de Ciências Administrativas, em 1959, definiu-se a descentralização como "transferência de poderes para autoridades eleitas localmente" ficando claro, então, que a expressão "Estado Descentralizado"implica descentralização política, incompatível com o Estado unitário. O Mais alto grau de descentralização política dá origem ao Estado federal, onde os estados membros gozam de autonomia constitucional e legislativa(....) O Federalismo caracteriza-se por duas leis: a da autonomia, que dá às coletividades-membros participam o caráter de Estado, pois cada qual tem seu sistema legislativo, administrativo e judiciário; e a da participação, que impede que o relacionamento entre as coletividades-membros e o estado federal seja de subordinação, pois apenas existe federalismo se as coletividades associadas participarem, por seus representantes, na constituição dos órgãos federais e na elaboração de suas decisões(....) Convém acentuar que no Brasil o município detem situação peculiar na Constituição Federal, tornando perfeita a afirmação de que, se a autonomia municipal não é da essência do federalismo em geral, ela é, sem dúvida, um elemento essencial ao federalismo brasileiro.(....) Um Sistema Nacional como o de Saúde, por exemplo, conterá normas jurídicas de obediência necessária para todo o conjunto federal, isso significando que não apenas os órgãos do governo federal ficarão obrigados como também os órgãos dos governos estaduais e, no caso brasileiro, os municipais." Dalari (102).

A realidade de nossos dias foi que as várias maneiras de se governar acabaram por chegar onde hoje estamos, em que correntes diferentes defendem um tamanho para o estado. $\mathrm{O}$ estado máximo, bem característico dos regimes totalitários de qualquer matiz: desde o socialismo real, o capitalismo pré-histórico do quinto mundo, às ditaduras e regimes autoritários, civis ou militares. Nestes, o estado se coloca de um tamanho tal que sua influência é sentida em todos os campos, praticamente sufocando os cidadãos. Um estado máximo, cada vez maior e mais distante da população: inatingivel e sem o mínimo compromisso de resposta ao povo. Contrapondo-se a este modelo, o neoliberalismo defende o estado mínimo em que há uma omissão patente do estado, que deixa tudo na dependência do mercado. Sabemos que nenhuma das duas propostas responde aos anseios do cidadão. Cada uma delas tem sua iniqüidade. O caminho que se trilha, nas modernas propostas democráticas é descobrir o tamanho exato desse Estado, capaz de atender às necessidades sociais de todos os cidadãos, sem se imiscuir em áreas em que sua presença seja dispensável. A busca desse estado ideal corre junto com a proposta e busca da descentralização do poder. Em 1985, a União Internacional de Governos Locais elabora, com seus filiados, a Declaração Mundial Sobre a Autonomia Municipal. Nesse documento defendem-se os seguintes princípios gerais ligados à descentralização do poder com fortalecimento do poder local: 
1. Descongestionamento do poder central;

2. Incremento e aceleração da ação governamental;

3. Vitalidade para as instituições públicas;

4. Facilitação do convívio harmonioso da comunidade;

5. Maior integração entre as pessoas;

6. Incentivo à vivência da cidadania: direitos e deveres;

7. Maior chance de dar respostas e respostas corretas quando a autoridade está mais perto do problema: vê melhor e é mais cobrada (antes, durante e depois);

8. O cidadão delega ao estado competências e, através da municipalização do poder, é mais fácil exercer-se, de volta, o controle social. (142)

Temos esses principios da descentralização a defender como a maneira, já afirmada acima, de que os homens públicos possam governar e serem mais úteis à população a nivel local.

A descentralização defendida no período pré-constitucional, e incluida na Constituição, é uma conquista que veio junto com a retomada democrática do país. Veio pelas mãos da democracia e para garantir essa mesma democracia. Quebrar a espinha dorsal de um governo centralizador, dominado duas décadas por uma ditadura militar era ponto fundamental dos defensores da abertura democrática. Descentralizar, criando um espaço de vivenciar melhor a democracia, o controle do cidadão sobre o Estado. O centralismo é um entulho antidemocrático que cria os empecilhos físicos e morais para que o cidadão participe e exerça seu poder.

A descentralização é princípio constitucional e a saúde é o setor que tem os avanços da reforma do Estado mais evidentes dentro de sua proposta o SUS. Não defendemos descentralização da União e dos Estados, passando somente ônus e tarefas aos Municípios, mas sim, como manda a Constituição: transferências de responsabilidades completas com novas competências de cooperação técnica e financeira. A tendência de governos centralizadores transferirem às esferas inferiores apenas obrigações e encargos, deverá ser revertida. O que se deseja sâo governos responsáveis que transfiram atividades, trabalho, mas com uma conseqüente transferência dos meios, o que está relacionado com a transferência de recursos.

A descentralização proposta não deveria parar no mais alto nível municipal. Ela deve ser estendida aos mais baixos níveis hierárquicos no município. Descentralizar para departamentos, distritos, unidades e serviços, de tal modo que a responsabilidade de decisão seja dividida em busca do princípio de eficácia e eficiência. 
Enquanto se luta pela municipalização, como expressão da descentralização e busca do novo, do eficiente na administração pública, ao mesmo tempo pode ser encontrada uma corruptela denominada de prefeiturização. Esse termo caricato, usado contra os municipalistas, tem várias conotações, de acordo com os interlocutores. A prefeiturização é apresentada como tudo de ruim que possa haver no processo de descentralização. Municipalização teve a qualificação automática de positiva e a prefeiturização, ao contrário a negativa. Prefeiturização se refere a situação em que a administração municipal, ao descentralizar, faz de tudo para repetir todos os processos e métodos condenados no centralismo. É como se fosse um administrador déspota, plenipotenciário, fazendo, em nivel local, tudo exatamente o contrário do que se defende na descentralização.

\section{PARTICIPAÇÃO DA COMUNIDADE: CIDADANIA E CONTROLE SOCIAL: SOCI- EDADE E ESTADO A SERVIÇO DO CIDADÃO}

"O estado de justiça social, com bem estar coletivo, só acontecerá quando, pelo processo democrático, cada pessoa assumir o controle da sociedade e do estado pela participação ativa e pela consciência e prática plenas de deveres e direitos de socio-proprietário de sua cidade, seu país e do mundo." (83)

A constituição de 1988 foi denominada como a Constituição Cidadã, não sem absoluta razão. Nela foi colocado o ser humano, cidadão do mundo e de seu pais, como centro, alvo e razão única de ser de qualquer ação do Estado.

A radicalização da defesa dos direitos de cada cidadão mostra-se para o Brasil como o caminho mais reto e largo para se chegar a um estado de justiça social, em que, cada um no individual e no coletivo, possa controlar a sociedade e o Estado para que ambos sejam subservientes aos interesses máximos da cidadania plena e de todos.

O velho conceito de democracia, como governo do povo, pelo povo e para o povo, foi reforçado pela Constituição Federal, que afirma que todo poder emana do povo que o exerce diretamente (democracia participativa), ou indiretamente, através de seus representantes eleitos (democracia representativa) CF 1 Parágrafo Único (16). A Saúde foi o setor que mais aprofundou determinados principios constitucionais, como este, da defesa da participação do cidadão como sócio- proprietário do Brasil. 
A participação e o controle social estão claros na área de Seguridade Social e Saúde nos artigos 10, 194, 198 e no ADCT, art.77 onde chega a ser nominado o papel controlar do Conselho de Saúde.

A Lei 8080 (27) e, principalmente, a 8142 (28), consideradas como Lei Orgânica da Saúde, determinam como se deve dar a participação, criando conselhos e conferências de saúde, em cada esfera de governo. Dá a competência de formular estratégias e controlar a execução da política de saúde. Determina o caráter permanente e deliberativo bem como a necessidade de homologação do chefe do executivo.

A questão, em seguida colocada, é a determinação de como deve ser composto esse Conselho: cidadãos usuários, prestadores de serviços, governo e profissionais de saúde, sendo que a representação dos usuários deve ser paritária em relação ao conjunto dos demais segmentos.

Vários municipios e estados têm tido problemas relacionados à composição do conselho de saúde. Dúvidas podem ser, ou não, esclarecidas à luz da lei e dos principios legais, nem sempre explicitos na saúde, mas colocados na constituição e leis e, muito mais, em tudo que norteou a concepção e criação do Sistema Único de Saúde. Há necessidade de se refletir sobre uma prática de luta, de décadas, em defesa do Controle Social. O Controle Social tem que ser entendido de maneira bem mais ampla que no sentido usual de controle exclusivamente sobre o Estado. É a posição do cidadão-dono que tem que controlar a sociedade como um todo e o estado, aqui representando todo o aparato dos governantes da União, Estados e Municípios.

A evolução para uma sociedade mais igualitária, diminuindo as desigualdades sociais, depende de cada cidadão assumir o papel de sócio-proprietário do bairro, cidade, país e chegando à socio-propriedade do mundo.

A participação ativa do cidadão e o Controle Social tem determinações constitucionais federais, estaduais e em leis orgânicas municipais. Controle sobre o todo e várias áreas. $\mathrm{Na}$ de saúde existem definições constitucionais e legais com duas expressões: CONSELHOS DE SAÚDE e CONFERÊNCIAS DE SAÚDE nas três esferas de governo.

Uma das novidades constitucionais, pós 1988, é o incentivo à participação da população. O exercício do poder, direta ou indiretamente pelo povo, conforme a CF tem 
que contar com canais formais e informais de manifestação CF, 1 Parágrafo Único (16). Assim nascem os Conselhos Setoriais na CF, nas Constituições Estaduais e na Constituição Municipal, na Lei Orgânica do Municipio. Saúde, Educação, Assistência Social, Previdência... são exemplos claros do espaço aberto à participação. Existem Conselhos obrigatórios e outros, de livre constituição. Atualmente, os acima citados, são todos de constituição obrigatória.

Na CF ficou explicitada a questão da participação na área de Seguridade Social. É preceito a organização da Seguridade Social "com base nos seguintes objetivos: caráter democrático e descentralizado da administração, mediante gestão quadripartite, com participação dos trabalhadores, dos empregadores, dos aposentados e do governo nos órgãos colegiados" CF 194, VII (16).

Vários princípios precisam ser esclarecidos para que não se confundam aqueles pétreos com os circunstanciais, fúteis e inconseqüentes. Abaixo, elencam-se alguns principios que, ainda que legais, permanecem controvertidos em sua prática, mais que no seu entendimento:

1. Os Conselhos pertencem à administração pública direta e fazem parte do órgão executivo. A validade das deliberações dos Conselhos está submissa à homologação do chefe do Executivo (Presidente, Governador, Prefeito ou seus delegados Ministros, Secretários) e este deve obrigatoriamente homologar suas resoluções.Não existe possibilidade de que o Conselho esteja desligado da Administração pois, é um órgão vinculado à estrutura do órgão da Administração Pública responsável pela Coordenação da Política Pública Setorial. Os Conselhos deverão ter um local de apoio próprio ou compartilhado com outros conselhos. $\mathrm{O}$ importante é que tenha um mínimo de infraestrutura. Jamais se justificaria, como significância de independência (não atrelamento) que o Conselho tivesse que ser instalado em um prédio próprio, longe das administrações só para efeito demonstração deste não atrelamento!

2. Os Conselhos são os que aconselham, apontam, deliberam. Jamais os que executam. Pensar que o Conselho seja "fazedor" é exatamente o descaminho. Quem executa as deliberações dos Conselhos é o executivo público do Setor, tanto na saúde, como educação, assistência social e previdência. Caráter executivo de Conselho é uma inversäo de valores. Portanto, qualquer infraestrutura de que o Conselho necessite deve ser do setor da administração a que ele esteja ligado. O Conselho não faz plano (colabora, palpita,aprova), não faz cadastro, não tem equipe própria para executar nada. Ele pede isto ao executivo que fornece através de suas estrutura. Cobra dele a informação e a análise etc. para subsidiar sua análise. Conselho não se sobrepõe à ação fim da secretaria setorial à qual pertence.

3. Os Fundos Setoriais são contas especiais para movimentarem, em particular, os recursos daquele determinado setor. Geralmente são gerenciados pelas secreta- 
rias setoriais e/ou as da fazenda. Nos fundos ficam todos recursos do setor: os orçamentos próprios, estaduais ou municipais do setor, as transferências intergovernamentais, as doações, rendas do mercado de capital e outras. É equivocado pensar e separar ações para o Fundo, exclusivamente em relação aos recursos extras do orçamento. O plano setorial, baseado no Plano Plurianual de Governo, na Lei de Diretrizes Orçamentárias e na Lei Orçamentária, deve conter as decisões do Conselho sobre o destino dos recursos.

4. Há Conselhos que não entenderam, ainda, o que sejam os Fundos Setoriais (Saúde, Educação, Previdência, Assistência Social) e afirmam que os recursos do fundo não devam ser utilizados para pagar pessoal, fazer as ações de apoio, as intermediárias, fazer as ações de governo! Como que querendo separar internamente no Fundo os recursos, por competências, por obrigações! Isto não é possível, pois os recursos uma vez ingressos no Fundo, não têm (a não ser aqueles vinculados por cláusula contratual ou convenial) um destino determinado, senão o global do setor. Estes fundos constitucionais, na sua essência, englobam os recursos orçamentários da área.

5. Vale lembrar que, quanto menos recursos forem gastos nos meios, mais recursos sobrarão para as atividades finalísticas. Quando da aprovação do Plano, os Conselhos devem atentar para a proporcionalidade dos gastos com atividadesfim e meio. Imagine-se que recursos maiores venham sendo utilizados nos meios que no fim. Deve haver alguma coisa errada.! Muitas vezes, a análise da propriedade dos gastos com saúde não vem sendo feita. Os gastos podem ser legais, de acordo com todas as normas vigentes, mas inadequados e não priorizados.

6. A grandeza de um Conselho, sua competência, suas decisões, devem estar alicerçadas na liberdade e no compromisso das pessoas que o compõem. Não são as condições materiais que garantem ou asseguram a soberania, independência, eficiência e eficácia dos Conselhos.

7. Conselhos são conquistas democráticas com as quais temos que aprender a conviver, tanto as administrações, quanto os conselheiros, para não nos contaminarmos pelo caminho com os descaminhos do autoritarismo, da patrulha ideológica e do simples não fazer, onde se escondem todas as incompetências.

Os conselhos são espaços democráticos para todos. Saber fazer uso deles pelo bem coletivo é um saber e uma arte que é preciso aprender.

\section{FINANCIAMENTO FEDERAL PARA A SAÚDE NA CONSTITUIÇÃO FEDERAL E NA LEGISLAÇÃO INFRACONSTITUCIONAL}

O movimento da Reforma Sanitária foi muito importante na luta pela formatação de um Sistema de Saúde universal, como direito do cidadão e dever do estado. A VIII Conferência Nacional de Saúde consagrou esses princípios que, encaminhados à Constituinte, transformaram-se no Sistema Único de Saúde - SUS. Nem tudo, é bem verdade, foi aproveitado. 
"No tema financiamento houve alto grau de consenso sobre alguns principios importantes que devem orientar a politica de financiamento setorial. O relatório parece mais indicativo do que conclusivo, revelando que esta discussão exige um maior aprofundamento....Financiamento do setor : idéia de um orçamento social para as várias politicas sociais de todas as esferas de governo; recursos nos fundos de saúde por esfera; recursos para a saúde minimamente pré-fixados; fontes alternativas e não apenas e principalmente a contribuição sobre a folha; melhor distribuição dos recursos de saúde $e$ não apenas pelo critério populacional; proposta de reforma tributária e de fontes alternativas para aumentar a receita como eliminar despesas de pessoas jurídicas de gastos com saúde, rever a de pessoas físicas, taxação de bens de consumo nocivos à saúde, de indústrias poluentes, de jogos de azar, de seguros automotivos, sobre incidência de acidentes de trabalho etc." (5)

Com toda a discussão na Constituinte, muita coisa não ficou como se desejava e uma delas foi em relação ao financiamento. A proposta da saúde era de que os recursos para a saúde estivessem separadas e fossem de fontes múltiplas e com quantidade e fontes definidas. Isto não foi possivel. A saúde foi englobada dentro da Seguridade Social, junto com Previdência e Assistência e, os recursos, ainda que de fontes múltiplas não puderam ficar definidos como já eram e continuaram sendo os recursos da educação. (138) A questão do financiamento da Saúde é um problema crônico. Ainda que anteriormente à CF de 1988 o problema fosse grande, hoje, parece ser maior com a extensão universal da cobertura dos serviços públicos de saúde. Discutiu-se muito no período pré-constitucional e foram apontadas várias saidas, como as acima tiradas na VIII Conferência Nacional de Saúde. Muitas delas foram preceito constitucional, mas não aconteceram como se pretendia.

O objeto deste estudo é a análise do financiamento da saúde no Brasil. Introduzimos os fundamentos da questão financiamento de modo a facilitar a compreensão dos demais capítulos deste trabalho, em que se pretendeu aprofundar o tema. O parâmetro de avaliação utilizado é o que consta da legislação referente ao financiamento da saúde. A partir dai, tomam-se alguns eixos de avaliação de como isto vem acontecendo. Citam-se, a seguir, artigos constitucionais e da legislação infraconstitucional, para facilitar o entendimento dos comentários a respeito.

Neste sentido, destacam-se, como fontes, a CF de 1988 (16) e Leis referentes à saúde e seguridade social e outras que fazem referência ao financiamento da Saúde (8080 (27), 8142 (28), 8212 (30). 


\section{CONSTITUIÇÃO DA REPÚBLICA FEDERATIVA DO BRASIL}

Art. $6^{\circ}$ - São direitos sociais a educação, a saúde, o trabalho, a moradia, o lazer, a segurança, a previdência social, a proteção à maternidade e à infância, a assistência aos desamparados, na forma desta Constituição.

Art. 22 - Compete privativamente à União legislar sobre: (....)XXIII - Seguridade Social(....) Parágrafo único. Lei complementar poderá autorizar os Estados sobre questões especificas das matérias relacionadas neste artigo.

Art. 23 - É competência comum da União, dos Estados, do Distrito Federal e dos Municipios:(....) Il cuidar da saúde e assistência pública, da proteção e garantia das pessoas portadoras de deficiência;

Art. 24 - Compete à União, aos Estados e ao Distrito Federal legislar concorrentemente sobre: (....) XII previdência social, proteção e defesa da saúde;

Art. 30 Compete aos Municípios, prestar, com a cooperação técnica e financeira da União e do estado, serviços de atendimento à saúde da população.

\section{CAPÍTULO II - DA SEGURIDADE SOCIAL}

Art. 194. (*) A seguridade social compreende um conjunto integrado de ações de iniciativa dos poderes públicos e da sociedade, destinadas a assegurar os direitos relativos à saúde, à previdência e à assistência social. Parágrafo único. Compete ao poder público, nos termos da lei, organizar a seguridade social, com base nos seguintes objetivos: I - universalidade da cobertura e do atendimento; II - uniformidade e equivalência dos benefícios e serviços às populações urbanas e rurais; III - seletividade e distributividade na prestação dos benefícios e serviços; IV - irredutibilidade do valor dos benefícios; $V$ - eqüidade na forma de participação no custeio; VI - diversidade da base de financiamento; VII - caráter democrático e descentralizado da gestão administrativa, com a participação da comunidade, em especial de trabalhadores, empresários e aposentados. ( $\left.^{\star}\right)$ Emenda Constitucional $N^{\circ} 20$, de 1998.

Art. 195. A seguridade social será financiada por toda a sociedade, de forma direta e indireta, nos temos da lei, mediante recursos provenientes dos orçamentos da União, dos Estados, do Distrito Federal e dos Municípios, e das seguintes contribuições sociais: I - do empregador, da empresa e da entidade a ela equiparada na forma da lei, incidente sobre: a) a folha de salários e demais rendimentos do trabalho pagos ou creditados, a qualquer título, à pessoa física que lhe preste serviço mesmo sem vínculo empregatício; b) a receita ou o faturamento; c) o lucro; (EC-20 de 15/12/98) II - do trabalhador e dos demais segurados da previdência social, não incidindo contribuição sobre aposentadoria e pensão concedidas pelo regime geral de previdência social de que trata o art. 201; sobre a receita de concursos prognósticos; § 10. As receitas dos Estados, do Distrito Federal e dos Municípios destinadas à seguridade social constarão dos respectivos orçamentos não integrando o orçamento da União. § 20. A proposta de orçamento da seguridade social será elaborada de forma integrada pelos órgãos responsáveis pela saúde, previdência social e assistência social, tendo em vista as metas e prioridades estabelecidas na lei de diretrizes orçamentárias, assegurada a cada área a gestão de seus recursos. $\S 30$. A pessoa jurídica em débito com o sistema de seguridade social l com o estabelecido em 
lei, não poderá contratar com o Poder Público nem dele receber benefícios ou incentivos fiscais ou crediticios. $\S 40$. A lei poderá instituir outras fontes destinas a garantir a manutenção ou expansão da seguridade social, obedecido o disposto no art. 154, I. §5o. Nenhum benefício ou serviço da seguridade social poderá ser criado, majorado ou estendido sem a correspondente fonte de custeio total. $\quad \S 60$. As contribuições sociais de que trata este artigo só poderão ser exigidas após decorridos noventa dias da data da publicação da lei que as houver instituido ou modificado, não Ihes aplicando o disposto no art. 150,III, b. $\S 70$. Serão isentas de contribuição para a seguridade social as entidades beneficentes de assistência social que atendam às exigências estabelecidas em lei. $\S 80.0$ produtor, o parceiro, o meeiro e o arrendatário rurais, o garimpeiro e o pescador artesanal, bem como aos respectivos cônjuges, que exerçam suas atividades em regime de economia familiar, sem empregados permanentes, contribuirão para a seguridade social mediante a aplicação de uma aliquota sobre o resultado da comercialização da produção e farão jus ao benefício nos termos da lei. (EC 20 de 15/12/98) $\S 9^{\circ}$ As contribuições sociais previstas no inciso I deste artigo poderão ter aliquotas ou bases de cálculos diferenciadas em razão da atividade econômica ou da utilização intensiva da mão-de-obra. (EC-20 de 15/12/98) § 10 A lei definirá os critérios de transferência de recursos para o sistema único de saúde e ações de assistência social da União para Estados, o Distrito Federal e os Municipios, e dos Estados para os Municipios, observada a respectiva contrapartida de recursos (EC-20 de 15/12/98). $\S E$ vedada a concessão de remissão ou anistia de contribuições sociais de que tratam os incisos I, a e II deste artigo, para débitos em montante superior ao fixado em lei complementar. (EC 20 de 15/12/1998). (16)

SEÇÃO II - DA SAÚDE -

Art. 196 - A saúde é direito de todos e dever do estado, garantido mediante politicas sociais e econômicas que visem à redução do risco de doença e de outros agravos e ao acesso universal e igualitário às ações e serviços para sua promoção, proteção e recuperação.

Art. 197 - São de relevância pública as ações e serviços de saúde, cabendo ao Poder Público dispor, nos termos da lei, sobre sua regulamentação, fiscalização e controle, devendo sua execução ser feita diretamente ou através de terceiros e, também, por pessoa física ou jurídica de direito privado.

Art. 198 - As ações e serviços públicos de saúde integram uma rede regionalizada e hierarquizada e constituem um sistema único, organizado de acordo com as seguintes diretrizes:I - descentralização, com direção única em cada esfera de governo; II - atendimento integral, com prioridade para as atividades preventivas, sem prejuizo dos serviços assistenciais; III - participação da comunidade. $\S 1^{\circ} \mathrm{O}$ sistema único de saúde será financiado, nos termos do art. 195 com recursos do orçamento da seguridade social, da União, dos Estados, do Distrito Federal e dos Municípios, além de outras fontes. § 2 A União, os Estados, o Distrito Federal e os Municípios aplicarão, anualmente, em ações e serviços públicos de saúde recursos mínimos derivados da aplicação de percentuais calculados sobre: I - no caso da União, na forma definida nos termos da lei complementar prevista no $\S 3^{\circ}$; II - no caso dos Estados e Distrito Federal, o produto da arrecadação dos impostos, a que se refere o art.155 e dos recursos 
que tratam os arts. 157 e 159, I, a, e inciso II, deduzidas as parcelas que forem transferidas aos respectivos municípios; III - no caso dos Municípios e do Distrito Federal, o produto da arrecadação dos impostos a que se refere o art. $156 \mathrm{e}$ dos recursos de que tratam os artigos 158 e 159, l, b e §3 (o §2 e incisos, EC m29 de 13/9/2000; $\S 3^{\circ}$ Lei Complementar, que será reavaliada pelo menos a cada cinco anos, estabelecerá: I - os percentuais de que trata o § 2; II - os critérios de rateio dos recursos da União vinculados à saúde destinados aos Estados, ao Distrito Federal e aos Municípios e dos Estados destinados a seus respectivos municipios, objetivando a progressiva redução das disparidades regionais; III - as normas de fiscalização, avaliação e controle das despesas com saúde nas esferas federal, estadual e municipal; IV - as normas de cálculo do montante a ser aplicado pela União. (§ 3 e incisos - EC 29 de 13/9/2000) (16).

\section{ATO DAS DISPOSIÇÕES CONSTITUCIONAIS TRANSITÓRIAS}

Acréscimo do Art. 77 pela EC-29 - 13-9-2001

Art $7^{\circ} \mathrm{O}$ Ato das Disposições Constitucionais Transitórias passa a vigorar acrescido do seguinte art. 77: Art. 77. Até o exercício financeiro de 2004, os recursos mínimos aplicados nas ações e serviços públicos de saúde serão equivalentes: I - no caso da União: a) no ano 2000, o montante empenhado em ações e serviços públicos de saúde no exercício financeiro de 1999 acrescido de, no mínimo, cinco por cento; b) do ano 2001 ao ano 2004, o valor apurado no ano anterior, corrigido pela variação nominal do Produto Interno Bruto - PIB;II no caso dos Estados e do Distrito Federal, doze por cento do produto da arrecadação dos impostos a que se refere o art. 155 e dos recursos de que tratam os arts. 157 e 159, inciso I, alínea a, e inciso II, deduzidas as parcelas que forem transferidas aos respectivos Municípios; e III - no caso dos Municípios e do Distrito Federal, quinze por cento do produto da arrecadação dos impostos a que se refere o art. 156 e dos recursos de que tratam os arts. 158 e 159, inciso I, alínea $b$ e $\S 3^{\circ}$. $\S 1^{\circ}$ Os Estados, o Distrito Federal e os Municípios que apliquem percentuais inferiores aos fixados nos incisos II e III deverão elevá-los gradualmente, até o exercício financeiro de 2004, reduzida a diferença à razão de, pelo menos, um quinto por ano, sendo que, a partir de 2000 , a aplicação será de pelo menos sete por cento. $\S 2^{\circ}$ Dos recursos da União apurados nos termos deste artigo, quinze por cento, no mínimo, serão aplicados nos Municípios, segundo o critério populacional, em ações e serviços básicos de saúde, na forma da lei. $\S 3^{\circ}$ Os recursos dos Estados, do Distrito Federal e dos Municípios destinados às ações e senviços públicos de saúde e os transferidos pela União para a mesma finalidade serão aplicados por meio de Fundo de Saúde que será acompanhado e fiscalizado por Conselho de Saúde, sem prejuizo do disposto no art. 74 da Constituição Federal. $\S 4^{\circ} \mathrm{Na}$ ausência da lei complementar a que se refere 0 art. $198, \S 3^{\circ}$, a partir do exercício financeiro de 2005, aplicar-se-á à União, aos Estados, ao Distrito Federal e aos Municípios o disposto neste artigo. Art $8^{\circ}$ Esta Emenda Constitucional entra em vigor na data de sua publicação.(16) 


\section{LEI No. 8.080, DE 19 DE SETEMBRO DE 1990}

Dispõe sobre as condições para a promoção, proteção e recuperação da saúde, a organização e o funcionamento dos serviços correspondentes e dá outras providências.

Art. 1o. - Esta lei regula em todo o território nacional, as ações e serviços de saúde executados isolada ou conjuntamente, em caráter permanente ou eventual, por pessoas naturais ou jurídicas de direito público ou privado.

Art. 2o. - A Saúde é um direito fundamental do ser humano, devendo o estado prover as condições indispensáveis ao seu pleno exercício. §10. - O dever do estado de garantir a saúde consiste na formulação e execução de políticas econômicas e sociais que visem à redução de riscos de doenças e de outros agravos e no estabelecimento de condições que assegurem acesso universal e igualitário às ações e aos serviços para a sua promoção, proteção e recuperação. §2o. - O dever do estado não inclui o das pessoas, da família das empresas e da sociedade.

Art. $3^{\circ}$. - A saúde tem como fatores determinantes e condicionantes, entre outros, a alimentação, a moradia, o saneamento básico, o meio ambiente, o trabaIho, a renda, a educação, ao transporte, o lazer e o acesso aos bens e serviços essenciais; os níveis de saúde da população expressam a organização social e econômica do País. Parágrafo único - Dizem respeito também à saúde as ações que, por força do disposto no artigo anterior, se destinam a garantir às pessoas e à coletividade condições de bem-estar físico mental e social. (....)

Art. 15 - A União, os Estados, o Distrito Federal e os Municípios exercerão, em seu âmbito administrativo, as seguintes atribuições: II - administração dos recursos orçamentários e financeiros destinados, em cada ano, a saúde; $X$ - elaboração de proposta orçamentária do Sistema Único de Saúde, de conformidade com o plano de saúde; XII - realização de operações externas de natureza financeira de interesse da saúde, autorizadas pelo Senado Federal;

Art. 16 - À direção nacional do Sistema Único de Saúde - SUS compete: XIII prestar cooperação técnica e financeira aos Estados, ao Distrito Federal e aos Municípios para o aperfeiçoamento da sua atuação institucional; (....)

Art. 26 - Os critérios e valores para a remuneração de serviços e os parâmetros de cobertura assistencial serão estabelecidos pela direção nacional do Sistema Único de Saúde - SUS, aprovados no Conselho Nacional de Saúde. $\S 1^{\circ}$. - Na fixação dos critérios, valores, formas de reajuste e de pagamento de remuneração aludida neste artigo, a direção nacional do Sistema Único de Saúde - SUS deverá fundamentar seu ato em demonstrativo económico-financeiro que garanta a efetiva qualidade de execução dos serviços contratados. $\S 2^{\circ}$. - Os serviços contratados submeter-se-ão às normas técnicas e administrativas e a princípios e diretrizes do Sistema Único de Saúde - SUS, mantido o equilíbrio econômico e financeiro do contrato. $\S 3^{\circ}$. - (VETADO) $\S 4^{\circ}$. - Aos proprietários, administradores e dirigentes de entidades ou serviços contratados é vedado exercer cargo de chefia ou função de confiança no Sistema Único de Saúde - SUS. (....)

Art. 32 - São considerados de outras fontes os recursos provenientes de: I (VETADO) II - serviços que possam ser prestados sem prejuizo da assistência 
$2^{\circ}$. - Nos casos de Estados e Municipios sujeitos a notório processo de migração, os critérios demográficos mencionados nesta Lei serão ponderados por outros indicadores de crescimento populacional, em especial o número de leitores registrados. $\S 3^{\circ}$. - (VETADO) § $4^{\circ}$. - (VETADO) $\S 5^{\circ}$. - (VETADO) $\S 6^{\circ}$. - O disposto no parágrafo anterior não prejudica a atuação dos órgãos de controle interno e externo e nem a aplicação de penalidades previstas em lei, em caso de irregularidade verificadas na gestão dos recursos transferidos.

Art. 36 - O processo de planejamento e orçamento do Sistema Único de Saúde - SUS, será ascendente, do nível local até o federal, ouvidos seus órgãos deliberativos, compatibilizando-se as necessidades da política de saúde com a disponibilidade de recursos em planos de saúde dos Municípios, dos estados, do Distrito Federal e da União. $\S 1^{\circ}$. - Os planos de saúde serão a base das atividades e programação de cada nível de direção do Sistema Único de Saúde SUS, e seu financiamento será previsto na respectiva proposta orçamentária. § $2^{\circ}$. - É vedada a transferência de recursos para o financiamento de ações não previstas nos planos de saúde, exceto em situações emergenciais ou de calamidade pública, na área de saúde.

Art. 37 - O Conselho Nacional de Saúde estabelecerá as diretrizes a serem obsenvadas na elaboração dos planos de saúde, em função das características epidemiológicas e da organização dos serviços em cada jurisdição administrativa.

Art. 38 - Não será permitida a destinação de subvenções e auxílios a instituições prestadoras de serviços de saúde com finalidade lucrativa.

Art. 43 - A gratuidade das ações e serviços de saúde fica preservada nos serviços públicos contratados, ressalvando-se as cláusulas dos contratos ou convênios estabelecidos com as entidades privadas. (27)

\section{LEI N. 8.142, DE 28 DE DEZEMBRO DE 1990}

Dispõe sobre a participação da comunidade na gestão do Sistema Único de Saúde - SUS e sobre as transferências intergovernamentais de recursos financeiros na área da saúde e dá outras providências.

Art. $2^{\circ}$. - Os recursos do Fundo Nacional de Saúde, - FNS serão alocados como: I - despesas de custeio e de capital do Ministério da Saúde, seus órgãos e entidades, da administração direta e indireta; II - investimentos previstos em lei orçamentária, de iniciativa do Poder Legislativo e aprovados pelo Congresso Nacional; III - investimentos previstos no Plano Qüinqüenal do Ministério da Saúde; IV - cobertura das ações e serviços de saúde a serem implementados pelos Municípios, Estados e Distrito Federal. Parágrafo Único - Os recursos referidos no inciso IV deste artigo destinar-se-ão a investimentos na rede de serviços, à cobertura assistencial ambulatorial e hospitalar e às demais ações de saúde.

Art. 3o. - Os recursos referidos no inciso $V$ do art. 2o. Desta lei serão repassados de forma regular e automática para os municípios, estados e municípios e Distrito Federal, de acordo com os critérios previstos no art. 35 da Lei no. 8.080 de 19 de setembro de 1990. $\S 1^{\circ}$. - Enquanto não for regulamentado a aplica- 
ção dos critérios previstos no art. 35 da Lei no. 8.080 , de 19 de setembro de 1990, será utilizado para o repasse de recursos, exclusivamente o critério estabelecido no $\S 1^{\circ}$. Do mesmo artigo. $\S 2^{\circ}$. - Os recursos referidos neste artigo serão destinados, pelo menos setenta por cento aos Municípios, afetando-se o restante aos estados. $\S 3^{\circ}$. - Os Municípios poderão estabelecer consórcio para execução de ações e serviços de saúde, remanejando, entre si, parcelas de recursos previstos no inciso IV do art. $\S 2^{\circ}$. Desta lei.

Art. 40. - Para receberem os recursos, de que trata o art. 3o. Desta lei,os Municípios, os Estados e o Distrito Federal deverão contar com: I - Fundo de Saúde; II - Conselho de Saúde, com composição paritária de acordo com o Decreto no. 99.438 de 7 de agosto de 1990; III - Plano de Saúde; IV - Relatórios de gestão que permitam o controle de que trata o $\S 4^{\circ}$. - do art. 33 da lei no. 8.080 de 19 de setembro de 1990; $V$ - Contrapartida de recursos para a saúde no respectivo orçamento ; VI - Comissão de elaboração do Plano de Carreira, Cargos e Salários _ PCCS, previsto o prazo de dois anos para sua implantação. Parágrafo único - O não atendimento pelos Municípios, ou pelos Estados, ou pelo Distrito Federal, dos requisitos estabelecidos neste artigo, implicará em que os recursos concernentes sejam administrados, respectivamente, pelos Estados ou pela União.

Art. 5o. É o Ministério da Saúde, mediante Portaria do Ministro de Estado, autorizado estabelecer condições para aplicação desta lei. (28)

\section{LEI N 8.212, DE 24 DE JULHO DE 1991.}

\section{LEI ORGÂNICA DA SEGURIDADE SOCIAL DA CONTRIBUIÇÃO DA UNIÃO}

Art. 16. A contribuição da União é constituída de recursos adicionais do Orçamento Fiscal, fixados obrigatoriamente na lei orçamentária anual. Parágrafo único. A União é responsável pela cobertura de eventuais insuficiências financeiras da Seguridade Social, quando decorrentes do pagamento de benefícios de prestação continuada da Previdência Social, na forma da Lei Orçamentária Anual. (....)

Art. 19. O Tesouro Nacional entregará os recursos destinados à execução do Orçamento da Seguridade Social aos respectivos órgãos e unidades gestoras nos mesmos prazos legais estabelecidos para a distribuição dos Fundos de Participação dos Estados, do Distrito Federal e dos Municípios: $\S 1^{\circ}$ Decorridos os prazos referidos no caput deste artigo, as dotações a serem repassadas sujeitar-se-ão a atualização monetária segundo os mesmos índices utilizados para efeito de correção dos tributos da União. $\S 2^{\circ}$ Os recursos oriundos da majoração das contribuições previstas nesta Lei ou da criação de novas contribuições destinadas à Seguridade Social somente poderão ser utilizados para atender as ações nas áreas de saúde, previdência e assistência social. (30) 


\section{DECRETO No 1.232, DE 30 DE AGOSTO DE 1994}

Dispõe sobre as condições e a forma de repasse regular e automático de recursos do Fundo Nacional de Saúde para os fundos de saúde estaduais, municipais e do Distrito Federal, e dá outras providências.

Art. $1^{\circ}$ Os recursos do Orçamento da Seguridade Social alocados ao Fundo Nacional de Saúde e destinados à cobertura dos serviços e ações de saúde a serem implementados pelos Estados, Distrito Federal e Municípios serão a estes transferidos, obedecida a programação financeira do Tesouro Nacional, independentemente de convênio ou instrumento congênere e segundo critérios, valores e parâmetros de cobertura assistencial, de acordo com a Lei $n^{\circ} 8.080$, de 19 de setembro de 1990, e exigências contidas neste decreto. § $1^{\circ}$ Enquanto não forem estabelecidas, com base nas características epidemiológicas e de organização dos serviços assistenciais previstas no art. 35 da Lei $n^{\circ} 8.080$, de 1990 , as diretrizes a serem observadas na elaboração dos planos de saúde, a distribuição dos recursos será feita exclusivamente segundo o quociente de sua divisão pelo número de habitantes, segundo estimativas populacionais fornecidas pelo IBGE, obedecidas as exigências deste decreto. $\S 2^{\circ}$ Fica estabelecido o prazo de 180 dias, a partir da data de publicação deste decreto, para que o Ministério da Saúde defina as características epidemiológicas e de organização dos serviços assistenciais referidas no parágrafo anterior.

Art. $2^{\circ}$ A transferência de que trata o art. $1^{\circ}$ fica condicionada à existência de fundo de saúde e à apresentação de plano de saúde, aprovado pelo respectivo Conselho de Saúde, do qual conste a contrapartida de recursos no Orçamento do Estado, do Distrito Federal ou do Município. $\S 1^{\circ}$ Os planos municipais de saúde serão consolidados na esfera regional e estadual e a transferência de recursos pelo Fundo Nacional de Saúde dos Municípios fica condicionada à indicação, pelas Comissões Bipartites da relação de Municípios que, além de cumprirem as exigências legais, participam dos projetos de regionalização e hierarquização aprovados naquelas comissões, assim como à compatibilização das necessidades da política de saúde com a disponibilidade de recursos. $\S 2^{\circ} \mathrm{O}$ plano de saúde discriminará o percentual destinado pelo Estado e pelo Municipio, nos respectivos orçamentos, para financiamento de suas atividades e programas. $\S 3^{\circ} \mathrm{O}$ Ministério da Saúde definirá os critérios e as condições mínimas exigidas para aprovação dos planos de saúde do município.

Art. $3^{\circ}$ Os recursos transferidos pelo Fundo Nacional de Saúde serão movimentados, em cada esfera de governo, sob a fiscalização do respectivo Conselho de Saúde, sem prejuízo da fiscalização exercida pelos órgãos do sistema de Controle Interno do Poder Executivo e do Tribunal de Contas da União.

Art. $4^{\circ}$ É vedada a transferência de recursos para o financiamento de ações não previstas nos planos de saúde, exceto em situações emergenciais ou de calamidade pública, na área da saúde.

Art. $5^{\circ}$ O Ministério da Saúde, por intermédio dos órgãos do Sistema Nacional de Auditoria e com base nos relatórios de gestão encaminhados pelos Estados, Distritos Federal e Municípios, acompanhará a conformidade da aplicação dos recursos transferidos à programação dos serviços e ações constantes dos planos de saúde. 
Art. $6^{\circ}$ A descentralização dos serviços de saúde para os Municipios e a regionalização da rede de serviços assistenciais serão promovidas e concretizadas com a cooperação técnica da União, tendo em vista o direito de acesso da população aos serviços de saúde, a integralidade da assistência e à igualdade do atendimento.

Art. $7^{\circ}$ A cooperação técnica da União com os Estados, o Distrito Federal e os Municipios, previstas no art. 16, inciso XIII, da Lei Orgânica da Saúde, e no art. 30, inciso VII, da Constituição Federal, será exercida com base na função coordenadora da direção nacional do Sistema Único de Saúde, tendo em vista a realização das metas do Sistema e a redução das desigualdades sociais e regionais.

Art. $8^{\circ}$ A União, por intermédio da direção nacional do SUS, incentivará os Estados, o Distrito Federal e os Municípios a adotarem politica de recursos humanos caracterizada pelos elementos essenciais de motivação do pessoal da área da saúde, de sua valorização profissional e de remuneração adequada.

Art. $9^{\circ}$ A União, por intermédio da direção nacional do SUS, sem prejuízo da atuação do Sistema de Controle Interno do Poder Executivo Federal, exercerá o controle finalístico global do Sistema Único de Saúde, utilizando-se, nesse sentido, dos instrumentos de coordenação de atividades e de avaliação de resultados, em âmbito nacional, previstos na Lei Orgânica da Saúde e explicitados neste decreto.

Art. 10. O atendimento de qualquer natureza na área do Sistema Único de Saúde, quando prestado a paciente que seja beneficiário de plano de saúde, deverá ser ressarcido pela entidade mantenedora do respectivo plano.

Art. 11. O Ministério da Saúde, por intermédio de seus órgãos competentes, adotará as medidas administrativas destinadas à operacionalização do disposto neste decreto. (26)

$\mathrm{Na}$ hierarquia da legislação abaixo da CF, Leis e Decretos referentes ao financiamento da saúde muito se produziu em termos de portarias, normas operacionais básicas, instruções normativas, circulares etc. Estes textos serão analisados dentro de seu contexto. 
II - OBJETIVO 


\section{OBJETIVO GERAL}

Analisar o comportamento do financiamento federal para a saúde no periodo pós constitucional, Brasil, 1988-2001

\section{OBJETIVOS ESPECÍFICOS}

- Analisar o financiamento previsto nas leis orçamentárias, planos plurianuais, leis de diretrizes orçamentárias e leis orçamentárias, à luz dos princípios constitucionais,no período 1988-2001.

- Analisar a execução orçamentária do Ministério da Saúde no período 19882001 à luz do determinado nos princípios constitucionais e o previsto nas leis orçamentárias. 
III - PROCESSO METODOLÓGICO 


\section{PROCESSO METODOLÓGICO}

Trata-se de um estudo de natureza qualitativa, baseado em pesquisa de fontes documentais oficiais, para cuja análise recorreu-se à bibliografia especializada do campo do Direito e da Saúde sobretudo por que diz respeito aos pressupostos teóricometodológicos.

\section{FONTES DOCUMENTAIS}

A fonte de dados para o estudo, em grande parte, constituem diplomas legais, como a Constituição Federal (16), leis, decretos, portarias, normas, instruções normativas e outros, de origem federal e de âmbito nacional, publicadas no período de 1988 a 2001 e referentes à saúde. Incluíram-se ainda documentos formais e alguns informais, não publicados, de prestação de contas e que demonstram como foram realmente utilizados os recursos.

\section{ETAPAS METODOLÓGICAS}

\subsection{COLETA DE DADOS}

- Levantamento bibliográfico sobre os principios fundamentais que sustentam a concepção de saúde no Brasil, presente em diplomas legais, como a Constituição Federal de 1988 (16), as Leis Orgânicas da Saúde com destaque da Lei 8080 (27) e $8142 .(28)$

- Levantamento dos diplomas legais federais sobre orçamento federal global, que se referem à saúde, no período 1988-2001, como os Planos Plurianuais, Leis de Diretrizes Orçamentárias, Leis Orçamentárias.

- Levantamento dos diplomas legais federais, no período 1988-2001 sobre o orçamento específico da saúde, bem como as regras sobre sua utilização expressas em decretos e portarias e com destaque as portarias das Normas $\mathrm{O}$ peracionais Básicas e de Assistência.

- Levantamento dos balanços, balancetes, relatórios de gestão sobre a utilização dos recursos do Ministério da Saúde no período 1988-2001. 


\subsection{PROCEDIMENTOS DE ORGANIZAÇÃO E ANÁLISE DOS DADOS}

\subsubsection{ORGANIZAÇÃO}

Os documentos acima descritos foram catalogados e organizados por ordem cronológica e, também, por ordem de temas dentro da seguinte priorização:

- Financiamento Federal para a Saúde no periodo pré-constitucional;

- Financiamento Federal para a Saúde no período de 1988-1990;

- Financiamento Federal para a Saúde no período de 1991;

- Financiamento Federal para a Saúde no período de 1992;

- Financiamento Federal para a Saúde no período de 1993-1997;

- Financiamento Federal para a Saúde no período de 1998-2000;

- Financiamento Federal para a Saúde no período de 2001.

\subsubsection{ANÁLISE}

Foi utilizada a metodologia descritivo-analítica tomando como material, os documentos legais acima descritos. A descrição e análise compreenderam três componentes: a) o discurso dos princípios da saúde; b) o discurso do financiamento da saúde e c)o efetivamente realizado no financeiro.

A análise tomou como base, o que está determinado na legislação como objeto da Saúde no Brasil, no período pós-constitucional (Constituição Federal (16), Lei 8080 (27) e 8142(28). A partir desse marco - o que determina a lei - foram analisados os documentos financeiros gerais e de saúde, tendo, como base as Leis do Plano Plurianual, de Diretrizes Orçamentárias e Lei orçamentária, decretos e portarias correlatos. Procedeu-se à análise de adequação dessas aos princípios do SUS.

Na segunda fase foram identificados e estudados os documentos legais ligados à execução orçamentária, com vistas a verificar até que ponto o executado representou o determinado, como princípio, e, concomitantemente, analisou-se o cumprimento em relação ao autorizado pelas leis orçamentárias. 
Essas atividades foram todas desenvolvidas pelo autor, que adotou a metodologia de analise "in processu". Considerando que o autor foi um dos atores privilegiados dentro do sistema de saúde, no período estudado, sendo um dos protagonistas de todo o processo de implantação do Sistema Único de Saúde no período pós-constitucional, a análise foi feita dentro dessa visão de sujeito no processo. Quer dizer, a atividade investigativa teve como pressuposto que o sujeito pesquisador não é neutro que faz parte, ao mesmo tempo, do objeto de estudo. Assim, a relação sujeito-objeto é entendida como de reciprocidade, na medida em que o pesquisador construiu o seu objeto de estudo, que nada mais é que sua prática social, com ela dialogando o tempo todo no processo de produção do presente estudo. 
III - DESENVOLVIMENTO DO TEMA 
1. O FINANCIAMENTO FEDERAL PARA A SAÚdE NO PERIOdO PRÉ E PÓS ZONSTITUCIONAL IMEDIATO - 1963-1990

\subsection{A III CONFERÊNCIA NACIONAL DE SAÚDE}

Qualquer análise da saúde no Brasil, no período mais recente, implica necessariamente omar, como referência, a III Conferência Nacional de Saúde, cujos anais só foram Jublicados 28 anos, depois por iniciativa do Movimento Socialista de Saúde do Partido Jemocrático Trabalhista e com a colaboração da Secretaria Municipal de Saúde de Niterói.

(4)

Fomos buscar, inicialmente, o depoimento do Ex-Ministro da Saúde, Wilson Fadul, à época do Presidente João Goulart e que foi quem convocou e conduziu a III Conferência Nacional de Saúde de 9 a 15 de dezembro de 1963.

"A III Conferência Nacional de Saúde revestiu-se de especial significado na medida em que propôs reforma profunda na estrutura sanitária do país e, pela primeira vez fixou com clareza uma Política Nacional de Saúde, capaz de atender às necessidades do nosso povo, a custos suportáveis pela nação. Sob esse aspecto, ela se constituiu num marco importante da história do pensamento dos sanitaristas brasileiros.

No processo de elaboração desse pensamento, sobretudo a partir de 1940, foi tomando corpo a idéia de que a saúde é inseparável do processo nacional de desenvolvimento, apresentando-se os indicadores dos niveis de saúde estreitamente relacionados ao grau de desenvolvimento econômico, social, político e cultural da comunidade.

A partir daí foi possivel repensar criticamente a Organização Sanitária Brasileira com a conseqüente correção de dois vícios que the reduziam o alcance e a eficiência: a insuportável centralização que deixava desprotegido um grande contingente da população e a atitude de passividade com que eram aceitas muitas medidas estranhas à nossa realidade.

Adotou, então, a III Conferência Nacional de Saúde a tese da Municipalização com o objetivo de descentralizar a execução das ações básicas de saúde, de modo a criar uma estrutura sanitária verdadeiramente nacional e flexível o bastante para adequar-se à realidade econômica, política e social da comunidade, num país de tão grandes diferenças regionais.

Como complemento indispensável a esta decisão, resolveu a Conferência recomendar a articulação das atividades sanitárias nos vários niveis das administrações: federal, estaduais e municipais, dando o primeiro passo para a implantação de um sistema nacional de saúde unificado.

Uma vez institucionalizada, esta política pressupunha o fortalecimento da rede pública. Nas duas últimas décadas, porém, mesmo sem abandonar o discurso municipalista, o Estado passou a promover a privatização da saúde, de maneira cada vez mais aberta, com recursos públicos formados principalmente pela contribuição compulsória dos previdenciários, com a inevitável deterioração da qualidade dos serviços prestados pelos órgãos governamentais. "(4) 
Os Temas Oficiais foram quatro: Situação Sanitária da População Brasileira; Distribuição das Atividades Médico-Sanitárias nos Niveis Federal, Estadual e Municipal; Municipalização dos Serviços de Saúde e Fixação de um Plano Nacional de Saúde.

O Presidente João Goulart, em seu discurso oficial marca o tom da III Conferência Nacional de Saúde.

"Permitam-me, porém, os eminentes técnicos dos sistemas de Saúde Pública do País, valendo-me da experiência do constante convívio com os trabalhadores das cidades e com a verdadeira massa de párias da nossa agricultura, que faça uma advertência, diante das enganadoras perspectivas que possam abrigar, segundo as quais é possivel obter-se uma profunda melhoria da saúde de nossas populações, com a simples aplicação de medidas de ordem médico-sanitária: a saúde, sabem os senhores mais do que eu, é um indice global, resultante de um conjunto de condições - boa alimentação, habitação higiênica, roupas adequadas, saudável regime de trabalho, educação, assistência médico-sanitária, diversões e ainda outros fatores que só podem ser conseguidos em conseqüência do desenvolvimento econômico da nação e da distribuição eqüitativa de suas riquezas. Parece-me aqui as palavras do Grande Presidente Getúlio Vargas, que, com a clarividência do estadista, que todos Ihe reconhecem, afirmava, em sua mensagem de 1951, ao Congresso Nacional: "O baixo nivel de Saúde do Brasil é fiel reflexo da pobreza que grava a grande maioria do nosso povo. Costuma-se inverter o problema atribuindo esta condição à deficiência do brasileiro, minado pela doença e oprimido pelo clima, incapaz de transformar em produção útil nossas gigantescas riquezas potenciais, quando na verdade o povo é doente porque ainda não possuiu os meios para comprar sua saúde, sob a forma de alimentação adequada, ambiente higiênico e sadio regime de trabalho. E que as causas fundamentais da baixa produtividade vulgarmente lançada a conta de má saúde do trabalhador rural, residem antes da aspereza do meio, nas agruras do clima e, sobretudo, nos métodos primitivos de trabalho, que obriga o homem a retirar de si próprio a energia que alhures é produto da eletricidade, da mecânica e da química." (....) O temário desta Conferência, indica que a política que o Ministério da Saúde deseja implantar na orientação das atividades médico sanitárias do país se enquadra precisamente dentro da filosofia de que a saúde da população brasileira será uma conseqüência do processo de desenvolvimento econômico nacional, mas que para ajudar este processo o Ministério da Saúde deve dar uma grande contribuição, incorporando os Municípios do país em uma rede básica de serviços médico-sanitários, que forneçam a todos os brasileiros um mínimo indispensável à defesa de sua vida. Quando esta rede, estabelecida com a cooperação técnica e financeira da União e dos Estados, alcançar todas as células municipais e se disseminar por suas cidades, vilas e localidades, a população brasileira, que vive no interior, em completo abandono no que se refere às medidas sanitárias, poderá solucionar muitos problemas, não raro angustiantes, da doença e reclamar outras medidas mais avançadas do seu interesse. De outra parte, o Governo mantém como ponto fundamental de sua política, as reformas indispensáveis da estrutura econômico-social do Brasil para que seja intensificado o desenvolvimento nacional e a população brasileira possa, assim, atingir os elevados níveis de saúde, como os já existentes em outros paises que realizaram estas reformas, etapas necessárias do progresso da sociedade humano." João Goulart (4).

A defesa de um sistema de saúde descentralizado e baseado nos municípios reafirma a importância da III Conferência Nacional de Saúde, na tentativa de garantir assistência à 
saúde para toda a população. Consultando o texto guia do terceiro tema da Conferência, a Municipalização, podem-se selecionar alguns parágrafos:

"Dois empecilhos tivemos no desenvolvimento da saúde pública brasileira: introdução de medidas médico-sanitárias bem sucedidas em outros paises, não chegam a funcionar no Brasil, não só por falta de recursos em pessoal e material, e por não serem necessárias às nossas condições sanitárias. Outro empecilho é a herança de D.João VI que impôs a centralização administrativa (....)".

“A Constituição da República em 1891, a descentralização foi estabelecida, cabendo aos estados a responsabilidade da administração sanitária. Aos municipios caberia a administração de serviços locais de seu interesse. É evidente que dentre estes, estavam os serviços sanitários de âmbito local (....)".

“A municipalização dos serviços médico-sanitários terá por finalidade, em primeiro lugar, implementar o dispositivo constitucional que, de fato, é acertado.... Os argumentos que se apresentam para justificar a inoportunidade da medida são os seguintes: incapacidade financeira, incapacidade técnica e influência acentuada da politica." (4)

O relatório final da III Conferência traz, entre outros, os seguintes tópicos e faz várias recomendações:

"Recomenda a adoção de medidas gerais que objetivarem impulsionar o processo de desenvolvimento econômico do pais; integrar os programas de Saúde Pública no programa global de desenvolvimento.

Recomenda que União, Estados e Municípios assumam competências... Competências dos Municípios: fixar o programa de saúde pública municipal, levando em conta os critérios estabelecidos nos Planos Diretores nacional e estaduais;... Estabelecer, em lei municipal, a obrigatoriedade de participação financeira do municipio na manutenção das atividades de saúde e saneamento.

Recomenda que os Governos Federal, Estaduais e Municipais, na mais estreita cooperação, estabeleçam, no menor prazo possível, em nível municipal, a estrutura sanitária básica do país, de forma a fornecer os cuidados médico-sanitários indispensáveis à defesa da vida de toda população brasileira; priorização para os municípios que não disponham de qualquer medida de defesa da saúde; que os serviços de saúde a serem implantados nos municípios deverão levar em conta na sua estrutura, as necessidades e possibilidades de cada um."(4)

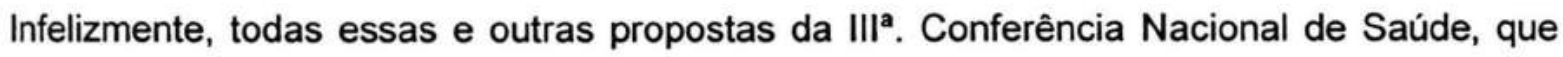
embasavam um sistema de saúde de base municipalista, sem perder a noção do federalismo, foi bloqueado pelo período de Ditadura Militar que ocorreu menos de seis meses depois da Conferência. O Centralismo das Ditaduras impedia qualquer idéia de descentralizaçăo. Vamos assistir nesta época duas medidas especiais que demonstram sobejamente qual era a proposta do Governo Militar sobre a saúde.

Á época era Ministro do Planejamento e Economia, Delfim Neto, que comandou e defendeu essas duas propostas: 1 . Incentivo a que as empresas industriais e comerciais cuidassem da 
saúde de seus trabalhadores, por meio de serviços próprios ou contratados e pagos por eles; para compensar, devolvia-se um percentual do recolhimento da contribuição de empregados e empregadores sobre a folha; 2 . optando para não expandir mais os serviços públicos de saúde previdenciários, incentivou o setor privado a investir na construção de serviços privados de saúde para atendimento, tanto da denominada medicina de grupo, como da previdência pública; como fator estimulador, ofereceu empréstimos subsidiados através da Caixa Econômica Federal, pelo Fundo de Apoio ao Desenvolvimento Social - FAS, com a promessa garantida de que depois pagariam com os próprios serviços prestados à Previdência.

\subsection{O MOVIMENTO MUNICIPALISTA DA SAÚDE - DÉCADA DE 70}

A década de 60 começara tão promissora. Era a década das grandes reformas brasileiras: a reforma da previdência; a reforma da saúde, III Conferência Nacional de Saúde; a reforma da educação, Lei de Diretrizes e Bases da Educação; a luta pela reforma agrária. Tudo isso foi cortado,como num sonho, em março de 64, pelo Golpe Militar, seguido dos anos duros da Ditadura Militar. Foram duas décadas dificeis para os brasileiros, para os direitos sociais, para a cidadania. Os Militares comandavam a Ditadura no País, agindo sob a égide de Atos Institucionais e trazendo a população sob o controle da censura, da falta de liberdade de imprensa, do bipartidarismo vertical e outras restrições. Conforme as colocações anteriores, fica evidente a proposta do Regime Militar para a saúde: privatização em larga escala.

Dentro desse panorama, a resistência ao sistema ia se organizando e consolidando nos porões da ditadura. Na década de 1970, grandes transformações começaram a ocorrer no Brasil. Nessa década desponta o movimento municipalista de saúde.

"Nascido em meio à crise e às contradições da crise do estado autoritário e, particularmente, a uma crise sem precedentes do setor, o Movimento Municipalista de Saúde crescerá e amadurecerá sempre de maneira articulada à conjuntura política nacional. A organização do Movimento Municipalista de Saúde, se dá a partir dos seguintes movimentos históricos: 1. período de resistência e baixa institucionalização (anterior a 1984); 2. primeiros passos como movimento organizado (1984 - 1987); 3. expansão e institucionalização (1987 - 1992); 4. consolidação (1992 em diante)". Flávio Goulart (108)

"Movimento Municipalista de Saúde: é a articulação, união e organização dos serviços municipais de saúde através de seus dirigentes e técnicos, na defesa de um conjunto de temas e objetivos relacionados à descentralização de recursos, de poder e ações do Setor Saúde". MULLER - 1991 (124)

Os primórdios dessa fase do movimento municipalista de saúde datam de 1975. Vários fatos acontecidos reuniam pessoas do setor progressista de saúde que discutiam a questão do 
direito de todos à saúde: movimento das universidades, movimento de técnicos interessados e movimento da população tanto nas Sociedades Amigos de Bairro e Associações de Moradores como nas Comunidades Eclesiais de Base (CEBs) da Igreja Católica.

Nelson Rodrigues dos Santos, um dos protagonistas mais importantes da saúde pública e do movimento de municipalização, descreve bem essa época:

"Durante toda a década de 70 houve um explosivo fenômeno de urbanização do pais, correlacionado com a situação econômica da população. Crescia o bolo, com a promessa de que iria ser dividido, formava-se uma imensa divida externa, com pauperização das pequenas cidades e zonas rurais, expulsando legiões de pessoas para as cidades médias e grandes. (....) Então, houve o desespero de prefeitos que desistiram dos apoios estaduais e federais, fizeram das tripas coração e começaram a alocar recursos municipais na saúde, com incremento, também do nivel de administração e gerência de serviços, de uma maneira que as políticas federais e estaduais jamais tinham alcançado. (....) Uma parte dos sanitaristas lotados nas secretarias estaduais de saúde começou a prestar apoio às prefeituras, que puderam absorver conhecimentos, de forma que os postinhos passaram a prestar assistência integral à saúde da população. (....) A questão da municipalização não surgiu de uma visão filosófica, doutrinária ou técnica, provinda da União e dos Estados. Houve um verdadeiro movimento municipal de saúde, no sentido de as prefeituras assumirem cada vez mais compromissos com a resolutividade, levando à população a extensão de cobertura, não mais meramente preventivista e contemporalizadora(.....)" (108).

Um fato importante para esse Movimento, foram as eleições municipais de 1976. Pela primeira vez o Partido de Oposição ao Governo Militar, Movimento Democrático Brasileiros MDB ganhou eleiçōes em vários municípios. No bojo das propostas para as prefeituras assumidas estava a de uma administração voltada para o social. Nesse período, existiu um movimento no Brasil retomando a luta pelo direito à saúde de todos os cidadãos. Chegou a hora de retomar as propostas da III Conferência Nacional de Saúde, cujo ponto central fôra colocar a saúde como direito de todos, e a municipalização como um caminho.

Para resumir o ocorrido nesta época - década de 70-80 - são citados, assistemicamente, alguns pontos:

- A ruptura dos prefeitos, eleitos em 1976, segundo o modelo de prefeitos tocadores de obras e sua desilusão - principalmente dos prefeitos de oposição - de não estarem recebendo recursos federais e estaduais para seus programas e projetos;

- A necessidade de se investir nas áreas sociais como prioridade municipalista foi mostrada, mediante projetos consolidados em vários municípios brasileiros à época: Niterói, Campinas, Londrina, São José dos Campos, Piracicaba, Sorocaba, Lages, Rezende, Cabo Frio, Boa Esperança (no ES), dentre outros;

- A organização e consolidação do Movimento Municipalista de Saúde, com a participação de técnicos de universidades e secretarias estaduais de saúde, dando o 
seu imprescindivel apoio na implantação de uma mentalidade de saúde pública integral nas administrações municipais. Os técnicos tinham a proposta progressista, sem campo para aplicá-la e os municípios tinham o campo, a vontade e, por baixa tradição, não tinham técnicos suficientes para tocar os novos projetos;

- O investimento financeiro foi a tradução prática desse movimento. O Movimento Municipalista de Saúde conseguiu destinar recursos públicos municipais para financiar a proposta. Nessa época não tinha havido nenhuma reforma tributária. Nenhum recurso financeiro novo chegava do Governo Federal, nem dos Governos Estaduais. Eram recursos financeiros exclusivamente municipais investidos numa área em que a tradição era a responsabilidade federal (INAMPS e FUNASA) e estadual, (Centros e Postos de Saúde.) Vários municípios brasileiros começaram a investir recursos em saúde, chegando alguns deles a colocar até $8 \%$ de seus orçamentos próprios para financiar o projeto de saúde. O sucesso dessa proposta tem, como fulcro, a destinação de recursos municipais para a saúde. Foi dinheiro alocado dentro da própria receita municipal e retirado, por priorização, de outras áreas como a de obras públicas;

- Reuniões e encontros regionais e nacionais de Secretários Municipais de Saúde(25) faziam pressão junto ao Governo Federal para que este alocasse mais recursos em saúde e financiasse os projetos municipais. Nessa época, a Previdência - Instituto Nacional de Previdência Social - INPS financiava o atendimento à saúde em hospitais privados lucrativos e não lucrativos e não repassava um único centavo para os hospitais públicos municipais. O Governo Federal, através do FAS, da Caixa Econômica Federal, seguindo projeto de Delfim Neto, financiava subsidiariamente a construção de hospitais privados e não estendia este mesmo financiamento à construção de unidades municipais de saúde: nem postos, nem unidades mistas, nem unidades hospitalares. No $1^{\circ}$.Encontro Municipal do Setor Saúde, realizado em Campinas em 1978, ficou estabelecido que:

"Os órgãos financiadores, tipo Fundo de Apoio ao Desenvolvimento Social - FAS, devem dar prioridade aos pedidos dos municípios e outros órgãos públicos para a instalação de uma rede de postos de atenção primária. Condenou-se a atual posição do FAS e congêneres, de dar prioridade e financiamentos para a rede privada, que os vem aplicando somente na instalação de empresas hospitalares."(108)

- Foram construídas inúmeras unidades de saúde adotando-se, até mesmo, uma nomenclatura nova "Unidade Básica de Saúde - UBS " e algumas unidades emergenciais e hospitais. Novos programas voltados para a atenção básica e integral 
à saúde, associando prevenção e assistência, novidade no sistema de saúde brasileiro, que era basicamente dicotomizado: o público cuidando de prevenção e o previdenciário, associado ao privado, cuidando de assistência. Em municípios, que já tinham algum serviço de saúde, este era mais voltado à assistência e, em especial, à urgência-emergência.

Pode - se, assim, resumir a importância do Movimento Municipalista de Saúde, que apresentavam proposta inovadora em seu conteúdo e em sua implantação, autorizando afirmar, com tranqüilidade, que esse foi o único dinheiro novo destinado à saúde pública nessa época. Veio de onde menos se podia esperar, pois continuava sendo o Governo Federal aquele que recolhia recursos de impostos e contribuições para a saúde. Isto faz parte de uma das resoluções do III Encontro Municipal do Setor Saúde e do II Encontro Nacional de Secretários Municipais de Saúde, realizado em São José dos Campos em 1982:

"Reforma tributária e aumento dos recursos destinados à saúde nas três esferas de governo, com ênfase nos serviços básicos de saúde; estabelecimento de convênios globais, por parte do Instituto Nacional de Assistência Médica da Previdência Social INAMPS, a todos os municipios". (108)

\subsection{PRÓ-SAÚDE E PREV-SAÚDE}

Apenas uma pequena alusão a este Programa-Projeto federal e que não conseguiu sair do papel. Nunca foi implantado, apesar de amplamente discutido. Pertence à história das propostas de um novo modelo global de saúde. Teve inúmeras versões circulando, mas a versão oficial denominada de Programa Nacional de Serviços Básicos de Saúde saiu mimeografada e datada de julho de 1980 e tinha 92 páginas. Esta foi assumida pelo Ministério da Saúde, da Previdência e Assistência, do Interior e a Presidência da República. (45)

O desencadeador desse programa foi o III Plano Nacional de Desenvolvimento aprovado pelo Congresso Nacional em maio de 1980 , baseado, por sua vez, na adesão brasileira às conclusões da reunião de Alma-Ata (1978):

"Explicita os principais objetivos e linhas de atuação governamental para o período 1980-1985 e estabelece orientações para o setor privado. E, no que interessa especificamente ao setor saúde, esclarece que, entre os grandes objetivos nacionais, a política de distribuição de renda(....) será orientada para a obtenção de crescente disponibilidade e acesso aos serviços de educação, saúde, saneamento e previdência social,bem como de moradia, alimentação e transporte." Dalari (102) 
Inicialmente, era o Pró-Saúde e depois se transformou em Prev-Saúde (Programa Nacional de Serviços Básicos de Saúde). A formulação desse projeto se deu em 1980. Sua base era garantir a atenção primária em saúde, proposta da Organização Mundial de Saúde em reunião de 1978 em Alma Ata, na União Soviética.

“Em 1980 foi formulado um projeto, inspirado em Alma Ata e nos programas de atenção primária: O Prev-Saúde (Pró-Saúde) elaborado por técnicos dos Ministérios da Saúde, da Previdência e Assistência Social e do Interior, envolvendo também as áreas de saneamento e habitação. As propostas de regionalização, hierarquização da rede de serviços, expansão da oferta de serviços básicos, integração das ações de saúde e participação comunitária estavam incluídas no Prev-Saúde. O projeto não chegou a ser assumido pelo governo e nem foi colocado em prática, em virtude das resistências intraburocráticas localizadas no INAMPS e da oposição das entidades que representavam o setor médico-empresarial e a medicina liberal. Foi mais um dos inúmeros planos aposentados precocemente e esquecido no fundo de qualquer gaveta da Esplanada nos Ministérios."

O mérito principal do PREV-SAÚDE, segundo interpretação de Suely Dalari (102) é que "as disposições nele contidas influíram de alguma forma sobre os responsáveis pelo setor saúde, que a partir dele passam, por exemplo, a avaliar aspectos de integração de serviços nunca dantes observados".

\subsection{PLANO CONASP}

O Plano Conasp (Conselho Consultivo de Administração de Saúde Previdenciária Nacional de Assistência à Saúde da Previdência Social) teve trajetória diferente da do PREV-SAÚDE. Este foi objeto de discussão ampliada em fóruns paralelos que conseguiam as várias versões oficiais e extra-oficiais dos gabinetes ministeriais e do INAMPS já que apenas algumas entidades tinham recebido oficialmente o Plano para ser analisado. De outro lado, cerca de dois anos depois sai oficialmente o Plano Conasp que, sem muita discussão e alarde nas bases, veio para ficar e introduzir importantes reformulações no financiamento e na prática de saúde. $(77,100,43)$

A crise da Previdência Social gerou várias medidas racionalizadoras e modificadoras de todo o sistema previdenciário e atingiu igualmente o setor de saúde com corte de gastos. 0 Presidente da República, em setembro de 1981, mediante Decreto 86.329/81, criou o Conselho Consultivo de Administração de Saúde Previdenciária - CONASP.

O Plano foi batizado de Plano de Reorientação da Assistência à Saúde no Âmbito da Previdência Social - PLANO CONASP e foi publicado em forma de portaria (3062 de agosto de 1982). Os pontos principais de sua proposta são "cobertura integral da população por meio de serviços básicos de saúde; planejamento dos serviços de saúde públicos e privados 
conforme um sistema regionalizado, hierarquizado e integrado, portanto descentralizado e desburocratizado; co-participação orçamentária das várias instituições envolvidas; responsabilidade politica e controle geral do sistema de saúde pelo estado (entendido aqui como o estado membro)." Dalari (102)

O PLANO CONASP, na visão de Hésio Cordeiro "propunha, como objetivos, a recuperação operacional do setor público, o aumento da eficiência e da qualidade, a racionalização do sistema como estratégia para a redução de custos, a criação de instrumentos de gerenciamento para maior previsibilidade orçamentária, a extensão da cobertura aos trabalhadores rurais". Hésio (100)

"Este documento do Conselho Consultivo da Administração de Saúde Previdenciária propõe como estratégia geral a "imediata vigência do Convênio trilateral"(Ministério da Previdência e Assistência Social, Ministério da Saúde e Secretarias Estaduais de Saúde)." Dalari (102)

O PLANO CONASP, como ficou conhecido por tantos quantos militam na área, teve, essencialmente quatro estratégias: 1) as Ações Integradas de Saúde - AIS entre União, Estados e Municipios; 2) a Autorização de Internação Hospitalar - AlH em substituição à Guia de Internação Hospitalar - GIH que seguia outra lógica; 3) a organização integrada das ações entre as três esferas de governo e 4) a introdução do Controle Social, mediante instalação obrigatória dos conselhos nas várias instâncias de Governo.

A oficialização da "parceria" era por meio de convênios assinados entre o MS, o INAMPS e Estados. Estes assinavam convênios com os municípios.

Alguns princípios podem ser elencados como do PLANO CONASP e que serão, mais uma vez, defendidos na posterior legislação do SUS: regionalização dos serviços de saúde, hierarquização destes serviços, em especial os públicos, a referência e contrareferência a partir da organização dos serviços básicos de saúde. A prevalência do público com a complementaridade e associação com o privado. A definição de parâmetros de cobertura assistencial explícitos na portaria 3046 que ainda hoje é utilizada como referência.

O PLANO CONASP pode ser considerado um marco na história do financiamento da saúde pública. O INAMPS, autarquia do Ministério de Previdência e Assistência Social - MPAS, começa a se conveniar com os serviços públicos, agregá-los como "prestadores de serviços" e, conseqüentemente, financiá-los. Dez anos antes - 1974 - o INAMPS fizera uma aventura expansionista na atividade ambulatorial criando o PPA - Plano de Pronta Ação, visando melhorar e ampliar o atendimento ambulatorial através da rede contratada de hospitais privados. Esta aparente melhora mostrou-se mais uma vez uma fonte de corrupção e multiplicação de serviços, muitas vezes, de duvidosa qualidade. 
O PLANO CONASP muda o sistema de financiamento dos serviços hospitalares. Anteriormente internava-se pela Previdência Social nos leitos contratados com o setor privado mediante a GIH, cujo o pagamento era feito por Unidades de Serviço (US), calculado, o custo internação por internação. Além de um sistema passivel de corrupção, o sistema de controle era muito precário. Pelo Plano CONASP, introduziu-se um sistema diferenciado e aperfeiçoado de auditoria médica e contábil e o sistema de pagamento utilizando a Autorização de Internação Hospitalar (AlH), não mais caso a caso, por procedimentos, mas através de um grupo de valores (cerca de 300 grupos de procedimentos), cujo calculo leva em contas valores médios de custos,e utilizando, como base, a média histórica. Muda o critério de financiamento da saúde. Isso se refere às internações hospitalares, em que, cada vez mais, concentravam-se os serviços em número e em curso.

A estratégia do PLANO CONASP para o setor ambulatorial foi diferente. Enquanto na área hospitalar o INAMPS só pagava internações no público universitário, a área ambulatorial é aberta à participação dos ambulatórios públicos do Ministério da Saúde, das Secretarias Estaduais de Saúde e dos Municípios. É criado pelo CONASP o Programa de Ações Integradas de Saúde - PAIS, e, depois, apenas AIS, como ficou conhecido. Uma única experiência pré AIS de financiamento de serviços públicos municipais foi feita em São José dos Campos, em 1981. Depois de muita pressão esse município conseguiu um convênio especial com o INAMPS, o qual começou a pagar um subsídio fixo à Secretaria Municipal de Saúde de São José dos Campos, referente à média de sua produção ambulatorial e de internações. Pelas AIS, na prática só a partir de 1983, estados e municípios que aderiram ao Plano CONASP, mediante termos aditivos, tiveram repasses relativos à sua capacidade de produção, associada aos parâmetros de cobertura da população. Não se tratava de pagamento por produção, mas o teto era calculado tendo-se, como base, a produção.

Toda essa revolução no sistema de financiamento tinha um balizamento, que eram as Comissões Interinstitucionais, em cada nível, com a presença dos gestores públicos e de representantes dos prestadores de serviços e da população. Foram criadas Comissões a partir do nível federal - Comissão Interinstitucional de Planejamento - CIPLAN, nos Estados, a Comissão Interinstitucional de Saúde - CIS, nas Regiōes a Comissão Regional Interinstitucional de Saúde - CRIS, nos Municípios as Comissões Interinstitucionais Municipais de Saúde - CIMS e as Comissões Locais Interinstitucionais de Saúde - CLIS para as regiōes de determinado Município. Esse avanço foi muito grande, pois tentou-se fazer uma estratégia de controle, ajudando a equilibrar o sistema com as opiniões e decisões colegiadas. 


\subsection{SUDS - SISTEMA UNIFICADO E DESCENTRALIZADO DE SAÚDE}

O Sistema Unificado e Descentralizado de Saúde - SUDS (102) foi uma conseqüência da pressão da VIII Conferência Nacional de Saúde. A VIII ${ }^{a}$. Conferência Nacional de Saúde, realizada em março de 1986, foi um marco importante na defesa da vida e da saúde. Ansiosamente esperada e cuidadosamente preparada foi a primeira Conferência Nacional de Saúde - CNS com participação popular e um número tão grande de participantes: mais de 4000 pessoas, sendo 1000 delegados. Conseguiu juntar, na discussão: sociedade civil, através de entidades representativas, grupos profissionais, partidos políticos e representantes governamentais. (6)

A VIII Conferência Nacional de Saúde,(5) em seu relatório final trouxe conclusões importantes que são sintetizadas abaixo:

- Saúde como direito: resultante de condições gerais e da forma de organização social; condições dignas de vida e de acesso universal e igualitário às ações e serviços de saúde; integração das politicas públicas favorecedoras de condições de saúde;

- Reformulação do Sistema Nacional de Saúde: criação de um sistema único de saúde, com novo modelo de organização, de condições de acesso e qualidade, com uma nova politica de recursos humanos; atribuições bem definidas das três esferas de governo, com ênfase na descentralização e municipalização; as AIS (CONASP) não podem impedir a implantação de um novo sistema, devendo ser reformuladas de imediato para haver maior controle da sociedade através das CIS,CRIS,CLIS,CIMS.

- Financiamento do setor: idéia de um orçamento social para as várias políticas sociais de todas as esferas de governo; a idéia de recursos nos fundos de saúde por esfera; recursos para a saúde minimamente pré-fixados; fontes alternativas e não apenas e, principalmente, a contribuição sobre a folha; melhor distribuição dos recursos de saúde e, não apenas, pelo critério populacional; proposta de reforma tributária.

- A proposta mais importante foi a de levar isso diretamente à Assembléia Nacional Constituinte com três conclusões em destaque: modificar a saúde extrapola o setor; o sistema de saúde não deve ser estatizado, mas há necessidade de fortalecimento $\mathrm{e}$ expansão do setor público; a previdência deve ficar separada da saúde, esta entregue a um outro órgão com características novas; novas formas de financiamento, mais amplas e a serem discutidas mais aprofundadamente. 
- Essas conclusões, principalmente a pressão para que houvesse uma saida para a saúde mais profunda que a vigente das AIS-AIH, levaram a que,já no ano seguinte, surgisse a proposta do SUDS.

Se o desejo do coletivo era que se partisse para a criação de um Sistema Único de Saúde, era porém, estratégico que essa passagem fosse feita experimentalmente e como processo. Dai, a idéia de se tentar uma unificação primeira dos sub-sistemas de saúde existentes: na esfera federal o MS e o MPAS com o INAMPS; as Secretarias Estaduais de Saúde - SESs e as Secretarias Municipais de Saúde - SMSs. Assim, nasce o SUDS em uma situação de extrema convergência de forças positivas da reforma sanitária que assumiram o INAMPS e o risco de fazer o SUDS.

"Os debates e recomendações que se seguiram à VIII CNS contribuiram para três niveis de ação politica e técnica da reforma sanitária: a luta pelo texto da saúde no capítulo da ordem social da nova Constituição; os movimentos táticos institucionais que iniciaram o processo de implementação da reforma e a mobilização da sociedade (entidades sindicais e comunitárias, partidos políticos, etc.) para ampliação das bases sociais do movimento sanitário. Paim defende a proposta de estratégia-ponte "para a reorientação das politicas de saúde e para a reorganização dos serviços enquanto se desenvolvessem trabalhos da Constituinte e da elaboração da legislação ordinária para o setor." Hésio (26)

As AIS assumiram esse papel, entre 1983 e 1986, e, a partir de 1987, a nova proposta é o SUDS que vai, exatamente, ser o aprofundamento das AIS. A proposta SUDS foi oficializada pelo Decreto 94.657 DE 20-7-87 (18), justificado por exposição de motivos conjunta dos Ministros da Previdência e da Saúde de 10-7-87. Em março de 1988, novo decreto presidencial, de número 95861 disciplina juridicamente os convênios. O SUDS vai existir formalmente entre os anos de 1987 e 1991, quando nasce formalmente o SUS pela NOB-91.

O SUDS definia claramente as competências e funções de cada uma das esferas de Governo. A União ficava sem a execução, mas com a gestão, coordenação, controle e avaliação do sistema nacional de saúde; pesquisa, cooperação técnica, regulamentação, normatização, garantia de redistribuição de recursos, planos nacionais de recursos humanos, informação, ciência e tecnologia, insumos críticos. Os Estados ficavam com a gestão, coordenação e avaliação do sistema estadual de saúde, adequação de normas à realidade estadual, execução de serviços de abrangência estadual e microrregional, plano estadual de saúde, planos estaduais de recursos humanos, informação, ciência e tecnologia e insumos críticos. Os municípios ficavam com a gestão, coordenação, controle e avaliação do sistema municipal de saúde, execução dos serviços de saúde, em especial, os básicos, as vigilâncias epidemiológica e sanitária, saúde ocupacional e de controle de endemias; 
gestão de convênios e contratos, plano municipal de saúde, implementação de planos municipais de recursos humanos, informação e distribuição de insumos críticos.

O INAMPS, ponte dos recursos da Previdência para a assistência à saúde nos próprios públicos, vai perder seu papel de efetor dos serviços de saúde e de grande comprador no privado; esta incumbência será transferida às Secretarias Estaduais de Saúde e aos Municipios. O INAMPS passa a ser o órgão controlador do plano, da execução global (o controle pontual dos contratados-conveniados será feito pelas Secretarias Estaduais de Saúde), dos repasses financeiros, do controle e avaliação globais. Os Estados assumem as Superintendências Estaduais, através dos próprios secretários estaduais de saúde ou indicados por ele. Alguns estados avançam mais, como os de São Paulo, Rio de Janeiro e Santa Catarina.

A decisão do montante de recursos a ser repassado a Estados era negociado sem critérios técnicos objetivos entre o Ministério da Saúde - INAMPS e as Secretarias Estaduais de Saúde. O orientador deveria ter sido a Programação e Orçamentação Integradas - POI, mas como o indicador tinha limitantes e, nem sempre, era seguido a rigor, evidentemente os critérios perdiam sua objetividade, o mesmo ocorrendo com os repasses de recursos dentro dos estados entre os vários municipios.

Foi feita transferência das unidades de saúde, Posto de Assistência Médica - PAM do INAMPS para Estados e Municípios já que a função de executar não deveria ser mais de nivel central. Na maioria dos estados os recursos alocados, para cada um deles, permanecia na administração central, ainda que os estados administrassem as autorizações de internações nos contratados-conveniados e autorizassem as despesas.

O SUDS representou a vontade politica de antecipar-se à CF e como uma necessidade de consolidação das AIS. Teve a ousadia de fazer inovações profundas apenas através de Exposições de Motivos e Decretos. "O reconhecimento do SUDS, instituído por decreto como uma nova estrutura respalda-se na assinatura de convênios, padronizados em seus termos, antecedendo normas constitucionais e mesmo a unificação da responsabilidade pela saúde num único aparato estatal do nível central." (6)

Em 10-7-87 - a Exposição de Motivos 31 justifica as diretrizes para consolidação das AIS através do Programa de Desenvolvimento de Sistema Unificado e Descentralizado de Saúde. Em 13-7-87 a Exposição de Motivos 32 justifica a criação do SUDS. Em 20-7-1987, como citado acima, oficialmente é instituído o SUDS pelo Decreto 94657 (18). Em 28-7-87 a Portaria 4090 e 4169 25/1/88, estrutura a Diretoria Geral do Inamps e a Direção Estadual para o SUDS. Em 13-10-87 resolução CIPLAN cria um sistema de assessoramento, controle 
e avaliação do SUDS. Além disso, foram editados vários documentos regulamentadores: repasse de recursos, prestação de contas, modelo de convênio, passagem de bens, cessão de uso.

Há que se reconhecerem as conquistas do SUDS, que podem ser resumidas no seguinte: 1 . Conquistas politicas: assumir compromisso da Nova República resgatando divida social. 2. Implementação de medidas consensuais de integração, já socialmente aceitas. 3. Movimento de reorganização setorial, caminhando para a descentralização,democratização, gestão colegiada. 4. Definição clara dos papéis das três esferas. Um viés: Ministério da Saúde ficou como um órgão técnico normativo e de política, ainda de forma centralizada. 5 . Como antevisão assumiu a idéia de repensar a CEME, SUCAM, PIONEIRAS SOCIAIS, INAM, FIOCRUZ, FUNDAÇÃO SESP, INAMPS. 6. Em relação aos recursos humanos, há uma proposta de se deixarem as novas contratações para Estados e Municípios.7. A Programação de Orçamentação Integrada, ainda que criticada, pelo centralismo e academicismo, teve como base o Distrito Sanitário. 8. Para o financiamento, três fontes de recursos estavam basicamente alocadas: o FAS (Fundo de Desenvolvimento Social) a FINAME e o FINSOCIAL.

"Ao mesmo tempo em que se desenvolvia o debate constitucional, levava-se adiante a implantação do SUDS como etapa preparatória para o SUS. Não é exagero afirmar que a estratégia de levar à prática as propostas consensuais da unificação e descentralização antes mesmo da aprovação do texto constitucional, garantiu que, pela primeira vez, uma proposta de reestruturação do Sistema de Saúde, tão abrangente, "saísse do papel". Ou melhor, levou à prática propostas que ainda estavam em maturação, que enfrentassem a realidade antes mesmo de irem "para o papel" como um pacote tão a gosto das tecnoburocracias do aparelho do Estado." (100)

"Na realidade, num primeiro momento não houve qualquer aumento dos recursos colocados à disposição do Sistema de Saúde, mas apenas a somatória do orçamento da Previdência Social com o orçamento do Estado e dos municipios que aderiram ao processo.... tanto estados como municipios foram aumentando a sua participação financeira." (137).

A legislação do SUDS foi se consolidando através de novos decretos como os 95861(20), 95892 (21), 96303 (22), 97275 (23) portarias, instruções normativas, ordens de serviço e circulares. Muito se construiu a caminho do SUS. O SUDS durou entre 1987 até, oficialmente, 1990 e, extra oficialmente, até mesmo 1993-4.

Vale fazer uma análise sucinta sobre a questão do financiamento da saúde, na época da vigência do SUDS. O maior aporte de recursos foi de duas esferas, a União e os Municípios. Muitos Estados, nesse período, baixaram ou mesmo quase zeraram seu investimento em saúde. No ano de 1988 , objeto de outro capítulo, consta de estudos que alguns estados, não só năo colocaram seus recursos próprios, como utilizaram recursos de transferências SUDS 
para outras finalidades. Os municipios, comprovadamente, foram investindo cada vez mais em saúde, partindo de seus recursos próprios desviados de outras áreas.

\section{O FINANCIAMENTO FEDERAL PARA A SAÚdE NO GOVERNO COLLOR - PLANO QÜINQÜENAL DE SAÚDE 1990-1995 E NOB-1991-1992}

\subsection{PLANO QÜINQÜENAL DE SAÚDE 1990-1995}

Em 1990 assumia o Governo de Brasil o Presidente Fernando Collor. Era Ministro da Saúde Alceni Guerra, médico e, até então, deputado federal. Talvez, pela primeira vez se fez no MS um Plano Qüinqüenal de Saúde - PQS, mais explícito e detalhado. Dava-se, assim, "forma, corpo e consistência às propostas de campanha do Brasil Novo, que visavam, como ainda visam, a obtermos uma ampla e radical reforma sanitária, retirando a saúde da condição perversa a que foi secularmente relegada no nosso país. Se as diretrizes do candidato Fernando Collor continham linhas básicas de ações para a saúde, o plano clarifica e detalha, a nivel do MS, o que a nossa equipe se propôs realizar para mudarmos a face da saúde, indo ao encontro das aspirações e necessidades de nosso povo."(47)

Esse plano qüinqüenal dedica um capítulo inteiro à apresentação das Diretrizes Políticas, incluindo os dispositivos legais da CF e da LOS. É estabelecida como missão do MS "coordenar e liderar o conjunto de ações de promoção, proteção e recuperação da saúde, identificando riscos e necessidades, prolongando e melhorando a qualidade de vida de todo o povo brasileiro e contribuindo para o desenvolvimento nacional'(47). No referido capitulo encontram-se considerações sobre o respeito.à cidadania universal, novo modelo de atenção à saúde, organização e administração do sistema, descentralização ("o sistema de saúde será descentralizado, deslocando-se o poder decisório para a proximidade dos fatos e das pessoas" (47), desenvolvimento de recursos humanos, informação em saúde, relações entre os setores público e privado, participação social, intercomplementariedade setorial, tecnologia de alta complexidade, financiamento setorial, ciência e tecnologia em saúde, condições ambientais e sanitárias, cooperação técnica, comunicação social.

Para o propósito deste trabalho, a que se fazer o destaque sobre o tema financiamento setorial.

"O MS, para o adequado financiamento do setor, deverá, incrementar os recursos com fontes não regressivas aumentando os investimentos públicos no período; diminuir a iniqüidade do sistema, seja em grupos sociais, seja em regiões geográficas; buscar uma composição equilibrada entre gastos federais, estaduais e municipais, de acordo 
com as respectivas competências; estabelecer critérios para transferências de recursos entre instâncias de governo; priorizar os investimentos na recuperação e na ampliação do setor público."(47)

Mais à frente, no capitulo referente à Estratégia Central, vem o item Financiamento Setorial que apresenta suas metas e atividades:

“Meta 1: Participação financeira dos estados e municipios, com destinação de, no mínimo, $10 \%$ de seus respectivos orçamentos, até 31 de dezembro de 1992. Atividades: definir a parcela de co-participação dos estados e municipios e do Distrito Federal nos respectivos planos de saúde, componentes do plano de saúde do SUS; vincular a liberação de recursos federais, não previstos na parcela de liberação automática, ao efetivo desembolso dos recursos dos Estados e Municípios e DF; obter dos conselhos estaduais e municipais de saúde um constante acompanhamento na elaboração dos planos de saúde, bem como na fiscalização da utilização comprometida dos recursos. Meta 2: Triplicação dos recursos públicos da União para o setor saúde, com aumento dos 1,8\% do PIB, em 1989, para 5,4\% do PIB até 31 de agosto de 1995. Atividades: identificar e utilizar fontes não regressivas de financiamento do setor saúde, considerando-se como não regressivas as partes não tradicionais de custeio de planos de saúde; acompanhar a arrecadação das contribuições compulsórias da Seguridade Social para assegurar a participação do setor saúde nestes recursos (CF Art.195,2); captar, através de organismos internacionais, recursos para projetos auto-financiáveis e de interesse estratégico para o setor saúde; identificar e utilizar fontes de recursos a fundo perdido; gerenciar a utilização dos recursos públicos para que produzam os resultados esperados, frente a prioridades estabelecidas, punindo o desperdício com as medidas legais pertinentes; constituir grupo intersetorial para identificar outras fontes de custeio alternativo para o financiamento do setor saúde; obter do Conselho Nacional de Saúde, um constante acompanhamento na elaboração do plano nacional de Saúde, bem como na fiscalização da utilização comprometida dos recursos."(47)

Ao se proceder a uma análise simples, pode-se dizer que esse Plano ficou como uma carta de propostas de um novo governo, em que se misturam propostas de campanha com as propostas reais de governo para os cinco anos. Nada de maior novidade, senão aquilo que já vinha expresso no arcabouço legal da CF e da LOS, desse mesmo período. Para o financiamento, as grandes propostas se resumem: no aumento da receita federal de I,8 do PIB para 5,4\%; fontes crescentes; diminuir iniqüidade;financiamento equilibrado das três esferas de governo, estados e municipios com, no mínimo, $10 \%$ até 31 de dezembro de 1992; estabelecer critérios para transferências de recursos entre esferas de governo (definido em fins de 90 pela LOS; transferências voluntárias na dependência de coinvestimento de estados e municípios; recuperar e implementar setor público; acompanhamento e fiscalização dos conselhos.O PQS Collor é um ponto importante nas quatro fases da descentralização e representa em suas NOB a descentralização tutelada fase caracterizada por Médice.(119) 
Um excelente discurso e PQS que, como pode ser visto mais adiante, através das NOB-91 e 92 e dos dados numéricos, não conseguiu ser cumprido em sua essência.

\subsection{NOB-91 e NOB-92 - O PARALELISMO ENTRE A DISCUSSÃO DO FINANCIAMENTO DA 8080 E O ENGENDRAMENTO DAS NOBs 91 e 92.}

Aprovados principios e bases para a saúde, na CF, muita coisa ficou na dependência de regulamentação. De outubro de 1988 até setembro de 1990 discutiu-se no Congresso Nacional a aprovação da Lei Orgânica da Saúde. Finalmente, em setembro, foi aprovada no Congresso, depois de muito embate. Não se podia pensar que seria fácil regulamentar os avanços. Vale dizer do papel da esquerda progressista que soube fazer suas alianças com a direita conservadora, para que Saúde ficasse como uma questão supra partidária. Não foi sem dificuldades e, muitas, que se chegou a esse acordo, mas só ele possibilitou a aprovação. Ao chegar à sanção Presidencial de Fernando Collor, os vetos apareceram, o que gerou o maior dos debates.

Entre os muitos vetos, duas questões foram mais focadas neles: os princípios do financiamento e os do controle social. A luta passou a ser entre Collor e os vetos e o Congresso, contra os vetos. Isto durou até dezembro de, 1990 quando as negociações desembocaram em se fazer uma outra lei que tratasse dessas duas questões essenciais ao SUS. Feita a negociação e com voto de liderança aprovou-se a Lei 8142 que complementou a 8080 . Assim, em dezembro de 90 , estavam no papel os principios e bases da CF e sua explicação e explicitação, através das Leis 8080 (27) e 8142. (28)

Agora, era o tempo de fazer acontecer. Havia a responsabilidade do Ministério da Saúde para o comando federal. O INAMPS era, então, uma autarquia ligada e dependente do Ministério da Saúde e que, não obstante todo o esforço para que fosse extinta, por artigo vetado na Lei 8080 , foi uma das questões que não vingou. $E$ agora, quem iria fazer o que? $O$ INAMPS, detentor de mais recursos e coordenador, há décadas, da assistência médica e tendo permanecido "vivo" não teve dúvidas em continuar controlando e mantendo o SUS, tomando, então, a frente na implantação do SUS.

Os municípios que anteriormente às AIS, não recebiam recursos federais e muito menos da Previdência (INAMPS no caso), com as AIS e o SUDS passaram a receber subsídios regulares e fixos. Eram poucos, insuficientes repassados via Estados.Estes, em alguns casos, ficavam com mais recursos que os que eram repassados aos municípios. Houve estados que, à época, deixaram de investir recursos próprios, só trabalhando com os recursos federais (AIS - SUDS) e, ainda, utilizando-se de parte deles para outras atividades, 
que não as de saúde. (Sólon-Piola - IPEA). Diante disto, os municípios buscavam, a qualquer custo, a possibilidade de receber recursos diretamente da União. A maneira de repasse que o INAMPS sabia fazer era por meio de convênios e com pagamento por produção. Durante a negociação da aprovação da 8080, a partir de 27 de julho de 1990, pela portaria do INAMPS 227 (63) (com autorização Ministerial da Portaria MS/GM 896 de 29/6/90), o INAMPS abriu-se e colocou algumas condições a serem comprovadas para que hospitais públicos estaduais e municipais recebessem recursos diretamente do MS-INAMPS, por produção e segundo a tabela. Claro que seguindo sua maneira típica de repassar: convênio/produção. Era assim que o INAMPS fazia com os filantrópicos e com os Hospitais Universitários, mesmo os públicos. Isto foi comemorado pelo municipalistas como vitória, pois ainda não estava aprovada a Lei 8080 e, pelo menos, era uma maneira de se receber recursos do INAMPS/MS.

Municípios e estados esperavam que, com a aprovação da Lei Orgânica da Saúde, o SUS fosse implantado, segundo as novas normas, e o financiamento seguisse o que lá estava escrito na $8080 / 35$ e $8142 / 2$. Qual não foi a surpresa de todos, quando uma enxurrada de portarias do INAMPS adentrou os gabinetes dos gestores públicos, em janeiro de 1991 . Eram as portarias do INAMPS 15,16,17,18,19 e 20 e a Resolução 258 de 7-1-91 NOB-91 da portaria 1481 (69) que tinha como anexo a NOB-91 e outros penduricalhos. Dentro delas nada relativo aos preceitos legais de dezembro de 90 , mas a consolidação daquilo que já vinha sendo implantado desde junho de 1990.

A portaria 15 tratou dos Hospitais Universitários, igualando o indice de valorização hospitalar IVH e criando o FIDEPS - Fator de Incentivo ao Desenvolvimento do Ensino e Pesquisa Universitária em Saúde.

A portaria 16 modifica o Sistema de Financiamento das Internações Hospitalares, novamente unificando todas as tabelas em um único valor por procedimentos e determinando quais seriam esses, valores a partir de então.

A portaria 17 extingue todas as tabelas e modalidades de remuneração das atividades ambulatoriais e determina novos valores e novos procedimentos.

A portaria 18 regulamenta o sistema de fornecimento de órteses e próteses, determinando condições, locais e forma de pagamento.

A portaria 19 define a quantidade de AlHs - Autorizações de Internações Hospitalares por Estados, o que anteriormente nunca tinha sido definido. 
A portaria 20 introduziu o conceito e práticas de uma nova maneira de repasse de recursos ambulatoriais criando um valor per-capita para cada estado ou grupo de estados e, conseqüentemente, um valor global para as atividade ambulatoriais. A denominação utilizada foi UCA - Unidade de Cobertura Ambulatorial, cujos recursos genéricos se denominaram RCA - Recursos de Cobertura Ambulatorial.

A grande questão foi a Resolução 258, de 7/1/1991, que teve, como anexo, a NOB-91. A palavra Norma Operacional Básica - NOB, era o jargão mais utilizado dentro do Ministério da Previdência e Assistência Social, em especial, na autarquia Instituto Nacional de Assistência Médica da Previdência Social - INAMPS. Nasceu a primeira delas, referente ao SUS dentro do INAMPS, a NOB-91. Daí para a frente, essa mesma - republicada - as demais foram só seqüência incorporada à nomenclatura inampiana pelo Ministério da Saúde.

Os considerandos da NOB-91 estão bons. A concepção é equivocada. Não seria um ato de má-fé, mas há um evidente descumprimento da CF e da LOS.

A NOB-91 é dividida em quatro grandes partes. I - Financiamento da atividade ambulatorial, que trata da nova sistemática da Unidade de Cobertura Ambulatorial, colocando as várias etapas operacionais (1 a 4); II - Instrumentos de acompanhamento, controle e avaliação da execução, que trata dos: Conselhos de Saúde (da 8142); dos Fundos de Saúde aprovados em lei e geridos pelo órgão de saúde, fiscalizados pelo Conselho; Consórcios Administrativos Intermunicipais; Relatórios de Gestão - único documento oficial que esboçou como deveria ser; Programação e Orçamentação da Saúde - que visa substituir a POI do antigo INAMPS; Planos de Aplicação dos Fundos; Prestação de Contas dos Fundos de Saúde. III - Controle e Acompanhamento. IV - Disposições Transitórias, que se refere ao repasse por convênios e por população.

Essa norma, para quem não está acompanhando de perto, mais profundamente, o processo e a parte legal, é comemorada como um avanço. Quando se fala em Conselho, Fundo, Plano e Relatório de Gestão nada mais se diz que aquilo que está dentro da legislação $8142 / 8080$. Mas, para quem tinha muita expectativa e esperança de uma implantação correta do SUS a NOB 91, foi quase uma afronta. Podem-se elencar as ilegalidades principais da NOB-91:

O primeiro questionamento jurídico foi sobre qual seria o poder do INAMPS de estar normatizando para o SUS, quando isto deveria ser função do Ministério da Saúde. Na 8142, 5 está escrito que: "É o Ministério da Saúde, mediante portaria do Ministro de Estado, autorizado a estabelecer condições para aplicação desta lei." Isto obrigou a que saisse 
portaria ministerial autorizando o INAMPS ao procedimento e reedição da NOB-91 (Portaria 1481 de 31 dez.1990 - data posterior à primeira edição da NOB-91. (69))

O sistema de pagamento por produção proposto pela NOB-91 era inconstitucional e ilegal, segundo as Leis 8080 e 8142 . A lei 8080 (27), no Art. 35, parágrafo $1^{\circ}$, diz: “Metade dos recursos destinados a estados e municipios será distribuida segundo o quociente de sua divisão pelo número de habitantes, independente de qualquer procedimento prévio". O Art.3, parágrafo $1^{\circ}$ da 8142 (28) diz: "Enquanto não for regulamentada a aplicação dos critérios previstos no $35 / 8080$, será utilizado, para o repasse dos recursos, exclusivamente o critério estabelecido no parágrafo primeiro do mesmo artigo" Com esses dois artigos de leis diferentes, só há uma maneira de interpretação: até regular o art. 35 , da 8080 , todos os recursos federais deverão ser repassados aos Estados, DF e Municipios, exclusivamente pelo critério populacional.

O repasse de recursos do MS-INAMPS, proposto pela NOB-91, era mediante mecanismo convenial. Aparentemente, medida sem importância, parecendo uma questão menor, mas não é assim. Primeiro, conceitualmente errado. O mecanismo convenial implica no acordo de vontades entre o convenente e o conveniado. Se não for de vontade de um, ou de outro, nada acontece. Entretanto, a Constituição Federal coloca muito claramente a Saúde como competência e responsabilidade das três esferas de governo: União, Estados e Municípios. Em decorrência, a esfera arrecadadora de recursos (no caso a União) não pode regatear ou condicionar o repasse dos recursos. As três esferas de governo têm suas competências advindas da Constituição e não do repasse, de competência da União para Estados e Municipios ou dos Estados para Municipios. É um direito constitucional superior a tudo. A CF e a lei de saúde, ao estabelecerem competências, algumas comuns, outras específicas, têm que assegurar recursos, automaticamente, para as três esferas de governo. Isto é o essencial do descumprimento da lei. Uma conseqüência prática do repasse, pela forma convenial, é que os recursos repassados por convênios têm que obedecer regras "absurdas" de uso dos recursos e de prestação de contas. Por exemplo: não se podem usar recursos de convênios para pagamento de pessoal, a não ser de forma terceirizada. Se a saúde tem sua atividade alicerçada na atenção pessoa a pessoa, como imaginar fazer ações de saúde sem pessoal? A aparente abertura para a contratação terceirizada descaracteriza o caráter público-estatal de parte do SUS, ainda que a 8080 permita a complementaridade do privado.

Constata-se a omissão pura e simples da Vigilância Sanitária e Epidemiológica, que poderiam estar completando a visão da integralidade da "ação de saúde", preceito constitucional. Mais uma vez se cristaliza a visão, apenas e exclusivamente, assistencialista. 
Ainda, verifica-se a falta de definição de normatização sobre um plano de investimentos. Não apenas a declaratória da necessidade, mas a operacionalização desses investimentos. Seria fundamental esse programa, como um dos determinantes de garantia da equidade.

O pagamento por produção de serviços tem o inconveniente de se individualizar o repasse de recursos, baseado em ações e procedimentos, sem a visão da necessidade de recursos globais para serem utilizados, de forma livre sob um plano, com aprovação do Conselho de Saúde. Tabelas defasadas com privilegiamento dos pagamentos de maior complexidade concentrado em alguns centros médicos são indutores da iniqüidade e da "desintegralidade".

A NOB-91 só trata dos recursos do INAMPS, omitindo, de vez, qualquer citação dos recursos referentes ao orçamento, ou melhor, de parte do orçamento administrado diretamente pelo Ministério da Saúde.

Outro aspecto diz respeito à distribuição de recursos de internações hospitalares e de cobertura ambulatorial, baseados exclusivamente na rede instalada e na capacidade de produzir. Onde mais serviços existem, mais recursos são transferidos. A distribuição das Autorizações de Internações Hospitalares - AlH continua iníqua, uma vez que, destina maior número delas aos locais onde existem mais serviços instalados e produtivos de internações. A média Brasil de disponibilidade de $\mathrm{AlHs}$ é para 9,3\% da população (153,3 milhões de brasileiros e cerca de 14 milhöes de AlHs.) Existem, entretanto, diferenças de distribuição para cada estado. Por exemplo: o Pará terá direito a um número de internações/ ano na faixa de $6 \%$ da população ano, já o Mato Grosso tem direito ao dobro, ou seja: terá AlHs suficientes para internar até $12 \%$ da população/ano. Sabe-se, perfeitamente, que esse valor não é determinado por nenhum critério epidemiológico ou social, mas apenas e tão somente, pelo critério de oferta de serviços. É a expressão da iniqüidade da assistência, ligada não às necessidades ou demanda, mas à oferta de serviços até em maior número de privados que públicos.

Houve uma reedição da NOB-91, em julho de 91, fazendo algumas mudanças sem, entretanto, mudar as questões estruturais dela.

A NOB-92 apenas deu continuidade à NOB-91. Não trouxe grandes modificações. Foi solicitada a contribuição de várias pessoas, no sentido de aprimorá-la. Mas os óbices e ilegalidades maiores continuariam, como continuaram, intocáveis. Municipalistas chamados a contribuir usaram a expressão: "Estamos enfeitando a corda do enforcamento". A expressão era utilizada, pois discordavam da essência, ainda que chamados a contribuir no periférico. A contribuição de modificação na NOB-91 para 92 foi periférica. O âmago persistiu intocável. Não pela má-fé ou falta de vontade direta dos responsáveis maiores, nem da 
equipe. A resultante das várias forças envolvidas na época era no sentido de conter a descentralização.

A segunda: surge, constitucionalmente, a figura do Conselho de Saúde, como órgão de acompanhamento e fiscalização do fundo de saúde. Só se tem que rejubilar com estas conquistas - ainda que possam ser transitórias. Elas vêm consagrar um entendimento que não ficou absolutamente claro nas leis 8080 e 8142 . A participação da sociedade no Controle Social, principalmente na área social, é preceito constitucional consagrado no Art 10 da CF "É assegurada a participação dos trabalhadores e empregadores nos colegiados de órgãos públicos em que seus interesses profissionais ou previdenciários sejam objeto de discussão e deliberação." O mesmo princípio se repete no art. 194,VII da CF: " caráter democrático e descentralizado da administração, mediante gestão quadripartite, com participação dos trabalhadores, dos empregadores, dos aposentados e do Governo nos órgãos colegiados." (este inciso teve modificações pela EC-20 de 15/12/98 (16).

\section{O FINANCIAMENTO FEDERAL PARA A SAÚDE NO GOVERNO ITAMAR - A DEFESA DA DESCENTRALIZAÇÃO DA NOB-93 - A OUSADIA DE CUMPRIR E FAZER CUMPRIR} A LEI

A NOB-93 nasce da discussão de que os Municípios e Estados não poderiam ficar recebendo por produção e mediante convênios. Essas questões já foram analisadas anteriormente. O CONASEMS e CONASS, muito articulados à época, tiveram uma postura contundente em relação à NOB-91.

A IX Conferência Nacional de Saúde aconteceu em setembro de 1992. O CONASEMS fez seu Encontro Nacional na antevéspera da IX, confirmando posições de luta. A definição do CONASEMS era a luta pela regulamentação do Art.35, da Lei 8080 , que estabelecia os critérios a serem utilizados na distribuição de recursos: $50 \%$ por quociente populacional e os outros $50 \%$, pelo perfil epidemiológico, demográfico, rede instalada (quali e quantitativa), desempenho técnico e financeiro no ano anterior, participação no orçamento estadual e municipal, previsão do plano qüinqüenal e ressarcimento dos recursos utilizados com outras esferas de governo. Nada dizia que precisava de mais regulamentação legal, apenas a 8142 referia-se a "enquanto não for regulamentada a aplicação dos critérios do art. 35 , que se distribuísse todo o recurso pelo quociente populacional". Diante das várias negativas de se chegar a essa distribuição, com o argumento de falta de dados, nem política, nem tecnicamente, conseguia-se mudar o critério de distribuição desses recursos. Mas o 
CONASEMS não abria mão do posicionamento político de defender a regulamentação do 35 , esquecendo-se, mesmo, que seria de auto-aplicação distribuir todos os recursos, por quociente populacional. Técnicos do CONASEMS levaram à sua Assembléia, antes da IX, a proposta de que, pelo menos, o repasse fosse feito direto e automático aos municípios, enquanto não se conseguia regulamentar o 35 , nem tão pouco aplicar totalmente o repasse por quociente populacional. Essa tese não encontrou repercussão. A proposta foi vetada na Assembléia do CONASEMS. A IX adotou o mesmo discurso de regulamentação urgente do Art. 35 , da 8080 . (27)

Politicamente, estava ocorrendo o processo do "impeachment" do Presidente Collor. A IX Conferência Nacional de Saúde expressou a indignação nacional, bradando: Fora Collor!

Com a renúncia de Collor, assumiu Itamar Franco, que entregou a Jamil Haddad o Ministério da Saúde. Os ditos "Municipalistas do CONASEMS" foram convidados a ajudar na nova administração do Ministério da Saúde. A Diretoria do CONASEMS apresentou uma proposta para aquele momento da saúde. (82) O CONASEMS apresentou ao Conselho Nacional de Saúde a mesma proposta. (131)

Carlos Mosconi assumiu a SAS e a Presidência do INAMPS. O Ministro constituiu o Grupo Especial de Descentralização - GED que começou, colegiadamente, a discutir uma proposta de descentralização, cuja expressão maior era a própria temática da IX: “Municipalização é o Caminho".

A proposta apresentada pelos municipalistas ao Ministro Jamil se concretizou no documento "Municipalização das Ações e Serviços de Saúde: A Ousadia de Cumprir e Fazer Cumprir as Leis",(59) elaborado após ampla discussão no GED, deu o tom à portaria da NOB-93. É uma declaração de princípios que embasam a NOB, sem, contudo, fazer parte dela. Destacam-se nesse documento os pressupostos colocados: "descentralização como processo envolvendo redefinição de papéis, reorganização institucional, reformulação de práticas das três esferas de governo com estabelecimento de novas relações entre eles e o controle social; como processo pressupõe diálogo, negociação e pactuação; implantação imediata do controle social; o processo não comporta rupturas entre as velhas e as novas práticas: necessita de transição." Foram criados grupos-tarefa para discutirem e proporem saídas para várias áreas, entre as quais se destacam: reorganização da esfera federal, financiamento, desenvolvimento científico e tecnológico, recursos humanos, planejamento e orçamento, vigilância epidemiológica e informação, qualidade da assistência, de processos e produtos, do ambiente e incentivo à participação e controle social. 
Para operacionalizar a pactuação, negociação, articulação e integração, foi colocada em prática e incentivada a Comissão Intergestores Tripartite, criada no ano anterior por pressão de Estados e Municípios, mas que de parte do Ministério da Saúde nunca funcionou. Com a NOB 93, além da tripartite e nos mesmos moldes, orientou a criação, em cada Estado, da Comissão Intergestores Bipartite, com representação do Estado e do conjunto de Municípios, através dos Conselhos Estaduais de Secretários Municipais de Saúde. Isso foi uma vitória de conseqüências duradouras há já praticamente dez anos. Institucionalizou-se o pacto. A CIT e CIBs foram a afirmação positiva de que entre um processo descentralizatório irresponsável, que, historicamente, era seguido de furores recentralizadores punidores, optou-se por uma descentralização compartilhada e co-responsável. A persistência dela, em todos esses anos, talvez, seja uma demonstração do acerto.

Para a assistência à saúde, a opção de processo e mudança transicional sem rupturas deu para identificar e demarcar três estágios de municípios e propor a eles - em relação à sua situação - "três sistemáticas de relacionamento: transicional incipiente, transicional parcial e transicional semiplena." Existe a "situação desejada (que era a plena), onde os Estados e Municipios assumem plenamente a gestão do SUS em suas tarefas de governo, o repasse financeiro passa a ser global, direto e automático". Para que esse processo se desse, a NOB-93 coloca para cada uma das situações transicionais: requisitos, responsabilidades, que deveriam ser cumpridas e prerrogativas que passariam a usufruir. Passada essa fase transicional, a seguir, introduzir-se-ia a gestão plena do sistema, que era a finalidade máxima, em que se cumpriria a lei, em sua totalidade. Foram feitos alguns quadros, de suma importância, pelo aspecto didático de demonstrar as novas propostas. No primeiro deles, fezse uma comparação das funções e processos de gestão em cada nivel de governo, analisando-se a situação atual (1993) e indicando qual seria a situação desejada com a base legal da 8080 e 8142 . No segundo, mostrou-se a proposta de gerenciamento dos municípios, desde a situação atual de prestador para as transicionais, até a plena. No terceiro, caracterizou-se a gestão de cada um dos estágios transicionais e o da plena. Para os Estados, partiu-se de uma situação incipiente, passando por uma transicional parcial, semiplena e, finalmente, à desejada (plena).

É comum omitir-se da NOB-93 a forma de gestāo, denominada gestão plena. Todos os quadros explicativos da NOB 93 e do documento que a precedeu fala nessa situação, cuja característica seria, principalmente, a gestão que cumprisse os princípios legais de forma inteira. Nessa situação: o financiamento seria de acordo com o art.35 da 8080(27), todos os recursos (teto financeiro) repassados fundo a fundo, contratando e pagando serviços terceirizados, quando necessários, complementarmente, gerenciamento completo da rede, 
planejamento controle e avaliação próprios, com cumprimento dos requisitos legais do plano, fundo, conselho de saúde (aprovando plano e contas), relatório de gestăo e outros.

A NOB - 93 teve, como característica, uma ampla discussão com os vários gestores, internamente no Ministério da Saúde, com os Conselheiros de Saúde, com os parceiros prestadores, com a sociedade como um todo. Vários pareceres foram colhidos antes da aprovaçăo e publicaçăo. Esse processo, que năo foi tăo aberto, principalmente na 91 , e pouco na 92, consolidou-se como caminho para as NOBs futuras.

Os Estados se sentiram desprestigiados. Custaram para cumprir sua parte, principalmente, na formaçăo de Conselhos, de Fundos e na organizaçăo das Comissões Intergestores Bipartite. A gestão transicional parcial năo aconteceu, pois ela dependia de procedimentos estaduais que năo ocorreram. Quando o próprio Ministério da Saúde conseguiu disponibilidade de recursos, os Estados năo tinham feito sua parte no cálculo dos recursos devidos a cada Município. Consta que um único Estado conseguiu fazer este repasse em um ou pouquíssimos meses.

Foi o horizonte colocado para o futuro quando se acabasse a transição. Inúmeros percalços se deram em sua implantação, sendo de maior gravidade o recorrente bloqueio a mais recursos para a saúde. A nova sistemática da NOB-93 implicava em mais recursos (pelo menos recomposição daqueles perdidos com Collor que reduziu à metade os recursos federais para a saúde), em colocar previamente recursos nas mãos de Estados e Municípios (pelo menos que não demorassem os 75 dias da média), visando à possibilidade de que eles mantivessem os serviços próprios, e contratassem e pagassem, em dia, os serviços comprados. Essa NOB foi colocada em ampla discussão e teve o apoio de inúmeras instituições, o que foi publicado na Revista Saúde em Debate. (140)

Após a posse do Dr. Adib Jatene, como Ministro da Saúde, muitos de seus assessores fossem contra a municipalização, passaram-se cinco meses com o processo parado. São Paulo - que era o carro chefe - demorou mais ainda, pois o Secretário Estadual de Saúde era, também, contra por ser do mesmo grupo. Só se conseguiu, quando os municípios da Região de Ribeirão Preto fizeram pressão intensa com parlamentares, com o Governador Covas e com o MS.

\section{O FINANCIAMENTO FEDERAL PARA A SAÚdE NO GOVERNO ITAMAR - A GRAVE CONVULSÃO DA SAÚDE EM 1993 - A CRISE BRITTO}




\section{O PRECEITO LEGAL DO FINANCIAMENTO DA SAÚDE COM RECURSOS DA CONTRIBUIÇÃO DOS EMPREGADORES E TRABALHADORES PARA O FINANCIAMENTO SOCIAL (CONTRIBUIÇÃO SOBRE A FOLHA).}

A base diversificada do financiamento está na CF, nos artigos 194 e 198(16). Os recursos das Contribuições Sociais, arrecadados pela União, incluem, entre outros, a Contribuição Social de Empregadores e Trabalhadores sobre a folha de pagamento. No ADCT está dito que $30 \%$ dos recursos da Seguridade Social, excetuado o FAT, devessem ir para a saúde no ano de 1989 e, nos anos seguintes, seria este percentual definido nas LDOs.

As LDOs são direcionadas pela Lei do Plano Plurianual, realizadas a cada quatro anos e modificadas quando necessário pelo mesmo processo de votação no Congresso Nacional. A Lei do Plano Plurianual, referente aos anos de 1991 e 1995, Lei 8173 de 30 de janeiro de 1991 (29) foi revista pela Lei 8446 (31), de 21-7-1992 que dispôs sobre o Plano Plurianual para o triênio 1993-1995. Essa Lei, promulgada por Collor, só entrou em vigência no ano de 1993 quando já era Presidente Itamar Franco, segundo a qual, no mínimo 30\% dos recursos da seguridade social, deveriam ser destinados à saúde, sendo que a contribuição, conhecida como Sobre a Folha de Pagamento, a Contribuição de Empregadores e Trabalhadores para o Financiamento da Seguridade Social, deveria ser, no mínimo, destinar $25 \%$ à saúde.

Embasadas na Lei do PPA a cada ano são votadas as Leis de Diretrizes Orçamentárias. A Lei 8447 (32), de 21-julho-1992, dispõe sobre as diretrizes orçamentárias para o exercício de 1993. A LDO-93 estabeleceu:

"Art. $2^{\circ}$ Constituem prioridades do Governo Federal: I - a educação e cultura, a saúde, a ciência e a tecnologia, com as seguintes ênfases: c) consolidação do sistema único de saúde;

Art. $3^{\circ}$ As prioridades definidas no artigo anterior e seus detalhamentos em projetos prioritários no Plano Plurianual terão precedência na alocação de recursos nos orçamentos de 1993, observadas as metas programáticas constantes do anexo desta lei.

Art. 16. A programação dos investimentos para 1993, nos orçamentos fiscal e da seguridade social, obedecerá, para fins de sua distribuição, aos seguintes critérios: I metade, proporcional à população de cada Estado; II - metade, inversamente proporcional à renda per capita de cada Estado. $1^{\circ}$ Excetua-se do disposto no caput do artigo a programação de investimentos: e) destinada aos projetos considerados prioritários no Plano Plurianual.

Art. 17. Não poderão ser destinados recursos para atender despesas com: VII - ações típicas dos Estados, do Distrito Federal e dos Municípios, ressalvados os casos previstos nos arts. 30, VI e VII, 200, 204, I, e 225, § 10, III, da Constituição, ou por autorizações especificas anteriormente concedidas em lei; $1^{\circ}$ Para efeito desta lei, entende-se como ações tipicas dos Estados, do Distrito Federal e dos Municipios, as ações governamentais que não são de competência exclusiva da União nem de competência comum à União, aos Estados, ao Distrito Federal e aos Municipios. $2^{\circ} \mathrm{A}$ 
destinação de recursos para atender despesas com ações e serviços públicos de saúde obedecerá ao princípio da descentralização, nos termos do art. 198, I, da Constituição.

Art. 18. Excluem - se das vedações contidas no artigo anterior, desde que especificamente identificadas nos orçamentos: I - no caso do inciso I: a) as unidades essenciais à expansão das atividades de saúde, saneamento básico, educação, trabalho, segurança, defesa da ordem jurídica, prestação judiciária, de arrecadação de impostos federais, reforma agrária, irrigação, pesquisa em desenvolvimento agropecuário, pesquisa e desenvolvimento tecnológico, proteção ao meio ambiente, preservação do patrimônio histórico nacional, representações diplomáticas no exterior e unidades operacionais das empresas referidas no art. $8^{\circ}$, desta lei, não se aplicando a exceção de que trata este inciso a imóveis residenciais;

Art. 22. É vedada a inclusão, na lei orçamentária anual e em seus créditos adicionais, de dotações a título de subvenções sociais, ressalvadas aquelas destinadas a: I Municípios, para atendimento de ações de educação, saúde e assistência social; Seção III - Das Diretrizes Especificas do Orçamento da Seguridade Social

Art. 37. O orçamento da seguridade social compreenderá as dotações destinadas a atender às ações de saúde, previdência e assistência social e obedecerá ao definido nos arts. 194, 195, 196, 200, 201, 203 e 212, § $4^{\circ}$, da Constituição, e contará, dentre outros, com recursos provenientes: I - das contribuições sociais a que se referem os arts. 195, I, II e III e 239, da Constituição; II - de receitas próprias dos órgãos, fundos e entidades que integram, exclusivamente, este orçamento; III - da contribuição dos servidores públicos de que tratam o art. 231 da Lei $n^{\circ} 8.112$, de 11 de dezembro de 1990 , e os arts. $9^{\circ}$ e 10 da Lei $n^{\circ} 8.162$, de 8 de janeiro de 1991, que será utilizada, prioritariamente, para atender despesas no âmbito dos encargos previdenciários da União; IV - de transferência de contribuição da União, fixada na lei orçamentária anual.

Art. 38. Para o estabelecimento dos valores a serem transferidos, na categoria de despesas correntes, a cada Estado, Distrito Federal e Municipios, será observado nas ações da área de saúde o disposto no art. 35 da Lei $n^{\circ} 8.080$, de 19 de setembro de 1990, e na Lei $n^{\circ}$ 8.142, de 28 de dezembro de 1990, e nas ações da área de assistência social e distribuição de cinqüenta por cento dos recursos na proporção direta das respectivas populações e do percentual restante na proporção inversa à renda per capita.

Art. 39. A proposta orçamentária da seguridade social: I - discriminará, no caso das ações descentralizadas de saúde e assistência social, em categorias de programação especificas, a transferência de recursos da União para cada Estado, para o Distrito Federal e para o conjunto de Municípios de cada unidade da Federação; II - destacará, no detalhamento da receita, as contribuições de empregados, de empregadores e de contribuintes autônomos; e, no detalhamento da despesa, as diferentes formas de beneficios; III - enfatizará a descentralização das ações de assistência social para os Municipios, em sua condição de executores das ações.

Art. 40. Serão destinados ao setor saúde, nos termos da Lei $n^{\circ} 8.080$, de 19 de setembro de 1990, um mínimo de trinta por cento dos recursos do orçamento da seguridade social, deduzida a parcela relativa ao seguro desemprego.

Art. 55. Caso o projeto da lei orçamentária anual não seja encaminhado à sanção do Presidente da República até o início do exercício de 1993, a programação constante do projeto de lei encaminhado pelo Poder Executivo, relativa às despesas com custeio, incluidas as com pessoal e encargos sociais, com investimentos em execução no exercício de 1992 e com serviço da divida, poderá ser executada, em cada mês, até o limite de 1/12 (um doze avos) do total de cada dotação atualizada, até que o projeto 
seja efetivamente encaminhado à sanção, na forma e nivel de detalhamento estabelecidos nesta lei, inclusive em meio magnético de processamento eletrônico.

Anexo - Das Metas Programáticas - I - Educação Cultura, Saúde e Ciência e Tecnologia: (....) f) universalização da atenção integral à saúde de crianças, adolescentes, gestantes e nutrizes com a finalidade de reduzir a mortalidade infantil e a mortalidade de menores de cinco anos para cinqüenta e cinco e sessenta por mil nascidos vivos, respectivamente, e a mortalidade da mulher e da criança; o) incentivo à pesquisa e desenvolvimento tecnológico nas áreas de química fina, biotecnologia e engenharia genética; p) ampliação do grau de controle das transfusões de sangue, com vistas a aproximar-se à meta de cem por cento; q) implantação do sistema de informações que permita adequado gerenciamento do SUS e a sua integração com as áreas de vigilância epidemiológica e sanitária; r) articulação de linhas especiais de financiamento a unidades e ações vinculadas ao SUS com meio de ampliar em vinte por cento os níveis atuais de atendimento; s) ampliação da oferta de leitos hospitalares, mediante incorporação da disponibilidade efetiva de mais 2500 leitos; $t$ ) ampliação da cobertura vacinal, com vistas à integral imunização das populações alvo. III - Recuperação e conservação i) melhoria das condições de saúde e da qualidade de vida no meio urbano e rural por meio de saneamento ambiental, compreendendo o atendimento às populações carentes com abastecimento de água potável, tratamento de resíduos sólidos e prestação de serviços de saúde, voltados principalmente para combate às doenças endêmicas, beneficiando cerca de 10.000.000 de pessoas no meio urbano e 1.000.000 de pessoas de áreas rurais. IV- a) instauração de ações concretas de valorização da cidadania e de consolidação de valores positivos no âmbito da sociedade."(32)

Finalmente, para coroar os preceitos constitucionais, do texto e do ADCT, da Lei do PPA, da LDO, vem a LO de 1993. A Lei Orçamentária da União de 1993 - em seu Suplemento, pág.928, publicado no DOU de 30-4-93, especifica a receita do MS, Fundo Nacional de Saúde, Instituto Nacional de Assistência Médica da Previdência Social (INAMPS) - 17110199 - Transferência das Contribuições dos empregadores e dos trabalhadores para a seguridade social: CR\$ 158.846.938.421.000; de um total de receita do INAMPS de CR\$ 285.709.357.743.000, ou seja, $56 \%$ de toda a receita devida à Assistência à Saúde, a ser transferida aos prestadores públicos e privados.

Esse era o preceito legal do financiamento federal para a saúde, vigente em 1993.

Em 1991, Antônio Britto, Deputado Federal pelo PMDB do Rio Grande do Sul, interessado na área da Seguridade Social e Previdência, fazia as seguintes declarações, em oficio, ao pessoal da saúde e a seus eleitores, como que prestando contas de seu trabalho na Comissão de Seguridade e Familia do Congresso Nacional.

“Caros Amigos. (.....) 1.09 - Um aspecto positivo. O Governo está cumprindo a nova legislação da Previdência Social e honrando o acordo firmado conosco. Começa a desembarcar do dinheiro da Seguridade Social para o pagamento dos Encargos Previdenciários da União (EPU). Os EPUs vão representar 11 por cento do OSS, em vez dos 9 a 10 por cento habituais. Causa: a correta contabilização nesta rubrica de 
todos os inativos e pensionistas. E aumento no número de aposentados do Governo, tendo em vista a suicida política de pessoal que está sendo adotada. Para o pagamento destes EPUs, em 91, 73 por cento dos recursos saíram da própria Seguridade Social. Em 92, este percentual reduz - se para 50,6 por cento, abaixo portanto do limite estabelecido pelo acordo (55 por cento). VALE LEMBRAR QUE ESTA REDUÇÃO DEVOLVE AOS COFRES DA SEGURIDADE SOCIAL 335 BILHŐES DE CRUZEIROS, A PREÇOS DE ABRIL DE 91 OU UM BILHÃO E 220 MILHŐES DE DOLARES.

1.10 - É igualmente positiva a política de especialização de fontes. Em 92, a Contribuição Previdenciária destina - se exclusivamente aos Benefícios e a Saúde. O Finsocial cobrirá os gastos de seguridade dos Ministérios da Saúde e da Ação Social, basicamente. A Contribuição sobre o lucro ficará para os EPUs.

1.11 - Uma fonte de grandes enganos está no Orçamento para a Saúde. O discurso oficial do Governo é, no mínimo, irresponsável. Pelos dados que têm sido divulgados, o Governo cumpre a Lei Orgânica da Saúde e utiliza 30,06 por cento do OSS, deduzidos os gastos com seguro - desemprego, para a Saúde. Em tempo de crise, o cumprimento da Lei é positivo.

1.12 - Algumas autoridades do Governo, no entanto, vêm dando uma interpretação falsa a este número e afirmando, sem responsabilidade, que em 92 haverá muito mais dinheiro para Hospitais, Postos de Saúde, ações tradicionais de Saúde, etc.

1.13 - Sugiro cautela. Para chegar aos 30,06 por cento, o Governo incluiu no OSS despesas que dele nunca constaram.

Entre elas: Merenda Escolar; Saneamento Básico; Programas de Nutrição Infantil; Inativos do Ministério da Saúde e do INAMPS; Mais os CIACs, no valor de Cr\$ 361,6 bilhões. Ou seja: apenas a simples soma destes elementos incluídos no Orçamento de Saúde revela a estratégia adotada pelo Governo para cumprir a Lei. Se o Ministério da Economia pode argumentar que estes gastos são classificados como Saúde pela Constituição e que só assim pode cumprir a exigência dos 30 por cento, não é menos verdade que não cabe a atitude demagógica de anunciar ampliação de recursos para setores, digamos, tradicionais ou clássicos de Saúde.

1.14 - Alguns elementos mais sobre o Orçamento de Saúde: O Ministério terá 16,25 por cento dos recursos do OSS, no valor de Cr\$ 2 trilhões, 178 bilhões. O restante das despesas de Saúde está em outros ministérios: Cr\$1, 863 trilhões. (São os Gastos com Saneamento, Merenda, CIACs, etc).

1.15 - Na estrutura de fontes do Ministério da Saúde, o Finsocial responde por 65 por cento. O Tesouro por 16 por cento."(74)

Britto, ainda parlamentar, foi o Relator Oficial da Comissão de Reforma Previdenciária. Dentre as conclusões desta Comissão, defendida por Britto, estava uma que dizia respeito diretamente à área de saúde. A Comissão, defendia, entre outros, dois principios fundamentais relativos à saúde. (113) O Primeiro deles, que a contribuição sobre salários fosse utilizada, exclusivamente, para pagamento de pensões e aposentadorias. $O$ segundo defendia a descentralização imediata dos recursos para a saúde, com repasses automáticos, segundo a Lei 8080. (27) Com a posse de Itamar Franco, tendo o PMDB como um aliado do Governo, Britto foi convidado e assumiu o Ministério da Previdência Social e, aos poucos, foi 
tentando implementar as medidas que defendera no Relatório da Comissão de Previdência, entre elas, as que se referiam à saúde.

O Ministro Britto encaminhava-se para colocar em prática aquilo que defendera no Congresso e na Comissão da Previdência. Seria uma decisão, não só contra a CF e a Lei, mas mesmo até contra deliberação do Conselho Nacional de Seguridade Social, pela Resolução n.6 de 12-5-1993 (44) a favor da saúde.

“Deliberar pela necessidade do cumprimento da Lei Orçamentária de 1993 especialmente no que diz respeito à transferência imediata ao Fundo Nacional de Saúde dos recursos provenientes da fonte 154/354 retidos pelo INSS, correspondente a $15,5 \%$ (quinze vírgula cinco por cento) da referida fonte, bem como do artigo 16 da Lei $n^{\circ}$ 8212, de 24 de julho de 1991 que especifica ser da União a responsabilidade pela cobertura com recursos do Tesouro Nacional, das "eventuais insuficiências financeiras da Seguridade Social" para que não haja prejuizo dos direitos e obrigações aos segurados da Previdência Social. J. Magalhães Júnior - Presidente".

O Ministro Britto, não obstante sem nenhum documento oficial, apenas por declarações de gabinete, suspende os repasses à saúde no mês de maio de 1993. A Crise do desfinanciamento da saúde, de imediato, começa a fazer suas vitimas. O MS sem recursos próprios para se manter e sem mesmo conseguir fazer as transferências aos Estados e aos municipios para pagar os serviços prestados pelos órgãos públicos e, muito menos ainda, o pagamento dos serviços prestados pelos hospitais filantrópicos e lucrativos.

Maio foi terrivel para todo o setor saúde, em todo o Brasil. Junho, o problema se avoluma. As conseqüências da Crise Britto, afetando o financiamento da Saúde, são patentes em vários textos.

A discussão do financiamento da saúde estava em todos os lugares. O Congresso Nacional não se omitiu da discussão do problema e a Comissão de Seguridade e Familia convocou uma audiência pública em que, perante os congressistas depuseram, entre outros, representantes do MS, Gilson Carvalho, e da Previdência, Sérgio Cutolo. Abaixo, na integra, o pronunciamento de Gilson Carvalho na Comissão de Seguridade, perante os parlamentares. (78)

"Inicialmente eu gostaria de lamentar. Quando nós, num momento deste, poderíamos estar aqui discutindo os problemas da Seguridade Social como um todo, estamos discutindo apenas os problemas da Saúde, justamente por que ela foi sufocada por um dos outros setores da Seguridade Social! Lamentável que a Comissão de Seguridade, que poderia estar discutindo amplamente o problema de todos, tenha que se deter sobre uma única área sufocada pela outra!...

Antes de iniciar propriamente minha fala tenho obrigação de fazer algumas observações sobre o que acaba de dizer o Sr. Sérgio Cutolo, Secretário Executivo do Ministério da Previdência e aqui representando o Sr. Ministro Antônio Brito. 
O Sr. Sérgio Cutolo afirmou: "com relação ao cumprimento da lei, a questão do orçamento, eu queria lembrar aqui que o orçamento define os recursos a serem repassados durante o ano. $O$ orçamento não traz nenhum tipo de fixação de prazo mensal ou diário, então no caso da fonte 154 (contribuição sobre a folha, recolhida pelo ministério da previdência e constitucionalmente destinada à saúde, previdência e assistência social) e seu repasse para o ministério da saúde, nós temos um montante de recursos a serem repassados. Estes recursos teriam que ser repassados ao longo do ano. Para caracterizar o descumprimento da lei, nós teríamos primeiro, que esperar $o$ ano inteiro passar (!!!...)".

Diante desta observação eu gostaria de presentear o sr. Sérgio cutolo com a lei 8080 que no seu artigo 34 diz o seguinte: "as autoridades responsáveis pela distribuição da receita efetivamente arrecada, transferirão automaticamente ao fundo nacional de saúde". Talvez não se tenha conhecimento disso e quero lhe passar uma cópia da Lei.

O Sr. Sérgio Cutolo afirma igualmente que a lei dá prioridade ao pagamento das aposentadorias, ou melhor, corrige ele, que se trata de um decreto. Então, se é apenas um Decreto temos a Lei Orçamentária, que prioriza o Sistema Único e Saúde.

Minha fala vai se deter no seguinte: temos hoje um sério problema a resolver, por estranheza a saúde perdeu a sua importância porque, diante de necessidades prementes e atuais, se toma a atitude de negar a ela a sua parte do financiamento da Seguridade Social. É uma atitude, quero crer, isolada, de um Ministro da República. Não estou compartilhando do que disse o Deputado Reinhold Stephanes, ou seja, de que é uma decisão de Governo. Isso seria extremamente grave, ainda mais quando o Deputado disse que isso revela um crime de responsabilidade. Está escrito na Constituição que, quando desobedecer à lei Orçamentária, quando agir contra os direitos individuais e sociais, qualquer Ministro e o presidente podem ser inclusos em crime de responsabilidade.

Causa - me estranheza que um Ministério vá a público dizer que vai cometer um delito. Vai deixar de repassar os recursos da Seguridade legalmente destinados à saúde, portanto é cometido o delito, são passados quase dois meses do delito e nada acontece. Isso nos preocupa sobremaneira. Em que estado de legalidade nós estamos? Qual é a reação dos Parlamentares desta casa em defesa do bem tão grande que é a saúde?

Não vou fazer discurso apaixonado. Não vou dizer das pessoas que estão sofrendo $e$ morrendo em filas. Não vou dizer nada disso porque pode parecer que eu, simplesmente, queria convencer as pessoas pela emoção. O Direito à Saúde é um direito adquirido. Isso gera responsabilidade. Está na lei para ser cumprido e não está sendo cumprido.

Estou hoje com problema real de falta de recursos para a saúde porque alguém decidiu fazer caixa para um possivel problema que pode acontecer na frente! Por que? Vários dias... sobrou caixa na previdência. Não é problema não sobrar caixa. O problema é que quem arrecada não tem o direito de reservar para si, exclusivamente, o que pertence ao caixa múltiplo da Previdência, Saúde e Assistência Social apenas por ele administrado. O caixa é para ser dividido entre as três áreas da Seguridade Social.

Então, em primeiro lugar, temos de discutir - se quiserem, temos sugestões para - a questão a curto prazo. O que se vai fazer para garantir recursos para a Seguridade? Tem que sair hoje daqui com uma decisão. Não se pode esperar, porque, a cada dia que passa, os problemas da saúde se agravam. Não estou aqui para defender a iniciativa privada, as entidades filantrópicas, absolutamente. Eu quero defender o direito de todos aqueles que trabalham para a saúde, como estados, prefeituras, 
hospitais filantropicos, hospitais contratados, que tem direitos adquiridos sobre os serviços já prestados e que não receberam sua devida remuneração.

Não esta incluído aí, como se falou, só o financiamento da parte assistencial. Estão incluidas todas as ações do Ministério da Saúde, como o combate ao cólera, o combate à malária, as ações de vigilância epidemiológica, de vigilância sanitária. É tudo isso que se está deixando de pagar. Não é exclusivamente a questão dos hospitais, a parte assistencial. Essa é uma questão que precisa ser discutida. Um País que não investiu muito na prevenção não pode cancelar uma e investir na outra. Tem que se fazer um movimento de substituição racional, que acontecerá a médio e longo prazo, nunca rapidamente.

Em segundo lugar, a médio e longo prazo, tem que se descobrir alguma saída. Está aí o problema do IPMF, o problema do Finsocial, que estou achando que é o "fim do social", porque, de repente, a justiça começará a devolver ao empregador o dinheiro que foi cobrado de nós, que foi incluído em todas as planilhas de custos. O cidadão não fez uma renúncia fiscal para que esse recurso voltasse ao empregador. Ele teria que voltar para cada um de nós que o pagou embutido nos custos de tudo que consumimos! E como ele já foi recolhido, temos que descobrir uma solução judicial para isso. Temos que achar uma fórmula para que 20 a $30 \%$ do Finsocial ou do IPMF fiquem para a saúde.

Tem a questão do seguro saúde, em que se tem utilizado os serviços do SUS. Nós não podemos cobrar do indivíduo por ele estar utilizando o serviço do SUS, entretanto as seguradoras são, por lei, obrigadas a ressarci. Elas estão lucrando duas vezes, ás custas do próprio cidadão. Já existe um decreto, elaborado pelo Ministério da Saúde está em discussão - obrigando o ressarcimento, pelas empresas dos seguros - saúde, dos serviços prestados dentro do Sistema SUS.

Outra questão a se discutir é a dos públicos, que nada estão recolhendo para a área da saúde. É uma decisão que pode até levar um certo tempo. Porque se fez a opção por um sistema estatuário nas várias prefeituras, a grande maioria delas nem constituíram o seu sistema próprio de saúde, nem estão recolhendo para o caixa comum para financiar o SUS que usufruem. A contribuição dos empregados e empregadores é a de quem tem o "privilégio" de ter emprego neste país e deve financiar o restante dos cidadãos.

Outra coisa que se poderia fazer são as contribuições voluntárias, a exemplo do que existe em relação ao Fundo da Criança e do Adolescente.Recolhe - se ao Fundo e desconta - se no Imposto de Renda. Poderia ser feita uma proposta para recolhimento aos fundos de saúde, com desconto no Imposto de Renda.

Quanto a questão do acidente de trabalho, nós já tivemos uma contribuição na ordem de $25 \%$ para financiar a Saúde. Até abril tivemos uma contribuição da ordem de $14,5 \%$ a $15 \%$. A partir de maio, sem os repasses da Previdência ficou sem nada a saúde. É outra fonte que pode entrar para aumentar o aposto de recursos.

Aqui foi dito sobre a ineficiência dos serviços públicos, dos serviços de saúde, as dificuldades que se tem para administrar e que talvez isso tenha levado à malversação dos recursos públicos. Acredito que os nossos problemas estão $80 \%$ na insuficiência e $20 \%$ na ineficiência. Essa ineficiência precisa ser corrigida. Discordo do Deputado Reinhold Stephanes quando diz que não temos nada. Temos hoje todo um programa aprovado na Constituição, que é o Sistema Único de Saúde, que precisa sair do papel para realidade. Através da descentralização é que iremos sair desse Estado grande, que não conseguiu gerenciar corretamente seus recursos na área de saúde, para uma administração na qual podemos buscar mais eficiência, sem dúvida, fazer com que os recursos rendam mais. A equipe de Jamil Haddad está apenas a seis meses à frente 
da administração na área da saúde. Têm sido tomadas uma série de medidas administrativas no sentido de corrigir, pelo menos tentar diminuir, o problema da corrupção dentro do sistema. Tínhamos um modelo de informática desatualizado. Começamos a oferecer uma série de problemas de controle. Conseguimos introduzir críticas nos leitos de UTI, nos leitos de psiquiatria, nas cirurgias múltiplas e numa série de outros procedimentos, e isso está resultando em diminuição de despesa. A mídia tem mostrado o descredenciamento de hospitais e de pessoas físicas que estavam fraudando, reconhecidamente, a área da saúde. Seria isso o que teria a falar. "

A discussão no Congresso Nacional espelha bem a dimensão da crise. Aqui são alencadas algumas posições oficiais como a do SINDHOSP, que historiou a crise na Circular 198/93 de 23 de junho de 1993 (88):

"Face ao momento crítico em que se encontram os Prestadores Privados de Saúde, devido aos atrasos e indefinições quanto aos serviços prestados ao INAMPS / SUS, as Entidades Maiores de Representação Nacional editaram a Circular / Conjuntura FENAESS / FBH - $n^{\circ} 005 / 93$, onde são fornecidas orientações quanto aos procedimentos a serem adotados diante da atual realidade. Para seu conhecimento, análise e tomada de posição, estamos reproduzindo, em inteiro teor, o referido documento: "

"Falta De Recursos Agrava A Situação Dos Prestadores De Serviços De Saúde. Senhor Presidente da República - CIRC. FENAESS / FB II - 005 - Um histórico dos fatos: 1 - As decepcionantes declarações do Ministro da Saúde à imprensa, contrariam a promessa feita pelo Presidente da República em reunião com os Ministros da Fazenda, Saúde e Previdência Social, presentes ainda Deputados Senadores, realizada no dia 16, quarta - feira, para solucionar o problema do financiamento do setor saúde. 2 - O Sr. Presidente prometeu que no dia seguinte até o final do expediente ele próprio ou o Sr. Ministro da Fazenda anunciaram as datas de pagamento dos serviços já prestados em março e abril, assim como, um cronograma para os pagamentos futuros. 3 - Entretanto nada ocorreu desde então, exceto notícias veiculares pela imprensa, onde os Ministros da Saúde e da Fazenda informaram que inicialmente, somente dois trilhões seriam liberados para pagamentos dos débitos de abril e numa segunda fase, até o final deste mês ou início do próximo, outros 8 trilhões deveriam ser pagos, restando ainda um valor aproximadamente um valor de 6 trilhões sem definição de data de pagamento. 4 - A esta altura dos acontecimentos, quando ainda sequer teremos recebido integralmente os serviços de abril, deveriamos estar recebendo aqueles prestados no mês de maio. Dai afirmarmos que, a cada dia nossa situação se agrava. 5 - O Financiamento da saúde de acordo com Orçamento da União e da Previdência Social, depende: a) $44 \%$ da arrecadação do COFINS.X FINSOCIAL), imposto decadente que deverá arrecadar menos da metade do programado: b) $35 \%$ da contribuição sobre a folha de salários, que deixou de ser repassada para o Ministério da Saúde por decisão do Ministro da Previdência Social. Para embasar esta decisão o Ministro Antônio Britto diz ter celebrado acordo com Ex Ministro Eliseu Resende com conhecimento e provavelmente, com referendo do Presidente da República. Dai se depreende que as responsabilidades foram integralmente transferidas para o Tesouro Nacional. Contraditoriamente, o Ministro da Fazenda vem fazendo declarações de que nosso setor gasta muito e que o Tesouro não tem como arcar, integralmente com o ônus para o seu financiamento. 6 - Como resultado da reunião do Presidente da República, acima citada, foi instituída Comissão Especial para propor soluções emergenciais e definitivas para o aporte de recursos 
para a área da saúde, no prazo de 15 dias. A primeira reunião desta Comissão está agendada para o dia 24, Quinta - feira onde estarăo presentes os presidentes das duas entidades e FENAESS e FHB, oportunidade em que se pretende propostas e sugestões por nós consideradas pertinentes e viáveis, as quais lhe serão enviadas oportunamente.

Por todo o exposto fica bem claro que os serviços prestados desde abril somados aqueles já prestados em maio e os que prestaremos daqui por diante poderão ou não ser pagos e, se o forem, não há qualquer perspectiva de prazo. Diante disso, a continuidade da prestação dos serviços está diretamente condicionada a existência de eventuais reservas financeiras do prestador, ou de sua capacidade de endividamento. Isto poderá perdurar por meses talvez até o final do ano.

Devemos ainda salientar que o agravamento do quadro funesto que hoje vivenciamos será, inexoravelmente, mais grave com o correr do tempo, mormente quando não se prevê medidas que levem ao um declínio efetivo da inflação e os pagamentos, quando realizados, săo atualizados monetariamente.

O QUE FAZER? 1 - Adotar, de imediato, as deliberações da Reunião Conjunta FENAESS / FHB, realizada no dia 3 deste mês, as quais foram aprovadas por unanimidade. 2 - Devem ser atendidas todas as recomendações constantes da Circular Conjunta FENAESS / FB II de $n^{\circ} 002$, de 9 de junho corrente.

O QUE ESTAMOS FAZENDO: 1 - Visando resguardar responsabilidade daqueles prestadores que, impossibilitamos de continuar prestando serviços dentro de padrões aceitáveis, optem pela suspensão de atendimento, já ajuizamos Protesto Judicial endereçado aos responsáveis, diretos e indiretos, pela área da saúde, tanto em nivel Federal quanto Estadual. 2 - Para impedir que sejam praticadas discriminações de pagamento, entre os prestadores, estamos impetrando Mandado de Segurança contra o Sr. Ministro da Saúde, para que seja respeitado o princípio de que todos são iguais perante a lei. 3 - Contato permanente com os Ministérios da Saúde e Fazenda, Deputados, Senadores e todas as autoridades que possam nos prestar colaboração e apoio. Atenciosamente. Francisco Ubiratan Dellape, Presidente da FENNAESS Carlos Eduardo Ferreira - Presidente da FBH".

No mesmo dia a imprensa foi comunicada da posição dos representantes do setor hospitalar privado filantrópico e lucrativo. Os Hospitais, como patrões, não entram em greve, mas fazem o "locaute":

"COMEÇA HOJE LOCAUTE DE HOSPITAIS EM TODO O PAIS. CERCA DE 1000 UNIDADES QUE TÊM CONVÊNIO COM O INAMPS DEVEM PARAR POR TEMPO INDETERMINADO; 350 MIL PESSOAS PODEM FICAR SEM ATENDIMENTO. O vice - presidente da Federação Brasileira dos Hospitais, Mansur José Mansur, disse ontem que o locaute dos hospitais que têm convênio com o INAMPS é por prazo indeterminado. Para o presidente da federação, Carlos Eduardo Ferreira, dos 4.500 hospitais particulares do Pais, aproximadamente mil devem aderir ao movimento. Desde o primeiro minuto de hoje, só estará sendo feito atendimento de emergência, em uma paralisação nacional destinada a pressionar o governo a pagar uma divida de Cr\$ 37 trilhões, referentes aos serviços prestados em abril e maio. Segundo Mansur, cerca de 350 mil pessoas deixarão de ser atendidas por dia. O locaute vai afetar principalmente pacientes em tratamento ambulatorial e alguns casos de internação. $A$ rede que mantém convênio realiza mensalmente cerca de 1,3 milhão de internações e oferece 550 mil leitos em todo o Pais. Mansur explicou que as sessões de diálise, quimioterapia e radioterapia, considerados casos de emergência, estão excluídas da paralisação. "Mas casos como uma operação de catarata serão desmarcados". 
Segundo Mansur, os hospitais com convênio respondem por $60 \%$ do atendimento ambulatorial e $80 \%$ das internações realizadas pelo Sistema Único de Saúde (SUS). $\mathrm{Na}$ terça - feira, uma comissão de representantes dos ministérios da Fazenda $e$ Previdência anunciou que o governo não teria condições de repassar os $15,5 \%$ da arrecadação do Inamps assegurados pela Lei de Diretrizes Orçamentárias. Eles alegam que o governo está priorizando o pagamento dos aposentados, mas como fica a situação da saúde?", indagou Mansur. Segundo ele, outras fontes de recursos também estão bloqueadas. " O FINSOCIAL está sub judice e o Fundo de Assistência ao Trabalhador só terá dinheiro no segundo semestre", garantiu. No início da semana, Ferreira apresentou um projeto de Lei à Câmara Federal criando uma arrecadação de emergência.

O Ministério da Saúde já liberou Cr\$ 2 trilhões para pagar atrasados e está prometendo repassar mais Cr\$ 8 trilhões. "Este dinheiro não cobre o nosso débito", reclamou Mansur. Ele explicou que a participação dos hospitais particulares e filantrópicos corresponde a $80 \%$ dos Cr\$37 trilhões devidos pelo governo. O restante refere - se a serviços prestados por hospitais municipais, estaduais e universitários, com convênio com o SUS". (115)

"HOSPITAIS DEIXAM DE ATENDER PACIENTES DO SUS NA $5^{a}$ - Santas Casas de São Paulo reduzem o atendimento aos pacientes do SUS e tentam melhorar as finanças com a criação de planos de saúde. A Federação Brasileira de Hospitais, em reunião com os presidentes das associações estaduais de hospitais de todo o País, decidiu suspender o atendimento aos pacientes do Sistema Único de Saúde (SUS) a partir de meia noite de quinta - feira. "É uma suspensão por falta de pagamento", assegurou o vice - presidente da entidade, Mansur José Mansur. "A maioria dos hospitais não tem condições de funcionar por falta de material".

Em todo estado de São Paulo, os Hospitais filantrópicos já vêm reduzindo o atendimento aos pacientes do SUS. Para reverter o caótico quadro financeiro, eles estão criando planos de saúde. "As Santas Casas estão diminuindo o atendimento no dia - a - dia por falta de recursos", assegurou o presidente da Federação das Misericórdias do Estado de São Paulo, Cândido Galvão. "Quem quiser ser atendido vai ter que pagar consulta particular ou um plano de saúde; os filantrópicos atenderão apenas uma os indigentes".

Segundo Galvão, essa foi a única saída encontrada pelas entidades para conseguir atender à população. "O SUS já quebrou, não existe mais", disse. "Os filantrópicos estão se afastando desse sistema para poder sobreviver e dar algum atendimento por meio dos recursos dos serviços pagantes".

A Santa Casa de Itapetininga, responsável pelo atendimento da população de 19 municipios da região e que atende uma média de 450 pessoas por dia, fechou ontem suas portas. Nenhum paciente foi atendido, os internados em condições estão tendo alta e os considerados em estado clínico delicado estão sendo transferidos para hospitais de Sorocaba e outros da região. A entidade tem 14 titulos protestados, fundo de garantia sem recolher há dois anos, deve Cr\$ 5,2 bilhões à funcionários desde abril e não tem mais material para trabalhar. O provedor Gesner Leite de Almeida explicou que o governo federal até agora não repassou Cr\$17 bilhões.

A situação deve se complicar hoje, quando outras seis Santas Casas da região prometem parar suas atividades, atendendo apenas casos de emergência, conforme informou o deputado Chafic Farhat, presidente do Sindicato dos Hospitais do Estado de São Paulo. "A tendência é que cada vez mais os filantrópicos deixem de atender aos pacientes do SUS", disse. "Os hospitais que já deixaram de atendê-los evoluiram muito". (116) 


\section{“FEDERAÇÃO VAI Ȧ JUSTIÇA CONTRA MINISTÉRIO DA SAÚDE.}

A Federação Nacional dos Estabelecimentos de Serviços de Saúde e a Federação Brasileira de Hospitais entraram ontem com um protesto judicial contra o Inamps e os Ministérios da Saúde, Previdência Social, Fazenda e Justiça para prevenir as responsabilidades que possam ser atribuídas aos servidores da saúde devido ao fechamento dos hospitais. Caso haja qualquer discriminação de pagamento entre os prestadores, as federações pretendem ainda entrar com um mandado de segurança contra o ministro da Saúde, Jamil Haddad.

A Sociedade Brasileira de Ortopedia e Traumatologia, por meio de carta enviada ao presidente Itamar Franco e aos conselhos regional e federal de medicina, adverte que as seqüelas, infecções ou mortes que por ventura ocorrerem não são de responsabilidade dos médicos." (116)

A posição do MS era de quem não tinha recursos próprios, pois não era órgão arrecadador. e a da Previdência de não repassar para a saúde a parte legal devida. A atitude de Britto, por livre arbítrio seu, ao arrepio da lei, levava a que vários Hospitais fossem à falência ou entrassem em estado pré-falimentar ou anunciassem seu breve fechamento. Notícia da Folha de São Paulo de 25-6-93 (114) descreve bem o quadro:

"CEM HOSPITAIS FECHAM POR FALTA DE DINHEIRO - Federação prevê que dezenas de outros devem parar hoje; governador anuncia "plano de emergência". Fleury recebeu ontem uma caravana de prefeitos do interior cujos hospitais estão em situação de penúria. Pela manhã, cerca de mil pessoas participaram de uma manifestação diante da Secretaria de Estado da Saúde. Eles exigiam uma posição do Estado diante da crise que atravessavam os hospitais, Fundação Umberto Primo e Sorocabanos, na capital, e a Santa Casa de Guarulhos.

SANTAS CASAS SÃO MAIS AFETADAS As cidades mais afetadas são aquelas que dependem de Santas Casas e hospitais filantrópicos. A quase totalidade de seus pacientes está ligada ao Inamps. Em algumas regiões do Estado, como Itapetininga e Ribeirão Preto, vários desses hospitais estão parados. Os hospitais públicos continuam atendendo em todo o país. Os particulares conveniados que pararem deverão atender as emergências. O sindicato está orientando os médicos a comparecerem aos hospitais e atenderem a todos os pacientes. A federação entrou na Justiça com protesto judicial, responsabilizando as autoridades caso algum paciente venha a morrer por falta de atendimento. A Santa Casa de Campo Grande (MS), o maior hospital do Estado, mantém seu pronto - socorro e ambulatório fechados há um mês por falta de recursos. Deixam de ser atendidos cerca de 700 pacientes por dia. 0 hospital tem a receber do SUS (Sistema Único de Saúde) Cr\$74,5 bilhöes, relativos aos meses de abril e maio. A divida com fornecedores é de Cr\$13 bilhões. $O$ presidente da associação Paraibana de Hospitais, Danilo Maciel, disse que $50 \%$ dos hospitais conveniados do estado param de atender os segurados da Previdência Social a partir de Oh de hoje. Segundo Maciel, $80 \%$ da população paraibana é atendida nos hospitais privados conveniados. O hospital Dom Bosco, o único hospital - geral da região norte de Belo Horizonte (MG), vem reduzindo em junho o atendimento aos segurados do INAMPS. Dos 110 leitos, cerca de $60 \%$ já foram desativados. A dívida do INAMPS totaliza Cr\$ 13 bilhões, referentes a internações e atendimento no pronto socorro desde fevereiro. Em Santa Catarina, os hospitais deverão suspender os atendimentos em convênio com o SUS a partir de sábado. De acordo com o presidente 
da Associação Catarinense dos Hospitais, Armando Taranto Júnior, 90\% da população do Estado ficará sem atendimento, porque há apenas 22 hospitais públicos e 201 privados"

"PREVIDÉNCIA E SAÚDE FAZEM A DANÇA DOS DESESPERADOS, AFIRMA BRITTO. A disputa por dinheiro entre a Saúde e a Previdência pode ser caracterizada como "a dança dos desesperados", segundo avaliou o ministro da Previdência, Antônio Britto, que continua decidido a não repassar $14,7 \%$ da arrecadação bruta do setor para o Inamps, estimada em US\$ 2,5 bilhões este ano. A solução, acrescentou, terá de ser encontrada a partir da reunião marcada para quarta - feira com os ministros da Saúde, Jamil Haddad, e da Fazenda, Fernando Henrique Cardoso, além dos líderes do Governo na Cámara e do Senado".

"Reconhecemos que não é fácil encontrar uma solução, mas é necessário haver uma saída", (130) disse o secretário - executivo da Previdência, Sérgio Cutolo. O orçamento da Previdência para este ano é de US\$17,5 bilhões, mas as despesas com beneficios estão estimadas em mais de US\$ 21 bilhões. Sérgio Cutolo explicou que no orçamento não estão incluídas as despesas com o pagamento dos atrasados, relativos ao reajuste de 147,06\% e com os reajustes bimestrais. Com esse orçamento e as despesas, acrescentou, haveria um déficit primário de mais de US\$ 5 bilhões. Esse déficit esta, projetado, no entanto para US\$ 2,3 bilhões. O secretário explicou ainda que, levando - se em conta as aplicações financeiras, economias com combate às fraudes e arrecadação, as contas da Previdência poderão fechar em equilibrio no final do ano, segundo o conceito de caixa, que inclui todas as despesas e receitas efetivas. Ressalvou, no entanto que a Previdência não terá condições de repassar US\$2,5 bilhões para a saúde este ano. O Ministro Cardoso será o mediador dessa história", disse Cutolo. Britto alega que as despesas da Previdência este ano, serão menores ou iguais à receita e que, por esse motivo, não há dinheiro para repassar à Saúde, que deveria ter fonte própria de financiamento. "A saúde é dever do Estado e direito do cidadão: e em todos os países essas despesas saem do orçamento fiscal, por intermédio do patrimônio, da renda ou do consumo", assinalou. Os técnicos da Previdência reconhecem, no entanto, que é dificil encontrar uma fonte própria de financiamento para a Saúde. Imposto sobre produtos è inviável porque só vale após um ano, contribuição social entra em vigor após 90 dias, mas já existe o Confins, destinado a Saúde. Nesse caso, outra contribuição sobre as empresas seria bitributação. "

O cerco à saúde se fechava, estrangulada pela falta de recursos. O Governador Fleury, de São Paulo, tomou a frente do movimento em São Paulo, congregando o público e o privado (109).

"FLEURY DA PRAZO PARA UNIÃO LIBERAR VERBAS. Governador quer que os repasses para municipios de $S P$ saiam em 30 dias; ele ameaça fazer passeata em Brasilia. O governador de São Paulo Luiz Antonio Fleury Filho (PMDB), escolheu a área de saúde para entrar em confronto com o governo federal. Fleury reuniu ontem no Palácio dos Bandeirantes cerca de 400 prefeitos para um ato público contra os atrasos na liberação de verbas da União para a saúde nos municípios do Estado. $O$ governador deu prazo de 30 dias para a normalização dos pagamentos. Caso contrário, disse, entrará na Justiça contra a União e levará os prefeitos a Brasilia em passeata. Conforme cálculos do governo paulista, a União pagou em junho os Cr\$ 442 bilhões referentes a março sem reajuste. "Não dá mais para contemporizar", afirmou Fleury, referindo - se aos atrasos na saúde." 
A mídia sabia diagnosticar o papel que Brito desempenhava. Cláudio Amaral, no Diário de Cuiabá, faz a seguinte avaliação:

\begin{abstract}
"BRITTO NÃO VẼ A HORA DE DEIXAR A PREVIDENNCIA - O Ministro da Previdência Social, deputado federal e jornalista Antonio Britto, não vê a hora de trocar de ministério. Mais que isto: está ansioso pela chegada do momento em que o presidente da República, Itamar Franco, deverá (ou poderá) Ihe dizer que sua missão no atual cargo está encerrada e que precisará dele num outro posto. A motivação principal foi a terceira nota da coluna Informe JB, assinada pela jomalista paulista Célia Chaim e publicada à página 6 do Jornal do Brasil. Sob o título "Reforço", ela revela que "começou a ganhar força entre os politicos que apóiam o governo a articulação para fazer o ministro Antonio Britto trocar de lugar". É que ele "deixaria a Previdência e passaria a fazer a articulaçăo política do governo, diretamente do Palácio do Planalto. Estas informações intrigam esta repórter, razão pela qual sai imediatamente a campo, colocando aos meus interlocutores a seguinte pergunta: "Por que razão o ministro Britto está querendo deixar o Ministério da Previdência Social?" Perguntei mais: "Por que Britto sairia logo agora, quando está com prestigio dos mais altos, tanto dentro do Governo Itamar Franco como junto à opinião pública, especialmente os aposentados?" "Britto chegou ao fim da linha, no Ministério da Previdência Social", garantiu - me um assessor de um deputado federal paulista com base eleitoral das mais férteis na região laranjeira do Interior de São Paulo. A partir de agora, ele só terá a perder no cargo. Porque a Previdência Social está com suas contas tão complicadas, que melhores resultados não mais serão possíveis. Assim sendo o prestígio de Britto só poderá cair, daqui prá frente. Não porque ele não seja competente ou não conheça o setor. Ele é reconhecidamente competente e conhece os meandros da Previdência como poucos, no Brasil. É pensando no futuro, portanto, que o próprio Britto está articulando sua transferência para o cargo de articulador político do presidente Itamar Franco. Porque nestas novas funções ele acredita que poderá auxiliar tanto o chefe da Nação como o ministro da Fazenda, Fernando Henrique Cardoso.E, por conseqüência, aparecer mais e melhor que agora. Isto é tudo o que Britto precisa para consolidar sua posição de candidato do PMDB ao Governo do Rio Grande do Sul, nas eleições de três de outubro de 1994. E, quem sabe, até mesmo à sucessão do presidente Itamar. “ (3)
\end{abstract}

Tudo se fazia em nome do ajuste fiscal, que era o carro-chefe do Governo Itamar, sufocado por uma inflação galopante e por sucessivas tentativas de realinhar a moeda. Sob esse pretexto, a área social e, em especial, a saúde, via-se tolhida e bloqueada. Qualquer tentativa de se buscarem mais recursos para a saúde levava a que autoridades da "planoeconomocracia" desancassem a área de saúde como eivada de corrupção e de má administração. Sempre se colocava a eficiência na frente e não a insuficiência de recursos. Uma forma de pagamento, utilizando uma tabela extremamente defasada em preços e prazos, não era considerada injustiça.

Na mídia, uma posição se destacava. Era de Luiz Nassif, articulista da Folha de São Paulo, na área econômica. Em 29/6/93 escrevia em sua coluna: (125) 
"O AJUSTE FISCAL E A SAÚDE. Há um certo engano na maneira como se está tratando o ajuste fiscal. Tem que se estabelecer regras rigidas, ajustar as contas, perseguir o equilíbrio fiscal. Mas há despesas que não podem ser postergadas. $A$ falta de recursos está desestruturando a rede de santas casas, praticamente o único esforço comunitário municipal que conseguiu sobreviver à desagregação do Estado no pais, garantindo assistência médica mesmo quando desabou a estrutura do INAMPS. Está comprometendo a municipalização da saúde e afetando a rede privada. Mata doentes no curto prazo e estabelece danos irreversíveis na estrutura de saúde. $A$ declaração do secretário - executivo do Ministério da Fazenda, Clóvis Carvalho, de que, antes de liberar recursos, vai - se analisar se estão sendo bem - aplicados, é retórica, para justificar o atraso. Mesmo assim, demonstra total insensibilidade em relação à situação atual da saúde e se insere nessa miragem estatística, que fez o próprio presidente da República considerar como excessivos os gastos em saúde do país. O que está em jogo não são números, mas vidas humanas. A essa altura da crise, tem que se inverter o cronograma. Primeiro, liberam - se as verbas necessárias para colocar os pagamentos em dia. Depois, analisa - se onde cortar."

O MS se mexia com toda a articulação possível, para conseguir resolver o impasse. Elizabeth Barros, Coordenadora Geral de Planejamento Setorial do MS, elaborou Nota Técnica sobre a questão do Financiamento da Seguridade Social, apresentando os dispositivos legais como pressupostos e objetivos, análise da partilha das receitas e, finalmente, emitiu seu parecer, em forma de considerações sobre a proposta de especialização de fontes no âmbito do orçamento da Seguridade Social. (9).

\section{“CONSIDERAÇÕES SOBRE A PROPOSTA DE ESPECIALIZAÇÃO DE FONTES NO ÂMBITO DO ORÇAMENTO DA SEGURIDADE SOCIAL.}

No contexto do plano de estabilização apresentado pela área econômica, ocupa lugar central, no que tange ao orçamento da Seguridade Social, a proposta de especialização da fonte 154, que se refere às receitas originárias das contribuições de empregados e empregadores iniciantes sobre a folha de salários e de contribuintes autônomos, destinando - a exclusivamente a suportar os gastos com benefícios da Previdência Social. As razões alegadas referem - se à necessidade de comprimir gastos públicos e de precisar limites aos dispêndios da Previdência Social. No curto prazo, essa medida permitirá à Previdência atender aos gastos com benefícios; a médio prazo, porém, exigiria restringir seus gastos ao volume de receitas provenientes dessa fonte. A realização desse intento exigiria a modificação de dispositivos legais, ainda não processada, como por exemplo o parágrafo único do artigo 16 da Lei 8212/91.

A Lei Orçamentária de 1993, recentemente sancionada, determina que 15,5\% da receita liquida dessa fonte seja destinada a suportar as despesas de manutenção do Sistema Único de Saúde, através do orçamento do Ministério da Saúde. O montante originário dessa fonte é responsável pela cobertura de 35,3\% das despesas previstas no Orçamento do Ministério da Saúde, particularmente gastos com a atenção ambulatorial e hospitalar. A proposta da área econômica é a de substituição da fonte 154 por outras fontes, não especificadas, provavelmente COFINS, no orçamento do Ministério da Saúde. Essa substituição por uma fonte cuja receita é de realização extremamente insegura, dado o questionamento judicial em curso acerca de sua constitucionalidade, já seria razão suficiente para que o Ministério da Saúde rejeitasse 
a proposta. Mas há, a nosso ver, aspectos mais graves em jogo. E o mais sério deles diz respeito às decisões implementadas que ferem dispositivos legais.

Em decorréncia de acordo entre os Ministérios da Fazenda e da Previdência Social, tendo em vista a especialização de fonte 154, foram suspensos os repasses do INSS ao Fundo Nacional de Saúde/INAMPS, havendo saldo a receber, referente à receita já realizada no mês de maio até esta data, da ordem de 9 trilhões de cruzeiros. Essa decisão constitui flagrante desrespeito ao disposto na lei orçamentánia e motivou Reunião Extraordinária do Conselho Nacional da Seguridade Social, em 12 de maio de 1993. Em resoluçăo aprovada por ampla maioria de seus membros o CNSS, no uso da atribuição que Ihe é conferida pelo inciso VII do artigo 7 da Lei 8212/91, deliberou pela necessidade do cumprimento da Lei Orçamentária de 1993, especialmente no que diz respeito à transferéncia imediata ao Fundo Nacional de Saúde dos recursos provenientes da fonte 154/354 (....)". Nenhuma ação, contudo, foi realizada para atender seja ao disposto na Lei Orçamentária seja essa deliberação do Conselho Nacional da Seguridade Social.

Preocupa - nos sobremaneira a prática de configuração de situações de fato que infrinjam normas legais. Um dos pressupostos da convivência social democrática é o do respeito às leis. E é o Estado o responsável por garantir essa condição. Face a leis consideradas inadequadas, a ação previsivel do aparato governamental deve ser a proposição de sua modificação pelos meios institucionais adequados, submetendo - se ao embate com as forças sociais nelas interessadas e, ao final, respeitando a superior deliberação do sistema institucionalmente incumbido de faze - lo. Qualquer forma diferente de agir configura a "lei da selva". E nos parece que é deste triste momento de nossa história que estamos propondo afastamento. Entendo, assim, que não é possivel à equipe do Ministério da Saúde avaliar esse procedimento proposto pelos técnicos do Ministério da Fazenda, coonestando uma prática incompatível com os princípios democráticos que nos propusemos a exercitar".

O FAT foi um recurso usual para empréstimo de recursos. O FAT é um recurso advindo do recolhimento do PIS-PASEP e que se destina ao financiamento do auxilio desemprego e à criação de novas oportunidades de trabalho. Quando em reserva, e não utilizado como disponibilidades financeiras, remuneradas pelo Banco do Brasil. A utilização dos recursos do FAT, como empréstimo para a saúde, necessita passar pela aprovação do Conselho Deliberativo do FAT - CODEFAT que tem, entre seus membros, além do governo, representantes dos trabalhadores e empresários. O uso desses recursos para a saúde, como empréstimo, envolvia a idéia de convencimento dos Conselheiros. Como o socorro à área de saúde acaba por mexer com a sensibilidade das pessoas, esse convencimento era feito sob o argumento de "salvação da saúde". Seria um empréstimo que, por conseguinte, Jeveria ser pago ao depois.

Jonseguido esse convencimento, o próximo passo era a autorização do legislativo, o que foi eito à época, por meio de uma medida provisória. (41) 


\section{Medida Provisória No 331 - De 30 de Junho De 1993}

Art. $1^{\circ} \mathrm{O}$ art. $2^{\circ}$ da Lei 8352, de 28 de dezembro de 1991, com a redação dada pelo art. $1^{\circ}$ da Lei $n^{\circ} 8458$, de 11 de setembro de 1992, passa a vigorar com a seguinte redação:

Art. $2^{\circ}$-IV- ao INAMPS, em caráter excepcional, para pagamento de Autorização de Internação Hospitalar - AIH e de Unidade de cobertura Ambulatorial - UCA, no exercício de 1993, desde que garantidos pelo Tesouro Nacional, mediante lançamento de Notas do Tesouro Nacional, série $F$, regulamentadas pelo Decreto $n^{\circ} 747$, de 5 de fevereiro de 1993, que poderão ser resgatadas antecipadamente, sempre até os valores que o FAT necessite sacar dos depósitos especiais para atender à manutenção de sua reserva mínima de liquidez ou às despesas com benefícios do seguro-desemprego e do abono que se trata o art. 239 da Constituiçăo Federal. $4^{\circ} \mathrm{O}$ empréstimo de que trata o inciso IV deste artigo não poderá exceder o valor corrente de Cr\$35.000.000.000.000,00 (trinta e cinco trilhões de cruzeiros), e terá prazo de vencimento de 6 (seis) meses, a contar da data da efetiva liberação dos recursos, prorrogável por mais 60 (sessenta) dias, no caso de não ter sido publicado até a data de vencimento do empréstimo, o Quadro de Detalhamento da Despesa - QDD, referente ao exercício de $1994.5^{\circ} \mathrm{Na}$ necessidade de se efetuarem resgates antecipados, conforme previsto nos incisos III e IV deste artigo, o Conselho Deliberativo do FAT - CODEFAT deverá comunicar o fato ao Ministério da Fazenda, por intermédio da Secretaria do Tesouro Nacional, com antecedência mínima de trinta dias da data do resgate.

Art. $2^{\circ} \mathrm{O} F A T$, através do CODEFAT, liberará imediatamente o empréstimo de que trata $04^{\circ}$ do art. $2^{\circ}$ da Lei $n^{\circ} 8352$, de 1991 , com a redação dada pelo art. $1^{\circ}$ desta Medida Provisória.

Art. $3^{\circ}$ Fica o Tesouro Nacional autorizado a emitir em favor do FAT títulos da dívida pública, nos montantes e condições necessárias para dar cumprimento ao disposto no inciso IV do art. $2^{\circ}$ da Lei $n^{\circ} 8352$, de 1991, com a redação dada pelo art. $1^{\circ}$ desta Medida Provisória, os quais serão mantidos em custódia pelo Banco do Brasil S. A. como garantia de operações que venham a ser contratadas pelo INAMPS.

Art. $4^{\circ}$ As leis orçamentánias da União consignarão no orçamento do INAMPS, à conta dos recursos de que trata a alínea "d" do parágrafo único do art. $1^{\circ}$ da Lei $n^{\circ} 8212$, de 24 de julho de 1991, dotações especificas para pagamento do serviço da divida decorrente das operações de que trata o inciso IV da Lei $n^{\circ} 8352$, de 1991,com a redação dada pelo art. $1^{\circ}$ desta Medida Provisória.

Art. $5^{\circ}$ Fica o Poder Executivo autorizado a abrir ao Orçamento da Seguridade Social da União (Lei $n^{\circ}$ 8652, de 29 de abril de 1993), em favor do Ministério da Saúde - Fundo Nacional de Saúde, crédito extraordinário no valor de Cr\$35.000.000.000.000,00 (trinta e cinco trilhões de cruzeiros), para atender à programação constante do anexo I desta Medida Provisória.

$1^{\circ}$ Os recursos necessários à execução do disposto no artigo anterior serão provenientes de Operações de Crédito Internas - em moeda.

$2^{\circ} \mathrm{Em}$ decorrência da abertura do presente crédito, fica alterada a receita do Instituto Nacional de Assistência Médica da Previdência Social - INAMPS, na forma do Anexo II desta Medida Provisória."

É interessante que, ainda que a Medida Provisória, acima, tenha sido de 30 de junho, o Decreto que a deveria preceder é de $1^{\circ}$ de Julho. Para que se pudesse fazer o empréstimo, seria condição "sine qua non" um Decreto, declarando a situação da saúde como de calamidade pública. É interessante que não é a situação de saúde, nem o SUS, que são 
declarados como em Estado de calamidade, senão exclusivamente "o setor hospitalar do SUS ". Decreto de $1^{\circ}$ de julho de 1993. Declara estado de calamidade pública do setor nospitalar do SUS, conforme abaixo:

“O PRESIDENTE DA CÂMARA DOS DEPUTADOS, no exercício do cargo de Presidente da República, usando da atribuição que lhe confere o art. 84, inciso IV, da Constituição e Considerando as razões expostas pelos Ministros de Estado da Fazenda, da Saúde, do Trabalho, da Previdência Social e chefe da Secretaria de Planejamento, Orçamento e Coordenação da Presidência da República na Exposição de Motivos que propõe a adoção de Medida Provisória para permitir a realização de operação de crédito junto ao Fundo de Amparo ao Trabalhador - FAT, para atendimento das necessidades de custeio das ações de manutenção das informações na rede hospitalar, do Sistema Único de Saúde - SUS. Considerando que a deficiência de recursos financeiros, impossibilitando o atendimento da rede hospitalar, priva a população do atendimento de suas necessidades básicas de saúde, com grave risco para a própria preservação da vida humana; Considerando que tal conjuntura impõe ao Governo a adoção de medidas urgentes e especiais. DECRETA: Art. $1^{\circ} \mathrm{E}$ declarado estado de calamidade pública do setor hospitalar integrante do Sistema Único de Saúde - SUS. Art. $2^{\circ}$ Este Decreto entra em vigor na data de sua publicação. Brasília, $1^{\circ}$ de julho de 1993; $172^{a}$ da Independência e $105^{a}$ da República." (23)

Esses recursos, agora possiveis, passaram pela parte operacional e só foram liberados para pagamento dos serviços prestados pelos Estados, pelos Municipios e pelos Hospitais privados, contratados e conveniados, no decorrer do mês de julho.

Em 23 de junho, o então Presidente do INAMPS, Dr. Carlos Mosconi, em entrevista ao Jornal O Estado de São Paulo, dava exatamente a dimensão do problema:

"INAMPS DEVE PAGAR DÉBITO DE ABRIL HOJE, DIZ MOSCONI. O repasse da parcela de Cr\$2 trilhões que o governo federal deve aos hospitais conveniados com o INAMPS era aguardado para a noite de ontem. Somente hoje, de acordo com o presidente do órgão, Carlos Mosconi, esse dinheiro será repassado aos hospitais. A divida relativa ao mês de abril é de Cr\$ 16,8 trilhões, mas o governo só prevê, até agora, o pagamento de Cr\$ 10 trilhões. Os Cr\$ 8 trilhões restantes devem sair no dia 30 , quando já estará vencendo a divida relativa a maio, no valor de Cr\$22 trilhões. Mosconi reconhece que a situação é grave, mas pede paciência. "A Previdência tem uma dívida de mais de Cr\$30 trilhões que seria suficiente para zerar todos os débitos", diz ele. "Estamos procurando meios para resolver o problema, e todos são testemunhas disso", justifica Mosconi." (116)

Ministro Britto, conhecido no meio, como um "algoz" da saúde, por uma providência extraoficial tomada, depois de passado o auge da crise, faz extenso depoimento, em release distribuído pelo Ministério da Previdência. Isso já era em início de julho. Abaixo a citação do texto de justificativa do Ministro Britto, utilizando-se material do jornal A Gazeta de Cuiabá, que o publicou na integra: 
"DESPESAS COM PREVIDENCIA SOCIAL E SAÚDE EM 1993. A grave crise vivida pelos hospitais brasileiros em função, entre outros fatores, do atraso do governo federal de pagamento de seus serviços, recoloca para a Nação uma das mais dramáticas dificuldades hoje vividas pelo setor público federal: o financiamento da Seguridade Social, em geral, e da Saúde Pública, em particular. Não é uma crise nova. A partir de 1988, com o advento da Constituição Federal desenhou - se, entre nós, a Seguridade Social, moderno conceito que devia integrar as ações e os recursos de saúde, previdência e assistência social.

Do ponto de vista administrativo, a integração não se deu e continuaram a existir, da União aos municípios, órgãos diferenciados quando não conflitantes cuidando das três áreas.Do ponto de vista do financiamento, a Seguridade Social passou a constituir um orçamento próprio, previsto para funcionar com recursos decorrentes de contribuições sobre a folha de salários, o lucro, o faturamento, sobre a receita de concursos de prognósticos além de transferências do Tesouro Nacional.

Este sistema de financiamento também tem revelado problemas em sua implementação. $E$, em conseqüência, ao longo dos últimos quatro anos, Saúde e Previdência Social viveram crises agudas para honrarem seus compromissos.

No caso específico da Saúde, basta lembrar que em 1991 suas contas não fecharam e dependeram de recursos do Fundo de Amparo ao Trabalhador - FAT. Em 1992, nova crise e outro empréstimo do FAT, além de antecipações de recursos, acima previsto, por parte da Previdência Social, que teve aumentado sua participação de 32,6 por cento. O governo Itamar Franco, ao assumir em outubro de 1992, encontra uma situação caótica. O orçamento da Seguridade Social para 1993, então encaminhado ao Congresso Nacional não previa recursos para mais do que oito meses em matéria de saúde. E, na Previdência Social, desconsiderava a existência, entre outros, dos seguintes passivos:

O pagamento dos $147 \%$, Custo: 5,3 bilhões de dólares, incluindo a incorporação do indice no custo dos benefícios e o pagamento das diferenças em 12 parcelas.

O pagamento de mais de um milhão e meio de aposentadorias, cuja concessão tinha sido artificialmente represada desde 1990. Custo: 1,6 bilhão de dólares. O pagamento dos atrasos, com correção monetária, de todas estas aposentadorias represadas. Custo: 300 milhões de dólares.A revisão, determinada pela lei, de um milhão trezentas e cinqüenta mil aposentadorias que vinham sendo pagas abaixo de seus valores reais. Custo: 400 milhões de dólares. O cumprimento de cem mil sentenças judiciais transitadas em julgado e simplesmente desconsideradas pela Previdência Social o total de despesas obrigatórias para 1993. Sem previsão de recursos orçamentários, chegava a 8 bilhões de dólares da Previdência Social. E ha no mínimo, 4 bilhões de dólares na Saúde. Total na Seguridade Social: 12 bilhões de dólares.A insuficiência de recursos não decorria apenas da existência de passivos extraordinários. É preciso considerar igualmente a frustração de receitas, que pela recessão quer por problemas administrativos mas também por dificuldades jurídicas.

O Finsocial, hoje Confins, deveria representar 20 por cento do Orçamento da Seguridade Social em 1992. Esperava -se arrecadar Cr\$24,5 trilhões e a arrecadação efetiva foi de ordem de Cr\$17,2 trilhões, em função das contestações judiciais a eles apresentadas. O valor total de recursos depositados judicialmente à conta daquelas duas contribuições passa de sete bilhões de dólares, muito mais do que os recursos que faltam à Seguridade Social.

A contribuição sobre os lucro, segundo fonte, vem apresentando resultado dentro do previsto. Mas não responde por mais do que 4,9 por cento das receitas da Seguridade Social.A terceira fonte, o Tesouro, vem produzindo a cada ano sua participação. Para 
1993, a previsão de recursos fiscais para a Seguridade Social não passa de 9,8 por cento do total. A Previdência Social continua em 1993 pagando despesas que seriam do Tesouro (aposentadorias de senviços públicos) no valor de 1,8 bilhões de dólares.A quarta fonte, a Contribuição sobre a Folha de Salários, é a única que cresce. Graças às medidas adotadas pelo Ministério da Previdência Social sua arrecadação em 1993, passará, apesar da crise econômica de dezenove para vinte e dois e meio bilhões de dólares.

A causa dos problemas da Seguridade Social vem de um confronto muito simples - de avaliar entre receitas e despesas - De um lado, gastos que ninguém pode ou quer comprimir com hospitais e aposentados no valor de cerca de trinta bilhões de dólares anuais. De outro lado a soma de receitas garantidas que até agora não passa de vinte e quatro bilhões de dólares anuais.

As tentativas de buscar as solução dentro destes números ofendem a matemática ou desconhecem a realidade. Leis que autorizam pagamentos ou repasses existem quer na Saúde, quer na Previdência Social. O que não existe é a receita total minimamente próxima a receita total. O governo Itamar Franco tentou uma solução estrutural e propôs ao Congresso Nacional a extinção de Confins e da Contribuição sobre o Lucro e a criação da Contribuição sobre Valor Adicionado o que resolveria problemas juridicos, ampliaria a arrecadação e praticamente equilibraria o orçamento. Entendeu, porém, o Congresso Nacional que tal matéria seria melhor apreciada durante e revisão constitucional.

A Previdência Social, diante deste quadro, sofreu um impacto adicional, decorrente da aprovação de uma nova politica salarial em dezembro passado, com custo de um bilhão e duzentos milhões de dólares sem fonte de receita.

Com a política salarial aprovada, mais os passivos descritos no item 7, a Previdência Social passou a trabalhar contra um déficit de cinco bilhões e setecentos milhões de dólares para 1993. E adotou um conjunto de medidas administrativas: foi o primeiro órgão do governo federal a cancelar obras novas, proibir construções e restringir investimentos; foi o primeiro órgão do governo federal a contingenciar seus gastos administrativos, com resultados de 200 milhões de dólares de economia em cinco meses; lançou uma grande campanha para cobranças das dividas. O Parcelamento atinge 55 mil débitos de empresas, no valor de 85 trilhões de cruzeiros, dos quais cinco já ingressaram no caixa da Previdência Social; passou a cobrar, de forma inédita, os débitos do setor público com resultados que permitem hoje constatar a melhor situação já registrada na história da Previdência Social; aumentou a arrecadação passando de uma média de 1.358 milhões de dólares para 1530 milhões de dólares mensais; combate às fraudes, promovendo revisões nos benefícios que já redundaram no cancelamento de setecentas mil aposentadorias e pensões no valor de setecentos milhões de dólares. O resumo deste esforço é que dos cinco bilhões e setecentos milhões de dólares de passivo, três bilhões e quinhentos milhões já foram equacionados. Sem aumento de alíquotas.

"E o passivo social está, igualmente, sendo enfrentado. O governo Itamar Franco: concedeu benefícios a dois milhões e cem mil brasileiros a maioria represados desde 90 e 91. Revisou 90 por cento das aposentadorias do chamado buraco negro. Pagou sete parcelas dos 147 por cento. Começou a pagar sentenças judiciais transitadas em julgado.

Todo este esforço gerencial se deu sem participação significativa do Tesouro que, pelas dificuldades conhecidas, não aportou os recursos acertados para o enfrentamento das despesas com a nova politica salarial, no valor de um bilhão e 
duzentos milhões de dólares. Nem repassou o previsto no orçamento e hoje deve à Previdência Social mais de 15 trilhões de cruzeiros, a valores corrigidos.

Assim, é fácil constatar que: A Seguridade Social tem hoje despesas acima das receitas previstas. A Previdência Social vem fazendo sua parte para ajudar a solucionar o problema. Ninguém como ela, cortou despesas e ampliou receitas.

Apesar disto, o problema continua e apenas será resolvido com medidas estruturais que revejam o sistema. Esta revisão está sendo feita por uma comissão de senadores, deputados federais, ministros e especialistas da área de Seguridade Social.Emergencialmente, os pagamentos à saúde estão sendo feitos, entre outros, com os recursos que o Tesouro deveria passar à Previdência Social. Nos últimos 30 dias, dezoito trilhões de cruzeiros foram repassados ao Ministério da Saúde.

A Previdência Social, por expressa determinação do ministro Antonio Britto, cumprindo orientação do presidente Itamar Franco, vai continuar desenvolvendo esforços para, em conjunto com outras áreas do governo e da sociedade, enfrentar estes passivos, herdados de administrações anteriores. E tem a confiança de que a crise atual sendo enfrentada de forma realista e atenta aos números serviu para mudanças concretas no sistema, capazes de evitar a repetição das dificuldades atuais. Antonio Britto é Ministro da Previdência Social e deputado federal." (75)

) Ministro Antônio Britto era um homem de mídia, experimentado e vivido, como jornalista a Globo, acostumado a análises políticas e, depois, como porta-voz do governo. Como arlamentar, dedicara boa parte de seus interesses ao estudo da Previdência Social. Com o residente Itamar Franco, tinha assumido o Governo, com o compromisso de resolver o roblema dos $147 \%$ devidos aos aposentados e não pagos por Collor. Britto tinha essa lissão, da qual não podia esquivar-se. Tinha o respaldo do Presidente. A única saída que ıe pareceu mais à mão foi a tentativa de administrar sozinho os recursos da Seguridade, zcolhidos pelo seu Ministério, relativos à Contribuição de Empregados e Empregadores obre a Folha de Pagamento.

altam declarações da época, publicadas em documentos oficiais ou da mídia, que omprovassem o acordo havido entre o Presidente da República, o Ministro da Fazenda ernando Henrique Cardoso (19-5-1993 a 30-3-94) e o Ministro Britto. Tudo leva a crer que ste acordo nunca ficou registrado e foi extra-oficial. Mas, pelo teor das conversas tidas com Ministro Britto, sempre foi dito por ele que aquela providência tomada de suspender as ansferências de recursos para a Saúde tinham sido decididas conjuntamente por ele, pelo residente e pelo Ministro da Fazenda.

ntretanto, Britto não foi nem um pouco discreto em comentar publicamente o resultado de ua providência, diga-se, ilegal, pois no mínimo contrariava a CF, que destinava os recursos $\mathrm{s}$ três áreas e a Lei 8080 , que determinava o repasse direto e automático das fontes rrecadadoras para o MS.

os Informes Mensais da Previdência, constavam as seguintes notas: 
"A situação do sistema previdenciário vem se agravando ao longo deste ano. Mantendo - se o atual descompasso entre as receitas e despesas, pode - se esperar que o saldo de caixa se torne negativo em junho. Na medida em que as receitas dificilmente acompanharăo o aumento provocado por esse reajuste, e a julgar pelo volume dos déficits registrados nos últimos meses, provavelmente não haverá disponibilidade de caixa própria para saldar os compromissos do sistema. Nesse contexto, o Ministério da Previdência Social vem negociando a suspensão das transferências da parcela da arrecadação bancária para a Saúde. Isso aliviaria de imediato o caixa, gerando uma massa de recursos adicionais de aproximadamente US\$ 200 milhões mensais, suficientes para que o sistema se mantenha solvente até o final do ano. Caso isso não venha a ocorrer, o Tesouro Nacional deverá realizar aportes adicionais de recursos de Previdência nos próximos meses. As transferências ao INAMPS somaram US\$ 273 milhöes, correspondendo a cerca de $16 \%$ da arrecadação bancária, compensando o repasse realizado a menos no mês anterior. Espera - se, entretanto, que em maio essas transferências deixem de acontecer, conforme vem sendo negociado no âmbito do Governo, a fim de manter a liquidez do sistema previdenciário." Maio 93- Vol. 5- $n^{\circ} 5$.

"A Previdência Social fechou o mês de maio com saldo de Cr\$ 15,3 trilhões, equivalentes a US\$ 413 milhões. Pela primeira vez desde janeiro deste ano, o saldo de caixa, medido em dólares, registrou variação mensal positiva. Esse desempenho, no entanto, foi alcançado pelo fato do Ministério da Previdência não ter repassado à Saúde os recursos correspondentes à arrecadação bancária. Caso somente reflete o fato da inadequabilidade das fontes de financiamento da Seguridade Social em cobrir todos os benefícios concedidos pela Constituição de 1988. Qual setor terá de ser financiado com recursos do Tesouro Nacional. Como forma de equilibrio as contas do sistema previdenciário, não foram repassados ao INAMPS os recursos vinculados à arrecadação bancária. Isso proporcionou ao INSS uma economia de US\$ 246,5 milhões, se calculada a transferência pela aliquota de $15,5 \%$, conforme previsto no Orçamento." Junho $1993-\mathrm{Vol} .5-n^{\circ} 6$.

"Por outro lado, as dificuldades financeiras verificadas especialmente a partir de abril, tornaram necessário um ajuste imediato do fluxo de recursos do sistema: ou se criavam fontes adicionais de receitas ou se reduziriam despesas. Essa última alternativa acabou sendo adotada como a politica de curto prazo para sanear o déficit iminente. Dessa forma, as transferências à Saúde foram substancialmente reduzidas a partir de maio, já que as demais despesas, por suas características, não poderiam ser comprimidas. Isso possibilitou uma economia de aproximadamente US\$500 milhões entre maio e junho (calculando - se a diferença entre o percentual estabelecido de repasse da arrecadação bancária e o montante efetivamente transferido), gerando um alívio momentâneo de caixa. Observando - se a evolução do saldo de caixa nota - se que se essa medida não tivesse sido adotada, em junho o sistema já estaria operando com saldos negativos. No acumulado do ano a redução das transferências atinge $35 \%$ em relação ao mesmo período de 1992. Essa variação positiva do saldo é creditada a dois fatores primordiais. Em primeiro lugar, a cessação das transferências à Saúde, a qual comprime a despesa em cerca de US\$ 250 milhões mensais". Agosto 1993 - Vol. $5-n^{\circ} 8$. 

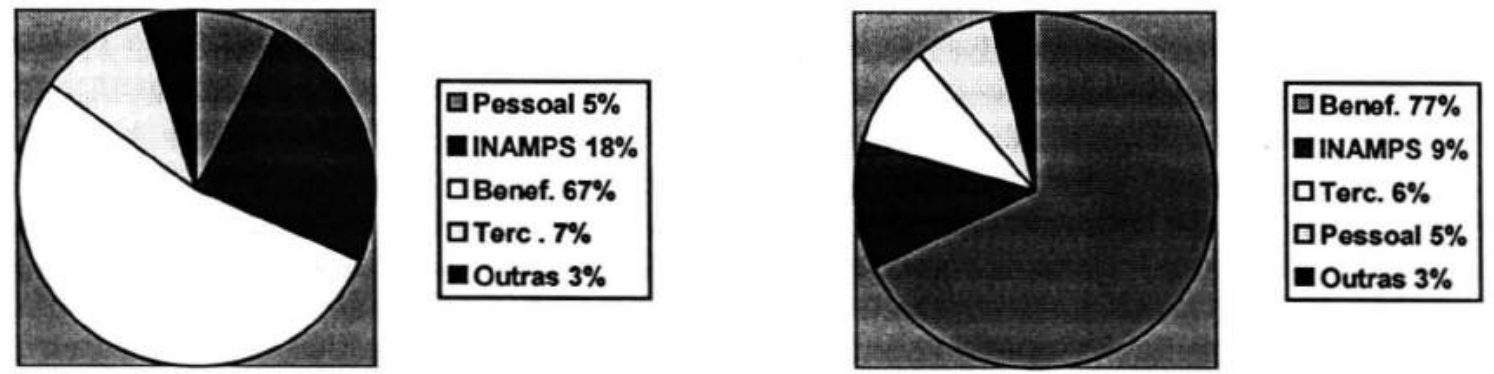

"Cabe enfatizar que para a obtenção de saldo final positivo, como o registrado no final do ano, a Previdência Social deixou repassar na maior parte do período os recursos que seriam destinados ao setor saúde. Em relação a 1992 o repasse foi menor em cerca de $64 \%$ significando uma economia da ordem de US\$2 bilhões se fosse mantido o mesmo valor registrado naquele ano. Pelo exposto, verifica - se que a folga de caixa apurada no final do exercício não corresponde a realidade financeira vivenciada no período, mas ao resultado de inúmeras negociações que culminaram na retenção de recursos, especialmente dos destinados ao setor saúde. A principal estratégia adotada pelo Sistema Previdenciário para equacionar suas contas ao longo do ano, em função do crescimento da despesa com beneficios, foi a de repassar quantidade menor de recursos para esses fins, especialmente para o setor saúde que, em 1993, recebeu o equivalente a US\$ 1.124 bilhão, valor que, em 1992, foi da ordem de US\$ 3.078 bilhões. Com isso, explica - se o decréscimo de $63 \%$ das transferências efetuadas no ano sob essa modalidade." Janeiro $94-$ Vol. $6-n^{\circ} 1$. (42)

Analisando os dados, pode-se perceber o quão injusta se tornava a forma de pagamento dos serviços prestados pelo, ainda, INAMPS, em que no mês de junho foram pagas contas de abril e em julho, contas de maio. Tomando - se o mês do serviço prestado em sua data mediana, que é 15, tem - se o seguinte quadro: os serviços devidos em 15 de abril foram pagos em 23 de junho. São passados 68 dias. Os prejuizos que tiveram as Secretarias Estaduais e Municipais de Saúde e os prestadores foi enorme, com conseqüências a curto, médio e longo prazo, principalmente, devido à perda do poder aquisitivo dos recursos em decorrência da altissima taxa inflacionária. Mais adiante, esses números são analisados. Outra questão analisada, e de não somenos importância, é que os recursos são utilizados para a contagem dos recursos para a saúde, com duas entradas: contabilizam-se os recursos no momento em que entram os empréstimos e, novamente, quando são pagos. Nessa conta iniqua são contados duas vezes os mesmos recursos, aumentando o valor percapita gasto com saúde de uma forma irreal. A seu tempo, especificamente, são analisados os números dessas duas questões.

Diante dessa situação caótica, os Secretários Municipais de Saúde decidiram entrar com denúncia contra o Ministro Britto. Como o CONASEMS não podia entrar judicialmente 
representando os Municípios, a saída foi um dos Secretários Municipais de Saúde entrar com representação, individualmente: Ana Muller, Secretária Municipal de Saúde de Jundiaí.

“EXCELENTISSIMO SENHOR PRESIDENTE DO SUPREMO TRIBUNAL FEDERAL. Ana Maria Consentino Muller, brasileira, solteira, médica, residente na Rua Barreto Leme, 1961 Apto. 151, em Campinas - SP, RG $n^{\circ} 4.757 .292$ - SSP, cidadã em pleno gozo de seus direitos políticos, portadora do Título Eleitoral $n^{\circ} 268.695 .601 / 08$, da Zona Eleitoral 065 do Estado de São Paulo, vem, com fundamento nos artigos $1^{\circ}$, inciso II, $5^{\circ}$ inciso XXXIV, "a", e 102, inciso I, "c", da Constituição da República, e especialmente nos artigos 13, 14 e seguintes, da lei $n^{\circ} 1.079$, de 10 de abril de 1950, e com base nos documentos anexos, e noutros indicados a final, oferecer contra Antonio Britto, Ministro de Estado da Previdência Social.

DENÚNCIA - Por crimes de responsabilidade, previstos nos artigos $7^{\circ}$, item 9, e 10, item 4, da Lei $n^{\circ} 1.079$, de 10 de abril de 1950, como a seguir exposto, para o fim de ser - Ihe decretada a perda do cargo.

PREÂMBULO - Carlos Maximiliano - (in "Hermenêutica e Aplicação do Direito" - Ed. Forense - $9^{a}$ ed. - pag. 216/217). "Considera - se de ordem pública as disposições que se enquadram nos domínios do Direito Público; entram, portanto, naquela categoria as constitucionais, as administrativas, as penais, as processuais, as de polícia e segurança e as de organização judiciária. Não parece ocioso especificar que também pertencem à classe referida as leis de impostos; as que regulam o serviço, a policia e a segurança das estradas de ferro; atribuem competência aos tribunais ou estabelecem as diversas ordens de jurisdição; salvaguardam os interesses da moral e das instituições sociais; organizam a proteção aos incapazes; ou cercam de garantias o trabalho com providências sobre horários, higiene, acidentes, pensões obrigatórias, etc".

Pontes de Miranda (in - "Comentários à Constituição de 1967" - Tomo III - Ed. Forense - pág. 373/374). Na Constituição de 1891, o art. 52 adotava o princípio da irresponsabilidade dos Ministros de Estados pelos conselhos que dessem ao Presidente da República; respondam (apenas) por seus atos. A Constituição de 1967, a semelhança da Constituição de 1934 e da Constituição de 1946, afastou a indagação psicológica; desinteressou - se de qualquer alusão às sugestões feitas pelos Ministro de Estado. O que Ihe importa é o elemento objetivo da assinatura, abstraindo - se de Ter sido praticado o ato, de sua própria deliberação, ou por ordem do Presidente da República. O Ministro de Estado é responsável pelo que assina e pelo que diz, em publicação, telefone, telégrafo, televisão, ou qualquer outro meio de transmissão daquilo que ele pensa. O que ele afirma, ou nega, pode ter conseqüências que se choquem com a esfera jurídica dos particulares, ou com o interesse público. Qualquer que seja o dano causado, injustamente, pode - se compor a figura do ato ilicito, ou do ato - fato ilícito, ou do fato ilicito, que seja para o sistema jurídico, crime de responsabilidade ou crime comum. Não se trata, portanto, somente de responsabilidade pelo que assina. Nem vem ao caso indagar - se se assinou conjuntamente com o Presidente da República, ou outro Ministro de Estado, ou sozinho".

José Celso de Mello Filho (in "Constituição Federal Anotada, 1986" - Ed. Saraiva pág. 275). "Os Ministros de Estado, nomeados em comissão pelo Presidente da República, são responsáveis pelos atos: a) que praticarem; b) que ordenarem; c) que assinarem, ainda que juntamente com o Presidente; ou d) que praticarem por ordem deste. Os crimes de responsabilidade dos Ministros de Estado sujeitá - los - a processo e julgamento perante o STF $(C F$, art. 119, I, b), ressalvo o disposto no inciso I do art. 42 do texto constitucional". 


\section{OS CRIMES CONTRA O EXERCICIO DE DIREITO INDIVIDUAL E SOCIAL E CONTRA A LEI ORÇAMENTARIA PRATICADOS PELO MINISTRO DA PREVIDÉNCIA SOCIAL.}

A Lei $n^{\circ} 1.079$, de 10 de abril de 1950, define, dentre outros, como crimes de responsabilidade contra o livre exercício dos direitos politicos, individuais e sociais, e contra lei orçamentária, os seguintes:

Artigo $7^{\circ}$, item 9: violar, patentemente, qualquer direito ou garantia individual constante do artigo $5^{\circ}$ e bem assim os direitos sociais assegurados no artigo $7^{\circ}$ da Constituição (atual); e Artigo 10, ítem 40: infringir, patentemente, e de qualquer modo, dispositivo da lei orçamentária.

Precedentemente, a Constituição garante aos brasileiros e aos estrangeiros residentes no País a inviolabilidade do direito à vida (art. $5^{\circ}$, "caput") e estabelece, como um dos direitos sociais, a saúde (art. $6^{\circ}$, "caput"), na forma, naturalmente, do que a Carta Magna dispõe a respeito da Seguridade Social (art. 194) e, especificamente, da Saúde (art. 196, e seguinte), assim:

"Art. 194. A Seguridade Social compreende um conjunto integrado de ações de iniciativa dos Poderes Públicos e da sociedade, destinado a assegurar os direitos à saúde..." "Art. 196. A Saúde é direito de todos e dever do Estado..." Art. 197. São de relevância pública as ações e serviços de saúde..."

Portanto, a saúde é direito de todos e dever do Estado, que o garantirá mediante politicas sociais e econômicas que visem à redução do risco de doença e de outros agravos, e ou acesso universal e igualitário às ações e serviços para sua promoção, proteção e recuperação. Em decorrência do dever do Poder Público de garantir o direito à saúde foi organizada a Seguridade Social, cujas ações e serviços são financiados, globalmente, por toda a sociedade, de forma direta e indireta, mediante recursos provenientes dos orçamentos da União, dos Estados, do Distrito Federal e dos Municipios, e de contribuições sociais dos empregadores, dos trabalhadores e outras (art. 195). Dito isto, como então se configura a violação patente do direito individual e coletivo à saúde, e da lei orçamentária, praticada pelo Ministro Antônio Britto, da Previdência Social? A violação está caracterizada na ostensiva e pública disposição do Ministro de Estado da Previdência Social de não transferir, para o setor da saúde, os recursos a este destinados pela constituição, pela lei de diretrizes orçamentárias e pela Lei de orçamento/93.

A CONEXÃO DOS CRIMES - Só o fato de infringir, patentemente, dispositivo da lei orçamentária já configura, por si só, um crime de responsabilidade imputável a Sua Excelência. E acontece que a prática de crime contra a lei orçamentária implica a comissão de crime contra o direito individual e coletivo à saúde, como acima se expôs. São dois crimes típicos, embora no presente caso haja conexão entre eles, de tal sorte que não se pode isolá - los, mas processa-los e julga-los conjuntamente.

Vejamos: A Constituição, como já foi salientado antes, instituiu a Seguridade Social para assegurar (também) os direitos à saúde (art. 194), e definiu as suas fontes de financiamento (195, incisos I, II e III).

Por sua vez, a Lei de Diretrizes Orçamentárias - 1993 ( $n^{\circ}$ 8.447, de 21 de julho de 1992 (32)) estabelece, no seu artigo 40, que "serão destinados ao setor saúde, nos termos da Lei $n^{\circ} 8.080$, de 19 de setembro de 1990, um mínimo de trinta por cento dos recursos do orçamento da seguridade social, deduzida a parcela relativa ao seguro desemprego".

Em seguida, a Lei do Orçamento ( $n^{\circ} 8652$, de 29 de abril de 1993), no seu Anexo I Suplemento $n^{\circ} 80$, de 30.4.93, prevê a Receita de 158,85 trilhões oriundos do Fundo 
de Previdência e Assistência Social - FPAS, administração pelo Ministério da Previdência Social resultado da contribuiçăo de empregados e empregadores.

Finalmente a Lei $n^{\circ} 8.080$, de 19 de setembro de 1990, no seu artigo 34, determina que "As autoridades responsáveis pela distribuição da receita efetivamente arrecadada transferirão automaticamente ao Fundo Nacional de Saúde - FNS, observado o critério do parágrafo único deste artigo, os recursos financeiros correspondentes às dotações consignadas no orçamento da Seguridade Social, a projetos e atividades a serem executadas no ámbito do Sistema Único de Saúde - SUS. Parágrafo único. $\mathrm{Na}$ distribuição dos recursos financeiros da Seguridade Social será observada a mesma proporçấo da despesa prevista de cada área, no orçamento da Seguridade Social".

Ora, o setor da Saúde (Ministério da Saúde/Sistema Único de Saúde) não recebeu, com o automatismo e a regularidade exigiveis, os recursos determinados pela LDO e consignados no Orçamento de 1993.

A situação financeira dramática do setor da Saúde e suas consequeências para o gozo da cidadania. E este o dramático resultado - sumamente danoso à vida e à saúde de milhares de cidadãos e à relação cooperativa entre o Poder Público e o setor privado complementar da assistência médico - hospitalar gratuita do SUS - traduzido em números reveladores da insensata obstinação do Ministro António Britto em reter recursos dos quais Sua Excelência era mero arrecadador e distribuidor:

10) RECURSOS QUE ENTRARAM, ATÉ O DIA 20/6/93, NO CAIXA DO FPAS, administrado pelo Ministério da Previdéncia Social: 290 trilhões de cruzeiros; com os RENDIMENTOS de 43 trilhões de cruzeiros no ano, esse montante passa a 333 trilhões de cruzeiros.

$\left.2^{\circ}\right)$ Pela Lei Orçamentária vigente o Ministério da Saúde deverá ficar com $15,5 \%$ de toda essa arrecadação (333 trilhões), o que resulta em 51,62 trilhões de cruzeiros.

$\left.3^{\circ}\right)$ Repasse anterior ao INAMPS: 20,8 trilhões de cruzeiros.

$\left.4^{\circ}\right)$ Recursos retidos pelo MPAS (diferença entre o que passou e o que deveria ter sido repassado): 51,62 trilhões de cruzeiros.

$\left.5^{\circ}\right)$ Como já foram repassados, até abril, 20,3 trilhões de cruzeiros, FALTA REPASSAR PARA O MINISTÉRIO DA SAÚDE 31,32 trilhões de cruzeiros.

Eis, pois, senhor Presidente, A TERRIVEL CONSEQÜENCIA DA RETENÇÃO DOS RECURSOS DO SUS PELO MPS: O MINISTÉRIO DA SAÚDE NÄO PAGOU ABSOLUTAMENTE NADA NOS MESES DE ABRIL E MAIO E JA ESTA TERMINADO O MẼS DE JUNHO COM A PRODUÇÃO MENSAL QUASE COMPLETA, tornando - se a Administração Pública inadimplente perante o setor privado contratado e conveniado, que ficou onerado de juros e outros encargos de empréstimos bancários e sem condições de prestar assistência à população, agora totalmente desamparada e perplexa diante da incúria do Poder Público.

A ilicitude do ato do Ministro de Estado. Assim, se o Ministro Antônio Britto, em cuja área está o órgão centralizador da arrecadação correspondente às contribuições de empregados e trabalhadores, DEIXA DE REPASSAR AO MINISTÉRIO DA SAÚDE como está fazendo e publicamente confirmado desde abril - OS RECURSOS DESTINADOS A GARANTIR O DIREITO INDIVIDUAL E COLETIVO A SAÚDE, O Ministro Antônio Britto está cometendo crime de responsabilidade, cujos efeitos não se esgotam na ilicitude do descumprimento da $L D O$ e da $L O$, mas atingem gravemente um direito social.

Cabe, por lei, ao Ministério da Saúde PAGAR OS SERVIÇOS CONTRATADOS E CONVENIADOS E REPASSAR RECURSOS A ESTADOS E MUNICIPIOS PARA O PAGAMENTO DA COBERTURA ASSISTENCIAL NO ÂMBITO DO SISTEMA ÚNICO DE SAÚDE. 
Para esse fim, o Ministro empenha os recursos orçamentánios destinados a essa cobertura e, após o empenho, contrata ou autoriza a prestação de serviços pelo privado que participa, complementarmente, do Sistema Único de Saúde.

Ora, se os recursos comprometidos, com base no orçamento, não estão disponíveis PORQUE O MINISTRO DA PREVIDÉNCIA SOCIAL OS RETEM INDEBITAMENTE, DEIXANDO DE REPASSÁ-LOS AO MINISTÉRIO DA SAÚDE, o Ministério da Saúde tem o "orçamentário" mas não tem o "financeiro", gerando - se, então, esta enorme e desastrosa crise no atendimento da população, com insuperáveis ônus para a Administração Pública, a credibilidade do Governo e - o mais importante - para a segurança da coletividade, sempre vítima indefesa dos descalabros produzidos por atos voluntariosos dos agentes políticos, como o ato do Ministro Antônio Britto!

Aplicação da Lei Orgânica da Saúde - Comentando o disposto nos citados artigos da Constituição e nos artigos $2^{\circ}$ e $3^{\circ}$ da Lei Orgânica de Saúde, Guido Ivan de Carvalho e Lenir Santos, na obra pioneira e bem acolhida na Administração e nos Tribunais, a respeito do "Sistema Único de Saúde: Comentários à Lei Orgânica da Saúde" (Ed. HUCITEC, 1992), Afirmam: "A Constituição da República, em seu artigo 196, consagrou o princípio de que "a saúde é direito de todos e dever do Estado, garantido mediante risco de doença e de outros agravos e ao acesso universal e igualitário às ações e serviços para a sua promoção, proteção e recuperação".

O artigo 196 é uma explicitação do disposto no artigo $1^{\circ}$ (a dignidade da pessoa humana como um dos fundamentos da República), no artigo $3^{\circ}$ (o bem de todos os cidadãos como um dos objetivos fundamentais da República), no artigo $5^{\circ}$, caput(inviolabilidade do direito à vida, à igualdade e à segurança, abrangendo esta o direito à integridade física e moral, e à saúde) e no artigo $6^{\circ}$ (a saúde como direito social). E com essa harmonização de princípios e fundamentos de ordem jurídica constitucional (e supraconstitucional, porque dizem respeito a direitos humanos fundamentais consagrados em documentos internacionais subscritos pela maioria das Nações), que devemos interpretar e aplicar os preceitos seguintes da Lei Orgânica da Saúde.

Enfatizando o Texto Constitucional, a Lei $n^{\circ} 8.080 / 90 \mathrm{diz}$, nos artigos $2^{\circ}$ e $3^{\circ}$ :

que a saúde é um direito fundamental do ser humano, devendo o Estado prover as condições indispensáveis ao seu pleno exercício;

que o dever do Estado de garantir a saúde consiste na reformulação e execução de politicas econômicas e sociais que visem à redução de riscos de doenças e outros agravos, e ao estabelecimento de condições que assegurem acesso universal e igualitário às ações e aos serviços de proteção, defesa, promoção, prevenção, preservação e recuperação da saúde;

que as politicas sociais e econômicas protetoras da saúde individual e coletiva são as que atuam diretamente sobre os fatores determinantes e condicionantes da saúde, como a alimentação, a moradia, o saneamento básico, o meio ambiente, o trabalho, a renda, a educação, o transporte, o lazer e o acesso aos bens e serviços essenciais;

que o dever do Estado de prover as condições indispensáveis ao exercício do direito do cidadão à saúde não exclui o dever das pessoas, da familia, das empresas e da sociedade;

que além das ações diretamente derivadas da política de saúde e das políticas econômicas e sociais, dizem respeito também à saúde as ações que se destinam a garantir às pessoas e à coletividade condições de bem - estar físico, mental e social, como, p.ex: a assistência do Poder Público ao cidadão para possibilitar - Ihe o melhor uso e gozo do seu potencial fisico e mental; a possibilidade concreta de uma 
comunidade constituir entidades que a representem e defendam os seus interesses vitais, prestando também colaboração ao Poder Público na execução das ações e dos serviços de saúde.

Assim a Constituição da República e a Lei Orgânica da Saúde a dizer do direito do cidadão à saúde e a impor ao Estado o dever de garantir - lo, seja diretamente, mediante assistência médica e hospitalar e ações preventivas, seja por via de políticas económicas e sociais que condicionam e determinam o estado de saúde individual e coletivo.

Portanto trata - se de um avanço o reconhecimento de um interesse vital merecedor da proteção do Estado, fruto da persistência e da conscientização da sociedade para manifestar - se, definindo as suas carências e pugnando pelos seus interesses".

O PEDIDO

Assim sendo, pelos fatos acima imputados, denuncia - se, a Antônio Britto, Ministro de Estado da Previdência Social, por infração aos artigos $7^{\circ}$, item 9, e 10, ítem 4, da Lei $n^{\circ}$ 1.079 , de 10 de abril de 1950, requerendo a signatária que, recebia esta nos termos da Constituição e do Regimento Interno do Tribunal, seja instaurado processo contra o citado Ministro de Estado e julgada nessa Egrégia Corte acusação ora formulada, com conhecimento final de sua procedência, para efeito de aplicação ao denunciado da pena de perda do cargo, sem prejuízo de outras cominações cabiveis.

Por fim, Senhor Presidente - para complementar e confirmar a negação do repasse e o montante dos recursos do Ministério da Saúde/ SUS retidos no Ministério da Previdência Social - requer, ainda, a signatária, sejam requisitados, ao Ministro ora denunciado, aos dados orçamentários, financeiros e contábeis referentes $A$ ARRECADAÇÃO, APLICAÇÃO E DISTRIBUIÇÃO DE RECURSOS DA SEGURIDADE SOCIAL, no período de janeiro a junho de 1993, aos quais não se teve acesso. Brasilia, de junho de 1993." (123)

Nada aconteceu. Nada foi desencadeado. O processo, ao que se saiba, nunca foi julgado. Este episódio teve conseqüências graves sobre a saúde da população. Questões mensuráveis e imensuráveis. Corrigiveis e incorrigiveis.

Algum estudo precisa ser feito para identificar onde se erra ao mover estes processos contra os Governos. Desconhece-se quais sejam os processos movidos contra o Governo e que o coletivo tenha ganho. Questões tão graves como estas e de conseqüências tão maléficas acabam se perdendo no tempo. Sem andamento por alegação de erro de processo ou sem julgamento. 


\section{FINANCIAMENTO FEDERAL PARA A SAÚDE NO GOVERNO ITAMAR - "NOB-94"}

A NOB-94 nunca saiu do papel para a realidade. Como é sua história política? Em setembro de 1993 sai do Ministério Jamil Haddad e entra Henrique Santillo. Nessa época, dirigia a SAS e presidia, ainda, o INAMPS Carlos Mosconi. Henrique Santillo continuou apoiando a política de descentralização. Perguntou-se, à época, o que poderia ser feito de avanço para o projeto que nem conseguira decolar sua NOB-93. (52)

Havia uma proposta de gestão plena, que partia do princípio de se cumprir a lei. Embasavase na idéia de que se tinha de cumprir a lei 8142. A lei 8080 no Art. 35(27), parágrafo $1^{\circ}$, diz: "Metade dos recursos destinados a estados e municípios será distribuída segundo o quociente de sua divisão pelo número de habitantes, independente de qualquer procedimento prévio". O Art.3, parágrafo $1^{\circ}$ da $8142(28)$ diz: "Enquanto não for regulamentada a aplicação dos critérios previstos no 35/8080, será utilizado, para o repasse dos recursos, exclusivamente o critério estabelecido no parágrafo primeiro do mesmo artigo" Com esses dois artigos, de leis diferentes, só existe uma maneira de interpretação : até regular o art.35 da 8080 , todos os recursos federais deverão ser repassados aos Estados, DF e Municípios, exclusivamente pelo critério populacional. Cumprir isto nada mais seria do que colocar recursos iguais para todos os Estados, DF e Municipios. Não se podia fazer isto simplesmente dividindo os recursos existentes e tirando de estados que estavam com maior valor per capita para outros que tivessem com menor. Qual a saida? Igualar os recursos pelo teto maior que seria o do Estado de São Paulo. O que fariam os Estados que passariam a ter maior aporte de recursos? 0 que se esperaria e incentivaria seria modificar o padrão através da utilização desses recursos em investimentos (recursos materiais, recursos humanos, melhor remuneração de trabalhadores de saúde para sua fixação no interior etc. etc.). O bordão, desta vez, era: "pela igualdade, a equidade" . Foram feitos estudos de impacto financeiro, e que resultou na necessidade de se acrescentar cerca de $30 \%$ aos recursos gastos com assistência. O projeto de "NOB-94", complementar e de aprofundamento da Nob-93, caracterizaria a gestão plena desejada com não pagamento mais por produção, mas com transferência fundo a fundo de um recurso único por quociente populacional, segundo a lei. Havia alguns estudos indicando esse caminho, entre os quais, cita-se " Uma fórmula para o financiamento Federal para a Saúde: Pela igualdade conquistando-se a equidade" (84)

Esse anteprojeto foi discutido pela equipe técnica do Ministério da Saúde, na Comissão Intergestores Tripartite. Quando chegou ao Ministério da Fazenda (leia-se FHC Ministro da Fazenda), para discussão do aporte de recursos, o projeto não foi aprovado. Que saida? Não se dispunham a colocar mais nenhum tostão para a saúde. Henrique Santillo, Ministro da 
jaúde, diante disso, tomou outro partido, corrigindo a tabela de serviços básicos, altamente lefasados, com $128 \%$ acima da inflação da época. Os aumentos foram feitos, meio na jurdina, pois não dependeram, nunca, da autorização explícita da Fazenda. Só souberam empos depois de implantado o aumento real, gerando grande mal-estar... para eles. Pela mportância desta proposta, pouquíssimo divulgada, vale a sua citação, na íntegra.

"AGENDA PARA O MINISTÉRIO DA SAÚDE EM 1994: DESCENTRALIZANDO A GESTÃO CONSTRUINDO O SISTEMA ÚNICO DE SAÜDE EM CUMPRIMENTO A CONSTITUIÇÃO. (SOS SAÚDE: DESCENTRALIZAÇÃO JÁ!)

\section{1 - INTRODUÇÃO}

A falta de garantia dos direitos fundamentais do cidadão brasileiro se agrava a cada dia. A saúde também é afetada, como resultado desta luta desigual, que aumenta o fosso entre aqueles que mais têm e os excluídos, os que nada ou pouco possuem.

Muitos projetos e programas têm sido elaborados mas nada tão ousado e correto quanto o que está na Constituição brasileira e na lei Orgânica da Saúde. Com efeito, passados mais de cinco anos de promulgação constitucional, foi o Setor Saúde o que mais avançou em termos de garantir a lei e sua correta regulamentação.

A necessária reforma do Estado brasileiro tem na Saúde o exemplo mais completo do que se deve fazer para garantia desse direito de cidadania.

O que se quer não é certamente um "Estado mínimo", garantindo apenas os direitos das minorias que mais possuem. Nem um estado tão grande que se consome no próprio processo de se imiscuir em cada meandro da vida social e econômica.

A luta que se propõe é por um Estado modesto, no tamanho exato para garantir direitos fundamentais de cidadania e exercendo seu papel regulador sobre os setores produtivos, inclusive na área da Saúde.

A presente Agenda para 1994 do Ministério da Saúde tem a determinação de garantir a continuidade de se cumprir a legislação e, por esse motivo, é inovadora. No ano que se passou e neste que se inicia o objetivo maior do Ministério é de efetivar à descentralização das ações e serviços de saúde oferecidos à população brasileira.

A Agenda - 94 do Ministério da Saúde defende: o aprofundamento da descentralização, com a gestão plena do Sistema Único de Saúde (SUS) nos Municípios e Estados.

\section{A LEGISLAÇÃO A SER CUMPRIDA}

$\mathrm{Na}$ área da saúde a rigor ninguém precisa, neste momento, criar mais nada em termos de legislação básica. O imperativo é se esforçar, de todas as maneiras possiveis para que se cumpram as leis existentes.

Existe uma Constituição que, entre outros pontos essenciais, defende o seguinte:

"As ações e serviços de saúde são de competência dos Municípios com a cooperação técnica e financeira dos Estados e da União". (Art. 30, Inciso VII).

"A Saúde, dentro do conceito da Seguridade Social, será financiada pela União, por Estados e Municípios e pelas contribuições sociais da Seguridade Social: recursos da contribuição de empregados e empregadores (sobre o faturamento, sobre o lucro e sobre a folna) e a receita dos concursos de prognósticos" (Art. 194, 1955).

"Universalidade da cobertura, equidade no custeio, diversidade da base do financiamento, caráter democrático e descentralização da gestão administrativa, com a 
participação da comunidade, em especial de trabalhadores, empresários e aposentados" Art. 194.

O arcabouço filosófico e normativo do SUS tem como princípios fundamentais:

a universalidade e equidade do acesso, o que significa a garantia da gratuidade. Em outras palavras: financiamento indireto por toda a sociedade;

a descentralização da gestão e dos serviços oferecidos à população;

a organização dos senviços de maneira hierarquizada, de complexidade crescente, regionalizada, utilizando voluntariamente a formação de consórcios entre gestores para melhor garantir a eficiência através da regionalização;

a integralidade das ações, dentro de uma visão holística do homem, e tendo como pressuposto a complementaridade da intervenção, que inclui a prevenção, a assistência e a recuperação da saúde;

a participação da sociedade, através do controle social - conferências e conselhos de saúde em cada esfera de governo;

racionalidade administrativa com planejamento ascendente integrado, revelando o caráter de gestão única em cada esfera de governo.

Está, portanto, na legislação toda a filosofia que rege o Sistema Único de Saúde. O desafio, a verdadeira ousadia , é vencer obstáculos e fazer com que tais postulados possam valer de fato, não só de direito. Só assim se terá cidadania, que compreende o direito universal dos brasileiros à saúde com qualidade.

\section{AGENDA 94 / SUS - O AVANÇO NA DESCENTRALIZAÇÃO COM A GESTÃO PLENA DO SISTEMA ÚNICO DE SAÚDE NOS MUNICIPIOS E NOS ESTADOS.}

A Norma Operacional Básica - SUS/ 93, que regulamenta o processo de descentralização das ações e serviços de saúde, estabelece como pontos essenciais:

a flexibilidade da própria Norma, quando afirma que prevalecem as decisões locais, desde que não contrariem as leis vigentes sobre seus dispositivos formais;

. a gradualidade, não necessariamente seqüencial, do processo de aperfeiçoamento da gestão, com as situações incipiente, parcial e semiplena adaptáveis a cada momento político institucional do gestor;

o estabelecimento de fóruns descentralizados de negociação e planejamento: as Comissões Intergestores Bipartite, nos Estados, e Tripartite em nivel federal.

A NOB SUS / 93 deixou praticamente em aberto como se operacionalizaria a etapa mais avançada, ou seja, a de gestão plena para Estados e Municípios. Ela foi definida como o momento em que os gestores não receberiam mais recursos sob a forma de repasses por produção ou por tetos históricos, mas sim na forma preconizada pela Lei 8.080 em seus artigos 34,35 e seguintes, mediante critérios epidemiológicos, de capacidade instalada e de produtividade, entre outros.

Com as dificuldades verificadas em sua regulamentação tais critérios deveriam ter sido substituidos pelo quociente populacional, como manda a Lei 8.142 / 90.

Diante da necessidade de provocar mudanças profundas no financiamento da saúde, através da superação dos atuais mecanismos de pagamento por produção, é que o Ministério da Saúde propõe, o mais rápido possível, implantar o nivel de Gestão Plena em Estados e Municipios, como manda a Lei, de forma responsável, exigindo - se as contrapartidas legais. 
Para se cumprir a legislaçăo e agilizar a proposta de descentralizaçăo é necessária uma estratégia bem definida. Os pontos fundamentais desta estratégia estăo descritos a baixo.

\subsection{A GARANTIA DE RECURSOS GLOBAIS SUFICIENTES}

Não será superada nenhuma das muitas resistências se não se garantirem recursos suficientes para o Setor Saúde. Historicamente se verificou que os US\$ 80 por habitante, correspondentes ao total do gasto do Govemo Federal com a saúde em 1987, foram reduzidos, em 1993, a apenas US\$ 40.

A reversão concreta de tal situaçăo anômala conta com o compromisso declarado do Presidente Itamar Franco e do Ministro da Fazenda Femando Henrique Cardoso, que têm afirmado textualmente que, em 1994, serão garantidos recursos suficientes para a área da saúde.

Existe um certo equivoco relacionado à descentralizaçăo da área de saúde, que considera que a mesma deva ser feita com a transferéncia de responsabilidades e ónus a Etados e Municipios. Muito pelo contrário. A Constituição brasileira estabelece que: A SAÚDE SERA FINANCIADA POR RECURSOS DA UNIÃO, ESTADOS, MUNICIPIOS E PELOS RECURSOS DA SEGURIDADE SOCIAL.

Se quem arrecada as contribuições sociais e as organiza no chamado Orçamento da Seguridade Social (OSS) é a Uniăo, enquanto este principio permanecer a descentralização na área da saúde deverá continuar sendo financiada em sua maior parte por transferência dos recursos do OSS a Estados e Municípios, além, é claro da garantia de contrapartidas Municipais e Estaduais.

Isto é essencial no processo de descentralização: a garantia de que os recursos da União serão transferidos regular e automaticamente a Estados e Municípios, concomitantemente a transferência das responsabilidades.

\subsection{O COMPROMISSO DE CADA ESFERA DE GOVERNO COM O FINANCIAMENTO DA SAÚDE.}

A soma de toda a arrecadação brasileira, após as transferências constitucionais de uma esfera a outra, produziu uma distribuição de receitas, no exercício de 1992, de 56 por cento para a União, 28 por cento para os Estados e 16 por cento para o conjunto dos municipios.

Cumpre analisar também o gasto com saúde por esfera de governo. Este estudo leva em conta exclusivamente os recursos resultantes da arrecadação de impostos, taxas e contribuições após as transferências intragovemamentais obrigatórias. Excluem - se os rendimentos de aplicações financeiras e os de empréstimos. Tem - se como resultado o quadro abaixo, referente ao exercício de 1990 (modificado a partir do trabalho de Médici).

BRASIL - DEZEMBRO DE 1993

\begin{tabular}{|l|c|c|r|}
\hline GOVERNO & $\begin{array}{l}\text { RECEITA } \\
\text { TOTAL US\$ bi }\end{array}$ & $\begin{array}{l}\text { SAÚDE } \\
\text { US\$ bi }\end{array}$ & $\%$ \\
\hline UNIÃO - & 72,4 & 9,4 & 16,8 \\
\hline ESTADOS (total) - & 38,7 & 1,9 & 5,2 \\
\hline MUNICIPIOS (total) & 17,9 & 1,5 & 8,6 \\
\hline TOTAL - & 129,0 & 12,8 & 10,0 \\
\hline
\end{tabular}

Fonte: MS 
Para 1994, os especialistas na área de financiamento da saúde já trabalham com algumas hipoteses de receitas e gastos. O quadro abaixo resume algumas destas informações, citando propostas apresentadas por Eduardo Jorge (A), Eugênio Vilaça Mendes (B) e Chafic Farah (C).

BRASIL - DEZEMBRO DE 1993

\begin{tabular}{|c|c|c|c|c|c|c|c|}
\hline \multirow{2}{*}{$\begin{array}{c}\text { RECURSOS } \\
\text { POR ESFERA } \\
\text { DE GOVERNO }\end{array}$} & \multirow{2}{*}{$\begin{array}{l}\text { RECEITA } \\
\text { TOTAL } \\
\text { US\$ bi } \\
\end{array}$} & \multicolumn{3}{|c|}{ RECEITA } & \multicolumn{3}{|c|}{ HIPÓTESES } \\
\hline & & $A$ & $\%$ & $B$ & $\%$ & C & $\%$ \\
\hline O. FISCAL & 46,3 & 4,6 & 10 & 4,6 & 10 & 8,4 & 18 \\
\hline O. SEG.S. & 29,0 & 8,7 & 30 & 8,7 & 30 & 5,2 & 18 \\
\hline BRASIL -TOT & 75,3 & 13,3 & & 13,3 & & 13,6 & \\
\hline ESTADOS & 39,0 & 3,9 & 10 & 5,9 & 15 & 3,9 & 10 \\
\hline MUNICIPIOS & 18,0 & 1,8 & 10 & 2,7 & 15 & 1,8 & 10 \\
\hline TOTAL & 132,3 & 19,0 & & 21,9 & & 19,3 & \\
\hline \multicolumn{2}{|c|}{ Per Capita (POP. 157mi) } & \multicolumn{2}{|c|}{ US\$ 121} & \multicolumn{2}{|c|}{ US\$ 139} & \multicolumn{2}{|c|}{ US\$ 123} \\
\hline
\end{tabular}

Fonte: MS

A necessidade mínima de recursos para se garantir uma atenção digna à saúde, considerando exclusivamente a assistência ambulatorial e hospitalar com pagamento sem defasagem de preços e de prazos, é da ordem de US\$ 8 bilhões,considerando se o pagamento no dia 15 do mês subseqüente à prestação dos serviços.

Esse valor foi obtido pela soma do maior valor médio por estado gasto com $A / H$, com maior valor de UCA atribuído a um estado, multiplicado pela população do Pais estimada para 1994.

Além da garantia de que os recursos sejam suficientes, compartilhados pela três esferas de governo e alocados de maneira direta e automática, deve ser cumprido um estrito calendário de transferências: no dia 15 do mês subseqüente à prestação do serviço.

Nessa proposta do Ministério da Saúde é tomado como economicamente viável um gasto de US\$ 8 bilhões para o custeio da assistência médica. Excluem - se outras despesas típicas de saúde como os programas promocionais e preventivos, a folha de pagamentos dos servidores federais remanescentes do INAMPS ou cedidos a outras esferas de governo e as transferências de convênios especificos para custeio e investimento. 
Os US\$ 8 bilhões representam um valor per capita de US\$ 51 para uma população estimada em 157 milhões de brasileiros, a serem gastos no financiamento de assistência hospitalar e ambulatorial.

Um pressuposto fundamental da presente proposta é um pacto entre Governo Federal, através do Ministério da Saúde, e os Estados e Municípios, para que estes garantam parte da assistência à saúde. Isto significa dividir solidariamente a responsabilidade pela alocação destes US\$ 8 bilhões, destinados exclusivamente à assistência à saúde.

A União se responsabiliza por 75 por cento desta despesa, o que equivale a US\$ 6 bilhões ou US\$39,4 per capita, enquanto Estados e Municipios solidariamente ficam com os 25 por cento restantes US\$ 2 bilhões ou US\$11,6 per capita. Isto dividido eqüitativamente representa US\$ 1 bilhão para o conjunto dos Estados (US\$5,80 p/c) $e$ o outro US\$ 1 bilhão para o conjunto dos Municípios (US\$ 5,80 p/c).

\subsection{OS DEMAIS GASTOS COM A SAÚDE DO BRASILEIRO}

A médio e longo prazo, o ideal é que União, Estados e Municípios somados cheguem ao mínimo de US\$110 dólares e a um montante desejável de US\$150 dólares per capita/ ano, considerando os custos totais da atenção à saúde e não apenas a garantia de assistência hospitalar e ambulatorial.

Além dos gastos diretos com a assistência hospitalar e ambulatorial, é necessária garantia de que as demais ações de caráter promocional, preventivo, curativo e programas especiais a determinados agravos à saúde, sejam mantidos com os recursos das três esferas de governo.

No que diz respeito à saúde dos cidadãos, o compromisso deve ser de incremento imediato do gasto com saúde, já que a realidade demonstra cabalmente que existe uma divida social acumulada. Tal compromisso representa investimento na promoção da vida e da dignidade do homem e não uma mera "despesa", como quer o economicismo tradicional.

3.4 A ESTRATÉGIA DO APORTE DE RECURSOS FEDERAIS E DA SEGURIDADE SOCIAL A ESTADOS E MUNICIPIOS NA GESTÃO PLENA

\section{QUE ESTADOS E MUNICIPIOS SERÃO INCLUIDOS NA GESTÃO PLENA?}

A meta é que sejam transferidos estes recursos à totalidade de Estados e Municipios que cumprirem as exigências legais e manifestarem interesse. A NOB - SUS/93 define bem que nenhum Estado ou Municipio deverá seguir os passos da descentralização como se fossem degraus.

Assim é que, com a presente proposta, Estados e Municipios que hoje estejam em situação incipiente na descentralização já poderão, se cumpridas as determinações legais, ingressar na gestão plena, sem necessidade de passar pela parcial ou semiplena.

Existem Estados que já fizeram sua opção em assumir a gestão semiplena. Com estes o Ministério da Saúde se propõe a dar início ao processo de gestão plena. Dentro deles é necessário um esforço enorme, integrando órgãos gestores estaduais e municipais nas Comissões Bipartites, com o apoio e cooperação técnica do Ministério da Saúde, para que a maioria dos seus municípios possa ingressar neste nivel de gestão mais rápido possivel. Os que não conseguirem permanecerão em estágios anteriores, recebendo recursos da maneira atual, ou seja: União pagando por produção.

\section{QUANTO DE RECURSOS DEVERA SER TRANSFERIDO?}

Já se viu anteriormente que, na dependência de negociações no Orçamento Federal, poderão ser gastos com assistência hospitalar e ambulatorial, via Seguridade Social, 
recursos na ordem de US\$ 6 bilhões, o que equivale a US\$39,4 per capita / ano. Tal montante somado aos US\$2 bilhões de contrapartida de Estados e Municípios elevará a US\$ 51 o gasto per capita / ano.

Desse modo, a esfera federal estará instituindo uma nova unidade de financiamento da assistência hospitalar e ambulatorial - Unidade SUS (USUS), no valor US\$ 39,4 per capita / ano. A Unidade SUS determina o montante de recursos a serem transferidos aos gestores estaduais e municipais no ano de 94, superando assim a lógica de pagamento a prestadores entre as três esferas de governo.

\section{COMO DEVERÃO SER TRANSFERIDOS OS RECURSOS?}

A transferência FUNDO a Fundo é a forma legal de se transferir recursos arrecadados por uma determinada esfera de governo quando existem competências já definidas em lei para cada uma delas. São competências constitucionais da União, Estados e Municípios e não transferência voluntária por simples acordo de vontades entre uma esfera e outra.

Existe minuta de decreto presidencial, já discutida amplamente e aperfeiçoada na Comissão Intergestores Tripartite, que deverá ser editado para que não reste mais nenhuma dúvida quanto à constitucionalidade e legalidade desta modalidade de transferência de recursos.

Do ponto de vista operacional, uma vez estabelecida a USUS com um valor per capita igual a US\$ 39,4, deverão ser observados os seguintes passos:

Este valor per capita será multiplicado pela população total de cada município, constituindo - se no montante devido a cada município. Por exemplo: um município de 100 mil habitantes que receba US\$ 40 por habitante / ano dever'multiplicar um valor pelo outro o que resultará em US\$ 4 milhões para o municipio por ano. Este valor, dividido pelos 12 meses, corresponde a US\$ 333 mil por mês.

Estes recursos serão os de origem federal para assistência direta à saúde. Somados a outros recursos federais, estaduais e municipais representarão a totalidade das verbas públicas destinadas à saúde naquele municipio.

Os municípios e até Estados não são, em sua maioria, auto - suficientes para resolver todos os problemas de saúde de sua população. Normalmente referenciam seus pacientes a outros municipios ou Estados e serviços, dependendo da necessidade. Dia virá em que os municípios, com experiência e responsabilidade, receberão os recursos diretamente desta maneira ou por arrecadação própria, farão os pagamentos aqueles que prestarem assistência complementar à sua população.

Enquanto não existe experiência e tradição e considerando a diversidade de estágios administrativos em que se encontram os municipios, propõe - se que esta distribuição de recursos se faça previamente ao repasse, mediante acordo firmado na Comissão Bipartite atendendo às projeções das referências de pacientes.

Estabelecidos tais valores de repasse, acordados com todos, a listagem é repassada ao Ministério da Saúde que transferirá aos Municípios e aos Estados o quantitativo determinado. Modelo semelhante deverá pautar as relações entre gestores estaduais no que diz respeito às referências que ultrapassarem suas fronteiras (municipios fronteiriços, referências terciárias etc.). Estas tabelas poderão ser alteradas a cada trimestre ou em período a ser definido na Comissão Intergestores Tripartite.

Municipios e Estados já têm a alguns meses instrumentos legais de contrato de prestação de serviços com o setor privado lucrativo e não lucrativo, constantes da portaria 1.286/93 e nos modelos facultativos de contrato anexos. A própria portaria 
ministerial que definir os valores de repasse servirá de comprovante de teto a ser recebido pelos Estados e Municipios.

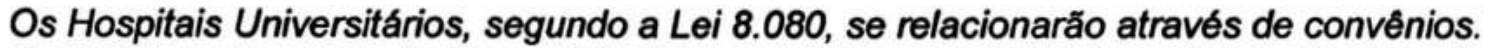
Quando sua abrangência for municipal os convênios se realizarão neste nível e quando for estadual pela Secretaria Estadual de Saúde.

\section{QUAL O DESTINO DOS SISTEMAS ATUAIS DE PAGAMENTO (AIH/UCA)?}

O Governo Federal utilizará esta nova lógica para transferir recursos: um montante per capita baseado nos valores médios nacionais mais altos, referentes à assisténcia hospitalar e ambulatorial, para que nenhum Estado e Municipio seja prejudicado com esta nova modalidade.

A emissão de $A l H$ será ato de responsabilidade dos gestores municipais, em caráter preferencial, e estaduais. Da mesma forma, a programação das metas físicas e dos recursos relacionados à cobertura ambulatorial.

As tradicionais AlH e UCA permanecem, portanto, como instrumentos de pagamento do sistema. Só que sob responsabilidade direta dos gestores municipais e estaduais e serão utilizados apenas na relação entre estes e os prestadores de serviços.

Quanto aos sistemas de informação SIH e SIA é fundamental que eles permaneçam em funcionamento e sejam gradativamente aperfeiçoados. Este processo não pode prescindir da participação do Ministério da Saúde, ao qual cabem competências legais de coordenação dos sistemas de informação em saúde em nível nacional.

\section{QUAL O PAPEL DOS ORGÃOS COLEGIADOS DO SUS?}

Para operacionalização efetiva deste processo vale lembrar a importância política e a legitimidade das Comissões Intergestores Bipartite, que deverão contar com equipe técnica qualificada, formada por técnicos dos órgãos gestores nela representados. $O$ mesmo deve ser garantido em nível nacional através da Tripartite, como órgão de consulta para dirimir e esclarecer dúvidas.

Em um e outro caso, as equipes técnicas trabalharão de maneira continua, enquanto os dirigentes dos órgãos gestores, em reuniōes periódicas, aprovarão e coordenarão o trabalho de tais equipes.

Quanto aos Conselhos de Saúde de cada esfera de governo, seu papel fundamental é o de deliberar sobre questões macro politicas, tais como definição de prioridades, critérios de alocação de recursos, apreciação dos planos de saúde, dos relatórios de gestão, da prestação de contas, etc.., As Comissões Intergestores cabe proceder aos encaminhamentos das questões operacionais do Sistema de Saúde, prestando, necessariamente, contas de seus atos aos Conselhos.

\section{AS CONQUISTAS DE UM NOVO SISTEMA DE SAÜDE}

Restringir os avanços á questão do financiamento é minimizar. De um lado porque se a insuficiência dos recursos representa 80 por cento dos problemas de saúde do Brasil, a primeira conquista que precisamos é retomar valores que já foram gastos com saúde pelo Governo Federal, em anos anteriores. De outro, porque várias conquistas devem se dar na implantação real do Sistema Único de Saúde (SUS).

\subsection{A REVIRAVOLTA NO MODELO ASSISTENCIAL}

$E$ essencial que se mexa no modelo assistencial pelo qual enveredamos. Urgente se faz uma reviravolta. Não podemos simplesmente ignorar experiências de outros paises e caminhar exatamente na direção de onde estão voltando por terem trilhado caminhos errados. 
Primeiro não podemos perder de vista o que queremos em relaçăo à saúde da populaçăo brasileira. Vamos garantir que modelo assistencial? O que ai esta já se condena quando garante o máximo para uns poucos e o mínimo ou mesmo nada para a maioria.

Algumas premissas deste novo modelo têm de ser discutidas e assumidas pelos três gestores públicos. O nível federal não poderá hegemonicamente determinar o que deva ser feito em todo o ternitório nacional. Esta postura é clara e está sendo assumida pela atual direção: o caráter regulador da instância federal năo será assumido como o único nivel a ditar normas, preceitos e programas.

Existe questões gerais, comuns a todos e de necessidade de normatização para todo o Estado brasileiro, bem como existem particularidades que caberá a cada gestor local buscar saída e normatizar local ou loco - regionalmente.

Este novo modelo implicará em respostas adequadas e diferentes das atuais, sobre várias questões como: a introdução de práticas médicas alternativas; a desospitalização e desmedicalização; a participação de cada cidadão no seu processo de cura de maneira mais ativa; a priorização dos serviços básicos e essenciais de saúde através da oferta e melhor remuneração; a atenção centrada em equipe multiprofissional e não apenas medicocêntrica.

\subsection{OS NOVOS PAPÉIS DAS ESFERAS DE GOVERNO}

Um novo pacto de gestão deverá ser feito entre as três esferas de governo para que cada uma delas desempenhe, da melhor forma possivel, seus papéis e competências legais. Sairemos de uma situação em que nivel federal tudo determina e interfere, para uma experiência de responsabilidade compartilhada por Estados e Municípios que têm competências legais próprias e não transferidas por negociação.

Também sairemos do clientelismo central que tanto maleficio fez aos cidadãos brasileiros em várias áreas, principalmente na área social, através das emendas parlamentares e de ajudas negociadas sem fundamentação técnica e sem um plano de nivel loco - regional e estadual.

Tudo isso pode virar coisa do passado, desde que haja vontade das três esferas de governo, reorientadas para um novo relacionamento. Não há clientelismo de uma via só. São duas as mãos: o que faz e o que quer se sujeitar a ser objeto deste clientelismo. Ambos errôneos e nada caracteristicos de estado soberano e democracias modernas.

Basicamente o nível municipal será o responsável pelas ações e serviços de saúde. Ele determinará o limite que pode desempenhar. O Estado só entra como agente na execução complementar das ações e serviços: referências e alta complexidade, onde os municipios forem insuficientes.

O nivel federal raramente será executor, exceto em vigilância de Portos, Aeroportos e Fronteiras, ações sob sua responsabilidade, mas passiveis de transferências a Estados e Municipios, que poderão cooperar na área.

A União caberá basicamente o papel regulador e de oferecer cooperação técnica a Estados e Municípios, promovendo o mais rápido possivel a concretização da descentralização.

\subsection{O CONTROLE DO SISTEMA ÚNICO DE SAÚDE}

Dois tipos de controle são essenciais ao sistema: o controle institucional e o controle social.

\subsubsection{O CONTROLE INSTITUCIONAL}


É imperativo que se constitua, como prescreve a Lei, os Sistema Nacional de Auditoria com seus trés subsistemas: Federal, Estadual e Municipal.

A proposta do novo é trocar o controle financeiro - orçamentário exclusivo pelo controle que leve à avaliação da qualidade da atenção prestada. Muitas vezes detem -se nos erros dos processo administrativo sem avaliar a qualidade da atenção prestada e o custo final baixo ou a maior resolutividade.

Ao se transferir responsabilidades de controle para o nível local, que comprará serviços de terceiros de forma descentralizada, estaremos dando um salto de qualidade enorme. Trocaremos o controle post factum, até o presente momento de mais uso, pelo controle prae factum.

Os serviços comprados de terceiros deverão ser autorizados depois de verificação caso a caso: alterações e acréscimos de procedimentos; papeleta e diagnóstico de alta compativel com a autorização e, por fim, conta cobrada compativel com a autorizada. Só então se dará autorização para cobrança e posterior pagamento.

Isto revoluciona o atual sistema que se mostrou ineficiente no controle, contribuindo para o alto nivel de fraudes e impossibilitando seu levantamento a posteriori.

Não será desdouro afirmar que ao passar o controle dos recursos para cada um dos niveis, estes, automaticamente, serão melhor controlados, pois a despesa real, superfaturada ou subfaturada, cairá sobre este mesmo gestor. Bem diferente de hoje quando um gestor deveria controlar o que o outro deveria pagar.

\subsubsection{O CONTROLE SOCIAL}

A primeira vista assusta ao serviço público, em quaisquer dos níveis, julgar - se controlado pelos cidadãos usuários dos serviços, bem como pelos prestadores, trabalhadores de saúde e outros. Uma falsa hegemonia da corporação dos trabalhadores públicos faz com que se esqueçam que, antes de tudo, somos cidadãos de um País. Devemos lutar para que a única ética que possa se sobrepor a todas seja a ética do cidadão, a ética da vida e não a ética das várias corporações profissionais, comerciais ou industriais.

No mundo inteiro quem já pode dar chance a que os cidadãos defendam seus direitos, controlem efetivamente tanto o setor público como o setor privado, puderam se aperceber das enormes vantagens tanto para os cidadãos como indiretamente até mesmo para as corporações.

É um novo modelo que aos poucos será consolidado. Ainda que hoje os Conselhos nem sempre enveredem por seus verdadeiros papéis, extrapolando de um lado e omitindo - se de outro. Compostos democraticamente ou manipulados vergonhosamente, nem por isso poderão ser proscritos e eliminados. Em localidades onde foram compostos corretamente e desempenham seu papel democrático com responsabilidade e sem casuismo, os Conselhos têm sido um excelente fator de melhora do Sistema de Saúde, colocando - o a serviço real da população.

Temos certeza de que com a somatória do controle institucional bem montado, com o controle social democrático, teremos dois instrumentos excelentes para coibir a ineficiência e eliminar a corrupção.

\subsubsection{OS RECURSOS HUMANOS}

Ainda por algum tempo teremos problemas com os recursos humanos de três esferas de governo convivendo muitas vezes sob um único mando, exteriorizando aquilo que sempre houve, mas que nestas circunstâncias ficam gritantes: a diferença de direitos e deveres, salários diretos e indiretos privilégios e regalias. 
Os Municipios têm demonstrado capacidade maior em criar novos caminhos na resoluçăo inerentes à transiçăo do SUS nesta área. Os problemas principais são despreparo técnico, baixa remuneraçăo, condições inadequadas de trabalho $e$ descompromisso com a população, além das reconhecidas omissão deficiência da politica de recursos humanos nas instituições de saúde.

Constata - se, atualmente, que a atividade liberal que foi o sonho para o qual a universidade preparou boa parte do pessoal estratégico de nivel superior, tais como médicos e dentistas, atuantes no sistema, năo tem correspondência na realidade. $A$ cada dia, maiores contingentes de profissionais de saúde migram do grupo de liberais para o grupo de assalariados. Esta migração é real, deve ser bem entendida e aceita pelos profissionais, e a luta pelas conquistas trabalhistas jamais poderá perder de vista o objetivo último e único: a promoção da saúde, na perspectiva da cidadania social.

5. O INVESTIMENTO FEDERAL NA COOPERAÇÄO TÉCNICA FINANCIANDO A CAPACITAÇÃO DOS NOVOS GESTORES ESTADUAIS E MUNICIPAIS.

Numa demonstração prática do desejo de que este novo modelo dê certo e se torne uma prática vitoriosa tecnicamente, inicia - se de imediato um mutirão cívico de preparo e aperfeiçoamento dos gestores públicos estaduais e municipais.

Estăo reservados de imediato US\$100 milhões exclusivamente para o treinamento e aperfeiçoamento dos gestores públicos. Será necessário que todos estejam preparados para que a gestão pública seja eficiente ao se descentralizar recursos e competências.

São estas as áreas julgadas essenciais ao treinamento descentralizado, através de técnicos competentes recrutados nos próprios estados e municípios:

- gerência financeira através dos Fundos de Saúde;

- gerência de Recursos Humanos como administração de profissionais das três esferas de governo: recrutamento, seleção, treinamento e educação continuada;

. administração do sistema de compras, de contratos e convênios com terceiros e a nova lei de licitação;

. administração do sistema de informações hospitalares e ambulatoriais, através de serviços próprios e não comprados de terceiros;

. montagem e funcionamento do Sistema de Auditoria, Controle e Avaliação Estaduais e Municipais, partes do SNA;

. montagem e funcionamento dos Conselhos de Saúde que possibilitarão o efetivo controle social;

. estes e outros temas que sejam considerados essenciais pelos novos gestores.

\section{CRONOGRAMA INICIAL}

Demonstração ao Ministro da Fazenda da necessidade de reformulação orçamentária do Ministério da Saúde para viabilizar a proposta e demanda da garantia de alocação e liberação dos recursos nos prazos previstos;

Demanda, ao Presidente da República, de aprovação da reformulação orçamentária do Ministério da Saúde, apresenta ao Ministro da Fazenda, e edição dos decretos que regulamentarão a transferência de recursos fundo a fundo e o Sistema Nacional de Auditoria;

Contato com parlamentares buscando obter compromissos até a aprovação da reformulação orçamentária do Ministério da Saúde; 
Mobilização de aliados políticos da proposta para buscarem, junto ao Congresso a
aprovação da reformulação orçamentária do Ministério da Saúde;

Divulgação da proposta à opinião pública buscando a manifestação de apoio da população junto aos seus representantes;

Publicação da portaria ministerial da saúde criando e normatizando a condição de gestão plena, após aprovação da reformulação orçamentária do Ministério da Saúde pelo Presidente da República;

Intensificação das negociações com os gestores estaduais e municipais do SUS que já demonstraram interesse, visando estabelecer os primeiros compromissos para a implantação da nova sistemática;

Publicação da resolução da Comissão Intergestores Tripartite aprovando o enquadramento de no mínimo dois e, no máximo cinco estados em conjunto com o maior número possivel dos seus municípios, na condição de gestão plena;

Publicação, por parte da SAS, do quadro demonstrativo dos valores a serem transferidos a cada um dos estados e municípios enquadrados na condição de gestão plena, conforme acordo firmado nas respectivas Bipartites;

Ampliação das negociações com os gestores estaduais e municipais do SUS com o objetivo de obter uma adesão crescente ao enquadramento na condição de gestão plena;

Montagem de um sistema de acompanhamento e de apoio técnico da esfera federal aos estados e municipios em gestão plena;

Elaboração de programa de capacitação dirigido aos gestores do SUS para apoiar as experiências de gestão plena em curso ou futuras;

Criação de veículos ou instrumentos de divulgação e debate das experiências de gestão plena." (46)

Uma NOB-94, complementar à de 93 não se sustentou, abortada que foi em seu nascedouro, pelo Ministério da Fazenda que não admitia nenhum comprometimento a mais de receitas federais para a saúde. Lamentável fato pois seria a consolidação do processo Jescentralizatório com igualdade e equidade.

\section{O FINANCIAMENTO FEDERAL PARA A SAÚDE NO GOVERNO ITAMAR: CRISE DA ZONVERSÃO DO REAL E SUAS REPERCUSSÕES ATÉ 2001}

Era 1994, primeiro trimestre. Governava o Brasil Itamar Franco. O Brasil estava em plena mplantação do Plano Real, correndo a transição entre a URV (Unidade de Real Valor) e a lova moeda. Todos os setores da economia brasileira negociavam com o Ministério da "azenda qual seria o valor de conversão entre a moeda antiga,o Cruzeiro Real e a nova, o eal. No Ministério da Fazenda estava o Ministro Ricupero, na Secretaria do Tesouro Vacional, Murilo Portugal e à frente de negociação de preços e suas respectivas :onversões, Milton Dalari. 
Todos os setores da economia faziam suas negociaçöes setoriais, visando adequar-se às determinações da Medida Provisória da URV e, posteriormente, a Medida Provisória do Real.

O setor saúde passou pelo mesmo processo. Pelo Ministério da Fazenda a negociação era capitaneada por Murilo Portugal e operacionalizada por Milton Dalari. Pelo setor saúde, os negociadores eram vários. Assumiu a frente o próprio Ministro Santillo e cerca de quatro a cinco assessores seus. Os demals negociadores oficiais vieram de vários segmentos envolvidos. Pelo setor de Gestores Públicos de Saúde: o Conselho Nacional de Secretários Estaduais de Saúde (CONASS) e o Conselho Nacional de Secretários Municipais de Saúde (CONASEMS). Pelo segmento dos Prestadores de Serviços de Saúde: Confederação Nacional de Saúde (CNS), anteriormente denominada Federação Nacional de Estabelecimentos de Saúde (FENAES); Confederação Nacional das Misericórdias (CMB), antes Federação das Misericórdias; Federação Brasileira de Hospitais (FBH). Representando de alguma maneira os cidadãos, negociava a Frente Parlamentar de Saúde, composta de inúmeros parlamentares interessados em defender o direito à saúde. Além dos interlocutores oficiais, estavam agregados outras instituições representativas, dentre as quais se destaca a Associação Brasileira de Hospitais Universitários e Escola ( ABRAHUE).

A negociação tinha o objetivo de buscar um valor de conversão, que fosse justo e suportável pelo erário público. O Ministério da Saúde tinha, basicamente, três grandes grupos de despesas: 1) despesas com transferências intergovernamentais entre o Ministério da Saúde e as Secretarias Estaduais e Municipais de Saúde, tanto mediante pagamento por produção de serviços, como por convênios específicos; 2) despesas com pagamento de serviços produzidos pelos prestadores públicos (universidades e hospitais militares) e privados (hospitais privados lucrativos e não lucrativos, como as Santas Casas de Misericórdia e outros); 3) despesas com as ações ainda desenvolvidas pelo Ministério da Saúde e o pagamento das despesas com pessoal, pagamento de divida e outros.

A necessidade estabelecida de recursos mensais para cobrir despesas com internações e atividades ambulatoriais, públicas e privadas era da ordem de $R \$ 600$ milhões (56) ( $R \$ 1,00$ igual a US\$1,00 em junho de 1994). Não se computavam, nessa previsão, despesas especificas do Ministério da Saúde, $\mathrm{R} \$ 311,80$ (Fundação Nacional de Saúde: $120 \mathrm{mi}$; Hospitais e Ambulatórios Próprios: $39 \mathrm{mi}$; Fundo Nacional de Saúde: $25 \mathrm{mi}$; Instituto de Alimentação e Nutrição: 20 mi; Recuperação da Rede Física de Saúde: 40 mi; Central de Medicamentos: $60 \mathrm{mi}$; Pioneiras Sociais: 7,80 mi e as despesas com pessoal, 191,50 mi. O montante dos recursos necessários mensalmente para o Ministério da Saúde era de R\$1.103,30 milhões. 
A discussão travada entre esses interlocutores referia-se ao montante de recursos necessários para pagamento das atividades ditas assistenciais (AlH - Autorização de Serviços Hospitalares e UCA - Unidade de Cobertura Ambulatorial).

A característica do pagamento aos prestadores de serviços de saúde pelo Ministério da Saúde, desde os tempos em que essa atividade era ligada ao INAMPS, foi de efetuá-lo com defasagem mínima de trinta dias, entre a conta apresentada e a data de pagamento.

A maneira justa de pagamento, em tempo de inflação elevada, seria o pagamento no dia do serviço prestado, ou com correção monetária agregada ou com compensação, em situação de atraso. Assim, nessa época, os serviços prestados num mês, eram pagos com defasagem de até 110 dias. Durante o ano de 1993, por exemplo, com alto índice inflacionário, a média de perda foi de $42,89 \%$, tendo chegado a um máximo de perda na fatura do mês de março e abril de 1993, com 51,45 \%, exatamente quando, na "Crise Britto", deixou-se de pagar fatura or 110 dias. Utilizou-se, à época, como ponto de comparação, a variação do dólar no dia da atura e no de pagamento. (56)

is partes interessadas nessa negociação, pelo lado da saúde, fizeram um resumo de suas ropostas de conversão do Cruzeiro Real, pelo Real.

) teor da proposta de oito itens é o seguinte:

"PROPOSTA DOS GESTORES PÚBLICOS E PRESTADORES DE SERVIÇOS DA ÁREA DE SAÚDE PARA CONVERSÃO DA TABELA DE PROCEDIMENTOS DO SUS PARA A NOVA MOEDA: O REAL"

1. A Conversão da Tabela em URV pelo dia 15 do mês da prestação de serviços (com base nos meses de fevereiro a maio) levaria a um gasto de $R \$ 740$ milhões por mês para a atenção ambulatorial e hospitalar, com gasto anual de $R \$ 8,88$ bilhões o que, ainda que justo e igual a todas as demais conversões feitas, não seria praticável no atual orçamento.

2. Buscou-se então a conversão para uma data suportável, tanto ao sistema de saúde, quanto ao orçamento, chegando-se a um valor de R\$ 615 milhões/mês, correspondente ao dia 5 do mês subseqüente à prestação do serviço. Este valor poderia ser ajustado até o teto mínimo de $R \$ 600$ milhões/mês o que corresponderia teoricamente ao $5^{\circ}$ dia útil de cada mês subseqüente à prestação dos serviços.

3. O pagamento já efetuado dos meses de novembro e dezembro de 1993 e janeiro a abril de 1994 consumiu $R \$ 2,2$ bilhões do orçamento de 1994. Para o mês de maio há uma previsão de gasto de $R \$ 500$ milhões restando, portanto, o pagamento de mais seis meses (junho a novembro, já que dezembro cai em 1995).

4. O que existe orçamentariamente para o pagamento da atividade assistencial (AlH/UCA) é $R \$ 4,6$ bilhões. Subtraindo-se o já pago, teríamos um saldo de $R \$ 1,9$ bilhões.

5. Para efetuar o pagamento de $R \$ 600$ milhões durante seis meses necessitamos um total de $R \$ 3,6$ bilhões. Sendo o saldo disponivel $R \$ 1,9$ bilhões teriamos um déficit de $R \$ 1,7$ bilhões. 
6. Deste total teríamos disponibilidade de mais $R \$ 800$ milhões com o adiamento do pagamento do FAT e transferéncia de sua responsabilidade para o Tesouro Nacional, bem como o não pagamento da Reserva de Contingência utilizada em 1994.

7. Faltariam ainda $R \$ 900$ milhões que seriam conseguidos através de remanejamento orçamentário no Congresso Nacional, de ajustes internos ao MS e de seus parceiros (Estados, Municípios e Prestadores), além da reposição financeira ao MS da parte do orçamento não utilizada no $1^{\circ}$ Semestre de 1994.

8. Enquanto a revisão orçamentária não for realizada, o Ministério da Saúde utilizará os recursos disponiveis no atual orçamento, assumindo a divida da diferença e fazendo o ajuste quando da geração da nova proposta orçamentária.

.CONASS- Conselho Nacional de Secretários de Saúde(Estaduais); .CONASEMSConselho Nacional de Secretánios Municipais de Saúde; .FBH- Federação Brasileira de Hospitais

.CMB- Confederação das Misericórdias do Brasil; .FENAESS- Federação Nacional das Entidades dos Serviços de Saúde " (89)

O setor saúde pública vinha se exaurindo e desfinanciando-se a cada dia. A crise era detectada por todos. A evidência se fazia pelo número de leitos que iam sendo desativados, aos poucos, por total incapacidade de manutenção. A crise não era só dos privados, mas igualmente dos próprios públicos que eram, à época, financiados pelo mesmo mecanismo. $\mathrm{O}$ desfinanciamento público levou a que, principalmente os municipios, cada vez tivessem que investir mais recursos próprios em saúde.

O desafio da negociação era fazer a conversão dos Cruzeiros Reais por um valor em Real mais próximo da realidade. $O$ embate era entre duas posições polares. O Governo defendia uma conversão por valor menor, considerando que há anos já se pagava defasadamente e a filosofia do real não era corrigir nenhum distorção antiga.

"Ao serem discutidas as conversões, a área financeira do Ministério da Fazenda pretendia manter as despesas em função do valor histórico do gasto, ou seja, consolidar de forma definitiva, uma deflação das tabelas que vinham sendo praticadas, mantendo o mencionado calote".(89)

De outro lado, o grupo capitaneado pelo Ministro Santillo da Saúde, defendia a correção pelo valor igual ao aplicado a todos os demais setores da economia. Nada de ilógico ou pretensioso, apenas a luta pela igualdade. No mesmo periodo, todos os insumos utilizados para a manutenção dos serviços de saúde tinham sido convertidos por esse indice, inclusive os salários dos funcionários (cerca de $60 \%$ do custo dos serviços de saúde). Não se podiam aplicar dois pesos e duas medidas. O custo dos hospitais e secretaria de saúde, integralmente corrigidos, e o pagamento desses serviços com perda minima de $33 \%$ !!! A posição do setor saúde tinha uma coerência.

As negociações se arrastaram e houve um momento em que o Ministério da Fazenda, na figura de Milton Dalari, propôs um acordo em que cada um dos lados perdia um pouco, mas 
sem prejuizo total. Não se faria conversão pelo valor comum aos demais setores. Em compensação, não se manteriam as perdas habituais dos últimos anos.

A negociação de valores ocorreu no mês de junho, quando ainda não tinha sido quitada a fatura de maio. Esta, usualmente só seria paga no inicio do mês de julho. Logicamente, a correção deveria ser feita pelo valor da URV prevista para essa data. Foi proposto, no acordo, que esse pagamento seria feito em três parcelas: em 10 de junho, $R \$ 203 \mathrm{mi}$, em 23 junho, $R \$ 28 \mathrm{mi}$ e, em 1 de julho, $R \$ 284 \mathrm{mi}$, o que daria um total para maio de $R \$ 515 \mathrm{mi}$.

O mês de junho foi o imediatamente anterior ao mês da implantação do real. Para esse mês foi feito um novo acordo. A fatura estimada era de CR $\$ 1.807 .239 .814 .128,00$ a ser paga em julho, portanto convertida pelo valor de URV de $30-6-94$, 2750,00. Isso daria $\mathbf{R} \$ 657,18$ ( $657,18 \mathrm{mi}$ de URVS). A fatura de junho se propôs um deflator de $29,89 \%$, o que resultaria em $\mathrm{R} \$ 506,00 \mathrm{mi}$, com o compromisso do Ministério da Fazenda de efetuar o pagamento de $66 \%$ da fatura ( $R \$ 334 \mathrm{mi}$ ) em 10 de julho e, $34 \%$ (172 mi), em 30 julho. Aceitava-se perder um pouco mais em junho para ganhar no prazo ( $66 \%$ da fatura, pago com 10 dias de sua apresentação!!!).

A partir do mês de julho, com a fatura no mesmo patamar de junho (1,8 trilhões de cruzeiros reais), aceitou-se fazer um deflator de $8,71 \%$, chegando-se ao número de $\mathrm{R} \$ 600$ milhões.

Por esse acordo, o Ministério da Saúde, Secretarias Estaduais e Municipais de Saúde e Prestadores, cediam em maio, junho, julho e nos meses subseqüentes. Ganhava-se pelo tempo de pagamento encurtado e pela estabilidade de valores do sistema Real. De outro lado, cedia o Ministério da Fazenda que, peremptoriamente, defendia o teto mensal de apenas $\mathrm{R} \$ 400 \mathrm{mi}$, abrindo mão na negociação com Dalari para disponibilizar os $\mathrm{R} \$ 600 \mathrm{mi}$ mensais.

O acordo tinha um condicionante, que era a possibilidade de se entrar no caixa da Saúde (Fundo Municipal de Saúde), de alguns recursos novos e outros remanejados. Por exemplo: adiamento do pagamento do FAT de R $\$ 632 \mathrm{mi}$, não devolução da reserva de Contingência R\$316 mi, e recursos a conseguir o Congresso Nacional, R\$752 mi. As duas outras maneiras de se equilibrar a necessidade de recursos foi o uso de deflator de $23,4 \%$ em junho e de $8,71 \%$ em julho e nos meses subseqüentes(58). Conversão da tabela pelo quinto dia útil do mês seguinte ao serviço prestado. Conversão oficial: tabela junho dividida pelo fator de conversão de 3013 (URV em 5 de julho/94).

O acordo surgido dessa mesa de negociação foi assinado pelo Ministério da Saúde, CONASS, CONASEMS, CNS, CMB, FBH. Ao se buscar a assinatura do Ministério da Fazenda, na pessoa de Murilo Portugal, então Secretário do Tesouro Nacional, este 
desconheceu todo o processo de negociação havido, em que esteve presente na maioria das vezes e outras, apenas seu negociador Milton Dalari.

Murilo Portugal assinou o documento com a seguinte ressalva: "Ressalvo não concordar: a) que a necessidade mensal seja $R \$ 600$ milhões; b) que tenha havido compromisso quanto ao percentual a ser repassado em 10-7-94; c) que o montante de julho seja 506 milhões, e sim, 400 milhões."

Por que razão esse teto foi defendido pelo Ministério da Fazenda? O teto de $\mathrm{R} \$ 400$ milhões era a média do que havia sido pago, mês a mês, antes da entrada do Real. Entretanto, não se pode esquecer que essa média nada mais era que uma média falsa, pois os recursos devidos e cobrados na fatura eram, em média, equivalentes a $\mathrm{R} \$ 588 \mathrm{mi}$ e o pago, apenas $\mathrm{R} \$ 348 \mathrm{mi}$, portanto uma perda real, irrefutável de $41 \%$. Esse pagamento levou a que Estados e Municipios e os prestadores públicos e privados, cada vez mais, ficassem inadimplentes e sem condições de manter em funcionamento seus serviços. A base de cálculo, proposta pelo Ministério da Fazenda, era extremamente injusta, dado que utilizava uma desvalorização monetária de até $1,5 \%$ ao dia, com atraso do pagamento em até 110 dias. Essa proposta não era aceitável por ninguém envolvido na prestação de serviços ao SUS. Uma injustiça pagar uma conta de $R \$ 600$ milhões, por apenas $R \$ 400$ milhões, alegando-se que sempre foi assim.(56)

O impasse foi criado, a partir da ressalva de Murilo Portugal no documento de negociação, em que oficialmente se explicitou a idéia de que os serviços prestados não seriam pagos pelo valor real da tabela, mas pelo valor deflacionado em $41 \%$. Mais do que apenas uma afirmativa, a premissa se mostrou concreta, quando valores e datas de pagamento de faturas consagraram a prática da deflação.

O que ocorreu depois desse "quase acordo"? No dia 11-7-94, o Ministério da Fazenda repassou $\mathrm{R} \$ 132,00 \mathrm{mi}$ ao Ministério da Saúde. Esses recursos foram utilizados para as despesas do próprio Ministério da Saúde, seguindo Aviso Ministerial (documento oficial de comunicação entre dois Ministérios), de 29-6 e 7-7-94. No Aviso de 29-6-94, o Ministério da Saúde colocava como sua necessidade emergencial: $R \$ 138,1 \mathrm{mi}$, acrescidos de mais $R \$$ 130 mi para a CEME para as despesas próprias do MS. No Aviso de 7-7-94, o MS refez os zálculos e as prioridades e colocou sua necessidade em $R \$ 27,8 \mathrm{mi}$ para pagamento do estante da conta assistêncial de maio, e $\mathrm{R} \$ 128,5$ para suas despesas próprias, totalizando ₹ $\$ 156,3 \mathrm{mi}$. Era a previsão minima de despesas (excetuando pessoal) para o mês de julho te 1994. Lembre-se que, até então, acreditava-se que seria mantido o compromisso de ransferência, em julho de 94 , de mais $\mathrm{R} \$ 506$ mi para pagamento da Assistência. 
Concomitantemente, o Ministério da Fazenda declara que transferirá ao Ministério da Saúde para pagamento dos serviços produzidos, apenas $\mathbf{R} \$ 268 \mathrm{mi}$ (quando o compromisso era de repasse de $\mathrm{R} \$ 506 \mathrm{mi}$ ) em $1^{\circ}$ agosto.

Estava posto o impasse. Eram dois e graves os problemas. 1. O valor total que passa a ser $\mathrm{R} \$ 268 \mathrm{mi}$, e não $\mathrm{R} \$ 506 \mathrm{mi}$. 2. O pagamento da fatura de junho, previsto para ser feito em grande parte (66\%), em 10 de julho, só seria pago em 1 de agosto, ou seja, 20 dias após o combinado. Na verdade: 60 dias ou 45 dias em média após o serviço prestado.

Nesse momento, há uma grande "queda de braço" entre o Ministério da Fazenda e o da Saúde. O Ministério da Fazenda afirma que seu único compromisso era o de repasse de $\mathrm{R} \$ 400 \mathrm{mi}$, mensalmente, ao Ministério da Saúde. Esses recursos deveriam ser utilizados para o total de despesas próprias do Ministério da Saúde e para o pagamento das faturas com os Estados, Municípios e prestadores públicos e privados. Considerava que, tendo repassado $\mathrm{R} \$ 132 \mathrm{mi}$, em 11-7-1994, só restava o repasse de $\mathrm{R} \$ 268 \mathrm{mi}$, o que faria em $1^{\circ}$ de agosto. De outro lado, o Ministério da Saúde tinha a realidade de suas despesas próprias. Tais despesas incluiam a Fundação Nacional de Saúde, com seus hospitais, postos, vacinação, combate a epidemias e endemias; os hospitais próprios do Ministério da Saúde, a CEME e outros. O Ministério da Saúde tinha demonstrado essas necessidades, explicitamente, nos Avisos Ministeriais de junho e inicio de julho, citados anteriormente.

Ficava clara, assim, a ruptura entre o Ministério da Fazenda e o da Saúde, incluindo aí todo - grupo de negociação (CONASS, CONASEMS, CMB, CNS, FBH E FRENTE PARLAMENTAR DE SAÚDE).

Três alternativas estavam postas: 1. conseguir mais recursos para pagar o teto estipulado; 2 diminuir as despesas, pagando aos prestadores públicos e privados valores abaixo daquele definido na tabela (ou através de deflator na tabela ou de glosa de um percentual de atendimentos já feitos); 3 . diminuição sumária em, no mínimo, $30 \%$ dos atendimentos prestados à população.

Lembre-se de que fazer um deflator na tabela seria extremamente injusto, pois a tabela de procedimentos SUS já havia sido construida com valores médios. Esses valores (como explicado acima) tinham tido, no "acordo", um deflator de quase $10 \%$, pois não se converteu pelo valor do indice legal de 2.750 URVs, mas pelo do oitavo dia do mês posterior, 3013 URVs. (56)

Os representantes dos gestores públicos: Ministério da Saúde, CONASS e CONASEMS, que se constituem na Comissão Intergestores Tripartite (CIT), em reunião de 26-7-94, aprovaram os seguintes pontos: 


\section{"1. Não aceitar deflator na tabela de julho de 1994;}

2. Não aceitar menos de $R \$ 506$ milhões em junho;

3. Exigir recursos concomitantes para as demais atividades;

4. Não abrir mão da Universalidade/integralidade e demais princípios constitucionais do SUS;

5. Reconhecimento pelo Governo Federal de que as parcelas não pagas do custeio do SAI/SIH e demais atividades, constituem dívidas a serem pagas no mês seguinte (57).

Os representantes dos prestadores de serviços privados de saúde, conveniados e contratados com o SUS, resolveram tomar uma atitude depois de verem frustradas todas as suas tentativas de negociação. Em 26-7-1994 decidiram de comum acordo a CNS, CMB e FBH criar A Comissão Tripartite dos Prestadores Privados de Serviços de Saúde com "o objetivo de propugnar pelos princípios e finalidades de cada uma das representações integrantes, perante os poderes constituidos, respeitados os interesses e diretrizes de cada entidade." (94)

Os principais termos desta Resolução 001 de 26-7-94 são os seguintes:

"Tendo em vista uma nova situação de calamidade pública em vias de eclosão, com prejuizos irreversíveis à saúde e à vida do sofrido povo brasileiro, a Comissão Tripartite comunica que: 1. o acordo estabelecido em 21-6-94... não foi, nem deverá ser cumprido. 2. tal inadimplência do Governo Federal para com a rede de prestadores de senviços de saúde de todo o país, está reinstalando o caos financeiro e, em conseqüência, a impossibilidade material de atendimento à população na sua transcendental necessidade: a de proteger a sua saúde e preservar a vida dos cidadãos. 3. os demais acordos visando a manutenção do pagamento pelos serviços prestados, estimados em $R \$ 600$ milhões também não serão honrados sob pretexto de que faltam recursos financeiros; 4 . ... os dados comprovam não haver recurso para pagamento dos serviços prestados em junho, havendo apenas um vislumbre de possibilidade da liberação de $R \$ 280$ milhões no inicio de agosto. Tais valores serão descontados quando do repasse destinado à quitação dos serviços prestados em julho. Está formada a bola de neve. .... A situação se repetira com maior gravidade em julho, pois o Ministério da fazenda afirma que o volume de recursos a ser liberado mensalmente para o Ministério da Saúde é da ordem de $R \$ 400$ milhões destinados a cobrir todas as necessidades do órgão. No entanto as tabelas do SUS quando foram convertidas para o REAL, (com uma defasagem nos valores dos procedimentos de, aproximadamente 63\%)apontam para uma previsão de gastos mensais de $R \$ 600$ milhões que somados aos programas e demais despesas do Ministério da Saúde atingem $R \$ 911$ milhões mensais. O déficit de $R \$ 511$ milhões, segundo o Ministério da Fazenda, deverá ser absorvido pela rede privada de prestadores de serviços. Como isso é inadmissivel e imoral, medidas cabiveis serão adotadas contra o calote pretendido. 5. Sob Tais condições, a Comissão Tripartite, ora instituida, coloca ao governo brasileiro, inexoravelmente, uma das seguintes alternativas: pagar imediatamente o que deve aos prestadores de serviços de saúde, evitando assim, trágicas conseqüências para o povo, principalmente os mais carentes; o governo assumir, perante a nação, a responsabilidade de não só determinar a redução ou corte dos atendimentos ambulatoriais, internações, cirurgias etc. mas também pelas mortes que possam ocorrer em decorrência dessa drástica medida; 6 . Face ao exposto as entidades signatárias estão recomendando aos seus filiados para, a partir de segunda-feira, 1 de agosto, não mais aceitar pacientes do SUS, ainda que previamente autorizados pelos respectivos órgãos gestores (Secretarias Estaduais e M1unicipais de Saúde). 7. a fim de resguardar o bom nome dos prestadores privados de senviços de saúde, a Comissão Tripartite já encaminhou interpelação extrajudicial a todos os 
integrantes do Grupo de Trabalho Interministerial para racionalização dos gastos com saúde, a fim de que nomeiem quais os possiveis fraudadores e quais os partícipes do aludido "pacto de fraude", conforme consta em seu relatório final. 8. Finalmente, a Comissão Tripartite comunica que a população deve ficar ciente de que as recomendações ora transmitidas visam única e simplesmente preservar a integridade das instituições de saúde as quais não podem arcar com os ônus dos atendimentos sob pena de incorrer no risco de não prestar a devida assistência aos pacientes por absoluta falta de recursos materiais e humanos." (90)

No dia 18 de agosto de 1994, as entidades componentes da Comissão Tripartite de Prestadores enviaram oficio ao Presidente Itamar Franco, relatando a situação de calamidade em que se encontrava o setor saúde e solicitando uma audiência.

Alguns trechos deste ofício:

“ $A$ redução proposta sob este artificio de raciocínio frio e irresponsável (pagar $R \$ 400$ mi para uma fatura de $R \$ 600$ mi), praticado pela equipe econômica do governo, significaria restringir em $33 \%$ o acesso aos serviços e ações de saúde, de uma população já tão precariamente atendida no seu mais elementar direito à plena cidadania.

Não se pode raciocinar, em matéria de direito à Saúde, como se estivessem limitando a oferta de roupas, sapatos, parafusos, etc., sob pena de instalarmos uma convulsão social de proporções inimagináveis.

A redução dos senviços ocasionará por força de conseqüência, a demissão maciça de trabalhadores na área de saúde, além de onerar o já combalido sistema com os custos altos dessas demissões, o que não poderá ser suportado pela rede de hospitais e serviços de saúde.

Não há reforma econômica, Senhor Presidente, passível de ser implantada em meio à revolta e a convulsão social, que decorreriam desse triste quadro.

O Plano não poderia, antes mesmo de sua plena implantação, ter como uma de suas premissas mais importantes o corte nos recursos da Saúde e, em conseqüência, no atendimento à população desvalida. Para evitar esta crise sem precedentes na história do Brasil, a qual, sem dúvida, será debitada ao Governo de Vossa Excelência, as entidades signatárias apelam para Vossa Decisão de Governante. Jamais governo algum teve a audácia de dizer aos prestadores de serviços que não iria honrar os serviços já contratados, autorizados e prestados em volume e valores publicados no Diário Oficial da União bem como aqueles a serem prestados nos meses subseqüentes, por força de um contrato que vigora há mais de trinta anos.

Este é um fato inédito.

Também não é verdade que os prestadores de serviços fraudem o Sistema em escandalosos $28 \%$. Apenas a deliberada confusão entre insuficiência e equivocos nas anotações com intenção de fraudar, que mesmo somadas não atingiram aquele patamar, explica essa coincidência com percentual de redução dos gastos reais de Saúde, pretendidos pelo Ministério da Fazenda. Por isso mesmo não foram divulgados os dados e provas fundamentando aquelas informações, o que continuamos aguardando.

O segundo objetivo desta é apelar para a intervenção pessoal de Vossa Excelência, no sentido de se evitar o caos, determinando às autoridades da Fazenda que respeitem os 
compromissos assumidos pelo Governo através do Ministério da Saúde, e principalmente pelo disposto na Constituição da República e leis ordinárias."

Em circular da Comissão Tripartite de Prestadores 002/94, de 23 de agosto de 94, é feito um retrospecto de tudo que tinha ocorrido nas negociações anteriores ao real.

“ O acordo assentado especificamente nos prazos de pagamento, não foi cumprido pelo Governo e não conseguimos qualquer garantia de que cronogramas futuros seriam respeitados. Este fato, autoriza as entidades a se insurgirem contra a conversão efetuada, recorrendo mesmo, à justiça, caso a categoria assim o determine.

O Ministério da Fazenda tenta perpetuar o volume de despesas em 400 milhões de reais mensais, embora os serviços contratados e prestados ultrapassem aos 600 milhões de reais, apesar de todos os argumentos apresentados pelos técnicos do Ministério da Saúde, apesar das planilhas de cálculos e apesar até mesmo, das declarações do Exmo.Sr. Ministro da Saúde, além de diversas matérias, estudos, dados e pronunciamentos das Entidades integrantes da Comissão Tripartite dos Prestadores.

Considerando finalmente que:

I - O Ministério da fazenda insiste na redução dos recursos de AlH (Autorização de Internação Hospitalar) e UCA (Unidade de Cobertura Ambulatorial) para niveis de 400 milhões de reais, com corte de, aproximadamente, 33\% (trinta e três por cento);

II - Que já existe Tabela de Procedimentos em reais, publicada que deve remunerar todos os serviços contratados e prestados pela rede privada;

III - Que o Ministério da Saúde se insurge contra qualquer tipo de redução de serviços prestados à população;

IV - Que já se instalou no Governo Federal, autêntica batalha entre os Ministros da Saúde e Fazenda, em torno de assunto tão relevante;

$V$ - Que, desse confronto, graves prejuizos advirão para a nossa categoria, impõem-se a cada prestador de senviços, como empresário, a reflexão e a decisão sobre a conveniência ou não de reduzir o volume de serviços prestados, avaliando o risco de, não o fazendo, expor sua empresa à insolvência ou prestará serviços, correndo o risco de não receber.

Contudo, as entidades continuarão sua luta, no sentido de evitar que triunfe a tese da redução de recursos para os atendimentos, tentando despertar a vontade politica do Sr.Presidente da República, com a finalidade de interferir nessa pendência entre ministérios o que só ocasionará prejuizos aos usuários" (89)

A crise de agrava, sem solução definitiva. Os repasses de recursos do Ministério da Fazenda ao Ministério da Saúde, escassos e com grande defasagem entre o dia dos serviços prestados e o do pagamento aos prestadores.

Culminando as negociações de agosto de 1994, o Ministro da Saúde conseguiu uma posição do Presidente Itamar Franco em relação ao assunto. Os valores necessários, mensalmente, para a saúde, somavam cerca de $\mathrm{R} \$ 911$ milhões, sendo $\mathrm{R} \$ 600$ milhões para a prestação de serviços por terceiros e $\mathrm{R} \$ 311$ milhões, para as demais despesas do Ministério da Saúde , excetuando-se cerca de $\mathrm{R} \$ 200$ milhões, destinados ao pagamento de pessoal. 
O que se conseguiu, nessa negociação direta com o Presidente Itamar Franco, foi que os recursos a serem destinados à saúde seriam da ordem de $\mathbf{R} \$ \mathbf{5 5 0}$ milhões mensais, sendo $\mathrm{R} \$ 500$ milhões para pagamento de AlH e RCA e, os restantes R\$50 milhões, para o Ministério da Saúde desenvolver suas atividades diretamente, sem incluir o pagamento de pessoal. A redução imposta era de $20 \%$ para os serviços prestados e de $80 \%$, para as atividades do Ministério da Saúde.

Em 30 de agosto de 1994, reuniu-se o Ministro Santillo com os membros da Comissão Tripartite de Prestadores na busca de um acordo transitório até o início do ano de 1995. Seria um esforço de ambos os lados para se adequar a um teto limite que se considerou como possivel. As entidades da Comissão Tripartite de Prestadores não se julgaram autorizadas a firmar o acordo e enviaram oficio consultando a categoria em 31-8-1994.

“Os representantes das entidades, argumentaram que os meses de julho e agosto deveriam ser pagos integralmente, pois os serviços já foram prestados. Quanto aos meses de setembro a dezembro, o Governo, com a redução anunciada, deverá assumir a responsabilidade do fato.

O Ministro Henrique Santillo ficou de baixar um ato do Ministério da Saúde, divulgando a redução dos recursos disponiveis para $R \$ 500$ milhões mensais.

Tendo em vista esta decisão governamental, que nos parece irreversível, concitamos, todos os prestadores a manter estreito contato com suas entidades estaduais que deverão, dentro do menor prazo possivel, convocar assembléia extraordinária para definir a posição oficial da categoria que será transmitida ao Senhor Ministro da Saúde, no momento oportuno.

Não faltem a esta assembléia, e, discutam até a exaustão os seus pontos de vista.

Entretanto, a partir de setembro, pela primeira vez, as regras do jogo foram expostas com crueza. A disponibilidade financeira era insuficiente para manter os mesmos serviços que vêm sendo prestados.

A decisão de continuar prestando serviços com a nova regra, adaptando-se à redução de recursos, a possibilidade de atender ao apelo do Ministro ou não, é privativa de cada empresa, que deve atender aos seus interesses e aos da população que serve.

Quanto aos serviços já prestados em julho e agosto, considerando irrenunciável o nosso direito de cobrança, até judicialmente, das diferenças a serem apuradas.

Para esta cobrança judicial deverão:

- Levantar os dados relativos aos serviços prestados em julho e agosto para posteriormente compara-los com valor efetivamente recebido.

Identificar a diferença devida encaminhando à sua representação estadual os documentos comprobatórios para efeito de cobrança judicial que será patrocinada pelas entidades." (91)

De outro lado, os Gestores Públicos de Saúde, Secretários Estaduais e Municipais de Saúde, através do CONASS e CONASEMS, respectivamente, estavam igualmente em situação de crise com a falta de pagamento dos serviços prestados. 
Em $1^{\circ}$ de Setembro enviaram ofício ao Ministro da Saúde, posicionando-se diante do novo teto de $\mathbf{R} \$ 550$ milhões, sendo $\mathbf{R} \$ 500$ para a Assistência e $\mathbf{R} \$ 50$ para as demais despesas do Ministério da Saúde, autorizado pelo Presidente da República. Do texto, destacam - se alguns tópicos:

"Preliminarmente o CONASS e o CONASEMS esperam que a medida de contenção anunciada, não se concretize, sob pena de o Governo e a Sociedade assistirem, em pouco tempo,ao colapso total das redes ambulatorial e hospitalar $e$ das ações preventivas e coletivas, umas e outras já mostrando deficiências no atendimento pela falta crescente de recursos. No fundo, a medida cogitada representaria mais um ato das autoridades fazendárias de menosprezo ao setor de Saúde, que, apesar do esforço dos dirigentes do SUS, ainda não consegue realizar plenamente os seus objetivos, decorrentes de mandamentos constitucionais e legais de assistência integral e gratuita à população. $O$ menosprezo do setor econômico à implantação de políticas sociais, sobretudo a saúde, ficaria mais acentuado ainda pelo rompimento de acordo do Ministério da fazenda firmado com o Ministro da Saúde, os gestores públicos estaduais e municipais e os prestadores privados de serviços de saúde, pelo qual se garantem hoje 600 milhões de reais/mês para assistência ambulatorial e hospitalar e não os $R \$ 500$ milhões de reais anunciados.

Entretanto, Senhor Ministro, se a hipótese da violência orçamentária se consumar, o CONASS e o CONASEMS não se omitirão; ao contrário, enfrentarão, solidariamente, com o Ministério da Saúde os efeitos negativos da restrição imposta ao SUS, e, sem abdicar da continuação da luta pela recuperação da parcela subtraida e por mais verbas para a saúde, denunciarão com mais ênfase e amplitude que a falha crônica de recursos para a ;área está levando a uma deteriorização progressiva do quadro sanitário brasileiro.

Que o Ministério da Saúde assuma como divida do MS, perante os gestores estaduais e municipais do SUS e prestadores privados, do pagamento dos serviços executados nos meses de julho e agosto, uma vez que foram autorizados tendo como base tabelas previamente publicadas e serviços autorizados." (76)

Esses fatos estavam na mídia como uma queda de braço entre o Ministério da Saúde e o Ministério da Fazenda.

"Fracassa tentativa de acordo entre ministros: Os ministérios da Saúde, Planejamento e Fazenda, não conseguiram chegar ontem a acordo sobre o repasse de verbas para a saúde. Henrique Santillo (saúde) e Beni Veras (planejamento) tem de apresentar hoje ao Presidente Itamar Franco, sugestões para cortar gastos com o setor saúde. Neste encontro, Santillo tentará convencer Itamar a elevar a verba. Santillo pressiona a área econômica para obter recursos mensais de cerca de $R \$ 650$ milhões para sua pasta. Desses R\$ 500 milhões são considerados indispensáveis. Na equipe econômica porém, há resistências. O argumento é que o Tesouro só dispõe de $R \$ 800$ milhões mensais para custear toda a máquina administrativa. Santillo disse que os gastos com outros programas do Ministério da Saúde exigem repasse de mais $R \$ 120$ milhões mensais. Mesmo sem garantia de verbas, Santillo evitou criticas à equipe econômica. Disse que pretendia compatibilizar as necessidades com a viabilidade orçamentária. O Ministro já usou palavras mais duras para se referir ao impasse sobre as verbas da Saúde. A maioria das criticas foi endereçada ao Ministro Beni Veras. Ontem , às 17:30, a Federação dos Hospitais ainda discutia com o Secretário do Tesouro, Murilo Portugal, a quitação da divida de julho do SUS (Sistema Único de Saúde) com os hospitais conveniados." (105) 
"Santillo diz que vacinação pára sem verba: Por falta de recursos, o Ministério da Saúde será obrigado paralisar os programas de aleitamento, de prevenção da AIDS e vacinação. A advertência é do Ministro Henrique Santillo que considera dramático o valor per capita de $R \$ 24,8$ repassado pelo Governo até agora. Estudos mostram que o Governo gasta hoje com um brasileiro doente o equivalente a $30 \%$ do que gastava em 1987, numa queda crescente".(106)

Em 6 de setembro, a Comissão Tripartite de Prestadores oficia ao Ministro Santillo:

"Considerando a declarada impossibilidade do Governo Federal em cumprir o acordo firmado entre a equipe econômica, Ministério da Saúde, Entidades Signatárias, CONASS e CONASEMS, com vistas à liberação de recursos financeiros da ordem de R\$600 milhões mensais para a cobertura dos gastos do SUS

Esclarecer ao povo brasileiro que a redução dos gastos mensais para $R \$ 500$ milhões obriga a reduzir os atendimentos até então prestados em $20 \%$, com o que não concordam e não aceitam medida tão drástica porque expõe os segmentos mais carentes da população à dor, sofrimento e falta de assistência.

Reivindicar ao Ministério da Saúde a manutenção dos atuais níveis de atendimento e o pagamento integral dos valores devidos, referentes aos meses de julho e agosto, com base nas tabelas vigentes bem como o pagamento das diferenças apuradas no mês de junho, da ordem de $29,89 \%$, resultantes da conversão do faturamento daquele mês pelo fator 3.572 em substituição daquele determinado pela Medida Provisória que dispõe sobre o plano real , fixado em 2.570.

Defender, por todos os meios legais, o recebimento dos valores acima mencionados, caso não haja solução conciliatória." (92)

De teor semelhante, a Comissão, em 14-9-94, enviou a Ciro Gomes, então Ministro da Fazenda, ofício, agora subscrito pelas entidades membro da Comissão e por parlamentares da Frente Parlamentar de Saúde. Solicita, complementarmente, "sejam agilizados os estudos para a concessão de linhas de crédito especiais aos prestadores privados de serviços de saúde, através dos órgãos creditícios oficiais, em valores baseados nos faturamentos globais dos meses de julho e agosto findos." (93)

Aviso Ministerial 1465, de 21 de setembro de 1994, do Ministro da Fazenda Ciro Gomes, ao Ministro da Saúde, Henrique Santillo, explicita oficialmente o acordo que tinha sido feito com - Presidente Itamar Franco do repasse de 550 milhões de reais/ mês para a saúde. Apresenta o cronograma de desembolso de $\mathrm{R} \$ 540$ milhões/ mês, segundo fontes Condiciona os restantes $\mathrm{R} \$ 10$ milhões a arrecadação de fonte. Ainda, acena que :

"Esclareço, outrossim, que as liberações mensais poderão vir a ser ampliadas para te cerca de $R \$ 600$ mi, caso a arrecadação do COFINS comporte esse crescimento.(....) Portanto considerada a necessidade de rigoroso controle das contas do Tesouro Nacional, imposta pela atual conjuntura, a ampliação das liberações para o Ministério da Saúde assume características de esforço extraordinário que o Governo Federal dedica a esse setor." (107) 
A Comissão Intergestores Tripartite, composta do MS, CONASS e CONASEMS, em sua reunião de 11-10-94, convidou os representantes dos Prestadores de serviços de saúde para uma reunião conjunta para análise de conjuntura do financiamento da saúde. Nessa reunião foi discutida uma estratégia de mobilização, para posterior definição.

“ 1. Garantia de pagamento total da fatura do mês. 2. Correções atuais ou futuras das tabelas ( a SAS está preparando estudos sobre as tabelas, para reordenar o sistema, levando em conta os índices de inflação e os dados da FIPE). 3. cortes nas despesas do SUS ou ajustes possíveis: o MS já analisou o assunto e concluiu que não é possível fazer cortes a curto prazo na prestação dos serviços, e os ajustes possíveis devem ser feitos através de controle/descentralização. O Coordenador da CIT reafirmou que é uma ilusão pensar em ajustes ou cortes nas tabelas para economizar, pois toda e qualquer economia de recursos do SUS tem que se transformar em mais oferta de atendimento, para atingir aqueles que não estão sendo atendidos. 4. Saldo - reconhecimento da divida - o Ministério da saúde reafirmou que o saldo será pago mês a mês, ficando, em conseqüência contas de maior número de meses a serem pagas em restos a pagar de 1995." (57)

Ficou, desta maneira, bem caracterizado não ter sido feito acordo nenhum entre o Ministério da Fazenda e o da Saúde, CONASS, CONASEMS, Entidades Prestadoras e Frente Parlamentar de Saúde.

O documento, citado de início e subscrito com reservas pelo Secretário do Tesouro Nacional, Murilo Portugal, descaracterizou-se como acordo. Não houve acordo escrito, pois as ressalvas feitas por ele eram profundas e essenciais. Esgotaram-se todas as tentativas de negociação: diretamente com Presidente Itamar Franco, com o Ministro da Fazenda Ciro Gomes e com o Ministro da Saúde Henrique Santillo que, estando do lado dos Estados e Municipios, bem como dos prestadores privados, nada podia fazer, dado que o MS não era órgão arrecadador de recursos.

Em 11-10-94, houve reunião da cúpula dirigente dos prestadores privados de saúde, que tomaram a decisão de sugerir às entidades entrarem judicialmente com pedidos de recebimento dos recursos, referentes ao pagamento de serviços já prestados. Surgiram ações em todo o território nacional. Alguns hospitais entraram individualmente, outros em grupo e, hoje, estão pipocando ações impetradas nos anos de 94 em diante.

A Federação Brasileira de Hospitais entrou com Ação ordinária de Cobrança em curso perante à $17^{a}$. Vara da Seção Judiciária do Distrito Federal, processo 95.6459-6. Gilson Carvalho, então Secretário Nacional de Assistência à Saúde, foi convidado a prestar esclarecimentos sobre o ocorrido nesse período. A declaração abaixo foi feita com reconhecimento de firma em Cartório e incorporada ao Processo acima.

A Declaração, em sua integra, é aqui apresentada: 
"Declaro, atendendo pedido da Federação Brasileira de Hospitais, na Condição de exSecretário de assistência à saúde do Ministério da Saúde, que entreguei cópia autenticada do documento intitulado "RESULTADO FINAL DA MESA DE NEGOCIAÇÃO (MS-MF-PRESTADORES)" No ministério da Saúde- SAS-DCAS que o deve ter repassado à Dra. Ana Valéria de Andrade Rabelo, representante da União Federal, a fim de quem pudesse ela instruir razões de apelação na Ação Ordinária de Cobrança em curso perante a $17^{\circ}$. Vara da seção Judiciária do Distrito Federal, processo 95.6459-6.

Declaro que referido documento, por mim elaborado, como memória de cálculo, não contem assinaturas finais dos representantes do Ministério da fazenda, Dr. Milton Dalari e Dr.Murilo Portugal; daquele porque não o assinou e deste porque o fez com observações restritivas e que negavam a proposta de acordo, razão pela qual este documento nem mesmo ficou arquivado no Ministério da Saúde, Secretaria de Assistência à Saúde. Consta, aliás, no mencionado documento, ressalva de discordância do Dr.Murilo Portugal, a saber:

Ressalvo não concordar: $\quad$ que a necessidade mensal seja $R \$ 600$ milhões; que tenha havido compromisso quanto ao percentual a ser repassado em 10-7-94;

que o montante de julho seja $R \$ 506$ milhões e sim $R \$ 400$ milhões.

(Rubrica de Murilo Portugal na lateral do documento.)

Declaro, mais, que existiam apenas duas partes nas negociações: de um lado o Ministério da Fazenda e de outro o Ministério da Saúde, com coordenação junto aos prestadores de senviços (FBH,FM, FENAES), os Secretários Estaduais e Municipais de Saúde (CONASS e CONASEMS). Registro o interesse do Ministério da Saúde numa conversão justa pois com ela seriam pagos todos os hospitais públicos, universitários e militares respectivamente do Ministério da Saúde, educação e Exército, os serviços de saúde dos Estados e dos Municípios e também, parte dos recursos seriam pagos aos Serviços Privados.

Declaro ter redigido e confirmo, integralmente, os termos do oficio dirigido ao Presidente da Federação Brasileira de Hospitais, no. 467/GS/SAS/MS de 20 de outubro de 1994, no qual explico que o "repasse do MF para o MS foi de apenas $R \$ 506$ milhões o que exigiu a aplicação de um DEFLATOR de $23,04 \%$ para se chegar ao limite financeiro repassado pelo MF".

Declaro, outrossim, que várias foram às reuniões nas quais alguns pontos obtiveram consenso, transcritos no documento por mim elaborado, tendo uma das partes, entretanto, o Ministério da Fazenda, estabelecido ressalvas as mais substantivas em relação aos temas em negociação, circunstância que não permitiu fosse o acordo efetivado e formalizado.

São José dos Campos, 16 de junho de 1997. Gilson de Cássia Marques de Carvalho (Firma reconhecida no $3^{\circ}$ Serviço Notarial de São José dos Campos - SP)" (56) 
Concluindo, pode - se afirmar com segurança: não houve nenhum acordo entre o Ministério da Fazenda, de um lado, e de outro, o conjunto do Ministério da Saúde, dos gestores públicos Secretários Estaduais e Municipais de Saúde e dos Prestadores Públicos e Privados de Saúde. Tudo que foi negociado durante meses rompeu-se no momento em que Murilo Portugal, do Ministério da Fazenda, fez as ressalvas que negavam tudo de essencial que antes tinha sido acordado. Tudo foi confirmado pela maneira como se efetuou o pagamento em valores e prazos.

Dai, pode-se julgar procedente que tenham havido ações, ainda hoje transitando, buscando receber diferenças entre o valor das faturas apresentadas e do pagamento efetuado pelo Ministério da Saúde.

Os recursos devidos, e reconhecidamente pendentes desse período, são:

- Faturamento de Junho de 1994 = diferença, a maior, de $29,89 \%$, resultante da conversão do faturamento daquele mês pelo fator de 3.572 , em substituição ao determinado pela Medida Provisória que dispõe sobre o Plano Real, fixado em 2.750.

- Faturamento de Julho de 1994 até o presente momento, e em todas as faturas e tetos daqui em diante $=$ diferença a maior de $9,6 \%$ resultante da conversão do faturamento do mês de julho pelo fator de 3.013 , em substituição ao determinado pela Medida Provisória, que dispõe sobre o Plano Real, fixado em 2.750.

Depois de anos de não pagamento desses valores, o montante correspondente das duas diferenças é estimado em vários, faturamentos mensais integrais a mais, corrigidos seus, valores. Essa defasagem de recursos, devidos por justiça, são suficientes para demonstrar a crise do setor nesse periodo e seu desfinanciamento crescente.

As diferenças são devidas a todos os prestadores públicos e privados incluindo-se, ai, as Secretarias Estaduais de Saúde e as Secretarias Municipais de Saúde. Conseqüentemente, municipios e estados, que à época eram prestadores de serviços e, hoje, estão em nivel de gestão plena, com tetos fixos estabelecidos, a partir de série histórica de produção, têm direito a pleitear em seus tetos o mesmo indice de correção.

O Governo federal continua ganhando juridicamente a causa, com todo seu poder e influência, como mostra a citação abaixo: 
“STJ NEGA A CORREÇÃO DA TABELA DO SUS - O governo começou a ganhar nos tribunais superiores as causas envolvendo o primeiro grande questionamento judicial do Plano Real: a correção, retroativa a 1994, da tabela de pagamentos feitos pelo SUS para os hospitais e clínicas conveniadas. Cálculos realizados pela Advocacia-Geral da União estimavam, no ano passado, que a discussão judicial pode gerar um desembolso imediato na casa de $R \$ 41$ bilhão e mais o aumento em pelo menos $R \$ 800$ milhões no orçamento anual do SUS. O presidente do Superior Tribunal de Justiça, ministro Paulo Costa Leite, suspendeu oito decisões dos Tribunais Regionais Federais e também da justiça Federal que autorizavam a correção de 9,56\% na tabela do SUS. Apenas uma dessas decisões beneficiava 89 hospitais, a maioria deles entidades privadas, dos estados do Rio Grande do Sul, Santa Catarina e Paraná. Surpreendentemente, embora particulares, eles estavam representados em ação civil pública pelo Ministério Público, que por lei não pode defender interesses privados. Outras sete ações suspensas pelo STJ eram individuais e envolviam hospitais de Curitiba e Maringá, no Paraná, de Porto Alegre e Novo Hamburgo, no Rio Grande do Sul, além de Goiânia. Costa Leite acatou os argumentos da Advocacia-Geral da União, de que mantidas as decisões dos TRF's e da primeira instância, elas provocariam um prejuizo de aproximadamente $R \$ 1$ bilhão aos cofres públicos. Isto porque, de acordo com a AGU, cerca de 300 hospitais e clinicas particulares que já acionaram a Justiça podem ser beneficiados pelas liminares e tutelas antecipadas - pagamento dos valores reclamados antes da decisão final do processo. Em função desta argumentação, o presidente do STJ entendeu que "vislumbra-se no caso o gravame ao sistema de saúde pública como um todo". A AGU também argumenta na matéria que nas reuniões realizadas em 1994 entre a Secretaria de Assistência à Saúde, do Ministério da Saúde, e a Federação Brasileira de Hospitais (FBH), foi acertado que o fator de conversão do cruzeiro real para real, para fins de correção da Tabela do SUS, seria 3.013, ao invés de 2.750. Ainda segundo informações da AGU, os hospitais, posteriormente, teriam desconsiderado o acordo feito com o governo e passaram a reclamar em massa esta diferença - de 9,56\% - na Justiça. "(96)

\section{O FINANCIAMENTO FEDERAL PARA A SAÚDE NO GOVERNO ITAMAR - CRISES}

\section{E AVANÇOS DE FINAL DE GOVERNO}

\subsection{A CRISE GERADORA DE COMISSÕES}

Em 1994, permanecia Presidente da República Itamar Franco e, como Ministro da Saúde, Henrique Santillo. A crise financeira do SUS continuava aguda e crônica. Era época de implantação paulatina do Plano Real. Havia uma conspiração real, forte, de grupos "palacianos" para desestabilizar o Ministro Santillo. Faziam parte desse conluio o Ministro Veras do Secretaria de Planejamento, Orçamento e Coordenação da Presidência da República (Seplan-PR) e seu executivo Raul Jungman, o Ministro Rubens Ricupero, da Fazenda, e o Secretário do Tesouro Nacional, Murilo Portugal. Foi assim que se criou uma crise de autoridade na ausência do Ministro da Saúde, em viagem à Suiça para reunião da Organização Mundial da Saúde. Foi como se tentasse uma intervenção branca no MS, tendo, como pano de fundo, o financiamento da saúde. A ousadia chegou a ponto de ser 
assinado um Decreto Presidencial, criando um Grupo de Trabalho Interministerial voltado para a racionalização dos gastos com a saúde e a melhoria do atendimento à população. Esse decreto, diferente dos demais que trazem a assinatura do Presidente e dos Ministros envolvidos na área, trouxe apenas a assinatura do Presidente e de Beni Veras, Secretário do Planejamento. O Decreto ia ser publicado, sem representação do MS. Negociações de última hora, por via telefônica, incluiram como representante da saúde o então Secretário de Assistência à Saúde do MS, Gilson de Cássia Marques de Carvalho, cujo nome saiu incorreto (Gilson de Assis Marques de Carvalho), exatamente devido a apenas ter sido incluído de última hora e por uma intervenção telefônica. Esse Decreto tem apenas três artigos, sendo o principal deles: "fica constituído, no âmbito da Secretaria de Planejamento, Orçamento e Coordenação da Presidência da República (Seplan-PR), Grupo de Trabalho Interministerial com o objetivo de, no prazo de 45 dias avaliar e propor alternativas que viabilizem a racionalização e assim o ideal aproveitamento dos recursos alocados à saúde." Nomeados para a mesma Comissão estavam Murilo Portugal (Secretário Nacional do Tesouro) Raul Jungman (Secretário Executivo da SEPLAN-PR) Osíris Lopes (Secretário da Receita Federal), Antônio Guerra (Diretor Executivo do IPEA), Gilson Carvalho (Saúdè) e Álvaro Ribeiro Costa (Subprocurador Geral da República). Este último ficou apenas como observador, já que, por sua função, não poderia participar de Grupos de Trabalho do Executivo. (25)

A seguir é apresentado o Relatório Final, com as conclusões do Grupo de Trabalho Interministerial para a racionalização dos gastos com saúde e melhoria do atendimento à população.

"APRESENTAÇÃO - O Grupo de Trabalho Interministerial criado pelo Decreto Presidencial de 04 de maio de 1994, com base nos relatórios parciais dos Grupos Temáticos e nos subsidios preparados pelo IPEA, apresenta a seguir o resumo da sua posição sobre os dois pontos básicos, objeto do trabalho, ou seja: racionalização dos gastos com saúde; e a melhoria do atendimento à população.

Enfatize - se que o objeto deste relatório é o papel do Governo Federal no Sistema Único de Saúde - SUS, e que é este, exclusivamente, o destinatário de suas constatações e propostas.

Participaram do trabalho equipes técnicas do Ministério da Fazenda (Secretaria do Tesouro Nacional - STN e Secretaria da Receita Federal - SRF), da SEPLAN/PR (Secretaria de Planejamento e Avaliação - SPA, Secretaria de Orçamento e Finanças SOF, Secretaria de Controle Interno - CISET, Instituto Brasileiro de Geografia e Estatística - IBGE e Instituto de Pesquisa Econômica Aplicada - IPEA), do Ministério da Saúde (Secretaria de Assistência à Saúde - SAS, Secretaria de Administração Geral SAG, Secretaria de Vigilância Sanitária - SVS e Fundação Nacional de Saúde - FNS), do Conselho Nacional de Secretários Estaduais de Saúde - CONASS e do Conselho Nacional de Secretários Municipais de Saúde - CONASSEMS. 
a) Os recursos públicos alocados à área de saúde são relativamente baixos, em termos internacionais, representando, em 1990, 3,19\% do PIB. Incluindo - se uma estimativa do gasto privado, chega - se a um total de $4,77 \%$ do PIB (estimativa para 1989).

b) A partir de maio de 1993, com a suspensão dos repasses da Previdência Social ao SUS, o Tesouro Nacional foi obrigado a arcar com todo o custeio do sistema de saúde na área federal. As liberações de recursos para esse fim representaram, de janeiro a junho de 1994, cerca de $60 \%$ do total liberado para custeio e investimento, excluídas as transferências e vinculações constitucionais, despesas de pessoal e pagamentos de encargos da divida interna e externa. Em outras palavras, a saúde absorveu quase 2/3 dos recursos de custeio e investimento de livre alocaçăo no Orçamento da União.

c) Tendo - se em vista que as autorizações de internação hospitalar AlH são emitidas, para cada ano, com base em um percentual de $10 \%$ da população residente, constatou - se, para 1994, uma emissão de mais 400mil AlH do que as 15,3 milhões necessárias, adotando - se o citado critério. Este excesso de internações autorizadas reflete, simplesmente, o uso pelo SUS de uma estimativa da população nacional de 157 milhões de habitantes, o que excede em 4 milhões a estimativa oficial do IBGE de 153 milhões de habitantes.

d) O próprio uso do percentual de $10 \%$ reflete um padrão de atendimento onde supostamente um a cada dez brasileiros é internado em um hospital durante o ano. Reflete assim, um modelo fortemente centrado na atenção hospitalar, reconhecidamente caro e ineficiente.

e) Os sistemas de controle e auditoria, nos três niveis de governo, são ineficientes e vulneráveis. Auditorias localizadas, realizadas pelo Ministério da Saúde, revelam que as fraudes, inconsistências e irregularidades no sistema de pagamento por serviços (AlH/UCA - Autorização de Internação Hospitalar/ Unidade de Cobertura Ambulatorial) chegam, na média nacional, a $28 \%$ dos valores pagos. Muito embora sejam dados preliminares, sujeitos a reavaliação, indicam a potencial gravidade dos problemas.

f) Em torno de $75 \%$ dos recursos destinam - se à área da assistência médico hospitalar, cujos procedimentos são os mais caros, o que gera distorções no modelo assistencial, privilegia a medicina curativa e contraria o dispositivo constitucional (art. 198) que, explicitamente, prioriza ações preventivas. Há, no entanto, que se considerar a relativa incompressibilidade dos gastos com assistência médico - hospitalar, fruto das demandas provocadas pelo atual perfil nosológico da população brasileira

g) As AlH são pagas tendo por base um sistema de informações vulnerável às fraudes e à corrupção.

h) Não existem sistemas de apuração de custos que permitam a elaboração de tabelas de pagamento baseadas em custos reais dos procedimentos, tornando problemáticos os processos permanentes de auditagem.

i) Os recursos transferidos para investimentos pelo Governo Federal a Estados e Municipios têm obedecido, historicamente, a critérios politicos, em detrimento a critérios técnicos. Perde - se, assim, um poderoso instrumental para a correção de distorçöes na distribuição espacial da oferta de serviços de saúde.

j) Estados e Municipios deixam, muitas vezes, de cumprir suas contrapartidas de recursos às transferências federais. Em certos casos, observa - se, inclusive, uma retração das alocações de recursos de origem estadual e municipal aos programas de saúde.

k) Os recursos federais ainda predominam na estrutura de custeio da saúde. Em 1990, último ano para o qual se têm estatística para as três esferas de governo, os recursos 
federais responderam por $72,7 \%$ do gasto total público em saúde, enquanto recursos dos Estados e Municipios, correspondiam a, respectivamente, 15,3\% e 12,0\%. Para o mesmo exercício a distribuição da receita tributária disponível total, por esfera de governo, foi a seguinte: União - 56,6\%; Estados - 28,5\%; Municípios - 14,9\%.

l) Existe uma tendência a gastos crescentes com saúde, devido a fatores universais de pressão sobre despesas, a exemplo de envelhecimento da população, elevação de custos médicos (entre 91 e 92 constatou - se que ela foi cerca de 100 pontos acima do IGP), incorporação de novas tecnologias e surgimentos de novas epidemias.

m) Alguns Estados e grande número de Municípios, principalmente os de pequeno porte, têm insuficiente capacidade técnica para a execução e controle das ações de saúde.

n) O processo de descentralização dos senviços de saúde está incomṕleto.

o) A estrutura do MS é pouco funcional para atender às necessidades de planejamento, supervisão e normatização de um sistema descentralizado.

p) O MS mantém ainda significativas atividades executivas nas áreas epidemiológica, de vigilância sanitária, e de própria assistência médica, esta última de caráter emergencial e transitório.

q) Normas de contratos de prestação de serviços de hospitais e ambulatórios privados, já definidas, não foram implantadas.

r) Há evidências de que empresas contratadas para processar as AlH/UCAs, fraudam o sistema.

s) Existe desinformação do paciente quanto aos custos e débitos imputados ao sistema/governo pelos procedimentos a que é submetido, embora já exista portaria neste sentido.

t) É freqüente a situação de médicos e outros servidores da área de saúde com militância simultânea no setor público e no setor privado - "dupla militância" - o que, aliado ao absenteísmo e falta de controle, tornam hospitais e ambulatórios inadministráveis.

u) A rede de serviços de saúde é mal distribuída, gerando concentração em determinadas áreas, metrópoles do Sul/Sudeste, e "vazios" hospitalares e ambulatoriais em outros, em particular o Norte, Centro - Oeste, Nordeste e Zona Rural. Isto demonstra, claramente, a falta de critérios que, historicamente, presidiu a instalação dos serviços de saúde no Pais.

v) Existe transferência de custos privados para o setor público, mediante o repasse dos casos crônicos, terminais ou complexos/caros dos planos de saúde supletivos (medicina de grupo, seguro saúde, planos de auto -gestão inclusive de órgãos governamentais, etc.) para os estabelecimentos do SUS.

\section{DIAGNOSTICO}

1) O estado atual do Sistema Único de Saúde - SUS - é preocupante. Seus controles gerenciais, econômicos e financeiros são frágeis, salvo em setores e áreas especificas elou localizadas.

2) A questão do financiamento, muito em evidência, não pode ser analisada independentemente da discussão da eficiência e eficácia do gasto. Os recursos são poucos, mas pode - se dizer que, na grande maioria do casos, gasta - se mal.

3) Como vício de origem e no cerne das vicissitudes do SUS, está a chamada "questão do terceiro pagador": os pacientes demandam mais e melhores serviços (sem, no 
entanto, pagar diretamente por eles); um prestador lucra, cada vez mais, pela prestação maior de serviços; e um "terceiro pagador", o contribuinte de tributos, através do governo, paga a conta. Este último tem, quando muito, o poder de auditar todo o processo. O resultado é inevitável: tendência à expansão do gasto e falta de incentivos a racionalização, eficiência e eficácia.

4) Se esta tendência é universal e não brasileira, a combinação nefasta do pior da centralização e da descentralização é, indubitavelmente, nossa. Desmantelou - se todo - ou quase todo - o aparato anterior, e temos tido dificuldades em implantar um novo modelo. A descentralização inacabada, tanto quanto a centralização insepulta, postergam a constituição de um melhor controle público na área da saúde.

5) Na medida em que se desarticularam os controles, a auditoria e o sistema de informações, já precários ao nível do INAMPS, abriu - se espaço para a persistência de toda uma cultura clientelistica, faltando, ainda, ao sistema transferência e eticidade.

6) Falta clareza na definição de responsabilidades no SUS: o Prefeito e o Governador gastam, mas, quem paga a conta, na maioria dos casos, é a União, distribuindo - se, assim, a primeira vantagem de uma efetiva descentralização, que é a proximidade entre contribuinte, o prestador de serviços e a autoridade responsável pelo gasto público.

7) Já, o relacionamento do SUS com o setor privado acaba gerando um "pacto de fraude", onde às baixas remunerações unitárias pagas, corresponde o seu superfaturamento posterior.

8) Aos antigos sistemas de planejamento e controle do INAMPS, sem sombra de dúvidas ineficientes e precários, mesmo porque centralizados, sucedeu - se, freqüentemente, o vácuo quase total em termos de gerência, sendo a informação básica pouco disponivel.

9) Em suma, reiteramos ser a descentralização condição necessária ao funcionamento da Saúde, mas, de nenhuma forma suficiente. A extensão da cobertura de saúde dos segurados da previdência à totalidade da população brasileira - conquista inegável do SUS, foi acompanhada por uma progressiva deteriorização da qualidade dos serviços.

10) Este caos foi herdado pelo Governo Itamar Franco, o qual tem enviado esforços para sua superação. O orçamento relativo à área de saúde submetido ao Congresso Nacional para o exercício de 1994, que em muito excede a média dos orçamentos dos últimos 10 anos, demonstra claramente a prioridade atribuída a este importante segmento da politica social. É importante, também, que se destaque, a partir de 1993, a reversão do declínio na alocação dos recursos do Tesouro, isto ao tempo em que a Saúde perde a cobertura tradicional dos recursos previdenciários, num contexto de aguda crise do Estado nacional, busca, sem tréguas, do equilibrio fiscal e da estabilização da economia.

11) As propostas que se seguem convergem para as necessárias medidas e estudos condizentes com a reestruturação do gasto público em saúde no Brasil, visando à melhoria do atendimento à população.

12) Mesmo reconhecendo os limites do alcance das sugestões propostas adiante, julga - se importante dar início a uma de ações imediatas e concentradas, com o objetivo de assegurar à área da saúde os instrumentos essenciais para o cumprimento de suas relevantes funções sociais.

\section{RECOMENDAÇŐES}

a) Realização de estudos, com vistas a uma futura revisão constitucional, a serem elaborados por técnicos dos Ministérios da Fazenda e Saúde e coordenadas pela SEPLAN, objetivando o custeio da prestação de serviços de saúde, diretamente por 
Estados e Municipios, no contexto das disposições constitucionais de descentralização e consolidação do SUS, retendo a União apenas a capacidade financeira para o equilibrio das disparidades regionais.

b) Contratação pelo MS de auditoria independente nos processos operacionais, financeiros, contábeis e patrimoniais do SUS, inclusive das empresas processadoras dos dados de AlH/UCA nos Estados e Municípios.

c) Recrutamento e/ou reciclagem do contingente necessário de autoridades de saúde, nas três esferas de governo, formando um núcleo orientado para o controle e avaliação do SUS e prevenção de fraudes e irregularidades.

d) Prosseguimento da reestruturação do MS, já encaminhada à SAF, a fim de compatibilizá - lo com as atribuições de gestão de um sistema descentralizado de saúde, limitando a expansão da rede federal ao que determina a Constituição.

e) Limitação das transferências negociadas aos investimentos em recuperação e expansão da rede assistencial pública, previstos em planos diretores estaduais e com o compromisso de contrapartida da unidade federada ou Município.

f) Revisão e aperfeiçoamento de cadastro de estabelecimentos de saúde contratados e conveniados.

g) Exigência da implantação de sistemas de apuração e análise de custos ao nivel de Estados, Municipios e unidades operacionais (hospitais e ambulatórios).

h) Proposição da criação de alçada independente e de aperfeiçoamento dos mecanismos de contratação e descontração de serviços de saúde ao setor privado, não vulneráveis às pressões politicas e/ou corporativas, inclusive com procedimentos baseados em licitação pública e fiscalização pelos Conselhos de Saúde nas várias esferas de governo.

i) Exigência do cumprimento das normas gerais, já editadas pelo MS, para contratação de unidades de prestação de serviços por parte de Estados e Municipios.

j) Suspensão, por prazo indeterminado, de modificações em tabelas de AlH/UCA que importam em aumentos de custos, já em vigor.

k) Implantação efetiva da conta hospitalar única, possibilitando ao cidadão, mediante comprovante/extrato, o controle dos lançamentos/custos correspondentes ao serviço que Ihe foi prestado.

l) Garantia do repasse efetivo dos recursos previstos na proposta orçamentária para 1994, e programação financeira correspondente, acordada entre o MF e o MS, com base no desempenho da arrecadação.

m) Realização de experiências piloto em cinco Estados, sendo um por região em 100 Municipios, definidos em razão da NOB 01/93 e na lei 8142/90, em substituição ao atual sistema de compra de serviços, compreendendo: - $m 1)$ repasse automático de recursos para custeio da rede de serviços, segundo critérios semelhantes aos do Fundo de Participação dos Municípios, até que se regulamente o art. 35 da lei 8080/90; m2) implantação de programa de recuperação dos serviços de emergência da rede hospitalar pública desses Estados e Municipios; m3) transferência aos Estados e Municípios citados da responsabilidade de gestão dos serviços de saúde, inclusive daqueles contratados com a iniciativa privada.

n) Reexame dos quantitativos de AIH/UCA, segundo dados de população residente, aceitos pelo IBGE. 
o) Adoção, no prazo de 60 dias, de medidas que visem à redução e progressiva eliminação da "dupla militância" de prestadores de serviços médicos e auditores da área da saúde.

p) Implantação, no prazo máximo de 60 dias, do Sistema Nacional de Auditoria, na forma prevista pelo art. 16, inciso XIX, da Lei 8080/90.

q) Implantação, no prazo máximo de 90 dias, de um sistema de processamento de dados descentralizado nos Estados e Municípios, em substituição ao atual DATASUS, reservando - se ao Ministério da Saúde, apenas, as funções de consolidação de uma base de dados estratégicos para o planejamento e controle das funções das ações de saúde ao nivel federal.

r) Proposição, dentro de 60 dias, de mecanismo de reembolso do SUS dos custos de atendimento prestado a beneficiários de planos de saúde.BSB 7/94.

Raul Belens Jungmann Pinto - Secretário Executivo - SEPLAN - PR, Coordenador; Murilo Portugal Filho - Secretario Nacional/MF - STN. Osires de Azevedo Lopes Filho Secretário Receita Federal/MF - SRF; Gilson de Cássia Marques de Carvalho Secretánio de Assistência à Saúde; Antonio José Guerra - Diretor Executivo do IPEA ; Álvaro Augusto Ribeiro Costa - Subprocurador Geral da República. (129)

Esse relatório passou por momentos de extrema polêmica, antes de sua concretização. $\mathrm{A}$ primeira versão era totalmente contrária ao $\mathrm{MS}$, representação minoritária no Grupo. A condução por Raul Jungman, Secretário executivo da SEPLAN, em todas as reuniōes, foi considerada extremamente tendenciosa. Não se conseguiu chegar a um completo consenso, o que levou a que o representante do MS fizesse uma declaração de voto, em separado, apresentando algumas ressalvas.

As ressalvas apresentadas foram as seguintes:

No item " $n$ " das constatações, onde se lê : "o processo de descentralização dos serviços de saúde está incompleto" acrescente-se o termo "por falta de descentralização do financiamento". Nessa época, o grande empecilho para a descentralização era a descentralização do financiamento e os prefeitos se mostravam reticentes em receber as tarefas, até então desenvolvidas pela União, mas sem os fundos financeiros correspondentes para bem desempenhar suas funções.

No item " $r$ " das constatações, onde se lê: "há evidências de que empresas contratadas para processar as AlHS-UCAs, fraudam o sistema" deve-se substituir o termo evidências por suspeitas e acrescentar, no final, "contratadas pelos Estados, Municipios e Privados" . A primeira alteração do termo é essencial, pois afirmar categoricamente que existem evidências, a pergunta seguinte deveria ser: quais medidas judiciais foram tomadas para se punir as evidências? $\mathrm{O}$ que fizeram os administradores que tinham essa evidência? $O$ ponto seguinte de se afirmar é que estes contratos ainda que pudessem parecer como do MS com os processadores privados de informáticas, suspeitava-se que ocorresse isto em contratos 
feitos pelos Estados, Municípios e pelo Setor privado. A acusação é de que houvesse um conluio entre processadores e gestores para que se superfaturassem as faturas em valor ou quantidade.

No item 10 do diagnóstico, onde se lê: "O orçamento relativo à área da saúde submetido ao Congresso Nacional para o exercício de 1994, que em muito excede a média dos orçamentos dos 10 últimos anos..." deve-se suprimir este pedaço de frase "que em muito excede a média dos orçamentos dos 10 últimos anos", por não corresponder à verdade, pois no Governo Sarney, antecessor de Collor, o investimento em saúde representava, pelo menos, uma vez e meia o orçamento previsto para 1994. No mesmo item, depois da expressão "política social" deve-se acrescentar "embora se tenha realizado apenas $34 \%$ do previsto nos seis primeiros meses do ano" . A afirmação era de que o destino do dinheiro apontava para a priorização do social, mas na verdade um orçamento de 12 meses, em média, deveria ter executado pelo menos $50 \%$ ou, até mais que este percentual, mas não o baixo percentual de $34 \%$.

No item "q" das recomendações, referia-se à implantação, no prazo máximo de 90 dias, de um sistema de processamento de dados descentralizado nos Estados e Municípios, em "substituição ao atual DATASUS". A ressalva era de se suprimir a exp̣ressão em substituição ao atual DATASUS. O que estava por trás disso era a proposta de se privatizar o sistema de informatização nos Estados e Municipios, quando defendiamos, de outro lado, a descentralização da DATASUS e não sua extinção.

Tendo sido concluido o estudo do Grupo de Trabalho de representantes ministeriais de primeiro escalão, cujas principais conclusões encontram-se elencadas acima, foi constituido agora não mais um Grupo de Trabalho mas uma Comissão para propor medidas relativas à racionalização dos gastos com a saúde e melhora do atendimento à população. A recomendação "a", do relatório acima, explicita o que se esperava dessa comissão :

"Realização de estudos, com vistas a uma futura revisão constitucional, a screm elaborados por técnicos dos Ministérios da Fazenda e Saúde e coordenadas pela SEPLAN, objetivando o custeio da prestação de serviços de saúde, diretamerite por Estados e Municipios, no contexto das disposições constitucionais de descentralização e consolidação do SUS, retendo a União apenas a capacidade financeira para o equilibrio das disparidades regionais".

Seria uma comissão mais de caráter executivo para propor e implementar medidas já sugeridas no relatório acima. O texto do Decreto, de 30-8-1994, é o abaixo: (24)

"Considerando o relatório conclusivo do Grupo de Trabalho interministerial criado pelo Decreto de 4 de maio de 1994, para a racionalização dos gastos com saúde e melhoria do atendimento à população, decreta:

Art. $1^{\circ}$ Fica instituida Comissão Interministerial com o objetivo de: 1 - apresentar propostas de medidas que objetivem estabelecer o custeio da prestação de serviços de 
saúde pelos Estados e pelos Municípios, reservando à União a capacidade financeira para o equilibrio das disparidades regionais; II - indicar e implementar medidas para a contratação, pelo Ministério da Saúde, de auditoria independente nos processos operacionais, financeiros, contábeis e patrimoniais do Sistema Único de Saúde (SUS); III - propor e implementar medidas que aperfeiçoem o processo de contratação de serviços de saúde junto ao setor privado, com procedimentos baseados em licitação pública e fiscalização pelos Conselhos de Saúde; IV - propor e implementar medidas visando à progressiva extinção de situações em que sejam acumuladas as funções de prestador de serviços médicos e de auditor da área de saúde; $V$ - propor medidas que estabeleçam o ressarcimento pelos beneficiánios de planos de saúde, das despesas de atendimento médico prestado pelo SUS.

Art. $2^{\circ}$ A Comissão Interministerial será coordenada pelo Secretário-Executivo do Ministério da Saúde e integrada por dois representantes de cada um dos seguintes órgãos, designados pelo Ministro de Estado da Saúde; I - Ministério da Saúde; II Ministério da Fazenda; III - Secretaria de Planejamento, Orçamento e Coordenação da Presidência da República. Parágrafo único. A Secretaria Executiva do Ministério da Saúde prestará à comissão o necessário apoio administrativo.

Art. $3^{\circ}$ A comissão será instalada pelo Ministro de Estado da Saúde, no prazo de cinco dias, e deverá apresentar relatório dos seus trabalhos dentro de sessenta dias, contados da data de sua instalação. Itamar Franco - Rubens Ricupero - Henrique Santillo - Beni Veras - Henrique Hargreaves "

A Comissão foi constituida em 22 de setembro de 1994 pela Portaria 1693/GM, com dois representantes de cada um dos seguintes Ministérios: Saúde, Fazenda e SEPLAN-PR. A comissão se reuniu várias vezes. Teve o prazo de 60 dias para terminar o trabalho. Acabou pedindo prorrogação do prazo e só apresentou Relatório Final em dezembro de 1994. Houve uma dissidência na fase de elaboração do Relatório Final, resultando em dois relatórios. O primeiro deles foi apresentado, em separado, pelos representantes do MS, Gilson Caleman e Adney Moraes. (122)

\section{"RELATORIO FINAL}

COMISSÃO INTERMINISTERIAL NOMEADA PELO DECRETO PRESIDENCIAL DE 30 $D E$ AGOSTO DE 1994. Propostas relativas à racionalização de gastos com a saúde $e$ melhora do atendimento à população.

Durante o governo Itamar Franco uma série de medidas foram executadas pelo Ministério da Saúde, visando a maior racionalização das práticas de saúde no país e de seus custos, bem como o incremento da qualidade dos serviços prestados à população.

Tendo como diretriz fundamental a descentralização das ações e serviços de saúde, aliás determinada pela Constituição de 1988, foi editada, em maio de 1993, a Norma Operacional Básica 01/93 do Sistema Único de Saúde (NOB SUS 01/93), que dispõe sobre a transferência de responsabilidades e recursos para a gestão descentralizada do sistema de saúde pelos estados e municipios.

No que diz respeito à descentralização, os efeitos do Decreto Presidencial de 4 de maio de 1994, que criou a Comissão Interministerial para a racionalização de gastos e melhoria da qualidade da saúde no país, da qual resultou, em última análise, o presente relatório, vieram a reforçar e incrementar a atuação normativa do Ministério da Saúde. 
Assim, foram editados ao longo do período de vigência da NOB SUS 01/93, os instrumentos normativos seguintes, que bem traduzem a disposição política descentralizadora do atual governo, inclusive nos aspectos concementes às atividades de controle da assistência à saúde e dos respectivos custos:

Decreto 1.105, de 6 de abril de 1994, que cria o Sistema Nacional de Auditoria na área da saúde.

Decreto 1.232 de 30 de agosto d 1994, que dispõe sobre a transferência de recursos do Fundo Nacional de Saúde para os fundos estaduais e municipais.

Portaria MS 1.286 de 26 de outubro de 1993, que explicita cláusulas necessárias nos contratos de prestação de serviços firmados entre os gestores do SUS e as pessoas fisicas e jurídicas prestadoras de serviços, em caráter complementar, ao SUS.

Portaria MS 1.475 de 12 de agosto de 1994, que dispõe sobre as medidas aplicáveis, no âmbito do Ministério da Saúde, em face da malversação, desvio ou aplicação irregular dos recursos financeiros da União alocados ao SUS.

Portaria MS 1.553 de 24 de agosto de 1994, que condiciona as transferências para investimentos na rede assistencial do SUS à previsão expressa dos mesmos nos Planos de Saúde dos Estados e Municípios.

Portaria MS 1.554 de 24 de agosto de 1994, que veda alterações em códigos de procedimentos das tabelas de remuneração dos Sistemas de Informação Ambulatorial e Hospitalar do SUS, que venham a gerar aumento de custos.

Portaria MS 1.695 de 23 de setembro de 1994, que define normas gerais sobre participação preferencial das entidades filantrópicas e sem fins lucrativos no SUS e define o regime de parceria entre poder público e iniciativa privada não lucrativa.

Portaria MS 1.827 de 31 de outubro de 1994, que define os tetos financeiros, por estado, relativos ao custeio da assistência ambulatorial e hospitalar.

Portaria SAS 199 de 03 de novembro de 1994, que define as regras operacionais para a situação semi - plena de gestão, para estados e municipios.

Portaria SAS/MS 200 e 203, de 7 e 10 de novembro de 1994, que estabelecem tetos financeiros para estados e municípios aprovados para a gestão semi - plena do SUS.

Considerando o disposto no Decreto Presidencial de 30 de agosto de 1994, a Comissão Interministerial procurou dar conta dos objetivos que lhe foram definidos através das propostas de ação apresentadas em seqüência.

Medidas referentes ao custeio da assistência à saúde pela União, Estados e Municípios.

O primeiro aspecto a considerar é o que se verifica, como tendência, da participação dos três entes federativos no financiamento à saúde.

Nos últimos anos, sem dúvida, as transferências federais representam o maior montante de recursos alocados ao sistema de saúde, até porque as receitas federais possuem maior magnitude que a soma das demais esferas.

Contudo, o panorama de anos mais recentes mostra um incremento na participação dos municipios no financiamento da saúde, sendo esta, aliás, a única esfera que aumentou seu aporte de recursos, enquanto as outras duas se retrairam.

Fórmulas do tipo "10\% de recursos orçamentários para a saúde" ou similares resultam em acréscimo pouco significativo no montante alocado, dada a pequena participação de estados e municípios na carga fiscal nacional (Médici, 1993). 
Além do mais, este tipo de medida imposto por Decreto ou Lei Ordinária resulta inócuo e além do mais inconstitucional, por configurar ingeréncia normativa de uma esfera de govemo sobre outra.

O Ministério da Saúde encaminhou ao Congresso Nacional, por ocasião da frustrada revisão constitucional de 1993 - 94, proposta que contempla estabelecimento de compromissos financeiros com a saúde, não só por parte dos órgãos gestores das três esferas de governo como também dos arrecadadores e autorizadores do gasto (ver Anexo deste relatório).

Como ação concreta, factivel e adequada ao atual momento de instalação de novos governos na União e Estados, a Comissão Interministerial propõe:

UM COMPROMISSO PELO FINANCIAMENTO DA SAÚDE, A SER FIRMADO LOGO NOS PRIMEIROS DIAS DO NOVO GOVERNO, ENTRE O PRESIDENTE DA REPÚBLICA, QUE O DESENCADEARA, E OS GOVERNADORES DOS ESTADOS, TENDO COMO META O ALCANCE, AINDA EM 1995, DE R\$ 120 A 150 PER CAPITAVANO NA SOMA DAS ALOCAÇŐES DE RECURSOS DAS TRÉS ESFERAS DE GOVERNO.

O REENCAMINHAMENTO, EM MOMENTO POLITICAMENTE FAVORÁVEL, DAS PROPOSTAS DE REVISÃO CONSTITUCIONAL QUE DEFINAM COM MAIS PRECISÃO O FINANCIAMENTO D SAÜDE, ATRIBUINDO RESPONSABILIDADES E CONTRAPARTIDAS DEFINIDAS AOS DIVERSOS NIVEIS DECISORIOS DO SISTEMA TENDO COMO REFERENCIA O DOCUMENTO APRESENTADO NO ANEXO.

Contratação de auditoria independente para o SUS.

Um melhor sistema de controle e avaliação é um dos pontos essenciais da implantação do SUS no pais.

Tal sistema deve partir, necessariamente de uma base conceitual adequada às novas diretrizes da descentralização e do comando único em cada esfera de governo, determinadas pela Constituição de 1988.

Entre tais diretrizes podem ser citadas; (a) o compartilhamento de responsabilidades entre as três esferas de Governo, formando um verdadeiro Sistema Nacional de Controle e Avaliação e Auditoria; (b) a combinação de auditoria sobre processos e produtos com aquela voltada aos resultados e impacto das ações em saúde; (c) a definição mais precisa das competências e atribuições de cada esfera de governo, em princípio, acarretando aos níveis centrais de governo a auditoria sobre o sistema e ao nivel municipal a auditoria sobre serviços, particularmente de abrangência local.

A contração de uma auditoria externa deverá ter preocupações relativas aos processos operacionais do sistema, particularmente nas áreas de informações e pagamentos. Com efeito, o controle voltado aos produtos e principalmente aos resultados do SUS deve ser construído como um processo permanente, dentro da esfera pública.

A proposta, então, é de que se contrate auditoria externa para avaliar os fluxos de informação e pagamentos do SUS, enquanto os outros aspectos vão se constituir em atributos básicos do Sistema Nacional de Auditoria, ora em conformação.

O termo de referência anexo estabelece as bases conceituais e operacionais para a contratação de tal auditoria (Anexo I).

Medidas para aperfeiçoamento do processo de contratação de serviços de saúde junto ao setor privado.

Conforme explicitado na introdução do presente relatório, o Ministério da Saúde vem produzindo normas a respeito desta questão desde o ano de 1993. 
Assim, tanto, a Portaria MS 1.286, prorrogada em sua vigência até 31 de março de 1995, como a portaria MS 1.695 estabeleceram diretrizes e cláusulas para a elaboração dos contratos e convênios descentralizados de prestação de senviços a serem firmados entre os gestores estaduais e municipais e os prestadores privados lucrativos e não lucrativos do SUS.

Tais contratos e convênios obedecem à disposição constitucional do direito público e, em princípio, filiam - se ao disposto na Lei 8.666. Algumas de suas cláusulas, contudo, foram explicitadas nos instrumentos normativos citados e tornadas obrigatórias, em função da especificidade do objeto da saúde. São elas:

Natureza e quantidade dos serviços a serem contratados.

Espécie, tipo de assistência, acomodações, critérios de avaliação e controle, disponibilidade de leitos, gratuitamente, etc.

Preço e condições de pagamento.

Obrigatoriedade de vistoria na prorrogação contratual;

Direitos e responsabilidades dos contraentes: indicação do $R T$, responsabilização dentro do limite de leitos, exoneração de responsabilidades em caso de atraso de pagamentos.

Medidas para extinção de situações de acumulação de funções de prestador e auditor na área da saúde.

Esta matéria já se encontra contemplada na Lei $8080 / 90$ que prescreve no $4^{\circ}$ de seu artigo 26: "aos proprietários, administradores e dirigentes de entidades ou serviços contratados é vedado exercer cargo de chefia ou função de confiança no Sistema Único de Saúde - SUS".

Nem por isso, contudo, tal preceito legal vem sendo obedecido amplamente no sistema de saúde.

A razão principal do não cumprimento da lei no campo específico da Auditoria em saúde é a relativa escassez de profissionais com militância exclusiva no setor público particularmente médicos. Tal situação tem raizes históricas e remonta às origens dos antigos Institutos de Aposentadoria e pensões isolados.

Assim, novas medidas normativas ou mesmo a regulamentação do artigo 26 , aliás auto - aplicável, seriam inteiramente inócuas, no atual momento.

A transferência do poder de auditoria aos estados e, principalmente aos municipios, tem demonstrado certa reversão deste quadro, já que tais instâncias vem criando sistemas de controle e avaliação com novos quadros funcionais, para os quais tem sido recrutados profissionais mais jovens e sem vínculos privados.

A descentralização por si só, portanto, já tem se mostrado capaz de corrigir esta distorção histórica do sistema de saúde brasileiro.

Como medidas eficazes, a curto prazo, para provocar mudanças em tal situação, esta Comissão propõe:

ACELERAR O PROCESSO DE DESCENTRALIZAÇÃO DAS AÇÕES E SERVIÇOS DE SAÚDE, INCLUSIVE DAS AÇÓES RELACIONADOS AO CONTROLE, AVALIAÇÃO E AUDITORIA.

ELABORAR ESTUDOS, PARA IMPLEMENTAÇÃO A NÍVEL FEDERAL E COMO RECOMENDAÇÃO PARA O DEMAIS NIVEIS DE GOVERNO, PARA EFETIVAÇÃO DA CARREIRA DE AUDITOR - MÉDICO DO SUS, NA QUAL A NÄO VINCULLAÇ̃O PRIVADA SEJA CONDIÇÃO SINE - QUA - NON. 
ESTABELECER, COMO CONDIÇÃO ESSENCIAL PARA A HABILITAÇÃO ȦS SITUAÇOES DIFERENCIADAS DE GESTÃO DA NOB SUS 01/93, QUE OS DIRIGENTES DE SAÚDE E SEUS ASSESSORES IMEDIATOS, PARTICULARMENTE AQUELES VINCULADOS AO CONTROLE E AVALIAÇÃO DOS SERVIÇOS CONTRATADOS, NÃO POSSUAM VINCULAÇÃO PRIVADA OU DELA SE AFASTEM FORMALMENTE O EXERCICIO DO CARGO.

Ressarcimento de serviços ao SUS pelos planos de saúde privados.

A este respeito, o Ministério da Saúde encaminhou ao Presidente da República, exposição de motivos acompanhada de minuta de decreto, onde se estabelece a regulamentação dos planos e seguros de saúde privados.

Tais documentos partem da constatação de que, a par da relevância social do tema, existe um imenso vácuo normativo que subsiste desde Decreto - lei 73 , instrumento que em 1966 instituiu o seguro saúde no Brasil.

Como aspectos mais importantes da minuta acima referida podem ser citados:

Definição de exigências básicas para funcionamento de empresas seguradoras, empresas de grupo e cooperativas médicas.

Autorização ao Conselho Federal de Medicina para expedir instruções complementares ao Decreto.

Vedação à exclusão de quaisquer doenças reconhecidas pela CID.

Obrigatoriedade quanto à assistência integral.

Eliminação de prazos de carência para emergências e urgências e sua regulamentação para outras situações.

Reembolso de despesas com assistência prestadas aos beneficiários de planos de saúde às unidades do SUS que tenham prestado o atendimento.

O item V do Decreto Presidencial que criou a Comissão Interministerial está, portanto, inteiramente contemplado em tal minuta de decreto, que inclusive o supera qualitativamente.

A Comissão recomenda, assim que sejam retomadas as discussões em torno do mesmo, para que sua assinatura possa ser feita a curto prazo pelo Presidente da República. Brasilia, 22 de novembro de 1994. Adnei Pereira de Moraes, Secretário Executivo Adjunto - Ministério da Saúde; Gilson Caleman - Diretor do Departamento de Desenvolvimento, Controle e Avaliação dos Serviços de Saúde.

ANEXO I - Contratação de auditoria independente para avaliar o SUS.

O seguinte termo de Referência visa operacionalizar o processo de auditoria externa independente referente aos sistemas de informações ambulatoriais e hospitalares (SIA ISUS E SIH ISUS) do Sistema Único de Saúde, nos termos inciso II, artigo $1^{\circ}$ do Decreto Presidencial de 30/08/94, tendo como justificativas os seguintes aspectos:

O Ministério da Saúde, particularmente no contexto do aprofundamento do processo de descentralização as ações e serviços de saúde estabelecido pela Norma Operacional Básica do SUS 01/93 (NOB SUS 93), aprovada pela Portaria 545 de 23/05/93 vem regulamentando progressivamente as questões relativas à informação voltada para o controle e avaliação do SUS.

Assim, por proposição do Ministro da Saúde, o Presidente da República houve por bem decretar, no decorrer de 1994, dois instrumentos fundamentais para a construção de um autêntico processo de controle e avaliação, em bases sistêmicas, nos termos da Lei Orgânica da Saúde. São eles o Decreto 1105, de 06/04/94, que dispõe sobre o Sistema 
Nacional de Auditoria e o Decreto 1232 de 30/08/94, que dispõe sobre as condições e a forma do repasse regular e automático de recursos do Fundo Nacional de Saúde aos fundos estaduais e municipais, além de estabelecer outras providências, voltadas para o controle dos recursos transferidos.

Além desses documentos legais referenciais, o orgão gestor nacional vem baixando uma série de medidas normativas, visando o aperfeiçoamento dos sistemas de informação, controle e avaliação do SUS, cuja súmula é mostrada em anexo. Exemplo de tais ações é a Portaria 1475, de 12/08/94, que dispõe sobre as medidas aplicáveis no âmbito do Ministério da Saúde, em face de malversação, desvio ou aplicação irregular dos recursos financeiros da União, alocados no SUS.

As atividades de controle a avaliação da assistência médica do SUS se assentam sobre dois sistemas nacionais de informação, o SIA ISUS - Sistema de Informações Ambulatoriais e o SIH/ SUS - Sistema de Informações Hospitalares. Tais sistemas, embora a complexidade da base de dados que os alicerçam e a heterogeneidade dos provedores de informação, encontram - se hoje fortemente enraizados na cultura institucional da saúde, sofrendo, além do mais, ao longo dos anos de sua vigência, processos de aperfeiçoamento constante.

Deve - se atentar para a dimensão do objeto a que os referidos sistemas de informação se referem. Com efeito, a rede do SUS, que engloba serviços governamentais, privados, filantrópicos e universitários compreende cerca de 6.100 hospitais, 510 mil leitos hospitalares e 50 mil pontos de atendimento ambulatorial realizando mais de 1,3 milhão de internações/ mês e mais de 100 milhões de procedimentos ambulatoriais/ mês.

O SUS ainda não está totalmente consolidado dentro dos ditames constitucionais de relevância pública, comando único em cada esfera de governo e controle social. Isto, naturalmente, dificulta o processo de gestão e o adequado rendimento dos sistemas de informações assistenciais. Contudo, o processo de descentralização desencadeado pela NOB SUS 93, já conta com a adesão de cerca de 1.900 municipios entre eles os de maior porte e de influência política.

A diversidade dos atores sociais do SUS e sua variada interação com os sistemas de informação assistencial, seja como provedores de informação, fiscalizadores, considerar um processo de auditoria para os referidos sistemas. Cabe buscar maior eficiência e eficácia de tais sistemas, sem perder, porém, a referência das diferentes necessidades dos atores.

A construção de sistemas de informação, bem como de auditoria controle e avaliação no SUS deve estar articulada com o espírito federativo da Constituição de 1988, que aponta para a co - responsabilidade e solidariedade na relação entre as esferas de governo. Tais sistemas devem ter como objetivo precípuo a garantia do alcance de resultados efetivos, com qualidade, da prestação de serviços de saúde, ao invés de se constituirem em meros instrumentos burocráticos, imunes a um caráter pedagógico, de natureza meramente contábil - financeira e inseridos em uma lógica post - facto.

A auditoria externa independente objeto do presente termo de referência deverá se pautar pelos seguintes objetivos, consentâneos com o presente momento de implantação do SUS, de conformidade com a análise situacional nas linhas acima:

Avaliar a qualidade das informações circulantes no sistema, em termos de sua consistência, coerência e confiabilidade, nos diversos momentos de coleta, processamento, aferição e difusão. 
Detectar nós críticos e pontos vulneráveis a distorções, desvios e fraudes nos sistemas de informação vigentes, de forma a propor a introdução de mecanismos de críticas e controles internos para os mesmos.

Desenvolver processos informacionais e pedagógicos para o integral aproveitamento dos atuais sistemas SIA e SIH como instrumentos de controle e garantia de qualidade das ações de saúde, em detrimento do caráter meramente "bancário" dos mesmos.

Desenvolver mecanismos e instrumentos de circulação e difusão das informações geradas nos sistemas referidos, tanto para servir ao controle social (accountability) como ao conjunto de usuários (gestores, prestadores, pesquisadores).

Desenvolver processos de internação dos sistemas de informação assistencial com outros sistemas de informação epidemiológica existentes no SUS (SISVAN, SINASC, SIM, SINAM, por exemplo).

Como metodologia, deverá ser buscada uma amostra eqüitativa dos diversos componentes dos sistemas SIA e SIH/SUS, assim discriminadas:

Inputs: avaliação junto a prestadores, sejam públicos ligados a gestores, públicos universitários, privados (lucrativos, filantrópicos, universitários).

Estrutura e processos: gestores estaduais e municipais, empresas de processamento oficiais estaduais, bureaux de consultorias, DATASUS.

Outputs: circulação e difusão intra - e extra - SUS das informações produzidas pelos dois sistemas; capacidade de processamento dos receptores.Resultados: impacto das informações nas ações de cada instância; subsidios para o planejamento; impacto no controle social; mecanismos de difusão e vulgarização das informações. "

A outra parte da Comissão, composta por membros de outros Ministérios, como Fazenda e Planejamento, elaborou seu relatório à parte, visto que o pessoal representante do MS não concordou com as conclusões. Este Relatório foi divulgado praticamente só um mês após o primeiro, ei - lo na integra. (136):

"COMISSÃO INTERMINISTERIAL NOMEADA PELO DECRETO PRESIDENCIAL DE 30 DE AGOSTO DE 1994. RELATORIO FINAL - INTRODUÇÃO

Apesar dos esforços empreendidos pelo Ministério da Saúde, a situação dos serviços prestados à população pelo Sistema Único de Saúde - SUS continua precária. Persistem problemas apontados pelo "Grupo Interministerial para Racionalização dos Gastos com Saúde e Melhoria do Atendimento a População" (Decreto de 04 de maio de 1994). Também o Relatório da "CPI do INAMPS", recém concluído, apresenta quadro dramático quanto ao panorama de saúde no País.

Assim, deixa - se de apresentar novo diagnóstico, tendo em vista que seria, em grande parte, mera repetição de trabalhos anteriores.

O presente relatório, resultante de diversificados levantamentos e debates relacionados com as determinações do Decreto, concentra - se em proposições de algumas medidas dentre as solicitadas, simples e diretas, exeqüiveis de serem implementadas a curto prazo, nas circunstâncias de transitoriedade atuais.

A - Medidas referentes ao item I: $1^{\circ}$ Propõe - se que o Ministério da Saúde promova entendimentos, especificos e diretos, com os gestores dos estados e municípios, buscando definição mais precisa, com posterior compromisso convencional entre as 
partes, no sentido de se estabelecer as contra - partes obrigatórias dos recursos orçamentários das diferentes esferas, como previsto constitucionalmente, de modo a se modificar significativamente a atual estrutura de custeio dos serviços de saúde do SUS que hoje é, em média, aproximadamente, de: $70 \%$ esfera federal; $15 \%$ esfera estadual;15\%esfera municipal; para, em média, aproximadamente: 50 a $40 \%$ esfera federal;30 a $35 \%$ esfera estadual; 20 a $25 \%$ esfera municipal; $2^{\circ}$ Propõe - se que o Ministério da Saúde, através de grupo de trabalho específico, acompanhe e ofereça sugestões à equipe de Governo que irá propor mudanças constitucionais e tributárias ao Poder Legislativo no próximo exercício, no sentido de viabilizar melhor forma de participação das três esferas de governo no financiamento do SUS. Esta comissão interministerial chegou ao consenso de que os cargos financeiros deste setor são de tal monta e com tais implicações técnicas, operacionais e étnicas que exigem o comprometimento efetivo dos três niveis de governo. $3^{\circ}$ Propõe - se que, ao longo do exercício de 1995, o Ministério da Saúde desenvolva estudos para viabilizar, concomitantemente com os recursos orçamentários (de impostos e de contribuições), novas fontes de custeio para os serviços de saúde, para facilitá-los, discipliná-los e melhor equalizá-los.

B - Medidas referentes ao item II: Propõe - se que o Ministério da Saúde inicie, mediante licitação pública, com a prévia e devida negociação política com os gestores estaduais e municipais, a prática de auditoria externa para os serviços do SUS. Dadas as condições de transição governamental e a evolução da implementação do SUS convém a introdução desta prática por etapas, sem abarcar de início todos os processos referidos no item II e outros aspectos passíveis da auditoria. De mais imediato e urgente, recomenda - se que o Ministério da Saúde, devidamente articulado $\mathrm{com}$ as mais esferas gestoras estadual e municipal, proceda a auditoria externa especializada: a) no sistema de controle, acompanhamento e avaliação de serviços hoje disponivel e em funcionamento. b) no sistema de registros, fluxos, análises e utilização de informações dos serviços, especialmente os referentes à AlH e UCA.

C - Medidas referentes ao item III: Propõe - se, de imediato, em face das disposições normativas do Ministério da Saúde, que se estude a instituição de Comissão Permanente junto à sua Secretaria de Assistência à Saúde, com componentes estatais e não - estatais, com o objetivo de promover, através de reuniões periódicas, a avaliação do cumprimento e dos resultados das portarias regulamentadoras e sua atualização.

D - Medidas referentes ao item IV: Propõe - se que o Ministério da Saúde forme comissão conjunta com a SAF, de modo a estudar e viabilizar nova disciplina nas relações de trabalho dos recursos humanos federais, no âmbito da saúde, de modo que se crie condições de trabalho especiais, de forma temporária ou permanente, onde o exercício de atividade fiscais, de controle, e até mesmo de auditoria, seja incompativel com o exercicio de atividades produtivas (sejam elas remuneradas por produtividade, por salários ou salários e produtividade, pois todas as remunerações são passiveis de convênios corruptoras na produção, por ganância, ou por ociosidades do trabalho). A partir das novas medidas disciplinadoras federais, por efeito demonstração ou por condicionamentos normativos ou financeiros, buscar - se - á expansão das medidas para outras áreas gestoras do Sistema Único de Saúde.

E - Medidas referentes ao item V: O ressarcimento das "despesas de atendimento médico prestado pelo SUS", a beneficiários de planos de saúde, no caso em que tais atendimentos estejam cobertos pelos respectivos planos, pode ser solicitado legitimamente por qualquer gestor de estabelecimento de saúde do SUS - pelo custo, pelo gasto ou pelo valor apropriado - de forma amigável ou judicialmente (cabendo ao operador do Plano repassar ou não esta despesa ao beneficiário atendido, no caso em 
que não se caracterizar urgência ou emergência e já tenham sido divulgadas as normas de atendimento). O exame de conveniência econômico - financeira e político administrativa dessa cobrança fica a cargo do gestor dos serviços de saúde, enquanto perdurar as atuais regulamentações dos "planos de saúde" onde os seus detentores (usuários e promotores) usufruem de benefícios fiscais (diretos ou indiretos). Independentemente da receita adicional que advirá para a SUS, a adoção desse procedimento justifica - se plenamente pelo aspecto de conscientização dos beneficiánios e gestores dos sistemas público e privado acerca de seus limites e privilégios. Assim, enquanto novas regulamentações públicas dos sistemas privados de atenção a saúde não se fizerem presentes, propõe - se que o Ministério da Saúde devidamente alicerçado pela sua Consultoria Jurídica - baixe instruções normativas direcionados aos seus estabelecimentos para que efetuem as cobranças, em caráter de ressarcimento, junto às empresas administradoras de planos ou seguro de saúde, permitindo, por efeito demonstração, que os gestores das demais esferas do poder público adotem igual procedimento. Brasília, 21 de dezembro de 1994. José Carlos Seixas - Pelo Ministério da Fazenda ; Almério Cançado de Amorim, Pelo Ministério da Fazenda - Francisco Eduardo B. de Oliveira - pela SEPLAN - PR - Silvio Caracas de Moura Júnior - pela SEPLAN - PR".

Jiante do relatório acima, assinado em separado pelos setores do Governo que discordavam zom o preceito constitucional de se garantir saúde para todos, são apresentados aqui alguns comentários sucintos sobre esse relatório final da Comissão, a partir das idéias que, na época, defendia, na condição de representante do MS:

a) O relatório representa apenas a opinião pessoal dos representantes dos Ministérios da Fazenda e Planejamento. O Ministério da Saúde já tinha apresentado seu relatório, que não foi aceito pelos demais. O Ministério da Saúde não assina esse relatório, por não concordar com seu conteúdo.

b) Estranha - se que uma comissão de tão alto nivel se reunira e, após, quatro meses não tenha absolutamente nada de concreto e de novo do que já não se sabia, para apresentar.

c) Na introdução cita os vários diagnósticos e sem, provavelmente, ter lido o relatório da CPI, "cita o quadro dramático" diagnosticado por ele (Relatório da CPI). Seria bom lembrar, (e quem leu o relatório ou lá esteve em alguma das sessões) o relatório não acrescentou absolutamente nenhuma novidade em relação àquilo que já se sabia e tinha sido objeto de resultado de trabalhos do próprio pessoal do Ministério da Saúde. Em único documento utiliza - se de relatório do TCU (feito a partir do pessoal da saúde) e das auditorias feitas pelo MS. Além disso, junta dados de épocas diferentes. Entretanto, o mais grave é a conclusão final: "Estima - se, que haja possibilidade de fraudes a nivel de $23 \%$, num total gasto para assistência à saúde de 7 bi US, o que resulta em 1,6 bi US". Conclusão falaciosa, sem nenhuma base: $1^{\circ}$ de onde surgiu o número $23 \%$ ? $2^{\circ}$ de onde o número de gastos com $\mathrm{SIH}$ SUS-UCA, em 93 e 94, serem da ordem de 7 bi? Sabidamente, em 1993, foram gastos 4,4 bi US e, em 1994, não se chega a 6 bi (ai sim por estimativa por não ter fechado o ano)". Diante 
da falácia maior, o que pensar do relatório, não lido, não analisado, mas citado pela comissão!?...

d) Propõe-se que o MS promova entendimentos específicos e diretos com estados e municípios através de convênios para que haja contrapartida maior de Estados e Municípios. Novamente aqui o desconhecimento da Constituição Brasileira, da Nova Federação, da Lei Orgânica de Saúde. Ninguém transfere responsabilidades à outra esfera de governo, por livre e espontânea vontade, na área de saúde. Está na CF que o Municipio é responsável pelas ações e serviços de saúde com a participação técnica e financeira de Estados e União. $\mathrm{Na}$ questão do financiamento os recursos da Seguridade Social não são do Governo Federal, mas sim arrecadados por ele e de propriedade das três esferas de governo para cumprir com suas competências constitucionais. "O FINANCIAMENTO DA SEGURIDADE SOCIAL SERA FEITO ATRAVÉS DOS ORÇAMENTOS DA UNIÃO; DOS ESTADOS, DO DISTRITO FEDERAL E DOS MUNICIPIOS E DAS SEGUINTES CONTRIBUIÇÕES SOCIAIS: doS empregadores sobre a folha, o faturamento e o lucro; dos trabalhadores e dos concursos prognósticos". É suficientemente claro que a União, quando afirma que financia com seus recursos a saúde em $75 \%$ dos seus custos, está, como no relatório da comissão, perpetuando uma falácia, pois esses recursos são das três esferas de governo. Realmente, tem - se que ter um entendimento correto da legislação que, no mesmo artigo, afirma que o orçamento da seguridade será elaborado pelos três órgãos a ela afetos... assegura a cada área a gestão de seus recursos.

Portanto qualquer conclusão a partir de que as três esferas deverão contribuir de forma mais igualitária é falsa, pois só uma delas, a federal, arrecada especificamente para as três. Dizer que esse dinheiro já é muito, é esquecer a quem pertence: a quem arrecada, ou a quem a constituição determina que caiba parte em repartição?

e) Outra questão esquecida é a de que as três esferas arrecadam diferentemente: dados de 92, cotados no primeiro relatório do grande grupo, a União, de tudo que arrecada, fica ao final com $56 \%$, todos os estados somados com $28 \%$ e todos os 5000 municípios com $16 \%$. Qualquer pessoa que raciocine chegará à conclusão que a contribuição não pode ser igual, senão percentualmente em relação ao total arrecadado. Percentualmente, em relação ao todo é ilógico, injusto e tendencioso. A proposta é que cada esfera entre com seus recursos fiscais de impostos na faixa de $10 \%$ (podendo chegar até $15 \%$ ) e no minimo $30 \%$ do OSS (sem o FAT) segundo as DT da CF e das LDO de 90, 91,92 e 93 e vetado nas LDO de 94 e 95. 
f) A proposta de $50,30,20$ ou $40,35,25$ desconhece o percentual de arrecadação de cada esfera, e com que finalidade é arrecadada.

g) Entrega de estudo ao Ministério da Saúde e oferecimento de propostas ao novo Governo sobre fontes de financiamento. Esse era um dos objetivos precípuos da Comissão. A comissão, após quatro meses, diz que isto é para ser feito pelo MS.

Propõe que o MS inicie licitação pública para fazer uma auditoria externa. A comissão primeira havia já indicado isso. A nova Comissão deveria verificar a viabilidade disso com proposta de governo.

O INPS/ INAMPS nunca licitou serviços para contratos. Aventa-se o uso de escolha clientelista por compadrio, tráfico de influência ou apadrinhamento político. A proposta da $1^{\text {a }}$ comissão foi inócua por dizer que se deveria descobrir alguma maneira de fazer contratos lícitos, o que pressupõe, esteja explícito na 8666 .

Já existe comissão de licitação. Comissão Tri e Bipartite; Conselhos Municipais, Estaduais e Nacional de Saúde; TCU; TCE; Legislativo; M.P.

Desde maio de 1993, segundo portaria Ministerial, que normatizou a Descentralizaçăo das Ações e Serviços de Saúde, já está explicito, depois de acordado na Comissão Intergestores Tripartite, que os profissionais de autorização de internação, controle a avaliação não deverão ter ligação ( com ou sem vinculo) com as instituições de saúde que desenvolvam ações para o SUS, privados lucrativos ou filantrópicos.

Já foi negociado, faz parte das propostas do SUS em implantação e, lamentavelmente, foi prática atrasada de várias décadas de INPS/ INAMPS.

O ressarcimento já está no Decreto Fundo a Fundo. É preciso, porém, que seja urgentemente regulamentado. A regulamentação é prévia e tem um caráter educativo e facilitador. A Comissão nem opinou, nem propôs, nem cobrou a regulamentação!!!...

Premido por pressões de todos os lados, principalmente, devido à nova proposta constitucional do SUS, também uma corrente do Congresso Nacional houve, por bem, investigar a saúde. Assim, também a Câmara dos Deputados criou uma CPI destinada a apurar as inúmeras irregularidades no INAMPS que, pela CF, tinha sido repassado ao MS e, praticamente, consistia em sua mais abrangente atividade. Foi requerente o Deputado Jackson Pereira, do PSDB-CE, que se encarregou igualmente da relatoria, embora ficasse com o Deputado Liberato Caboclo, do PDT-SP, a Presidência da Comissão. A CPI foi instalada em 8-7-1994 (plena crise da Saúde com implantação do Plano Real e a falta crônica de recursos), e selecionou alguns documentos, como base de seu trabalho. Não houve 
inovação. Tomou, como base, um Relatório Consolidado, do TCU (dezembro de 1993) , O Relatório Consolidado da própria Auditoria da Direção Geral do INAMPS (dezembro de 1993) , e o resumo de 1000 auditorias realizadas pelo próprio MS, pelo seu SNA.

A CPI tinha como "objetivo principal de suas investigações aferir a correção da utilização dos recursos públicos da União na área da saúde, a CPI abrangeu também o Sistema Único de Saúde - SUS" (12). Só por essa frase, retirada da Introdução do Relatório Final da CPI, é possivel entender os equívocos da $\mathrm{CPI}$.

Os encaminhamentos da CPI podem ser resumidos da seguinte maneira, destacados para cada órgão: 1) Ministério Público Federal: promover a responsabilização dos implicados em várias irregularidades financeiras e de uso dos cargos; 2) Polícia Federal: apurar fraudes no SUS, inclusive, cobranças indevidas de pacientes; 3) SNA: auditar inúmeros hospitais; 4) MS: descredenciar pessoas e hospitais; 5) CFM: fiscalizar hospitais e acompanhar fraudes.

Como recomendações, enumera várias ao Sistema Nacional de Auditoria que deve ser implementado, à Procuradoria Geral da República, ao Tribunal de Contas da União , Ministério da Fazenda, Banco Central, Conselhos Federais de Medicina e Enfermagem, MS, Secretarias Estaduais e Municipais de Saúde. Todo o trabalho foi baseado em trabalhos anteriores e direcionado a tomar medidas, diante de denúncias já havidas, ou apuradas pelo próprio MS, cujo encaminhamento já vinha acontecendo. Nenhuma novidade no decorrer, nem nas conclusões, que já não fosse do conhecimento público e/ou do órgão competente, para apurar e tomar providências.

\subsection{TRANSFERÊNCIAS DE RECURSOS FEDERAIS PARA ESTADOS E MUNICÍPIOS SOB}

\section{A FORMA DE REPASSE FUNDO A FUNDO}

A proposta da equipe, que assumiu o MS em 1992, com Itamar Franco, tendo à frente o Ministro Jamil Haddad e o Presidente do INAMPS, Carlos Mosconi, era radicalizar na descentralização, cumprindo os preceitos legais constitucionais.

Um dos nós era a maneira de se fazer o repasse de recursos diretamente do Fundo Nacional de Saúde aos Fundos Estaduais e Municipais de Saúde. Fugia do repasse de forma convenial, característico de uma transferência voluntária por acordo de vontades, e que contrariava a CF, que obrigava o MS a transferir recursos a Estados e Municípios, como arrecadador de recursos para obrigações e competências constitucionais das três esferas de governo. 
lavia uma ameaça permanente de atores contrários à descentralização da saúde e à assagem das atividades do INAMPS diretamente para o MS, com sua descentralização osterior a Estados e Municípios. Esse repasse direto e automático de recursos horripilava os centralistas. Para dirimir a dúvida da possibilidade, ou não, desse repasse, chamado de épasse de Recursos Fundo a Fundo, o Presidente do INAMPS e Secretário Nacional de sssistência à Saúde, Carlos Mosconi, fez uma consulta formal ao Tribunal de Contas sobre a onduta a seguir.

lepois de bom tempo e criticando erros do processo de consulta, o TCU deu o seguinte arecer:

“Grupo I - Classe I - TC - 005.399/93 - 9

Consulta formulada pelo Presidente do Instituto Nacional de Assistência Médica da Previdência Social - INAMPS, Dr. Carlos Eduardo Venturelli Mosconi, na qual solicita provimento do Tribunal "no sentido de garantir o repasse direto de recursos, fundo a fundo, sem necessidade de convênio ou instrumento congênere entre a União e o Estado ou Município...", por entender que os preceitos constitucionais e da Lei Orgânica de Saúde comportam esse procedimento.

2. Junta aos autos (f. 04/12), para subsidiar o exame da matéria, cópia do texto do livro "Sistema Único de Saúde", de Guido Ivan de Carvalho e Lenir Santos, Editora Hucitec, 1992 (páginas 213 a 219).

3. No exame efetuado, a $4^{a}$ IGCE enfatiza que o Presidente do INAMPS, nos termos do art. 123 do Regimento Interno, está arrolado entre as autoridades competentes para formular consulta a este Tribunal.

4. Adverte, no entanto, que o documento não se apresenta acompanhado do parecer do órgão de assistência técnica ou jurídica da autoridade consulente, como exige o $1^{\circ}$ do art. acima referido, e que por isso caberia a restituição da Consulta, nos termos da Ordem de Serviço $n^{\circ}$ 15/91.

5. Mas, em que peso esse aspecto, a Unidade Técnica, por considerar relevante a matéria, examina o mérito da questão, nos termos a seguir resumido.

CONCLUSÃO DO MINISTÉRIO PÚBLICO - O Procurador - Geral em substituição, Dr. Jatir Batista da Cunha, em que pese considerar que o Oficio PR/INAMPS $n^{\circ} 363 / 93$, de 13.04.93, não constitui, a rigor, uma consulta, "posto que requer um tipo de autorização de natureza gerencial que até foge a atribuições desta Corte", sustenta que a resposta sugerida pela $4^{a}$ IGCE, "além de estar amparada nas normas operacionais emanadas do próprio Ministério da Saúde, a quem compete o provimento almejado pelo solicitante, guarda coerência com a tendência da lei." É o relatório.

VOTO

A Consulta, como visto no relatório acima, não traz, consigo, o parecer do órgão de assistência técnica ou jurídica da autoridade consulente, como exige o $1^{\circ}$ do art. 123 do Regimento Interno deste Tribunal, fato que ensejaria a sua restituição à origem, nos termos da Ordem de Serviço $n^{\circ}$ 15/91.

1. Todavia, ante a relevância da matéria e até como forma de se orientar a autoridade consulente, entendo que este Tribunal, possa relegar a preliminar suscitada e, por conseguinte, receber o Ofício PRINAMPS - $n^{\circ} 363 / 93$, de 13.04.93, expedido pelo 
Presidente do INAMPS, como consulta, para, dando - Ihe provimento, responder nos termos propostos pela Inspetoria - Geral e pelo Ministério Público.

2. Ademais, não há como pensar em elasticidade de compreensão para as circunstâncias operacionais do INAMPS. Pelo contrário, é preciso em todos os momentos aperfeiçoa - lo para o cumprimento da legislação. O INAMPS, a Nação reclama, necessita deixar de ser a apoteose do negativo. Nem Ihe podemos permitir a repetição dos versos, de Cassiano Ricardo: "Gastei o meu futuro em coisas que não fiz, é tarde. É muito tarde".

DECISÃO No 248/93 - PLENÁRIO - Processo n TC - 005.399/93 - 9.

Classe I - Assunto: Consulta Interessado: Carlos Eduardo Venturelli Mosconi Orgão: Instituto Nacional de Assistência Médica da Previdência Social - INAMPS. Relator: Ministro Marcos Vinícios Vilaça Representante do Ministério Público: Dr. Jatir Batista da Cunha. Orgão de Instrução: $4^{\circ}$ IGCE

Decisão: O Tribunal Pleno, diante das razões expostas pelo Relator decide: receber a presente consulta, para, ao dar - Ihe provimento, responder ao Presidente do INAMPS, que foge à competência do Tribunal autorizar ou "...garantir o repasse direto de recursos, fundo a fundo, sem necessidade de convênio ou instrumento congênere, entre a União e o Estado ou Municipio, ..." como pretendido; e que até que sejam editadas normas especificas sobre o Sistema Único de Saúde - SUS e na ausência de outros instrumentos jurídicos que regulamentem os repasses de recursos desse sistema, deverão ser observadas as disposições legais relativas aos convênios, acordos e ajuste, nos termos do item 8.3 da Norma Operacional Básica - SUS / 1992, editada pela Portaria / SNAS / MS $n^{\circ}$ 234/92, prorrogada pela de $n^{\circ} 412 / 93$, emanada do próprio Ministério da Saúde; encaminhar cópia do Relatório e do Voto, bem como desta decisão ao Exm ${ }^{\circ}$ Sr. Ministro de Estado da Saúde, para efeito de supervisão ministerial. Ata $n^{\circ}$ 25/93 - Plenánio - Data da Sessão: 23/06/1993. - Marcos Vinícios Vilaça - Ministro Relator" (73)

No resumo do resumo, o TCU, primeiro aponta erro de encaminhamento, dizendo, inclusive, que o INAMPS, a Nação reclama, necessita deixar de ser a apoteose do negativo. Nem lhe podemos permitir a repetição dos versos, de Cassiano Ricardo: "Gastei o meu futuro em coisas que não fiz, é tarde. É muito tarde".

A seguir, dá o veredicto ( segundo nossa leitura, óbvio para quem não tem competência de ditar normas, senão fazer com que as sigam): quem deve dizer como fazer é o MS e enquanto ele não diz como será o repasse, continua-se com a obrigação de repassar recursos através do mecanismo convenial : "O Tribunal Pleno decide receber a presente consulta, para responder ao Presidente do INAMPS, que foge à competência do Tribunal autorizar ou (....)garantir o repasse direto de recursos, fundo a fundo, sem necessidade de convênio ou instrumento congênere, entre a União e o Estado ou Municipio, (....)" como pretendido e que até que sejam editadas normas especificas sobre o SUS e na ausência de outros instrumentos jurídicos que regulamentem os repasses de recursos desse sistema, deverão ser observadas as disposiçōes legais relativas aos convênios, acordos e ajuste" 
Dispositivos de outras normas administrativas do Ministério da Fazenda norteavam os repasses, mediante convênios, acordos e ajustes. Eram normas que não se aplicavam às necessidades dos gestores de saúde, e nada tinham a ver com os dispositivos constitucionais referentes à saúde. Essas normas eram prejudiciais pois, entre outras coisas, impedia-se que com esses recursos os Municípios e Estados contratassem pessoal, o que inviabilizava o SUS, cuja principal atividade é o atendimento, quase que individual e artesanal à população.

O próximo passo foi a tentativa de convencimento de se fazer um Decreto Presidencial, aí sim, com a autorização expressa de fazer os repasses Fundo a Fundo. Muitos estudos, reuniōes foram feitos com a Advocacia Geral da República, que apresentava argumentações e contra argumentações. O Setor correspondente do Ministério da Fazenda, também, houve por bem, ser de parecer "a priori" contrário, por considerar que novas regras colidiam com a regulamentação excessiva do MF. Fizeram-se várias minutas. Passou-se por diversos crivos e avaliações, mas pouco progresso significava sua promulgação. A luta durou o ano de 1993 inteiro, como mostrado acima, e imaginava-se que, no começo de 1994, se conseguiria, finalmente, o mecanismo de repasse dos recursos. Secretarias Estaduais de Saúde estavam entre as primeiras instâncias federativas que se habilitavam. O jornalista Luis Nassif abordou a questão em sua coluna diária na Folha de São Paulo (126)

\section{"O INICIO OFICIAL DO FEDERALISMO}

Nos próximos dias, antes de deixar o cargo e voltar para casa, para se candidatar a deputado federal, o secretário nacional de Saúde. Carlos Eduardo Mosconi, dará início a mais importante experiência federativa da história brasileira - rompendo, pela primeira vez de maneira organizada, com quatro séculos de centralismo ineficiente, corruptor e incontrolável, que marcou o Estado Brasileiro.

Serão assinados oficialmente os primeiros quatro convênios com os Estados - Paraná, Ceará, Mato Grosso do Sul e Distrito Federal - para transferência total da gestão das verbas de saúde, em um processo que será fiscalizado diretamente pelas comunidades municipais.

O novo modelo - iniciado por Mosconi e que contou com o apoio amplo do ministro da Saúde Henrique Santillo, do presidente da República e do ministro da Fazenda Fernando Henrique Cardoso - enterrará de vez o sistema atual de pagamento centralizado por serviços prestados, que deu margem a toda sorte de corrupção e desperdício.

Agora, os recursos serão diretamente transferidos do Fundo Nacional de Saúde (FNS) para os Fundos Municipais de Saúde (FMS), dentro de um modelo hierarquizado, estruturado de maneira a impedir arbitrariedades e manipulações.

Na base da pirâmide estão os Conselhos Municipais de Saúde - constituidos de representantes do Executivo municipal e das comunidades locais - que administrarão os Fundos. Cada municipio receberá o equivalente a US\$ 54 anuais por habitante divididos em 12 prestações mensais, sem intermediação politica. 
O Sistema é bastante flexível, para permitir a diferenciação entre municípios. Municipio que não tiver estrutura para tratamentos mais sofisticados, por exemplo, firma convênios com municípios vizinhos, pagando pelo atendimento de seus doentes.

INSTÂNCIAS DE APELAÇÃO Estes convênios serão definidos no âmbito de uma Câmara Bipartite - constituída pelo secretário estadual e pelos secretários municipais de saúde - incumbida de estipular critérios técnicos para a atuação dos Conselhos Municipais. Inclusive para impedir a atuação de lobbies médicos sobre os preços de atendimento.

Por sua vez, as Bipartites respondem a uma Câmara Tripartite - formado pelo Secretánio Nacional de Saúde e pelos secretários estaduais e municipais - incumbida, também, de dirimir pendências estaduais. Recentemente, o governador de Alagoas destituiu a Comissão Bipartite, por ter tomado decisão contrária a ele. A Comissão Tripartite acolheu reclamação do prefeito de Maceió, e de mais 17 municipios, e passou a repassar diretamente aos municipios os recursos locais.

Com a definição de um valor "per capita" para as verbas de saúde elimina - se um dos buracos negros do Orçamento. Hoje em dia, paga - se por qualquer procedimento médico, sem limites nem controle.

Mesmo assim, é idéia do Ministério da Saúde elevar os gastos de US\$ 29 (em 1993) para US\$ 54 "per capita" - o ideal é por volta de US\$100. Para tanto, se irá propor que a União banque 75\% dos recursos - aumentando de US\$ 4,2 bilhões para US\$ 6 bilhões os recursos federais - e Estados e municipios entrem com US\$1 bilhão cada".

Pode-se verificar que alguns setores da mídia estavam atentos ao que se passava na área de saúde e torciam para que a implantação do SUS, em sua concepção inicial, desse certo. Infelizmente, não foi no início de 1994 , como se desejava e previa, que foi aprovado o diploma legal, que iria autorizar a última medida, imprescindivel a essa fase da descentralização.

A medida só foi concretizada já no final do governo Itamar, em agosto de 1994. Quase dois anos foram necessários para se conseguir a aprovação da medida essencial para a viabilização da descentralização dos recursos.

Isto veio a acontecer com o Decreto 1232, de 30-8-1994(26), cujo texto assim se resume:

“O PRESIDENTE DA REPÚBLICA , no uso da atribuição que the confere o art. 84, inciso IV, da Constituição, e tendo em vista o disposto na Lei $n^{\circ} 8.080$, de 19 de setembro de 1990, e na Lei $n^{\circ} 8.142$, de 28 de dezembro de 1990.

"Art. $1^{\circ}$ Os recursos do Orçamento da Seguridade Social alocados ao Fundo Nacional de Saúde e destinados à cobertura dos serviços e ações de saúde a serem implementados pelos Estados, Distrito Federal e Municipios serão a estes transferidos, obedecida a programação financeira do Tesouro Nacional, independentemente de convênio ou instrumento congênere e segundo critérios, valores e parâmetros de cobertura assistencial, de acordo com a Lei $n^{\circ} 8.080$, de 19 de setembro de 1990, e exigências contidas neste decreto. $\S 1^{\circ}$ Enquanto não forem estabelecidas, com base nas caracteristicas epidemiológicas e de organização dos serviços assistenciais previstas no art. 35 da Lei $n^{\circ} 8.080$, de 1990, as diretrizes a serem observadas na elaboração dos planos de saúde, a distribuição dos recursos será feita exclusivamente segundo o quociente de sua divisão pelo número de habitantes, segundo estimativas 
populacionais fornecidas pelo IBGE, obedecidas as exigências deste decreto. § $2^{\circ}$ Fica estabelecido o prazo de 180 dias, a partir da data de publicação deste decreto, para que - Ministério da Saúde defina as características epidemiológicas e de organização dos serviços assistenciais referidas no parágrafo anterior.

Art. $2^{\circ} \mathrm{A}$ transferéncia de que trata o art. $1^{\circ}$ fica condicionada à existência de fundo de saúde e à apresentação de plano de saúde, aprovado pelo respectivo Conselho de Saúde, do qual conste a contrapartida de recursos no Orçamento do Estado, do Distrito Federal ou do Município. $\S 1^{\circ}$ Os planos municipais de saúde serão consolidados na esfera regional e estadual e a transferência de recursos pelo Fundo Nacional de Saúde dos Municipios fica condicionada à indicação, pelas Comissões Bipartites da relação de Municípios que, além de cumprirem as exigências legais, participam dos projetos de regionalização e hierarquização aprovados naquelas comissões, assim como à compatibilização das necessidades da política de saúde com a disponibilidade de recursos. $\S 2^{\circ} \mathrm{O}$ plano de saúde discriminará o percentual destinado pelo Estado e pelo Município, nos respectivos orçamentos, para financiamento de suas atividades $e$ programas. $\S 3^{\circ} \mathrm{O}$ Ministério da Saúde definirá os critérios e as condições mínimas exigidas para aprovação dos planos de saúde do município.

Art. $3^{\circ}$ Os recursos transferidos pelo Fundo Nacional de Saúde serão movimentados, em cada esfera de governo, sob a fiscalização do respectivo Conselho de Saúde, sem prejuízo da fiscalização exercida pelos órgãos do sistema de Controle Interno do Poder Executivo e do Tribunal de Contas da União.

Art. $4^{\circ}$ É vedada a transferência de recursos para o financiamento de ações não previstas nos planos de saúde, exceto em situações emergenciais ou de calamidade pública, na área da saúde.

Art. $5^{\circ}$ O Ministério da Saúde, por intermédio dos órgãos do Sistema Nacional de Auditoria e com base nos relatórios de gestão encaminhados pelos Estados, Distritos Federal e Municípios, acompanhará a conformidade da aplicação dos recursos transferidos à programação dos serviços e ações constantes dos planos de saúde.

Art. $6^{\circ}$ A descentralização dos serviços de saúde para os Municípios e a regionalização da rede de serviços assistenciais serão promovidas e concretizadas com a cooperação técnica da União, tendo em vista o direito de acesso da população aos serviços de saúde, a integralidade da assistência e à igualdade do atendimento.

Art. $7^{\circ}$ A cooperação técnica da União com os Estados, o Distrito Federal e os Municipios, previstas no art. 16, inciso XIII, da Lei Orgánica da Saúde, e no art. 30, inciso VII, da Constituição Federal, será exercida com base na função coordenadora da direção nacional do Sistema Único de Saúde, tendo em vista a realização das metas do Sistema e a redução das desigualdades sociais e regionais.

Art. $8^{\circ}$ A União, por intermédio da direção nacional do SUS, incentivará os Estados, o Distrito Federal e os Municípios a adotarem política de recursos humanos caracterizada pelos elementos essenciais de motivação do pessoal da área da saúde, de sua valorização profissional e de remuneração adequada.

Art. $9^{\circ}$ A União, por intermédio da direção nacional do SUS, sem prejuizo da atuação do Sistema de Controle Interno do Poder Executivo Federal, exercerá o controle finalístico global do Sistema Único de Saúde, utilizando-se, nesse sentido, dos instrumentos de coordenação de atividades e de avaliação de resultados, em âmbito nacional, previstos na Lei Orgânica da Saúde e explicitados neste decreto.

Art. 10. O atendimento de qualquer natureza na área do Sistema Único de Saúde. quando prestado a paciente que seja beneficiário de plano de saúde, deverá ser ressarcido pela entidade mantenedora do respectivo plano. 
Art. 11. O Ministério da Saúde, por intermédio de seus órgãos competentes, adotará as medidas administrativas destinadas à operacionalização do disposto neste decreto.

Art. 12. Este decreto entra em vigor na data de sua publicação.

Brasília, 30 de agosto de $1994 ; 173^{\circ}$ da Independência e $106^{\circ}$ da República. ITAMAR FRANCO Henrique Santillo"

O Decreto visava, e visa, a operacionalização do SUS. Aquilo que já devia ter estado na CF, depois vetado na 8080 e, agora, finalmente estabelecido através de Decreto, por orientação primeira do próprio TCU.

As conquistas na direção de implantar e implementar o SUS são evidentes e dentre elas salientam - se:

- Define que os repasses financeiros da União a Estados e Municípios serão feitos, independentemente de procedimento convenial ou similar. Aparentemente, parece apenas uma formatação sem importância, mas muda radicalmente o conceito sobre de quem é a posse dos recursos e o que pode ser feito com ele, fugindo das amarras das normatizações do MF sobre uso dos recursos transferidos por convênios;

- Reafirma a necessidade de se estabelecerem critérios, valores e parâmetros de cobertura assistencial para a transferência de recursos. Comando da 8080 reafirmado aqui: sair do critério de repasse, por simples série histórica de produção;

- Reafirma o entendimento da 8080 , combinado com o da 8142 que, enquanto não se estabelecem os critérios do art.35 da 8080 , todo o recurso devesse ser transferido pelo quociente populacional. Para tanto, estabelece-se o prazo de 180 dias para viabilizar esse comando, portanto, seis meses, a partir de 30 de agosto, ou até fim de fevereiro de 1995;

- Reafirma a exigência para repasse da 8142: ter fundo e plano de saúde;

- Define que os planos estaduais e municipais sejam aprovados nos respectivos conselhos e nas CIBs e que participem de projetos de regionalização e hierarquização dos serviços de saúde;

- Exigência de que Estados e Municípios indiquem, nos planos, os percentuais de orçamento que investem em saúde - o que consta da 8080-35 (27);

- Conselho fiscaliza os fundos de saúde de cada esfera de governo;

- Só podem ser financiadas ações que constem do plano de saúde; 
- Os relatórios de gestão serão utilizados para verificar a conformidade do realizado com o planejado;

- Reafirma o objeto da cooperação técnica da União com Estados e Municípios;

- Recomenda cuidados com os $\mathrm{RH}$, através de motivação e remuneração adequada;

- Trata do Ressarcimento dos Planos e Seguros de Saúde, reafirmando o preceito legal já constante da Lei 8689 .

Isto aconteceu em 30 de agosto de 1994. Havia mais uma etapa a ser cumprida, pois esse Decreto 1232 trazia, em seu artigo 11: O MS adotará as medidas administrativas destinadas à operacionalização do disposto neste decreto. Mais um desafio: fazer a regulação da operacionalização vencer os "donos da administração do dinheiro", que se mantinham ostensivamente, por vezes, e outras, simuladamente, contra qualquer medida descentralizatória dos recursos financeiros.

Veio ai a Portaria do MS, que tentou fazer todos os remendos e, mais uma vez, diminuir um pouco - ainda que sutilmente - as aberturas do Decreto 1232. Foi a Portaria do Gabinete do Ministro da Saúde, $n^{\circ} 1827$, de 31 de outubro de 1994. (65)

"O Ministério de Estado da Saúde, no uso de suas atribuições, legais e;

Considerando o disposto do Decreto $n^{\circ} 1232$, de 30 de agosto de 1994, sobre a transferência regular e automática de recursos do Fundo Nacional de Saúde para os Fundos Estaduais, Municipais e do Distrito Federal;

Considerando que, para a implementação das condições de gestão parcial e semiplena do SUS nos Estados e Municípios, de acordo com a NOB $n^{\circ}$ 01/93, se impõe a definição de tetos financeiros para custeio das Atividades Hospitalares e Ambulatoriais;

Considerando as recomendações da Comissão Interministerial nomeada pelo Decreto de 04 de maio de 1994, e, especialmente as recomendações da Comissão Intergestores Tripartite, resolve:

Art. $1^{\circ}$ - Determinar que a Secretaria de Assistência à Saúde, do Ministério da Saúde defina os tetos financeiros de cada Estado relativos ao custeio das atividades de Assistência Ambulatorial e Hospitalar(SIA e SIHI SUS) e elabore as normas complementares para a aplicação desta Portaria.

Art. $2^{\circ}$ - Caberá às Comissões Intergestores Bipartites, em cada Estado, definir os tetos financeiros da Secretaria Estadual de Saúde e da Secretaria de Saúde, ou órgão equivalente, de cada Municipio. $1^{\circ}$ - $A$ definição do teto financeiro correspondente à Secretaria Estadual obedecerá à programação das ações desenvolvidas pela sua rede própria e por serviços contratados e conveniados, de referência estadual, sob sua gestão. $2^{\circ}$ - A definição sob o teto financeiro de cada Município obedecerá à programação das ações desenvolvidas pela sua rede própria, contratada/ conveniada e das ações e serviços de referência locall regional. $3^{\circ}$ - As secretarias Estaduais de Saúde deverão informar a Secretaria de Assistência à Saúde, do Ministério da Saúde, os tetos fixados pelas Comissões Intergestores Bipartite para cada um dos Municípios e para a Secretaria Estadual de Saúde. 
Art. $3^{\circ}$ - Os recursos financeiros referentes aos tetos de Estados e Municípios na condição de gestão semiplena serão transferidos, mensalmente, para os Fundos Estaduais e Municipais de Saúde, de forma direta, até o dia 10 do mês de competência da execução de serviços, nos termos do Decreto $n^{\circ} 1.232 / 94$.

Art. $4^{\circ}$ - Os recursos referentes à diferença entre o teto financeiro estabelecido e o valor efetivamente pago aos Estados e Municípios na condição de gestão parcial serão transferidos, mensalmente, para os Fundos Estaduais e Municipais de Saúde, de forma, direta, nos termos do Decreto $n^{\circ} 1.232 / 94$.

Art. $5^{\circ}$ - Os tetos financeiros serão corrigidos ao mesmo tempo e na mesma proporção das tabelas básicas de remuneração de procedimentos hospitalares e ambulatoriais (SIH e SIA - SUS).

Art. $6^{\circ}$ - Os Estados e Municípios na condição de gestão semiplena ou parcial deverão enviar, anualmente, ao Ministério da Saúde, relatório de gestão acompanhado dos balanços orçamentánio, financeiro e patrimonial, com demonstrativo orçamentário das aplicações na área da Saúde, e comprovante da remessa das contas anuais ao Tribunal de Contas a que estiverem jurisdicionados, nos termos da Portaria 1.105/94.

Art. $7^{\circ}$ - Observados os planos de saúde aprovados pelos Conselhos Estaduais e Municipais de Saúde, os recursos transferidos para os fundos estaduais e municipais de saúde, em decorrência desta Portaria, serão considerados receita própria dos Estados e Municipios nos termos dos artigos $6^{\circ}, 1^{\circ}$ e $11,1^{\circ}$ e $2^{\circ}$ da Lei $n^{\circ} 4.320$, de 17/03/64, mas serão aplicados em despesas correntes e de capital segundo a categoria econômica de que forem deduzidos do Orçamento do Ministério da Saúde, ressalvo o disposto no artigo 43 da referida lei.

Art. $8^{\circ}$ - No exercício da fiscalização que lhes compete, nos termos do artigo $3^{\circ}$ do Decreto $n^{\circ} 1.232 / 94$, os Conselhos de Saúde suscitarão, perante os órgãos do Sistema Nacional de Auditoria, a apuração de quaisquer irregularidades que tenham identificado na aplicação dos recursos transferidos pelo Ministério da Saúde, para a adoção das providências determinadas no artigo 10 do Decreto n¹105, de 6 de abril de 1994.

Art. $9^{\circ}$ - Enquanto não se efetiva o procedimento licitatório, de observância obrigatória, para a contratação de serviços privados complementares, os Estados e Municipios na condição de gestão semiplena efetuarão o controle, a avaliação e o pagamento dos serviços prestados pelas entidades contratadas e conveniadas anteriormente à vigência da portaria/ GM 1.286/93 e da Portaria /GM 994/94.

Art. 10 - Esta Portaria entra em vigor na data de sua publicação, com efeitos financeiros a partir de 01 de novembro de 1994.

Art. 11 - Ficam revogadas as disposições em contrário. Henrique Santillo".

Dava a entender que, assim, terminava a via-crúcis da transferência financeira da União para Estados e Municípios, de forma regular e automática Fundo a Fundo.

A essência dessa portaria operacional consiste em:

Definição de tetos fixos, como limite anual de transferências de recursos para cada um dos Estados, que deveriam, então, colocar os limites de cada um de seus municípios, com aprovação na CIB. Seria preciso separar o que era atividade Estadual e o que era de responsabilidade dos municipios. Pela primeira vez, definia-se teto municipal no financeiro e 
de forma pública. Essa foi uma exigência do MF, da Secretaria do Tesouro Nacional, que não admitiam que, ainda que esse teto constasse da Lei Orçamentária Anual, ele deveria ser melhor explicitado, ou colocado em bases mais reais. Exigia-se, como medida legal, que se definisse quanto cada Estado poderia gastar. Não se permitiria mais que os limites estaduais fossem sendo alterados aleatoriamente, em descumprimento à CF. Todos sabiam da "certitude" do comando Constitucional e Legal, mas a prática, desde a época do INAMPS, era de rompimento rotineiro deste teto. O MF, neste particular, nada mais fez que exigir o cumprimento da legislação. Mas houve resistência até o último instante e o ultimato do MF. A CIT relutou em aceitar a imposição legal. Era um constrangimento ao gasto com saúde, mas as despesas não poderiam ser realizadas independentemente de limite financeiro. Como saúde era uma área de despesa continuada de prestação de serviços pelos próprios e pelos contratados, as despesas corriam, mais ou menos, sem muita amarra do teto final. A publicação dos tetos de cada Estado ocorreu logo após a portaria ministerial. A decisão da CIT veio em forma da RESOLUÇÃO No 12 / 94.(57)

“A Comissão Intergestores Tripartite, em reunião ordinária realizada no dia 11 de outubro de 1994 e, considerando decisão tomada na reunião ordinária do dia 27/09/94, sobre a definição de tetos financeiros para todas as Unidades Federadas, resolve:

Os tetos financeiros dos Estados serão utilizados para a cobertura das atividades hospitalares e ambulatoriais, incluindo o fornecimento de cioclosporina e eritropoetina, órteses e próteses ambulatoriais, medicamentos excepcionais e tratamento fora de domicilio, programa de agentes comunitários de saúde, programa de interiorização e programa de saúde da familia.

A Secretaria de Assistência á Saúde do Ministério da Saúde baixará as normas complementares que se fizerem necessárias para a divulgação e cumprimento dessa Resolução. Brasilia, 11 de outubro de 1994. MS - CONASS - CONASEMS".

Estabelecia claramente o prazo de transferência dos recursos para os Municipios em Gestão Semi-Plena, segundo a NOB-93 que, a partir de primeiro de novembro, teriam a transferência total de recursos federais para os fundos municipais de saúde. O grande tento foi o estabelecimento do repasse, fundo a fundo, para esses municípios, até o dia 10 de competência dos serviços produzidos. Para quem amargava, até o advento do real, de uma defasagem de até 110 dias e média de 75 dias para o pagamento das despesas, a garantia do repasse no primeiro decêndio do mês de prestação representou um grande avanço.

A questão seguinte dizia respeito à gestão parcial, segundo a NOB-93. Os municípios passariam a ter um sistema de vasos comunicantes (até então incomunicáveis) de recebimento dos recursos que economizassem em uma das duas áreas - a ambulatorial e a hospitalar - respeitado o respectivo teto. Era a semiplenitude inicial para quem não tinha, ainda, se organizado para assumir a Semi-Plena. Um incentivo concreto à mudança do modelo. Valia, também, para os Estados. Era algo mais que o simples pagamento por 
produção de serviços. Era um teto garantido e, se houvesse menos gasto com a doença... poder-se-ia gastar com outras prioridades, como a promoção, prevenção e o atendimento ambulatorial primário ou intermediário.

Estabeleceu-se a correção dos valores dos tetos na mesma proporção em que se corrigissem os valores de tabela, independentemente da remuneração ser feita pelos valores de tabela.

O tento maior foi passar a considerar os recursos transferidos, fundo a fundo, como recursos próprios dos Municípios e Estados. Era uma simples portaria, que criava uma jurisprudência, a favor de estados e municípios. Isto só foi concretizado com mais peso, a partir da EC-29, de $13 / 9 / 2000$.

Entretanto, colocou-se aí um senão - tipicamente introduzido pelos orçamentistas profissionais: os recursos viriam "carimbados". Os recursos de investimento só poderiam ser usados para investimentos e, os de custeio, para o custeio ou despesas correntes. Qual a implicação disto? Os recursos "economizados", por exemplo, no custeio de internações desnecessárias só poderiam ser utilizados para as despesas ditas correntes, e não poderiam ser utilizados para aquisição de equipamentos, nem construções. Não deixaram de imprimir a marca registrada das limitaçōes: podem decidir a descentralização que quiserem, mas vamos colocar algumas peias!....

Aos Conselhos, é lembrada sua competência fiscalizatória e de apurar irregularidades.

É transferido aos Municipios, em gestão Semi-Plena, a capacidade de gerenciar contratos e convênios federais ou estaduais com prestadores, até concretizarem os próprios convênios, segundo legislação de 93 e 94.

O Ministro Santillo, em $1^{\circ}$ de novembro de 1994, informa ao Presidente Itamar a nova forma de transferência de recursos do MS para Estados e Municípios, a ser implementada. (135)

O auge da vitória da descentralização foi a assinatura das primeiras autorizações de pagamento para os primeiros 19 municipios brasileiros, que entraram em gestão Semi-Plena recebendo os recursos diretamente do MS ao Fundo Municipal de Saúde, em 11-11-1994. Os primeiros municipios contemplados foram: Fortim -CE, Itapiuna - CE, Iracema-CE, QuixadáCE, Alfenas -MG, Betim-MG, Belo Horizonte -MG, Sete Lagoas -MG, Panambi -RS, Santa Rosa -RS, Blumenau-SC, Joinville-SC, Assis-SP, Diadema -SP, Mauá-SP, São Vicente-SP, Santos-SP, Votorantin -SP, Sertãozinho-SP. Logo depois, em dezembro mais alguns municipios que, ainda que já habilitados meses atrás, ultimavam seu preparo, entre eles, São José dos Campos -SP (61) 
O comentário oficial sobre essa data, fica por conta do então Secretário de Assistência à Saúde do MS, Gilson Carvalho, que divulgou a seguinte nota:

\section{" AVANÇO DA DESCENTRALIZAÇÃO NA ÁREA DA SAÚDE}

O Presidente Itamar Franco dá um passo a mais na descentralização dos serviços de saúde.

Pela primeira vez, serão repassados recursos direta e automaticamente a Municípios, seguindo o que determina o Decreto Presidencial n 1232, de 30 de agosto de 1994.

O Ministro da Saúde, Henrique Santillo determinou que se depositem os primeiros 29 milhões de reais referentes à cota mensal para as ações do SUS no mês de novembro, nestes municípios.

Há um preceito constitucional que determina a descentralização dos serviços de saúde buscando mais eficiência, melhor controle tanto institucional de governo, quanto dos cidadãos pelo controle social. Nestas cidades, onde os recursos já serão repassados direta e automaticamente, é obrigatório cumprir o plano de saúde. Os recursos devem ser administrados no Fundo de Saúde com toda transparência legal e controlados pelos Conselhos de Saúde. Nestas cidades já existem Conselhos de Saúde compostos em uma das partes por cidadãos usuários dos serviços de saúde (representantes sindicais de trabalhadores e patronais, de associações de moradores, de doentes e deficientes, etc.); a outra metade é composta de membros da administração pública, de prestadores de serviços e Trabalhadores de Saúde.

No mundo inteiro as experiências de descentralização da administração pública e privada são vitoriosas. O controle do processo será feito pelas próprias administrações municipais e pelos cidadãos através de um Sistema Nacional de Auditoria, com participação integrada das três esferas de governo.

Os municipios que entram nesta primeira fase são os seguintes: No Estado do Ceará: Iracema, Itapiuna, Quixadá, Fortim; em Minas Gerais: Alfenas, Belo Horizonte, Betim, Sete Lagoas; Rio Grande do Sul: Panambi e Santa Rosa; em Santa Catarina: Blumenau e Joinville; em São Paulo: Assis, Diadema, Mauá, Santos, São Vicente, Sertãozinho e Votorantim.

Além destes existe o estado de São Paulo, como um todo, e outros municípios já habilitados, que apenas aguardam repasse de recursos financeiros do Ministério da Fazenda, para igualmente se enquadrarem nesta nova fase de gestão. Brasilia - DF, 11 de novembro de 1994. Gilson de Cássia Marques de Carvalho." (80)

O apoio dos movimentos, instituições e entidades foi muito grande, diante desta nova medida rumo ao cumprimento integral da lei. Destaca-se entre estas opiniões aquela emitida pela FSP da USP.

O Ministro da Saúde, Henrique Santillo, organizou uma cerimônia oficial junto ao Palácio do Planalto para marcar o momento. Devido à agenda do presidente Itamar Franco a Sessão Solene de comemoração do fato só pode ser realizada em $1^{\circ}$ de dezembro. A convocação ficou por conta do Ministro da Saúde do CONASS e do CONASEMS(54): 
"O Ministério da Saúde, o Conselho Nacional de Secretários Estaduais de Saúde e o Conselho Nacional de Secretários Municipais de Saúde, têm a honra de convidar vossa excelência a participar de

cerimônia em homenagem ao excelentíssimo Senhor Presidente Itamar Franco, pela determinação de ter cumprido a Constituição Federal, incentivando o processo de descentralização do Sistema Único de Saúde, através da assinatura dos documentos legais que assim o permitiram, bem como da passagem direta e automática de recursos fundo a fundo do governo federal às primeiras secretarias municipais de saúde. Esta cerimônia realizar-se-á às 11 horas e trinta minutos, do dia $1^{\circ}$ de dezembro, no salão leste do Palácio do Planalto.".

Assim, concluiu-se mais uma fase importante na implantação do SUS. Termina o Governo Itamar Franco e entrávamos no Governo Fernando Henrique Cardoso.

\section{O FINANCIAMENTO FEDERAL PARA A SAÚDE NO GOVERNO FHC - A BUSCA DE MAIS RECURSOS E A CPMF}

\subsection{O FINANCIAMENTO DA SAÚDE EM 1995 E A REFORMA DA SEGURIDADE}

A grande proposta do Governo FHC foi o condicionamento da reforma constitucional à governabilidade. Uma das áreas consideradas de grande empecilho à modernidade neoliberal era a área de Seguridade Social, na qual se encontra a saúde. O nó central era o financiamento da Seguridade Social. Tanto da "gratuidade" da Saúde, quanto dos altos custos da Previdência Pública.

Iniciou-se, então, a batalha da reforma da Seguridade Social, mediante a Revisão Constitucional. Em março de 95, entre as muitas reformas constitucionais propostas, enviadas pelo Executivo para análise e votação no Congresso, estava a da REFORMA DA SEGURIDADE SOCIAL. A constituição de 88 consagrou o princípio dos benefícios sociais, juntando à Seguridade Social: PREVIDÊNCIA, SAÚDE e ASSISTÊNCIA SOCIAL. Isto significava a tomada de partido em defesa da idéia de se criar um estado de bem estar social com os direitos mínimos dos cidadãos garantidos.

A saúde, pela primeira vez, numa Constituição Brasileira, foi premiada com cinco artigos especificos e outros mais, espalhados pelo texto constitucional.

Consagrou-se na Constituição o princípio de que SAÚDE É DIREITO DE TODOS E DEVER DO ESTADO. ASSEGURADO POR POLITICAS ECONÓMICAS E SOCIAIS. CONSTITUINDO UM SISTEMA COM GESTOR ÚNICO EM CADA ESFERA DE GOVERNO, SOB A ÉGIDE DA DESCENTRALIZAÇÃO PARA OS MUNICIPIOS E 
SUPLEMENTARMENTE PARA OS ESTADOS. PRIORIDADE PARA A PREVENÇÃO AINDA QUE AÇŐES ASSISTENCIAIS SEJAM IMPRESCINDIVEIS. SAÚDE COMO RELEVÂNCIA PÚBLICA SEM SER ESTATAL. AINDA QUE A EXECUÇÃO SEJA FEITA PRIORITARIAMENTE PELO PÚBLICO, COMPLEMENTARMENTE ENTRA O PRIVADO COM PREFERÊNCIA PELO FILANTRÓPICO E PELO SEM FINS LUCRATIVOS.

Havia duas correntes fortemente divergentes quanto à necessidade de se fazer, ou não, alguma alteração constitucional. De um lado, os defensores da reforma que juram que com esta Constituição será impossível ao Brasil chegar ao desenvolvimento compativel com sua necessidade. Nosso atraso como nação é debitado, aos erros da Constituição. De outro lado, aqueles que são unânimes em afirmar que nosso atraso é devido, exatamente, a não termos implementado até o momento, questões fundamentais de nossa Constituição. Defendem que inúmeros avanços nem foram ainda regulamentados e colocados em prática e assim sendo, fica impossivel avaliar o acerto daquilo que ali é defendido.

Mostrando um dos lados há a opinião do Prof. Dr. Geraldo Ataliba, catedrático da USP e PUC em direito constitucional e financeiro e consultor de vários parlamentares. Suas opiniões foram emitidas em entrevista para o Jornal do Conselho Regional de Medicina do Estado de São Paulo.(7) Prof. Geraldo Ataliba afirma:

“Não há nenhuma necessidade, absolutamente, de fazer esta reforma. O que está pôr trás deste movimento são os 40 bilhões de reais ligados à previdência privada, os 50 milhões do petróleo, os 30 milhões da telefonia e não sei quanto do programa energético em geral. São interesses de banqueiros internacionais, os mesmos que fizeram a farra do México, mandam no FMI, no Banco Mundial e exploram o mundo. Eles é que querem esta reforma. Como não podem dizer "estamos querendo passar a mão na grana brasileira que está nestes quatro ou cinco itens, dizem que é necessário mexer na constituição. "

Cita opiniões internacionais favoráveis ao que há de moderno e inovador na Constituição Federal e explica o porque de determinadas questões que poderiam estar nas leis ordinárias, e que acabaram ficando na constituição:

"A constituição tem minúcias, diz algumas coisas que a rigor seriam puramente uma questão de lei e não de constituição. Mas a assembléia constituinte fez isto porque as forças políticas brasileiras representam a elite. Teoricamente, a elite aceita gastar dinheiro com os pobres, quer promover o cidadão. Mas na hora de tomar a decisão, a escolha é sempre outra. Então, na hora em que o povo brasileiro estava lá pressionando, entraram todos estes itens - salário mínimo, leis trabalhistas, aposentadoria, obrigatoriedade de gastar dinheiro com educação, previdência social etc... Muito do que está na constituição não está sendo obedecido. Mas, estando lá, pelo menos esperamos que um dia se cumpra. Se for tirado de lá, são idéias que vão ficar esquecidas, desaparecendo até mesmo dos discursos.". 
Em relação à saúde, comenta:

"O único interesse em reformas na saúde diz respeito às companhias de seguro de saúde que giram milhões. Quem está preocupado com a saúde cumpre a constituição que é muito boa nessa matéria. Ela revela uma verdadeira preocupação com a saúde pública brasileira, dá amplo campo de liberdade para a iniciativa privada e incumbe o estado de suprir as carências. Se fôssemos depender da iniciativa privada apenas $15 \%$ do povo teria assistência. Esta é a realidade brasileira, um país extremamente injusto na distribuição de renda. Em matéria de saúde só devem haver mudanças que interessem as empresas de seguro saúde. Elas têm poder e dinheiro e já compraram muita gente." (7)

Essa posição veemente contra qualquer reforma constitucional do Prof.Ataliba encontra eco em uma parte da população e da classe política, mas não é uma unanimidade. De outro lado, o Presidente da República, e todos os que o seguem, defendiam ardorosamente a necessidade de se mudar a Constituição sob pena de termos um pais ingovernável. Defendiam tão firmemente e com tanta crença esse lado que deram às reformas constitucionais prioridade absoluta, chegando mesmo ao imobilismo de três meses de governo, à espera das grandes aberturas que se darão com a aprovação das faladas reformas.

Na proposta do governo de reformar a Saúde estavam em destaque duas questões que, aos mais desavisados pareciam sem importância. As duas, referentes ao financiamento.

É essencial que se entenda uma diferença de abordagem da Previdência e da Saúde dentro da Seguridade Social. A Previdência tem peculiaridades, dado que seus direitos se referem a questões individuais especificas, "determinadas situações em que uns são tratados diferentemente de outros", em que alguns detêm situações, ainda que legais, privilegiadas. Nas discussões afloram sempre confrontos entre os que têm esses privilégios e aqueles que não os têm. Diferentemente a Saúde parte de seu caráter universal em que todos vão buscar direitos iguais. Mais que individual é a discussão de um direito coletivo, mais abrangente. No primeiro enfoque, não se diz respeito a ninguém em particular, mas a todos, tomados como universo.

Abaixo, apresentamos uma análise da proposta de Reforma Constitucional, nos pontos que afetam a saúde.

Primeiro, a questão que poderia ser denominada como a única boa, mas só se persistir a inclusão legal da saúde na partilha dos recursos da Contribuição de Empregados e Empregadores.

Aumento de recursos para a saúde: analisando as várias propostas governamentais, identificam-se aquelas que visam o aumento da receita: contribuição sobre toda força de 
trabalho, mesmo não registrada; recolhimento prévio ao pagamento de acordos e sentenças judiciais e alguns outros. Além destas, muitas das que diminuem despesas, automaticamente, representam um aumento da receita. Todas essas medidas, visando aumento de recursos para o caixa da seguridade social, representam aumento de recursos para a saúde. Isto está no espírito do legislador das normas da Seguridade, que não determinou a especializaçăo de fontes. Se fosse intençăo dos constituintes especializar a contribuição de empregados e empregadores apenas para a Previdência, teriam eles explicitado isto na Constituiçăo. Como não o fizeram, ao se preservar o conceito indivisível de solidariedade entre previdência, saúde e assistência social, todos os recursos que forem arrecadados pela Seguridade Social deverão ser divididos entre os componentes da seguridade (Previdência, Saúde e Assistência Social), segundo critérios de participação definidos pelo Conselho de Seguridade sobre as propostas elaboradas em cada um dos setores que o compõem. Temerariamente, pode - se afirmar que é o único ponto positivo de tudo que se colocou para a saúde na proposta governamental de reforma, ainda que sob o temor de que qualquer Ministro, em busca de poder, possa, arbitrariamente, usurpar recursos da saúde advindos da Contribuição de Empregados e Empregadores, repetindo a história ocorrida, desde maio de 1993, com Britto.

Repartição colegiada de recursos, a cada ano, repartição a ser definida em lei? A legislação determina que a discussão, a cada ano, da partilha de recursos entre as três áreas, seja feita de acordo com entendimentos e hoje, não mais aprovado no Conselho de Seguridade Social. Isto foi resultado de uma disputa constante entre a área social e a econômica e se concretizou como um avanço. A proposta de Reforma derruba por terra essa conquista. Fica apenas o aceno de que uma lei definirá a partilha da União para Estados e Municípios e dos Estados para Municipios. Na proposta constava "a lei federal definirá os critérios de transferência de recursos para o SUS e Assistência Social da União para Estados, DF e Municipios e dos Estados para Municipios, observada a respectiva contrapartida de recursos". Haveria, ainda aí, um condicionante: observada a respectiva contrapartida de recursos, essa hipótese que, à primeira vista, pode ser olhada como um bem, exigindo, principalmente de Estados e Municípios que entrem com recursos próprios para a saúde, na verdade pode ser indicadora de menos recursos da União para a Saúde. O pensamento dominante entre os economocratas é de que a União não poderia arcar sozinha com as despesas de saúde e teria que dividi-las com Estados e Municípios. Entretanto, o montante que tem que ser dividido, segundo o pensamento deles, são os atuais parcos recursos repassados pela União. Não se trata de um acréscimo de recursos, mas sim, de um encolhimento dos recursos da União a serem cobertos com recursos estaduais e municipais 
(como se muitos deles já não contribuíssem até em percentuais excessivos diante de sua renda!). Chegou - se a afirmar, sem protesto de ninguém do Ministério da Saúde, que Estados e Municípios năo colocavam recursos próprios para a saúde!...

Quatro palavrinhas jogavam o SUS por água abaixo...A proposta mais danosa e prejudicial que se ousa fazer à saúde concretizou-se em quatro palavrinhas. "A SAÚDE É DIREITO DE TODOS E DEVER DO ESTADO, GARANTIDO, NOS TERMOS DA LEI, MEDIANTE POLITICAS SOCIAIS E ECONOMICAS(....)". Como podem poucas palavras, como as acima, modificar radicalmente todo um projeto engendrado durante tantos e tantos anos! Alguém, sem consultar as autoridades de saúde deste país, sem ouvir os técnicos do setor, sem ouvir - Conselho Nacional de Saúde, sem ouvir os cidadăos usuários... provavelmente numa ousadia... na arrogância de quem governa e pouco ou nada importa o que é pensamento da maioria, muitas vezes ciente, numa penada, trucida um projeto de cidadania: O DIREITO UNIVERSAL E IGUALITÁRIO A SAÚDE. Esta foi a ousadia de alguém que resolve qualificar como será o direito à saúde e qual será o nível de dever do Estado!!!... É sabido que, conseguir garantir na Constituição os princípios fundamentais do SUS, foi um trabalho longo de mobilização de toda a sociedade. $O$ fruto disso foi a garantia de transformar determinadas premissas em cláusulas pétreas ou que, pelo menos, delas se aproximassem e só uma maioria qualificada no Congresso (três quintos e quatro votações) poderia alterar esses princípios.... Aparece, então, alguém, pelo atalho, e diz que, de agora em diante, A LEI FEDERAL é que vai definir como é "este tal de direito à saúde" e a quem se aplica, bem como qual é a dimensão e dever do Estado, se para todos ou se será qualificado, só para desqualificados!!!... A Lei Federai, que poderia ser aprovada por maioria simples ou mesmo, apenas por acordo de lideranças, sem toda discussão e peso de uma alteração constitucional, é que iria definir o direito à saúde!!!...

O atestado do fracasso: serviços de saúde especiais dirigidos ao atendimento do funcionalismo. Eis ai uma chaga aberta que precisa ser pensada e, se possivel, curada. $O$ que existe em nosso pais é tão chocante e foge à lógica mais rudimentar. Os trabalhadores do governo, na administração direta e indireta, nas três esferas de governo, conseguiram através dos tempos, serviços de saúde próprios. Entenda-se aqui como próprios, tanto aqueles estatais, como os comprados de terceiros, através de sistemas de auto-gestão e até mesmo, da compra total de serviços de empresas de medicina de grupo ou de cooperativa médica. É o mais veemente atestado de que os serviços de saúde PÚBLICOS não estariam sendo úteis e válidos, nem mesmo para os funcionários públicos! A proposta "sapientissima" de emenda do governo é que, de ora em diante, estados e municípios podem recolher contribuições de seus funcionários destinados a um sistema de assistência à saúde em 
beneficio destes!!! "OS ESTADOS, DF, MUNICIPIOS PODERÃO INSTITUIR CONTRIBUIÇÃO, COBRADA DE SEUS SERVIDORES, PARA O CUSTEIO, EM BENEFICIO DESTES, DE SISTEMA DE ASSISTÉNCIA A SAÚDE". Acabava de ser lançado um outro sistema de saúde, paralelo, destinado aos servidores públicos: SAS. CLARO QUE O GROSSO DESSE SISTEMA SERA FINANCIADO PELO PÚBLICO, QUE É DE TODOS, E DE ONDE SAIRÃO RECURSOS ESPECIALMENTE DEDICADOS A SAÚdE DOS SERVIDORES.

Vale citar uma curiosidade, que passou quase desapercebida, diante da gravidade da essência desses quatro pontos. A Proposta da Reforma da Seguridade, encaminhada pelo Executivo ao Congresso, năo trazia a assinatura do Ministro da Saúde, ainda que trouxesse a assinatura do Ministro da Educação, cuja área não pertence à Seguridade Social! $O$ fato pareceu por demais estranho. Numa primeira hipótese, o Governo não daria a mínima importância às posições técnicas do Ministério da Saúde, a ponto de imiscuir - se em sua área, destruir o Sistema Único de Saúde, sem aos menos consultá-lo. Em outra hipótese, seria a inapetência do próprio Ministério da Saúde que se omitiu da discussão, para prazer e gozo dos demais autores da proposta. Essa versão fecha com dito público do Ministro, que afirmou ter feito um pacto de não se intrometer, ele Ministro, na reforma constitucional. Dizendo-se técnico, e não político, e não entender da reforma constitucional abria mão desta discussão, desde que fossem garantidos os recursos à saúde. Ambas as hipóteses são extremamente graves. Mais do que emissão de juízo de valores, exceto na questão saúde, aqui são mostradas as alterações propostas pelo Governo para a área de Seguridade Social.

Vários setores da sociedade, em especial da área de saúde, juntamente com um grupo de parlamentares progressistas, começaram a se posicionar contra essa "Reforma" que destruía o Sistema Único de Saúde. A posição de apoio veio de, além dos parlamentares, de entidades de classe da área de saúde (sindicatos, associações, autarquias de regulação profissional), grupos de técnicos, central de trabalhadores etc. Também, havia os "contra" por não quererem aumento na carga tributária e por não confiarem em que recursos novos arrecadados seriam destinados a saúde. Abaixo, o texto de uma memória relativa ao financiamento, divulgado pelo denominado Grupo de Trabalho em Defesa da Saúde.(110)

\section{"A REFORMA CONSTITUCIONAL DE 1995 E A DEFESA DO SUS}

O processo de revisão Constitucional, que agora concretamente inicia, propiciou o surgimento de diversas propostas de modificações que afetam, direta ou indiretamente, a área de Saúde. No âmbito específico da saúde as proposições apresentadas podem, segundo seus principais objetivos, serem elencadas em dois grandes grupos: a) as que visam o aperfeiçoamento do SUS, sobretudo em relação ao seu financiamento $e$ gestão; e b) as que buscam os principios doutrinários do SUS. Ainda que as propostas de aperfeiçoamento do modelo vigente sejam majoritárias, existem propostas que 
transformam radicalmente o sistema de saúde. $E$, o que é grave, observa - se uma inexplicável letargia na defesa da doutrina e princípios do SUS por parte de lideranças politicas e de representações sociais que lutaram por sua aprovação na Constituição de 1988. Dentre as emendas apresentadas com o objetivo de descaracterizar o SUS, merece destaque a que visa instituir o "pluralismo de sistemas assistenciais", sob pretexto de assegurar o direito de liberdade de escolha. O que esse argumento encobre, no entanto, é a intenção de segmentar o mercado da assistência médico hospitalar, reservando à iniciativa privada, mediante renúncia fiscal, a atenção à parcela da população integrada ao mercado de trabalho e ao sistema público as ações de prevenção e promoção e o atendimento à ampla massa de excluídos.

A experiência histórica brasileira registra antecedentes de organização do sistema de saúde baseada no pluralismo de sistemas assistenciais. Os resultados são bem conhecidos: a ampliação das diferenças de acesso e de qualidade de atenção entre pessoas e entre regiōes do pais, com sua perversa cristalização das desigualdades. $O$ sistema de saúde hoje existente - dado que o SUS ainda não foi totalmente implantado - reflete em grande parte as distorções decorrentes desse modelo, particularmente no que diz respeito à distribuição da rede de serviços, que acabou por reproduzir os padrões de concentração espacial da atividade económica. Apreciações apresentadas, que não levam em conta a conjuntura desfavorável que tem acompanhado o processo de implantação do SUS, extraordinário decréscimo de recursos federais destinados à saúde (mais de 50\% desde 1989), acompanhado de vontade política vacilante, colocam em risco conquistas sociais legítimas da área como a universalidade no acesso, a busca da equidade e a aceleração do processo de reforma do Estado (descentralização e democratização).

É inegável o quadro de deterioração do sistema de saúde, mas é injusto atribuí-lo ao SUS. Afinal, a situação só não é mais caótica devido ao aumento da participação municipal - que o modelo propicia - participação esta que tem "amortecido" a brutal retração dos recursos federais. Isso que nos leva a perguntar: sem o SUS, como estaria, hoje, nosso sistema de saúde?

Querem transformar a vítima em vilão do "desfinanciamento" da Seguridade Social, mesmo sabendo que das três áreas que a compõem, a saúde foi a que sofreu maior perda de recursos nos últimos anos. Urge, portanto, para os que estão ao lado das conquistas legitimas da população:

Lutar pela preservação do corpo doutrinário do SUS;

Resguardar a Seguridade Social como preceito de garantia de direitos sociais básicos nas áreas de saúde, assistência e previdência;

Defender o princípio da solidariedade no financiamento das áreas que compõem a seguridade social, através da participação equânime de cada uma delas;

Garantir volume aceitável de recursos para saúde (nesse sentido foram encaminhados diversas emendas);

Defender a vinculação/especialização de fontes para a área da saúde, caso isso seja incorporado em relação à previdência social;

Buscar formas automáticas para a transferência dos recursos federais para custeio do sistema (mecanismo similar aos fundos de participação) com o objetivo de acelerar $e$ garantir a sua efetiva descentralização. Assegurar um maior comprometimento de receitas estaduais e municipais para a saúde." (110)

A batalha não foi em vão. Mostrou-se que cidadãos unidos podiam manter conquistas, sendo a maior delas a do direito à vida e à saúde. O dia 27 de novembro de 1995 irá para o 
calendário do Sistema Único de Saúde (SUS) como o dia em que DAVI deu a primeira "tunda" em GOLIAS. Os economocratas, que há anos dirigem este país, substituindo constituição, leis e poderes constituídos pelo seu livre pensar, tiveram sua primeira derrota. Quem bateu foi o indefeso SUS, que vem sendo massacrado sarcasticamente pelo pensamento "economocrático desenvolvimentista". A vitória foi a retirada do projeto de reforma da saúde, no bojo da reforma constitucional.

Passaram-se alguns meses de debate intenso e profundo em defesa do SUS. Quando o relator da Comissão, Dep.Pinotti, já tinha pronto seu parecer contrário à reforma no que tangia à saúde, o Presidente assume postura de manter a saúde como estava. Numa atitude sábia, sabendo que perderia a batalha no Congresso, enviou ao Congresso Nacional uma exposição de motivos e o pedido de retirada do Projeto de Emenda Constitucional, dispensando o Congresso de apreciá-la, por julgá-la desnecessária e inadequada. (Como fazem falta os bons assessores jurídicos para trabalharem no "pré" e não deixarem o Presidente em maus lençóis para, depois do leite derramado, correrem atrás do prejuizo!). 0 documento presidencial dizia: "SOLICITO AOS MEMBROS DO CONGRESSO NACIONAL A RETIRADA DA PROPOSTA DE EMENDA CONSTITUCIONAL N 32, DE 1995, QUE “DA NOVA REDAÇÃO AO ART.196 DA CONSTITUIÇÃO FEDERAL (QUE ACRESCENTOU, NOS TERMOS DA LEI, AO DIREITO DE TODOS À SAÚDE) (....)"

A Exposição de Motivos, que acompanhou a solicitação presidencial, afirmava:

"Tal providência atende à expectativa que se firmou nos escalões competentes do executivo posteriormente à apresentação da PEC, de que os objetivos por esta visados, quais sejam, a racionalização da despesa e a diversificação das fontes de financiamento do sistema único de saúde, poderão ser em grande parte atendidos mediante medidas infraconstitucionais, prescindindo da alteração proposta no art.196 da Carta Magna".

O texto é suficientemente claro para confirmar o que se afirmou, por dedução lógica. Os escalōes competentes do Governo (que deveriam subsidiar previamente o Presidente) só tomaram conhecimento e FIRMARAM EXPECTATIVA, POSTERIORMENTE $\AA$ APRESENTAÇÃO DA PEC.

Foram muitos os que entraram na luta contra a reforma neoliberal pretendida, restringindo o direito universal à saúde: aqueles que falaram aos quatro ventos; os que escreveram contra; a Comissão Especial do Congresso, encarregada de analisar a PEC 32, que elaborou um excelente relatório conclusivo pela retirada da emenda; os que trabalharam costurando negociações. E, aqui, vale um voto de louvor ao trabalho do Deputado Carlos Mosconi que, nos bastidores, trabalhou para que o Presidente retirasse a Proposta de Emenda Constitucional. 
Havia em relação à saúde, outros pontos fundamentais que estavam na PEC da Seguridade e que, igualmente, eram ameaçadoras ao SUS, e só vieram a cair mais tarde. Um deles é o que permitia a Estados e Municípios criar serviços de saúde, à parte, para seus servidores. Providência oportunista para calar a boca de sindicatos. Ser simpático aos servidores públicos, aos quais se promete um benefício em detrimento dos próprios servidores públicos - cidadăos. Năo há privilégio que năo acarrete ônus para os excluídos desse privilégio. Criar um sistema de saúde próprio para os servidores públicos permite fazer duas leituras. Se for para ser melhor que o SUS, significa tirar dos que năo têm face aparente (os cidadãos restantes) e que não podem protestar (năo serão consultados) para privilegiar só alguns... de face conhecida. Se for para fazer o que o SUS consegue fazer com seus minguados recursos, seria uma duplicidade de meios para o mesmo fim... mais uma ineficiência a ser combatida. Finalmente, o mais importante: mudar o texto constitucional, acrescentando esse artigo, fere a Constituição em vários outros artigos dos direitos sociais e dos principios de universalidade e gestão única do SUS. Constitui uma emenda inconstitucional.

\subsection{A BUSCA DE MAIS RECURSOS PARA A SAÚDE}

Como explicitado nos itens anteriores, o maior embaraço para a implantação do SUS constitucional foi, e é, o financiamento da saúde.

Em 1995, assumia o Governo Fernando Henrique Cardoso, tendo, como Ministro da Saúde Adib Jatene. $O$ quadro do financiamento da saúde, em resumo, era o seguinte: tentativa de cumprimento da CF no item de financiamento, dentro de uma proposta de cumprimento gradual como processo; o prolongamento da crise, provocada pelo Ministro Britto do MPAS, retirando recursos sabidamente da Saúde e destinando-os apenas à Previdência Social; a recuperação parcial do sistema de pagamento com o Plano Real, ainda que com as diferenças acima relatadas; o estrangulamento nos repasses de recursos do MF para a Saúde levando a atrasos de pagamento ao finalizar o Governo Itamar; implantação do repasse Fundo a Fundo e primeiros municípios assumindo a gestão de todos os recursos destinados a seu Municipio.

O discurso era de que o Ministério da Saúde, no Governo Itamar, "brigava" muito com o Ministério da Fazenda e que isso era indesejável. Várias manifestações criticas foram feitas, à época, por membros de uma corrente que apoiava a candidatura de $\mathrm{FHC}$ e que assumiria posteriormente o MS. Uma demonstração inequivoca foi quando da aprovação da proposta de Orçamento da Saúde para 1995, ocorrida no Conselho Nacional de Saúde. O grande 
questionamento dos representantes foi pretender um orçamento $25 \%$ menor que aquele de 20 bilhões de reais pretendido pelo CNS. Seriam doze bilhőes de reais (à época 12 bilhões de dólares) dedicados à assistência, incluindo ações de promoção, prevençăo, como as vacinas e o controle epidemiológico de doenças, diagnóstico precoce e tratamento de cânceres controláveis e incontroláveis. Os adeptos a essa corrente, à época instrumentalizada pelo próprio Ministério da Fazenda, tendo Ricúpero como Ministro - que o problema era o mau uso dos recursos. Para o ano de 1995, R $\$ 15$ bilhões seriam suficientes para todas as despesas do MS, menor que os $\mathbf{2 0}$ bilhőes pretendidos. Que o momento era de contenção de despesas.(49) Essa posição era assumida por Dr.Seixas, membro do Conselho Nacional de Saúde como Representante dos portadores de doenças e porta-voz do grupo FHC, candidato à Presidência da República.

O programa de governo de FHC para a saúde destacava determinados tópicos em relação ao financiamento:

“Não menos importante, contudo, é assegurar recursos suficientes e estáveis para aplicação na área de saúde. As despesas federais representam historicamente, cerca de $75 \%$ dos gastos públicos totais do financiamento da saúde. Portanto, garantir fontes estáveis e suficientes de recursos será uma das principais ações do Governo Fernando Henrique. Esse objetivo será alcançado com a reforma tributária e fiscal, indispensável para mudar o quadro atual. É necessário, também estimular os estados e municipios a aumentarem significativamente seus gastos com saúde, de acordo com as competências definidas para cada esfera de governo. Este sistema de financiamento compartilhado deverá funcionar através de mecanismos automáticos de repasse entre as instâncias governamentais, segundo critérios redistributivos. Os planos estaduais de saúde, elaborados levando em conta os planos municipais, definirão onde e como gastar. As transferências negociadas estarão restritas aos investimentos prioritários de caráter redistributivo. Será rompido, assim, o mecanismo perverso da descentralização tutelada, expresso em transferências negociadas através de convênios e por intermediações clientelistas entre os niveis de governo. Contudo, não basta aumentar os recursos para a saúde, porque além de gastar pouco, o Brasil gasta mal. É preciso fazer render ao máximo cada real, aplicado no setor. Paralelamente à garantia de recursos estáveis e suficientes, serão promovidas profundas mudanças para assegurar a boa utilização do dinheiro público na saúde.

Medidas do Governo Fernando Henrique para a saúde: Aplicação na área da saúde de no mínimo $R \$ 80 / p e r$ capita anuais (obs: comentánio aqui ou no final - em 1994 = 1 real, 0,85 dólares; 80 reais = a 94 dólares; 94 dólares em julho de $2001=231$ reais; 231 reais $X 170$ milhões de brasileiros 39 bilhões de reais.... contra os atuais otimistas 26 bilhões de reais!...); estímulo ao incremento dos gastos dos estados e municípios em saúde, por meio do financiamento compartilhado; transferência global dos recursos, sem vinculações pré-determinadas, diretamente do Fundo Nacional de Saúde, para os Fundos Estaduais e Municipais de Saúde; estabelecimento de mecanismos e critérios redistribuitivos para a transferência de recursos materiais e financeiros entre regiões e entre grupos sociais em situação de exclusão." (132)

Jatene, ao assumir o Ministério da Saúde declarava: 
“A nova ética social expressa na CF estendendo o atendimento a toda a população não foi acompanhada pelo aporte de recursos necessários para cumprir a determinação constitucional. O presidente (FHC) está consciente deste problema fundamental e a área económica certamente não medirá esforços para corrigir esta anomalia. A limitação de recursos frustrou a unificaçăo de comando do setor saúde deste ministério, que havia sido reivindicada por todos os envolvidos." (52)

O financiamento da saúde continuava sendo seu maior problema. Propostas inovadoras custavam a deslanchar por falta de recursos para seu financiamento. A própria dificuldade de os municípios implantarem o SUS tinha sua origem, em grande parte, no receio dos Prefeitos de assumirem uma área sem recursos e que passaria a ser de sua responsabilidade. 0 desfinanciamento era suficientemente forte para justificar o caos em que se encontrava o setor saúde. Não se pode pensar em um sistema de saúde que pague a maioria de seus procedimentos com menor valor que o custo, e pagos por volta do décimo dia do segundo mês subseqüente. Não se podia argumentar que com o Plano Real (julho de 94) não havia inflação, pois o dinheiro para pagar funcionários e outras despesas tem seu custo, quando tomado emprestado junto ao sistema financeiro. Se há defasagem no tempo de recebimento, e as despesas não podem esperar, só resta uma saida: tomar dinheiro emprestado e a alto custo! Hospitais e Santas Casas, principalmente os de pequeno e médio porte (locais e distritais), que prestam serviços, exclusivamente ou na quase totalidade ao SUS, ou faliram ou entraram em pré-falência, consumindo suas derradeiras energias no custeio do essencial.

Em 1995, no primeiro ano de Governo FHC, houve aparente aumento de recursos federais para a saúde, mas sem repercussão na base, pois foi às custas de pagamento de divida e aumento de gastos com pessoal. $\mathrm{O}$ gasto com a manutenção da assistência à saúde foi menor que o do início do plano real (segundo semestre de 1994). A Fundação Nacional de Saúde, responsável pelo atendimento a grande parte da população do norte, nordeste e centro-oeste do país, com ações assistenciais e preventivas, encontrava-se em completo estado de sucateamento, impossibilitada até mesmo de descentralizar para os municípios, antes de recuperar, no mínimo, prédios e equipamentos. A mudança do modelo assistencial, com visão mais ampla de saúde, envolvendo promoçăo, prevenção, assistência e reabilitação não se dará sem maior soma de recursos. Ninguém será temerário de, simples e puramente, em meio a tanta carência, retirar recursos da assistência e jogá-los de forma importante em prevenção!

Os argumentos, até agora, falam todos da necessidade de se obter maior soma de recursos para a área da saúde, em cumprimento à Constituição e à Lei Orgânica de Saúde. 
Enquanto até dezembro de 1995 existiu lei, não cumprida, que garantiria naquele ano os 20 bilhões de reais que a saúde precisava, em 1996 não se dispunha mais dela. Era a lei do Plano Plurianual de Governo que, em sua última versão aprovada, com vigência até dezembro de 1995, trazia escrito que a saúde deveria ficar com no mínimo $30 \%$ dos recursos da Seguridade Social. Não se cumpriu. Não aconteceu nada ao desobediente executivo. Nada foi questionado nem pelo legislativo, nem pelo judiciário, nem pela promotoria pública. Muito pelo contrário, não ligaram para as denúncias feitas pela sociedade civil, individualmente por técnicos ou por organizações sociais. Existia a determinação legal, mas descumprida. A LDO (Lei de Diretrizes Orçamentárias) não cumpriu o PPA (Plano Plurianual). A LO (Lei Orçamentária) não cumpriu o PPA. Não se alocaram os recursos devidos e previstos pelo PPA.

Em 1995, o objetivo era apenas que o governo tivesse vontade política de cumprir as leis, pois já estavam garantidos os $30 \%$ da seguridade social para a saúde. Não houve nenhum aumento na tabela de procedimentos em 17 meses de REAL, a não ser um abono concretizado apenas por quatro meses, sem caixa para se pagar os meses restantes de $95 \mathrm{e}$ completar em 96. Diante de uma defasagem de remuneração dos serviços do SUS, o Ministro Jatene "Resolve Autorizar, em caráter excepcional, a aplicação do fator de recomposição de $25 \%$ (vinte e cinco por cento) nos valores da Tabela do SIA e SIH a partir de julho de $1995^{n}$. O pagamento desse reajuste por serviços já prestados não se deu, a ponto de a Confederação Nacional de Saúde - Hospitais, Estabelecimentos e Serviços, em reunião de 23-5-1996, decidir "adotar medidas administrativas e judiciais que se fizerem necessárias à obtenção do reajuste de $25 \%$ definidos pela Portaria GM 2277." (103)

\subsection{A CONTRIBUIÇÃO PROVISÓRIA SOBRE A MOVIMENTAÇÃO FINANCEIRA - CPMF}

Em 1995, já se sabia que, a partir de 1996, não se tinha garantia nenhuma dos recursos da seguridade, apenas o preceito constitucional de que parte deles seria da saúde. De quanto seria esta parte, quem definia era o Ministério da Fazenda e da Previdência Social, independente do quanto fosse defendido pelo MS e sem nenhum respeito a percentuais históricos de participação da saúde no orçamento da Seguridade Social.

Já nos anos anteriores, o Governo teimava em descumprir as leis que determinavam um montante de recursos para a saúde. A idéia do Governo, assumida pelo Ministro Jatene, era de que os recursos federais eram, de fato, insuficientes para todas as necessidades. Conseqüentemente, para se aumentarem os recursos para a saúde, dever-se-ia instituir uma 
nova fonte de recurso, embora o preceito de destino de recursos à saúde, dos já existentes, nem vinha sendo cumprido.

A oposiçăo apresentava propostas alternativas ao Governo para que ele não fosse buscar recursos, criando novos impostos ou contribuiçőes, mas utilizasse os recursos já existentes, de forma redirecionada. O Deputado Arlindo Chinaglia, desde o início, demonstrava sempre sua oposição e lembrava, mesmo muito tempo depois do início da PEC da CPMF, alternativas possiveis:

"É verdade que a saúde está na UTI, mas se o Governo quisesse salvá-la e ter dinheiro rápido e imediato, desde o primeiro dia de governo poderia ter tomado providências tais como: 1) emitir Títulos Públicos de Longo Prazo, como foi feito com o PROER (socorro aos bancos); 2) editar medida provisória como foi feito com a dívida dos usineiros, os grandes latifundiários devedores do Banco do Brasil; 3) fazer remanejamento de verbas orçamentárias indicando a priorização da saúde; 4) reduzir em um terço as taxas exorbitantes de juros." (87)

Entretanto, alternativas foram fugindo dos horizontes e das mãos. A lei do PPA, descumprida acintosamente, teve sua substituta aprovada para vigorar em 1996, em que não constava a obrigatoriedade dos $30 \%$ do OSS para a saúde. Era o torniquete para forçar a aprovação da CPMF.

Foi, baseado nas dificuldades financeiras enfrentadas pela saúde e na carta de intenções do Programa de Governo de FHC, que se empreendeu a cruzada em busca de mais recursos para a saúde, mediante a criação de Contribuição Provisória sobre a Movimentação Financeira - CPMF.

Houve uma experiência inicial de taxação da movimentação financeira, através do "Imposto do Cheque", e que acabou melancolicamente. Sofreu inúmeros questionamentos jurídicos sobre sua legalidade e o seu efeito cascata. Tudo começou com o Imposto Provisório sobre a Movimentação Financeira, IPMF. A lei complementar 77, de 13 de julho de 1993 (40), instituiu o Imposto Provisório sobre a Movimentação ou Transmissão de Valores e de Créditos e Direitos de Natureza Financeira - IPMF e outras. Todo imposto, segundo princípio constitucional, não pode ter destinação específica, mas sim ser utilizado na atividade geral do Estado, exceção feita à Educação, que fica com percentual de todos os impostos. Outra característica é que só entra em vigor no ano seguinte à sua promulgação. Portanto, essa lei só passou a ter efeito em 1994. A alíquota era de 0,25\% e a vigência foi até $31-12-1994$. Em vão, tentou-se introduzir uma emenda à lei, proposta por Eduardo Jorge, que defendia que $20 \%$ do IPMF fosse destinado à saúde, diretamente depositado no Fundo de Saúde. (112)

Diante da falta crônica de recursos para a saúde, agravada com a especificação de fonte, feita pelo Ministro Britto em 1993, reservando exclusivamente para a Previdência 
Contribuição sobre a Folha de Pagamentos, o que mais se empenhava o Ministério da Saúde era na busca de recursos financeiros.

Professor Elias Jorge, pós graduado em finanças públicas, então funcionário do Ministério da Saúde, assessorava o Conselho Nacional de Saúde. Comentou ele com o Conselheiro Aboim sobre a possibilidade de se manter o IPMF exclusivamente para a saúde.

Proposto pelo Conselheiro Aboim, isso foi consolidado em reunião plenária do Conselho Nacional de Saúde em sua Quadragésima Segunda Reunião Ordinária, realizada nos dias 14 e 15 de dezembro de 1994, resultando na Resolução 148, de 15-12-1994 (51):

“...Aprovar moção dirigida ao Presidente da República, reafirmando a necessidade de encontrar solução estrutural, para o financiamento público da saúde no Brasil, que está consubstanciada nas propostas encaminhadas pelo Presidente do Conselho Nacional de Saúde (Henrique Santillo) ao presidente do Congresso Nacional, através do aviso 939 de 13-12-93, solicitando ainda que, como solução emergencial, se estude a viabilidade de criar a Contribuição Sobre a Movimentação Financeira para a Seguridade Social, nos termos em que foi instituído o IPMF, através de Lei Complementar, com destinação dos recursos arrecadados para solucionar os impasses atualmente existentes na Previdência, na Assistência Social e com prioridade de destinação dos recursos para as ações de promoção de atenção coletiva e preventiva em saúde. "(40)

Em novembro de 1994, o IPEA realizou um Fórum de discussão das novas políticas sociais, em que se abordou o financiamento e gestão do SUS. José Roberto Rodrigues Afonso, Economista do BNDES, defendia uma posição muito clara em relação ao financiamento da saúde:

"A curto prazo, não há como mudar, sem risco de perdas de receita, a estrutura de financiamento concebida em linhas gerais na Constituição de 1988, baseada nas contribuições sociais. Ainda mais numa conjuntura extremamente favorável estabilidade dos preços com retomada do crescimento -, a arrecadação das contribuições sobre receitas e lucros atinge patamares inéditos. $\dot{E}$ praticamente impossível sua substituição por novos tributos (IPMF permanente, valor adicionado etc.) sem que se perca (e muita) arrecadação e se provoque um grande rearranjo na incidência tributária setorial. " (1)

Essa proposta foi assumida pelo Ministro Adib Jatene, que passou a defendê-la como imprescindivel às ações de saúde. Ao assumir o Ministério da Saúde, sem possibilidade de dispor de mais recursos do Tesouro Nacional, dos impostos e contribuições já existentes, a saida era carrear novos recursos. Entre outras fontes alternativas, buscou-se no Banco Mundial um aporte de recursos para investimentos. Levou à frente um projeto, que já era inicialmente seu, na primeira gestão do MS no Governo Collor, teve continuidade com o Ministro Santillo. Voltou a alavancá-lo com a denominação de REFORSUS. A solicitação era de 650 bi de dólares, negociados com o Banco Mundial - BIRD e com o Banco Interamericano de Desenvolvimento - BID. Outra fonte de recursos buscada foi a do 
ressarcimento dos planos de saúde de serviços prestados pelo SUS à sua clientela, projeto iniciado com o Ministro Jamil Haddad e negado, por contestação, na justiça pela administraçăo de Planos de Saúde e Seguros de Saúde. Jatene apresentou, pela Presidência, o projeto de Lei, cujos frutos são hoje colhidos por Serra.

A CPMF foi a saída em busca de um primeiro recurso, diretamente destinado à saúde e recolhido aos cofres do Fundo Nacional de Saúde.

Seria impossível ficar sem uma saída, uma Contribuição nova, a CPMF em questão, pois, o Orçamento da União proposto à aprovação do Congresso Nacional já contava com R\$ 6 bilhões para a saúde. Talvez, tenha sido das primeiras vezes em que uma Contribuição ainda não aprovada, já tenha constado oficialmente na proposta orçamentária com recursos de tal monta. A não aprovação da CPMF representava para a saúde a inviabilidade de se manter o Sistema Único de Saúde. Se a escassez de recursos, em 1995, foi maléfica ao sistema, imagine-se a perpetuação do caos e o aprofundamento da crise, se não se contasse com praticamente $1 / 3$ dos recursos previstos.

O Conselho Nacional de Saúde, além de ter sugerido, apoiou de pronto quando o Governo apresentou a proposta oficialmente. Foi um apoio por unanimidade à criação da CMF para o custeio da Seguridade Social, particularmente da saúde, em bases similares ao CPMF.

O Ministério da Saúde fez um esforço coletivo para convencimento da população, empresários e parlamentares. Editou um livreto "Subsídios à votação da CPMF", do qual são extraidos alguns trechos: $(60)$

"Entre as alternativas de captação de recursos de custeio, a CPMF foi a escolhida por quatro motivos principais: a) rapidez de aporte de recursos a partir do momento de sua implantação; b) a existência de uma rede de arrecadação, que inclusive, já tem prática no seu recolhimento; c) o fato de não ser regressiva, na medida em que mais contribui quem mais tem; e, d) o fato de não ser baseada na declaração contribuinte o que evita sonegações e alcança aquela porção da economia informal intocada por tributos de qualquer natureza."

"Quanto à sua baixa popularidade nas pesquisas de opinião, não existe na verdade um imposto que seja popular. Existe sim, e isso foi já muitas vezes demonstrado, a solidariedade entre as pessoas. Essa é a grande questão posta em cheque. O sistema de saúde não pode esperar mais e, em acabando, quem mais tem a perder são aqueles que não podem pagar seguros de saúde ou os portadores de patologia que não são cobertas por eles. Não queremos mais impostos. Desejamos sim, mais saúde para toda a população."

Assim foi lançada a proposta do Governo. Paralelamente, outras iniciativas ocorreram. $\mathrm{O}$ Senador Vilson Kleinubing propôs, em 8 de junho de 1995, não uma lei, mas uma Emenda Constitucional que levou o número de 37 , instituindo o IPMF, mas com a finalidade de 
arrecadar recursos para pagar as dívidas contraídas pelos governos da União, dos Estados e dos Municípios. (143)

O Senador Valadares apresentou a Emenda Constitucional 40, de 22 de junho de 1995, dispondo sobre a instituiçăo de Contribuiçăo Social de Emergência para Financiamento das Ações e Serviços de Saúde. Apenas quatro artigos, colocando a alíquota de $0,25 \%$ sobre movimentação financeira e transmissão de valores, totalmente destinados à saúde e por prazo de dois anos (IDEM).

O Governo FHC apresentou finalmente, a Proposta de Emenda Constitucional criando a CPMF, PEC-256-A95, que passou a ser discutida em todos os fóruns, contando com adeptos e opositores.

O CONASS, CONASEMS, MS, OPAS/OMS, ABRES E IDISA em maio de 1995, em Maceió, realizaram Oficina de trabalho sobre o Financiamento do SUS:

"A CPMF pode ser alternativa temporária para a sobrevivência do SUS e proporcionar o fôlego necessário para a efetivação de propostas estruturais. Não é substitutiva do financiamento prescrito na CF e na Lei. O seu recolhimento pela rede bancária deve ser depositado direta e automaticamente no Fundo nacional de Saúde".

A ABRASCO, em seu Boletim n.56, ANO XIII - Abril/Jun de 1995 (9), comenta sobre a proposta de criação da CPMF, e, sabiamente, já alerta sobre seus riscos:

"A proposta de criação da Contribuição sobre Movimentação Financeira, defendida pelo Ministério da Saúde, como forma de viabilizar, a curto prazo, o aporte adicional de recursos para a saúde. Oferece, além da dificuldade política de ser tributação adicional, o risco de ser fonte substitutiva de receita, caso não se defina mecanismo que garanta a preservação da destinação das demais contribuições da Seguridade Social. O aporte adicional que a CPMF traria, caso destinada exclusivamente ao setor Saúde, seria da ordem de $R \$ 5$ bilhões/ano."

A época da Constituinte, havia um movimento no Congresso, comandado pelo Parlamentar José Serra, no sentido de se impedir a vinculação de receitas, a não ser em relação à educação. A mesma objeção era agora evocada em relação à CPMF, com destinação para a saúde. Ainda, no Boletim da ABRASCO:

"Todas as propostas (de recursos definidos para a saúde) esbarram na posição inflexivel da área econômica do governo, contrána a qualquer forma de vinculação de receita. Os argumentos técnicos de engessamento do gasto público, ainda que relevantes, não podem contudo, se sobre por aos evidentes prejuízos que a prática de penalizar o setor Saúde com cortes orçamentários provoca, sempre que ajustes nas contas públicas se fazem necessários."

A Deputada Maria da Conceição Tavares em documento interno de trabalho O Caráter progressivo da Tributação sobre a Circulação Financeira (141) pronunciou-se: 
“Tributação sobre movimentação financeira é relevante pois as transações financeiras săo fator relevante na globalização da economia;

- CPMF pode aumentar a receita pública sem penalizar os setores produtivos e segmentos sociais o que mais contribui sobre a carga tributánia.

. Exercícios feitos fundamentam a tese da progressividade:

1. $70,6 \%$ da PEA não são atingidos pelo tributo pois não usam cheque (grupo I rendimento médio de 1,3 sm - 50\% do grupo II rendimento médio de $4 \mathrm{sm}$ )

2. $29,4 \%$ da PEA são os mais atingidos = grupo $V$ (acima de 20 e média de $38,7 \mathrm{sm}=$ $3,4 \%$ da população referência , < de $12 \%$ dos que tem conta bancária, $29,2 \%$ da renda total e 63,5\% da arrecadação do IPMF) grupo III e IV (entre 7,2 e 14,2 sm = 18,\% da população referência, $62 \%$ do universo tributado (que tem conta) $38,6 \%$ da renda $e$ 31,1 da arrecadação

3. Considerando os coeficientes de circulação financeira : os do grupo II pagam 0,13 $(0,25 \times 0,5$ (50\%do grupo paga), se tomarmos o grupo todo temos que tomar 0,13$))$ a $0,25 \%$ (só a parte que paga) os do grupo V pagam $0,70 \%(0,25 \times 2,8)$

4. A progressividade se dá tanto no volume quanto na relação proporcional de uma rendimento e de outro (mais o imposto que a diferença proporcional entre eles) o diferencial de imposto é de 54,2 vezes e o de faixa de rendimento de 5,6 vezes entre as faixas II e $\mathrm{V}$ de rendimento

5. Todo o cálculo é baseado no coeficiente de circulação financeira : menos de $3 \mathrm{sm}$ zero; 3-5: $50 \%(0,5) ; 5$ a 10: $1 ; 10$ a $20: 1,1$ (1 + 0,10 coef.aplicação) e 20 e mais :2,8 $(2,5$ (cascata) $+0,30$ de coef. aplicação)".

As opiniōes se polarizavam entre os que defendiam ou atacavam a introdução da CPMF destinada à saúde.

Quando da discussão sobre a PEC 256-A-95, na Comissão Especial da Câmara dos

Deputados, na Reunião 180/96 o Deputado Roberto Campos fez o seguinte pronunciamento:

“Só mesmo uma situação de catástrofe como a da atual situação da saúde pública me levaria a votar para o que, afinal de contas, é uma perversão fiscal. Trata-se de uma perversão fiscal para fim nobre. Perversão fiscal, porque a idéia do Imposto sobre Transações Financeiras foi originalmente concebida para simplificar o Sistema Financeiro. Houve duas versões discutidas na Câmara dos Deputados. A primeira versão foi a do chamado imposto único. O imposto sobre Transações Financeiras de fácil coleta e metodologia simples substituiria todos os impostos de natureza declaratória, que se prestam à sonegação, à corrupção e uma enorme burocratização. Ficariam apenas com categoria diferente, os impostos de política econômica, cujos propósitos não fossem meramente declaratónios. Essa proposta pareceu chocante demais, inovadora demais e uma espécie de medo de inovação, perpassou esta Casa. O Governo Federal criou duas perversões fiscais: uma, com fins indefinidos e esta , com fins nobres. A perversão fiscal com fins indefinidos foi a criação do IPMF. Nunca aqueles que cogitaram do Imposto sobre Transações Financeiras e imaginaram apenas um imposto a mais, superposto a uma estrutura complexa e corrupta e sim como imposto substitutivo de alguma coisa, com o propósito simplificador. O IPMF que já foi extinto, nada simplificou. Ele se agregou a uma estrutura, que ainda temos que reformar e que, obviamente é uma estrutura caduca. Impõe severos cursos de obediência às firmas, sob forma de uma enorme burocracia fiscal e impõe ao Governo 
custos enormes de controle com superposição de vários fiscos. Ressurge agora o Imposto sobre Transaçőes Financeiras, que a meu ver é um bom imposto. Não me filio a um grupo de economistas, que considero detrimentoso à economia. Eu o apoio como imposto eminentemente simplificador, justo, porque é insonegável, incluindo a rigor aspectos de progressividade, que não săo facilmente percebidos. Fala-se muito na regressividade do Imposto sobre Transaçöes Financeira. Mas, o fato é que ele incide sobre transaçōes financeiras e sobre grupos e classes que mais fazem transações financeiras não são certamente os ex-privilegiados da fortuna. Esses sim, são os únicos que praticam o uso da moeda manual, escapando portanto ao Sistema Bancário. O que fazer com a saúde? O Ministro Jatene nos desafiou a todos a propor alternativas. $E$ nenhum de nós realmente tinha alternativas válidas para socorrer essa situação de emergência. E repito: somente uma situação me levaria a perfilhar a má utilização de um bom imposto que é o Imposto sobre Transações Financeiras" (13)

O Deputado Roberto Campos faz algumas sugestões para assegurar mais, recursos para a saúde, dentre elas, diminuir a demanda aos serviços públicos de saúde, fazenda uma negociação de impostos e contribuições (renúncia fiscal) com as empresas privadas para que elas assegurem saúde para seus trabalhadores. Outra, seria a Contribuição Financeira para a saúde, como substituto de todos os outros impostos.

“Eu estaria, diz Roberto Campos, disposto a enfrentar a atribulação de uma alíquota muito maior do Imposto Sobre Transações Financeiras, desde que fosse para limpeza do terreno e simplificação da nossa complexa estrutura fiscal. Em suma, Sr.Presidente da Comissão, muito constrangido e em face de uma situação catastrófica, votarei pela perversão fiscal que constitui a autorização de uma boa metodologia fiscal para finalidades especificas da Saúde" (13)

Na Audiência Pública, sobre a PEC 256-A955 e sobre a CPMF, realizada em 21-3-1996, com convidados, teve só unanimidade na defesa da CPMF. Falaram representantes de várias instituições: Federação das Misericórdias, Federação Brasileira de Hospitais, Associação Brasileira de Hospitais Universitários, CONASS - Conselho Nacional de Secretários Estaduais de Saúde e CONASSEMS - Conselho Nacional de Secretários Municipais de Saúde. Apenas a CPMF foi defendida por unanimemente. Os argumentos foram vários, mas todos centraram na atual crise do setor saúde, devido ao financiamento. (13)

O pronunciamento do Presidente da Federação Brasileira de Hospitais: "Estamos convencidos que a aprovação da CPMF proposta pelo Governo deverá contribuir para evitar o caos na saúde. E, o pior, estamos conscientes também que a CPMF não resolverá a crise estrutural da saúde no Brasil. É apenas um paliativo. Uma solução transitória e emergencial enquanto se busca uma solução perene" (104)

$\mathrm{Na}$ mesma época, por parte da imprensa, houve apoios esparsos à CPMF, mais pelo prestigio e convencimento do Ministro Jatene, que por convicção. Na revista Manchete, de 
22 de junho de 1996 (86), Carlos Chagas, em artigo intitulado "Um auto-de-fé para o Dr. Jatene" defende a CPMF e denuncia o desmonte do público para privilegiamento do setor privado na área de saúde:

"Nesse momento, entra o Dr.Jatene, que pretendem levar à fogueira por estar lutando pela sobrevivência e melhoria da rede pública nacional de saúde. Ele encontrou uma saída na criação da CPMF. O novo imposto sobre o cheque. A partir daí, transformouse no mais perigoso dos bruxos. Precisa ser queimado. "Só pensa no novo imposto, esqueceu os demais setores do Ministério, năo visita vítimas de abusos e erros do sistema de saúde etc." O Jogo da velhacaria é de vasos comunicantes. Parte do sistema financeiro, a parte malsă, apesar de minoritária, treme de medo com a perspectiva do novo imposto, que servirá subsidiariamente para revelar falcatruas e maracutaias executadas através de contas-fantasma e correntistas laranjas. Ficarão todos expostos e conhecidos. A eles se aliam aqueles que desejam a falência completa dos serviços públicos de saúde, para ficarem os serviços privados como única opçăo para todos. A Câmara vota nos próximos dias a CPMF que o Senado já aprovou. Vamos ver se aprova, em vez dela, um auto-de-fé para o Dr.Jatene."

Alguns depoimentos favoráveis, como o do Presidente do CONASS:

“As propostas dos Secretários Estaduais de Saúde se dividem em quatro categorias, considerando emergencialmente a Contribuição Social sobre Movimentação Financeira como alternativa temporária para a sobrevivência do sistema e o fôlego necessário para a efetivação das propostas estruturais. Não é substitutiva do financiamento prescrito na Constituição e na Lei. O seu recolhimento pela rede bancária deve ser depositado direta e automaticamente no Fundo Nacional de Saúde. A outra ordem de medidas que consideramos fundamentais, do ponto de vista do financiamento, para a consolidação do SUS é a liberação integral das fontes especificas da Seguridade Social para a sua finalidade constitucional, para a Previdência Social, Saúde e Assistência Social, sem retenção no Tesouro Nacional, de recursos destas fontes para outras finalidades; destinar ao SUS pelo menos $30 \%$ de cada uma das fontes especificas da seguridade social e 10 a 15\% da receita de impostos das três esferas de governo; cumprir a legislação quanto ao encaminhamento prévio das propostas orçamentárias ao Conselho Nacional de Seguridade Social e ao Conselho Nacional de Saúde; fazer constar, no plano plunianual de governo, qüinqüenal, parâmetros indicativos para a elaboração anual de leis e diretrizes orçamentárias, no que se refere ao SUS; fazer constar na Lei de Custeio da Seguridade Social, os critérios de partilha entre os setores que compõem a seguridade; adotar providências necessárias para que a transferência Ministério da Fazenda - Tesouro Nacional e Previdência e Assistência Social, INSS e FPAS para o Ministério da Saúde e Fundo Nacional, sejam regulares e automáticas, em cumprimento à Constituição e à lei. $O$ mesmo deve vigorar para as transferências do Fundo Nacional de Saúde, para os fundos estaduais e municipais de saúde. Alternativas de outra ordem adicionais. Apesar de questões na viabilização de alguns e no mérito de outras, as alternativas apresentadas ilustram o imenso potencial de fontes e mecanismos financiadores, sem a criação de novos impostos e contribuição permanente. Entendemos a contribuição sobre movimentação financeira como provisória para, no prazo dos dois próximos anos, instaurarem-se as outras medidas estruturais. Adicionalmente amplia a base de concursos prognósticos com elevação de aliquotas e a destinação ao orçamento da seguridade e ao SUS; tributação das grandes fortunas e, caso venha a ser instituída, a contribuição sobre o valor agregado, poderá completar parcela incluindo ou não a aliquota complementar, enfatizar impostos existentes, mais adequados para viabilizar as transferências regulares e automáticas, 
como aquelas que compõem a receita compartilhada IPI, IR (....) parcelas de recursos recolhidos por empresas e cooperativas de saúde, através de planos privados de saúde, que devem ser transferidos ao SUS que vem remunerando serviços a seus segurados; retenção nos estados e municipios dos recursos de arrecadação federal correspondente ao financiamento federal do SUS; criaçăo por lei, do selo "Seguridade Social" sobre o consumo do fumo, bebidas alcoólicas e refrigerantes."

Outro depoimento foi do CONASEMS, através de seu assessor Gilson Carvalho. O CONASEMS, desde o início, esteve a favor da CPMF. Posição não compartilhada, de início, por vários Secretários de Saúde e pelo depoente:

\begin{abstract}
"Talvez muitos estranhem que aqui hoje eu esteja defendendo a CPMF, pois fui um dos críticos mais ferrenhos no ano passado, quando se apresentava esta proposta. $E$ por quê? Fui crítico ferrenho porque em 1995 defendia que o Governo cumprisse as leis existentes. Tínhamos até 1995 o PPA que exigia do Governo a retirada de $30 \%$ do OSS para serem colocados na área de saúde e o Governo colocava apenas $20 \%$. E, eu argumentava: o que adiantava uma nova lei, se a lei existente não estava sendo cumprida? Então tínhamos que forçar a que se cumprisse o que estava aí, porque em se cumprindo os $30 \%$ até 1995, representaria 20 bilhões de reais no ano passado para a área da saúde, que era mais do que se tivesse a aprovação da CPMF. Esse era um dos motivos. Hoje, infelizmente, estamos seguindo a lei do mal menor. Hoje, se não tivermos a CPMF, não temos outra tábua de salvação transitória para a área de saúde. Estou convicto disso. Não há nenhuma possibilidade. Já estamos praticamente com meio dinheiro desse perdido. Vai ser menos dinheiro. Tivemos 14,7 bilhões de dólares no ano passado e vamos ter 14 neste ano. Menos dinheiro. Se viesse a CPMF, desde o começo do ano, nós teríamos mais 6 bilhões. Iríamos a 20. Como não tem ainda, ou vai ter só a partir do segundo ano, teremos efetivamente de 3 bi para menos. Então, teremos apenas 17 bilhões de reais, o que é insuficiente, não há dúvidas.. ... Vi vários estudos iniciais que a CPMF seria uma contribuição de caráter regressivo, quer dizer, quem menos tem mais contribuiria. Contudo, diante do estudo da Dep.Conceição Tavares convenci-me diante do caráter da progressividade da CPMF. S.Excia. pega dados do IBGE e demonstra, por classes do salário mínimo, que, exatamente as classes menos favorecidas, vão estar contribuindo com menos... o $0,25 \%$ vai virar para alguns em 0,13 e para a grande parte $0,00 \%$ grupo um nem vai contribuir, que são os salários até 3 salários mínimos, e o grupo 2, que é o seguinte, vai contribuir apenas com metade dele $(0,13 \%)$. $E$, os grupos seguintes vão contribuir com $0,70 \%$ porque entra no ciclo do investimento. Então, há realmente o efeito cascata da CPMF, demonstrando o caráter progressivo da CPMF." (14)
\end{abstract}

Havia um primeiro entendimento de que o Ministro Jatene solicitava a aprovação da CPMF sem a aquiescência do Governo, sem a aprovação do Presidente. Que o Governo tolerava a hipótese da CPMF, mas não a endossava. Isto está, de certo modo, descartado diante de pronunciamento do Ministro Pedro Parente.

"Devo dizer que voto favoravelmente a esta proposta (CPMF) por termos sido colocados na parede pelo Governo, porque, o Sr. Ministro fez a sua previsão orçamentária e mandou para o Ministério do Planejamento. Sua Excia. o fez de uma maneira que seria necessária para que pudesse conduzir o Ministério, mas o Sr.Ministro do Planejamento cortou os seus recursos, colocando essa imposição para 
que nós estivéssemos discutindo, para que votássemos essa contribuiçăo financeira. Dep.José Rocha."

Muitas manifestações foram feitas por parlamentares em defesa da CPMF. Chegou-se mesmo, a se formar "uma tropa de choque" pluri e supra partidária, com reuniões no Gabinete do Ministro da Saúde, formando o Comitê Nacional em Defesa do Sistema Único de Saúde. Em uma dessas reuniōes, ocorrida em 18-6-1996, montaram-se várias estratégias em defesa da aprovaçăo da CPMF. As atividades foram divididas entre os presentes, incluindo: publicar documento sobre a atuação do MS, ocupar espaço na mídia; o Ministro da Saúde efetuar contatos com Ministros da Fazenda e Planejamento, definindo isençőes; envio de fax para deputados indecisos ou contra; visitas a estes deputados; entrevista coletiva do Ministro da Saúde; contato com o pessoal da Pastoral da Criança para acionar os deputados de suas regiőes; reunião com os deputados favoráveis para trabalharem junto aos demais.

Individualmente, outros deputados se pronunciaram em defesa, como o Deputado Melquias Neto, em entrevista publicada no jornal do CNS, Saúde Hoje, de junho de 1996 (120), em que responde à questão polêmica da posição do Governo, se estava ou não empenhado na aprovação da CPMF "O Governo já demonstrou muito interesse na aprovação da CPMF. $A$ minha análise é de que, no momento, o governo tem uma outra prioridade que é a reforma constitucional, é nesse sentido que estão sendo feitos todos os esforços. Mas, eu tenho certeza de que quando a CPMF for para a votação no plenário o governo colocará todos os seus lideres para trabalhar visando a aprovação."

Mesmo as opiniões favoráveis vinham com as ressalvas devidas. Tinha-se medo de que o Governo não cumprisse mais uma vez a lei, que desviasse os recursos para outras áreas, que substituísse as fontes de financiamento. Os empresários sempre estiveram contra, por motivos óbvios, e tiveram o apoio de economistas que, quase diariamente, estavam na mídia dizendo das mazelas de um novo imposto. Os argumentos eram vários, mas entre estes se destacavam: o fato de ser mais um imposto que iria aumentar os custos da produção, tirando do empresário ou do consumidor ou de ambos; o caráter de ser um imposto em cascata que incidiria sobre os demais; o caráter quase que insonegável de seu sistema de arrecadação.

É interessante comentar quem estava de um lado e do outro, contra e a favor, pois por motivos diferentes, se juntavam opostos. Contra estavam os empresários e os economistas que thes davam o apoio e, por incrivel que pareça, a esquerda mais radical, que levava consigo, às vezes, as pessoas da comunidade. Diga-se que nesse momento de discussão e aprovação da CPMF estavam ocorrendo as Conferências Estaduais de Saúde, prévias à X 
Conferência Nacional de Saúde, realizada em 2 a 6 de setembro de 1996. Em várias destas Conferências Estaduais de Saúde, negou-se apoio à aprovação da CPMF.

De outro lado, em apoio à CPMF estiveram economistas como Roberto Campos, cujo pronunciamento foi citado anteriormente, representando uma corrente política mais à direita e Maria da Conceição Tavares, representando a esquerda. Junto com eles estavam o Ministério da Saúde, Secretários Estaduais e Municipais de Saúde e vários grupos de técnicos da área de saúde e estudiosos do financiamento em saúde.

A X Conferência Nacional de Saúde, em suas resoluções, não traz um apoio formal à CPMF, cuja aprovação havia sido prévia à Conferência (15/8/96):

"Os Governos devem definir uma política de financiamento consistente e de longo prazo para o SUS (....) para que não sejam necessárias soluções provisórias como a Contribuição Provisória sobre a Movimentação Financeira - CPMF." "A receita da CPMF deve ser depositada diretamente no Fundo Nacional de Saúde devendo ser exclusivamente aplicada nos serviços de saúde do SUS. O Ministério da Saúde deve garantir a democratização da alocação destes recursos através de deliberação do CNS e prestar contas mensalmente aos Conselhos de Saúde da arrecadação e das despesas realizadas com os recursos da CPMF, bem como divulgar estes dados pelos meios de comunicação." (48)

Podemos sintetizar as posiçōes favoráveis à CPMF, com restriçōes em quatro pontos: 1) Ainda que apoiando transitoriamente a CPMF continuavam contra a criação de novos impostos e contribuições sem que houvesse uma ampla e consistente reforma fiscal, dentro do principio da eqüidade, que é o da justiça, segundo o qual contribui com mais quem mais tem e com menos, quem menos tem. 2) discordar das muitas vezes em que o Governo utiliza-se do apelativo da saúde para conseguir mais recursos e logo a seguir os utiliza em outras finalidades, deixando novamente a área da saúde sem recursos, a exemplo do que historicamente aconteceu com o aumento de aliquotas de INPS/INAMPS, do FINSOCIAL/COFINS, do Fundo Social de Emergência etc. 3) A discussão de um novo imposto-contribuição tem que passar sempre por ampla discussão com a sociedade, em que se possam clarear todos os pontos contra e a favor, para que se possam neutralizar, ao máximo, seus efeitos indesejáveis e deletérios. 4) Fazer constar na aprovação da CPMF que ela seja exclusiva para a saúde, depositado direta e automaticamente, de acordo com o fluxo de arrecadação e que não represente nenhuma diminuição dos demais recursos já devidos à saúde, como em orçamentos anteriores (em cumprimento das leis), incluindo aí o orçamento de 1996 que deveria ter partido de um patamar minimo de 17 bilhões aos quais se somariam os possiveis 6 bilhões da CPMF.

Finalmente, em 15 de agosto de 1996, depois de tramitar no Congresso Nacional, com duas aprovações na Câmara e duas no Senado, foi aprovada a Emenda Constitucional 12 (15) em 
que se outorga competência à União, para instituir contribuiçăo provisória sobre movimentaçăo ou transmissão de valores e de créditos e direitos de natureza financeira. $A$ alíquota estabelecida foi de $0,20 \%$ e com vigência máxima por 24 meses. $O$ destino integral deveria ser ao Fundo Nacional de Saúde para financiamento das ações e serviços de saúde.

A Emenda Constitucional 12 foi regulamentada pela a Lei de Criação da CPMF -9311, de 24-10-96. (34) Nessa lei, sumariamente ficou definido: que os lançamentos de movimentação financeira seriam os fatores geradores; as isenções de lançamento, que foram devidamente explicitadas entre as quais se destacam movimentação em poupança ou conta do mesmo titular; o limite máximo da aliquota de contribuição seria de vinte centésimos por cento; o prazo de vigência seria de 13 meses, após seu início de vigência (90 dias após a aprovação da lei de regulamentação). O artigo mais importante para a saúde é o seguinte:

"O produto da arrecadação da contribuição, de que trata esta lei, será destinado integralmente ao Fundo Nacional de Saúde, para financiamento das ações e serviços de saúde, sendo que sua entrega obedecerá aos prazos e condições estabelecidas, de que trata o Art.159 da CF. É vedada a utilização dos recursos arrecadados com a aplicação desta Lei em pagamento de serviços prestados pelas instituições hospitalares com finalidade lucrativa." Art.18 (15)

Posteriormente e, praticamente logo depois, antes mesmo de sua vigência (aguardava o período de 90 dias) o Dep.Arnaldo Faria de Sá propôs pelo Projeto de Lei 2527, de 1996, a revogação da Lei 9311 da CPMF, com a justificativa da saída do Ministro Adib Jatene, fator julgado por ele como impeditivo da aplicação dos recursos arrecadados com a CPMF, dentro de seus propósitos originais. (34) Já em 1997 o Governo propôs pela Lei 3553/97 o aumento do prazo de vigência para 24 meses, os 13 iniciais, acrescidos de mais 11 meses. Como a EC 12 já havia aprovado por 24 meses apenas a Lei permitiu essa prorrogação, dentro do limite dado pela EC. A aprovação ocorreu já no final do ano de 1997. (15)

Em março de 1999, foi aprovada a EC 21 que prorrogou (ainda que com um lapso de cerca de 4 a 5 meses) por mais três anos $(1999,2000$ e 2001) a CPMF agora com nova aliquota de trinta e oito centésimos por cento nos primeiros doze meses e 30 nos meses subseqüentes, sendo, o "a mais" que os 20 centésimos da saúde, destinados à Previdência Social. (15)

No ano de 2001, o Governo já faz uma movimentação, diante do término do prazo de 36 meses, para a prorrogação da CPMF ou sua definição não mais como Provisória, mas como definitiva.

A CPMF, desde sua implantação e começo da arrecadação em noventa dias após a Lei de regulamentação (24-10-1996), ou seja, 23 de janeiro de 1997 foi, e continua sendo, alvo de 
inúmeras polêmicas. O Ministro Adib Jatene lutou pela aprovação da CPMF durante dois anos, 1995 e 1996 e, quando do início da arrecadação, não era mais ministro.

Com o início do pagamento da CPMF pelo cidadão, todos queriam saber para onde estava indo o dinheiro arrecadado. O que era feito com os recursos. Qual a expectativa de repercussão direta na saúde da população. A expectativa nacional depois de praticamente dois anos de discussão, era de que a CPMF mudaria de imediato a face da saúde.

A grande polêmica foi se os recursos advindos da CPMF seriam a mais para a saúde ou podiam substituir fontes. A declaração do Ministro Albuquerque, um ano depois da vigência da CPMF e, logo após sua demissão do MS, são emblemáticas para esclarecimento dessa questão fundamental.

Em primeiro pronunciamento no Jornal do CONASEMS (121) ainda Ministro Carlos Albuquerque:

“O Ministério da Saúde tinha um orçamento de $R \$ 20,3$ bi em 1997. O Govemo aplicou a todos os Ministérios o contingenciamento, reduzindo o orçamento do Ministério da Saúde para $R \$ 19,1$. O que nós esperávamos - o povo, o parlamento, os ministros que a CPMF se acrescentasse à base. Só que fomos ingênuos, pois a lei não dizia isto. $\mathrm{Na} L D O$ está bem claro que o orçamento da saúde é de $R \$ 21,3$ bi."

A declaração, a seguir, foi feita pelo Ministro Albuquerque, assim que deixou o Ministério da Saúde.

"O engodo ao povo foi aprovar a CPMF e não dizer que a CPMF era algo que não poderia ser acrescentado; pode olhar na lei, lá está assim. Para acrescentar a CPMF à base do financiamento que vinha do Tesouro, da Seguridade Social, seria preciso, da maneira como a lei foi aprovada, passar por uma reforma da LDO a cada mês. Isso não foi feito de maneira a atender aquilo que se pretendia, que se dizia pretender. Eu não imagino que as pessoas, que o Congresso, os políticos, sejam ingênuos. Ingênuo, como dizem os politicos, sou eu. Farsa? Engodo. O que houve foi um acordo para a aprovação.. .. A lei precisaria ser especificada: o orçamento do Ministério da Saúde se constituirá de tantos por cento da seguridade social, mais a receita da CPMF. Isso é que eu digo; não pode ter havido tanta ingenuidade. Metade da perda da CPMF a gente recuperou com o descontigenciamento (700 milhões). Não sei se foram uns $R \$ 7$ bi, mas pode ser.... (Talvez seja este o motivo pelo qual o ex-ministro Jatene, como disse a alguns, se sentiu traído, enganado?) Talvez tenha ocorrido apenas uma combinação verbal, mas não sei. O que sei é a realidade dos fatos." (10)

O Dep.Arlindo Chinaglia, ferrenho opositor à CPMF escrevia em janeiro de 1997:

"CFMF: chantagem e um falso dilema. A CPMF entrou em vigor em 23 de janeiro. $E$ mais um imposto com que a maioria dos brasileiros e brasileiras terá que arcar para, supostamente socorrer a saúde.. Não reconhecemos necessidade, nem razão, nem sinceridade no Governo. Por isso votamos contra a CPMF e continuaremos a luta em defesa da saúde e do SUS." (87) 
Em janeiro de 1997, onze dias antes de entrar em vigor a CPMF, a mídia já mostrava o que aconteceria, com a saúde, mesmo com a CPMF. (139) O jornal O Estado de Săo Paulo de 12-1-97, fazia uma análise:

"CPMF é insuficiente para resolver crise da saúde. Maior parte dos recursos está comprometida com o pagamento de divida e de hospitais. $\mathrm{Na}$ avaliação do Governo a contribuição ajudará a arrumar a casa. A qualidade tão desejada dependerá de um novo modelo, com maior participação financeira de estados e municípios e da eficiência gerencial do sistema."

Houve vários questionamentos sobre a utilizaçăo desses recursos arrecadados e que geraram polêmicas. $O$ primeiro deles foi quanto ao uso dos recursos da CPMF para pagamento da divida, junto ao Fundo de Amparo ao Trabalhador (FAT) (Empréstimo que Jatene tinha feito para pagamento dos hospitais diante do atraso da CPMF). Correram ações na justiça solicitando que não se pagasse dívida anterior com recursos da CPMF. Uma das ações, no Rio de Janeiro, teve ganho de causa em caráter liminar.

O mais significativo desses atos foi uma Ação Direta de Inconstitucionalidade (1640-7), requerida pelo PT, PC do B, PDT, PSB e PV. Pedia-se a inconstitucionalidade da Lei 9438/97 na parte que disciplinava a utilização de recursos da Contribuição Provisória sobre a Movimentação Financeira - CPMF. Essa ação foi iniciada no começo de 1997, mas teve julgamento contrário e, só em início de 1998. Não se caracterizou como desvio de finalidade a destinação da CPMF para pagamento de dividas junto ao FAT. (62)

Outra polêmica foi quanto à diminuição de repasse do Ministério da Fazenda de recursos de outras fontes para a saúde. Como os recursos da CPMF, constitucionalmente deveriam ser exclusivamente da saúde, há provas de que diminuíram os recursos de outras fontes. Foi uma das preocupações compartilhadas, anteriormente à aprovação da CPMF, por várias pessoas e entidades. A não suspensão de outras fontes de financiamento com o advento do CPMF foi condicionante de vários apoios dados à CPMF. De outro lado, foi o medo de que isto acontecesse que levou outros a não apoiarem a aprovação da CPMF.

Tanto numa situação, como noutra, o que aconteceu foi a diminuição dos recursos para a área de saúde. Nenhuma instituição ou órgão público iria receber recursos da CPMF com destino livre para se utilizar no que quisesse. Recebeu sim, com destino específico, definido pela Lei Orçamentária da União para 1997.

O previsto, indesejável e abominável aconteceu. O Governo, com a aprovação da CPMF e com a omissão na lei de que ele seria um recurso a mais para a saúde, ludibriou a opinião pública, lesou os cidadãos que assim subentendiam, quando o próprio Governo advogava 
sua aprovação. Sim, "fomos todos inocentes", como disse acima o Ministro Albuquerque, pois não existe brasileiro que não tenha entendido que os recursos totais da CPMF viriam diretamente para a saúde como um recurso a mais. Não foi este o apelo pela mídia? Adotar e aprovar a CPMF para a saúde? Pouquíssimos podiam imaginar que, ao entrar a CPMF, o Governo iria diminuir as outras fontes de recursos que chegavam para a saúde. Se assim fosse, um Governo claro teria dito isso aos cidadãos. Não teria sonegado a informaçăo correta. Essa atitude de lesa-cidadania levou a que os recursos da saúde não aumentassem o suficiente. Vejamos alguns dados.

A Lei da CPMF foi aprovada em 24 de outubro de 96, só tendo seus efeitos a partir de 23 de janeiro de 1997 (90 dias após como manda a CF). Em 1997, os recursos arrecadados pela CPMF representaram $R \$ 6,9$ bi. A expectativa de todos os brasileiros, incluindo técnicos em financiamento da saúde, era de que esses recursos deveriam se somar aos $R \$ 14,3$ bi que foram o total de recursos do Ministério da Saúde em 1996. Isso daria um orçamento do MS de $\mathrm{R} \$ 21,2$ bi em 1997 (14,3 de $96+6,9$ da CPMF de 97). Entretanto, a execução do orçamento do MS, em 1997, foi de $\mathrm{R} \$ 17,6$. Subtraindo do que deveria ter sido $(21,2 \mathrm{bi})$ ficaram faltando na conta $\mathrm{R} \$ 3,6$ bi. Como assim? Então o recurso da CPMF não foi todo para a saúde? Claro que foi todo destinado à saúde, só que com uma mão se colocou a CPMF para a saúde e com a outra, foram subtraídas outras fontes que a vinham financiando, como COFINS, CSLL etc.

Reagiu-se a isto já em 1997. Mas, em 1998, a história se repetiu. Tínhamos que ter o parâmetro de 1996 (14,3 bi) aos quais deveriam ter sido somados os $\mathrm{R} \$ 8,08$ bi arrecadados como CPMF em 1998. A soma resultaria num orçamento de $\mathrm{R} \$ 22,38 \mathrm{bi}$, mas o realizado pelo Ministério da Saúde foi $R \$ 18,91$. A diferença foi de $R \$ 3,47$ bi. Dinheiro da CPMF de novo, todinho na saúde, mas as outras fontes sumiram num montante de $R \$ 3,47$ bi.

0 ocorrido fez com que muita gente, que havia apoiado, inicialmente, a implantação da CPMF para a saúde, ficasse terminantemente contra. $O$ argumento era que afinal não se tinha um Governo confiável. Mais uma autorização, de novo, sacrificio para a população (novo imposto) poderia utilizar a saúde e seu apelo emotivo, para levar recursos para outras áreas. Com tanta certeza, cidadãos se sentiram traídos, pois tinham dado ainda uma chance para o Governo que, antes, já tinha usado dos mesmos artificios. Basta lembrar de fatos antigos em que o aumento da aliquota de contribuição sobre a folha subiu de 6 para $8 \%$ para garantir a saúde e não aconteceu. O FINSOCIAL, que era $0,5 \%$ e foi transformado em COFINS com taxa de $2,0 \%$ para a saúde e não aconteceu. O Fundo Social de Emergência que retirou $20 \%$ da receita de estados e municipios e que tinha em seus objetivos sociais a saúde e... não aconteceu. 
Desde que foi instituída a CPMF, em 1997, já se denunciava que ela deveria vir direto para a saúde e que dela não se podia descontar o percentual de $\mathbf{2 0 \%}$ do Fundo de Estabilização Fiscal - FEF, como o Governo vinha fazendo, e que năo se poderia pagar divida com tais recursos, já que eram para as ações e serviços de saúde. Depois de ter feito exatamente o contrário, o Governo continuou descontando o FEF, ainda que depois o repassasse à saúde. Quem devia controlar o Governo, o Tribunal de Contas da União, só foi se preocupar com a questão, amplamente denunciada, quando estava no fim. Em final de 1998, declarou que os recursos deveriam vir direto ao Fundo Nacional de Saúde e que não se podia descontar dele o FEF. Até dezembro, descumprindo o relatório do TCU, o MS continuou retirando a cota do FEF.

Os recursos da CPMF vieram, como já dito anteriormente, todos para a saúde. Vieram não diretamente ao Fundo, como manda a Lei, e parte como "devolução" do FEF. Foram utilizados em transferências aos municípios ou fundo a fundo, ou como pagamento por produção, ou outros. Isso foi fácil, pois bastava usar estes recursos com este destino e utilizar os demais com outros.

A realidade de 97 e 98 mostrou que os que não acreditavam no Governo, tinham razão. Até mesmo o Ministro Serra assim reconheceu no final de 98:

“A saúde foi usada como pretexto para aprovação da CPMF. O imposto serviu para aumentar a receita do governo e não do setor. A CPMF substituiu outras fontes que deixaram de ser transferidas ao ministério. A CPMF é receita para o governo. Não é receita da saúde. O imposto foi aprovado como se fosse para a saúde mas, na verdade, a saúde serviu para que a CPMF fosse aprovada. Esse problema foi mal equacionado na época, embora a CPMF exista a pretexto da saúde - acrescentou Serra" (117)

Durante o segundo semestre de 1998, quando estava prestes a cessar a vigência da CPMF, a discussão voltou à tona. O Governo não se sentia em condições de abrir mão dos recursos (8 bi em 1998) e lutou pela prorrogação.

Neste meio tempo, rediscutia-se mais uma vez a necessidade de garantir recursos definitivos e suficientes para a saúde. A proposta mais antiga e, mais permanentemente discutida, de definição do quantitativo de recursos para a saúde é a do Dep.Eduardo Jorge, que data de 1993. Ela ficou conhecida como Proposta de Emenda Constitucional - PEC 169. Seu teor é de que a saúde seja financiada por no mínimo $30 \%$ das Contribuições Sociais da Seguridade Social (previstos no art.195 da CF) e 10\% dos recursos fiscais da União, dos Estados e dos Municipios. O Conselho Nacional de saúde fez uma adendo à proposta, colocando que 
deveria ser $30 \%$ do Orçamento total da Seguridade Social e não apenas das contribuições sociais. O Dep. Carlos Mosconi, em 1995, depois de o Ministro Britto ter tirado da saúde cerca de $\mathbf{2 5 0}$ milhões de dólares mensais, referentes à contribuição sobre a folha de pagamento de pessoal, propôs através da PEC-82 que, em contrapartida, para compensar a perda imposta unilateralmente por Britto, a Contribuição para o Financiamento Social COFINS e a Contribuição Sobre o Lucro Líquido - CSLL ficassem integralmente para a saúde. O Governo FHC, através do Ministro Serra, fez uma tentativa de aprovar uma emenda mais completa que a do Mosconi. Utilizou-se do Dep. Urcisino e elaborou a PEC-82A, complementar ao do Mosconi. Nessa proposta, está mantida a CPMF com parte destes recursos diretamente dirigidas aos Municípios para garantir a Saúde. Essa proposta foi aprovada na Comissão de Seguridade e Familia e iria ao Plenário do Congresso Nacional. O fato novo de setembro, com a crise fiscal, levou ao pacote de ajuste que, então, incluiu a permanência da CPMF não mais com destino total à saúde, mas com a CPMF de $0,20 \%$ destinada à saúde e $0,18 \%$ destinada à Previdência. Morreu aí a proposta da PEC-82-A.

Hoje, a legislação da CPMF (Emenda Constitucional de 19-3-99) garante a prorrogação da CPMF por mais 36 meses, com aliquota de $0,38 \%$ nos primeiros 12 meses e $30 \%$ nos meses subseqüentes. $O$ excedente aos $0,20 \%$, destinado à saúde, o será à Previdência Social. O periodo em que a CPMF não foi arrecadado (23 de janeiro/ 19 de junho) trouxe perdas de receitas equivalentes à diferença entre os recursos previstos e não realizados. $A$ compensação dessa frustração da receita foi feita com títulos da divida pública interna.

A polêmica criada com a CPMF tem levado a vários equívocos. Analisemos alguns deles:

O primeiro equívoco:

- "Estes recursos serão utilizados, mas ninguém sabe em que. Vai se perder no meio dos outros recursos".

Estes recursos, chegando ao Ministério da Saúde, Fundo Nacional de Saúde, são utilizados de acordo com a destinação constante do orçamento da União.

Assim, nos 13 meses (janeiro de 1997 a março de 1998), periodo definido legalmente como de arrecadação, o previsto de receita 5,3 bilhões de reais (as primeiras arrecadações já apontavam para uma arrecadação superir a 6 bilhões!), tinha sua destinação para cobrir gastos assim distribuídos, segundo o Ministério da Saúde: pagamento de Empréstimo do FAT feito em 1996 - R $\$ 1,3$ bi ; pagamento de abono de $25 \%$ feito na tabela desde julho de 1995 e em débito desde junho de 1996 R $\$ 1,1$ bi ; pagamento de serviços prestados pelos Hospitais R $\$ 1,7$ bi; ações preventivas (Saúde da Familia, Agentes Comunitários de Saúde, Programa de Redução da Mortalidade Infantil) R\$0,478 bi; Programa do Leite $\mathrm{R} \$ 0,90$ bi; 
Programa de Combate ao Dengue $\mathrm{R} \$ 0,24$ bi; Programa de Combate a Endemias (malária, chagas, esquistossomose) $\mathrm{R} \$ 0,150$ bi Medicamentos para determinados programas $\mathrm{R} \$ 0,150$ bi.

\section{Equivoco dois:}

-“o Ministro anterior deixou débitos e já gastou por conta, antes da arrecadação".

No orçamento do Ministério da Saúde para 1996 estavam previstos 20 bilhões de reais sendo 6 bilhões de estimativa de arrecadação, via CPMF. A CPMF, entretanto não pôde ser arrecadada em 1996 e desta forma, ficaram várias pendências e compromissos a serem pagos. Se isso não tivesse acontecido, poderíamos pensar que o Ministro Jatene teria feito previsões orçamentárias sem sentido e base: eram necessários 20 bi, mas só chegaram 14 e não aconteceu nada! Seria um sinal evidente da desnecessidade! Assim, com toda a crise por falta de recursos, pagamento vil a prestadores ( $R \$ 2,08$ a consulta, $R \$ 1,12$ por atendimento psicológico, R\$114 por parto normal, R\$61 por operação de garganta etc) não se podia deixar de garantir algum recurso por antecipação. Foi dai que o Ministro Adib conseguiu o empréstimo de $\mathrm{R} \$ 1,3$ bi junto ao Fundo de Amparo ao Trabalhador (FAT) e ainda deixou despesas não pagas como o abono de $25 \%$, que foi pago quatro meses do ano de 96.

\section{Equivoco três:}

- "A CPMF não será utilizada em saúde pública, em prevenção. Apenas $21 \%$ dos recursos da CPMF serão utilizados em medicina preventiva."

Nesses tempos, mais do que nunca, modifica-se o conceito desintegrador da assistência à saúde. Lutamos por uma visão de integralidade horizontal, sem distinção entre promoção, prevenção, assistência e reabilitação. Tudo fazendo parte, como componente de um mesmo conjunto. Separar recursos de malária, esquistossomose, Chagas, unicamente dentro da rubrica de prevenção seria esquecer-se dos gastos com tratamento, de caráter assistencial, aos milhares de pacientes já infectados e sofrendo com essas doenças. Precisam-se enfatizar medidas preventivas, sem dúvidas. Mas faz parte da prevenção, em inúmeras doenças, a assistência e tratamento para aqueles que já estão doentes. A prevenção das meningites também se faz através do tratamento dos doentes de meningite, pois são estes doentes que, se não tratados e isolados, irão transmitir a doença a outros. Dentro das rubricas do orçamento do Ministério da Saúde, grande parte dos recursos utilizados pela vacinação, providência eminentemente preventiva, está sendo rubricada dentro dos recursos chamados pelos reducionistas de "recursos de assistência". Estão dentro do Sistema de Informações Ambulatoriais (SIA-SUS) e são pagas por produção a estados e municipios. 
Equívoco quatro:

-"os recursos da CPMF não vêm para os municípios, vão sumir lá por cima no governo federal".

Outro engano. Com a arrecadação da CPMF, foi possível pagar mais parcelas do abono de $25 \%$, concedido a partir de julho de 1995 sobre os serviços de saúde do Brasil inteiro. Estavam atrasados há vários meses, desde 95 e 96 . Mais da metade desses recursos foi gasta com os serviços públicos, que garantem ações preventivas e curativas. Entre os serviços públicos existe uma grande parte de serviços municipais distribuídos no Brasil inteiro. Está dentro do orçamento. Assim também acontecerá com os municípios que contarem com o Programa de Saúde de Família, Programa de Agentes Comunitários de Saúde, Programa de Controle da Malária, Chagas, Esquistossomose e Dengue, Programa de distribuição do leite etc.

\section{O FINANCIAMENTO FEDERAL PARA A SAÚDE NO GOVERNO FHC - NOB-96 E “NOB-98" - INÍCIO DO PROCESSO RECENTRALIZADOR NA IMPLANTAÇÃO DO SUS}

\subsection{NOB-1996}

Como já dito acima, a mudança do Ministro, em 1995, criou constrangimentos à implantação do SUS pela NOB-93. Paralisou-se o processo durante meses e depois foi retomado. Defendia-se que as NOBs devessem ser dinâmicas e, se necessário, sofrer mudanças e se adequar à realidades do processo. Assim, defendi a rediscussão de uma nova NOB. Houve quase unanimidade quanto a necessidade de mudar a NOB-93. Era a convicção de que era necessário evoluir, aperfeiçoar, corrigir possiveis desvios de rota, os defeitos descobertos depois. Evoluir na ampliação da descentralização de competências e meios de execução das competências. Fica sempre o receio: as mudanças serão avanços ou, quando autorizadas, assumirão retrocesso? A resposta é o risco assumido de querer evoluir!

Os pontos essenciais que os municipios defendiam, desde os primeiros movimentos de mudança e criação de uma NOB-96 (68), eram:

1. Necessidade de avançar com uma nova orientação. Jamais retroceder no processo de descentralização;

2. Fazer a descentralização com duas tônicas: aprofundamento e agilização do processo; 
2. Fazer a descentralização com duas tônicas: aprofundamento e agilização do processo;

3. Fidelidade à legislaçăo vigente: toda mudança teria que ser em estrita obediência às leis. "A ousadia de cumprir e fazer cumprir a lei";

4. Tentar diminuir a burocracia do processo, sem com isto enfraquecer os pré-requisitos necessários para se assumir novas funções;

5. Oferecer mais vantagens e autonomia às formas de gestão menos complexas, de tal modo que se conseguisse entusiasmar os municipios de menor porte que só entram neste novo compromisso se souberem "levar" alguma vantagem mais coletiva, que individual;

6. Esvaziar a tendência estadual, com o aval do MS, a uma descentralizaçăo baseada no poder estadual, subdividido em regiōes estaduais de saúde (regionais de saúde), sem nenhum poder de controle de um executivo, legislativo, conselho e CIBs, em que apenas os estados teriam o mando. $O$ risco de fisiologismo e clientelismo é muito grande;

7. Esvaziar a tendência estadual em querer que retornar à antiga prática, de que os recursos federais devam passar pelas esferas estaduais antes de chegar aos municípios;

8. Dar mais autonomia aos municípios iniciantes no processo, com chegada de, pelo menos, parte dos recursos em valores per-capita e não por simples produção;

9. Criar o nivel de gestão plena com ampliação e aprofundamento do processo, que seria o coroamento da descentralização, como já se previa na NOB-93;

10. Descentralização de outras áreas do Ministério da Saúde e não apenas a área da Secretaria de Assistência à Saúde. Ênfase nas áreas de VS - Vigilância Sanitária, VE Vigilância Epidemiológica, FUNASA - Fundação Nacional de Saúde, CEME - Central de Medicamentos, INAN - Instituto Nacional de Alimentação e Nutrição e a própria Comunicação Social do Ministério da Saúde.

Esse embate na construção da NOB 96 foi se dando durante meses, com momentos de fluxo e refluxo. De um lado, os Municípios, o mais das vezes associados à representação estadual, defendendo os princípios acima. De outro, o Ministério, por intermédio de suas várias Secretarias e, até mesmo, entre facções de Secretarias do MS, com o intuito, mais implícito que explícito, de marcar a nova administração do Ministério da Saúde, através de mudança da nomenclatura anterior dos "estágios de gestão".

Outro ponto defendido pelo Ministério foi em relação aos valores financeiros de transferências. Em um estudo preliminar verificou-se que no momento em que se mudasse o critério de pagamento por produção para os serviços básicos, calculando-se um per-capita 
único, chegar-se-ia a um valor acima do atual para alguns estados e abaixo, para outros $\mathrm{A}$ única possibilidade de se fazer isto seria carreando mais recursos para financiamento das açőes básicas que, de ora em diante, passarão a ser não um pagamento por produção, mas um valor per-capita.

A NOB-96 foi publicada em setembro, no bojo da IX Conferência Nacional de Saúde. Como houve resistência e manifestações contrárias durante o decorrer da IX CNS, o Ministro Adib optou por apresentá-la em forma de consulta pública, por sessenta dias, após os quais saiu republicada.

Vamos dar uma passada resumida sobre o texto da NOB-96. Em sua introdução, reafirma os principios básicos do SUS, enfatiza a regionalização, o cadastramento e vinculação de clientela, fluxos de referência e contra referência, ampliação das transferências regulares e automáticas para todos os niveis de gestão (novo) e ampliação da programação pactuada e integrada - PPI (novo... de volta ao velho.). A PPI é um instrumento que deverá ser pactuado e envolve o estabelecimento de objetivos, metas, recursos, tetos financeiro-orçamentários etc.

Em relação à gestão da assistência, há reafirmação dos mecanismos de gestão: conselhos, tripartite, bipartite. A ênfase é dada em cima do planejamento nos três níveis de atenção: básico, alta complexidade e hospitalar. Planejamento ascendente, com autonomia no municipio.

Relembra-se a importância de implantação do controle, avaliação, auditoria, determinados pelo Decreto 1651/95 (16). Coloca-se o nivel federal vigiando os serviços próprios, o contratado federal, os sistemas estaduais de saúde, o sistema estadual de controle, avaliação e auditoria e os recursos transferidos. O nivel estadual controla o seu próprio, o contratado, os sistemas municipais de saúde e o sistema municipal de controle avaliação e auditoria. Os municípios controlam o seu próprio, o contratado e o de consórcio a que pertençam.

A questão mais importante é a mudança no financiamento, que continua sendo responsabilidade das três esferas de governo. $O$ financiamento será estabelecido por tetos e os tetos serão resultados da programação pactuada e integrada. A União, como a soma dos Estados e os Estados, a soma dos Municipios.

Estabelece um teto financeiro para Vigilância Sanitária. É algo novo, cuja programação é elaborada nos Estados pela PPI e submetido à Secretaria de Vigilância Sanitária do Ministério da Saúde. 
O financiamento da União se dará através de repasse a Estados e Municípios, diferentemente da NOB-93. Aparecem novos montantes de recursos, com novas siglas e novos critérios de repasses:

1. PAB - Piso de Assistência Básica - financiamento distribuído per capita (previsto inicialmente para 96 a $R \$ 12,00 / \mathrm{hab} / a n o$, executado em início de 1998 e até 2001 como R\$10,00/hab/ano) tomando-se a populaçăo total de um Município, para este ser responsável pela assistência básica (consultas, odontologia e procedimentos básicos - AVEINAM). Os recursos serão transferidos direta e automaticamente, fundo a fundo, aos Municípios que cumprirem os requisitos e para Estados, quando se tratar de municípios não habilitados.

2. FAI-PAB - Fator de Ajuste à Implantação do PAB - financiamento como um fator de ajuste de até $\mathbf{R} \$ \mathbf{0 , 5 0 / h a b / a n o , ~ n o s ~ m u n i c i ́ p i o s ~ q u e ~ a v a n c ̧ a r e m ~ n a ~ o r g a n i z a c ̧ a ̃ o ~ d e ~ u m ~ s i s t e m a ~ d e ~}$ atenção básica, com gastos superiores ao PAB nacional.

3. PSF - Programa de Saúde da Família - financiamento destinado àqueles municípios que querem desenvolver, como estratégia, o programa de saúde da família. Esses municípios passam a ter mais recursos, segundo os percentuais definidos. (+ $3 \%$ do PAB para cada $5 \%$ da população coberta até $60 \%$ da população total; $5 \%$ para cada $5 \%$ entre 60 e $90 \%$ e $7 \%$ para cada $5 \%$ acima de $90 \%$ da população). Há um limite de ganho de $80 \%$ do valor do PAB.

4. PACS - Programa de Agentes Comunitários de Saúde - financiamento destinado a Municipios que querem desenvolver como estratégia o programa de agentes comunitários de saúde. Seguem regras especificas como o PSF quanto a percentuais de financiamento. (+ $1 \%$ do PAB para cada $5 \%$ da população coberta até $60 \%$; $2 \%$ para cada $5 \%$ entre 60 e $90 \%$ e $3 \%$ para cada $5 \%$ cima de $90 \%$ da população). Há um limite de ganho de $30 \%$ do valor do PAB. Não pode haver concomitância de ganho entre PACS E PSF.

5. FAE - Fração Assistencial Especializada - financiamento definido na PPI para procedimentos ambulatoriais de média complexidade, medicamentos excepcionais, órteses e próteses e tratamento fora do domicilio, transferido a Estados habilitados (deduzidas transferências já feitas aos municípios).

6. TFAM - Teto Financeiro de Assistência do Município - financiamento referente ao total das ações assistenciais assumidas pelo Municipio.

7.TFAE - Teto Financeiro de Assistência do Estado - financiamento referente ao total das ações assistenciais assumidas pelos Estados. (deduzidas transferências já feitas aos municipios). 
8. IVR - Indice de Valorizacăo de Resultados - financiamento correspondente até a $2 \%$ do teto estadual e atribuível ao estado que tiver cumprido metas estabelecidas. Pode ser repassado, em parte ou total, aos municípios do Estado, dependendo de definiçăo da comissão bipartite.

9. RSP - Remuneracão de Servicos Produzidos - financiamento destinado à remuneração de serviços produzidos de internaçőes hospitalares (AIH) e de procedimentos de alto custo (APAC).

10. Fatores de Incentivo e Indices de Valorização - financiamento atribuído por critérios federais e avaliação da CIB, como é hoje o FIDEPS (fator de incentivo ao desenvolvimento de ensino e pesquisa em saúde) e IVH-E (índice de valorização hospitalar de emergência), IVISA (indice de valorização do impacto da vigilância sanitária)

11. TFS - Teto Financeiro de Vigilância Sanitária - financiamento para custeio das ações de Vigilância Sanitária, pagos a Estados e Municípios. Tetos são estabelecidos pelo MS (órgão competente) e Comissão Intergestores Tripartite, em nivel nacional. Nos Estados, os tetos são estabelecidos nas Bipartites. Nesse teto são incluidos grupos de atividades: piso básico de vigilância sanitária (PBVS) para os procedimentos básicos de V. Sanitária, índice de valorização do impacto em vigilância (IVISA), e pagamento, por produção, de ações de média e alta complexidade em Vigilância Sanitária e "programa desconcentrado de ações de vigilância sanitária", PDAVS.

12. TFECD - Teto Financeiro de Epidemiologia e Controle de Doencas - financiamento a ser transferido por produção, convênio, ou fundo a fundo a estados e municípios (sem valor e critérios ainda estabelecidos).

13. FINANCIAMENTO DE INVESTIMENTOS: financiamento para investimentos que tenham sido aprovados em uma programação nacional e que tenha passado pela aprovação nas bipartites de cada Estado. Recursos a serem transferidos por convênios específicos.

As condições de gestão para os municipios ficam apenas duas: a gestão plena da atenção básica e a gestão plena do sistema municipal de saúde. Para cada uma delas continuam sendo explicitadas as responsabilidades, os requisitos e as prerrogativas.

\section{GESTÃo PLENA DA ATENÇÃO BÁSICA}

Responsabilidades: elaboração do programa (básico domiciliar e comunitário), referência especializada e hospitalar com incorporação negociada à programação estadual; gerência de unidades próprias, estaduais e federais (definidas CIB e CIT); cadastramento de usuários; 
prestaçăo de serviços básicos ou compra fora na relação gestor-gestor, segundo PPI; contratação, controle, auditoria e pagamento de prestadores do PAB; alimentação do SIASUS; SIH-SUS cadastro atualizado de unidades; avaliação de impacto; execução das ações básicas de Vigilância Sanitária, VECD; relatório anual de gestão e aprovação pelo CMS.

Requisitos: funcionamento do Conselho, fundo, plano local e PPI do estado e alocação de recursos; comprovaçăo de capacidade técnica e administrativa e de gasto em saúde no ano anterior; pleito aprovado no conselho e CIB; médico formalmente designado para autorização, controle e auditoria de procedimentos e serviços realizados; capacidade de fazer Vigilância Sanitária, Epidemiológica e pessoal disponível para supervisăo e auditoria.

Prerrogativas: recebe PAB, PBVS, PBVE fundo a fundo.

\section{GESTÃO PLENA DO SISTEMA MUNICIPAL}

Responsabilidades: elaboração do programa (básico domiciliar e comunitário), referência especializada e hospitalar, com incorporação negociada à programação estadual; gerência de unidades ambulatoriais e hospitalares próprias, estaduais e federais (definidas na CIB e $\mathrm{CIT}$ ) ; cadastramento de usuários; prestação de serviços ou compra fora, na relação gestorgestor, segundo PPI; normalização e operação de centrais de controle de procedimentos ambulatoriais e hospitalares; contratação, controle, auditoria e pagamento de prestadores incluidos no TFGM; administração da oferta de procedimentos ambulatoriais e hospitalares de alto custo e complexidade, segundo PPI; operação e alimentação do SIH-SUS e SIASUS; cadastro atualizado de unidades; avaliação de impacto; execução das ações básicas de Vigilância Sanitária, Epidemiológica e Controle de Doenças;

Requisitos: funcionamento do Conselho, fundo e alocação de recursos próprios; comprovação de capacidade técnica e administrativa e de gasto em saúde no ano anterior; pleito aprovado no CMS e CIB ; médico formalmente designado para autorização, controle e auditoria de procedimentos e serviços realizados; capacidade de fazer Vigilância Sanitária, Epidemiológica e pessoal disponivel para supervisão e auditoria; relatório anual de gestão e aprovação pelo conselho; plano municipal de saúde aprovado no conselho e participação na PPI estadual com indicação de indicadores sob os quais se fará a avaliação; componente municipal do SNA; oferta no território de PAB e de apoio diagnóstico de patologia e radiologia.

Prerrogativas: recebe teto financeiro global do município, PBVS, PBVE, remuneração por serviços prestados de serviços de Vigilância Sanitária, de média e alta complexidade, e 
remuneração pela execução do PDAVS; normalizaçăo complementar na contratação incluindo tabela própria.

\section{CONDIÇŐES DE GESTÃO DOS ESTADOS}

Condiç̋es comuns aos dois niveis de gestão estadual: gestão avançada do sistema estadual e gestão plena do sistema estadual

Responsabilidades: elaboração da PPI aprovada na bipartite; plano estadual de prioridade de investimentos, negociada na CIB e aprovada no CES; gerência da hemorede, laboratórios de referência; formulação e execução da política do sangue e hemoterapia; organização da referência e operação de câmara de compensação de AlH e procedimentos de alto custocomplexidade; política farmacêutica; normatização complementar de administração da oferta e controle de prestação de serviços ambulatoriais, hospitalares, alto custo, tratamento fora de domicilio e medicamentos e insumos especiais; cadastro de unidades; cooperação técnica e financeira com os municipios objetivando a descentralização; implementação da política de integração entre saneamento e saúde; coordenação de V. Epidemiológica e Controle de Doenças; controle de V. Sanitária; execução de ações básicas de V.Sanitária nos municípios não habilitados e de média e alta complexidade; execução do PDAVS.

Requisitos: ter Conselho, Comissão Bipartite, fundo; plano com metas pactuadas e programação integrada, estratégias de descentralização de reorganização e de critérios e indicadores de acompanhamento, aprovado no conselho com critérios, e indicadores aprovados no conselho; relatório de gestão; estruturação do componente estadual do SNA; capacidade técnica e administrativa; participação de recursos estaduais no financiamento; comitê interinstitucional de epidemiologia; funcionamento da vigilância sanitária e epidemiológica; pleito para CIT aprovado pelo CES e CIB.

\section{GESTÃO AVANÇADA DO SISTEMA ESTADUAL}

Responsabilidades especificas: contratação, controle, auditoria e pagamento dos serviços sob responsabilidade estadual, $\mathrm{PAB}$ e $\mathrm{FAE}$ não transferidos aos municípios; operação sistema SIA-SUS.

Requisitos específicos: PPI ambulatorial, hospitalar e de alto custo com referência intermunicipal e critérios para sua elaboração; $60 \%$ dos municipios habilitados ou $40 \%$ desde que contenham $60 \%$ da população; $30 \%$ do teto estadual comprometido com transferências regulares e automáticas aos municipios. 
Prerrogativas: transferência regular e automática do PAB, FAE E PBVS dos Municípios não habilitados; transferência fundo a fundo do IVISA; remuneraçăo dos serviços produzidos em V. Sanitária e transferência de recursos referentes às ações de VECD.

\section{GESTÃO PLENA DO SISTEMA ESTADUAL:}

Responsabilidades especificas: contratação, controle, auditoria no total de serviços sob responsabilidade estadual definidos $\mathrm{CIB}$; operação dos sistemas de processamento de dados ambulatoriais e hospitalar.

Requisitos especificos: PPI completa; mecanismos de controle de prestaçăo de serviços ambulatoriais e hospitalares em operação; centrais de controle de leitos, de procedimentos de alto custo, de marcação de consultas especializadas e de procedimentos hospitalares de alta complexidade; $80 \%$ dos municípios habitados ou $50 \%$ com $80 \%$ da população; $50 \%$ do teto estadual comprometido com transferências regulares e automáticas aos municipios.

Prerrogativas: recebe total do teto estadual exceto o que vai direto a municipios; IVR, IVISA, PBVS dos Municípios não habilitados e remuneração VS por serviços produzidos; normatização complementar inclusive de tabela de valores aprovada na CIB e no CES.

\section{DISPOSIÇÕES TRANSITORIAS:}

Responsabilidades descritas poderão ser acrescidas de outras pactuadas; da NOB 93 para a 96: habilitação só pela comprovação de cumprimento dos novos requisitos com prazo estipulado; habilitação nas CIBs e ratificação na CIT; quando estado em convencional, CIT decide; instrumentos de habilitação foram colocados em anexo; necessidade de explicitar a transição ainda não definida; permanência de Estados e Municípios nas condições de gestão estarão sujeitas a acompanhamento bipartite e tripartite; municipio em gestão básica com falta de serviços poderá negociar com gestor vizinho sua referência; complementações: acontecerão na CIT e por Instruções Normativas do Ministério da Saúde.

Este é o resumo do conteúdo na NOB-96, principalmente na parte que toca ao financiamento. Para facilitar o entendimento, apresentam-se quadros sobre os modos de gestão municipal e suas responsabilidades, requisitos e prerrogativas. 
NOB-96 GESTÃO MUNICIPAL - RESPONSABILIDADES

\begin{tabular}{|c|c|c|}
\hline RESPONSABILIDADES & PAB & PSM \\
\hline 1. PROGRAMAÇÃO MUNICIPAL DO BÁSICO - PPI & $\mathbf{x}$ & $+\mathrm{H}-\mathrm{E}$ \\
\hline 2.GERÊNCIA AMBULATÓRIO PRÓPRIO- (E/F NEG. CIB-CIT) & $x$ & $+\mathrm{H}-\mathrm{E}$ \\
\hline 3.REORGANIZAÇÃO . UNIDADES E CADASTRO NACIONAL USUÁRIOS & $\mathbf{x}$ & $\mathbf{x}$ \\
\hline 4.PRESTAČÃO BÁSICO(PAB) - ACOMPANHAMENTO .REFERÊNCIA PPI & $\mathbf{x}$ & $x$ \\
\hline 5.CONTRATO-CONTROLE-AUDITORIA PRESTADORES PAB & $\mathbf{x}$ & $+\mathrm{H}-\mathrm{E}$ \\
\hline 6.ACORDO CIB = AUTORIZACCÃO AIH E ESPECIALIDADES & $\mathbf{x}$ & HEC \\
\hline 7.OPERAÇÃO SIS E ALIMENTAÇÃO BANCO DE DADOS & $\mathrm{x}$ & $+\mathrm{SIH}$ \\
\hline 8. CADASTRO UNIDADES SOB GESTÃO & $\mathrm{x}$ & $\mathrm{x}$ \\
\hline 9. AVALIAÇÃO DE IMPACTO & $\mathbf{x}$ & $\mathrm{x}$ \\
\hline 10.EXECUÇĀO AÇŌES BÁSICAS DE VIG.SANITÁRIA & $x$ & MAC \\
\hline 11.EXECUÇÃO A. BÁSICAS DE EPIDEMIOLOGIA E CONTROLE DOENÇAS & $\mathbf{x}$ & $\mathrm{x}$ \\
\hline 12.RELATÓRIO GESTÃO (ANUAL) APROVADO CONSELHO & $x$ & $\mathrm{x}$ \\
\hline
\end{tabular}

NOB-96 GESTÃO MUNICIPAL - REQUISITOS

\begin{tabular}{|c|c|c|c|}
\hline REQUISITOS & INSTRUMENTOS & PAB & PSM \\
\hline 1.CONSELHO & $\begin{array}{l}\text { ATO CRIAÇÃO- ATA APROVAÇÃO DO PLEITO } \\
\text { (PSM=ATAS ÚLTIMO TRIMESTRE) }\end{array}$ & $\mathrm{x}$ & $\mathrm{x}$ \\
\hline 2.FUNDO & ATO- CADASTRO - EXTRATO TRIM. & $x$ & $\mathrm{x}$ \\
\hline 3.PLANO-PPI - \$PROG. & PLANO - ATA CMS APROVA- DECLARAÇĀO TETO & $x$ & $x$ \\
\hline $\begin{array}{l}\text { 4.CAP..TÉC/ADM/MAT. } \\
\text { CAD/PAG/CON/AVA }\end{array}$ & $\begin{array}{l}\text { DECLARAÇÃO SES-DATASUS E } \\
\text { EXPLICITANDO AUDITORIA }\end{array}$ & $x$ & * \\
\hline 5.\$MUN. ANTERIOR-ATUAL & FORMULÁRIO PREENCHIDO & $\mathrm{x}$ & $x$ \\
\hline 6. PLEITO APRO.CMS & OFICIO À CIB E ATA & $\mathrm{x}$ & $\mathrm{x}$ \\
\hline 7. MÉDICO NAC & DECLARAÇÃO SMS & $\mathrm{x}$ & $\mathrm{x}$ \\
\hline 8. CAP. VIG. SANITÁR. & ATO MUNICIPAL ATRIBUIÇĀO E COMPETÊNCIA & $\mathrm{x}$ & ** \\
\hline 9.CAP. VIG. EPIDEMIO. & DECLARAÇĀO SMS E SES CAPA. E COMP. & $\mathrm{x}$ & *** \\
\hline 10.RH PARA NAC & DECLARAÇÃO SMS COM RESPONSAB. MUN. & $\mathrm{x}$ & $\mathrm{x}$ \\
\hline 11.SNA - COMP. MUN. & ATO CRIAÇĀO DO SNA & - & $\mathrm{x}$ \\
\hline 12.REL.GESTÃO -CMS & R.GESTÃO - ATA APROVAÇÃO CMS & - & $\mathrm{x}$ \\
\hline $\begin{array}{l}\text { 13.GARANTIR NO } \\
\text { MUNICIPIO PAB-LAB-RX }\end{array}$ & FICHA CADASTRAL AMBULATORIAL & - & $x$ \\
\hline
\end{tabular}




\footnotetext{
* + AVAL. DE IMPACTO + SIH + RUBRICA PIPAG. + ALIMENTAR BANCO DADOS NACIONAL

* REGULAMENTAÇÃO

*** INVESTIMENTO - IDENTIFICAÇÃO DE ÓBITO MATERNO-INFANTIL - ANÁLISE DADOS COMPROMISSO SIM-SINASC-SINAM
}

NOB-96 GESTÃO MUNICIPAL - PRERROGATIVAS

\begin{tabular}{|l|c|c|}
\hline PRERROGATIVAS & PAB & $\begin{array}{l}\text { PLENA } \\
\text { MUNICIPAL }\end{array}$ SISTEMA \\
\hline 1. PAB - FUNDO A FUNDO - 10 A 18 & $\mathrm{X}$ & $\mathrm{X}$ \\
\hline 2.PBVECD - FUNDO A FUNDO & $\mathrm{X}$ & $\begin{array}{c}\text { + MÉDIA E ALTA } \\
\text { COMP.+PREST.PDAVS }\end{array}$ \\
\hline $\begin{array}{l}\text { 3.SUBORDINAÇÃO A A GESTÃO MUNICIPAL DOS } \\
\text { SERVIÇOS ESTATAIS E PRIVADOS }\end{array}$ & $\mathrm{X}$ & $\begin{array}{c}\text { + HOSPITAIS E } \\
\text { ESPECIALIDADES }\end{array}$ \\
\hline $\begin{array}{l}\text { 4.TETO FINANCEIRO DE ASSISTENCIA- TFA - F/F } \\
\text { 5.NORMATIZAÇÃO COMPLEMENTAR INCLUINDO } \\
\text { POSSIBILIDADE DE TABELA PROPRIA }\end{array}$ & $?$ & $\mathrm{X}$ \\
\hline
\end{tabular}

\section{COMENTÁRIOS À NOB-96}

Conforme o mencionado anteriormente, a discussão foi grande durante a construção da NOB-1996. O dilema: manter a garantia das conquistas da NOB-93, em vigor, ou arriscar aprimorar, escrevendo uma nova NOB e correr o risco de retroceder, ao perder no confronto de forças progressistas e retrógradas.

Nenhuma certeza se tinha do que poderia ocorrer. Apesar disso, arriscou-se na boa-fé de que os interlocutores teriam verdadeira vontade politica de serem ousados em cumprir ou fazer cumprir a lei.

O primeiro grande nó da NOB-96, em relação à sua aplicabilidade e financiamento, foi a falta de definições, até o final do ano de 1998. Não se podia aplicar a NOB-93, pois estava interrompida sua condição de habilitação. De outro lado, não se implantava a NOB-96, pois faltavam várias definições. 
As indefinições da NOB-96 eram nós críticos que precisavam ser deslindados urgentemente, para que os municípios tivessem condições de se habilitarem dentro do processo de municipalização. Citamos alguns deles.

1. Cartão SUS - 15.1.1 e outros - cadastramento nacional de usuários do SUS, com vistas à vinculação de clientela e à sistematização da oferta de serviços.

2. PPI (Programação Pactuada e Integrada)- item 11.1.6 - “(....) no tocante a recursos de origem federal, os critérios, prazos e fluxos de elaboração da programação integrada e de suas reprogramações periódicas ou extraordinárias são fixadas em ato normativo do MS e traduzem as negociações efetuadas na CIT e as deliberações do CNS". A definição de como seria, não houve. (Só foi acontecer em 2001). A dúvida maior era de Estados, como SP, que já vinham fazendo alguma coisa parecida e não se sabia se seria validada como PPI.

3. Cadastro de Unidades Assistenciais - 11.2.1 - Haverá um sistema de cadastro nacional, não definido. A época, uma Comissão já havia estudado e apresentado o cadastro hospitalar, mas que não havia sido ainda implantado. No atual sistema, temos questões sérias não adequadas ao momento atual, como o sistema de apresentação de CGC, que exige mesmo dos públicos um cadastro individual de cada unidade prestadora com CGC de filial. Isto, hoje, tem outras repercussões relacionadas ao Ministério do Trabalho e Previdência, como registro e folha de pagamento de pessoal individualizada por CGC, inadequados à administração pública, principalmente aos Municipios.

4. Banco de Dados Nacionais - 11.2.2 - idem, pois depende de formulários nacionais.

5. Relatório de Gestão Anual - 11.2.6 - “(....) cujo roteiro de elaboração será apresentado pelo MS e apreciado pela CIT e pelo CNS".

6 PAB(Piso Assistencial Básico) - 12.1 - "(...) o elenco de procedimentos custeados pelo $\mathrm{PAB}$, assim como o valor per capita nacional único - base do cálculo deste piso - são propostos pela CIT e votados pelo CNS."

7. FAE (Fração Assistencial Especializada) - 12.1.3. - "(...) o órgão competente do MS formaliza, por Portaria, esse elenco a partir de negociação da CIT e que deve ser objeto de programação integrada, quanto à oferta global ao estado".

8. TFAM (Teto Financeiro da Assistência do Municipio) e TFAE (Teto Financeiro da Assistência do Estado) - 12.1 .4 e 12.1 .5 - "(....)corresponde ao TFA fixado na CIT e formalizado em portaria correspondente do MS (SAS/MS)" 
9. IVR (Índice de Valorização de Resultados) - 12.1.6 - “(....) segundo critérios definidos pela CIT e fixados, em Portaria, pelo órgão competente do MS (SAS)." "Os recursos do IVR podem ser transferidos pela SES às SMS, conforme definição da CIB"

10. RPAACC (Remuneração de Procedimentos Ambulatoriais de Alto Custo/Complexidade) - 12.2.2- “ (....)compreende procedimentos ambulatoriais integrantes do SIA definidos na CIT e formalizados por portaria própria do MS (SAS)."

11. FIDEPS (Fator de Incentivo ao Desenvolvimento do Ensino e da Pesquisa em Saúde) e IVH-E (Índice de Valorização Hospitalar de Emergência) "(....) critérios definidos em nível federal e à avaliação da CIB em cada Estado".

12. PBVS (Piso Básico de Vigilância Sanitária) -13.1.1- "(....)o elenco de procedimentos custeados pelo PBVS, assim como o valor per capita nacional único - base de cálculo deste piso são definidos em negociação da CIT e formalizados por portaria do órgão competente do MS previamente aprovados pelo CNS."

13. IVISA (Índice de Valorização do Impacto em Vigilância Sanitária) - 13.1.2 - “(....) segundo critérios definidos na CIT fixados em portaria previamente aprovados pelo CNS".

14.PDAVS (Programa Desconcentrado de Ações de Vigilância Sanitária) - “(....)após negociação e aprovação na CIT e prévia aprovação no CNS. SVS-MS publica tabela de procedimentos do PDAVS".

15. AMACVS (Ações de Média e Alta Complexidade em Vigilância Sanitária) - 13.2.2 "(....) essas ações e o valor de sua remuneração são definidos em negociação na CIT e formalizados em portaria própria da SAS, previamente aprovados no CNS"

16. TFECD (Teto Financeiro de Epidemiologia e Controle de Doenças) - 14 "(....) o elenco de procedimentos a serem custeados com o TFECD é definido em negociação na CIT, aprovados pelo CNS e formalizado em ato próprio do MS". "O valor deste teto para cada estado é definido em negociação na CIT... formalizado em ato próprio do MS"

17. TRAFF (Transferência Regular e Automática Fundo a Fundo) - 14.1- "(....) condições de gestão aprovada na CIT e no CNS Condições de Gestão aprovadas na CIT e no CNS ou NOB e PPI aprovadas no CNS e CIT?"

18. RSP (Remuneração Por Serviços Produzidos) - 14.2 - "(...) ações de epidemiologia e controle de doenças conforme tabela de procedimentos discutida na CIB e aprovadas pelo CNS" 
19. IPC (Transferência por Convênios) - 14.3 -“(....)transferência voluntária da área de epidemiologia. ..mediante programação e critérios discutidos na CIT e aprovados pelo CNS." 20. PROGRAMAČÃO, PLANO, RELATÓRIO DE GESTÃO MUNICIPAL - haverá definições padrão nacional, ou pelo menos indicativos para: programação, plano, comprovação de capacidade técnica e administrativa, capacidade para desenvolvimento de ações de VS e VE - relatório de gestão

21. PERMANÊNCIA EM CONDIC̨ÃO DE GESTÃO MUNICIPAL - 17.6 - "(....)permanência nas atuais condições de gestão dos Municípios... data limite a ser fixada pela CIT."

22. PERMANÊNCIA EM CONDICÃO DE GESTÃO ESTADUAL 17.9 - "(....)permanência nas futuras condições de gestão dos Municípios.... tendo por base critérios estabelecidos pela CIB e pela CIT e aprovados pelos respectivos conselhos de saúde." (Inclui-se aí o CNS?)

23. PERMANÊNCIA EM CONDIC̣ÃO DE GESTÃO ESTADUAL 17.10 - "(....)permanência nas futuras condições de gestão dos estados.... processo permanente de acompanhamento e avaliação, realizado pelo MS e submetido à apreciação da CIT, tendo por base critérios estabelecidos por esta comissão e aprovados pelo CNS."

24. PERMANÊNCIA EM CONDIÇÃO DE GESTÃO ESTADUAL 17.12- “(....)ficam as CIBS autorizadas a estabelecer fatores diferenciados de ajuste até um valor máximo fixado pela CIT e formalizado por portaria do MS-SAS."

25. IVR - 17.14 "IVR (....)conforme critérios estabelecidos pela CIT e formalizados por portaria do MS-SAS"

26.REGULAMENTAÇÕES COMPLEMENTARES-17.17-“(...) as regulamentações complementares necessárias à operacionalização desta nob são objeto de discussão e negociação na cit, observadas as diretrizes estabelecidas pelo cns, com posterior formalização, mediante portaria do MS."

27. FORMULARIOS ANEXOS - 17.5- no anexo 1 fala-se em "(....) formulários a serem feitos e aprovados pela CIT e aprovados pelo MS"

Com todas essas indefinições, prorrogando-se por mais de um ano, a NOB-96 acabou não sendo implantada, em sua primeira versão. Nada aconteceu em relação ao financiamento proposto pela NOB-96. Sua implantação, com todas estas pendências teria um périplo, necessário, mas que demandava tempo, quais sejam a CIT, CIB, CES, CNS, sem contar a quinta e mais limitante dessas instâncias. O MS dobrou-se ao Ministério da Fazenda e este submeteu o MS ao engessamento financeiro e temporal. Foi imposto ao MS que a aprovação de qualquer aumento de recursos deveria passar pelos Ministérios da Fazenda e 
Planejamento, dado que noventa por cento destas definições acima acarretariam aumento de recursos (só uma delas, o PAB, levava a aumento da ordem de $\mathrm{R} \$ 400$ milhões/ano). Se a proposta da NOB 96 fosse para se trabalhar com os mesmos recursos anteriores, e ainda se amarrando pedaços dele às várias rubricas acima, podia se concluir que a NOB seria a anti-autonomia da descentralização.

Saidas foram propostas por técnicos e gestores, sem, contudo, sensibilizar o Ministério da Saúde. Entre as saidas, destacavam-se: a) regime de urgência para uma comissão preparar todas as definições, com prazo limitado e específico; b) convocação da CIT para em "estado de reunião permanente" apreciar de uma única vez todos os estudos feitos; c) convocação do CNS para, em "estado de reunião permanente" apreciar, de uma única vez, todos os estudos feitos, considerando parecer dos gestores membros do conselho (MS-CONASSCONASEMS) e da CIT, já como parecer para análise do conselho; d) análise em regime de urgência dos Ministérios do Planejamento e Fazenda; e) autorização para que os Municípios e Estados pudessem dar entrada nas CIBs e CIT de seus pleitos com as definições ainda que precárias de hoje, sujeitas à revisão de um lado e de outro, diante de qualquer mudança com que não se concorde com a nova regulamentação.

Docentes da UNICAMP, Wanderley e Emerson, fizeram críticas acerbas ao que denominaram de uma Nob em sintonia com os projetos neoliberalizantes do governo. "A NOB-96 fragmenta a integralidade da ação, criando uma Cesta Básica para os cidadãos minimos e dá liberdade para o setor privado crescer"(....)“A NOB-96 fere a autonomia de gestão dos municipios"(....)"Dois equivocos estão impedindo um maior avanço na consolidação do SUS: indução (pelo financiamento) ao modelo epidemiológico penalizando municipio que não adotar o programa e o risco do cartão SUS como forma de barras o acesso dos cidadãos aos serviços de sua escolha."

A junção dos dois itens: impossibilidade de continuar habilitando na NOB antiga e impossibilidade de se habilitar na nova (cerca de trinta indefinições) causou a natimortalidade da NOB-96. Mudou, logo em seguida, o Ministro, assumindo interinamente Dr. Seixas, como possibilidade de continuidade a Jatene e, logo em seguida, foi nomeado outro. A situação drástica era a seguinte: ninguém entra e ninguém sai. Ninguém se habilita, progride ou regride. Estágio de paralisia catatônica, que persistiu por cerca de 15 meses oficialmente, e mais alguns extra-oficialmente.

\section{2 - "NOB-98" - O PACOTE DAS NOVAS PORTARIAS DO MS}


A NOB-98 não existiu com esta denominação. Não é assim divulgada, nem conhecida. É uma força de expressão em decorrência do que ocorreu no início de 1998. A NOB-96 não foi implantada e, antes de o ser, sofreu radicais modificações, razão pela qual denomino de "NOB-98". Na verdade, foi um pacote de uma série de novas portarias surgidas no início de 1998 e que modificam a essência da NOB-96.

As indefinições da NOB-96, não resolvidas, e a impossibilidade de continuarem os municipios a se habilitarem na NOB-93, foram motivo para que novas forças tomassem conta do processo descentralizatório do SUS e modificassem radicalmente a NOB-96. Os técnicos quase que foram os mesmos, mas os dirigentes mudaram e, sob novo comando, estes e aqueles deram asas e pernas ao maior processo recentralizatório do SUS, continuado mais tarde e, de forma definitiva, com a NOAS-2001. Nunca se tinha avançado tanto, como a partir da NOB-1993. Nunca se conseguiu regredir tão rapidamente após a "NOB-98", chegando aos absurdos na NOAS-2001.

O Ministério da Saúde editou um conjunto de Portarias (64) que alteraram profundamente a NOB 01/96 e dando outras providências, com profundas repercussões na organização e funcionamento do SUS. Houve uma ampla participação de técnicos do MS, CONASS e CONASEMS na discussão dessas modificações na NOB-96. Isto é inegável. O processo de discussão foi prolongado. Houve uma suposta negociação final na CIT e no CNS. Mas, as decisões foram unilaterais em meio a negociações. Existem regras claras sobre as competências do Ministério da Saúde e o respeito que deve a instâncias colegiadas legalmente constituidas. No momento em que não se cumprem essas regras há um nítido rompimento da ordem, justamente por quem deveria dar exemplo a Estados e Municipios do cumprimento das leis. De respeito ao Conselho Nacional de Saúde. De exercício democrático.

Alguns pontos acordados, vários pontos por acordar. O MS rompe esse acordo e vai ao Palácio do Planalto, com o aval do Presidente, assinar oficialmente as portarias, com todas as alterações, às 12 hs do dia 18 de dezembro de 1997. Depois da cerimônia, às 15:45 hs dá-se conhecimento à CIT do teor das portarias a que ninguém tinha tido acesso! Considerase aprovado o pacote baseado em reunião anterior da $\mathrm{CIT}$, em que não tinha havido consenso no que diz respeito a pontos principais e essenciais! Uma suposta aprovação no Conselho Nacional de Saúde: ao ser questionado o Secretário de Politicas de Saúde do MS, que respondia pelo pacote do MS, sobre a não aprovação no Conselho Nacional de Saúde, afirmou publicamente que tinha sido aprovado com o parecer do Conselheiro Carlyle, na reunião do dia 3 e 4/dez/97. Nessa ocasião, não foram apresentadas as novas portarias e nem discutido seu conteúdo, principalmente as modificações na NOB 96 . São erros do 
processo que levaram de roldão os princípios da pactuação e negociação, tão essenciais ao passo seguinte, que seria a implantação.

Além do citado erro de processo, verifica-se na NOB-98 os erros de conteúdo. Ela modificou formal e explicitamente a NOB-96, tornando sem efeito uma série de itens, como, por exemplo: elenco e valor do PAB, discutidos na CIT e CNS, e revisados os valores na mesma proporção do aumento dos procedimentos do SIA; modificações no teto de PACS-PSF, em que acréscimo do PAB estava aberto a todos os municípios; no PBVE, cujo valor deveria ser definido na CIT e CNS; recebimento por todos do Piso Básico de Vigilância Sanitária; tetos superiores de $\mathrm{PAB}$ para municípios que reconhecidamente apresentam maior produção; pagamento por produção para municípios não habilitados.

Mudou o conceito original do PAB, que deixou de ser um Piso de Assistência Básica e passou a ser um Piso de Atenção Básica, tendo uma parte fixa (assistência + Vigilância Sanitária inicialmente) e uma parte variável de incentivos. Também definiu que o PAB representava um recurso exclusivamente de custeio, o que tem implicações jurídicas evidentes no seu uso para despesas de investimento. Isto afetaria, principalmente, os pequenos municípios que, se não tivessem capacidade instalada (investimento) para utilizálo com custeio, acabariam cometendo a ilegalidade de usá-lo como recurso de capital ou, simplesmente, comprando serviços de outros municípios, ou terceirizando no próprio municipio. A primeira versão foi modificada depois, por um manual de orientação do PAB. É interessante que o PAB foi introduzido em início de 1998 e só no dia 13 de novembro saiu a Portaria 3925 (70) com o Manual para a Organização da Atenção Básica (Manual do PAB). Nesse manual, por muita pressão, abriu-se a utilização dos recursos do $\mathrm{PAB}$ para quaisquer categorias de despesas constantes dos Planos de Saúde e aprovadas no orçamento, desde que utilizadas exclusivamente na atenção básica.

Introduz-se o conceito de parte variável do PAB: Vigilância Sanitária, Epidemiológica, Ambiental, Assistência Farmacêutica, PACS, PSF. O artigo $5^{\circ}$ relaciona os incentivos e afirma que serão definidos com base em critérios técnicos específicos de cada programa. $A$ CIT, neste, perderia a função de aprovar os critérios para pagamento destes e de futuros incentivos? Neste mesmo artigo o parágrafo $6^{\circ}$ fala em normas complementares. Sem definição de quem aprovaria e editaria. $\mathrm{O}$ artigo $6^{\circ}$ define que serão suspensos os repasses do PAB para o municipio que deixar de alimentar quatro grandes bancos de dados nacionais (e outros que vierem a ser criados). Em relação ao SIA e o SIH-SUS, a penalidade de suspensão será para o gestor que não alimentá-los pelo prazo de 2 meses consecutivos, após um prazo de carência de 6 meses. Poucos municipios brasileiros dispunham, em 1998, desses 6 grandes sistemas. Nem o MS e os Estados teriam estrutura técnica para implantá- 
los em todos os municípios brasileiros, no prazo estipulado. Caso isto não ocorresse, pelo texto, somente o município seria penalizado. As SES não foram citadas perante a obrigatoriedade de encaminhar os dados ao MS. Contrariando a NOB-96 e o exposto no artigo $5^{\circ}$, os procedimentos básicos de Vigilância Sanitária são incluídos na parte fixa do PAB. Portanto, nenhuma perspectiva de recursos novos para a Vigilância Sanitária, muito pelo contrário: introdução de uma nova série de procedimentos a serem financiados com os mesmos recursos - já diminuídos - do PAB.

O artigo $8^{\circ}$ define que, em 1998, os procedimentos básicos da vigilância sanitária comporão a parte fixa do PAB. Não tinha sido aprovado na CIT nem a definição nem quais os procedimentos. A relação apresentada pelo MS, no anexo para o novo $\mathrm{PAB}$, inclui quase todos os procedimentos da VS, definidos pela própria SVS, como de média complexidade. Não se definiu quem pagaria a conta. Nenhuma perspectiva de melhora do setor, a não ser "desviando" recursos de outras áreas.

Duas questões fundamentais na portaria que define o teto da assistência: o espirito e os valores estabelecidos. É deixada de lado a CF, que estabelece competências para as três esferas de Governo. A portaria diz mais ou menos que "estes são os meus recursos" e Estados e Municipios que se virem para completar o que for necessário!!!... Nessa hora, lembrou-se até mesmo de evocar a Constituição... mas só na parte que atende aos interesses do MS. O Governo Federal, em cumprimento à Constituição, não pode se esquecer de que é mandatário na mesma CF que entrem recursos do orçamento fiscal da União, além das Contribuições Sociais.

A portaria, em seu artigo $3^{\circ}$, reinterpreta a Constituição Federal, ao afirmar que cabe a Estados e Municipios complementar a parcela de recursos federais destinadas às ações e serviços de saúde. Ou seja, se a cada ano a parcela federal de recursos para a saúde diminuir e as necessidades aumentarem, a União já fez sua parte! Entretanto, o que está escrito na Constituição Federal é que "o Sistema Único de Saúde será financiado com recursos provenientes dos orçamentos da União, dos Estados, do DF e dos Municípios e das seguintes contribuições sociais..." Ou seja, fala das responsabilidades comuns no financiamento, jamais na complementaridade dos demais niveis em relação ao que aporta a União, principalmente se considerar em exclusivamente os recursos da Seguridade Social.

Em nenhum fórum foi definido o prazo de 60 dias para habilitação dos municipios e os critérios para corte, definido no art. $4^{\circ}$. A nova instrução normativa sequer tinha sido definida e o prazo já estava correndo. Na Comissão Técnica Tripartite o CONASS e CONASEMS questionaram o critério e a resposta do MS foi que ainda não havia proposta. Fixa em 10 
reais o valor fixo do PAB (incluído aí o abono de $25 \%$ ) e usa a população do IBGE de 1997 , em pleno ano de 1998. Constata-se uma perversidade nesse raciocínio, pois quanto maior a população (e já se sabia que a população de 1998 estava estimada pelo próprio IBGE como sendo maior que a de 1997). O total do fixo do PAB, na portaria acima, foi de $R \$ 1,741$.(10 reais para cada um dos brasileiros, acrescida a diferença para pagar aqueles, cujos tetos já estão acima de 10 reais/ano). Não será a produção de dezembro, nem a média de 1997 , mas sim, a média de 1996! Este era um dos grandes problemas apontados para não se aceitar na CIT trabalhar com população de 1997 e produção de 1996 . Perdem todos os Municípios que melhoraram sua produção no decorrer de 1996 e em todo o ano de 1997. De outro lado, os municípios que não se habilitassem nos 60 dias na NOB-96, teriam seus tetos congelados na média de 1996, até um teto máximo dos 10 reais/ano.

Se em 98 a Vigilância Sanitária estava na parte fixa do PAB, não é claro como seria aplicado o incentivo financeiro anunciado. Se na VS, em separado. ou no PAB. Apresenta normas e diretrizes do PACS-PSF que merecem uma análise mais detalhada. Vale apenas um comentário: a normatização do programa fecha a possibilidade de regulamentação de propostas de práticas similares do PACS-PSF (questão prevista na NOB-96), uma vez que define, inclusive, a composição das equipes PACS-PSF e detalha o que deve ser considerado, para efeito de remuneração. Além disso, não estabelece critérios de repasse, apesar de já estar revogado o critério da NOB 96. A definição de critérios de alocação dos recursos para o PACS-PSF veio só a posteriori, e sempre com valores definidos unilateralmente pelo MS.

Foi criada Comissão para elaborar, em 120 dias, nova tabela de procedimentos por especialidades, compatibilizados com CID10 e com valores referenciais. A proposta vai à Comissão de revisão e modernização. Novamente, deixa-se de lado o caráter decisório da CIT e do CNS. A descentralização do processamento de AIH teve o limite em $1^{\circ}$ de junho de 1998. Passam à responsabilidade das Secretarias Estaduais e Municipais de saúde: a) compra de equipamentos de informática b) atualização do banco de dados do SIH c) execução, guarda e recuperação de informações fiscais, contábeis e judiciais (IR. Pensão etc). Punição: quem não cumprir, pára de receber fundo a fundo e perde habilitação. sistema, não estando, ainda, em condições de uso, permanecia dúvidas sobre o prazo que o MS teria para colocá-lo á disposição dos municipios. Quem iria capacitar as secretarias municipais de saúde para a utilização do sistema. $\mathrm{O}$ art. $5^{\circ}$ dá poderes à SAS de suspender a condição de gestão de estados e municipios que não alimentarem o banco de dados do SIH. A SAS não teria esta competência, uma vez que quem habilita é a CIT. Além disso, 
essa penalidade é diferente de outra, aplicada para o mesmo caso, presente na portaria 1882 , art. $6^{\circ}$. (70) Não ficou claro qual das penalidades prevaleceria.

A portaria introduz novos grupos para o SIA (básico, especializado, alta complexidadecusto). Novos dígitos de codificação. Nova tabela com novos códigos, anexo I, a se implantar a partir de $1^{\circ}$ de maio. Até maio, valeria a tabela antiga com incorporações necessárias, anexo II. Perderam-se os estudos feitos pela Comissão mista.

O que foi aprovado na Comissão Técnica da Tripartite, cumprindo resolução da própria CIT é que não haveria tabela de transição entre janeiro e maio de 1998. O MS desconheceu ambas as decisões e publicou a tabela intermediária, com procedimentos que inflam o PAB (inclusive na vigilância sanitária), procedimento de apoio diagnóstico para AIDS, Ressonância Magnética, etc., sem que se apresente qualquer previsão de impacto financeiro. Não se definiu claramente que esfera de governo iria pagar pelos novos procedimentos incluídos na tabela.

Determina o recadastramento hospitalar, segundo formulário a ser apresentado pelo DATASUS e que não sabemos se foi o trabalhado conjuntamente pelo Ministério e representantes do CONASS e CONASEMS. Para os Serviços de Apoio Diagnóstico e Terapêutico não se tem indicativo de onde saiu o modelo. Para os serviços ambulatoriais fica determinada a criação de Comissão para apresentar proposta de instrumento. Dá-se poder aos municípios habilitados em gestão plena do sistema municipal de saúde para atualizar em cadastro de prestadores. Enquanto não fica claro para o municipio permanecer em gestão semiplena, se ele terá a mesma prerrogativa.

Encarrega a Vigilância Sanitária até, 31 de janeiro, de publicar instrumentos normativos para expedição de licença de funcionamento de estabelecimento de saúde. Havia dúvida se seria constitucional. Se não feriria a autonomia das demais instâncias para legislar nesta matéria. Não ficou claro o que são normas complementares. Incorpora a internação domiciliar e amplia a oferta de hospital-dia para outros agravos à saúde não previstos e não se define quem paga a conta de novos procedimentos, como a internação domiciliar no SIH-SUS.

Secretarias Estaduais e Municipais de Saúde, ouvido o Conselho de Saúde, estabelecerão valores financeiros para pagamento de serviços básicos. Não habilitados seguirão pactuação da bipartite. As interrogações foram várias, pois se deixaria de estabelecer os valores minimos nacionais, sem se aquilatar quais os riscos e conseqüências disto. A Lei 8080 no Art.26 diz: "Os critérios e valores para remuneração dos serviços e os parâmetros de cobertura assistencial serão estabelecidos pela direção nacional do SUS e aprovadas no Conselho Nacional de Saúde". A portaria 1286, de 93, e a NOB-96 citam a tabela nacional 
como referência mínima no item 15.2.3, letra b. As novas portarias de 98 cancelam esses municipais e estaduais fixarem valor de remuneração para procedimentos, menor que os da tabela. É um risco. Não se questiona a possibilidade de tabelas próprias, mas sim, a inexistência de uma tabela de valores mínimos nacionais.

Concluindo sobre a NOB-98, formalmente 96, pelas razões até aqui colocadas, mais uma vez, depara-se com o risco de ver o processo de implantação do SUS em dificuldades. O que poderia ser um avanço, como pretendia a NOB-96, pode ter trazido, em seu bojo, algumas graves ameaças:

a) a volta do principio totalitário do Ministério da Saúde de decidir, sozinho, não respeitando nem a instância colegiada dos gestores públicos, CIT, nem o Conselho Nacional de Saúde;

b) a idéia de que os recursos da seguridade social são exclusivamente da União e que, ao repassá-los, em menor parte, para os municipios e estados, já estará cumprindo com sua obrigação;

c) a substituição de fontes praticada em 1997 com o adendo da CPMF, pode ser agravada em 1998, como demonstra a proposta orçamentária aprovada pelo Congresso nacional;

d) a conseqüente transferência da responsabilidade a Estados e Municipios de financiarem cada vez mais sozinhos, a saúde, com intensa divulgação pela mídia de que a União já faz sua parte;

e) o PAB, a princípio desejável e consoante os princípios constitucionais, esconde em seus valores o engodo maior de se dizer que, agora sim, estão sendo financiadas as ações básicas, quando em 1996 os valores do PAB eram da ordem de 12 reais habitante/ano, o $\mathrm{PAB}$ é implantado em fevereiro de 98 , ao valor de apenas 10 reais, permanecendo assim até pelo menos o inicio de 2002.

10. O FINANCIAMENTO FEDERAL PARA A SAÚdE NO GOVERNO FHC - A PEC-169EC-29, de 13/9/2000

Muitas foram as bandeiras da seguridade social e saúde, defendidas por técnicos, administradores e trabalhadores de saúde, e cidadãos usuários: conceito de seguridade social como direito do cidadão e dever do estado; seguridade social, incluindo: previdência social, saúde e assistência social; solidariedade entre as três áreas, incluindo vantagens e 
riscos (diversidade de fontes de financiamento para todas as áreas); solidariedade no financiamento por todos os cidadãos que financiam, direta ou indiretamente, através de impostos e contribuições ou quando compram qualquer coisa, porque estão embutidos no preço os impostos e contribuições feitos em relação ao produto;concepção legal de que impostos financiam as ações do Estado, em geral, não podem ter vinculação específica e só podem ser criados ou alterados para vigência no ano seguinte;concepção legal de que contribuições financiam ações específicas do Estado e são criadas com destino determinado e podem ter vigência 90 dias após sua aprovação;conhecimento de que para financiar a seguridade a constituição de 88 criou ou majorou contribuições como: a) contribuição sobre o lucro liquido (CSLL), que não existia, e, em 1998, arrecada cerca de 8 bi de reais; b) a contribuição sobre o faturamento, que mudou de FINSOCIAL para COFINS e a aliquota, que era de $0,5 \%$ sobre o faturamento, passou para $2,0 \%$, o que hoje representa 15 bi de reais (um aumento que representa, hoje, 15 bi ou $75 \%$ dos 20 bi total de arrecadação do COFINS);c) a contribuição sobre a folha de salários, que aumentou de alíquota de $8 \%$ para $10 \%$, com a justificativa de mais recursos para a saúde; defesa da diversificação de fontes e das contribuições sobre o lucro e o faturamento para compensar a automação e incorporação de tecnologia que levam à diminuição da mão de obra e, conseqüentemente, à diminuição real da contribuição sobre a folha de salários. (111)

Várias questões, muitas delas dependentes da vontade política de governantes, levaram a que os recursos previstos, e que seriam suficientes para garantir a seguridade social (previdência social, saúde e assistência social), acabassem por serem insuficientes: sonegação estimada em, no mínimo, $1 / 1$ ou $50 \%$; perdas, por uso dos recursos da seguridade social fora da finalidade = utilização em outras áreas; desvio para o Fundo de Estabilização Fiscal (FEF), inicialmente Fundo Social de Emergência (FSE); perda, por pagamento dos inativos - Encargos Previdenciários da União (EPU) com recursos da arrecadação diária, e não com recursos de reserva capitalizada do governo; esses recursos continuam sendo retirados de cada área, como da saúde, não representando serviços de saúde; perda especifica da saúde por ter o então Ministro da Previdência Social, Antonio Britto, com autorização do Ministro da Fazenda Fernando Henrique Cardoso, especializado fonte de contribuição sobre a folha de empregados e empregadores (1993) e o conseqũente endividamento do Ministério da Saúde por pedidos constantes de empréstimos ao FAT e, hoje, estar pagando por eles com recursos próprios que deveriam ser gastos com saúde: cerca de 2 bi em 95, 500 mi em 96, 2 bi em 97 e 2 bi em 98 ; perdas, até o momento incontroláveis, por corrupção e por má utilização de recursos em toda a seguridade social; descumprimento sistemático pelo Governo Federal daquilo que estava nas Disposições 
Transitórias da Constituição Federal (CF), na Lei do Plano Plurianual (93 a 95), nas LDOs de $90,91,92,93 \ldots$ legislação que determinava a destinação para a saúde de no mínimo $30 \%$ das Contribuições Sociais da Seguridade Social. (111)

Há um consenso entre aqueles que pensam saúde, neste pais, que a saída para a crise setorial passa, necessariamente, por determinação legal de FONTES DE FINANCIAMENTO DA SAÚdE DEFINIDAS, DEFINITIVAS E SUFICIENTES. NÃO É PROBLEMA, NEM CAUSA DE SOLUÇÃo ÚNICA, MAS, INEQUIVOCADAMENTE MULTICAUSAL, E DETERMINANTE DE OUTRAS.

Essas fontes suficientes estavam inscritas na Constituição Federal de 1988, com uma clareza meridiana, nos artigos 194 e 195. Falava-se da Seguridade Social, da solidariedade entre as três áreas Previdência, Assistência Social e Saúde. Estava escrito que as três áreas, incluindo a saúde, seriam financiadas pelos recursos fiscais das três esferas de governo: União, Estados e Municípios e pelos recursos das contribuições sociais dos empregados sobre a folha de pagamento, dos patrōes sobre a folha, sobre o faturamento e sobre o lucro. Além disto, parte dos recursos dos concursos prognósticos (loto, sena, supersena etc.). CF. ART.195 (16)

\begin{abstract}
"A Seguridade Social será financiada por toda a sociedade, de forma direta e indireta, nos termos da lei, mediante recursos provenientes dos orçamentos da União, dos Estados do Distrito Federal e dos Municipios e das seguintes contribuições sociais: empregadores (folha, lucro, faturamento), trabalhadores e sobre a receita dos concursos prognósticos." "As receitas dos Estados, do Distrito Federal e dos Municípios destinados à Seguridade Social constarão dos respectivos orçamentos não integrando o orçamento da União." CF. DT ART.55.
\end{abstract}

"Até que seja aprovada a LDO, trinta por cento do mínimo do orçamento da Seguridade Social, excluido o seguro desemprego serão destinados ao setor saúde".

Houve uma tentativa, à época, de se determinar, constitucionalmente, em que percentual os recursos iriam para cada uma das três áreas, ou pelo menos, para a área da saúde, a exemplo da determinação de que se reservasse um percentual para a educação (18\% federal e $25 \%$ de estados e municipios). O embate foi grande e a decisão final da Constituição foi de que, por um gesto de maturidade politica, optar-se-ia para que o Brasil, a cada ano, determinasse na Lei de Diretrizes Orçamentárias, o quanto deveria ser destinado à saúde. Para o ano de 1989 , ficou sacramentado no ADCT o percentual de $30 \%$ dos recursos do orçamento da seguridade social, excetuando-se os recursos do Fundo de Amparo ao Trabalhador (FAT). 
Dai para frente, a cada ano, saía na LDO a mesma determinação dos $30 \%$ $(1990,91,92,93 \ldots)$ Em 94, foi retirado, argumentando-se o interesse nacional!... Além disto, a Lei do Plano Plurianual (1993-95) determinava os mesmos $30 \%$ e o mínimo de $25 \%$ dos recursos das contribuições sociais, recolhidas sobre a folha dos trabalhadores e patrões, que deveriam ser destinado à saúde.

Sem comentários: a média dos últimos anos (durante a vigência das leis e do PPA até 31 de dezembro de 1995) foi de $20 \%$ dos recursos da Seguridade Social (nos anos de 91 e 92 o percentual foi de apenas $14 \%$, menos da metade do que mandava a lei). Nem se fale a respeito da determinação legal dos $25 \%$ dos recursos da contribuição de empregados e empregadores, que foram reduzidos a $15 \%$ e, desde maio de 1993, (por decisão ilegal do então ministro Britto, já relatada anteriormente), em desrespeito a toda legislação, passaram a ser um zero absoluto.

Essa foi a trajetória enfrentada pela saúde: determinações na CF da origem dos recursos (recursos fiscais e da seguridade) e quantificações feitas, através de LDOs. As leis não foram obedecidas. Não aconteceu absolutamente nada. Qual seria a saída?

Logo após a Crise Britto, relatada anteriormente, por pressão da sociedade, de parlamentares e de técnicos da área de saúde, constituiu - se uma Comissão para Propor Medidas Objetivas e emergenciais a Serem Implementadas para a Solução dos Problemas de Assistência Médica e Hospitalar, que se reuniu no período de 17 a 29 de junho de 1993.

Essa Comissão teve como Membros oficiais: Sen. Elcio Alvares - Dep. Eduardo Jorge Antônio Ermírio de Moraes: Soc. Civil - Clóvis de Barros Carvalho: MF - Elias Antônio Jorge: MS - Sérgio Cutolo dos Santos: MPS - Luiz Augusto Paranhos Sampaio: Advocacia Geral da União.

Além desses membros oficiais, vários parlamentares de diversos partidos participaram ativamente, como também assessoraram alguns técnicos da área de saúde.

Do Relatório Final dessa Comissão consta:

\section{"DIAGNOSTIICO DE SITUAÇÃO:}

Há um déficit real atual do $M$. Saúde como do M. Previdência. Até 30 de junho: Saúde terá receita de 63,7 trilhões e despesas de 118,4 trilhões e déficit de 58,5 tri. Previdência terá receita de 287,9 trilhões e despesas de 302,6 trilhões e déficit de 23,8 tri. SAÚDE TERMINA 93 COM DÉFICIT DE 180,4 TRI. (US\$ 2,8 BI) PREVIDÉNCIA TERMINA 93 COM DÉFICIT DE 318,8 TRI (US\$ 3,4 BI) Déficit total (Saúde + Previdência) Cr\$ 498,97 trilhões ou US\$ 6,8 bilhões (base: inflação decrescente de 26 a 16\% até dez: benefícios com reajuste de $60 \%$ no bimestre e zerando no quadrimestre: pessoal com 50\% do INPC no bimestre e $80 \%$ no quadrimestre). 
MEDIDA ESSENCIAL: Tesouro transfere 46,9 tri para OSS. destes 23,1 para a Previdência e 23,1 para a saúde. Dos da Previdência ela transfere 21,5 imediatamente para a saúde visando quitar o débito. Assim a saúde teria 45,3 trilhões em 30 de junho para pagar o semestre.PAGAMENTO DOS SERVIÇOS PRESTADOS ATÉ 30 DIAS APOS PORTARIA 42/91.

MEDIDAS IMEDIATAS (quitar débitos até maio de 93) quitação imediata dos débitos do tesouro para com a seguridade (tesouro deve à Previdência e Previdência deve à saúde); além disto segundo a lei: tesouro tem que cobrir déficit de Seguridade Social; caso não existam estes recursos no Tesouro, declara - se Estado de Calamidade Pública e busquem - se recursos numa das seguintes fontes: . FAT-MINISTÉRIO DO TRABALHO (através de medida provisória) ;: RECURSOS DO PROGRAMA DE PRIVATIZAÇÃO (existem US\$ 105 milhões). RECURSOS DA REMUNERAÇÃO DAS DISPONIBILIDADES DO TN;

MEDIDAS DE CURTO PRAZO (junho a dezembro de 93) corte dos investimentos e remanejamento para a Previdéncia e Saúde;liberação dos aproximados US\$ 8 bi do finsocial/ cofins; $20 \%$ do IPMF = US $\$ 120 \mathrm{mi} /$ mês;partição e recolhimento ao FNS dos recursos oriundos da folha e recolhidos pela Previdência;transferência automática de todas as arrecadações com crédito automático ao Fundo Nacional de Saúde;aprovação da Lei que aumenta contribuição do Servidor Público à Previdência; campanha de mobilização para diminuir sonegação;criação de Comitê de Apoio à Seguridade Social (composição: parlamentares, representantes de ministérios) para acompanhamento do processo no $2^{\circ}$ semestre de 93; pagamento da rede contratada conveniada até 30 do mês seguinte; ou no máximo: $50 \%$ até o dia 30 e $50 \%$ até o dia 10 do mês seguinte; correção monetária diária em caso de atraso; gasto de pessoal pagos exclusivamente com recursos do tesouro; OBS: mesmo com IPMF, com cortes de investimentos e com pagamento de pessoal serão necessários mais recursos do tesouro.

\section{MEDIDAS DE EFEITO A MÉDIO PRAZO}

MANTER VINCULAÇÃO DA SAÚDE A SEGURIDADE SOCIAL ;EXPLICITAR BEM O CONCEITO DE SEGURIDADE: desvincular despesas que não são pertinentes: $40 \%$ do PIS/ PASEP para o BNDES: EPU: servidores dos ministérios da SS e órgãos vinculados:garantia de recursos para a saúde (duas propostas em debate) não menos de $30 \%$ do OSS e não menos de $10 \%$ dos orçamentos fiscais da união e das receitas de impostos dos estados e municípios:não menos de $18 \%$ das receitas de contribuições sociais e impostos federais:definição de recursos para investimentos setoriais substituir o FAS);resolver, de vez, a questão do Finsocial/ Cofins; reembolso dos seguros saúde;garantia dos $50 \%$ do DPVAT estendendo - se aos transportes públicos municipais e interestaduais;estender aliquota sobre prêmio de seguro não obrigatório;rever financiamento público para plano de saúde e benefícios de servidores públicos;rever filantropias que levam a renúncias fiscais;estudos para sobretaxa de cigarros e bebidas;parcelamento do débito (LUCRO E FATURAMENTO) para agilizar arrecadação;aumento da alíquota do Cofins para instituições financeiras: incluir nos objetivos da FAT recursos para a saúde;PREVIDÊNCIA SOCIAL: rever benefícios como aposentadorias especiais; por tempo de serviço e diferenciado entre homem e mulher, combate contínuo e permanente às fraudes; revisão dos regimes de previdência estaduais e municipais: tanto quanto a parcelamento como unificação; regime de seguro social básico para todos até $10 \mathrm{SM}$ e facultativo quanto previdência complementar;SAÚDE: conselhos de saúde exercendo controle social efetivo;aceleração do cronograma de descentralização com co-responsabilidade dos três niveis; acompanhamento de situação (por exemplo 3 estados e 50 municipios); planos diretores de saúde estaduais com distritalização e regionalização (1994); estabelecimento do Sistema Nacional de Auditoria;implantação e melhoria dos 
sistemas informatizados SIH/SIA;substituição do atual sistema de pagamento por $\mathrm{AlH} e$ UCA; rebalanceamento entre ações preventivas e curativas; fim do abatimento de despesas médico - hospitalares no IR; criação da Câmara Setorial para politica de insumos: governo, prestadores, produtores, trabalhadores de saúde e usuários; estabelecimento de critérios para incorporação tecnológica de equipamentos controle das SES, supervisão do MS;ASSISTENCIA SOCIAL: caracterização adequada das ações de assistência social; descentralização para municipio evitando execução federal; GERAL: MAIOR AUSTERIDADE NOS TRES MINISTERIOS: GESTÃO FINANCEIRA E ORÇAMENTARIA; DESENCADEAR DISCUSSÃO SOBRE CONVENIENNCIA E OPORTUNIDADE DE CRIAÇÃO DO MINISTÉRIO DA SEGURIDADE SOCIAL INTEGRANDO AS TRES AREAS. “ (134)

Diante do acima exposto, pode-se aquilatar o tamanho do problema do financiamento para a saúde. A saída mais lógica era colocar o quantitativo dos recursos, ainda que percentualmente, na Constituição Federal. Desobedecer leis tem sido fácil. Uma determinação expressa na Constituição parece ser mais dificil. Atendendo aos reclamos da população, de técnicos e administradores públicos algumas propostas foram feitas no sentido de garantir recursos definidos, definitivos e suficientes para a área de saúde, as quais são aqui apresentadas.

Havia várias Propostas de Emendas Constitucionais em discussão, há anos, no Congresso Nacional. Será apresentada uma análise sobre cada uma delas.

Muitas existiram informalmente e nem chegaram a conseguir assinaturas suficientes para encaminhamento. Destaca-se uma delas, encabeçada à época, pelo Dep. Chafic Farah, que era proposta de emenda à constituição de fev-1993. (12)

"Altera o inciso IV do art. 167 e o art. 198 da Constituição Federal. As Mesas da Câmara dos Deputados e do Senado Federal, nos termos do art. 60 da constituição Federal, promulgam a seguinte Emenda ao texto constitucional:

Art. $1^{\circ}$ - $O$ art. 167 da Constituição de República Federativa do Brasil passa a vigorar com a seguinte redação: Art. 167 - ... IV - a vinculação da receita de impostos, a órgão, fundo ou despesa, ressalvadas a repartição do produto da arrecadação dos impostos a que se referem os arts. 158 e 159, a destinação de recursos para manutenção $e$ desenvolvimento do ensino, como determinado pelo art. 212, a destinação de recursos para o sistema único de saúde, conforme o disposto no $1^{\circ}$ do art. 198, e a prestação de garantias às operações de crédito por antecipação de receitas, previstas no art. 165 , (parágrafo) 8;",

Art. $2^{\circ}$ - O art. 198 da Constituição da República Federativa do Brasil passa a vigorar com a seguinte redação: “Art. 198 - .... $1^{\circ}$ - O Sistema Único de Saúde será financiado, nos termos do art. 195, com recursos do orçamento da Seguridade Social, da União, dos Estados, do Distrito Federal e dos Municípios, além de outras fontes. $2^{\circ}$ - A União aplicará no sistema único de saúde, anualmente, nunca menos de dezoito por cento da receita de impostos e contribuições. Sala de Sessões, fevereiro de 1993. Dep. Chafic Farhat."

As PECs, efetivamente encaminhadas, foram: 
A) PEC-169 - 1993, Proposta de Emenda Constitucional dos Deputados Eduardo Jorge e Waldir Pires, com subscrição de vários outros deputados, encaminhada em 7 de julho de 1993. Modifica inicialmente o art. 167, abre a exceção de se vincular receita para saúde, igualmente como a educação. Art. 198 da CF passa a ter a seguinte redação... "A união aplicará anualmente, na implementação do Sistema Único de Saúde, nunca menos de trinta por cento das receitas de contribuições sociais, que compõem o orçamento da seguridade social, e dez por cento da receita resultante dos impostos. Os Estados, o DF e os Municípios aplicarão anualmente, na implementação do Sistema Único de Saúde, nunca menos de $10 \%$ da receitas resultante dos impostos." (128)

B) O Relator da PEC 169, Deputado Darciso Perondi / PMDB-RS, modificou a proposta para: $30 \%$ do Orçamento da Seguridade Social e 10\% dos impostos de Estados e Municípios; substitutivo à PEC-198 - comissão especial - relator Deputado Darciso Perondi. Em resumo, confirma a proposta inicial do Eduardo Jorge, mas faz uma restrição: coloca para a União apenas a obrigatoriedade dos trinta por cento do orçamento da seguridade social e retira os $10 \%$ da receita, resultante de impostos da União. Foi constituída na Câmara dos Deputados uma Comissão Especial, destinada a proferir parecer à PEC-169/93. O relator foi o Deputado Darciso Perondi que, expressando a opinião da maioria dos deputados participantes da Comissão, emitiu, em 1995, o seu relatório, apresentando um substitutivo.

C) O Deputado José Pinotti / PSB-SP defendia, no mínimo, $5 \%$ do Produto Interno Bruto (PIB) do ano anterior.

D) A PEC 82-95, do Deputado Carlos Mosconi/PSDB-MG, considerando a especialização feita pelo Ministro Britto, defende toda a arrecadação da COFINS e da CSLL para a saúde, não entrando no mérito dos impostos estaduais e municipais.

E)O Relator da PEC-82-95, Deputado Ursicino Queiroz/ PFL-BA, modificou a proposta de Mosconi para $100 \%$ da CPMF, $64 \%$ da CSLL e COFINS e $12 \%$, no mínimo, dos impostos dos Estados e 15\%, no mínimo, dos Municípios; $15 \%$ dos recursos federais, diretamente por quociente populacional para os Municípios, transitoriedade, em cinco anos (UNIÃO de $48 \%$ a $64 \%$ e Estado e Municípios de onde estiverem, crescer a $20 \%$ ao ano até o percentual proposto); definições dos quantitativos nas disposições transitórias até definição em Lei Complementar; (Esta proposta foi aprovada na Comissão de Seguridade e Família, em $1^{\circ} \mathrm{de}$ julho de 1998 - mesmo depois de chegar à Comissão a proposta aprovada no Conselho Nacional de Saúde).

F) O Ministro da Saúde, José Serra, propôs $60 \%$ a $70 \%$ do COFINS, CSLL, CPMF e $8 \%$ a $12 \%$ dos impostos dos Estados e $11 \%$ a $15 \%$ dos Municipios, com crescimento em 5 anos 
até o patamar mínimo. A Proposta de Serra evoluiu e passou por várias formulações em discussão com as lideranças partidárias e que, praticamente, foi por ele explicitada no II Encontro Nacional de Conselheiros de Saúde: $30 \%$ das Contribuições Sociais, retirando-se delas a Contribuição para o PIS-PASEP; manter a CPMF, só que agora financiando a Seguridade Social, como um todo, e não apenas a saúde; exigir $12,5 \%$ do orçamento próprio dos Estados e 15\% dos Municípios; fazer um escalonamento desses compromissos, até se chegar ao teto; considerar toda a esta proposta como transitória, por uma série de anos, como 5,7 ou 10 , quando passaria por avaliação de resultados.

G) A Comissão de Acompanhamento Orçamentário do Conselho Nacional de Saúde apresentou ao Conselho a proposta de $100 \%$ da CPMF e, em cinco anos, de $60 \%$ a $80 \%$ da COFINS e CSSL, de $6 \%$ a $12 \%$ para os Estados e de $9 \%$ a $15 \%$ para os Municípios.

H) O Conselho Nacional de Saúde, depois de analisada a sugestão de sua Comissão de Acompanhamento Orçamentário, pela Resolução №281, de $1^{\circ}$ de julho de 1998 , propôs o mínimo de $30 \%$ do Orçamento da Seguridade Social e de $7 \%$ a $13 \%$ para Estados e Municipios, com garantias do Congresso Nacional e Governo Federal de que estes recursos sejam utilizados, exclusivamente, em saúde (não se pode se pagar dividas, nem usar para pagamento de inativos, que deve ser feito com recursos de impostos); não incide FEF nem outros contingenciamentos e a delegação para a Comissão de Acompanhamento Orçamentário de negociar, a proposta na Comissão de Seguridade e Familia do Congresso.

Pela importância histórica, a Resolução $\mathrm{n}^{\circ} 281$, de $1^{\circ}$ de julho de 1998 , é citada na integra:

“O Plenário do Conselho Nacional de Saúde, em sua $78^{\circ}$ Reunião Ordinária do dia $1^{\circ}$ de julho de 1998, no uso de suas competências regimentais e atribuições conferidas pela Lei 8080 de 19 de setembro de 1990 e pela Lei 8142 de 28 de dezembro de 1990 considerando:que no horizonte da discussão das PECs que pretendem garantir recursos para a saúde, dentro do Orçamento da Seguridade Social, existem fatos novos; que a idéia de solidariedade total e completa entre as fontes diversas da Seguridade para se financiar Saúde, Previdência e Assistência, já foi quebrada de fato desde 1993 quando se especializou a fonte de receita sobre a folha de empregados $e$ empregadores, exclusivamente para a Previdência; que este fato, anteriormente feito na ilegalidade, hoje está legitimado na Emenda Constitucional sobre a Previdência. No artigo 167 fica claro que "é vedada a utilização de recursos provenientes das contribuições sociais de que trata o art.195 i, a e ii (recursos da contribuição de empregados e empregadores sobre a folha) para a realização de despesas distintas do pagamento de beneficios do regime geral de previdência social de que trata o art.201"; que propostas alternativas já estão em discussão juntando as várias PECs sobre o assunto e acrescidas do parecer do relator; as reflexões da Comissão de Acompanhamento Orçamentário desse CNS, sobre a questão, consubstanciadas em documentos apresentados na $77^{\circ}$ e na $78^{\circ}$; a necessidade de encaminhamento ao Congresso Nacional e particularmente à Comissão Especial que discute parecer sobre a PEC-82 da posição atualizada do CNS : 


\section{Propor a incorporação dos seguintes parâmetros}

1.1 A União contribuirá anualmente para a manutenção e desenvolvimento do SUS com no mínimo $30 \%$ dos valores do Orçamento da Seguridade Social;

1.2 Os Estados e o Distrito Federal contribuirão com o produto da arrecadação de impostos a que se refere o art.155 e dos recursos de que tratam os arts. 157 e 159, inciso I, a, e II, deduzidas as parcelas que forem transferidas aos respectivos municípios, em valores não inferiores a 7\% no ano de 1999 e com aumentos escalonados de 1,5\% ao ano, até atingir em cinco anos, o patamar mínimo de $13 \%$.

1.3 Os Municípios e o Distrito Federal contribuirão com o produto de arrecadação dos impostos a que se refere o art.156 e dos recursos de que tratam os art. 158 e 159, inciso $I, b$ e $\S 3^{\circ}$, em valores não inferiores a $7 \%$ no ano de 1999 e com aumentos escalonados de $1,5 \%$ ao ano, até atingir em cinco anos, o patamar mínimo de $13 \%$.

1.4 Fica vedada a utilização destes recursos da saúde para pagamento dos Encargos Previdenciários da União de Estados e Municípios no âmbito do SUS.

1.5 Estados, Distrito Federal e Municipios que hoje estejam com valores percentuais maiores que os patamares mínimos indicados nos itens 1.2 e 1.3, não poderão reduzilos a menos que estes patamares; aqueles que estiverem participando com valores percentuais entre o mínimo previsto para 1999 e o mínimo para 2003, deverão considerá-los como valores iniciais e aumentá-los escalonadamente até os patamares mínimos respectivos.

1.6 Na hipótese de substituição das atuais Contribuições Sociais, isolada ou conjuntamente, a legislação que as substituir ou extinguir assegurará a destinação para a saúde de recursos totais da União em no mínimo $25 \%$ de sua receita corrente de impostos, taxas e contribuições, excluidas as transferências constitucionais de impostos para Estados e Municipios.

1.7 Os recursos hoje arrecadados no Orçamento da Seguridade Social, como receita de serviços hospitalares e de taxas como as de Vigilância Sanitária, deverão continuar mantidos para a Saúde.

1.8 Dos recursos da Seguridade Social, hoje classificados como outras receitas correntes, correspondentes a pagamento de principal e juros de mora da CSLL, COFINS ou porventura da CPMF, deverão ser destinados à Saúde nos mesmos percentuais estabelecidos para suas arrecadações correntes.

1.9 Outras receitas correntes do Orçamento da Seguridade Social que hoje estão destinadas especificamente à saúde, deverão ser mantidas como tal.

1.10 As receitas provenientes da remuneração das disponibilidades financeiras de recursos próprios da saúde, existentes no fundo de saúde ou no órgão arrecadador, se incorporarão, igualmente como receita da saúde.

1.11 O repasse dos recursos, arrecadados pela União e destinados às ações e serviços de saúde de Estados, Distrito Federal e Municípios, serão transferidos Fundo a Fundo, segundo critérios da Lei Complementar, de forma equivalente aos repasses diretos e automáticos do FPM e FPE, a serem utilizados em despesas de custeio e de investimento da área de saúde, previstas nos planos de saúde, aprovados nos respectivos Conselhos de Saúde, sendo objeto de prestação de contas aos Conselhos, ao Legislativo e aos respectivos Tribunais de Contas de Estados, Distrito Federal e Municipios nos mesmos termos dos demais recursos próprios estaduais e municipais.

1.12. É vedada a retenção ou qualquer restrição à entrega e ao emprego dos recursos da União para o Sistema Único de Saúde. 
1.13. Garantia de que os recursos vinculados não serăo utilizados para pagamento de dividas financeiras decorrentes de expedientes utilizados para suprir perdas orçamentárias, a exemplo dos empréstimos junto ao FAT.

1.14. Garantia explícita não se repitam descumprimentos da legislação, a exemplo do que ocorreu com a lei do Plano Plurianual de 1992/1995, LDOs de 1990,91,92,93 e 1998, Lei Orçamentária de 1993, etc.

2. Delegar à Comissão do CNS para o Acompanhamento Orçamentário o encaminhamento e as negociações da proposta acima.

JOSÉ SERRA - Presidente do Conselho Nacional de Saúde - Homologo a Resolução CNS $n^{\circ} 281$ de $1^{\circ}$ de julho de 1998, nos termos do Decreto de Delegação de Competência de 12 de novembro de 1991. JOSÉ SERRA - Ministro de Estado da Saúde "

\section{DISCUSSÃO}

Economistas e planejadores do Governo jamais apoiaram a idéia de determinação de um percentual fixo para a área da saúde. Sempre foram avessos a esta idéia, sob o argumento de que engessaria o orçamento. Se todas as áreas e setores fixassem percentuais orçamentários, não haveria recursos suficientes!

Do texto constitucional, podem-se tirar as seguintes conclusões: A) A seguridade será financiada diretamente com as contribuições sociais a ela destinadas (art.195) e indiretamente, com recursos provenientes do orçamento, que são gerais e não específicos da Seguridade. B) Faz a separação entre recursos dos orçamentos da União, Estados e Municípios e os recursos da seguridade. Denomina recursos do orçamento, sob o entendimento de que ele seja resultante dos impostos, pois, logo a seguir, fala das Contribuições Sociais: e das seguintes contribuições sociais... Contrapõe recurso de orçamento com recursos de contribuições sociais, quando, na verdade, o orçamento da União se divide em três: orçamento fiscal, orçamento da seguridade e orçamento de investimento das estatais. Nesse texto, toma como se iguais fossem, os termos orçamento (puro e simples) e orçamento fiscal. C) As receitas dos Estados, dos Municípios, destinados à seguridade social, constarão dos respectivos orçamentos não integrando o orçamento da União. Isto reafirma que os recursos do orçamento da União devam constar dentro da Seguridade Social. D) Fica claro que os recursos do orçamento próprio da União, Estados e Municipios são independentes do das contribuições sociais e se juntam num mesmo caixa para fazer um bolo só: recursos "próprios" - "orçamentários" - "do orçamento fiscal" - "da receita resultante de impostos". E) A proposta de Eduardo Jorge manda tirar do montante de recursos da seguridade social o quantitativo referente ao seguro desemprego, que são os recursos do FAT. Já Darciso Perondi, o Deputado relator, não deduz esses recursos antes da partição, ficando logicamente para a saúde, com pelo menos $30 \%$ dos recursos do FAT. 
F) Existe imprecisão quando a CF, no art.195, fala em "recursos provenientes dos orçamentos da União, dos Estados e Municípios". Entender aí todo o orçamento? Entender apenas o orçamento fiscal?. G) Eduardo Jorge fala em "receita resultante de impostos". Existe uma dúvida, sempre levantada: incluem-se ai as receitas de transferências obrigatórias? As transferências com destinação especifica: a da educação, e da merenda escolar, a própria do SUS? Trata-se aqui de entender como a receita livre, da qual se retira a aliquota da educação, e referente a pessoal? H) Existem receitas de contribuições sociais, dentro da seguridade social, que estão sob outras rubricas, como outras receitas correntes, em que se encontram todos os pagamentos atrasados de contribuição de empregados, empregadores, financiamento do social , sobre o lucro líquido etc. Isto precisaria ser incluído na nova redação da PEC169. Igualmente, as receitas de serviços da seguridade, em que se encontram receitas específicas da saúde.

As duas definições essenciais têm que ser aprimoradas: de qual montante se vai retirar o recurso para a saúde e sob que quantidade. Quanto ao montante a proposta técnica, sempre pretendida, é a seguinte: deve-se tirar da receita do orçamento fiscal, fazendo parte dela, as transferências constitucionais obrigatórias. Em relação às transferências intergovernamentais, incluindo-se as vindas de outras esferas e excluindo-se as enviadas para outras esferas. Igualmente, excluem-se as transferências especificas para determinadas áreas ou projetos: empréstimos e receitas a fundo perdido, vinculados a determinada área, recursos do fundo educacional, da merenda escolar e outros. Não se excluem outras despesas, como pessoal etc.. O que resta fazer é formatar este entendimento para que não pairem dúvidas jurídicas das Câmaras, Assembléia e Executivos. Quais são os termos exatos a serem colocados para que isso seja entendido?

De outro lado, tem-se que definir a questão do percentual desse montante, de modo factivel. As opiniões são que o percentual deverá estar entre 10 e 15\%. Como definir isto: de uma hora para outra? Escalonado para se chegar a cada ano a valores maiores que os anteriores? Defendia-se que se formulasse algo, da seguinte maneira: para os próximos anos, deve-se programar para que o percentual dos orçamentos da União, Estados e Municípios chegue a um total de $5 \%$ da receita, acima definida, sendo que a cada ano, a partir já de 1998, acrescente-se um mínimo de $30 \%$ sobre o montante atual e assim, crescentemente, até o limite total. Por exemplo: $\mathrm{O}$ municipio $\mathrm{X}$ que esteja investindo $5 \%+$ ( $30 \%$ de $5 \%$ ) o que resultaria em $6,5 \%$; no segundo ano, $6,5+(30 \%$ de $6,5 \%)=8.45 \%$; no terceiro, $8.45 \%+(30 \%$ de $8.45 \%)=10,98 \%$; no quarto ano, $10.98 \%+(30 \%$ de $10,98 \%)=$ $14,28 \%$ e, no quinto ano, $15 \%$ ". É imprescindivel que se comece de um patamar minimo, como, por exemplo, 5,6 ou $7 \%$ e, depois, o escalonamento. Talvez esse cálculo fosse mais 
viável, podendo-se fazer simulações, chegando na fixação de $10 \%, 12 \%, 15 \%$, com aumentos de $30,35,40,45,50 \%$ a cada ano, até se atingir o limite final estabelecido. Finalmente, a questão do percentual de recursos do orçamento da União que deva ir para a saúde. Se se considerar legalisticamente, seria um percentual dos três orçamentos (fiscal, da seguridade e de investimento das estatais), o que carece de qualquer lógica . O segundo ponto é que, do jeito que está, também, no artigo 195, os recursos o orçamento da UNIÃO devem ser juntados à seguridade social e, portanto, serem divididos com as três áreas: saúde, previdência e assistência. Se se definir $10 \%$ os recursos para a Seguridade, a Saúde ficará com apenas $30 \%$ desses $10 \%$, se for preservado este percentual da seguridade para a saúde. Isto representará apenas $3 \%$ do orçamento (fiscal da União para a saúde. Daí, a necessidade de se definir. Para completar a indefinição, pergunta-se: desses recursos, vai sair o pagamento dos inativos da saúde, ou sairão dos recursos da previdência? Hoje, das transferências à saúde saem recursos para pagar os inativos. Engrossa o percentual de gastos "per capita" com saúde. Nenhuma empresa coloca, em seus custos, os inativos e nem os incluem para dizer qualquer "per capita" em relação ao seu negócio. Entretanto o governo federal assim o contabiliza "falsamente aumentando o seu per capita com saúde!" Para confirmar o engano: os recursos de empréstimos são contados duas vezes: uma, no momento em que o empréstimo entra como receita, e outra, quando ele sai como pagamento do principal e do serviço de divida!!! ...)

A discussão de saídas para a saúde ficou alguns anos parada e só foi retomada, oficialmente, por volta de 1998, como relatado acima, em que o Dep.Ursicino Queirós PFLBA analisa a PEC-82, do Deputado Carlos Mosconi, PSDB-MG, e propõe modificações.

O objetivo segundo o relator, foi compatibilizar a PEC do Dep.Mosconi, do Dep. Eduardo Jorge e de outros, assim como opiniões recebidas em audiências públicas. Análise de artigos, para melhor compreendê-los: a) muda o artigo 34 , da CF, inciso VII, letra $E=$ autoriza intervenção da união sobre os estados que não aplicarem receita de impostos estaduais e transferências na manutenção do ensino e nas ações e serviços públicos de saúde. b) Muda o artigo 35, da CF, inciso III = autoriza Estado a intervir nos Municípios que não tiverem aplicado o minimo exigido da receita municipal na manutenção e desenvolvimento do ensino e nas ações e serviços públicos de saúde c) Muda o artigo 160, da $C F$, parágrafo único $=$ condiciona $\circ$ repasse dos recursos da União a Estados $\mathrm{e}$ Municipios (seção da repartição das receitas tributárias) ao pagamento de seus créditos e ao cumprimento das alterações que serão feitas no artigo 198, obrigando Estados e Municípios a colocarem recursos próprios para a saúde. A propósito, existe uma preocupação diante de uma história repetida. O que acontecerá quando uma administração municipal não colocar 
seus recursos próprios para a saúde: os recursos federais não serão repassados ou não serão destinados? A população será punida duplamente? Com a primeira privação e, depois, com a segunda? Seria o caso de mudar e passar a sofrer intervenção da esfera superior? Esta questão acontece há muitos anos e vários pareceres jurídicos, desde a época do INAMPS, não permitiram que pagamento de dívidas com o governo federal (previdência e inadimplências) impedisse os repasses federais. d) Muda 0 artigo 167 , inciso IV = acrescenta a autorização para vinculação de receita e desativação de recursos para as ações e serviços públicos de saúde. Medida necessária ao objetivo maior de vinculação de recursos para a saúde. e) muda artigo 198; o parágrafo único vira $\S 1$ e é acrescido o $2^{\circ}=$ a União, Estados, DF e Municipios aplicarão anualmente, em ações e serviços públicos de saúde recursos minimos equivalentes à aplicação de percentuais calculados sobre: União (CONFINS e CSSLL (exceto PIS-PASEP) ; Estados (Impostos (CF 155), I.Renda recolhido (CF 157) e transferências obrigatórias (CF 159) - deduzidas transferências aos municipios); Municipios (Impostos (CF156) e transferências (CF 158 e 159); Lei complementar estabelecerá os percentuais de que trata o parágrafo anterior, que serão reavaliados pelos menos a cada cinco anos. Este é o ponto mais frágil. Vai ser remetido à lei complementar para fixação dos percentuais da União, Estados e Municipios. Volta-se ao modelo que não deu certo na constituição de 1988. Lá, também, a fixação de percentual ficou no ADTC, com a recomendação de que a lei fixasse os percentuais a cada ano: assim aconteceu na LDO, de 90,91,92,93, e no PPA que fixou este percentual, de 1993 até 1995 (31 dez). A lei do PPA, era clara: no mínimo $30 \%$ dos recursos das contribuições sociais (exceto FAT) e, no mínimo, $25 \%$ da Contribuição de Empregados e Empregadores sobre a Folha. Isto foi descumprido, inclusive, pelo ex-ministro Britto que parou de repassar esses recursos, desde maio de 93, em plena vigência da lei e não aconteceu absolutamente nada! A novidade que se pretende com uma emenda constitucional, na área de saúde, é dizer constitucionalmente quanto deverá ser destinado à saúde. f) muda o artigo 74, das disposições transitórias, que trata da CPMF: o produto será dedicado integralmente à saúde, não se aplicando art. 72 , inciso IV; $40 \%$ desses recursos serão rateados, segundo critério populacional, para aplicação no SUS; a vigência será definida em lei. Aqui está implicita a manutenção da CPMF. Não obstante a relutância de setores politicos e de militâncias em se aceitar a manutenção da CPMF, não há a minima chance de se ter recursos suficientes para a área de seguridade sem a CPMF, já que não aconteceu, nesse tempo de vigência a discussão e aprovação da reforma fiscal. Novamente, a questão aqui colocada, da permanência ou transitoriedade da CPMF que passa a ser decidida em lei comum. Estratégia de tramitação no Congresso, pois, em momento algum, se fala nela explicitamente? A novidade de reservar quarenta por cento per capita, a ser destinado diretamente aos Municipios atende ao principio da lei 8080 e 8142 . 
que falam de $50 \%$ repassados por quociente populacional. Precisa ser discutido se esses recursos vão ser ligados, ou não, obrigatoriamente, a uma sub-utilização dentro da saúde. Melhor seria usar o termo da $\mathbf{8 0 8 0}$ "quociente populacional" e acrescentar a palavra único e não critério populacional, que permitiria outras interpretações, até mesmo, a de se estabelecerem critérios diferentes para Estado ou grupo de Estados. O PAB, iniciado em janeiro de 1998 , representou cerca de $R \$ 2$ bi, e os $40 \%$ da CPMF cerca de $R \$ 3,2$. Esse recurso daí para a frente, seria considerado um recurso municipal - receita própria constitucional - e, portanto, de livre uso (deveria ser colocado de uso único em saúde?), com prestação de contas direta a seu próprio Tribunal de Contas, segundo as regras atuais. f) acréscimo do artigo 75 nas disposições transitórias da $\mathrm{CF}=$ até 0 advento da lei que estabelecerá os percentuais dos recursos para a saúde, o mínimo a ser aplicado será: $64 \%$ do CONFINS e CSLL (exceto FAT) e antes de ser deduzido o FEF; Estados, 12\% do próprio e transferências constitucionais entradas e saídas; Municípios 15\%. Da União: 1999, 48\%, $2000,52 \%, 2001,56 \%$; 2002, 60\%, 2003, 64\%; dos Municípios: sair de onde estão até chegar aos $15 \%$, aumentando, a cada ano, um quinto da diferença. Ressalvou-se que no caso de extinção dessas receitas, os valores equivalentes deverão ser mantidos. Complementa-se com o que foi dito acima, a respeito de regulamentação, por lei, versus explicitação já na Constituição. Os estudos numéricos dessas hipóteses vão mostrar como fica o financiamento dos próximos anos. Deve haver realmente uma gradualidade. Dúvidas se, na área federal, a gradualidade tem que ser tanta assim. Estados: tomando de uma média otimista, hoje, de que Estados estejam investindo $5 \%$ em saúde e, segundo a regra proposta de reduzir a diferença à razão de, pelo menos, $1 / 5$ por ano, teriam $=99=6,4 \%$; $2000=7,8 \% ; 2001=9,2 \% ; 2002=10,6 \% ; 2003=12 \%$. Municipios: da mesma maneira partindo de $7 \%$, teriam: $99=8,6 \% ; 2000=10,2 \% ; 2001=11,8 \% ; 2002=13,4 \% ; 2003=15 \%$.

Algumas questões não abordadas e fundamentais: a) Receitas não previstas ou definidas e que fazem parte do orçamento da seguridade social, como ficarão? Por exemplo: contribuição para o fundo de saúde; receita de serviços de saúde hospitalar; taxas vigilância; receita denominada como "outras receitas correntes" e que correspondem ao principal, juros e taxas de contribuições não recolhidas (CONFINS, CSSLL, CSF etc). b) no entender está faltando uma definição que deverá entrar em algum lugar da CF, para resolver o impasse em relação à utilização dos recursos do SUS pelos Estados e Municípios e de como deverá ser a prestação de contas. A indefinição e todos os problemas com CAUDI, CISET, TCU, PGR e outros. Não há outra saída, senão ser introduzido algum artigo, parágrafo ou inciso em que conste algo com o seguinte espírito: considerando que as receitas da seguridade social, ainda que arrecadadas pela União, pertencem às três esferas de governo que têm 
competências especificas, a serem cumpridas na área de saúde (CF art.30 inciso VII), e que a descentralização não se faz de competência própria da União, mas de competências de outras esferas de governo, até então desenvolvidas pela União, fica decidido que o repasse desses recursos para a área de saúde seguirão os critérios legais de lei complementar vigente, sendo transferidos, fundo a fundo, como transferências constitucionais, ao modo do FPE e FPM e que só poderão ser utilizadas na área de saúde, em despesas de custeio ou investimento previstas nos respectivos planos de saúde, aprovados nos respectivos Conselhos de Saúde e serão objeto de prestação de contas ao respectivo Tribunal de Contas dos Estados ou Municípios, nos mesmos moldes que todos os demais recursos estaduais ou municipais. A questão levantada acima que é sobre a receita da CPMF, que viria direta para o município, portanto, automaticamente, partição constitucional de livre uso e prestação de contas ao respectivo TC. c) como vai ficar a questão de pagamento das dívidas que hoje oneram a saúde, saindo de seu orçamento próprio? Continuaria assim? Este dinheiro da saúde pagará dívidas? d) como vai ficar o pagamento dos inativos da saúde, que continuam saindo dos recursos próprios do orçamento? Hoje, significam anualmente $R \$ 1,7$ bi e, nos próximo anos, vai aumentando com novas aposentadorias. Será que o aumento até o ano 2003 vai ser suficiente para pagar os acréscimos de inativos que devem chegar aos 5 bi quando de seu teto máximo? Inativo pago com dinheiro da saúde significa menos gente trabalhando e custo igual, ou maior, pelo crescimento vegetativo da folha de pagamento. Esse é um grande problema. Esse dinheiro da saúde pagará inativos (EPU = Encargos Previdenciários da União).

A discussão continuou nos anos de 1998, 1999 e 2000. Destacam- se aqui duas posições, pela sua representatividade. Os atores que as emitiram são de grande importância no cenário nacional da saúde: o CONASS e o CONASEMS.

"POSIÇÃO DO CONSELHO NACIONAL DE SECRETÁRIOS MUNICIPAIS DE SAÚDE - CONASEMS SOBRE A "EMENDA AGLUTINATIVA SUBSTITUTIVA À PEC 82-AV95" - PROPOSTA DE 20/10/99 DADA EM BRASILIA EM 26 DE OUTUBRO DE 1999.

As propostas originais da PEC-169/93 e 82-AV95 vinculavam ao SUS, percentuais de receitas federais (COFINS, Contribuição sobre Lucro Liquido de Empresas e CPMF) e também receitas líquidas de Estados, Distrito Federal e Municípios.

Após a grande mobilização feita junto à Câmara dos Deputados, em setembro passado, a Comissão de Seguridade Social e Familia, apresentou em 30/09/99, uma proposta substitutiva que definia, para os recursos federais, um valor per capita $e$ progressivo (R\$180,00 a $R \$ 200,00$, entre 2.000 e 2.004) e para os estados uma destinação de $7 \%$ a $12 \%$ de suas receitas líquidas e aos municipios de $7 \%$ a $15 \%$. Até essa fase do processo de negociação houve apoio do CONASEMS.

Após negociações da Comissão de Parlamentares com a área econômica do Governo Federal, foi apresentada uma nova proposta com as seguintes caracteristicas: manutenção no corpo da PEC, da vinculação das receitas liquidas para 
Estados, Distrito Federal e Municípios; transferência da definição dos recursos federais para o "Ato das Disposições Transitórias"; definir como recursos da União para o ano de 2.000, "o montante efetivamente gasto em ações e serviços de saúde no exercício financeiro de 1999 acrescido de cinco por cento"; para os anos de 2.001 a 2.004: "o valor apurado no ano anterior, corrigido pelo crescimento populacional do país, mais a variação do produto interno bruto - PIB".

Nesta versão atual de 20/10/99 desfigura-se por completo qualquer propósito das propostas originais ou seja, a luta histórica do setor saúde pela vinculação dos orçamentos fiscais Federal, Estadual e Municipal e do orçamento da Seguridade Social. Defini-se com todas as letras e detalhes o montante de recursos dos Estados e dos Municípios e em relação a União apresenta-se uma proposta nunca imaginada de dificil entendimento e controle, perdendo-se portanto o princípio de vinculação por parte da União e descaracterizando a versão inicial da PEC da saúde.

CONCLUINDO:

Considerando os motivos acima expostos e outros de menor repercussões para o sistema de saúde do país, O CONSELHO NACIONAL DE SECRETARIOS MUNICIPAIS DE SAÚDE - CONASEMS, posiciona-se contrário a VOTAÇÃO DA EMENDA AGLUTINATIVA SUBSTITUTIVA ENTRE AS PECS. (PROPOSTA DE 20/10/99) Neste sentido, o CONASEMS reivindica que sejam retomadas imediatamente as discussões com base nas propostas originais das PECS. Nos colocamos também a disposição para dar contribuições as negociações com vista à aprovação de uma proposta que assegure um financiamento estável e definitivo para o Sistema Único de Saúde - SUS. Gilberto Tanos Natalini Presidente do CONASEMS." (99)

O CONASS - Conselho Nacional de Secretários Estaduais de Saúde, através de sua Secretaria Técnica, fez as seguintes considerações para serem discutidas e aprimoradas na $9^{2}$ assembléia para subsidiar um documento do CONASS, a ser encaminhado à CSSF da Câmara dos Deputados:

“Com a proposta de substituição de vinculação de receitas (COFINS, CSLL e CPMF) por um valor per capita (para os recursos federais) não estariamos abrindo mão do conceito de SEGURIDADE SOCIAL criado na Constituição Federal ? A definição de um valor per capita para a saúde pode ser considerada vinculação de recursos ? É possivel definir valor per capita na Constituição Federal? Entendemos ser melhor uma proposta que mantenha a vinculação de fontes para os recursos federais (COFINS, CSLL e CPMF ou seus sucedâneos) e defina também um valor per capita como piso dos valores a serem aportados pelo Governo Federal.

A proposta deverá deixar claro que sobre os valores de receitas vinculados à saúde e sobre os valores per capita definidos, não incidirão os descontos do FEF. Como garantir correção monetária dos valores per capita anuais? A proposta de acordo não menciona os critérios de atualização populacional a serem adotados. Em 1999 o gasto com saúde incluindo pessoal do GDF e Hospitais Universitários deverá fechar entre R\$ 20,5 bilhões e $R \$ 21,0$ bilhões. A proposta de acordo do substitutivo propõe um per capita que varia entre $R \$ 180,00$ (ano 2.000) e $R \$ 200,00$ (em 2.004). Isto representaria $R \$ 29,5$ bilhões em 2.000 e $R \$ 32,7$ bilhões em 2.004. Entretanto, a área econômica do Governo Federal vem acenando com valores bem menores para o ano 2.000. Para balizar as negociações calculamos: $R \$ 140,00$ per capita corresponde a RS 22,9 bilhões; $R \$ 150,00$ per capita corresponde a $R \$ 24,5$ bilhões; $R \$ 160,00$ per capita 
corresponde a $R \$ 26,2$ bilhões; $R \$ 170,00$ per capita corresponde a $R \$ 27,8$ bilhões; $e$ $R \$ 180,00$ per capita corresponde a $R \$ 29,5$ bilhöes.

Para a concessão de um reajuste de $40 \%$ nas tabelas de procedimentos seriam necessários um orçamento de $R \$ 23,5$ bi. mais $R \$ 1,0$ bi. para pessoal do GDF e Hospitais Universitários, totalizando $R \$ 24,4$ bilhões (per capita de $R \$ 160,00$ ). Para a concessão de um reajuste de $90 \%$ nas tabelas de procedimentos seriam necessários um orçamento de $R \$ 28,5$ bi. mais $R \$ 1,0$ bi. para pessoal do GDF e Hospitais Universitários, totalizando $R \$ 29,5$ bilhões (per capita de $R \$ 180,00$ ).

Os Estados e os Municípios deverão aportar 7\% de suas receitas líquidas em 2.000, devendo os Estados deverão atingir 12\% e os Municípios 15\% em 2.004. Considerando que alguns estados aportam hoje aproximadamente 3,5\% de suas receitas líquidas, seria possivel dobrarem em um ano os recursos para a saúde? A versão anterior do substitutivo previa um incremento anual de 1/5 da diferença entre o percentual atual e os $12 \%$ a serem atingidos no ano 2.004. Esta nos parece uma progressão mais factivel para os estados. Os Estados já fecharam seus orçamentos para 2.000, que estão em fase de aprovação nas respectivas Assembléias Legislativas. Como alterá-los para cumprir determinações da PEC a ser aprovada? A PEC a ser aprovada deverá deixar claro a vinculação dos recursos a gastos em serviços e ações de saúde integrantes do SUS excluindo assim hospitais militares, de previdência estaduais e outros serviços de saúde que não integrem o SUS. (ver Art. $1^{\circ}$ )

A PEC a ser aprovada deverá deixar claro que a vinculação dos recursos para a saúde exclui os recursos alocados para a função saneamento. O parágrafo $5^{\circ}$ do Art. $3^{\circ}$ propõe criar fundos de saúde para consórcios. Isto significaria criar uma nova instância gestora para repasses do SUS, que hoje são apenas União, Estados e Municipios. Esta proposta além de indesejável por ferir a autonomia de estados e municípios, nos parece inconstitucional.

O parágrafo $5^{\circ}$ do Art. $8^{\circ}$, define que os recursos serão "aplicados por meio de um fundo contábil e acompanhado por entidades organizadas da sociedade civil". Entendemos que devia ser "aplicados por meio dos fundo de saúde e acompanhado pelos conselhos de saúde." (79)

Abaixo um demonstrativo de algumas estimativas de valores segundo as PECs em números de 2000. 
A) PROPOSTA PEC 169 - DEP.EDUARDO JORGE: UNIÃO $=27,054+4,906=31,960$ ESTADOS $=6,195$ MUNICIPIOS $=3,731$ TOTAL $=R \$ 41,8886 \mathrm{BI}$

B) PROPOSTA DO RELATOR DEP. PERONDI:U=31,354,E=6,195; $M=3,731$;TOTAL 41,280 C) PROPOSTA DO DEP. MOSCONI COM PARECER DO DEP.URSICINO

\begin{tabular}{|l|r|r|r|r|r|r|}
\hline & RECEITA & 1.999 & 2.000 & 2.001 & 2.002 & 2.003 \\
\hline CPMF $100 \%$ & 8.087 & 8.087 & 8.087 & 8.087 & 8.087 & 8.087 \\
\hline COFINS & 19.894 & $(48 \%) 9.549$ & $(52) 10.344$ & $(56) 11.141$ & $(60) 11.936$ & $(64) 12.732$ \\
\hline LUCRO & 7.779 & 3.734 & 4.045 & 4.356 & 4.667 & 4.978 \\
\hline União & 35.760 & 21.370 & 22.476 & 23.584 & 24.690 & 25.797 \\
\hline ESTADOS & 61.947 & $(6 \%) 3.717$ & $(7,5) 4.646$ & $(9) 5.575$ & $(10,5) 6.504$ & $(12) 7.434$ \\
\hline MUNICIPIOS & 37.315 & $(9 \%) 3.358$ & $(10,5) 3.918$ & $(12) 4.478$ & $(13,5) 5.038$ & $(15) 5.597$ \\
\hline TOTAL UEM & & 28,445 & 31,040 & 33,637 & 36,232 & 38,828 \\
\hline
\end{tabular}

D) PROPOSTA DO MINISTRO SERRA

\begin{tabular}{|l|r|r|r|r|r|r|}
\hline & RECEITA & 1.999 & 2.000 & 2.001 & 2.002 & 2003 \\
\hline COFINS & 19.894 & $60 \%$ & $63 \%$ & $66 \%$ & $69 \%$ & $70 \%$ \\
\hline CSLL & 7.779 & $60 \%$ & $63 \%$ & $66 \%$ & $69 \%$ & $70 \%$ \\
\hline CPMF & 8.087 & $60 \%$ & $63 \%$ & $66 \%$ & $69 \%$ & $70 \%$ \\
\hline UNIĀO & 35.760 & 21.456 & 22.528 & 23.601 & 24.674 & 25.032 \\
\hline ESTADOS & 61.947 & $4.955(8 \%)$ & $5.575(9 \%)$ & $6.194(10)$ & $6.814(11)$ & $7.433(12)$ \\
\hline MUNICÍPIOS & 37.315 & $4.104(11)$ & $4.477(12)$ & $4.850(13)$ & $5.224(14)$ & $5.597(15)$ \\
\hline TOTAL UEM & & 30,515 & 32,580 & 34,645 & 36,712 & 38,062 \\
\hline
\end{tabular}

E) PROPOSTA DA COMISSÃO DE ORÇAMENTO E FINANCIAMENTO DO CNS

\begin{tabular}{|l|r|r|r|r|r|r|}
\hline & RECEITA & 1999 & 2000 & 2001 & 2002 & 2003 \\
\hline COFINS & 19.894 & $(60) 11.936$ & $(65) 12.932$ & $(70) 13.926$ & $(75) 14.921$ & $(80) 15.915$ \\
\hline CSLL & 7.779 & 4.667 & 5.056 & 5.445 & 5.834 & 6.223 \\
\hline CPMF & 8.087 & 8.087 & 8.087 & 8.087 & 8.087 & 8.087 \\
\hline ST- UNIÃO & 35,760 & 24,690 & 26,075 & 27,458 & 28,842 & 30,225 \\
\hline ESTADOS & 61.947 & $(7 \%) 4,336$ & $(8,5) 5,265$ & $(10) 6,195$ & $(11,5) 7,124$ & $(13) 8,053$ \\
\hline MUNICIPIOS & 37.315 & $(7 \%) 2,612$ & $(8,5) 3,172$ & $(10) 3,732$ & $(11,5) 4,291$ & $(13) 4,851$ \\
\hline TOTAL UEM & & 31,638 & 34,512 & 37,385 & 40,257 & 43,129 \\
\hline
\end{tabular}


F) O CNS APROVOU(1-7-98): UNIÃO= $30 \%$ DO OSS; $13 \%$ ESTADOS E MUNICIPIOS; DELEGOU A COMISSÃO DE ORÇAMENTO E FINANCIAMENTO DO CNS A NEGOCIAÇÃO

Abaixo um quadro resumo de todas as hipóteses estimativas:

\begin{tabular}{|c|c|c|c|c|c|c|c|c|}
\hline ANO & \multicolumn{4}{|c|}{ INICIAL OU 1999} & \multicolumn{4}{|c|}{ FINAL OU 2003} \\
\hline PROPOSTAS & UNIÃO & ESTA & MUNI & TOTAL & UNIÃO & ESTA & MUNICI & TOTAL \\
\hline $\begin{array}{l}\text { PEC169 EDU. } \\
\text { JORGE }\end{array}$ & & & & & 31,96 & 6,20 & 3,73 & 41,89 \\
\hline RELATOR PERONDI & & & & & 31,35 & 6,20 & 3,73 & 41,28 \\
\hline PEC PINOTTI & & & & & & & & 42,50 \\
\hline PEC.82 MOSCONI & & & & & 27,57 & Ñ.PREV & Ñ.PREV & \\
\hline RELATOR URSICINO & 21,37 & 3,72 & 4,65 & 28,45 & 25,58 & 7,43 & 5,60 & 38,83 \\
\hline M.SAÚDE SERRA & 21,46 & 4,96 & 4,10 & 30,52 & 25,03 & 7,43 & 5,60 & 38,06 \\
\hline COMISSÃO DO CNS. & 24,69 & 3,72 & 3,36 & 31,76 & 30,22 & 7,43 & 5,60 & 43,26 \\
\hline CNS - SEM CPMF & 28,71 & 4,34 & 2,61 & 35,66 & 28,71 & 8,05 & 4,85 & 41,71 \\
\hline CNS - COM CPMF & 31,35 & 4,34 & 2,61 & 38,20 & 31,35 & 8.05 & 4,85 & 44,25 \\
\hline
\end{tabular}

Para o conhecimento do financiamento federal da saúde, é importante o estudo completo e aprofundado do dispositivo constitucional, em vigor, que modificou o financiamento tanto federal como de Estados e Municipios. A seguir, na integra, a emenda constitucional aprovada no Congresso - 29 de 13 de setembro de 2000.

"As Mesas da Câmara dos Deputados e do Senado Federal, nos termos do $\S 3^{\circ}$ do art. 60 da Constituição Federal, promulgam a seguinte Emenda ao texto constitucional:

Art $1^{\circ} \mathrm{A}$ alínea e do inciso VII do art. 34 passa a vigorar com a seguinte redação:

“Art.34 ..." "VII - "e) aplicação do mínimo exigido da receita resultante de impostos estaduais, compreendida a proveniente de transferências, na manutenção e desenvolvimento do ensino e nas ações e serviços públicos de saúde."

Art $2^{\circ} \mathrm{O}$ inciso III do art. 35 passa a vigorar com a seguinte redação: "Art. $35 .$. " " III não tiver sido aplicado o mínimo exigido da receita municipal na manutenção $e$ desenvolvimento do ensino e nas ações e serviços públicos de saúde;"

Art $3^{\circ} \mathrm{O} \S 1^{\circ}$ do art. 156 da Constituição Federal passa a vigorar com a seguinte redação:

"Art.156..." "§ $1^{\circ}$ Sem prejuizo da progressividade no tempo a que se refere o art. 182, $\S 4^{\circ}$, inciso II, o imposto previsto no inciso I poderá:" "I - ser progressivo em razão do valor do imóvel; e" "II - ter aliquotas diferentes de acordo com a localização e o uso do imóvel." Art $4^{\circ} \mathrm{O}$ parágrafo único do art. 160 passa a vigorar com a seguinte redação: 
"Art.160..." "Parágrafo único. A vedação prevista neste artigo não impede a União e os Estados de condicionarem a entrega de recursos:" "I - ao pagamento de seus créditos, inclusive de suas autarquias;" "II - ao cumprimento do disposto no art. 198, § 20, incisos II e III."

Art $5^{\circ} \mathrm{O}$ inciso IV do art. 167 passa a vigorar com a seguinte redação: "Art.167..." IV - a vinculação de receita de impostos a órgão, fundo ou despesa, ressalvadas a repartição do produto da arrecadação dos impostos a que se referem os arts. 158 e 159; a destinação de recursos para as ações e serviços públicos de saúde e para manutenção e desenvolvimento do ensino, como determinado, respectivamente, pelos arts. 198, $\S$ $2^{\circ}$, e 212, e a prestação de garantias às operações de crédito por antecipação de receita, previstas no art. $165, \S 8^{\circ}$, bem como o disposto no $\S 4^{\circ}$ deste artigo;" "..."

Art $6^{\circ} \mathrm{O}$ art. 198 passa a vigorar acrescido dos seguintes $\S \S 2^{\circ}$ e $3^{\circ}$, numerando-se 0 atual parágrafo único como §10: “Art.198 ..." \$ $1^{\circ}$ (parágrafo único original).

“" "§ $2^{\circ}$ A União, os Estados, o Distrito Federal e os Municípios aplicarão, anualınente, em ações e serviços públicos de saúde recursos mínimos derivados da aplicação de percentuais calculados sobre:" "I - no caso da União, na forma definida nos termos da lei complementar prevista no § $3^{\circ}$;" "II - no caso dos Estados e do Distrito Federal, o produto da arrecadação dos impostos a que se refere o art. 155 e dos recursos de que tratam os arts. 157 e 159, inciso I, alínea a, e inciso II, deduzidas as parcelas que forem transferidas aos respectivos Municípios;" "ill - no caso dos Municípios e do Distrito Federal, o produto da arrecadação dos impostos a que se refere o art. 156 e dos recursos de que tratam os arts. 158 e 159, inciso l, alínea b e $\S 3^{\circ}$." "§ $3^{\circ}$ Lei complementar, que será reavaliada pelo menos a cada cinco anos, estabelecerá:" "I os percentuais de que trata o $\S 2^{\circ}$;" "II - os critérios de rateio dos recurrsos da União vinculados à saúde destinados aos Estados, ao Distrito Federal e aos Municípics, e dos Estados destinados a seus respectivos Municípios, objetivando a progressiva reduçäo das disparidades regionais;" "III - as normas de fiscalização, avaliação e controle dəs despesas com saúde nas esferas federal, estadual, distrital e municipal;" "IV - as normas de cálculo do montante a ser aplicado pela União."

Art $7^{\circ} .0$ Ato das Disposições Constitucionais Transitórias passa a vigcrar acresçico do seguinte art. 77: "Art. 77. Até o exercício financeiro de 2004, os recursos mínimos aplicados nas ações e serviços públicos de saúde serão equivalentes:" "I - no caso da União:" " a) no ano 2000, o montante empenhado em ações e serviços públicos de saúde no exercício financeiro de 1999 acrescido de, no mínimo, cinco por cento;" " b) do ano 2001 ao ano 2004, o valor apurado no ano anterior, corrigido pela variação nominal do Produto Interno Bruto - PIB;" "II - no caso dos Estados e do Distrito Federal, doze por cento do produto da arrecadação dos impostos a que se refere o art. 155 e dos recursos de que tratam os arts. 157 e 159, inciso I, alinea a , e iriciso II, deduzidas as parcelas que forem transferidas aos respectivos Municípios; e" "Ili - no caso dos Municipios e do Distrito Federal, quinze por cento do produto da arrecadação dos in:postos a que se refere o art. 156 e dos recursos de que tratam os arts. 158 e 159 , inciso I, alinea b e $\S 3^{\circ}$." "§ $1^{\circ}$ Os Estados, o Distrito Federal e os Municipics que apliquem percentuais inferiores aos fixados nos incisos II e II! deverão ele:vá-los gradua!mente, até o exercício financeirc de 2004, reduzida a diferença à razão de, pclo menos, um quinto por ano, sendo que, a partir de 2000, a aplicação será de pelo menos sete por cento." "§ $2^{\circ}$ Dos recursos da União apurados nos termos deste artigo, quinze por cento, no mínimo, serão aplicados nos Municipios, segundo o critério populacional, em ações e serviços básicos de saúde, na forma da lei." "§ $3^{\circ}$ Os recursos dos Estados, do Distrito Federal e dos Municipios destinados ès ą̧.ões e serviços públicos de saúde e os transferidos pela União para a mesma finalidadie serão aplicados por meio de Fundo de Saúde que será acompanhado e fiscalizado por Conselho de Saúde, sem prejuizo do disposto no art. 74 da Constitliç̧ão Federal." "§ $4^{\circ}$ 
Na ausência da lei complementar a que se refere o art. $198, \S 3^{\circ}$, a partir do exercício financeiro de 2005, aplicar-se-á à União, aos Estados, ao Distrito Federal e aos Municipios o disposto neste artigo."

Art $8^{\circ}$ Esta Emenda Constitucional entra em vigor na data de sua publicação. Brasília, 13 de setembro de 2000 "

Várias questões foram questionadas, desde o início, o CONASS, oficialmente, solicitou um posicionamento do MS, que saiu em termos de NOTA TÉCNICA SIS/DPI N. ${ }^{\circ} 002 / 2001$ (98) em que ocorreram novos balizamentos para a EC-29, como pode ser observado no texto abaixo:

“Considerando que a EC-29 somente foi promulgada em setembro, quando já está quase concluída a execução orçamentária de 2000 , a partir de que ano a União, os Estados, o Distrito Federal e os Municípios estão obrigados a cumprir a vinculação orçamentária prevista pois o artigo $8^{\circ}$ da Emenda Constitucional dispôs de forma expressa que a mesma entraria em vigor na data de sua publicação. Assim, desde 14 de setembro de 2000, União, Estados, Distrito Federal e Municipios, nos exatos termos dos novos dispositivos constitucionais, ficaram obrigados a vincular parte de suas receitas a ações e serviços de saúde. O fato de a publicação da Emenda ter alcançado o orçamento do ano 2000 em execução não eximiu os entes federativos do cumprimento do dispositivo legal devendo os estados evoluir a partir de $7 \%$ em 2000 e crescendo 1,25\% ao mês até os $12 \mathrm{em} 2004$. Para que os entes federativos possam os percentuais mínimos exigidos para o exercício de 2001, faz-se necessário que tenham a autorização orçamentária correspondente. Caso não haja a devida autorização, a própria Constituição Federal já dispõe de mecanismos para a solução deste problema. Dispõe o $\S 8^{\circ}$ do artigo 165: "Art. 165 - A lei orçamentária anual não conterá dispositivo estranho à previsão da receita e à fixação da despesa, não se incluindo na proibição a autorização para abertura de créditos suplementares e contratação de operações de crédito, ainda que por antecipação da receita, nos termos da lei." Vê-se, portanto, que a autorização para abertura de créditos suplementares é prevista na nossa Lei Maior, que complementa o dispositivo através do artigo 167 , inciso $\mathrm{V}$, dispondo que é vedada a "abertura de créditos suplementares ou especial sem prévia autorização legislativa $e$ sem a indicação dos recursos correspondentes". A regulamentação sobre a forma como os créditos suplementares podem ser realizados vem expressa na Lei 4.320/64, que prevê os mecanismos técnicos que resolveriam o problema. Com efeito, o artigo $7^{\circ}$ da Lei 4.320/64 dispõe que a Lei de Orçamento pode conter autorização ao Executivo para abrir créditos suplementares até determinada importância. A autorização legislativa a que se refere a Lei 4.320/64 pode vir já embutida na Lei Orçamentária, ou ainda pode ser aprovada no decorrer do exercício financeiro. De qualquer forma, sempre que tal ato for concretizado, deve-se indicar os recursos que irão cobrir tal suplementação. São quatro as possiveis fontes de recursos para os créditos suplementares: superávit financeiro, excesso de arrecadação. Anulação parcial ou total de dotação orçamentária, operação de crédito.

$\mathrm{Na}$ atual redação do artigo 198 da Constituição (§§ $2^{\circ}$ e $3^{\circ}$ ) encontra-se o fundamento Constitucional que obriga os entes federativos a vincularem os recursos que serão aplicados no setor da Saúde, além de cuidar da regulamentação que deverá ser dada às novas regras. Estes recursos serão calculados de acordo com a realidade de cada ente federativo, aplicando-se um percentual especifico para cada um e sobre uma parcela da receita definida nos incisos do $\S 2^{\circ}$, de forma individualizada.

É importante ressaltar que a contabilização de dados de receitas próprias de Estados, Municipios e Distrito Federal não pode incluir os valores pagos e transferidos pelo 
Fundo Nacional de Saúde às esferas de governo subnacionais, que serão contabilizados pela União como gasto da esfera federal para efeito de cumprimento da EC n. ${ }^{\circ} 29 / 2000$. Tais valores se referem principalmente a: pagamentos pela prestação de serviços hospitalares e ambulatoriais; transferências fundo a fundo aos Estados e Municípios habilitados nas condições de gestão previstas na Norma Operacional Básica - NOB 01/96;

Ademais, vale lembrar que é inadequada a apropriação, por Estados e Municípios, de receitas provenientes de eventuais transferências intergovernamentais na área de saúde, que podem acontecer, por exemplo, quando firmado consórcio intermunicipal onde o Município-sede recebe recursos de outros Municipios da região ou do Estado para financiamento de serviços específicos. Outra questão importante diz respeito aos empréstimos para o setor saúde. Os recursos provenientes de empréstimos não são computados como receita vinculável, tendo em vista que a vinculação só diz respeito às receitas indicadas no texto inserido pela emenda. No que concerne ao gasto, entende-se que os recursos provenientes de empréstimos e efetivamente gastos em ações e senviços de saúde deverão ser computados para fins de verificação do cumprimento da EC n. ${ }^{\circ}$ 29. Por outro lado, o pagamento desses empréstimos não deverá ser computado, evitando-se, assim, a dupla contagem do gasto em saúde. $O$ Sistema de Informações de Gastos Públicos em Saúde - SIOPS, implantado em 1999 pelo Ministério da Saúde, constitui importante mecanismo para apuração do valor exato gasto em saúde pelos entes federativos. Gerenciado pela Secretaria de Gestão de Investimentos em Saúde - SIS, do Ministério da Saúde, o SIOPS agrega informações sobre receitas gerais e gastos em saúde das três esferas de governo, através de sistemas informatizados.

Dentre os indicadores gerados pelo Sistema estão o referente ao cumprimento da vinculação constitucional para a área de saúde, qual seja, o percentual de recursos próprios provenientes de impostos e transferências aplicados em saúde. Sua fórmula para apuração do valor exato é como segue:(Despesa Total com Saúde Transferências para o SUS) x 100.

A "Lei Kandir" refere-se à imunidade de ICMS nas remessas de mercadorias para o exterior, tendo acarretado na perda de receita para os Estados. Acordo firmado entre a União e os Poderes Executivos estaduais prevê compensações financeiras aos Estados. Essas compensações devem ser qualificadas como receitas públicas repassadas pela União e diretamente relacionadas com o tributo estadual, devendo, portanto, também ser submetidas à vinculação, para efeito de destinação de recursos mínimos à saúde. Em relação à vinculação constitucional para a educação, cumpre apontar que a base de cálculo das receitas vinculáveis é rigorosamente igual à aplicada à saúde. Neste sentido, não é cabivel sustentar que primeiro extrai-se os recursos para a educação para, só então, verificar a parte a ser destinada à saúde. Embora a EC 29 não preveja, para a União, a receita que deve ser vinculada e a percentagem mínima a ser aplicada, nem por isso deixou de estabelecer qual o montante de recursos mínimos a serem aplicados em ações e senviços públicos de saúde até o ano de 2004. Tal montante encontra-se claramente definido: no ano 2000, o montante empenhado em ações e senviços públicos de saúde no exercício de 1999 acrescido de, no mínimo, cinco por cento; do ano de 2001 ao ano de 2004, o valor apurado no ano anterior, corrigido pela variação nominal do Produto Interno Bruto - PIB (valor nominal é apenas a expressão monetária em reais, sem levar em conta outras variáveis, como ocorre com o valor real).

O Sistema de Informações de Gastos Públicos em Saúde - SIOPS, implantado em 1999 pelo Ministério da Saúde, é o principal meio de fiscalização, avaliação e controle da execução das normas da Emenda Constitucional $n^{\circ}$ 29/2000. A Norma Operacional 
da Assistência à Saúde - NOAS, aprovada pela Portaria GM n. ${ }^{\circ} 95 / 00$, de 26 de janeiro de 2001, dispõe, nos itens 47, 48 e 50, que é requisito à habilitação de Municípios e Estados a comprovação, por meio da alimentação do SIOPS, da dotação orçamentária do ano e o dispêndio do ano anterior correspondente à contrapartida de recursos financeiros proprios do Tesouro Municipal e do Tesouro Estadual, de acordo com a Emenda Constitucional n. ${ }^{\circ} 29 / 2000$.

A Constituição Federal prevê a intervenção federal nos Estados e destes nos Municipios quando não for aplicada a receita mínima em ações e serviços de saúde. Dispõe o mandamento constitucional: "Art. 34 - A União não intervirá nos Estados nem no Distrito Federal, exceto para: (....) VII - assegurar a observância dos seguintes principios constitucionais: e) aplicação do mínimo exigido da receita resultante de impostos estaduais, compreendida a proveniente de transferências, na manutenção e desenvolvimento do ensino e nas ações e serviços públicos de saúde." "Art. 35 - O Estado não intervirá em seus Municípios, nem a União nos Municípios localizados em território federal, exceto quando: (....) III - não tiver sido aplicado o mínimo exigido da receita municipal na manutençăo e desenvolvimento do ensino e nas ações e serviços públicos de saúde."

Em que pese a aplicabilidade imediata do mandamento constitucional, a Lei Complementar poderá prever mecanismos e formas de ajustamento, sempre que identificada e comprovada a não aplicação dos recursos mínimos por algum ente federativo. Entretanto, esgotados os procedimentos que serão definidos na lei complementar, não há como se afastar a possibilidade de aplicação da sanção prevista. A EC 29 prevê a suspensão de repasses constitucionais e assim poderá proceder o administrador quando defrontado com a não aplicação correta dos mandamentos constitucionais no que se refere à aplicação dos recursos mínimos para a saúde. Se o Estado ou o Município não obsenva a regra constitucional e deixa de aplicar recursos mínimos em ações e serviços de saúde, nem ajusta a aplicação dos recursos na execução do seu orçamento, abre-se a possibilidade da aplicação da sanção, já que o regramento constitucional é claro neste sentido. Certamente que, quando da aplicação de uma sanção desta gravidade, deverá haver mecanismos que garantam a continuidade da assistência à saúde do cidadão. Igualmente, deverá o gestor do ente federativo responsável pela infração responder pelos seus atos, arcando com as sanções de natureza civil, penal e administrativa cabiveis. Também deverá haver mecanismos que garantam que os recursos aplicados a menor em saúde sejam aplicados pelo ente federativo faltoso, através de compensação nos meses subseqüentes à aplicação da sanção.

Do contrário, quem deixasse de aplicar recursos mínimos em ações e serviços de saúde não sofreria qualquer tipo de penalidade, pois não estaria sequer obrigado a empenhar o que deixou de aplicar para honrar os pagamentos dos serviços contratados e conveniados. O objetivo da Constituição é completamente outro: obrigar o ente federativo a aplicar recursos mínimos em saúde. $E$, para tanto, é preciso que exista sanções ou mesmo mecanismos que o façam destinar recursos que inicialmente não foram aplicados na finalidade constitucional exigida.

A Lei Complementar deverá prever uma forma de suspensão de repasse de recursos que garanta as premissas acima elencadas. Sem prejuizo dos mecanismos atualmente existentes, o Projeto de Lei Complementar terá capítulo especial dedicado à criação e aperfeiçoamento de mecanismos que, ao mesmo tempo em que permite o exame e fiscalização do destino das verbas transferidas pelo Governo Federal pelos órgãos de controle em cada esfera federativa, também possibilitará o acompanhamento pela União Federal do caminho percorrido por estes recursos. Importante ressaltar a 
relevância dos Conselhos Nacional, Estaduais e Municipais de saúde no controle das contas do setor.

Antes de se iniciar qualquer discussão a respeito, necessário se faz examinar o contexto em que se insere a expressão: "Art. 198 (....) § $3^{\circ}$. Lei complementar, que será reavaliada pelo menos a cada cinco anos, estabelecerá: (....) II - os critérios de rateio dos recursos da União vinculados à saúde destinados aos Estados, ao Distrito Federal e aos Municípios, e dos Estados destinados aos seus respectivos Municípios, objetivando a progressiva redução das disparidades regionais; (...)" A questão, tal como formulada, pede a definição de "redução de disparidades regionais", tarefa que a Constituição expressamente atribui à lei complementar. Cabe, neste momento, identificar o objetivo geral da norma, buscando as informações necessárias na fonte: a própria Constituição. "Art. 198. As ações e serviços públicos de saúde integram uma rede regionalizada e hierarquizada e constituem um sistema único, organizado de acordo com as seguintes diretrizes: I - descentralização, com direção única em cada esfera de governo;ll - atendimento integral, com prioridade para ações preventivas, sem prejuizo dos serviços assistenciais;III - participação da comunidade."

Tendo em vista os objetivos da norma constitucional em que se insere o $\S 3^{\circ}$, introduzido pela Emenda à Constituição $n .^{\circ} 29$, de 14 de setembro de 2000, a necessidade de reavaliação da Lei Complementar que virá para regulamentar o dispositivo em apreço decorre da consideração, feita pelo legislador reformador, de que a distribuição de recursos deve levar em conta as diferenças regionais existentes no âmbito da federação brasileira. Alguns indicadores devem ser considerados para a análise periódica das desigualdades regionais. Podemos listar alguns, como o nivel de mortalidade infantil; a expectativa de vida das pessoas; os dados epidemiológicos; as variáveis de acesso aos serviços de saúde; a rede instalada; a quantidade de médicos e enfermeiros por habitante; a renda média da população; a quantidade de água tratada disponível, dentre outros indicadores. A definição dos indicadores das desigualdades regionais deverá ser fruto de amplo debate nacional e de profundo estudo dos dados existentes para a avaliação das condições reais de cada região do país. Exatamente por isso é que o dispositivo em apreço trata com sensibilidade a questão, prevendo a revisão de $5 \mathrm{em} 5$ anos, já que as disparidades regionais são dinâmicas, devendo a política de redução de disparidades evoluir até o momento em que tais disparidades, se nunca poderão ser anuladas, alcancem patamar mínimo.

A previsão de rateio, levando-se em conta as diferenças de cada Região, em última instância atende ao princípio isonômico, norte de toda Constituição, e objetivo que , certamente, direcionará o legislador complementar. Brasília, em 31 de janeiro de 2001". (98)

Logo em seguida, em meio a várias interpretações, destaca-se um parecer dos Profs. Rosa Maria Marques (PUC-SP) e Aquilas Mendes (FAAP). (118):

"A recente aprovação da proposta da emenda constitucional (PEC) da saúde, que vincula recursos fiscais para o setor levou a que muitos festejassem o início de um período próspero de recursos para o SUS. Nossa percepção é de que ela não chega a resolver o problema da insuficiência de recursos da área e tampouco sua relação com as diversas fontes da Seguridade. De fato, a PEC introduz uma inovação ao vincular recursos para o financiamento da saúde, pois define o quanto das receitas resultantes de impostos e transferências constitucionais dos estados e municípios deve ser destinado para a área. Essas esferas de governo deverão alocar, no primeiro ano, pelo menos, $7 \%$ dessas receitas, sendo que o percentual crescerá anualmente até atingir, para os estados, 12\% em 2004 e, para os municipios, 15\%. Quanto à União, fica definido: para o primeiro ano, o aporte de pelo menos $5 \%$ em relação ao orçamento 
empenhado do período anterior, para os seguintes, o valor apurado no ano anterior é corrigido pela variação do PIB nominal. Não fica explícita, contudo, a origem dos recursos. Dessa forma, a PEC ao garantir vinculação somente para os recursos provenientes de impostos dos estados e municípios, suscita muita dúvida e incerteza em relação aos rumos do financiamento da saúde.

Estudo recente do Centro de Estudos e Pesquisas de Administração Municipal (Cepam) mostra que o nível inicial de gasto exigido pela PEC para 2000 (7\%) já foi atingido pelos municipios paulistas em 1995 (13,8\%), enquanto o desejável para 2004 (15\%) havia sido superado em 1997 (16,2\%). Essa realidade não é restrita aos municipios paulistas. Segundo o Sistema de Informações sobre o Orçamento Público em Saúde (Siops), em levantamento realizado pelo Ministério da Saúde junto a 1.500 municípios, em 1998 o percentual destinado à saúde foi de 15\% das receitas de impostos e transferências constitucionais. Isso demonstra que, para os municípios, a vinculação de recursos não alterará o quadro do financiamento da saúde.

O que se pode cogitar é que a Lei de Responsabilidade Fiscal venha afetar o nivel de gasto municipal já alcançado na área da saúde. Isso porque, na permanência de renúncias fiscais - motivadas pelo jogo de interesses -, o corte de despesa que se fizer necessário ocorrerá exatamente junto às despesas "comprimiveis", isto é, em material de consumo e serviços de terceiros. Na área da saúde, isso significa medicamentos, material hospitalar e laboratorial e compra de serviços ambulatoriais e hospitalares junto à rede privada (filantrópica e lucrativa).

No caso dos Estados, considerando que sua maioria, vem destinando 6\% de suas receitas de impostos e transferências constitucionais para a saúde, de fato a PEC ampliou sua participação. Contudo, se o crescimento econômico observarlo no primeiro semestre deste ano não se mantiver, os estados tenderão a aplicar o mínimo previsto pela PEC. Como é sabido, o ICMS - principal receita dos estados - tem registrado queda nos últimos anos, diante da retração econômica.

Quanto às contribuições da Seguridade Social (Cofins e Contribuição sobre o Lucro Liquido - CSLL), a PEC é omissa, não definindo nenhuma vinculação, como se não houvesse nenhuma disputa por seus recursos. Desde que a Previdência deixoul de partilhar com as demais áreas (Assistência Social e Saúde) as contribuições sobre a folha, o SUS foi obrigado a depender, cada vez mais, do Tesouro Nacional e de negociações junto à esfera econômica federal. Nos anos segtintes, a Previdência, não contente em absorver a totalidade das contribuições sobre a folha, avançou sobre as demais fontes da Seguridade. Entre 1996 e 1999, a Previdência aumentou sua participação no uso dos recursos da Cofins e da CSLL de 29,09\% para 33,61\%. Isso aguçou a disputa entre as áreas e determinou, como argumento a criação da CPMF. Contudo, o governo federal usou a CPMF para diminuir a participação da Ccfins e da CSLL no financiamento da saúde. Entre 1996 e 1999, essa participação caiu de 40,5\% para $26,8 \%$ e de $21,1 \%$ para $12,9 \%$, respectivamente.

Isso somente foi possivel porque o governo federal obteve poder de alocação de $20 \%$ da receita da Seguridade mediante o Fundo de Estabilização Fiscal (hoje Desvinculação dos Recursos da União - DRU, e antes ironicamente chamado de Fundo de Emergência Social).

Além disso, é preciso atentar para o impacto da proposta de reforma tributária scbre o financiamento futuro da saúde. Se permanecer a essência do projeto em discussão no Congresso desde 1995, a Cofins e CSLL serão extintas e nada consta sobre qua! fonte irá cumprir seu papel. Em 1999, a Cofins e a CSLL foram responsáveis por 39,7\% (RS 7,7 bilhões) dos recursos da área da saúde. A extinção dessas contribuições e o fato 
de a PEC não mencioná-las indicam que o governo federal pretende financiar a saúde com impostos.

Essa "reengenharia" poderia ser entendida como garantia de recursos mínimos, pois a PEC supõe a manutenção do nivel de gasto federal realizado no primeiro ano de sua vigência. Para contestar essa interpretação, é suficiente perguntarmos se o nível do primeiro ano (orçamento empenhado do ano anterior mais 5\%, mantido o poder de compra) será adequado às necessidades de saúde da população.

A evolução recente do gasto federal nessa área atesta o contránio. $O$ que quase ninguém se dá conta é que, enquanto a reforma tributária não for aprovada, as receitas da Cofins e da CSLL deixam de ser, por força da PEC, da Seguridade Social e podem ser usados pelo governo federal a seu bel-prazer. Estaria, assim, atingido o objetivo perseguido pelo governo federal, isto é, a completa desvinculação das contribuições sociais da Seguridade.

A PEC, por melhores que tenham sido as intenções de seus proponentes originais, apenas sancionou o comprometimento atual dos municipios e do governo federal. Mediante uma pequena elevação da participação dos estados, abriu-se mão das contribuições. Afinal, ninguém espera que a reforma tributária venha de repente, "a galope". Enquanto isso, apenas nos resta exigir que a regulamentação da PEC dê conta da definição de gasto em saúde, em especial na área de atenção básica e dos mecanismos de transferência e de aplicação dos recursos da esfera federal. "

\section{ANÁLISE E COMENTÁRIOS À EC-29, de 13/9/2000:}

Cada um dos artigos da EC-29, de 13/9/2000 será analisado, complementando com os artigos citados e correlatos, fazendo comentários e, ao final, tecendo consideraçōes sobre a proposta de regulamentação:

"Art $1^{\circ} \mathrm{A}$ alínea e do inciso VII do art. 34 passa a vigorar com a seguinte redação: “Art.34 ...VII -... e)aplicação do mínimo exigido da receita resultante de impostos estaduais,compreendida a proveniente de transferências, na manutenção e desenvolvimento do ensino e nas ações e serviços públicos de saúde."

Art $2^{\circ} \mathrm{O}$ inciso III do art. 35 passa a vigorar com a seguinte redação: "Art. 35 ... III - não tiver sido aplicado o mínimo exigido da receita municipal na manutenção $e$ desenvolvimento do ensino e nas ações e serviços públicos de saúde;"

\section{COMENTÁRIOS:}

Intervenção federal se Estados, e federal e estadual se Municipios não colocarem recursos definidos na saúde (isto já existia em relação à educação e agora passa a valer também para a saúde). Importante ficar claro que a intervenção não pode ser a simples parada de repasse de recursos, para não prejudicar, duplamente, a população (ficar sem os recursos do Estado/Município e ainda da União/Estado). Olhar estes artigos combinados com o Art. 40. que muda o artigo 160, da CF, acrescentando que a União e o Estado podem condicionar a entrega de recursos ao pagamento de débitos com Estados e Municípios e (o novo) se Estados e Municipios não estiverem colocando os percentuais de seus impostos para a saúde (198 II e IIII). Veja igualmente os comentários relativos ao artigo $4^{\circ}$. 
Conceito de receita de Estados e Municípios do qual se vai retirar o percentual para a saúde. Para Estados, o conceito deste mínimo: receita de impostos estaduais, compreendida a de transferências. Para Municípios, fala-se apenas em receita municipal. A imprecisão deste termo pode levar a interpretações errôneas: inclui-se o FUNDEF? as transferências do SUS? outras receitas municipais como a de empréstimos ou convênios? De outro lado, fica incompatível com o texto do Art. $6^{\circ}$ (muda o 198), que diz de que receitas se vai tirar o percentual. Tratar isto no comentário e proposta do art. $6^{\circ}$.

CONCEITO DE AÇŐES E SERVIÇOS DE SAÚDE. Esta questão será repetida, daqui para a frente: ações e serviços públicos de saúde. O que se define aqui dentro deste conceito? Hoje, já estão incluídos os hospitais universitários (prestação de serviço e incentivo ensino e pesquisa) e o pagamento dos inativos e ações de saneamento da Fundaçăo Nacional de Saúde. Sob a denominação de ações e serviços de saúde, na concepção ampla da CF e da LOS, poder-se-ia querer acoplar todo o saneamento, o meio ambiente, as despesas totais com os hospitais universitários, os hospitais militares, com os serviços de saúde específicos dos servidores dos outros órgãos federais do executivo, legislativo ou judiciário. Destaque especial ao que vem ocorrendo com a inclusão do pagamento dos inativos da saúde, como despesas de saúde. No ano 2000 , dos $\mathrm{R} \$ 4,3$ bi de pagamento de pessoal, estima-se que quase a metade será gasta com inativos (isto equivale a dizer que, dos $\mathrm{R} \$ 20,37$ bi, orçamentariamente previstos para o ano 2000 , na verdade apenas 18,37 serão para a ação final de saúde. Cerca de 2 bi serão para os inativos (não sai do orçamento geral da União, mas aloca-se na saúde!!!... como despesa de saúde!...). R $\$ 18,37$ bi, rateado pelos 163,7 milhões de brasileiros resulta um per-capita de $\mathrm{R} \$ 112$ reais, ou seja, US 62 per-capita. (se tomar apenas os 12 bi da assistência, teriam R\$73 ou US 41 PC.) Qual o argumento que se teria, a posteriori, para que Estados e Municipios, cuja maioria, hoje, não inclui seus inativos, passasse a inclui-los? e seus hospitais militares estaduais e de serviços próprios de servidores, por que não colocar nas despesas de saúde? . Tudo seria permitido para todos? Se assim for, e não ficar definido, será menos dinheiro que hoje(....) "troca de meia dúzia por 4 ou $4,5 ! ! ! "$

O Conselho Nacional de Saúde coordenou um estudo de diversos órgãos e instituições, tentando trazer subsídios para a discussão sobre a EC-29 de 13/9/2000. Os participantes são o próprio MS, Associação Brasileira dos Membros do Tribunal de Contas, Ministério Público Federal,CONASS, CONASEMS, Consultores do legislativo e do Orçamento e Finanças do Congresso Nacional, convidados pelas Comissões de Seguridade Social e Familia da Câmara Federal e a de Assuntos Sociais do Senado. O documento se intitula 
Subsidios para a discussão e decisões sobre a implementação e regulação da EC-29 de 13/9/2000. (50)

"A EC 29 vinculou recursos para serem aplicados em ações e serviços de saúde, sem entretanto fornecer a abrangência deste conceito. A Lei Complementar deverá estabelecer um conceito normativo de "ações e serviços públicos de saúde", importante na medida em que definirá precisamente o universo de atividades que tem seu financiamento contabilizado e cujas despesas devem ser acompanhadas, para fins de cumprimento do dispositivo constitucional. Os principais critérios para a definição do conceito são o de eqüidade e universalidade de acesso aos serviços de saúde em todos os níveis de atenção à saúde, tal como determinado pelo art. 194, parágrafo único, I, da CF, e reafirmado pelo art. $7^{\circ}$ da Lei $n^{\circ} 8.080$, de 19 de setembro de 1990.

Já existe consenso de que as seguintes ações e serviços devam ser relacionadas entre as ações e serviços públicos de saúde beneficiadas pela vinculação de receitas: Ações e serviços constantes nos planos de saúde dos Municípios, Estados, Distrito Federal e União; ações e serviços executados pelos órgãos do Sistema Único de Saúde; controle de qualidade, pesquisa científica e tecnológica, e produção de insumos em saúde (medicamentos, imunobiológicos, reagentes, sangue e hemoderivados, equipamentos para a saúde, dentre outros); vigilância sanitária; vigilância epidemiológica e farmacoepidemiológica; saúde do trabalhador; assistência terapêutica e farmacêutica; ao nivel domiciliar e de pequenas comunidades, ações de saneamento básico e meio ambiente associadas a controle de vetores; e ao nivel de ações complementares e especificas para grupos de risco nutricional, ações de alimentação e nutrição.

Por outro lado, há consenso de que as seguintes ações e serviços não devam figurar entre as atividades beneficiadas: Gastos com pessoal inativo; serviços suplementares ao Sistema Único de Saúde, dedicados, total ou parcialmente, ao atendimento de clientelas fechadas (excluidos em função da incompatibilidade com o critério de universalidade de acesso); e serviço da divida (juros e amortização); ações de preservação e correção do meio ambiente, realizadas pelos órgãos de meio ambiente dos entes federativos e por entidades não governamentais; ações de saneamento básico de redes públicas e tratamento de água e esgotos, realizadas por companhias, autarquias e empresas de saneamento com recursos provenientes de taxas e tarifas, $e$ ações de limpeza urbana e remoção de resíduos sólidos (lixo) realizadas por órgãos municipais especificos ou empresas terceirizadas."

\section{CONTRIBUIÇÃO ÀS PROPOSTAS DE REGULAMENTAÇÃO:}

a) A intervenção da União sobre Estados e Municipios, ou do Estado sobre os Municípios não pode significar diminuição de transferências, nem em volume, nem em qualidade.

b) Ações e serviços de saúde são aqueles tradicionalmente desempenhados pelos serviços de saúde públicos, próprios e contratados, incluindo ações de promoção, prevenção, assistência e reabilitação. Ações e serviços públicos de saúde são aqueles de clientela universalizada, não incluindo saneamento, por terem fonte própria de recursos previstos na legislação federal, em especial, lei 8080 , art.32, nem gastos de pessoal inativo e nem pessoal da saúde do GDF, atualmente pagos pelo Ministério da Fazenda, nem financiamento de serviços de saúde próprios para servidores. Só poderão ser incluidos os hospitais 
públicos de outros ministérios ou secretarias estaduais ou municipais, que não de saúde, e mesmo as de saúde, se estes estiverem exclusivamente dedicados à clientela universal do SUS, com vagas disponíveis diretamente ligadas ao gestor único de saúde da área de abrangência.

Art $3^{\circ} \mathrm{O} \S 1^{\circ}$ do art. 156 da Constituição Federal passa a vigorar com a seguinte redação:

"Art.156..." "§ $1^{\circ}$ Sem prejuizo da progressividade no tempo a que se refere o art. 182, $\S 4^{\circ}$, inciso II, o imposto previsto no inciso I poderá:" "I - ser progressivo em razão do

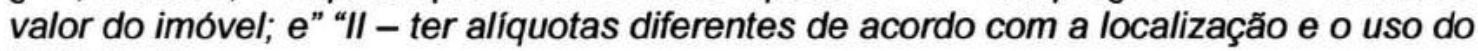
imóvel ..."

\section{COMENTÁRIOS:}

Este é um artigo que "pegou carona" no corpo da lei da saúde. Entretanto, abre a possibilidade de aumento da arrecadação municipal. Localização, uso e valor de imóvel passam a ser motivo de maior valor do IPTU. Um pouco de equidade tributária. Uma de suas defesas é diante de novas obrigações acenarem com nova fonte de recursos para os Municipios. Faz parte de uma técnica de legislação brasileira(....) no meio de uma lei se passa um artigo que não tem nada a ver e que, se viesse sozinho, em lei do mesmo tema, teria dificuldades para ser aprovada. Lembro-me da medida provisória do real, que incluia um artigo permitindo que se vendessem remédios em supermercados e outros estabelecimentos, que não as farmácias! Talvez tenha que se identificar (consegue-se) o grupo que conseguiu apresentar tal proposta para verificar se é auto aplicável ou se, igualmente, requer regulamentação.

Art $4^{\circ} \mathrm{O}$ parágrafo único do art. 160 passa a vigorar com a seguinte redação:

"Art.160 ..." "Parágrafo único. A vedação prevista neste artigo não impede a União e os Estados de condicionarem a entrega de recursos:" "I - ao pagamento de seus créditos, inclusive de suas autarquias;" "II - ao cumprimento do disposto no art. $198, \S 2^{\circ}$, incisos II e III."

\section{COMENTÁRIOS:}

Para facilitar a compreensão, explicitam-se estas "citações circulares": Art.198, 2: A União, os Estados, o Distrito Federal e os Municipios aplicarão, anualmente, em ações e serviços públicos de saúde, recursos minimos derivados da aplicação de percentuais calculados sobre: I - no caso da União, na forma definida nos termos da lei complementar prevista no art.3 (inicialmente no ADCT e depois a cada cinco anos) II - no caso dos Estados e do Distrito Federal, o produto da arrecadação dos impostos a que se refere o art.155 (IPVAICMS-ITCM) e dos recursos de que tratam os arts.157(IR pagamentos seus e $20 \%$ dos 
impostos que a União vier a instituir) e 159 , inciso I, a (21,5 \% do IR e IPI=FPE) e II,(10\% IPI - importação) deduzidas as parcelas que forem transferidas aos respectivos Municípios;ill no caso dos Municípios e do DF o produto da arrecadação dos impostos a que se refere o art.156 (IPTU, ITBVI, ISSQN) e dos recursos de que tratam os arts.158 (IR dos servidores, $50 \%$ ITR, 50 IPVA) e 159, inciso I, b (22,5 de IR e IPI = FPM) e 3 (rateio dos $25 \%$ do ICMS).

Os recursos acima são referentes à repartição de receitas tributárias; FPM,FPE ICMS,etc. No inciso I, fala-se da obrigação da União de destinar dinheiro à saúde. No inciso II, fala-se dos Estados e no III, dos municípios. Inicialmente, tinha havido um lapso na aprovação no Congresso e constavam incisos I e II . Isto queria dizer que a União não repassaria recursos para a própria União, se ela for inadimplente com o SUS, idem, para Estados. E teriam ficado faltando os Municípios. Este lapso foi corrigido na versão do Senado, constando, agora, os incisos II e III... Nesta hipótese, assim seria a leitura: União não passa recursos para Estados e Municípios que não estiverem colocando recursos próprios? Estados não passam recursos para Municipios que não tiverem repassando recursos próprios para a saúde? É este o espírito da lei ? Isto é pior: a população perde as duas fontes de recursos!!! Isto é factivel ou não? A punição, além do não repasse, somaria ao previsto no art. $1^{\circ}$ que redefine o 34, e que trata de intervenção. É importante que se junte a regulamentação do art. $1^{\circ}$ com este.

\section{CONTRIBUIÇÃO ÀS PROPOSTAS DE REGULAMENTAÇÃO:}

Não se pode reter, para pagamento de débitos, as transferências da União a Estados e Municipios e de Estados aos Municipios diretamente referentes ao Sistema Único de Saúde, exceto transferências voluntárias. As receitas dos Estados sobre qual total incidirá o percentual da saúde são as seguintes: IPVA (50\%); ICMS (75\%), ITCM, ir retido na fonte referente a rendimentos pagos; $10 \%$ IPI de exportação, proporcional; FPE; deduzidas as parcelas repassadas aos Municipios. As receitas dos Municipios sobre qual total incidirá o percentual destinado à saúde são as seguintes: IPTU, ITBVI, 50\% ITR, 50\% IPVA, FPM, $25 \%$ do ICMS proporcional, IR retido na fonte referente a rendimentos pagos. Não se incluem os recursos referentes à diferença, a menor ou maior, do FUNDEF, os recursos de repasses estaduais e federais para o SUS e transferências outras voluntárias feitas a Estados e Municipios, recursos arrecadados dos servidores para o sistema de previdência, recursos advindos de empréstimos. Para cálculo de percentual destinado ao Legislativo não se incluem no montante de recursos, aqueles destinados ao SUS e provenientes da União para Estados e Municipios e de Estados para Municipios. 


\section{Art $5^{\circ} \mathrm{O}$ inciso IV do art. 167 passa a vigorar com a seguinte redação:}

"Art.167..."IV - a vinculação de receita de impostos a órgão, fundo ou despesa, ressalvadas a repartição do produto da arrecadação dos impostos a que se referem os arts. 158 e 159, a destinação de recursos para as ações e serviços públicos de saúde e para manutenção e desenvolvimento do ensino, como determinado, respectivamente, pelos arts. $198, \S 2^{\circ}$, e 212, e a prestação de garantias às operações de crédito por antecipação de receita, previstas no art. $165, \S 8^{\circ}$, bem como o disposto no $\S 4^{\circ}$ deste artigo;"

\section{COMENTÁRIOS:}

Modifica o artigo 167, da CF, autorizando a vinculação de receita de impostos para as ações e serviços públicos de saúde. Normalmente, é proibido usar recursos de impostos com finalidades determinadas. A exceção era a educação e, agora, a autorização foi ampliada para as ações de saúde.

\section{CONTRIBUIÇÃO ȦS PROPOSTAS DE REGULAMENTAÇÃO:}

Essas já foram definidas em artigos anteriores, referentes à questão fundamental: o que significam ações e serviços públicos de saúde.

Art $6^{\circ} \mathrm{O}$ art. 198 passa a vigorar acrescido dos seguintes $\S \S 2^{\circ}$ e $3^{\circ}$, numerando-se o atual parágrafo único como $\S 1^{\circ}$ : "Art.198..." $§ 1^{\circ}$ (parágrafo único original." "§ $2^{\circ} \mathrm{A}$ União, os Estados, o Distrito Federal e os Municipios aplicarão, anualmente, em ações e serviços públicos de saúde recursos mínimos derivados da aplicação de percentuais calculados sobre:" "I - no caso da União, na forma definida nos termos da lei complementar prevista no § $3^{\circ}$;" "II - no caso dos Estados e do Distrito Federal, o produto da arrecadação dos impostos a que se refere o art. 155 e dos recursos de que tratam os arts. 157 e 159, inciso I, alinea a, e inciso II, deduzidas as parcelas que forem transferidas aos respectivos Municipios;" "III - no caso dos Municipios e do Distrito Federal, o produto da arrecadação dos impostos a que se refere o art. 156 e dos recursos de que tratam os arts. 158 e 159 , inciso I, alínea b e $\S 3^{\circ}$."

\section{COMENTÁRIOS :}

Modifica o artigo 198, da CF, dizendo que União, Estados e Municipios aplicarão, anualmente, em ações e serviços públicos de saúde recursos minimos, derivados da aplicação de percentuais, calculados sobre: União segundo Lei complementar; Estados e Municipios, de suas receitas próprias especificadas. Depois de tanta mudança de redação, acabou restando incompatibilidade e contradição entre os artigos, parágrafos e incisos. $\mathrm{O}$ caput do $\S 2$ fala em "recursos minimos derivados de percentuais calculados sobre"... para Estados e Municipios fala-se, a seguir, dos montantes, mas em relação à União tira-se a 
regência de "percentuais sobre" e fala-se de "forma definida". Repete-se, da mesma forma que a Lei complementar estabelecerá percentuais, segundo $§ 2^{\circ}$ (para União, Estados e Municipios) e logo a seguir fala de normas de cálculo do montante a ser aplicado pela União. Considera-se a questão de definição do montante de recursos de Estados e Municípios tenha sido explicitado anteriormente.

\section{CONTRIBUIÇÃO ASS PROPOSTAS DE REGULAMENTAÇÃO:}

Estas já se encontram acima, apresentadas no art. $1^{\circ}$.

Art. 6 § 3 "§ $3^{\circ}$ Lei complementar, que será reavaliada pelo menos a cada cinco anos, estabelecerá:" "I - os percentuais de que trata o $§ 2^{\circ}$;" "II - os critérios de rateio dos recursos da União vinculados à saúde destinados aos Estados, ao Distrito Federal e aos Municípios, e dos Estados destinados a seus respectivos Municípios, objetivando a progressiva redução das disparidades regionais;" "III - as normas de fiscalização, avaliação e controle das despesas com saúde nas esferas federal, estadual, distrital e municipal;" "IV - as normas de cálculo do montante a ser aplicado pela União."

\section{COMENTÁRIOS:}

A lei complementar falará dos percentuais, dos critérios de rateio, objetivando a progressiva redução das disparidades regionais, das normas de fiscalização, avaliação e controle das despesas com saúde e das normas de cálculo do montante a ser aplicado pela União. COMENTÁRIOS: Fica claro que quem definirá o quanto, o percentual, a forma de cálculo será uma LEI COMPLEMENTAR . Isto, na prática, quer dizer que sairá da Constituição a definição dos percentuais e passará a ser definido por lei comum. A PEC está vigorando apenas por cinco anos, reavaliada a cada cinco anos. A luta pela PEC foi para constitucionalizar o percentual de recursos destinados à saúde e é preciso estar ciente de que, daqui a cinco anos, isto sai de novo da Constituição (ADCT) para uma Lei Complementar.

Pode-se deduzir que, em decorrência das ADCT, essa Lei Complementar não poderá existir antes de 2005? (art.7). Nessa data, tudo poderá ser resolvido por lei que se aprova por maioria simples? Poderá ser feita Lei Complementar, antes de 2005, que não defina os montantes da União Estados e Municipios para a saúde, mas que trate de rateio, controle e avaliação? E de outros assuntos explicativos desta PEC? Poderá tudo, só não poderá determinar nada a respeito de valores destinados à saúde pela União, Estados e Municipios?

A definição dos critérios de rateio de recursos da União para Estados e Municipios já está de certa forma colocada na 8080, art.35. Essa Lei complementar é hierarquicamente superior à 8080 ? Vai-se revogar o 35 ? Politicamente é sustentável? O art. 35 , da 8080 , tem vários 
limitantes: a) não se conseguiu, em pesquisa inicial do IPEA (Solon e Piola) ver diferença significativa entre a distribuição dos recursos pelos seis critérios, ou simplesmente pelo quociente populacional; b) há uma dificuldade em se ter dados suficientes e confiáveis de uma série de componentes do perfil epidemiológico, populacional e outros, o que invalidaria seu uso; c) não houve, no 35 , nenhuma alusão sob que pesos utilizar aqueles critérios: populacionais, por exemplo, a quem favorecer: o de população mais nova ou mais velha? $\mathrm{Na}$ vacinação, a maior ou menor cobertura? Nos serviços de saúde, quem tem mais já investe mais do seu recurso próprio ou quem tem mesmo e nunca investiu no social? Esses e outros foram motivos suficientemente fortes para até hoje não se brincar de aplicar o 35 . Entretanto, a 8142 diz claramente que, enquanto não se definir os $35 \%$, todo o montante de recursos deverá ser rateado pelo quociente populacional. Isto está sendo descumprido, e tudo que parece querer a administração, é defender, na prática, a idéia de tirar de Estados que estão com per-capita maior para redistribuí-lo aos de menor. Proposta suicida. Defendo, em escritos anteriores, desde 1992, a proposta de, pela igualdade do rateio, chegar-se à equidade na distribuição dos recursos, nivelando por cima, e não no meio, nem por baixo. Essa foi a proposta da NOB-94, abortada no nascedouro pelo Ministério da Fazenda.

Outro particular diz respeito à atribuição da Lei Complementar de determinar as normas de fiscalização, avaliação e controle das despesas com saúde nas esferas federal, estadual, distrital e municipal. Nada até 2005 ? Ou prevalece aquilo que aí está, hoje, com o SNA? A anterior vale até a próxima ou, desde que dito que será numa próxima, fica automaticamente sem valor a anterior?

Esta Lei complementar será superior, ou igual à lei 8689 , que já trata do Sistema Nacional de Auditoria? E, em relação à Lei de Responsabilidade Fiscal? O grande nó critico é compatibilizar as competências de fiscalização, avaliação e controle das três esferas de governo. A União se julga no direito de fiscalizar e controlar as esferas, estadual e municipal a partir da idéia de que é um ente federado superior, que está acima das duas outras esferas e pode por e dispor a respeito. Outro pressuposto é que ela pode controlar a si mesma (controle interno, tribunal de contas nomeado pela União etc.), enquanto seria antiético estados e municipios terem seu controle próprio e de seu respectivo Tribunal de Contas! Dois pesos e duas medidas. Se devesse haver o controle de uma esfera sobre as outras, o principio deveria ser de dupla mão, em que União controlaria Estados e Municipios; Estados controlariam União e Municipios e Municipios controlariam a União e os Estados!!!...

De uma vez por todas, esta questão necessita ficar resolvida. Em inúmeras discussões, de anos e mais anos, a unanimidade - excetuando os controlistas centralistas - é de que a União faria a fiscalização, avaliação e controle do sistema de saúde como um todo, 
auditando a situação geral de saúde, dados de produção, dados de investimento em saúde etc. Os Estados, no âmbito estadual, e os serviços, sob sua jurisdição direta, e os Municípios, os serviços municipais e o conjunto do município.

$O$ pensamento de alguns juristas, é que a fiscalização e controle financeiros seriam feitos da seguinte maneira. (106): a União repassaria recursos para o Estado X, para o Município Y; ela teria que prestar contas de toda a base legal para esse repasse, da documentação competente a ser solicitada a cada Estado e do comprovante de que o Estado recebeu os recursos. A despesa constante seria "x pago ao Estado tal, ao Município tal". Ponto final. Aí pararia a competência do Tribunal de Contas da União (o mesmo que paga, com recursos públicos, plano de saúde próprio para seus funcionários, que paga pós-graduação de seus funcionários com recursos do FAT, etc. etc.) Os Municípios e Estados que recebessem esses recursos, que seriam suas receitas, deveriam prestar contas aos seus respectivos Tribunais, dentro da rotina de todas as outras suas contas. $O$ atual sistema, que diz ser federativo, e que cada esfera mantém sua autonomia teria, nessa prática de prestação de contas, o contra-testemunho. A negação do princípio federativo e a contradição: "olhem municipios: os recursos do ITR que repasso a vocês, o FPM vocês podem prestar contas aos seus Tribunais de Contas, mas este recurso do SUS vocês têm que mandar prestações de contas para mim, MS, segundo minhas normais federais, e para seu TC, segundo as normas deles".

A proposta deve ser aquela que foi aprovada em reunião do Conselho Nacional de Saúde e na Comissão Intergestores Tripartite, e que foi apresentada ao Ministro Serra, que assumiu o compromisso de encaminhá-la, como medida provisória, há já quase dois anos. Nada a se estranhar, pois os recursos Ministério da Assistência Social, repassados aos municípios têm, aprovado em lei, que a prestação de contas deverá ser feita aos respectivos Tribunais e não centralizadamente.

\section{CONTRIBUIÇÃO ÀS PROPOSTAS DE REGULAMENTAÇÃO:}

Os critérios de rateio dos recursos da União para Estados e Municipios, objetivando a progressiva redução das disparidades regionais, deveria ser através de um per capita igual para todos os Estados, cujo padrão seria o maior per-capita atual de Estado, acrescido de $10 \%$. (Aqui devem ser propostos estudos aprofundados do IPEA e de outros institutos).

As prestações de contas das transferências da União a Estados e Municípios deveriam ser feitas aos respectivos Tribunais de Contas, segundo as normas estabelecidas para as prestações de contas gerais de cada estado ou municipio. As ações de auditoria e controle 
deverão ser hierarquizadas. A União controla os serviços próprios e contratados, sob sua responsabilidade, e o sistema de saúde, como um todo. Os Estados controlam os serviços próprios e contratados, sob sua responsabilidade, e o sistema de saúde estadual, como um todo. Os Municípios controlam os serviços próprios e contratados, sob sua responsabilidade, e o sistema municipal de saúde, como um todo.

Art $7^{\circ} \mathrm{O}$ Ato das Disposições Constitucionais Transitórias passa a vigorar acrescido do seguinte art. 77: "Art. 77. Até o exercício financeiro de 2004, os recursos mínimos aplicados nas ações e serviços públicos de saúde serão equivalentes:" "I - no caso da União:" " a) no ano 2000, o montante empenhado em ações e serviços públicos de saúde no exercício financeiro de 1999 acrescido de, no mínimo, cinco por cento;" " b) do ano 2001 ao ano 2004, o valor apurado no ano anterior, corrigido pela variação nominal do Produto Interno Bruto - PIB;" "II - no caso dos Estados e do Distrito Federal, doze por cento do produto da arrecadação dos impostos a que se refere $o$ art. 155 e dos recursos de que tratam os arts. 157 e 159, inciso I, alinea a, e inciso II, deduzidas as parcelas que forem transferidas aos respectivos Municipios; e" "III - no caso dos Municípios e do Distrito Federal, quinze por cento do produto da arrecadação dos impostos a que se refere o art. 156 e dos recursos de que tratam os arts. 158 e 159 , inciso I, alínea b e $\S 3^{\circ}$." "§ $1^{\circ}$ Os Estados, o Distrito Federal e os Municípios que apliquem percentuais inferiores aos fixados nos incisos II e III deverão elevá-los gradualmente, até o exercício financeiro de 2004, reduzida a diferença à razão de, pelo menos, um quinto por ano, sendo que, a partir de 2000, a aplicação será de pelo menos sete por cento." "§ $2^{\circ}$ Dos recursos da União apurados nos termos deste artigo, quinze por cento, no mínimo, serão aplicados nos Municípios, segundo o critério populacional, em ações e serviços básicos de saúde, na forma da lei." "§ $3^{\circ}$ Os recursos dos Estados, do Distrito Federal e dos Municípios destinados às ações e serviços públicos de saúde e os transferidos pela União para a mesma finalidade serão aplicados por meio de Fundo de Saúde que será acompanhado e fiscalizado por Conselho de Saúde, sem prejuizo do disposto no art. 74 da Constituição Federal." "§ $4^{\circ}$ $\mathrm{Na}$ ausência da lei complementar a que se refere o art. 198, $\S 3^{\circ}$, a partir do exercício financeiro de 2005, aplicar-se-á à União, aos Estados, ao Distrito Federal e aos Municipios o disposto neste artigo."

\section{COMENTÁRIOS:}

Acrescenta artigo nas Disposições Constitucionais transitórias em que se definem os recursos mínimos aplicáveis em saúde até o ano de 2004 (quando poderá ser feita lei complementar ou permanecer como está). Para a União, a determinação é que se aplique em 2000, no mínimo o empenhado em 1999, acrescido de $5 \%$. Nos anos seguintes, $\underline{o}$ apurado no ano anterior corrigido pela variação nominal do PIB. Estados, em 2004, $12 \%$ de sua receita própria (já definida no art.6/198), começando de no mínimo $7 \%$, tendo como base o patamar de 99 e a meta de 2004, corrigido em I/5 por ano. Municípios, em 2004, 15\% de sua receita própria (já definida no art.6/198), começando de no mínimo $7 \%$, tendo como base o patamar de 99 e a meta de 2004 corrigido em $1 / 5$ ao ano. Destina 15\% dos recursos da União para o básico (definir em Lei). Determina a aplicação, através de Fundo, e fiscalização 
pelo Conselho. Já se sonhou com 35 bi em 2000 e muito mais até 2004, chegando a 29 bi $(\mathrm{R} \$ 180 / \mathrm{PC}$, para $162,7 \mathrm{mi}$ de brasileiros $=\mathrm{R} \$ 29,5 \mathrm{bi})$. A proposta foi de que se chegasse a um montante, em 2000 , de cerca de 21,3 . (5\% sobre os 20,3 empenhados e considerados como executados em 99). O limite mínimo de negociação possível como participação da União é de 23,5 bi. Seria suficiente para dar um aumento de $40 \%$ para a tabela (muito aquém dos quase $100 \%$ de defasagem só por conta da inflação. Já foi dado ganho de causa para os valores da tabela, aplicados a todo o Brasil, com correção de 9,6\% (usurpada no real). Isso resulta numa correção irrefutável de 1,1 bi (mais do que estão prometendo - 1 bi). A Comissão de Seguridade mobilizou cerca de 3000 pessoas a Brasília, entre usuários, profissionais, gestores e prestadores, tendo como uma das motivações o aumento da tabela em $90 \%$ (vai-se trocar por menos um zero: $9 \%$ valor este conquistado no Judiciário, e não no Congresso!!!). Como ficará a Comissão de Seguridade nessa hora? Como ficará o conjunto dos Deputados em relação às suas bases? De outro lado, Estados e Municípios, ficarão bem amarrados em percentuais de seus orçamentos. Só existem estimativas sem nenhuma segurança de acerto. Não se sabe ao certo quanto investem Estados e Municípios em saúde: nem o montante, nem o percentual. Há alguns estudos parciais que são utilizados nessa estimativa. A receita estimada para Estados seria de $\mathrm{R} \$ 4,644$ bi e para os Municípios, $\mathrm{R} \$ 2,797 \mathrm{bi}$, totalizando $\mathrm{R} \$ 7,441 \mathrm{bi}$.

Mas, isto são águas passadas. Tem-se que contentar com aquilo que se conseguiu e achar que está bem assim. Comemorar o incomemorável. A dúvida maior é quanto à interpretação desses prazos, considerando que a PEC só foi aprovada no segundo semestre de 2000 . A dúvida era: vale como está na PEC a partir de 2000 até 2004, ou passará a vigorar entre 2001 e 2005 ? Se, a partir de 2000, como ficam percentuais não atingidos, não aprovados nos PPAs e nas LDO e LO? Se esses percentuais não forem atingidos em 2000 as metas de 2001 serão feitas considerando como se 2000 tivesse existido? A interpretação, que tem predominado, é que em 2000 já se devesse obedecer a EC-29.

\section{CONTRIBUIÇÃO ÀS PROPOSTAS DE REGULAMENTAÇÃO:}

Definir previamente o periodo da vigência para depois regulamentar. Tanto se válido 2000 , como outra data, ambas as posições requerem regulamentação. Por exemplo, se válido 2000 no papel, e não acontecer ou não pode acontecer, o texto poderia ser alguma coisa com o conteúdo abaixo. A União, Estados e Municípios que no ano de 2000 não estavam dentro dos tetos previstos na emenda constitucional deverão seguir o seguinte: estimar para 2000 os limites de gastos com saúde segundo a emenda constitucional e prever para 2001 
as regras como se em 2000 tivessem sido aplicadas. (Um Município que, em 2000, investiu apenas 5\% em saúde e deveria ter investido no mínimo 7\% em 2001 estará passando de 5\% (2000) para $9 \%$ em 2001. Partindo-se do pressuposto de que 2000 existiu e teria sido $7 \%$.) A União partiria dos 20,3 bi em $1999+5 \%$ em $2000=21,3$ e para 2001 o acréscimo da "variação nominal do produto interno bruto - PIB" (2001/2000) que, em hipótese otimista poderá ser $10 \%$ ( $6 \%$ inflação e $4 \%$ de crescimento real do PIB) o que equivale a 23,43 bi em 2001.

Art. $7^{\circ}$ - $\S 2$ "§ $2^{\circ}$ Dos recursos da União apurados nos termos deste artigo, quinze por cento, no mínimo, serão aplicados nos Municípios, segundo o critério populacional, em ações e serviços básicos de saúde, na forma da lei."

COMENTÁRIOS:

O mais preocupante, em relação ao dispositivo, art $7^{\circ} \S 20$, que obriga a que $15 \%$ dos recursos da União sejam aplicados per capita, nos municipios e para a atenção básica. Ficou dito que isto acontecerá na forma da lei. E até existir esta lei como fica? Seria a mesma lei complementar ou outra lei ordinária? Alguns questionamentos: 15\% para os Municípios como um todo ou divididos entre os Municípios? Para financiar o PAB- Fixo ? Variável? Ambos? Será para custeio? Investimento ou para os dois? Pode-se ter uma idéia sobre isto analisando o que foi gasto em 1999 nos serviços básicos e qual seria a estimativa para o ano de 2000. Em 1999 foram gastos com os serviços básicos, aqui entendido como PAB, incluindo o fixo e variável 2,185 bi que representa $10,76 \%$ do total da União ( $R \$ 20,3$ bi). Para 2000 , considerando o teto da União de 21,3 bi há uma estimativa de gastos com o PAB de $\mathrm{R} \$ 2,509$ bi o que representa $11,78 \%$. A vingar a regra, em 2000 , teriam que ter para gastar no básico $R \$ 3,195$ bi. Seria ótimo se assim for. Quais os receios: colocar isto no básico a partir de recursos novos ou de mudança de rubricas? Colocar estes recursos e redefinir o que seja básico alocando mais e mais procedimentos no básico? Outra questão é se destinado ao básico no custeio ou no investimento. Hoje, ainda que seja livre o uso em ambos, desde que seja no básico, a base de cálculo do PAB foi exclusivamente o valor dos procedimentos, ou seja o atribuivel a seu custeio.

\section{CONTRIBUIÇÃO ÀS PROPOSTAS DE REGULAMENTAÇÃO:}

Para efeito deste artigo a atenção básica é entendida como ... E compreende os seguintes serviços e ações ... (usar, por exemplo, critérios da portaria do PAB e seu anexo, melhorados) o valor corresponde ao custeio destas atividades, ainda que possa ser utilizado para investimento e custeio, incluindo despesas com pessoal. Se forem posteriormente 
pactuadas novas ações básicas este percentual deverá ser reajustado acima do mínimo de $15 \%$.

Art. 7 §3 “Os recursos dos Estados, do Distrito Federal e dos Municípios destinados às ações e serviços públicos de saúde e os transferidos pela União para a mesma finalidade, serão aplicados por meio de Fundo de Saúde que será acompanhado e fiscalizado por Conselho de Saúde, sem prejuizo do disposto no art.74 da Constituição Federal".

\section{COMENTÁRIOS:}

A questão do Fundo de Saúde e de seu acompanhamento e fiscalização pelo Conselho de Saúde, até então colocada apenas em leis ordinárias, como na 8080 e 8142, agora ficou consagrada na CF. Lamentavelmente não no corpo constitucional e permanentemente, mas, apenas nas ADCT. Após cinco anos, pode desaparecer ou apenas ficar numa Lei Complementar. Enquanto isto, comemore-se uma das grandes conquistas da EC-29. A Lei Complementar poderá melhor regulamentar esse item. Existem definições para serem completadas. Alguns pontos: que recursos devem estar dentro do Fundo? Apenas as transferências estaduais, e federais? A alusão da EC aos recursos municipais deixa claro que também os próprios deverão estar dentro do Fundo de Saúde? O mesmo para os fundos estaduais? Quem administra esse fundo, quem é o ordenador de despesas? Quem assina os cheques? Quem presta contas? Quantas contas se pode ter? Como se prestam contas? Etc. etc. Qual a relação com o Conselho de Saúde? Podem ser feitas despesas não constantes do plano? E, inúmeros outros questionamentos.

\section{CONTRIBUIÇÃO ÀS PROPOSTAS DE REGULAMENTAÇÃO:}

Segundo a EC-29, de 13/9/2000, e as leis 8080 e 8142 , todas as instâncias de governo devem ter um Fundo de Saúde que é criado por lei, não tem personalidade juridica, pois pertence ao ente jurídico da esfera de governo que o mantém (União, Estado e Município) , é administrado pelo gestor único de saúde de cada esfera de governo que é o ordenador de despesas, responsável direto pelas despesas e presta contas periodicamente de receitas e despesas, de acordo com a lei 8689 e a LRF - Lei Complementar 101/2000.

O Fundo de Saúde pode administrar várias contas em vários estabelecimentos bancários, todas com a titularidade do respectivo, Fundo de Saúde, sob responsabilidade do gestor. Os recursos com finalidade específica e prestação de contas própria deverão ser administrados em conta separadas para facilitar a administração. Os recursos de receitas gerais, não especificas, poderão ser administradas em contas gerais. 
Todos os recursos de saúde deverão ser depositados e administrados pelo Fundo de Saúde: os recursos próprios da esfera de governo e os recursos de transferências de outras esferas, federal ou estadual. Nos Estados o Fundo Estadual de Saúde recebe e administra os recursos de saúde próprios e as transferências da União e de Municípios. Nos Municípios, o Fundo Municipal de Saúde recebe e administra os recursos próprios e as transferências da União e dos Estados.

Só poderão ser feitas despesas com saúde (União, Estados e Municípios) que estejam previstas no Plano de Saúde, aprovadas pelo respectivo Conselho de Saúde e constantes do orçamento aprovado no legislativo.

O Conselho de Saúde, de cada esfera de governo, tem como obrigação acompanhar e fiscalizar os Fundos de Saúde e, para isto, tem-se que facilitar este trabalho com informações e recursos humanos e materiais para que ele possa desempenhar essas funções.

A prestação de contas deverá ser feita, segundo a CF e leis específicas, em caráter permanente e aberto a todos os cidadãos, incluindo meios eletrônicos e em audiência pública no Legislativo, a cada três meses.

Art.7 §4 “Na ausência de lei complementar a que se refere o art.198 § 3 a partir do exercício financeiro de 2005, aplicar-se-á à União, aos estados, ao Distrito Federal e aos Municipios o disposto neste artigo."

COMENTÁRIOS:

Aqui, de novo, a questão da Lei Complementar. Pode parecer que, de repente, é melhor não ter Lei Complementar pois, assim sendo, mantém-se o parâmetro inscrito nas Disposições Transitórias da CF. Mantém-se a PEC dentro da Constituição. Olhem só o dilema deparado: ou permanece nas Disposições Transitórias com uma participação financeira da UNIÃO pifia, ou sai do texto constitucional e vai-se para uma Lei Complementar para arriscar conseguir mais recursos da União.

\section{CONTRIBUIÇÃO ÀS PROPOSTAS DE REGULAMENTAÇÃO:}

A discutir, na dependência da interpretação da lei complementar.

A QUESTÃO DO VALOR APURADO

A EC diz que, no ano 2000, o montante dos recursos da União para a saúde deve ser "NO MINIMO 5\% A MAIS QUE O MONTANTE EMPENHADO EM 1999; NO ANO 2001 A 2004 O 


\section{VALOR APURADO NO ANO ANTERIOR, CORRIGIDO PELA VARIAÇÃO NOMINAL DO PIB"}

Os considerandos "óbvios" são os seguintes: a) trata-se de, no mínimo - portanto, qualquer montante maior é possível, desejável e constitucional b) montante empenhado significa o montante do orçamento comprometido no ano em curso, incluindo aquilo que pertence ao ano, mesmo que fique para ser pago no ano seguinte; c) é claro, evidente, patente, lógico, que o termo "valor apurado", nesse contexto e nesta frase, significa o mesmo que "montante empenhado", da frase acima. (Poderia ter inúmeros significados e conter uma enorme gama de categorias de dados! Não se pode interpretar - a não ser por má fé - que o valor apurado que ai está, não se refira ao montante empenhado acima!) d) o fulcro da questão é a expressão "ano anterior": refere-se sempre a 1999 ou a cada um dos anos subseqüentes? Para 2001, o ano de 99 ou o ano de 2000?

A conclusão, pela simples leitura acima é que: o montante de recursos de 2000 será o montante empenhado em 1999, acrescido de 5\% ; em 2001 o montante empenhado (valor apurado) de 2000 acrescido da variação nominal do PIB; em 2002, o montante empenhado (valor apurado) de 2001, acrescido da variação nominal do PIB; assim por diante, em 2003 e 2004.

Entendendo-se dessa maneira - com o que concordam inúmeros técnicos, por princípio, e pela leitura e interpretação da letra constitucional (EC-29) - é que o que foi empenhado em 1999 serve de base, exclusivamente, para o ano de 2000. Se em 2000, conseguiram-se mais recursos que a variação nominal do PIB, o montante de 2001 será calculado em cima, também, do conseguido a mais em 2000 e assim por diante. Sempre tendo como base o ano anterior. Tudo porque a EC-29 explicita que o que definiu foi o "mínimo", não fechando, nem questionando, nem obstaculizando que possa ser mais que o minimo.

Entretanto - com o poder que Ihes é conferido o Ministério da Fazenda (leia-se Malan) e a Advocacia Geral da União (leia-se FHC e equipe palaciana) entendem (só eles) o seguinte:

"É diferente o entendimento do que está na EC. valor apurado no ano anterior deve reportar sempre à base 1999. O valor de 1999 que será a base de cálculo de cada ano. Assim, ainda que, em 2000, tenha sido conseguido mais que os cinco por cento previstos como mínimo para 2000, o que vai valer para 2001 é a base 1999, mais os cinco por cento (de 2000) e só em cima disto a variação nominal do PIB."

Observação importante é que os números utilizados, aqui, referem-se ao orçamento global do Ministério da Saúde, por uma questão de facilidade de compreensão. A hipótese polêmica é sobre a inclusão, ou não, de pessoal, inativos, dividas e outros. 
Hipótese A : Em 1999, o montante empenhado pelo Ministério da Saúde foi de $\mathrm{R} \$ 20,334$ bi. (valor sob a observação acima!) Em 2000, pela EC-29, deveria chegar, no mínimo, a $\mathrm{R} \$ 21,351$ bi mas, pelo prestígio pessoal do Serra e sua força de pressăo, chegou-se a $\mathrm{R} \$ 23,544$ bi aprovados ainda que o executado tenha sido de $\mathrm{R} \$ 22,699$ bi. Qual a lógica seguinte? A lógica é que, para 2001, o montante fosse o executado de 2000 (22,699 bi), acrescido da variaçăo nominal do PIB (aplicado $12 \%$ para o período - mas ainda não fechado e a estimativa é de $18,83 \%$ ), o que equivaleria ao mínimo de $\mathbf{R} \$ 25,422$. (Conseguiram-se aprovar 26 bi, devido ao recurso extra do saneamento básico - Alvorada que não se computa como de rotina, pois apenas, excepcionalmente, foi colocado no orçamento do Ministério da Saúde).

Hipótese B : (defendia por Malan et caterva) em 1999, os mesmos R\$20.334 bi; em 2000 os mesmos $\mathrm{R} \$ 23,544$ bi (EC mais a diferença conseguida pelo Serra); em 2001 (aí começa a diferença que vai repercutir por todos os demais anos), toma-se a base 1999 (20,3 bi), acrescente-se apenas os $5 \%$ de 2000 (vira 21,351 ) e, a isto, acrescentam-se os $12 \%$ da estimada variação nominal do PIB , o que equivale a R\$23,913 bi.

Na Hipótese B o Ministério da Saúde (toda a população brasileira) perdem, oficialmente, a importância de $\mathrm{R} \$ 1,5$ bi. Isto é para ser chorado ou comemorado? Nada de acréscimo sobre acréscimo conquistado. Cada ano, a saúde, para aumentar seus recursos - com aumentos congelados na base de 1999 - terá que lutar tostão a tostão.

Resultado da luta dos oito anos, entre a PEC-169 e a EC-29, foi a restrição aos recursos básicos e uma interpretação maquiavélica mais restritiva, ainda para este ano de 2001 e os anos seguintes. Preparem-se para ver o que (na dependência do Governo e do Congresso) accntecerá ou poderá acontecer, a partir de 2005, quando esse montante puder ser definido não mais pela Constituição, mas por uma simples Lei Complementar.

“Corn relação às receitas vinculadas da União, a Emenda Constitucional 29 dispõe que, durante o periodo de transição, aplica-se o disposto no Art. 77, I, do Ato das Disposições Constitucionais Transitarias. Dessa forma, para o ano 2000 será aplicado o montante empenhado em ações e serviços públicos de saúde no exercício financeiro de 1999, acrescido de, no mínimo, cinco por cento (ADCT, art. 77, I, "a"); e para os anos de 2001 a 2004, o valor apurado no ano anterior, corrigido pela variação nominal do Produto Interno Bruto - PIB (ADCT, art. 77, I, "b"). Com relação ao valor a ser aplicado no ano de 2000 não há controvérsias, já que o texto constitucional é claro ao definir a sua fórmula de cálculo (montante e•mpenhado em 1999 mais cinco por cento). Entretanto, existe uma grande discussão atualmente sobre o conceito de "valor apurado no ano anterior", expresso no texto constitucional e referente aos valores que a União deve aplicar no periodo de transição. A controvérsia gira em torno de duas interpretações: A primeira interpretação analisa o termo "valor apurado no ano anterior" como sendo o valor apurado para o ano 2000 acrescido das variaçōes nominais do PIB ano a ano. Convencionou-se denominar esta interpretação como "base fixa", ou seja, o 
"valor apurado no ano anterior" é o calculado para o ano 2000 com base na aplicação da fórmula expressa no art. 77, I, "a", dos ADCT, aplicando-se, sobre esse valor, ano a ano, a variação nominal do PIB. Por essa interpretação não importa o quanto a União venha a empenhar efetivamente a partir de 2000 , mas apenas qual a variação do PIB a ser acrescida ao montante definido para o ano de 2000. Esta interpretação é defendida pela Procuradoria Geral da Fazenda Nacional e pela Advocacia Geral da União. A segunda interpretação analisa o termo o "valor apurado do ano anterior" como sendo o efetivamente apurado no ano anterior. Por essa interpretação o valor apurado no ano anterior pode ser superior ao valor resultante do cálculo feito através da primeira interpretação. Isto porque o montante efetivamente empenhado nos anos do período de transição podem ser superiores ao montante calculado com base na interpretação PGFM/AGU. Essa interpretação vem sendo chamada de base móvel, ou seja, o valor apurado no ano anterior seria calculado ano a ano, de acordo com o efetivamente empenhado em ações e serviços públicos de saúde. Para essa corrente, a interpretação da AGU/PGFM serviria, tão somente, para estipular o mínimo a ser aplicado pela União. Caso verifique-se que foi aplicado valor maior, o que vale como base é esse valor maior e não mais o piso (valor empenhado em 1999 acrescido de 5\%). A interpretação encontra apoio em pareceres da Consultoria Jurídica e da Subsecretária de Planejamento e Orçamento do Ministério da Saúde e do Conselho Nacional de Saúde, constituindo-se em recomendação deste Grupo de Técnico." (50)

Imaginem como ficam os da base executiva municipalista, sobre quais costados caem todas as mazelas da insuficiência e ineficiência do SUS, com menos recursos a serem transferidos!!! Já havia lamentado, anteriormente que, pelo fato de o Ministério da Saúde não ter executado até dezembro de 2000 o montante aprovado (perdeu cerca de 845 milhões de reais, entre o orçamento aprovado e o executado! gerou superávit!), a perda acumulada até o ano 2004 seria de 5 bi de reais! E, agora, a prevalecer a interpretação restritiva e o bloqueio do orçamento do Ministério da Saúde, a saúde vai correr o risco de perder algo próximo de 10 bilhões de reais até 2004 .

O Boletim Semanal do CONASS, de 5-9-01 (97), traz a notícia e a posição da entidade sobre o assunto:

"A Frente Parlamentar de Saúde realizou uma manifestação, no último dia 29, contra as alterações promovidas na EC $n^{\circ} 29$. Esta Emenda foi aprovada para dotar a saúde de recursos mínimos e crescentes, a cada ano, até o exercício de 2004. Assim, se estabeleceu que o setor teria, em 2000, recursos iguais ao "montante empenhado em ações e serviços públicos de saúde no exercício financeiro de 1999 acrescido de, no mínimo, 5\%".

De 2001 a 2004, o orçamento da saúde seria o "valor apurado no ano anterior, corrigido pela variação nominal do Produto interno Bruto-PIB". Isso assegurava, a partir de 2000 , recursos anuais crescentes para a saúde, segundo a variação do PIB. Entenderam os parlamentares, ao aprovarem a EC 29, que o crescimento econômico (expresso na variação do PIB) deve ser direcionado para melhorar a vida da população. O Ministério da Fazenda entendeu de outro modo. Já em 2001, o orçamento da saúde foi reduzido. Como a despesa com saúde, em 2000 , foi superior à regra de 1999 , mais $5 \%$, a Fazenda mudou a conta: em vez do valor 
de 2000 , mais o PIB, calculou o valor de 1999 , mais $5 \%$ (menor do que o efetivamente gasto em 2000). Só então acrescentou a variação nominal do PIB, ou seja, corrigiu a verba da saúde pelo mínimo. Essa alteração, no método de cálculo, faz uma grande diferença no orçamento da saúde. Segundo o Deputado Urcisino Queiroz, em 2001, foram subtraídos R\$1,2 bilhăo que correspondem a, aproximadamente, um ano de internações no SUS. Para 2002, a LDO deveria restabelecer a forma correta do cálculo dos recursos mínimos para a saúde, evitando outra manobra do executivo. Mas não o fez. E a emenda de partidos da oposição, que retomava o cálculo correto, foi derrotada pela maioria, composta pelos partidos do governo. Por causa disso, o orçamento da saúde para 2002 será diminuído em $\mathrm{R} \$ 1,4$ bilhão. "É um erro que pode matar, pelos prejuizos que causa aos muitos programas do Ministério da Saúde e ao próprio SUS, que garante o atendimento médico e hospitalar a mais de 120 milhões de brasileiros", concluiu o Coordenador da Frente Parlamentar de Saúde, Deputado Urcisino Queiroz.

\section{A QUESTÃO DA VARIAÇÃO NOMINAL DO PIB}

Não se esquecer, ainda, a polêmica sobre os anos, com base nos quais se vai medir a variação nominal do PIB. Existem três maneiras: 1) toma-se a variação passada: para 2002 a variação entre 2000 e 1999 2) toma-se a variação para 2002, aquela entre 2001 e 2000 3) toma-se a variação para 2002, aquela entre 2002 e 2001. O que significam essas possibilidades? Imagine-se o orçamento para 2002 preparado, através, da LDO e da LO encaminhada o Congresso no segundo semestre de 2001 para aprovação, como foi, até dezembro de 2001. Que dado já se tinha disponivel da variação do PIB em 2001 para ser usado para o orçamento de 2002 ? O dado concreto é a variação entre 2000 e 1999. O dado que ficará disponivel no meio do ano de 2002 será a variação entre 2001 e 2000 . O dado da variação entre 2002 e 2001 só será disponivel em 2003. Essa última hipótese é a defendida pela turma da economia... a pior possivel! Como cobrar a execução orçamentária de 2002, durante o ano de 2002, baseado em dados que só serão conhecidos em 2003 ? O que se defende é que os dados de comparação para 2002 sejam o crescimento nominal do PIB, entre os anos de 2001 e 2000 . O que cresceu o PIB no ano anterior aplica-se ao ano seguinte. Não há outra maneira razoável. Não vale para trás, pois fica extremamente defasado. Não vale para a frente, que se torna incontrolável. O correto na opinião de inúmeros técnicos, incluindo-se ai o sábio e ponderado Prof. Elias Jorge, amigo de jornada, é a utilização do parâmetro mais próximo do ano em curso e com informação disponivel e aplicável. 
"Há, por fim, um problema quanto ao índice de variação nominal do Produto Interno Bruto - PIB que deve ser adotado para o cálculo dos montantes referentes aos anos de 2001 a 2004 (CF, art. 77, I, "b"). O obstáculo refere-se ao fato de que, para apuração dos recursos mínimos aplicáveis às ações e serviços públicos de saúde em 2002, deve ser adotado o indice referente a 2001. Há, assim, o inconveniente de que o índice referente a 2001 só estará disponível no segundo semestre de 2002, o que impede que o índice seja utilizado para a apuração do valor no momento de elaboração e votação da lei orçamentária de 2002, que ocorre ainda em 2001. O fato se repete nos anos seguintes, até 2004. O Grupo Técnico entende que a solução para essa questão deve contemplar a criação de mecanismo de aplicação automática a partir de estatísticas oficiais acerca do PIB, o que assegura um processo transparente e desprovido de dúvidas para definição dos recursos destinados à saúde. O dado disponível quando da elaboração e votação da Lei Orçamentária é o do ano anterior àquele em que se elabora o orçamento, portanto, para o orçamento do ano de 2002 o dado disponível é o do ano de 2000." (50)

\section{CONCLUSÃO:}

Na luta da saúde, dos últimos anos, tinha-se o slogan, "carro-chefe" na aprovação da PEC 169: "Recursos definidos, definitivos e suficientes para a saúde!".

Aconteceu, entretanto o lastimável. A PEC, da luta de sete anos, não é a EC-29 aprovada. A PEC-169 e a 32-A foram adulteradas, amputadas, estupradas. Restou um "monstrengo", que é a EC-29. A União fica responsável para garantir no mínimo $5 \%$ a mais do que os recursos empenhados em 1999 e, nos anos seguintes, a correção pelo valor nominal do PIB. Os Estados deverão investir, no mínimo, 12\% e Municipios, no mínimo 15\% de seus orçamentos próprios . Quem não tiver atingido esses patamares mínimos, terá um prazo de tolerância para atingi-los, entre os anos de 2000 e 2004. Deverão iniciar, no mínimo, com 7\% em 2000, e nos anos seguintes, cobrir a diferença.

Nestas siglas e percentuais esconde-se uma postura de governo de, mais uma vez, deixar o social à deriva. A proposta foi totalmente manipulada pelo Governo. Não foi o Ministro da Saúde o mentor (para seu projeto pessoal hoje é essencial que a saúde tenha mais recursos), mas teve que se submeter às autoridades econômicas que usaram seu próprio argumento de que não se deveriam vincular receitas constitucionalmente... (já existiam cerca de 30 vinculações, e não é a saúde que vai colocar o Estado a perder). As autoridades econômicas, com o beneplácito de FHC, desresponsabilizaram a União e descarregaram mais ônus sobre Estados e Municípios. Diminuiram os recursos de contribuição da União para a saúde e aumentaram os percentuais de Estados e Municipios

Esse golpe de mestre - aprovar uma PEC pela qual tanto se lutava, mas com parâmetros e valores que a equipe econômica desejava - abalou todo mundo. Parlamentares, supra partidariamente, Iutaram pela PEC original. Aprovaram ,baseados na necessidade de obter 
mais recursos para melhorar o aporte de recursos para Municipios, Estados e os prestadores filantrópicos e privados lucrativos. No momento exato, houve a virada do conteúdo correspondente a pelo menos, umas dez propostas. Das ortodoxas, às heterodoxas passando pelas estapafúrdias. E aí, o governo exerceu pressão junto aos parlamentares progressistas de vários partidos: "se vocês não aprovarem esta PEC, vou dizer à população que a culpa de não termos dinheiro para a saúde é de vocês".(O dito esteve implícito, dispensando verbalização.) Depois da apelação, só restou a saudade de uma PEC boa e suficiente e o autoconsolar-se: "Dos males o menor. Não conseguimos tudo, mas conseguimos um pouquinho. Pelo menos, apertamos os Estados que são os que menos investem em saúde. Etc. Etc..." O próprio Ministro Serra sabe bem o que aconteceu: "Digase de passagem que a "PEC da saúde, ao contrário do que afirmam alguns, na média, não exige mais dos Estados e dos Municípios do que da União."FSP-9-7-00. A honestidade obrigou-o a recorrer ao atenuador "na média". Sabe bem ele que, na realidade, o ônus ficou com Estados e Municípios. Ë impossível não reconhecer que Estados e Municipios estão retirando de seus recursos gerais, e a União nada tira de suas receitas fiscais. Apenas repassa recursos da seguridade que é a única, constitucionalmente habilitada, a recolher para as três esferas de governo se desincumbirem de suas funções. Não só não repassa do dela, mas também desvia recursos da seguridade para outras áreas, o que é inconstitucional.

A prova cabal de que a EC atual é ruim para a saúde, e que dificilmente se conseguirá comprometer a União para cobrar-lhe responsabilidade, é mostrar as alternativas de resultados. Com a PEC 169 , de autoria de Eduardo Jorge, teriam possibilidade de conseguir, de hoje em diante, R\$ 42 bi. Com a PEC de Mosconi, hoje, 28 bi e, em 2004, R\$ 39 bi. Com a proposta do Conselho Nacional de Saúde, semelhante à da PEC-169, mas com ajustes, R\$38, hoje, e R $\$ 44,25$ em 2004. USANDO OS MESMOS PARÃMETROS, COM A PEC APROVADA E QUE VIROU A EC-29, TERIAMOS EM 2001 R\$29 BI , PODENDO CHEGAR A R\$33 BI EM 2004. (Que fique bem claro que esses dados são estimativos, pois ninguém sabe corretamente qual o montante dos gastos com saúde no conjunto dos Estados e Municipios. Entretanto, os erros possiveis e previstos, são constantes para todas as hipóteses (Se aumentarmos a base dos Estados e Municípios para a EC-29, temos que fazer o mesmo para a PEC-169 e outras ,e todas crescerão.)

O caminho aponta para uma saida "esquizofrênica". Cidadãos, administradores, parlamentares, técnicos, associações, universidades (ou parte delas), durante anos e mais anos, buscamos uma forma de financiamento definido, definitivo e suficiente para a saúde. A luta mais antiga è de 35 anos atrás e, a mais recente, de 20 anos. Conquistou-se na CF a 
fonte, mas não a explicitação do quanto. A primeira PEC para correção dessa omissão data de 93 e, de lá para cá, muito se discutiu. Não se caminhou, a não ser no segundo semestre de 99. A expectativa era sempre de definir os recursos e chegar aos valores trazidos à saúde pela CF e por suas modificações posteriores (CPMF e outras). Quando estava tudo preparado, pronto para a votação no Congresso, os negociadores do Executivo mudam a proposta de duas formas: no conteúdo das fontes e base de cálculo (anti-seguridade) e no quantitativo dos recursos.

Esquizofrênico é o grupo de batalhadores do direito à vida e à saúde se posicionar: aceitar a proposta indecorosa, que nem mesmo corrige a inflaçăo de 99/2000,ou romper e dizer que assim não dá e é preferivel deixar como está? Estratégica e taticamente o que é pior? Ou melhor?

O Governo sabe muito bem como colocou a faca na jugular dos progressistas. Se não se aprovasse essa proposta, o Governo iria alegar, sempre ,que só não se definiu o montante de recursos para a saúde, porque "os parlamentares progressistas eram contra".

Só amarração para Estados e Municipios e nenhuma para a União! A expressão mais correta ,talvez, seja a de "algemas para Municípios e Estados e laço frouxo de cetim para a União".

Tendo sido esta a decisão do Congresso cabe , a contragosto, acatar o decidido.

A estratégia agora é que, pelo menos, se "enfeite a corda do enforcamento", corrigindo minimamente as distorções maiores através de uma ampla regulamentação.

Estão colocadas algumas sugestões para começo de discussão. Algumas podem passar ou podem ficar para a parte de regulamentação, por decreto. O importante é estar socializando essa discussão o quanto antes.

Para encerrar, faça-se um cálculo na "conta simplista do vendeiro". Se executado pelo Ministério da Saúde, o orçamento otimista e enxertado (dinheiro do Projeto Alvorada) no ano de 2001 - é o equivalente a 26 bi de reais. Se dolarizado esse montante, para um dólar médio de 2001 (continua-se otimista!) ao valor de 2,35 reais, ter-se-á um orçamento de 2001 , de US\$ 11 bi. Vale lembrar dos tempos do "tudo pelo social", do Governo Sarney, em 89 , ano em que a União gastou em saúde os mesmos cerca de 11 bi de dólares para uma população bem menor que a atual. A época, o governo federal colocava mais dinheiro em saúde??? Em 1989 o valor per capita para a saúde (dinheiro da União) era cerca de 80 dólares e 12 anos depois, em 2001 - na melhor das hipóteses (super-hiper-otimista), 
chegou-se a pouco mais que 65 dólares por habitante ano!!!... E,o Governo continua defendendo a falácia de que os recursos para a saúde dobraram!!!

A notícia recém- divulgada pela imprensa é que chegará a 102,9 bilhões o montante de recursos para o PROER salvar os bancos. Agora, os estatais. Por que entraram em crise? Quem levou a perdas: os programas sociais redistribuitivos ou os grandes empréstimos de caráter político e político-partidário? empréstimos para empresas pobres de sócios milionários? R\$102 bi são quase quatro orçamentos anuais da saúde da fonte federal! Para salvar o BAN-SUS (o que financia o direito universal, eqüitativo e solidário ao cidadão) continua não existindo PROER.

Ficar contente? Rejubilar-se que, pelo menos, não se perdeu tudo? Aplaudir a EC-29 e seus percalços - uns conhecidos e outros que só o tempo mostrará? Ao contrário, o caminho é Indignar-se contra isto e transformar nossa luta em atos e fatos. Entender e explicar isto a todo mundo. Explicar à sociedade, aos cidadãos. Atiçar conselheiros nacionais, estaduais e municipais. A plenária de conselheiros. Provocar o Congresso. Desencadear ação dos aliados da saúde na Procuradoria Geral da República.

O próximo desafio é fazer a regulamentação da EC. Os artigos introduzidos determinam a elaboração de uma Lei Complementar ,que regulamente o que lá está. É um desafio, pois, se não se ficou contente com o texto constitucional, pode-se ficar mais decepcionado com aquilo que ficar regulamentado. $O$ texto constitucional pode ser melhorado, clareado, como também, pode ser piorado e mais enfraquecido, ainda. É, ou não é um desafio tentar participar da elaboração da lei complementar , que vai ser apresentada ao Congresso Nacional para discussão e aprovação ?

11. O FINANCIAMENTO FEDERAL PARA A SAÚDE NO GOVERNO FHC - NOB 2001 EUFEMISTICAMENTE DENOMINADA DE NOAS-2001

Um comentário apenas é apresentado, pois a NOAS/NOB não seria objeto principal das discussōes que se esgotariam no ano de 2000. Como a negociação da NOAS-2001 se deu no decorrer do ano 2000, a opção foi fazer um breve relato do que ocorreu com ela.

O pacote chegou ao modo de NOBs anteriores, de novo em meio a negociações não concluidas e cheia de indefinições. Aprovação final se deu na CIT e no CNS, na virada do ano ,e publicada no início de 2001. Segundo minha leitura e de inúmeros técnicos, uma mudança radical na operacionalização do SUS, em momento totalmente inadequado. No 
início de 2001, ocorreu a entrada de novos prefeitos e secretários de saúde, praticamente em todo o Brasil, exceção se faça aos reeleitos, e que mantiveram seus Secretários de Saúde.

Já nasceu com o novo no seu nome. Seu batismo de Norma Operacional da Assistência à Saúde - NOAS, caracteriza bem seu espirito. Marcar terreno. Dizer ao "mundo" que o Ministro e equipe eram outros diferentes dos que antecederam. NOB seria coisa do passado. Agora tudo seria novo. Até o nome: NOAS.

Uma enxurrada de portarias, com respectivas instruções normativas, e mais portarias e portarias. Muda tudo. Só não muda o espírito recentralizador, que teve início na NOB-96, agravou-se na NOB-98 (NOB-96 modificada) e consagrou-se na NOAS-2001.(71)

Hoje, os recursos estão todos centralizados e fatiados. Os Municipios, para receberem recursos, mesmo estando em plenitude de gestão, têm que se submeter a mais de duas dezenas de formas. Regras próprias. Recursos financeiros incomunicáveis. Decisão centralizada e execução de subalternos descentralizada.

Esses são alguns comentários de análise da versão oficial da NOAS, que foi precedida de uma infinidade de versões. Umas, com discussão e aval e outras, como simples imposição do Ministério da Saúde.

Que fique clara a posição de defesa inconteste do processo de regionalização e hierarquização e, que este seja feito de forma ascendente. A defesa é de que se faça uma descentralização,com ênfase na municipalização e com regionalização ascendente.

Há de se concordar, como muitos, com grande parte do texto da NOAS, principalmente se modificada a concepção básica da descentralização proposta. Existe discordância do princípio que descentralização se faça de cima para baixo, com processo comandado pelo MS e pelos Estados, e não como processo pactuado de baixo para cima, em que estejam em igualdade de possibilidade de decisão as três esferas de governo,posição que defendemos. Isto fica mais preocupante, principalmente quando a proposta contraria a CF e a Lei 8080 e fatia a gestão do SUS, recentralizando a alta complexidade nas mãos do MS, a média nas mãos do Estado, deixando aos Municípios, apenas, desconcentradamente, a assistência básica... ampliada.

Os comentários aqui são pontuais, buscando o aprimoramento do documento em sua aplicação prática. Ainda que vários gestores mostrassem isso antes, foram vencidos pelas negociações e imposições da CIT e pelo espetacular "balão" dado ao Conselho Nacional de Saúde. 
Por vezes, gestores legisladores, através de equivocos de portarias, deixam de cumprir os preceitos constitucionais e da legislação maior infraconstitucional. Portarias, instruções, normas e circulares não podem inovar, em desobediência à lei maior.

Uma outra observação prévia. Depois de vários meses de debates, o Ministério da Saúde fez um movimento final de apressamento de aprovação, mesmo restando questões essenciais, ainda , por definir. Mostrou assim, uma postura de pouca ética e até suspeita em sua intencionalidade, na medida em que a maioria dos gestores que deveriam implantá-la, só iriam tomar posse a partir de janeiro. Não se poderia esperar mais alguns meses para tratar com aqueles que iriam enfrentar os próximos quatro anos de gestão? Muitos iniciantes na função gestora, entre eles,terão que implantá-la.

Uma análise sumária. A primeira questão a ser esclarecida é a citação na portaria que a NOAS foi aprovada pelo Conselho Nacional de Saúde ,em 15-12-2000. Conselheiros e Coordenação do Conselho aprovaram o documento do Conselheiro Carlyle, que versava sobre descentralização. Não se aprovou a NOAS em seu inteiro teor, como aqui é citado. CNS ou cúpula do MS, um dos dois ou os dois, estão possivelmente equivocados. Houve pressão do Conselho Nacional de Saúde e sua Coordenação, para que entidades partícipes da CIT aprovassem a NOAS ,ainda que sempre dissessem que não estavam avalizando aquela NOAS. Nem sua integra, nem em parte dela, mas apenas o documento do próprio CNS sobre o processo de descentralização. No quinto, considerando o início da portaria, está literalmente escrito: "considerando as contribuições do CONASS E CONASEMS e seguidas da aprovação da CIT e CNS em 15-12-2000, resolve aprovar a norma operacional da assistência à saúde". Nada a reclamar: Aprovada ficou. Publicada está, nestes termos, e com a aprovação do CNS. Ex-libris.

Logo na introdução, é lembrado como avanço o papel dos Estados na organização de consórcios intermunicipais. Esta é uma questão em que não há unanimidade em considerar avanço. Estados houve que, politicamente, impuseram consórcios verticais , até com fins "eleitoreiros". Consórcios cartoriais que năo se efetivaram. Muito pelo contrário, queimaram possibilidade futura de os municipios se entusiasmarem em montar um consórcio público, ascendente, ético e sem manipulações.

Parte-se da premissa correta de que o espaço territorial-populacional e a área de abrangência político administrativa não comportam ou correspondem a uma rede regionalizada (pouquissimas capitais brasileiras conseguem ser independentes e ter 0 sistema regionalizado e hierarquizado completo dentro dela.) Agora, a partir dai, apresentar como solução, colocar o sistema centrado em micro-macro-regiões, sob responsabilidade 
coordenadora do Estado, pura e simplesmente, é outro equívoco. Onde vai ficar explicitado que tal divisão não pode repetir as atuais Diretorias Regionais dos Estados? Estes espaços são administrados exclusivamente pelo Gestor Estadual, sem nenhum outro poder controlador, como legislativo próprio. Historicamente, o espaço das Regionais foi loteado entre os deputados da região. É um tipo de desvio da regionalização, que precisa ser prevenido e contornado.

Item 1- Traz uma afirmativa inócua ou errônea: “a regionalização é estratégia de hierarquização." Seria isto? Busca de equidade? Toda a organização do SUS não é pela garantia da equidade? Regionalização e hierarquização não são dois dos princípios organizativos do SUS ,que se completam, ou um é estratégia para se conseguir o outro?

Item 2 - Plano Diretor de Regionalização. Não dá para se acertar, de uma vez por todas a questão dos vários planos que se superpõem? É essencial que se faça, antes de tudo, a adequação física e temporal do PLANO DE SAÚDE à Lei do Plano Plurianual, Lei das Diretrizes Orçamentárias e Lei Orçamentária Anual. Não se vê nenhuma preocupação de se defender e fazer essas ligações essenciais, para que ambos os planos não continuem como peça de ficção. Correndo paralelamente sem ligação. Em segundo lugar, a multiplicidade de planos: Plano de Regionalização, o Plano de Atenção Básica o Plano de Medicamentos, de Vigilância Sanitária, de Controle de Doenças etc. etc. Serão Planos "em consonância" ou parte do Plano de Saúde?

Item 4, A e B - São introduzidos inúmeros novos conceitos para que o sistema funcione: Região de Saúde (macro-região, micro-região) Módulo Assistencial, Módulo Territorial etc. Sem contar que questionam o termo resolutividade como não existente no dicionário - ainda que filólogos digam que a língua é dinâmica e que o termo é cabível e compatível com seu significado, ao passo que "resolubilidade", segundo o Aurélio, significa a qualidade de resolvivel. O que queremos dizer é que o problema foi resolvido ou que o problema tem possibilidade de ser resolvido, ou seja - resolvivel?

Item 5.1 - De novo ,o medo dos acréscimos não pactuados. Anuncia-se que a SAS publicará, em 30 dias, regulamentação especifica sobre o Plano Diretor de Regionalização. E a Tripartite, será ouvida? Nada consta, apesar do pacto de que constaria. Ou virá o "pacotaço"? Corrigiram em alguns itens a necessidade de pactuação prévia na CIT, mas em vários itens continua a mesma prática de decisão plenipotenciária do MS. Sozinho.

Item 6.4 - O PAB será ampliado e a definição de valores será, em 60 dias, pela SAS e SPS. Definição de valores numa situação tão crucial, vai ser decidido só pelo MS. Assim, mais uma vez, a CIT nem o Conselho Nacional de Saúde terão participação. Ainda que a Lei 8080 
(portarias são escravas da lei e não podem nem infringi-las nem inová-las) determine que qualquer mudança no financiamento deva passar pelo CNS. Existe uma grande dúvida: este dinheiro complementar do PAB será um dinheiro novo ou será subtraído dos recursos referentes à média complexidade?

Nesse mesmo item está escrito que Municípios com PAB superior ao PAB ampliado não receberão diferença. Mais sufoco para os Municípios que terão aumentadas suas responsabilidades e, não terão recursos aumentados. Esses Municípios deveriam ser identificados (para se saber seu volume) e saber como ficarão. Serão prejudicados duas vezes se esses recursos resultarem de subtração daqueles destinados à média complexidade. O PAB continuará sendo a forma subreptícia de induzir à cesta básica do Banco Mundial? (145)

Item 8 - Ainda a questão do financiamento. Vai-se estabelecer um valor per capita para os procedimentos de média complexidade - aqui, por insistência - vai-se ouvir a CIT. Como será calculado esse valor? Todos sabem que será feito um estudo de valores médios da produção dos últimos meses ou ano e ai será estabelecido o valor cabivel. O contraditório do contraditório é o discurso de não se fazer nenhum pagamento, por produção/tabela (fonte de corrupção e distorções, sic), substituido pelo "modernoso" que seria a orçamentação, por contrato de gestão etc. etc. Espetacular, caso houvesse o mais singelo estudo do custo dos procedimentos para a elaboração da tabela SUS! Só que, na hora de se estabelecer este valor per capita, (justamente por falta de estudos de custos), a prática tem sido tomar os mesmos valores condenados da tabela. Série histórica de tabela tem inúmeras distorções, pois a mesma é iniqua e imoral, historicamente. Vamos fazer per capita e acertar um valor justo. $A$ iniqüidade havida com o PAB vai se repetir aqui. $O P A B$ foi calculado em 96 no valor de 12 reais por habitante é implantado, em 98, no valor de 10, congelado até hoje 2001. Qual a correção legal de 12 de setembro de 96 a fevereiro de 2001 ? Isto é iniqüidade ou justiça? Como discutir a expansão da equidade com um financiamento iniquo e imoral? Vaise congelar o iniquo e depois deixar nas mãos do Município, sem transferências de fundos, a responsabilidade de adequar ao mercado ou valores de compra de serviços. Uma novidade prevista - ajusta, como luva, à atual política falaciosa - aumentar o PAB, por exemplo, em mais 0,50 centavos ou 1 real, não como correção, mas para compensar os novos procedimentos a ele agregados. Vai se afirmar, em seguida, que subiu o PAB em $10 \%$, o equivalente a mais de um ano de inflação!

Item 9 e ss. - Entra-se na qualificação das microrregiões de saúde. Está criada uma outra instância de governo, sob a tutela dos governos estaduais, onde os Municipios serão meros efetores manipulados. Quem se habilita é a micro-macro-região. Quem vai analisar é a SAS 
e haverá aprovação na CIT. Se cada micro-região comportar dez municípios, serão 500 microregiōes a serem analisadas pela SAS e aprovadas pela CIT, à razão de cinqüenta micro-regiōes, por reunião mensal da CIT. Ou então, está se apostando que não serão tantas as microregiões e que o sistema não "colará". Não se trata de ser contra nenhuma regionalizaçăo, mas de defender parte de outro pressuposto que é a autonomia municipal. 0 poder municipal. Municipios se unem e assumem a responsabilidade em determinada região. Eles se habilitam e se qualificam. A região de saúde está sob sua autoridade de esfera de governo, com a cooperação técnica e financeira da União e dos Estados (CF $30, \mathrm{VII})$.

Item 10, E - Mais uma vez, explicita-se a possível hegemonia do Estado nesse espaço de regionalização. Os Municípios farão compromisso com o estado, e não, eles próprios entre si. Se mais não houvesse, só isto seria suficiente para se pensar o que poderia estar por detrás disso tudo, senão a defesa da estadualização, em detrimento à municipalização.

Item 11.1 - Fica introduzido um item não encontrado nas versões de estudo, anteriores. Deve ter vindo para cobrir uma lacuna. Mas, sabe-se que quando a matriz é falsa fica mais falsa, ainda , a sua emenda. Olhem só o absurdo: Municipios que têm, em seu território, laboratório, raio $\mathrm{x}$, ultra-som obstétrico, mas não tenham os demais requisitos para estar na Plena do Sistema, vão ter que pedir licença ao município-sede de sua micro região, celebrar um acordo com ela, para sua população não ter que ir para outra cidade, tendo serviços na própria! É o absurdo dos absurdos , conseqüente ao fato de se ter limitado quem pode estar na Gestão Plena. Esta prerrogativa, agora, só dada segundo a existência de determinados compromissos e serviços. Não mais como princípio autonômico dos Municípios que deveriam estar recebendo suas cotas financeiras e complementando os serviços não existentes em seu território, e disponiveis nos municipios vizinhos! Não seriam mais todos os municipios que poderiam pleitear nem a gestão plena do básico, nem a plena do sistema. É uma reviravolta na proposta de descentralização da NOB-93, que possibilitava a habilitação, mais pela vontade e capacidade de gestão, e menos, pela existência de serviços em território próprio.

Item 13.1 - Entrega-se ao Gestor Estadual a adoção de critérios para a organização regionalizada das ações de média complexidade. Onde estão os Municipios nessa discussão? Isso é uma estadualização. Os Estados não mais fazendo a descentralização para os municípios, mas a desconcentração.

Item 14 - Volta-se a dar atribuiçōes exclusivas ao Estado como a PPI. Fala-se em coordenação pelo Estado, sem citar a realização conjunta com os municipios. 
Item 14.1 - Novamente, os parâmetros físicos e financeiros e prioridades ficam entregues à definição exclusiva do Estado. Grave: suprimiu-se aqui a expressão da versão aprovada na última CIT ,de 2000, a qual remetia à aprovação da CIB.

Item 14.3 - Introduziu-se na versão publicada " o valor médio das AlHs", dentre os critérios objetivos para a programação de internações hospitalares. Outra questão perigosa pois, enquanto os valores médios são baixos, o número de internações é um e, quando sobe o valor médio as internações, com o mesmo teto, o número de internações tem que cair automaticamente, pois o teto não consegue pagar mais. Diminui-se o número de internações por falta de recursos e não na dependência de melhora dos serviços ambulatoriais. Esperase estrangulamento do sistema.

Item 15.2. Cristaliza uma das questões que falharam no sistema de referência, até agora. A tese de se transferir automaticamente a Municípios pólo, cotas físicas e financeiras dos Municipios dependentes mostrou-se ruim, ineficiente, por vários motivos analisados a posteriori. Defendo a tese de que os recursos devidos a um determinado Município devam estar em suas mãos, para que ele decida onde comprar, e ele próprio fazer os repasses financeiros gestor-gestor, até mesmo poder mudar de município suas referências, diante de circunstâncias reais de mais facilidade e eficiência. (Exceto a alta complexidade que deve ser estruturada por um sistema resseguro-simile.)

Item 16 -Faz-se a apologia da tripartição, definindo como campo hegemônico do Ministério da Saúde a alta complexidade-custo. Aqui, mostra-se bem claramente a proposta em desenvolvimento: a tese da atual administração é de que o Ministério da Saúde cuide da Alta Complexidade, Estados, da Média e Municipios ,da Baixa.. A preocupação é que não se encontra nem na Constituição Federal, nem na Lei 8080, o fundamento desta posição usurpadora do nivel central. Em nenhuma lei está dito que a alta complexidade é propriedade de execução do Ministério da Saúde. Nada escrito nas competências da Lei 8080. A recente portaria 132, do GM-MS (66), confirma esta posição. Dá-se um passo a mais nessa "reengenharia" administrativa: o pagamento da alta complexidade será feito diretamente pelo Ministério da Saúde. Não se entende, até agora ,com que base jurídica serão feitos pagamentos a instituições públicas e privadas, sem convênio-contrato direto entre elas e o Ministério da Saúde! Pela nova Portaria retorna-se oficialmente ao passado, como objetivo permanente. Qual é a posição da Procuradoria Juridica e do TCU. E qual é a opinião da Auditoria e Controle do MS, que condena Estados e Municípios que pagam sem convênio (aqui sim, com toda razão)? Espera-se o mesmo rigor. Para amenizar o impacto da decisão acima é colocado que o Estado é um pouquinho solidário com isto tudo, em relação à alta complexidade. 
Item 17 - O que é "gestão política da alta complexidade" transferida ao Estado? Este novo termo administrativo-sociológico significa o quê? Em seguida a ele, vem a expressão que "serão intransferiveis as funções de definição de prioridades." Intransferíveis da União para Estados? De Estados para Municípios? Lamentavelmente ,os municípios ficam fora de toda a discussão sobre a alta complexidade. A questão fica entre União e Estados!

Item 18,D - Os Municípios que contem com alta complexidade e estiverem em gestão plena do sistema, além de tudo, farão os pagamentos de seus prestadores. Isto já foi mudado pela portaria 132, do GM, que transfere o pagamento direto ao Ministério da Saúde, que vai pagar ao prestador (com o qual não tem nenhum documento autorizativo de pagamento: nem contrato, nem convênio). Esses Municipios farão todas as medidas administrativas, mas... 0 pagamento será direto do Ministério da Saúde, isto sob o argumento - veraz - de assegurar o comando único sobre os prestadores! Como ter comando único se tem que seguir todas as regras centralizadas e o pagamento é centralizado? Quem diz o que deve ser feito e quem paga: municipio ou União e Estado? Qual o poder de negociação? qual a autoridade desse Município sobre o prestador?

Item 18,1 - Vem a questão dos municípios em gestão do Básico e que têm serviços de alta complexidade e que serão administrados pelo Estado, que poderá "por concessão" delegar tais funções aos gestores municipais, e que serão pagos pela União, diretamente aos prestadores?

Item 20.B - No momento em que se fala do FAEC, com o financiador de parte das ações de alta complexidade-custo, transfere-se ao Ministério da Saúde (SE-SAS) a competência para regulamenta-la em 60 dias. Sem ouvir o Conselho, nem a Tripartite? Isto é que foi pactuado? Item 21 - O MS definirá os valores de recursos destinados ao custeio da assistência de alta complexidade para cada Estado. Cadê CIT ? E, nos Estados, estes definem os tetos municipais. Cadê CIB?

Item 24.3 - Fala-se em PPI e ,no documento sobre ela, a ser apresentado a CIT,já está em circulação e precisa ser analisado, com cuidado, pelos vários gestores. Quem já acessou ao documento da PPI, preocupa-se. Há coisas excelentes e necessárias, mas outras terrificas. Os municipios, ainda uma vez, serão submersos na burocracia de processo a que serão submetidos.

Item 34 e ss. - Falam do controle e avaliação, fogem da polêmica que é a discussão da Auditoria, separando-se propositadamente dela. Todos esses campos são aqueles que o SNA tem que trabalhar. Mais uma vez, fugiu-se da definição de quem faz o quê no SNA, em cada um de seus componentes Federal, Estadual e Municipal. Medo da contenda com o 
pessoal do SNA? Necessidade de reforçar esse poder autoritário e militaresco, escondido atrás da porta, intimidando os gestores da ponta do sistema? Esta, naturalmente mais fraca e a única a ter que cumprir miriades de normas, que muitas vezes nem os próprios auditores conhecem todas. É possivel que nem mesmo aqueles que a ditam e fazem, conheçam profundamente as suas e as demais de um e outro!

No item 40 - Introduz-se a questão da regulação,em um enfoque que, é reducionista e equivocado. A função de regulação do Estado na área da saúde, exercida pelas três esferas de governo, é muito mais que a acepção tomada em alguns lugares como "regulação da oferta de serviços", criando-se centrais reguladoras envolvidas na oferta e demanda de serviços de urgência, pré hospitalares, hospitalares, leitos, consultas e outros. Esta é uma visão reducionista . Regular, dentro do SUS, é muito mais que tudo isto e deve envolver todo o SUS. A NOAS poderia melhorar e aprofundar tal regulação. As atuais centrais de regulação estão tendo funções muito mais próximas de uma central de vagas, encaminhamentos, segundo normas e rotinas. Pouco. A regulação deve ser de todo o sistema e uma das fatias, bem pequena, aliás, diante da enormidade das ações do SUS, é a de regular a oferta de serviços! Não se pode queimar uma palavra genérica, para, pomposamente, limitar sua compreensão utilizando-a apenas para denominação de uma parte. A Central de Regulação, se alguma divisão administrativa-funcional assim devesse ser chamada, só poderia referir-se a todo o processo de regulação do SUS, incluindo-se, ai, a regulação administrativa, a de serviços, a de epidemiologia, a de sanitária, de exercício profissional, de ética etc. etc.

Item 42 - A questão dos hospitais públicos sobre gestão de outro nível. Aqui ,mais um risco e um equivoco. A critica ao sistema de pagamento, por produção, está sendo substituída pelo pagamento de um fixo por metas estabelecidas. Muito cuidado. O caminho sugerido passa pelo teto médio, de meses ou ano de pagamento, por produção. Valores de uma tabela defasada, sem lógica, fruto de clientelismos e pressões de especialidades médicas e prestadores de especialidade. Nessa hora, se tratar de um hospital municipal, sob gestão do Estado, podem ter certeza que este hospital será prejudicado com pagamento por metas. Já com os hospitais estaduais, colocados sob a gestão do Municipio, a pressão pode ser ao contrário. O Estado - respaldado até pelo próprio Ministério da Saúde - tem muita força para sugar dos Municipios valores até exorbitantes para pagamento de suas metas estabelecidas. O passado e o presente apontam.

Capitulo III - Trata das condições de habilitação e desabilitação dos Estados e Municipios, segundo a nova categorização. Municipios só poderão habilitar-se na Gestão Plena da

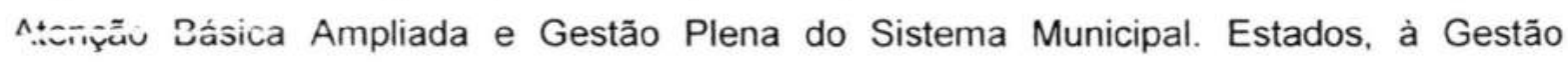


Avançada do Sistema Estadual e Gestão Plena do Sistema Estadual. Isso deixa uma porção de situações na área de limbo, como é comentado, à frente, nas disposições transitórias.

Item 46,2 - Pelo entendido, há um corte fatal. Está escrito : "cabe à Secretaria Estadual de Saúde a gestão do SUS nos municípios não habilitados, enquanto for mantida a situação de não habilitação." É um ponto de vista, em que pode haver engano, mas, se se seguir, à risca, tudo que se tem que fazer, grande parte dos Municípios brasileiros cairá na situação de não habilitado. Salvo, se houver aprovações cartoriais. Aqui vale uma outra observação, o que vai ser condicionante não é a existência de determinados serviços no próprio território. Isto está garantido no anexo 3 (realização ou referência), ainda que exista relutância dentro do MS em se aceitar esta idéia. Querem cercar os Municípios que não têm todos os serviços básicos em seu território para que eles não sejam habilitados, aí, em gestão nenhuma. Os Municípios precisam ter a capacidade gerencial e política de cuidar da saúde de sua população, com os serviços possiveis existentes em seu território e comprando fora o não existente na relação gestor-gestor. Isso é descentralização em Estado Nacional, dentro da perspectiva federativa?

Item 48 - Fala em Plano Municipal de Saúde, agora com uma obrigação: deve contemplar a Agenda de Compromissos Municipais. O que é isto? De onde tiraram mais esta? Este "deve contemplar" significa que está acima ou abaixo do plano? PPA,LDO,LO, PLANO DE REGIONALIZAÇÃO, PLANO DE SAÚDE, AGENDA DE COMPROMISSOS MUNICIPAIS, articulada com a PPI e, ainda mais um de QUADRO DE METAS e mais os Planos e Compromissos da vigilância sanitária, epidemiológica, nutrição, farmácia... e ainda o Pacto de Indicador da Atenção Básica. Não estará havendo exagero? Será necessária uma racionalização nesse emaranhado de documentos que se misturam, imbricam e, na sua complexidade, acabam não significando mais nada. Como ficam mais de $70 \%$ dos pequenos Municipios brasileiros?

$\mathrm{Na}$ habilitação estadual, responsabilidades, requisitos e prerrogativas compativeis com as novas funções dadas aos Estados. Muitas, que ele próprio não cumpriu, e outras, que fazem parte da carta de intenções de dar aos Estados mais status de gestor de saúde.

Capitulo III.2 - Trata da desabilitação. É necessário ter esse mecanismo dentro do SUS. A única coisa essencial não ficou clara em lugar nenhum. Nada foi dito sobre o direito de defesa prévio do município em desabilitação. Os critérios que sujeitam à desabilitação não estão precisos, o que permite a arbitrariedade do guarda da esquina.

Não há que se concordar com a suspensão imediata, feita centralmente pelo Ministério da Saúde. Acho inegociável o direito de defesa, ou da mínima explicação, devido à 
complexidade das relações em nível local e a possivel interferência político-partidária, o autoritarismo de auditores etc. etc. Cometer-se-ia uma injustiça com a penalização prévia sem assegurar o direito constitucional de defesa.

A desabilitação automática, quando o gestor deixar de pagar prestadores,por mais que sessenta dias após a apresentação da fatura, é uma arma de dois gumes. A Portaria de Contratos e Convênios, em vigor, desde outubro de 1993 (67) delimita em 5 dias, após o recebimento dos recursos federais, o prazo de pagamento aos prestadores. Dizer, oficialmente, que punição só haverá quando o prazo for maior que sessenta dias, incorre-se num contra-senso. Com prazos menores de inadimplência, já se deve correr o processo pelos trâmites normais - com direito de defesa. Não se pode pedir aval da CIT para a inconstitucionalidade de não se dar o direito de defesa.

Capitulo IV, 46 das Disposições Transitórias. Há, ai, uma questão não clara. Fala-se que os Municípios poderão habilitar-se em duas condições de gestão Plena do Básico Ampliada e Plena do Sistema. No item 58 , em que se trata dos já habilitados em Gestão Plena do Básico, não há prazo para passar ao básico ampliado. Portanto, admite-se a existência permanente, além do não habilitado, daqueles que queiram continuar apenas na Plena do Básico? Mais à frente, fala em rebaixar de plena do sistema, encaminhando-se a que? $\AA$ plena do básico que não mais existe? Se não há mais Plena do Básico, e voltam todos ao estado de desabilitação, como fica o pagamento dos serviços prestados, se não se paga mais nada por tabela, por produção? E os Estados serão rebaixados a que? Na verdade,há uma grande confusão na habilitação entre os itens $46,58,59,60,61,64.1$ etc. É preciso se entender e descomplicar.

Quanto aos anexos, a preocupação sempre é o valor a ser estabelecido para as novas competências na atenção básica, e o valor per capita para as ações de média complexidade. Nada é demais, desde que o financiamento acompanhe de maneira, no mínimo justa, para que os Municipios e Estados possam dar conta do que fazer.

O Anexo IV demarca, ainda uma vez, a nova filosofia do processo descentralizatório, já criticada. Traz o teor de um documento a ser celebrado entre o Município e o Estado, estabelecendo compromisso de um municipio fazer referência aos demais. Ao contrário do que se defende: a união livre de Municípios, pactuando, comprometendo-se entre si, e Estado e União, garantindo cooperação técnica e financeira aos Municipios.

O Anexo $\mathrm{V}$ traz o compromisso de pagamento dos Municipios aos hospitais estaduais colocados em sua jurisdição e sob sua gestão. A opinião cautelosa, em relação a isto, já foi 
emitida no devido lugar. Muito cuidado, sob dois aspectos: primeiro uma tabela defasada e, segundo, o poder maior do Estado de tiranizar e exigir mais do que deve.

Para completar as ilegalidades e o processo recentralizatório, já foi engendrada a NOAS 2002 que faz alguns remendos na NOAS 2001, confirmando erros, equívocos e politica inconstitucional e ilegal de saúde. Não se corrigem os problemas, aprofundam-se as mudanças, na contramão das leis.

A defesa da Regionalização é consenso entre técnicos e políticos. O que se questiona, é o modo como quer o nivel central fazê-la. Anseia-se pelo aperfeiçoamento do processo, com o aval do Conselho Nacional de Saúde.

Para finalizar uma análise sobre as NOBs e NOAS publicadas nos últimos 12 anos pelo Ministério da Saúde lembre-se Cordoni (101) em considerações sobre a politica de saúde nos anos 90, a reforma sanitária e as NOBs publicadas: "Universalização e equidade... não parecem ter sido buscadas pelos elaboradores das normas (NOBs)". 
V - DISCUSSÃO 


\section{DISCUSSÃO SOBRE OS EIXOS ESSENCIAIS DA BASE LEGAL DO FINANCIAMENTO FEDERAL DA SAÚDE}

\section{CONCEITO DE SAÚDE, PARA EFEITO DE FINANCIAMENTO}

\subsection{O LEGAL}

A Saúde está inclusa dentro do conceito de Seguridade Social - CF 194 (16). Introduz-se, pela CF de 1988, a idéia do pós-guerra, na Europa, de se criar um "estado de bem-estar social". A Seguridade Social brasileira traz o conceito de conjunto integrado de ações destinadas a assegurar o direito à saúde, previdência e assistência social.

A questão mais polêmica é o que se deve entender como saúde, o que incluir no "conjunto de ações" para assegurar saúde. A amplitude desse conceito é complexa. Envolve desde os condicionantes gerais até as providências muito especificas, como a ministração de um medicamento. O conceito ampliado de saúde, discutido na Introdução, incluindo todos os condicionantes gerais, não cabe aqui como campo da saúde, quando se trata do financiamento. Não é o reducionismo de querer colocar o conceito de saúde aqui, somente na sua concepção assistencial. Por convenção, o campo especifico da saúde, como área de saber e exercício profissional, diz respeito à assistência, em sua visão ampla, em que se inclui o tratamento, a recuperação e reabilitação, mas também todas as medidas de promoção e prevenção, especificas do setor saúde. É uma convenção. Mas a delimitação é essencial, não só para efeito de financiamento, mas também para efeito de identificação do campo especifico da saúde. Não se entenda isto erroneamente. Não se está questionando, nem negando a determinação do econômico, do social, do intersetorial nas condições de saúde da população. $O$ que se discute a delimitação do campo de trabalho e atuação, especificos da saúde e de seu pessoal. Por essa razão refere-se à intersetorialidade, preceito constitucional para a saúde: a integração da saúde com outros setores. Não se pode entender esta convicção dos determinantes da saúde-doença, como responsabilização da Saúde por todos os outros setores. Nem sempre se quer entender desta maneira, e isto tem, mais que ajudado, atrapalhado o setor saúde. Não se usa o conceito expandido para se agregarem mais recursos à saúde. O contumaz é, sob o pretexto de conceito amplo de saúde, retirar recursos "especificos da saúde" para outras áreas, como saneamento, meio 
ambiente, coleta e destino de lixo, merenda escolar, assistência social integral, melhorias viárias e outras.

Esse entendimento da saúde é imprescindivel para o a delimitação do objeto do financiamento em saúde. Lenir Santos, eminente jurista, dedicada ao estudo do direito sanitário, procura dirimir uma dúvida antiga sobre qual seja o significado exato que se deva dar ao termo "recursos destinados à saúde" (85)

"Que fique desde logo delimitado o campo de aplicação dos recursos destinados à saúde, por dois motivos: I. os investimentos decorrentes de políticas econômicas, sociais e cientifico-tecnológicas destinadas a equacionar e combater os fatores determinantes e condicionantes da saúde da população e proporcionar bem-estar físico, mental e social às pessoas e à coletividade - não podem ser classificados como recursos investidos no SUS; são investimentos prévios às ações e aos serviços de saúde propriamente ditos e devem ser realizados, teleologicamente, visando reduzir os dispêndios diretos com saúde; tal entendimento não restringe o amplo conceito de saúde. A saúde permeia a maioria das atividades econômico-sociais desenvolvidas pelo governo, e por isso cabe ao Ministério da Saúde participar da formulação de politicas e interagir com outros órgãos e setores públicos; 2. Para caracterizar os gastos com a atenção integral e cobertura total no âmbito do SUS, que tenderão a crescer na exata medida em que os Poderes Públicos deixarem de enfrentar, com decisão política e aporte suficiente de recursos, os fatores determinantes e condicionantes do estado de saúde: saneamento básico, meio ambiente, habitação, alimentação, transporte etc Além do mais, como a EC-29 de 13/9/2000 definiu percentuais mínimos de investimentos da União, dos Estados, do Distrito Federal e dos Municipios para a saúde pública, essa demarcação é imperiosa, sob pena de diversas ações e serviços públicos passarem a ser considerados como saúde, subterfúgio que poderá reduzir os investimentos na área da saúde."

O CONASS solicitou um balizamento oficial do MS sobre a interpretação devida dos termos

da EC-29, de 13/9/2000, o que resultou em Nota Técnica do MS SIS/DPI n. ${ }^{\circ}$ 002/2001 (98)

"É verdade que, atualmente, não existe um conceito normativo e explicito de ações e serviços de saúde. E esta realmente será uma das tarefas da Lei Complementar, que, conforme já se disse, esmiuçará o conteúdo da Emenda. Enquanto isso não ocorre, o que se deve fazer, então, é buscar a orientação dada pelo Capítulo II do Título VIII da Carta, onde encontram-se os parâmetros de identificação do que sejam ações e serviços de saúde. Com efeito, o primeiro dispositivo do aludido capitulo, o artigo 194, que insere a saúde no âmbito da seguridade social, estabelece que esta será organizada de acordo com os seguintes objetivos, dentre outros: 1) universalidade da cobertura e do atendimento; 2) uniformidade e equivalência dos benefícios e serviços às populações urbanas e rurais; 3) seletividade e distributividade na prestação dos benefícios e serviços. Para que se tenha idéia da tamanha importância desses objetivos, ao tratar especificamente da saúde, ainda no mesmo capitulo, o legislador constituinte foi enfático, repetindo-os no artigo 196: "A saúde é direito de todos e dever do Estado, garantindo mediante políticas sociais e econômicas que visem à redução do risco de doença e de outros agravos e ao acesso universal e igualitário às ações e aos serviços para a sua promoção, proteção e recuperação."

A tentativa de regulamentar a EC-29 levou a que se produzisse um documento de entendimento comum sobre a definição das ações e serviços de saúde. Grupo Técnico que 
elaborou este documento foi formado por membros do Conselho Nacional de Saúde, da Associação Brasileira dos Membros dos Tribunais de Contas, do Ministério Público Federal, do Ministério da Saúde, do Conselho Nacional de Secretários Estaduais de Saúde, do Conselho Nacional de Secretários Municipais de Saúde, e Consultores Legislativos e de Orçamento e Finanças do Congresso Nacional, convidados pelas Comissões de Seguridade Social e Família da Câmara Federal, e a de Assuntos Sociais do Senado (50)

"A EC 29 vinculou recursos para serem aplicados em ações e serviços de saúde, sem entretanto fornecer a abrangência deste conceito. A Lei Complementar deverá estabelecer um conceito normativo de "ações e serviços públicos de saúde", importante na medida em que definirá precisamente o universo de atividades que tem seu financiamento contabilizado e cujas despesas devem ser acompanhadas, para fins de cumprimento do dispositivo constitucional. Os principais critérios para a definição do conceito são o de eqüidade e universalidade de acesso aos serviços de saúde em todos os niveis de atenção à saúde, tal como determinado pelo art. 194, parágrafo único, $I$, da CF, e reafirmado pelo art. $7^{\circ}$ da Lei $n^{\circ} 8.080$, de 19 de setembro de 1990. Já existe consenso de que as seguintes ações e serviços devam ser relacionadas entre as ações e serviços públicos de saúde beneficiadas pela vinculação de receitas:Ações e serviços constantes nos planos de saúde dos Municipios, Estados, Distrito Federal e União; ações e serviços executados pelos órgãos do Sistema Único de Saúde; controle de qualidade, pesquisa científica e tecnológica, e produção de insumos em saúde (medicamentos, imunobiológicos, reagentes, sangue e hemoderivados, equipamentos para a saúde, dentre outros); vigilância sanitária; vigilância epidemiológica e farmacoepidemiológica; saúde do trabalhador;assistência terapêutica e farmacêutica; ao nível domiciliar e de pequenas comunidades, ações de saneamento básico e meio ambiente associadas a controle de vetores; e ao nivel de ações complementares e especificas para grupos de risco nutricional, ações de alimentação e nutrição. Por outro lado, há consenso de que as seguintes ações e serviços não devam figurar entre as atividades beneficiadas: Gastos com pessoal inativo; senviços suplementares ao Sistema Único de Saúde, dedicados, total ou parcialmente, ao atendimento de clientelas fechadas (excluidos em função da incompatibilidade com o critério de universalidade de acesso); e serviço da dívida (juros e amortização); ações de preservação e correção do meio ambiente, realizadas pelos órgãos de meio ambiente dos entes federativos e por entidades não governamentais; ações de saneamento básico de redes públicas $e$ tratamento de água e esgotos, realizadas por companhias, autarquias e empresas de saneamento com recursos provenientes de taxas e tarifas, e ações de limpeza urbana e remoção de resíduos sólidos (lixo) realizadas por órgãos municipais especificos ou empresas terceirizadas."

O referido documento foi assumido pelo Plenário do Conselho Nacional de Saúde para subsidiar a Lei Complementar a que se refere a EC-29, de 13/9/2000. Essa posição foi reiterada, mais uma vez, na reunião ordinária do CNS de dezembro de 2001.

A partir dai, pode-se concluir que ainda que a CF tenha definido saúde em sua maior amplitude, não será este o objeto de financiamento com os recursos vinculados pela EC-29, como sendo da saúde. "A saúde é um direito... garantido mediante politicas sociais e econômicas que visem à redução do risco da doença e de outros agravos e ao acesso 
universal e igualitário..." CF 196. As políticas econômicas e sociais visam: a redução do risco-doença e o acesso universal. Do econômico e social dependem, não só as condições gerais de vida da população, mas também o acesso aos serviços de saúde. Na lei 8080 , art. $3^{\circ}$, são colocados os fatores determinantes da saúde: casa, comida, saneamento, o meio ambiente, o trabalho, a renda, educação, transporte, lazer. No Parágrafo Único do mesmo Art. $3^{\circ}$, existe uma frase, cujo texto tem servido e sido usado para aumentar a amplitude da concepção de ações de saúde financiáveis pelos recursos específicos da saúde-seguridade social: "dizem respeito também à saúde as ações que, por força do disposto no artigo anterior, se destinam a garantir às pessoas e à coletividade condições de bem-estar físico, mental e social." Em se interpretando assim, tudo significaria saúde e seria financiável pelos recursos específicos e próprios das ações e serviços de saúde.

Ainda relacionado ao tema, vale lembrar a questão do saneamento e do meio ambiente. Está presente no Art. 200 da CF e no Art. $6^{\circ}$, inciso II da Lei 8080 , que é competência do SUS a atribuição de "participar da formulação da política e da execução das ações de saneamento básico". É de consenso que as ações referentes ao saneamento e ao meio ambiente refiramse diretamente à área da saúde, dado que estão determinando as condições de saúde da população. Só que, ao se convencionar como serão financiadas as ações referentes à saúde, combinações e acordos foram feitos explicitando de onde seriam retirados os recursos para cada tipo de atividade. Foram, assim convencionados, não partindo pelo seu conceito básico: para as ações diretas e mais especificas de atenção às pessoas, serão utilizados recursos da seguridade social, compostos de contribuições e de recursos orçamentários fiscais; para as ações de saneamento, acordou-se o que vai explicitado na Lei 8080 , art. 32 §3 "As ações de saneamento que venham a ser executadas, supletivamente, pelo SUS, serão financiadas por recursos tarifários especificos e outros da União, Estados, Distrito Federal e Municípios e, em particular, do Sistema Financeiro de Habitação". O termo "recursos tarifários" refere-se às taxas especificas que são pagas pelo saneamento (água, esgoto e lixo). Os recursos outros deverão vir do orçamento fiscal e já alocados diretamente para as ações de saneamento.

O mesmo se diga das ações de assistência social, que tem recursos alocados dentro da Seguridade Social, com finalidade especifica. Devem ser mantidos e administrados, através de fundos especificos de assistência social.

\subsection{O REAL}


Várias distorções ocorreram na prática, em relação à amplitude desse conceito. A questão do saneamento foi uma delas, pois historicamente o MS, através da FUNASA, realizou e financiou ações de saneamento básico em alguns municípios de sua área de atuação. De outro lado, a construção de fossas, como medida controladora de endemias, esteve, de alguma maneira, contemplada no orçamento do MS. Não massivamente, mas com alguns poucos recursos em relação ao montante, recursos estes nem sempre executados na proporção do que estava orçamentado.

O grave distúrbio de alocação de recursos ocorrido no financiamento federal para a saúde foi a colocação de dois tipos de despesas consumidoras de grande soma de recursos. Essas despesas acabaram sendo indutoras de que Estados e Municípios começassem a fazer o mesmo. Abaixo uma análise do ocorrido sobre essas duas questões: despesas com INATIVOS e PAGAMENTO DE DIVIDA. 
GASTOS COM SAÚDE E PAGAMENTO DA DÍVIDA E INATIVOS - MS 1993-1999

\begin{tabular}{|c|c|c|c|c|c|c|c|c|c|c|}
\hline DESCRIÇÃO & 1993 & 1994 & 1995 & 1996 & 1997 & 1998 & 1999 & 2000 & 2001 & 2002 \\
\hline \multicolumn{11}{|l|}{$\mathrm{R} \$ \mathrm{BI}$ de Dez-2001 } \\
\hline GASTO BRUTO- MI R\$ DEZ 2001 & 18,62 & 18,87 & 26,98 & 23,41 & 28,11 & 25,62 & 26,37 & 26,67 & 25,04 & 27,31 \\
\hline GASTO COM INATIVOS & 1,36 & 1,34 & 2,38 & 2,41 & 2,35 & 2,55 & 2,41 & 2,58 & 2,39 & 2,20 \\
\hline GASTO COM DIVIDA & 0,09 & 0,54 & 2,43 & 0,81 & 2,38 & 0,81 & 0,20 & 1,80 & 0,25 & 0,47 \\
\hline SUBTOTAL DÍVIDA & 1,45 & 1,88 & 4,81 & 3,21 & 4,73 & 3,36 & 2,62 & 2,76 & 2,51 & 2,66 \\
\hline \multicolumn{11}{|l|}{ R\$ BI de Dez-2001 } \\
\hline GASTO LIQUIDO S/ INATIV. & 17,25 & 17,53 & 24,60 & 21,01 & 25,76 & 23,06 & 23,96 & 24,10 & 22,65 & 25,11 \\
\hline GASTO LÍQUIDO S/ DIVIDA & 18,53 & 18,34 & 24,55 & 22,61 & 25,73 & 24,81 & 26,16 & 26,49 & 24,79 & 26,84 \\
\hline GASTO LÍQUIDO T & 17,16 & 16,99 & 22,17 & 20,20 & 23,38 & 22,25 & 23,75 & 23,92 & 22,54 & 124,0 \\
\hline PERCENTUAL DE PERDA & $\%$ & $\%$ & $\%$ & $\%$ & $\%$ & $\%$ & $\%$ & $\%$ & $\%$ & $\%$ \\
\hline PERDA \% COM INATIVOS & 7,91 & 7,67 & 9,69 & 11,45 & 9,13 & 11,07 & 10,06 & 9,67 & 9,55 & 8,05 \\
\hline PERDA \% COM DIVIDA & 0,47 & 2,93 & 9,90 & 3,58 & 9,26 & 3,26 & 0,78 & 0,67 & 0,99 & 1,71 \\
\hline PERDA TOTAL \% DIV+INA & 8,46 & 11,07 & 21,72 & 15,91 & 20,25 & 15,10 & 11,01 & 10,34 & 10,00 & 9,76 \\
\hline \multicolumn{11}{|l|}{$\mathrm{R} \$ 1,00$} \\
\hline VALOR PER CAPITA (PC) & $\mathrm{PC}$ & PC & PC & $\mathrm{PC}$ & PC & $\mathrm{PC}$ & PC & $\mathrm{PC}$ & $\mathrm{PC}$ & $\mathrm{PC}$ \\
\hline PER CAPITA SOBRE BRUTO & 120 & 120 & 170 & 145 & 172 & 155 & 157 & 157 & 145 & 158 \\
\hline PC SOBRE LÍQUIDO S/INAT. & 112 & 112 & 155 & 130 & 158 & 139 & 143 & 142 & 131 & 146 \\
\hline PC SOBRE LIQUI. S/DIVIDA & 120 & 117 & 154 & 140 & 157 & 150 & 156 & 156 & 144 & 156 \\
\hline GASTO LIQUIDO TOTAL-PC & 111 & 108 & 139 & 125 & 143 & 134 & 141 & 142 & 131 & 143 \\
\hline EVOLUÇÃO \% DO PC & 100 & 98 & 125 & 113 & 129 & 121 & 127 & 127 & 118 & 129 \\
\hline
\end{tabular}

Fonte e Observações:

1) 1993-1999 - Dados extraídos do Siafi-Sidor, corrigidos dez/99 por Piola (127)

2) 2000-2002 - Dados do MS - CNS - COF do CNS

3) 2001 e 2002 - Dos valores brutos totais subtraiu-se o R\$ do Projeto Alvorada 2001 - deduzido $\mathrm{R} \$ 1,16$ bi; 2002 - deduzido $\mathrm{R} \$ 1,25$ bi

4) Estudos do Autor incluindo atualização para dez 2001 - pelo IGP-DI 


\section{INCLUSÃO DE INATIVOS}

O pagamento dos Encargos Previdenciários da União - EPU deveria ser feito através de repartição simples (solidariedade entre gerações), o que não dispensaria um Sistema de Capitalização durante os muitos anos em que se recolheu contribuição previdenciária: parte dos funcionários públicos e parte que seria devida pela própria União. Isto não ocorreu e vem funcionando exclusivamente no sistema de caixa: as contribuições que ingressaram no período, somadas ao desembolso de outras receitas, são utilizados para pagamento dos EPU a cada mês.

A novidade ficou por conta de outro detalhe: as despesas de pagamento de inativos foi somada às outras despesas de pagamento do pessoal ativo e debitadas na conta de cada Ministério.

Com isso, o MS teve aumentadas suas despesas consideradas com saúde e na série histórica apresentada, pode-se verificar o quanto de despesa com inativos deveria ser pago com outros recursos da União, de outros orçamentos que não os próprios da saúde. Isso reduz, na realidade, o suposto montante de recursos destinados pelo MS às reais despesas de saúde.

O gasto com inativos do MS representou, em média, $8,44 \%$ do gasto total. Tomando-se o indice 100, em 1993, vamos a 176, em 1999. Aumento anual por aumento de aposentados no serviço público. Existe ainda a possibilidade de crescimento no momento em que os salários dos aposentados, represados há oito anos, sofrerem algum tipo de aumento.

O maior perigo, entretanto é o efeito cascata que vem ocorrendo. Quando a saúde, por meio da EC-29, conseguiu a determinação do montante de recursos destinados à saúde pela União, Estados e Municipios, o exemplo federal passa a ser "autorizativo" para que os municipios façam o mesmo. A exemplo do que ocorre com a MDE (Manutenção e Desenvolvimento do Ensino) que, por força da Lei $7348 / 85$, imposta pela área econômica do Governo, como condição para implantar a Emenda Calmon. Infelizmente, esta aberração sobreviveu à CF de 1988 e à nova LDB.

\section{INCLUSÃO DA DÍVIDA}

Sempre houve o entendimento de que dividas contraidas especificamente com organismos internacionais ou nacionais para a área da saúde devessem ser pagas com recursos da saúde. Seriam historicamente os pagamentos das dividas especificas da saúde. 
O que ocorreu de estranho foi que foram alocadas à saúde despesas de outros "empréstimos", cujos montantes eram responsáveis por grande parte do financiamento da saúde. Empréstimos que foram contraídos junto ao próprio Governo para cobrir "dividas" de não aporte de receitas previstas para a saúde.

A discussão é sobre os empréstimos devidos ao FAT e já relatados acima na crise de financiamento de 1992, 1993 etc. Na falta de recursos federais para a saúde, foram buscados empréstimos junto ao Fundo de Amparo ao Trabalhador - FAT, um recurso oriundo do PIS-PASEP e administrado por um Conselho, com presença, inclusive, de trabalhadores. A seqüência desses empréstimos, ocorridos nos anos de 1992-1993-1995 e 1996 era a seguinte: demonstração da necessidade, concordância dos Ministérios envolvidos (Saúde, Fazenda, Planejamento, Presidência da República), pedido de autorização ao Conselho de Desenvolvimento do Fundo de Amparo ao Trabalhador CODEFAT, pedido de autorização ao Congresso Nacional, incorporação ao orçamento.

\section{EMPRÉSTIMO DO FAT PARA O MS - 1992-96}

\begin{tabular}{|l|c|c|c|c|c|}
\hline ANOS & 1992 & 1993 & 1994 & 1995 & 1996 \\
\hline CORRENTE & 4.991 .759 .000 .000 & 34.310 .000 .000 & 0 & 1.183 .845 .360 & 1.199 .999 .329 \\
\hline
\end{tabular}

Fonte: MS-SPO - moeda corrente

Esses empréstimos deveriam ter sido pagos com recursos de Títulos do Tesouro Nacional e não com recursos próprios ou alocados no orçamento da saúde. Lembre-se de que, em 1998, a Secretaria do Tesouro Nacional amortizou diretamente 1,782 milhão da divida do FAT - não incluidos nos valores acima. Mas, na hora dos pagamentos, acabaram por consumir recursos importantes destinados diretamente à saúde, nos anos de 1995 e 1997 , quando foi paga a maior parte destes empréstimos chegou a consumir praticamente $10 \%$ dos recursos totais do MS. Esses recursos acabaram sendo computados duas vezes, sempre que se estabeleceu o valor per-capita. Uma vez, quando os recursos foram tomados como empréstimo e outra vez, quando se pagou o empréstimo. Por exemplo, no ano de 1995, quando se gastou $9,9 \%$ do orçamento para pagar a divida, num montante corrigido para dezembro de 2001 de 2,4 bilhões, o resultado de uma e outra contagem mostra diferença significativa. Sem desconto do pagamento da divida (que seria uma contagem dupla) dariam 169,68 reais per-capita, e computando-se de forma correta tem-se 154,39 reais per-capita. Séries históricas comparativas mostram a diferença com total evidência. $A$ evolução do per-capita de 1993 a 2002 passa pelos seguintes valores: 120, 120, 170, 145, 
$172,155,157,157,157,145,158$ quando tomados os gastos brutos (para 2002: previsão orçamentária) e $111,108,139,125,143,134,141,142,131,143$ quando os gastos líquidos. A perda total com inativos e pagamento de dívida nos anos de 1995 e 1997 chegou a consumir $21,72 \%$ e 20,25\%, respectivamente. A média dos anos de 1993 e 1999 foi de $13,58 \%$. Esses recursos não representaram nenhum incremento de gasto com saúde, muito pelo contrário. No caso dos inativos, vem subindo a cada ano e com previsão de montante cada vez maior.

\section{FONTE DOS RECURSOS PARA A SAÚDE}

\subsection{O LEGAL}

Inicialmente, o entendimento mínimo sobre as receitas públicas. As receitas públicas, da União, Estados e Municipios, estão expressas nos artigos da CF 145,149,195.(16) São elas as seguintes: tributos (inclui impostos, taxas especificas, contribuição de melhoria por obras públicas) contribuições sociais, contribuições econômicas e de interesse de categorias profissionais e econômicas, como instrumento de atuação nas respectivas áreas.

As contribuições são criadas para uma determinada finalidade e de uso exclusivo nelas. Contribuições econômicas para o econômico, sociais para o social, contribuição de interesses profissionais para estes interesses, contribuições de melhorias para as melhorias. As taxas são especificas para serviços especificos. O que sobra sem destino específico são os impostos, que, pelo artigo 167 , só poderão ter percentual vinculado às ações e serviços públicos de saúde e à educação. As demais áreas serão financiadas por estes recursos, mas não se pode apartar recursos diretamente para elas. Quando se falar de recursos provenientes do orçamento da União, a que se refere o Art. 195 da CF, que correspondem a recursos referentes a impostos, denominados de fonte 100 . Em resumo, o preceito legal é o uso para a saúde de contribuições sociais (até 1998 incluindo a Contribuição sobre a Folha de Pagamento) e os recursos arrecadados como IMPOSTOS - fonte 100.

Na competência conferida ao poder público de organizar a Seguridade Social está expresso, como um dos objetivos, a diversidade das fontes de financiamento (CF 194 - VI). No Art. 195 é dada a base de financiamento da seguridade (onde está a saúde) colocando em primeiro lugar que, quem financia tudo, absolutamente tudo, é a própria sociedade. O dever do Estado em garantir a saúde é um dever conseqüente ao dever da sociedade em financiar a 
saúde. Explicitamente, toda ela. Qualquer interpretação restritiva contrariaria o preceito constitucional. (Uma das propostas correntes de mudança no financiamento da saúde é eximir de contribuição as pessoas da sociedade que paguem seus planos próprios de saúde e previdência). O financiamento legal será feito de duas maneiras: diretamente e indiretamente. Eis outro ponto de confusão. O entendimento correto é que, quando a sociedade contribui com seus impostos, sem destinação específica, ela está contribuindo indiretamente, o que aqui se denomina de "orçamentos da União, dos Estados, do Distrito Federal e dos Municipios". Quando a sociedade contribui com as contribuições sociais especificas da seguridade ela está financiando diretamente. A interpretação equivocada é quando se quer entender que, com o "diretamente", abre-se o suporte legal para se fazer alguma cobrança de qualquer dos serviços públicos desta área. Defender a interpretação de que este "diretamente" refere-se ao momento de se receber o serviço ou benefício é uma falácia. Nada tem a ver com a interpretação correta de que o termo "diretamente" significa o recolhimento de contribuiçöes sociais destinadas especificamente à Seguridade Social, onde está a saúde. $O$ cidadão recolhe impostos indiretamente e paga contribuições diretamente, de forma prévia, não no momento de receber os serviços.

A diversidade de fontes, salientada no Art. 194 e desejada em todos os estudos prévios, vem garantida: o empregador recolhe as contribuiçōes sobre a folha, o faturamento e o lucro; o trabalhador a contribuição sobre a folha (Contribuição sobre a Folha hoje destinada exclusivamente à Previdência Social e não mais à Seguridade como um todo CF 167,XI EC -98 (16)) e sobre os concursos prognósticos.

A omissão, ilação, evasão e sonegação fiscal terminam por ser uma apropriação indébita de impostos e contribuições pagas pelo consumidor final, embutidas no preço das mercadorias e serviços. Contra as empresas concorrentes, que pagam seus impostos e contribuições corretamente, é uma prática capitalista desleal. Em última análise, o contribuinte e o cidadão consumidor de produtos e serviços, em cujas planilhas de custos estão incluídas todas as despesas com impostos, taxas, contribuições, acabam sendo lesados duas vezes. A primeira ao recolher embutido no preço da mercadoria e estes não serem transferidos ao Estado e a segunda, quando, justamente por falta desses recursos, ele não pode usufruir dos serviços devidos.

Além disso, a partir de 1996 foi instituída a CPMF - Contribuição Provisória Sobre a Movimentação Financeira, destinada exclusivamente à saúde. Inicialmente no percentual de $0,2 \%$. Depois, foi aumentada para 0,38 para que esse recurso, além dos $0,2 \%$, fosse destinado à Previdência (ADTC Art.74 - (16)). Posteriormente reduzido para 0,30, a partir de junho de 2000 , voltou a ser $0,38 \%$ para que o $0,08 \%$ fosse destinado ao Fundo de Combate 
à Pobreza (EC-31 de 14-12-2000 (15)) Há indicações de que será prorrogado, em 2002, com aliquota de $0,38 \%$, até dezembro de 2003 . A área econômica do Governo Federal, que foi terminantemente contra a instituição da CPMF, proposta inicialmente pelo Conselho Nacional de Saúde, durante os anos de 1995 a 1997, hoje não abre mão de sua prorrogação.

Ao examinarmos os artigos especificos que tratam de saúde, encontra-se no art.198 $\S 1^{\circ}$ que o SUS será financiado com recursos do orçamento da seguridade social e das três esferas de governo além de outras fontes. Estas outras fontes foram definidas depois na Lei 8080 como sendo: os serviços prestados pelo SUS sem prejuizo da assistência, ajuda, contribuições, doações, donativos, alienações patrimoniais e rendimentos de capital, taxas, multas, emolumentos e preços públicos arrecadados no âmbito do SUS e rendas eventuais, inclusive comerciais e industriais.

EC-29, de 13/9/2000, definiu, pelo menos transitoriamente (por cinco anos), as bases de um novo financiamento da saúde. Uma de suas alterações essenciais está contida no art. 198. Nele se definem recursos minimos para a União, constantes de Lei Complementar e, no momento, nas disposições transitórias da CF art. 77. Em 2000, para a União no mínimo 5\% a mais do que o empenhado em 1999 e de 2001 a 2004, o valor apurado no ano anterior corrigido pela variação nominal do PIB. Entenda-se como variação nominal do PIB o seu crescimento real, somado à inflação do período. Para Estados, um percentual de sua receita própria que ficou definido como sendo $12 \%$ e, para os Municípios, a mesma determinação, mas com percentual de $15 \%$. Foi feita uma concessão para os entes federados que não estivessem neste patamar. Foi-lhes dada a possibilidade de iniciarem no mínimo em $7 \%$ e atingirem esta diferença à razão de $1 / 5$ ao ano. Frise-se que se tratam de recursos mínimos, cabendo aos poderes constituidos definirem maior ou menor percentual de recursos para a saúde. O legal é o mínimo. Nada impede que esse mínimo seja superado.

Da mesma forma, ficaram para a Lei Complementar, no mínimo qüinqüenal, as normas de cálculo do montante a ser aplicado pela União. No meu entender, há uma redundância entre o inciso I e IV, do art. $3^{\circ}$ do 198 , quando se diz no primeiro da definição de percentuais, incluindo a União e no IV das normas de cálculo do montante a ser aplicado pela União, isto já depois da EC-29 de 13/9/2000. A obrigatoriedade do ingresso de recursos fiscais da União para o orçamento da seguridade social está no Art. 195 e bem explicitado na Lei 8212, de julho de 1990, Art. 16: "A contribuição da União é constituída de recursos adicionais do orçamento fiscal, fixados obrigatoriamente na lei orçamentária anual. Parágrafo único: $A$ União é responsável pela cobertura de eventuais insuficiências financeiras da Seguridade Social, quando decorrentes do pagamento de benefícios de prestação continuada da 
Previdência Social, na forma da Lei Orçamentária Anual." Este dispositivo legal teve sua origem na ausência de contribuição histórica da União (que era um dos pólos na responsabilidade de financiamento tripartite) e na apropriação indébita da STN da receita tripartite de empregadores e empregados.

Em relação ao Seguro Obrigatório de Danos Pessoais Causados por Veículos Automotores Terrestres - DPVAT, a Lei 8212 de Custeio da Seguridade Social, determinou, após estudos, que $50 \%$ dos recursos pagos referentes ao DPVAT devam ser destinados ao financiamento do SUS, o responsável pelo atendimento à saúde da população.. Esta determinação legal deixava a cargo do SUS a garantia do atendimento à saúde das pessoas acidentadas por acidentes automobilísticos. A implantação desse sistema resultou em outra prática que é referida no relato da situaçăo real.

Outra receita com grande controvérsia foi o Fundo Social de Emergência, depois Fundo de Estabilização Fiscal. O FSE foi criado de maneira a aumentar a receita da União, retendo $20 \%$ da arrecadação de todos os impostos e contribuições. Foi criado, inicialmente, para os anos de 1994 e 1995 pela EC-1 da Revisão Constitucional em 1-3-1994, alterando o Art.72 no inciso IV. Na EC-10, de 4-3-96, mudou-se a denominação para Fundo de Estabilização Fiscal, modificando-se o inciso IV do 72 , colocando-se $20 \%$ de impostos e contribuições "existentes e a serem criados". A EC-17, de 22-4-97, estabelece o FEF até dezembro de 1999 e mantém a redação do inciso IV. Finalmente, em 21-3-2000, a EC 27 coloca na ADCT a desvinculação de $\mathbf{2 0} \%$ de impostos e contribuições existentes e que vierem a ser criados. O entendimento disso é importante, na medida em que esses artigos e seus textos confirmam a jurisprudência que, até março de 2000, a União não poderia ter descontado os $20 \%$ do FSE-FEF da CPMF, que foi instituida pela EC 12, de 15 de agosto de 1996, portanto, posterior (até março de 2000) à determinação que todos impostos e contribuições tinham que ter o desconto de $20 \%$. A EC 12 diz claramente que o produto da arrecadação da CPMF deverá ser destinado integralmente ao Fundo Nacional de Saúde para financiamento das ações e serviços de saúde. Tem precedência a última modificação na CF que foi a do CPMF até finalmente vir em março de 2000 a EC-27. (16)

\subsection{O REAL}

O que ocorreu em todos esses anos, em relação às várias fontes da Saúde, está demonstrado no quadro abaixo. 
DISTRIBUIÇÃO PERCENTUAL DE FONTES DE RECURSOS - INAMPS-MS - 1988 A 2001

\begin{tabular}{|c|c|c|c|c|c|c|c|c|c|c|c|c|}
\hline Fonte de Recurso & 1990 & 1991 & 1992 & 1993 & 1994 & 1995 & 1996 & 1997 & 1998 & 1999 & 2000 & 2001 \\
\hline 100 - Recursos Ordinários & 1,4 & 5,1 & 12,9 & 7,2 & 0,0 & 3,2 & 0,0 & 0,9 & 9,6 & 15,1 & 4,9 & 14,7 \\
\hline 122 - Renda Líquida de Concursos de Prognósticos & 1,3 & 2,1 & 3,4 & 1,3 & 0,3 & 0,4 & 0,4 & 0,8 & & & & \\
\hline 129 - Recursos de Concessర̋es e Permissőes & & & & & & & & & & 3,1 & & \\
\hline 143 - Tit.Resp. TN - Div. Públ. Mob. Federal & & & & & & & & 1,2 & 9,2 & $0,5 \mathrm{c}$ & 0,4 & 0,7 \\
\hline 144 - Tit.Resp.TN - Outras Aplicações & & & & & 1,5 & 2,2 & 2,9 & 2,4 & & $0,3 \mathrm{c}$ & 0,2 & 0,3 \\
\hline 146 - Operaçōes de Crédito Internas - Em Moeda & 1,1 & 11,1 & 16,1 & 2,5 & & 7,9 & 8,3 & & & & & \\
\hline 148 - Operaçōes de Crédito Externas - Em Moeda & & & & & 1,1 & 1,1 & 0,9 & 0,5 & 1,0 & 1,5 & 2,0 & 0,7 \\
\hline 149 - Op. Crédito Externas - Em Bens/Serviços & & & & & & & & & & & 0,6 & \\
\hline 150 - Recursos Diretamente Arrecadados & 18,7 & 3,0 & 4,4 & 4,2 & 1,6 & 2,3 & 2,3 & 2,2 & 2,2 & 3,3 & 3,0 & 2,6 \\
\hline 151 - C. Social Lucro Liq. PJ - CSSLL & 13,3 & 18,4 & 1,5 & 3,5 & 15,6 & 20,1 & 20,6 & 19,1 & 7,2 & 12,9 & 12,3 & 5,5 \\
\hline 153 - C.Financiamento da SS-CONFINS & 20,6 & 24,7 & 25,1 & 41,5 & 37,6 & 45,2 & 42,1 & 25,2 & 23,5 & 26,2 & 37,5 & 42,7 \\
\hline 154- Contribuiçăo de Empregados e Empregadores & 36,8 & 34,7 & 35,3 & 35,3 & & & & & 0,8 & & & \\
\hline 155 - C. Provisória Mov.Financeira - CPMF & & & & & & & & 27.5 & 33,6 & 22,0 & 30,7 & 30,2 \\
\hline 156 - C. p/ o Plano de Seguridade Social do Servidor & & & & & 1,1 & 4,3 & 3,3 & & & & & 1,1 \\
\hline 179 - Fundo de Combate a Pobreza & & & & & & & & & & & & 0,6 \\
\hline 192 - Saldo Ex.Anteriores - Rec. TN & & & & & & & & & & & 7,0 & \\
\hline 199 - FSE (Emergência) FEF (Estabilizaçăo Fiscal) & & & & & 38,1 & 11,7 & 17,9 & 19,4 & 12,0 & 14,5 & & \\
\hline 250 - Recursos Diretamente Arrecadados & & & & & 0,3 & 0,2 & 0,2 & 0,2 & 0,2 & 0,1 & 0,2 & 0,7 \\
\hline 281 - Recursos de Convênios e Saldos & & & & & & & & & & & & \\
\hline 290 - Recursos Diversos & & & & & & & & & & & & \\
\hline 292 - Saldo Ex. Anteriores - Recursos Diversos & & & & & & & 0,1 & & & & & \\
\hline 353 - C. Fundo de Investimento Social - EPU & & & & & 1,1 & & & & & & & \\
\hline 354 - C.Empre.I Trabalhadores Seg.Social & & & & & & & & & & & & \\
\hline 361 - Recursos de Convênios & & & & & & & & & & & & \\
\hline 1100 - Contra Partida da Fonte 100 & & & & & & & 0,1 & 0,2 & 0,1 & & 0,3 & \\
\hline 1151 - Contra Partida da Fonte 151 & & & & & & & & & & 0,2 & 0,0 & \\
\hline 3153 - Contra Partida da Fonte 153 & & & & & & 1,0 & 0,3 & 0,2 & 0,1 & 0,2 & 0,5 & 0,2 \\
\hline 4143 - T. Resp. TN Div. Públ. Mob. Federal Exterior & & & & & & & & & 0,2 & & & \\
\hline 4144 - T.Resp.TN - Outras Aplicaçסes - Exterior & & & & & & 0,5 & 0,5 & 0,4 & 0,2 & & & \\
\hline 4151 - CSSLL - Pessoas Jurídicas - Exterior & & & & & & & & 0,0 & & & & \\
\hline Outros năo incluidos nos citados & 6,6 & 1,0 & 1,3 & 4,5 & 1,8 & & & & & & & \\
\hline Total Geral & 100 & 100 & 100 & 100 & 100 & 100 & 100 & 100 & 100 & 100 & 100 & 100 \\
\hline
\end{tabular}


Os problemas e ilegalidade aí existentes podem ser analisados por grupo de fontes. Pode-se começar pela fonte fiscal.

\section{FONTE FISCAL - RECURSOS ORDINÁRIOS}

Os recursos fiscais da União são basicamente de duas grandes fontes: IR - Imposto de Renda e IPI - Imposto sobre Produtos Industrializados (com todas as suas dezenas de componentes).

O artigo 195 e 198 definem que a saúde será financiada por recursos provenientes dos orçamentos da União, Estados e Municípios e das contribuições sociais. Vê-se nitidamente que há uma separação do que sejam " recursos provenientes dos orçamentos da União" daqueles provenientes das Contribuições sociais. Juntos correspondem aos recursos do Orçamento da Seguridade Social

O que há de determinação legal corresponde ao uso dos recursos fiscais orçamentários, mas nenhum indicativo da proporção em que tais recursos entrariam. A defesa da saúde era de que na própria constituição devesse estar colocado, no mínimo, $10 \%$ dos recursos fiscais da União Estados e Municípios. Não ocorreu lá, nem na Lei 8080.

RECURSOS FISCAIS - \% ENTRE AS RECEITAS DO INAMPS-MS 1988 A 2001

\begin{tabular}{|c|c|c|c|c|c|c|c|c|c|c|c|c|}
\hline ANO & 1990 & 1991 & 1992 & 1993 & 1994 & 1995 & 1996 & 1997 & 1998 & 1999 & 2000 & 2001 \\
\hline 100 - Ordinários & 1,4 & 5,1 & 12,9 & 7,2 & 0,0 & 3,2 & 0,0 & 0,9 & 9,6 & 15,1 & 4,9 & 11,4 \\
\hline
\end{tabular}

Fonte: 1995-2001: MPO/SOF- 1988-1994:MS-SAG-DPO

Enquanto nos anos que precederam a real implantação do SUS, após a Lei 8080 , de setembro de 1990 , os recursos ordinários representaram uma média elevada bem acima de $10 \%$, nos anos 90 a 97 esses valores ficaram bem abaixo de $10 \%$. Sobressai o $7,2 \%$ de 1993, devido à crise da retirada dos recursos da contribuição sobre a folha. 
A luta foi muito grande em relação a se colocar na CF um percentual determinado de recursos para a saúde. Finalmente, conseguiu-se colocar nas ADCT, em seu artigo 55 "Até que seja aprovada a lei de diretrizes orçamentárias, trinta por cento, no mínimo, do orçamento da seguridade social, excluído o seguro-desemprego, serão destinados à saúde." (16) Até que seja aprovada a Lei de Diretrizes Orçamentárias. Isto ficou entendido que a LDO, a cada ano, devesse definir o percentual destinado à saúde, o que ocorreu na LDO de 1990, 91, 92, 93. Na LDO de 1994, aprovada em 1993, foi cancelado este preceito pela Presidência da República, sob o argumento que já era impossível cumprir e se caracterizava como contrário ao interesse nacional. O veto presidencial alegava ser claro que, pelas limitações estruturais, o artigo que obrigava os $30 \%$ era inexeqüível e, por isso, contrário ao interesse público!!! Entretanto, permaneceu na Lei do PPA - 8446 (31) que dispunha sobre a revisão do PPA para o triênio 1993-1995. "(....) a destinação de 30\% do Orçamento da Seguridade Social, excluindo o Seguro Desemprego, seriam objetivos fundamentais para o MS".

É bom que se faça essa distinção. Muitos, em escritos e propostas de emendas constitucionais confundiram OSS com Contribuições Sociais. O OSS tem vários outros recursos além daqueles das Contribuições Sociais. Defender $30 \%$ das Contribuições sociais é muito menos do que $30 \%$ do OSS. O pagamento do principal, juros, multa e correção de débitos de contribuições, o que não é pouco, entra como Outras Receitas e não mais como Contribuições Sociais.

Portanto, nos anos de 1989 a 1995, era obrigatório que 30\% dos recursos do orçamento da seguridade social fossem alocados à saúde. Isto não ocorreu e resultou em perdas para a saúde. Os recursos da Seguridade Social, pela própria CF, deveriam estar sendo utilizados exclusivamente para as áreas definidas no artigo 194: previdência, saúde e assistência social. Não foi isto que aconteceu. São recursos que a saúde acabou perdendo, através dos anos.

\section{CONTRIBUIÇÃO DE EMPREGADOS E EMPREGADORES SOBRE A FOLHA DE PAGAMENTO}

Foi apresentada, anteriormente, a Crise Britto e seus efeitos deletérios sobre o financiamento da saúde. Historicamente, a Contribuição de Empregados e Empregadores, destinada á saúde, representou cerca de $30 \%$ da arrecadação total. No período préconstitucional, de 1980 a 1988 , a média foi de $26,82 \%$. No período pós constitucional imediato (89-90-91)foi de $28,84 \%$. Em 1992, no final do Governo Collor, que vinha 
diminuindo o gasto com saúde e no início da gestão do Ministro Britto, já começa a diminuir esse percentual: em 1992, 15,34\% e, em 1993, 4,9\%, ainda que na LO do mesmo ano tivessem sido alocados $15,5 \%$ desses recursos para a saúde.

CONTRIBUIÇÃO SOBRE A FOLHA -\% ENTRE AS RECEITAS DO INAMPS-MS 1980-86

\begin{tabular}{|c|c|c|c|c|c|c|c|}
\hline ANO & 1980 & 1981 & 1982 & 1983 & 1984 & 1985 & 1986 \\
\hline$\%$ & 28,49 & 24,96 & 22,33 & 21,18 & 22,94 & 24,82 & 23,19 \\
\hline ANO & 1987 & 1988 & 1989 & 1990 & 1991 & 1992 & 1993 \\
\hline$\%$ & 34,68 & 38,75 & 30,31 & 23,18 & 33,02 & 15,37 & 4,9 \\
\hline
\end{tabular}

Fonte: 1980-89: MS-DAF; 1990-93:MPAS

A ilegalidade cometida nessa alocação de recursos foi o descumprimento da Lei do PPA 8446 (31), que dispunha sobre a revisão do PPA para o triênio 1993-1995. “ (....) a destinação de um percentual estável e mínimo de $25 \%$ sobre o montante da Contribuição dos Empregadores e Trabalhadores para a Seguridade Social." Lembre-se de que a origem dos $\mathbf{2 5 \%}$ está ligada ao aumento da contribuição dos empregados, de $6 \%$ para $\mathbf{8} \%$, sendo que os $2 \%$ eram para garantir o direito à saúde ( $2 \%$ que corresponde aos $25 \%$ de $6 \%$ para $8 \%)$.

Nenhum documento indica que tenha sido revogada essa determinação legal, vigente até 31 de dezembro de 1995. A alteração legal desse dispositivo só ocorreu em 15 de dezembro de 1998, com a EC-20 (16): que altera o art.167 e coloca no inciso XI a proibição de utilização da contribuiçăo sobre a folha para pagamento, que não seja o de benefícios do regime geral de Previdência Social.

\section{DPVAT}

Havia uma hipótese de que os recursos referentes ao DPVAT deveriam estar sofrendo perda, de um lado, na tramitação entre o recolhimento dos recursos e a chegada ao Fundo Nacional de Saúde, de outro, ou na sonegação ou no pagamento fraudulento de atendimentos de saúde não prestados ou cobrados em excesso como denunciou inúmeras vezes a mídia.

As seguradoras pagavam atendimento à saúde no setor privado e descontavam os recursos pagos da cota dos $50 \%$ referentes ao SUS, transferindo apenas o líquido. Como o 
pagamento não estava em suas contas, muito pouco se fazia para auditar estas contas. Procedimento que passaram a fiscalizar melhor, quando mudou a orientação.

Diante dessa suspeita e após alguns estudos, provocou-se o Ministério Público que negociou uma saída com o Ministério da Saúde a edição do Decreto Presidencial 2867, em 8 de dezembro de 1998. A principal modificação é que, a partir de 1999, os recursos passaram a ser depositados diretamente entre os órgãos arrecadadores e o Fundo Nacional de Saúde. Ganhou-se em tempo e em possiveis perdas.

ARRECADAÇÃO DO DPVAT DESTINADO À SAÚDE - 1997-2000

R\$ 1

\begin{tabular}{|l|c|c|c|c|}
\hline DPVAT & 1997 & 1998 & 1999 & 2000 \\
\hline $\begin{array}{l}\text { TOTAL } \\
\text { (R\$1) }\end{array}$ & $375.775 .240,03$ & $469.357 .462,95$ & $577.989 .751,62$ & $550.485 .403,18$ \\
\hline$\%$ & 100 & 125 & 154 & 146 \\
\hline
\end{tabular}

Fonte: Fundo Nacional de Saúde

Todas as variações, acima apresentadas, foram resultado da alteração do processo arrecadatório, pois não houve um aumento real do valor do DPVAT. Interessante que, já em 1998 , notou-se um aumento de $25 \%$ na arrecadação. Como hipótese, fica o efeito moral dos estudos que já estavam sendo feitos, algumas auditorias promovidas pelo Ministério da Saúde e, principalmente, a entrada do Ministério Público Federal na área para sanar os problemas. O aumento de $54 \%$, em 1999 , frustrou em parte uma expectativa de quantos estavam envolvidos nessa mudança, pois otimistamente se esperava uma arrecadação de cerca de 1 milhão de reais.

Ainda, há necessidade de outras providências e avaliação das tendências juridicas, para que essa arrecadação possa melhorar um pouco mais quantitativamente. A mídia, periodicamente, aponta situações em que os arrecadadores (agências e escritórios) recolhem da clientela e deixam de fazer o devido recolhimento bancário.

\section{CPMF}

Relatos anteriores mostram toda a luta para se conseguirem mais recursos para a área de saúde, por meio da CPMF.

Essas receitas entraram, não como receita a mais para a área da saúde, como todos os políticos, os técnicos da saúde e os cidadãos usuários dos serviços de saúde. Diante disso, 
- Ministro da Saúde, à época, declarou publicamente, que a CPMF foi um engodo e que nós fomos inocentes (11). Houve uma substituição de fontes. Entrou a CPMF e saíram outras fontes que tradicionalmente financiavam a saúde. Inocentemente, técnicos e parlamentares imaginaram que, colocando à salvaguarda de que os recursos da CPMF devessem ser destinados prioritariamente ao pagamento do público, fossem garantir algum avanço. Isto sempre será inócuo, pois há despesa para todas as fontes e se pode usar a CPMF para o público, sem significar nada de importante ou distintivo.

Houve uso indevido da CPMF para pagamento de dívida, descontos para o FSE-FEF e uso em outras finalidades, o que foi coibido, por pressão, logo nos primeiros meses. A questão da ilegalidade de desconto de $20 \%$ ao FSE-FEF fica suficientemente demonstrada acima na descrição e datas das emendas constitucionais. A EC-12, da CPMF, foi posterior à determinação de desconto de $20 \%$ desde sua edição, em agosto de 1996 , até o advento da EC-27, de 21-3-2000. Entretanto, o mal maior persistiu: a substituição de fontes: entrada da CPMF para financiar a saúde e saída de outras fontes.

Só três exemplos das promessas não cumpridas pelo MS, contidas no documento Subsídios à votação da CPMF $(60)$, que os recursos arrecadados pela CPMF seriam utilizados para pagar o valor per-capita de 1 real por habitante/mês, destinado às ações básicas de saúde (PAB). A falácia foi um valor per-capita, implantado em 1998, de $R \$ 0,83$ habitante/mês, e um aumento, quatro anos depois, para $R \$ 0,87$, habitante/mês. $O$ que foi anunciado e prometido em 1996 seria $\mathrm{R} \$ 1,0$ habitante-mês!... O outro é em referência à dengue, em que a CPMF era anunciada no mesmo documento como mais recursos destinados ao controle da dengue. Para isto, foi feito o Programa de Erradicação do Ãedes (transmissor da dengue), que acabou por não sair do papel, como devia e que nos leva agora, em 2000, a amargar com a maior das epidemias, incluindo óbitos por dengue hemorrágico. O terceiro e último exemplo é a citação de que se precisaria corrigir os valores da tabela de procedimentos pagos a Estados, Municípios e aos prestadores privados. Estimava-se um impacto financeiro de $R \$ 4,1$ bilhões ano. (60)

\section{CONTRIBUIÇÕES SOCIAIS - \% ENTRE AS RECEITAS DO INAMPS-MS 1988 A 2001}

\begin{tabular}{|l|c|c|c|c|c|c|c|c|c|c|c|c|}
\hline & 90 & 91 & 92 & 93 & 94 & 95 & 96 & 97 & 98 & 99 & 00 & 01 \\
\hline 151 - C. Social Lucro Liq. PJ - CSSLL & 13,3 & 18,4 & 1,5 & 3,5 & 15,6 & 20,1 & 20,6 & 19,1 & 7,2 & 12,9 & 12,3 & 5,5 \\
\hline 153 - C.Financiamento da SS-CONFINS & 20,6 & 24,7 & 25,1 & 41,5 & 37,6 & 45,2 & 42,1 & 25,2 & 23,5 & 26,2 & 37,5 & 42,7 \\
\hline $154-$ Cont. de Empreg. e Empregadores & 36,8 & 34,7 & 35,3 & 35,3 & & & & & 0,8 & & & \\
\hline 155 - C. Provisória Mov.Financeira - CPMF & & & & & & & & 27,5 & 33,6 & 22,0 & 30,7 & 30,2 \\
\hline
\end{tabular}

Fonte: 1995-2001: MPO/SOF- 1990 -1994:MS-SAG-DPO 
A CPMF é repassada ao MS $80 \%$ diretamente e $20 \%$, em forma de FEF, a posteriori. Os dados acima são a comprovação da substituição, pura e simples, de fonte, já explicada no texto inicial. A CSSLL que, de 94 a 97, representou 18,85\% em média, já em 1998, 7,2\%, depois $12,9,12,3$ e em 2001, menos de $10 \%$. A COFINS, entre 93 e 96 , teve uma média de $41,85 \%$ de participação, caindo com o advento da CPMF para $24,9 \%$, em média, nos anos de 1997, 98,99; no ano de 1999, os valores da CPMF caíram 2,5 bi. A arrecadação teve um lapso de tempo, em que não ocorreu, entre uma lei e outra. Arrecadou-se apenas até 21 de janeiro, e só voltou a ser recolhido em 23 de junho. A partir dai, a alíquota foi de $0,38 \%$, sendo que apenas $0,20 \%$ para o MS e, o restante, $0,18 \%$, para o Ministério da Previdência.

Considerando que a entrada de recursos da CPMF levou à diminuição das demais fontes, em especial da CSSLL e do COFINS, na verdade, pelo sofisma, perderam-se cerca de 3,6 bi só em 1997, dos 6,9 bi arrecadados de CPMF. Em 1998, a perda estimada foi de 3,48 bi de reais.

Outra questão foi a remuneração das disponibilidades financeiras dos recursos administrados pelo Tesouro Nacional e referentes a Contribuições Sociais, que deveriam ser acrescidos a ela. Em época de inflação de dois digitos ao mês, reter a remuneração destas disponibilidades constituia uma grande perda para a área social. Assim, foi feito contumazmente.

O mesmo, em relação aos recursos do FINSOCIAL, cujo percentual evoluiu de $\mathbf{0 , 5} \%$ para $2,0 \%$, atualmente $3 \%$. Muitos contribuintes deixaram de recolher e outros depositaram em juizo. Mais tarde, concedeu-se anistia, com possibilidade de pagamento dos atrasados em dezenas de meses. Esses recursos não retornaram rotineiramente para a área social e o percentual de $30 \%$, no mínimo, não foi empregado na saúde.

Os recursos dos concursos prognósticos que, segundo a CF, parte deve ajudar a financiar a Seguridade Social. Discute-se se os percentuais realmente vêm e estranha-se que nos últimos anos de 1998 em diante, esta fonte não conste entre as usuais da saúde. Presumese que tenha sido destinada, preferencialmente, ao financiamento da Assistência Social, confirmando a tendência de especialização de fontes dentro da Seguridade Social. Sua participação ficou, entre os anos de 1990 a 1997, em 1,2\% na média.

O Fundo Social de Emergência, em 1994, foi responsável pelo aporte de $38,1 \%$ do orçamento do MS. Nos anos seguintes, entre 1995 e 1999, a média baixou, e muito, ficando em $15,08 \%$. 
Como último comentário, fica a questão do Conselho Nacional de Seguridade Social, que foi simplesmente extinto. No entender de todos, exceto o Governo, existe obrigatoriedade determinada pela CF, em seu artigo 194 que, inicialmente por dez anos, vigorou com a seguinte redação: " caráter democrático e descentralizado da gestão administrativa, com a participação da comunidade, em especial dos trabalhadores, empresários e aposentados". A EC 20, de 5-12-1998: "gestão democrática e descentralizada da administração mediante gestão quadripartite, com participação dos trabalhadores, dos empregadores, dos aposentados e do Governo nos órgãos colegiados". Muda-se para determinar a presença do Governo (o que já vinha acontecendo desde o início), a denominação de órgãos colegiados (Conselhos) e a fechar a participação nesses quatro representantes e não mais deixando aberta com participação da comunidade e, em especial, dos três componentes: trabalhadores, empresários e aposentados.

\section{DISTRIBUIÇÃO DOS RECURSOS FEDERAIS DA SAÚDE PARA AS TRÊS ESFERAS DE GOVERNO}

\subsection{O LEGAL}

A lógica da distribuição dos recursos deveria ser a das competências de cada esfera de governo. Essa definição é essencial. Existe um recurso financeiro comum que é a receita das contribuições sociais arrecadada pela União, exclusivamente, mas destinado à saúde nas três esferas de governo. Para saber como rateá-lo, o primeiro conteúdo de que temos que apropriar é a definição daquilo que será feito pelas respectivas esferas de governo.

A CF, 23, II, diz que é comum às três esferas de governo cuidar da saúde e assistência pública, da proteção e garantia das pessoas portadoras de deficiências. $\mathrm{Na} \mathrm{CF}, 30, \mathrm{VII}$, as duas questōes são respondidas em conjunto, pois escrito está que compete aos municipios prestarem serviços de atendimento à saúde da população, com a cooperação técnica e financeira da União e do Estado. Primeiro se define diretamente uma competência, bem abrangente e única: prestar serviços de assistência à saúde. Logo a seguir se afirma que os recursos para isso devem proceder da cooperação financeira e técnica da União e do Estado. No capitulo, especificamente dedicado à saúde na CF, nada se diz da competência de cada esfera. São dadas caracteristicas como universalidade, integralidade, 
descentralização, gestão única em cada esfera de governo, como sendo do SUS e/ou do Poder Público, como um todo, e nunca especificando o que cabe a cada esfera de governo. A CF (16) deixa, entretanto, fortes indicativos de quem teria a competência do quê. Coloca, sim, uma questão fundamental no Art.194, VII, sobre o objetivo da organização da seguridade social: "caráter descentralizado da administração" e no Art. 198,I, a organização dos serviços públicos de saúde com a diretriz da "descentralização com direção única em cada esfera de governo". Isto só foi melhor definido na legislação infraconstitucional. É a Lei 8080 (27), que define, em seu capítulo IV, as competências e atribuições de cada esfera de governo e a Lei 8142 (28) e, assim mesmo, sem estabelecer que parte de recursos ficaria com o MS, parte, com os Estados e parte, com os Municípios. Baseando-se em termos genéricos, pode-se alguns artigos da Lei 8080 (27) com determinações neste sentido. No Art.16, XV, "promover a descentralização para as Unidades Federadas e para os Municípios, dos serviços e ações de saúde, respectivamente de abrangência estadual e municipal" $A$ lógica de quem faz. Como o MS não mais faz, não tem competência legal de execução, ele tem, como mandado, transferir a Estados e Municípios serviços e ações de saúde. No Art.17, I afirma categoricamente que à direção estadual do SUS compete "promover a descentralização para os Municipios dos serviços e das ações de saúde".

O Art. 15, da 8080, define as atribuiçōes para as três esferas de governo, esclarecendo que, cada uma delas as exercerá no seu âmbito administrativo. Logo a seguir, são colocadas as competências de cada esfera de governo. A direção nacional do SUS (8080 art. 16), assim denominado o MS, tem inúmeras competências, muitas delas definidas como coordenação, participação, normatização e apenas uma delas executiva terminal. A vigilância de aeroportos e fronteiras (VII) é de execução própria do MS, ainda que podendo ser complementada por Estados, Distrito Federal e Municípios. Os Estados, direção estadual do SUS, (8080 art.17) têm como competência uma execução apenas supletiva em relação às ações e serviços de saúde (III), e complementar (IV) à execução de ações e serviços de vigilância sanitária, epidemiológica, alimentação e nutrição, saúde do trabalhador. Aos Municípios, direção municipal do SUS, compete $(8080$, art. 18,1$)$ a execuçăo dos serviços públicos de saúde. Completa-se, assim, na LOS, a competência acenada pelo art. 30 , VII, da CF. (16)

Definidas as competências, o passo seguinte é conhecer o que existe na legislação sobre a alocação dos recursos do SUS para cada uma das esferas de governo, segundo essas competências. 
A grande dúvida, que sempre se teve, foi sobre a posse dos recursos da Seguridade Social arrecadados pelo Governo Federal. Esses recursos destinados à saúde são recursos federais e transferiveis, por acordo de vontade, para Estados e Municípios, ou são recursos de direito das três esferas de governo? O argumento jurídico, sempre defendido por Guido Carvalho e Lenir Santos, é de que os recursos arrecadados pela União, dentro da Seguridade, destinados à Saúde, Previdência e Assistência Social, não são de propriedade da União, mas das três esferas de governo pois, tanto União, como Estados e Municípios, têm competências próprias e responsabilidades em relação à saúde. Não há possibilidade de se conferir competência a uma esfera de governo, sem que os meios the sejam garantidos, ou esses dependam da "magnanimidade" daquele que está constitucionalmente encarregado de arrecadar esses recursos.

\section{Citam-se Guido e Lenir, que se manifestam sobre essa questão:}

"A União, os Estados, o Distrito Federal e os Municípios têm a sua competência determinada pela Constituição. Portanto, estão em pé de igualdade entre si, porque nenhuma dessas esferas de governo recebe sua competência de outra, mas da Constituição. Como conseqüência disso, temos: 1. a descentralização estabelecida pela Constituição é essencialmente política, ou político-administrativa, e não apenas administrativa; 2. sendo política, deve-se concretizar sem nenhum entrave, requisito ou pressuposto administrativo; 3. logo, a efetivação da descentralização política não pode depender de convênio, que é instrumento administrativo de atuação. Essas e outras afirmações feitas nas edições anteriores dessa obra, num debate constante com agentes do Ministério da Saúde que insistiam em adotar a forma convenial (com todas as conseqüências que encerra no tocante aplicação dos recursos, prestação de contas etc.), foi encerrado com a Emenda Constitucional n. 29/2.000 que colocou uma pá cal nesse assunto ao dispor sobre a obrigatoriedade das transferências da União para os Estados, Distrito Federal e Municípios e dos Estados para os Municípios. Também, a Lei de Responsabilidade Fiscal, art. 25, tratou as transferências do Sistema Único de Saúde como "transferências obrigatórias". Assim, após longos anos de debates e lutas, ficou consagrada a obrigatoriedade das transferências de recursos no próprio texto constitucional. Essa disposição foi fruto da persistência dos incansáveis defensores da saúde pública. Sendo essas transferências obrigatórias, o instrumento convenial é descabido, uma vez que regula transferências voluntárias, a serem negociadas, caso a caso, entre os convenentes que poderão recusar-se a assinar o ato negocial, deixando, assim, pactuar aquela cooperação. O SUS não depende da vontade do agente político. A sua atuação (Prefeitos e Governadores) no campo da saúde é um dever imposto pela Constituição. Afirmávamos, em escritos anteriores, ser descabido celebrar convênio entre as esferas de governo condutoras do Sistema Único de Saúde para a "integração no SUS e transferência de recursos", pois ações e serviços de saúde já são, constitucional e legalmente, de responsabilidade da União. dos Estados, do Distrito Federal e dos Municipios e o Decreto n. 1.232/94 regulou essa transferência, determinando ser automática e regular, sem a celebração de qualquer forma de ajuste. Como esse debate foi intenso nos anos 90, uma vez que havia muita resistência do Ministério da Saúde, principalmente de seus auditores, a respeito da transferência direta e automática, sem a necessidade do instrumento convenial julgamos conveniente mencioná-lo aqui novamente, ainda que, conforme dito acima, a Emenda Constitucional n. 29, pôs fim a essa discussão! "(85). 
Antes da EC-29, de 13/9/2000, usava-se a Lei $8142,2^{\circ}$, que determinava em quê deviam ser utilizados os recursos do Fundo Nacional de Saúde - onde devem estar todos os recursos do MS. Primeiro, para custear a atividade do próprio MS, ou seja, suas despesas de custeio e capital. Em segundo, os investimentos da Lei Orçamentária e do Plano Qüinqüenal de Governo, que podem ser para o próprio MS ou para Estados e Municípios. Finalmente, para financiar as ações e serviços de saúde implementados pelos Estados, Distrito Federal e Municípios. Destes, $70 \%$ devem ser destinados aos Municípios e $30 \%$, aos Estados.

O financiamento da saúde compreende dois grupos distintos quanto à origem de recursos: os recursos do orçamento União, Estados e Municípios (já caracterizados acima como sendo originários dos impostos) e os recursos originários de contribuições sociais. Como só a União pode arrecadar recursos de contribuições sociais, e estes são a grande maioria dos recursos, têm que ser distribuídos para Estados e Municípios cumprirem suas competências legais. O mando constitucional está já no Art.30, inciso VII, em que se determina que os Municípios farão as ações de saúde com a cooperação técnica e financeira da União e do Estado.

A partir da EC-20, de 15-12-1998 (16), fica mais explicitado, ainda, no Art.195 § 10 "a lei definirá os critérios de transferência de recursos para o SUS e ações de assistência social da União para Estados, DF e Municípios e dos Estados para Municípios, observada a respectiva contrapartida de recursos".

Nos acréscimos ao Art.198, da EC-29, de 13/9/2000 (16), surgiu o §3, em que se reafirma, mais uma vez, que "Lei Complementar estabelecerá os critérios de rateio de recursos da União à saúde, destinados aos Estados, ao Distrito Federal e aos Municípios e dos Estados destinados a seus respectivos Municípios, objetivando a progressiva redução das disparidades sociais."

A lei 8080 , em 1990, regulamentou o SUS e tratou de estabelecer que deveria haver repasse (Art.33 §4) "MS acompanhará a aplicaçăo dos recursos repassados a Estados e Municípios" e, no Art 35, estabelecem-se oficialmente, os critérios de repasse.

\subsection{O REAL}

No periodo pós-constitucional, os recursos para a saúde deveriam estar sendo repassados, segundo o critério das competências estabelecidas para cada esfera de governo. Os dispositivos legais constitucionais determinam a existência de um recurso próprio de cada esfera de governo e um recurso comum às três esferas de governo, ainda que arrecadado 
pela União. Enquanto não se clarear, de vez, a divisão das competências, qualquer partição dos recursos será feita com dificuldades. A grosso modo, dir-se-ia que, além de funções comuns às três esferas, quais sejam as de regulação, fiscalização, controle nas várias subáreas e nos respectivos âmbitos, existe uma demarcação quanto à execução. Municípios: prestar serviços de atendimento à saúde da população, Estados, execução complementar e União, cuidando de portos, aeroportos e fronteiras.

Sabe-se que nenhuma transformação mais profunda, mesmo que em cumprimento da lei, por mais auto-aplicável que seja, em determinadas situações, dada a complexidade, acaba por não acontecer de maneira rápida. As NOBs, há exatos 10 anos, não conseguiram aproximar os critérios de repartição dos recursos financeiros da União das competências de cada esfera de governo. Misturou-se distribuiçăo por competência do fazer com a competência de gerir os recursos e passá-los, segundo critérios fechados de decisão do que fazer. No pré-constitucional, o repasse de recursos federais previdenciários era feito por orçamentação para os próprios e por pagamento de produção de serviços aos prestadores públicos e privados, entendendo-se entre aqueles os próprios federais (universitários, militares, de servidores e outros), municipais e estaduais. Além dos recursos federais, os estaduais e municipais financiavam os próprios públicos por orçamentação e os demais, por compra de serviços dos prestadores privados.

Esperava-se a virada no pós constitucional mas, de imediato, nada aconteceu, senão a continuada compra de serviços produzidos, e alguns outros recursos passados globalmente (SUDS), mas dentro dos critérios, quase exclusivos, de tetos de produção. As NOBs 91 e 92 consagraram a descentralização, mediante do pagamento por serviços produzidos às esferas públicas e ao setor privado (a lógica do INAMPS). Veio a NOB-93 e propôs-se a gradualidade em se transferirem recursos totais e globais para Municípios e Estados, partindo do princípio de que a competência do fazer era primordialmente dos municípios (só ou consorciados) aos Estados, a competência de executar supletivamente as ações e serviços de saúde e à União, de não estar trabalhando na área de execução de ações e serviços de saúde. O Financiamento, seguindo essa proposta constitucional, dava a todo e qualquer município a possibilidade de que ele ficasse com a totalidade dos recursos que the eram devidos para que executasse as ações e comprasse serviços em outros municipios, na medida de sua impossibilidade e na relação gestor-gestor. A semi-plenitude da gestão estaria ao alcance de todo e qualquer municipio, desde o pequeno ao maior.

Com a NOB-96 (68), as Portarias de 1998 (64) e a NOAS-2001 (71), não se parte mais para atendimento aos critérios de competência e define-se uma nova trajetória, inconstitucional, que é a da recentralização. Partiu-se do pressuposto de que competências foram retiradas 
da União e do Estado, com uma municipalização afoita e, o caminho legal (para alguns ilegal) seria o voltar a entregar à União e, principalmente, aos Estados, a competência do fazer ou, escamoteadamente, a competência de decidir o que fazer.

Como afirma enfaticamente Beth Barros:

“A fragmentação do financiamento da NOB-96, a nosso ver, inaugurou um processo de "recentralização seletiva" que vem a se consolidar com a edição da NOAS que redefiniu funções das esferas de governo e fragmentou a gestão do sistema segundo niveis de complexidade tecnológica da assistência, subtraindo ao gestor municipal poder de decisão sobre determinadas áreas do sistema. O objetivo parece ser o de especializar as instâncias de governo segundo níveis de complexidade da atenção tornando os municípios responsáveis pela atenção básica e reservando à união e aos estados a gestão da média e alta complexidade" (8)

Há nitidamente, como redigido no corpo do texto, apresentado em capítulo anterior, a intencionalidade teórica e prática de infringir o dispositivo legal, estabelecendo-se competências inconstitucionais para as várias esferas de governo.

A conseqüência prática da falta de entendimento de quem deve ficar com os recursos e de qual esfera de Governo tem a competência do fazer, é a posição de mando do dinheiro, assumida pelo Ministério da Saúde.

Esse é o entendimento do Tribunal de Contas da União que dá a linha para os órgãos de controle interno e externo do Ministério da Saúde. A conseqüência é que a CISET, do Ministério da Fazenda, faz todos os seus controles muito mais em cima de Estados e Municípios, que do próprio Ministério da Saúde.

O controle interno repete há anos a mesma defesa: os recursos repassados a Estados e Municípios devem ser auditados na integra. As prestações de contas têm que ser feitas ao Governo Federal, mediante relatórios de gestão. A atividade de controle e avaliação veio com o viés inampiano. Duvida-se que, nos trinta anos de terceirização quase plena feita pelo INAMPS, quando inúmeros auditores médicos auditavam os próprios serviços e hospitais em que trabalhavam, houvesse uma fiscalização tão efetiva e permanente. As fraudes foram um apanágio desse Sistema, na verdade, terceirizado e sem controle efetivo. Após a extinção constitucional do INAMPS, o mesmo grupo de auditores voltou suas baterias para o controle dos Estados e Municipios. O que se constata é que a auditoria e controle do Ministério da Saúde, que deveria ter, como missão, auditar o próprio Ministério da Saúde, deixe de fazê-lo e se detenha e aprofunde no controle e auditoria de Estados e Municipios.

Todas as ilegalidades apontadas nesta análise nunca foram denunciadas pelos órgãos de controle, avaliação e auditoria do Ministério da Saúde. Não se tem conhecimento de um 
documento sequer, nem mesmo individual, apontando tais erros. Não fazendo eles, quem o fará? As auditorias estaduais, e municipais não têm a competência legal de auditar o Ministério da Saúde. Deixar-se-ia exclusivamente ao controle e auditoria externos? Áqueles que nem mesmo conhecem a proficuidade das normas e orientações federais para a saúde (só em 2001 foram divulgadas entre as publicadas, cerca de 2300 portarias técnicas do MS à razão de 10 portarias por dia útil!)

Diante da concepção, a nosso ver equivocada, sob a argumentação acima, de que OS RECURSOS DO MINISTÉRIO DA SAÚDE SÃO PROPRIEDADE DO MINISTÉRIO DA SAÚDE, o movimento descentralizatório que veio num crescendo no pós constitucional até 1993, teve a inversăo da direçăo, a partir de 1998, quando se pôs em prática a NOB 96, com as modificaçőes radicais das portarias do final de 1997, início de 1998.

Hoje, no auge do processo recentralizatório, partindo do pressuposto de que o dinheiro é federal e o Ministério da Saúde pode fazer o que bem quiser dele, os repasses de recursos passaram a serem feitos, utilizando-se várias dezenas de maneiras do faze-lo. 


\section{DENOMINAÇÃO DEREPASSES DERECURSOS -MS-2001}

\begin{tabular}{|c|c|}
\hline \multicolumn{2}{|c|}{ PAGAMENTOS FEITOS A ÓRGÃOS FEDERAIS } \\
\hline 1 & Atendimento ambulatorial (MS) \\
\hline 2 & Internaçōes hospitalares (MS) \\
\hline \multicolumn{2}{|r|}{ TRANSFERÊNCIAS - MÉDIA E ALTA COMPLEXIDADE } \\
\hline 3 & AIDS - Açőes Estratégicas \\
\hline 4 & Acompanhamento Pós Transplante - Açסes Estratégicas \\
\hline 5 & Acompanhamento a Deficiente. Auditivo - Ações Estratégicas \\
\hline 6 & Antigeno HLA \\
\hline 7 & Assistência a municipios em calamidade \\
\hline 8 & Assistência hospitalar e ambulatorial (MAC) \\
\hline 9 & Campanha de Oftalmologia - Açőes Estratégicas \\
\hline 10 & Campanha de acompanhamento a paciente deficiente auditivo \\
\hline 11 & Campanha de acompanhamento pós-transplantes \\
\hline 12 & Campanha de cirurgia cardiovascular \\
\hline 13 & Campanha de cirurgia da catarata \\
\hline 14 & Campanha de cirurgia da próstata \\
\hline 15 & Campanha de cirurgia de hérnia inguinal \\
\hline 16 & Campanha de Epilepsia \\
\hline 17 & Campanha de pré-natal \\
\hline 18 & Campanha de quimioterapia \\
\hline 19 & Campanha de radioterapia \\
\hline 20 & Campanha de retinopatia diabética \\
\hline 21 & Campanha de vacinação \\
\hline 22 & Campanha de vacinaçăo anti-rábica \\
\hline 23 & Cirurgia de varizes \\
\hline 24 & Cirurgia de deformidade crânio-facial \\
\hline 25 & Cirurgia de mama \\
\hline 26 & Cirurgia oncológica \\
\hline 27 & Cirurgias eletivas - Açōes Estratégicas \\
\hline 28 & Co-financiamento carga viral HIV e TCD4/CD8 \\
\hline 29 & Co-financiamento para custeio assistência unidades próprias \\
\hline 30 & Complemento teto financeiro - plena \\
\hline 31 & Câmara de compensaçăo de alta complexidade \\
\hline 32 & Câncer de Colo Uterino - Açōes Estratégicas \\
\hline 33 & Deformidade Crânio-Facial - Açōes Estratégicas \\
\hline 34 & Fator de recomposição $25 \%$ (plena) \\
\hline 35 & Financiamento. atividades cadastramento avaliação estabelecimento saúde \\
\hline 36 & Gestantes de alto risco - extra teto \\
\hline 37 & Gestâo plena sistema municipal - alta complexidade \\
\hline 38 & Gestão plena sistema municipal - média complexidade \\
\hline 39 & Histocompatibilidade - Ações Estratégicas \\
\hline
\end{tabular}




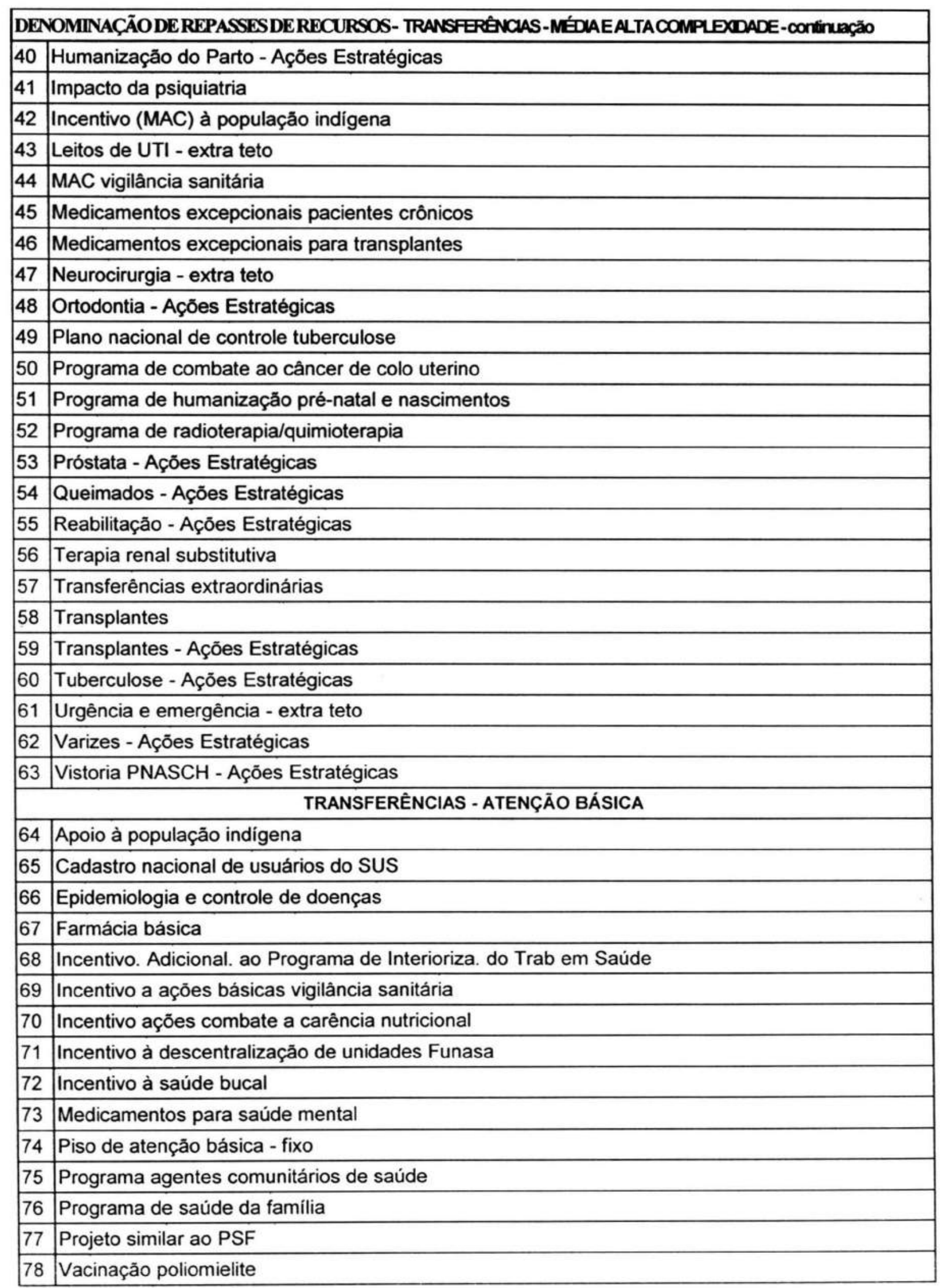


As várias NOBs e a NOAS, em sua essência, contrariam o princípio da descentralização e do cumprimento das competências legais. Cada esfera tem uma competência e tem que ter meios para cumprir suas competências.

O princípio da descentralização encontra-se violado. Municípios e Estados não dispõem dos recursos, não definem o quê fazer e têm que cumprir programação do Ministério da Saúde. Anteriormente foram mencionadas quase 80 maneiras de se receber recursos. Grande parte delas, priorizada pelo Ministério da Saúde, sem estudo de prioridades loco-regionais. Se Estados e Municípios aderirem a determinada campanha ou programa, têm recursos financeiros (sempre com mil exigências e trâmites burocráticos), caso contrário não os têm. Como um dos muitos exemplos, cita-se o programa, que visa a fixação de trabalhadores de saúde no interior, pelo qual municípios podem passar a ter profissionais, desde que cumpram a programação, seleção e gestão centralizada. O programa, em si, não tem nada de novo, pois Getúlio Vargas, já em 1945, assinara Decreto Lei (ainda em vigor), garantindo médicos para os municipios sem profissionais, com recursos federais. Depois da CF de 1988, esse sistema é, no mínimo, inconstitucional.

Se a definição do quantitativo de recursos para cada esfera de governo não se fez, até hoje não se sabe quanto de recursos do Ministério da Saúde deverá ser transferido a Estados e Municipios. Não havendo essa definição a seguinte, expressa em lei, que Estados ficam com $30 \%$ e Municipios, com $70 \%$, fica impossivel ser praticado e controlado.

Os centralistas interpretam a questão, da seguinte maneira: os recursos estão indo para Municípios e Estados. Em praticamente sua totalidade. É uma menor parte que fica com o MS, para pagamento de pessoal, divida e manutenção do MS. Assim, a interpretação fica perfeita. Não se discute se $70 \%$ estăo nas mãos do Municipio para serem utilizados, segundo plano próprio, aprovação de seu Conselho de Saúde e do Legislativo. Isto não acontece, também, em relação aos Estados. Em nenhum tipo de informação divulgada pelo MS é mostrado quanto está sendo transferido a Municipios e Estados. Uma coisa é transferir recursos para Estados e Municípios utilizarem. Outra é pagar prestadores de serviços que se localizam nos Estados e Municipios e, assim, computar a destinação descentralizada. Se procedesse segundo esse raciocinio, o INAMPS, em seu auge, praticava a maior das descentralizações, dado que a grande maioria de seus recursos pagava serviços localizados nos Estados e Municipios.

Mais à frente, são discutidas duas questões: os critérios de rateio (que são os acima e não os legais) e as maneiras de fazer chegar esses recursos a Estados e Municípios, que ainda que denominadas e praticadas Fundo a Fundo, nada têm a ver com o repasse regular e 
automático. A sistemática é de passagem de recursos entre o FNS e os Estaduais e ou Municipais, como repasse inter Fundos. Entretanto, sob essa nomenclatura estão sendo "escondidas" todas as formas condenadas de repasse de recursos, como mediante convênios voluntários com distribuição, por critérios não técnicos e clientelistas, do pagamento por produção de serviços, por pagamento aos profissionais de saúde pelo Código 7, que representa a forma de terceirização do trabalho médico, em separado ao da Instituição a que pertence. E... outras mais.

\section{CRITÉRIOS DE RATEIO DOS RECURSOS FEDERAIS DA SAÚDE ENTRE AS TRÊS ESFERAS DE GOVERNO}

\subsection{O LEGAL}

Admitido como Constitucional e legal que os recursos do Orçamento da Seguridade Social são de propriedade das três esferas de governo, ainda que arrecadada apenas por uma delas, fica agora a questão seguinte: quem fica com quanto, para fazer o quê? Qual é o critério de rateio desses recursos? Qual a sistemática de rateio?

Como visto antes, a EC-20, de 15-12-1998, pela primeira vez, dentro das diretrizes da seguridade social (CF $195 \S 10^{\circ}$ ) dispõe sobre a saúde, deslocando para a lei a definição de critérios de transferências de recursos para o Sistema Único de Saúde, da União para Estados, o Distrito Federal e os Municípios, e dos Estados para os Municipios, observada a respectiva contrapartida de recursos.

O mesmo pode ser verificado, quando do Art.198 $\S 3$ introduzido pela EC-29, de 13/9/2000, em que a definição fica na dependência de Lei Complementar. (16)

No Art.195,10, com modificações de 1998, duas questões novas se colocaram: no caso, a lei com definição dos critérios de transferência de recursos da União para Estados e Municípios a que se refere, deve ser uma nova lei, ou aplica-se ai o que já está definido na Lei 8080 ? E em relação ao repasse dos Estados para Municípios, que lei definirá os critérios? Lei Federal ou Lei em cada Estado? A outra questão é que ai se assume que os repasses são condicionados à contrapartida, conceito antes questionado pois, se a compreensão que saúde seja de competência e responsabilidade de cada esfera de governo, é conseqüente que o repasse de recursos financeiros entre quem tem a competência e faculdade de arrecadar, não pode ser condicionado a que se tenha e demonstre contrapartidas. Estas 
duas questões podem ser consideradas inconsistentes e superadas, se levado em consideraçăo o entendimento de Lenir Santos de que o fato de ser posterior a EC-29, de 13/9/2000, à EC-20, a segunda, automaticamente, deixa sem valor o § 10 do 195 .

"Cabe, ainda, destacar que, tanto o § 10 do art. 195 da CF, quanto o § $3^{\circ}$ do art. 198 , tratam do mesmo assunto, ou seja, critérios para o rateio dos recursos da União, destinados aos Estados, Distrito Federal e Municipios, tendo ambos sido acrescidos na Constituição mediante emenda à Constituição EC 20/98 e EC 29/2000 (15). O primeiro (§ 10 do art. 195) exige lei ordinária e, além do SUS, menciona, ainda, a assistência social e a necessidade de contrapartida dos entes recebedores; o segundo, exige lei complementar e só se refere ao SUS. Vê-se que os dois parágrafos dispõem sobre o mesmo tema, devendo considerar-se o estatuído no último ( $\$ 3^{\circ}$, do artigo 198). Como já existem duas leis ordinárias dispondo sobre o assunto, ambas recepcionadas pela Constituição, uma vez que não a contrariam (Leis ns. 8.080/90 e 8.142/90). Enquanto a lei complementar não disciplinar a matéria, prevalece o disposto nas leis ordinárias ora vigentes." (85)

Uma das bases fundamentais do rateio seria a definição clara de competências de cada esfera de governo. A lógica deve ser que os recursos financeiros devem ficar nas mãos de quem tem a competência do fazer. O que dispõe a lei sobre a competência, o dever-fazer, da União, Estados e Municípios. Isto já foi discutido anteriormente e não se tem qualificado, nem quantificado para que se estabeleça esse critério como mandatório. Genericamente se sabe, mas não com limites nítidos estabelecidos.

A CF nada diz a respeito de como será a partição das receitas federais, que são de arrecadação comum das três esferas de governo. Esta definição está na Lei 8080 , art.36 (16) segundo a qual o processo de planejamento e orçamento do SUS deverá ser ascendente, do Municipio à União, ouvidos os Conselhos de Saúde compatibilizando-se necessidades com disponibilidades de recursos nos vários planos. Cabe ao Conselho Nacional de Saúde estabelecer diretrizes a serem observadas na elaboração dos planos de saúde, em função da epidemiologia e da organização de serviços em cada jurisdição administrativa (Lei 8080,37 ). A base do "quanto" está ligada ao planejamento e orçamentação de cada esfera de governo. Para receber financiamento é condição estar dentro do Plano. Nada que não conste do plano, exceto emergências, poderá receber transferências.(Lei $8080,36, \S 2^{\circ}$ ). A primeira referência que se faz a essa partição, por esfera de governo, é na Lei 8142, art.2, IV, define que os recursos do Fundo Nacional de Saúde serão alocados para cobertura das ações e serviços de saúde a serem implementados pelos Municípios, Estados e Distrito Federal e, logo a seguir, no art. $3 \S 2$, que determina que esses recursos sejam destinados, pelo menos, setenta por cento aos Municípios e o restante, aos Estados. Qual o percentual para o MS? Nada declarado, só a base do Plano (Lei 8080,36 ). Do que deve ser passado a Estados e Municípios: $70 \%$, no mínimo, para Municipios e $30 \%$ para Estados. 
O art.77, do Ato de Disposições Constitucionais Transitórias, ainda, além do acima, tem a definição do percentual mínimo de $15 \%$ das transferências da União para serem empregadas em serviços básicos de saúde nos Municípios, e pelo critério populacional. Isso é questionado por Lenir Santos :

"Por sua vez, o art. $77, \S 3^{\circ}$, do $A D C T$, obriga que a União aplique no Município, no mínimo, $15 \%$ dos recursos transferidos em ações e serviços básicos de saúde, na forma da lei. Aqui trata-se de edição de lei ordinária e não de lei complementar. A má redação desse parágrafo é patente. À União não compete aplicar recursos no município, mas sim transferir recursos para o município executar o seu plano de saúde, devendo, observar que, dos recursos recebidos da União, quinze por cento, no mínimo, serão aplicados em ações e senviços básicos de saúde." (85)

Sem declarar o que seria devido a cada esfera de governo, a Lei 8080 definiu, já em 1990, quais seriam os critérios de transferência dos recursos. Ainda que em 2000, com a EC-29, de 13/9/2000, como já referido, tenha passado para o texto constitucional (art. 198, § 3) que Lei Complementar, que será reavaliada pelo menos a cada cinco anos, estabelecerá os critérios de rateio entre os recursos da União vinculados à saúde, destinados a Estados, Distrito Federal e Municípios e de Estados a Municípios; como não existe essa lei complementar, ainda, prevalece o que está explícito na 8080 .

A Lei 8080,35 (27) apresenta sete critérios para serem utilizados no estabelecimento de valores a serem transferidos a Estados, Distrito Federal e Municípios. Determina que definição deve ser feita de acordo com análise técnica de programas e projetos. Os sete critérios: perfil demográfico, perfil epidemiológico, rede de saúde da área (qualidade e quantidade), o que foi feito técnica, financeira e economicamente no ano anterior, recursos próprios dos Municípios e Estados, previsão de investimentos e ressarcimento do atendimento a serviços prestados para outras esferas. Logo, a seguir, é colocado que $50 \%$ dos recursos devidos a Estados e Municípios será pelo quociente populacional, puro e simples, com a ressalva de que em Municípios sujeitos a processo migratório intenso poderão ser usados outros critérios, como o número de eleitores.

A lei 8142 (28), publicada no mesmo dia, já prevendo que a definição técnica os referidos critérios poderia demandar tempo, fez uma "emenda" ao que está definido no art. 35 da 8080. No $\S 1$ do art. $3^{\circ}$, explicita que, enquanto não se regular o art.35, o repasse de recursos será feito, exclusivamente, pelo quociente populacional ( $\S 1^{\circ} \mathrm{do}$ art.35).

Sólon e Piola (144) desenvolveram pesquisa importante, logo após o advento da Lei 8080 (27), em que fizeram as primeiras simulações sobre a possibilidade à época, de se aplicar o art.35. Isto foi há dez anos. Concluíram que a divisão, segundo critérios propostos pelo Art.35, no final, resultariam quase que no mesmo quantitativo final, se esses recursos 
fossem distribuídos per capita. Volta-se à pergunta: é possível financiar, hoje, a eqüidade sem aumento de recursos financeiros? Conhecemos algumas opções que não se pode deixar de reconhecer: a) regulando o acesso aos serviços de saúde e às ações simples e complexas; b) combatendo as várias discriminações: cobrança por fora, por tráfico de influência, por acesso indireto facilitado aos procedimentos mais complexos; c) com uma redistribuição eqüitativa dos recursos nos procedimentos de maior incidência ou mais impacto, e não apenas pelo critério da maior pressão. O que se defende é um caminho de se construir a eqüidade, a partir de maior aporte de recursos. Existe uma proposta apresentada, em texto, de 1992. (84) Analisando a atual distribuição de recursos, extremamente desigual, verifica-se que persiste até hoje. A proposta, ainda, é de que, neste momento, a distribuição igual de recursos per capita, além de ser a única legal (Lei 8142), é uma maneira de se atingir a EQÜIDADE PELA IGUALDADE. Dados como os acima, referentes ao ano de 2000, mostram que a distribuição dos recursos federais para a Saúde corresponde a R\$62,7 - PC em média. Se se tomar o maior per-capita, este se encontra no Estado de São Paulo, $\mathrm{R} \$ 72,75$. A proposta é a de elevar o valor de cada Estado brasileiro ao maior valor percapita ${ }_{1} \circ$ de São Paulo. O teto atual da totalidade dos recursos repassados a estados é de $\mathrm{R} \$ 10 \mathrm{bi}$, com o per-capita de $\mathrm{R} \$ 62,70$. Se se elevarem todos os Estados ao teto per-capita de São Paulo, de $R \$ 72,75$, o gasto seria de $R \$ 11,6$ bi. Apenas $R \$ 1,6$ bi a mais, ou seja, apenas $8,1 \%$ a mais de recursos. Esses estudos vêm sendo feitos desde 1992 e eram a essência da abortada "NOB-94", já citada em detalhes. (46)

Ao fazer essa equalização, possibilitar-se-ia que Estados que têm teto mais baixo tivessem um aporte maior de recursos, possibilitando melhora da rede de serviços, tanto em quantidade, quanto em qualidade. A aparente sobra de recursos quebraria o círculo da insuficiência, gerador de mais insuficiência e ineficiência. Essa proposta se contrapõe frontalmente a uma proposta sofismática de tirar de quem mais tem para dar para os que menos têm. Tal proposta é cínica e levaria ao aprofundamento do caos do sistema, segundo nosso modo de entender.

\subsection{O REAL}

Este é um dos preceitos descumpridos da determinação legal. Definido o montante de recursos, da parte destinada a Estados e Municipios, $70 \%$ deveriam no mínimo, ficar com os municípios e $30 \%$, com os Estados.

O critério de repasse é claro: $50 \%$ pelo quociente populacional e $50 \%$ por outros critérios (art.35): enquanto não se definem os critérios, deve-se repassar o montante de recursos 
totalmente pelo quociente populacional. Montante de dinheiro, dividido pela população, resulta no valor per-capita que, em cada Estado e Municipio, será o multiplicador pela sua população.

As várias NOBs, desde o comando da lei em 1990, descumprem sistematicamente a Lei.

Em 1990, com a NOB-91 e 92, os recursos eram repassados como pagamento por produção. Ainda que o montante destinado às atividades ambulatoriais fosse estabelecido como um valor per-capita para cada estado, a definição desse valor tinha, como base, a produção pretérita e continuava, internamente a cada Estado, sendo repassado aos Municipios, mediante cadastro e cotas históricas de produção.

Entretanto, nada do que é prescrito aconteceu até hoje. Tomemos a 8080 , no art.35, já citado: dos recursos destinados a Estados e Municípios, 50\% deve ser repassado por quociente populacional. O que ocorre hoje? Apenas, a partir de 1998, quando se introduziu o $\mathrm{PAB}$, passou-se a passar um recurso exclusivamente pelo critério populacional. É seu componente fixo. Esse componente representa 10,47\% em 1998, 14,40\%, em 1999, e $13,16 \%$, em 2000 .

As outras formas de repasse passam ao largo daquelas definidas no artigo 35,8080 . Quanto é repassado, segundo o perfil demográfico da região (não simples número de população)? Pelo perfil epidemiológico da populaçăo a ser coberta? Pelo desempenho técnico, econômico e financeiro no período anterior? Pelos niveis de participação do setor saúde nos orçamentos estaduais e municipais? Pela previsão do Plano qüinqüenal de investimentos em saúde? Pelo ressarcimento do atendimento e serviços prestados para outras esferas de governo?

Poder-se-ia dizer apenas que o critério predominante, ainda, é o da capacidade produtiva da rede de saúde na área. Muito mais por critérios quantitativos, que qualitativos. Critério perpetuador da iniqũidade, na medida em que continua repassando recursos a quem já tem serviços e os que não têm continuam sem a possibilidade de ter o financiamento para consegui-los.

A que critérios atende a atual sistemática de repasse pelas cerca de oitenta formas citadas acima? Até que ponto a NOAS editada em 2001 busca o atendimento aos ditames legais de critérios de repasse? Ou justamente esta e outras normas em vigor cristalizam a ilegalidade de se caminhar ao arrepio da lei? 
VALORES GASTOS COM O SUS - MS - 1998 A 2000

\begin{tabular}{|c|c|c|c|}
\hline Programas & $1998(\mathrm{R} \$)$ & $1999(\mathrm{R} \$)$ & $2000(\mathrm{R} \$)$ \\
\hline GAP SIAVSUS & 2.955.406.797,71 & $2.233 .925 .404,79$ & 2.117.699.056,46 \\
\hline AlH/SUS & $2.890 .678 .330,56$ & $2.643 .351 .020,64$ & $2.383 .971 .109,96$ \\
\hline ASSIST.AMB.-HOSP. INDIGENA & 0,00 & 0,00 & $16.795 .984,00$ \\
\hline GESTÃO SEMIPLENA & $966.201 .563,66$ & $5.126 .809,15$ & 0,00 \\
\hline GESTÃO PLENA MUNICIPAL & 1.596.669.172,19 & $3.535 .867 .889,34$ & 4.314.441.577,31 \\
\hline GESTÃO PLENA ESTADUAL & $22.402 .569,49$ & 56.512 .633 .49 & $552.586 .709,12$ \\
\hline GESTÃO PLENA (FUNASA) & 0,00 & $25.079 .185,64$ & $17.476 .206,42$ \\
\hline GESTÃO AVAN. ESTADUAL & $7.820 .895,85$ & $95.241 .624,12$ & 0,00 \\
\hline PROGRAMA MED. S. MENTAL & 0,00 & 0,00 & $20.362 .745,37$ \\
\hline FIDEPS & 0,00 & 0,00 & $284.823 .809,84$ \\
\hline TTO FORA DOMICÍLIO TFD & $3.059 .751,89$ & $918.933,08$ & $2.965 .165,31$ \\
\hline PISO DE ATENÇÃO BÁSICA & $1.013 .007 .518,87$ & 1.581.331.333,97 & $1.748 .045 .142,60$ \\
\hline CARÊNCIAS NUTRICIONAIS & $36.446 .937,50$ & $127.101 .390,00$ & $152.997 .288,75$ \\
\hline PAB/PACS-PSF & $112.618 .860,52$ & 298.718.919,06 & $628.314 .317,19$ \\
\hline PAB/PVS & $21.560 .663,01$ & $36.442 .665,89$ & $48.179 .793,75$ \\
\hline PAB/FARMÁCIA BÁSICA & 0,00 & $110.218 .990,86$ & $168.615 .385,12$ \\
\hline EXTRA-TETO (FAEC) & 0,00 & $233.887 .392,82$ & $561.710 .800,99$ \\
\hline CALAMIDADES PÜBLICAS & 0,00 & 0,00 & $4.544 .967,00$ \\
\hline CAMP. VACINAÇÃO & 0,00 & 0,00 & $13.061 .407,75$ \\
\hline CAMP. VAC. ANTI-RÁBICA & 0,00 & 0,00 & $7.711 .095,50$ \\
\hline TFECD & 0,00 & 0,00 & $243.046 .618,74$ \\
\hline CONVÊNIOS/EMENDAS * & $16.228 .843,00$ & 0,00 & 0,00 \\
\hline CONVÊNIOS MUNICIPALIZAÇÃO * & $34.180 .000,00$ & 0,00 & 0,00 \\
\hline TOTAL & $9.676 .281 .904,25$ & $10.983 .724,192,85$ & $13.287 .349 .181,18$ \\
\hline
\end{tabular}

("): os convênios firmados pelo Ministério da Saúde em 2000 encontram-se em "convenios firmados".

Fonte: FUNDO NACIONAL DE SAÚDE

Destes recursos poder-se-ia afirmar com segurança que apenas aqueles relativos ao PAB se enquadrariam exatamente nos critérios legais de repasse. Os recursos que mais se aproximariam disto seriam aqueles globais relativos à Gestão Plena do Sistema e SemiPlena. Pecam igualmente pois tanto em um como no outro o montante foi calculado em cima da série histórica apenas de produção anterior. A NOB-93 tinha elencado entre os vários “ estádios" de gestão a Gestão Semi-Plena e Plena. A Plena era exatamente aquela em que 
se atendia aos critérios de repasse do artigo 35 da 8080 . A semi-plena era o caminho para se chegar lá. A NOB-96 utilizou-se a meu ver indevidamente a denominação de gestão plena quando não é um avanço na autonomia, nem no cumprimento da lei. Mesmo estes municípios ficam sujeitos a recebimento de recursos, através de outras formas como os das campanhas e de programas especiais.

Não é novo um sistema de alocação de recursos, tomando-se como base o quociente populacional. Está expresso na Lei 8080 (50\% do volume de recursos federais deverá ser partilhado pelo quociente populacional) e na Lei 8142 , que determina o repasse de $100 \%$ pelo critério populacional, enquanto não se definem os demais indicadores de eqüidade (art.35 da 8080). Foi colocada na NOB 93 como uma expressão de desejo, reservando-se o termo de gestão plena para o momento em que os critérios de distribuição de recursos não fossem mais exclusivamente por produção. Veio a NOB 96, só aplicada em 1998, com a introdução, ainda que tímida, de um valor único per-capita o PAB.

O PAB, tentativamente, é uma expressão da equidade, além de representar um acerto no cumprimento da Constituição, da lei 8080,8142 e da NOB de 1996. Há alguns erros, entretanto: o baixo valor (base 96); o bloqueio da implantação em 18 meses seguido de uma implantação afoita. A afoiteza é clara quando se passam quase dez meses para se fazer uma regulamentação.

Não são despreziveis os riscos de se transformar o PAB na cesta básica dos pobres, com a entrega do restante à economia de mercado.

Se tomarmos os recursos da Seguridade Social para a saúde, destinados à assistência, como um todo, teremos a certeza da iniqüidade na sua distribuição. Vejam-se os dados abaixo, pelas regiões do Brasil.

RECURSOS FEDERAIS PARA A SAÚDE POR REGIÃO - BRASIL - 2000

\begin{tabular}{|l|c|c|}
\hline REGIÃO & VALOR PER CAPITA R\$ & COMPARATIVO COM MÉDIA BR \\
\hline NORTE & 45,17 & MENOS $17,53 \%$ \\
\hline NORDESTE & 55,95 & MENOS $6,75 \%$ \\
\hline SUDESTE & 68,70 & MAIS $6 \%$ \\
\hline SUL & 68,14 & MAIS 5,44\% \\
\hline CENTRO OESTE & 59,96 & MENOS $2,74 \%$ \\
\hline BRASIL & 62,70 & \\
\hline
\end{tabular}

Fonte: MS - Estudos de Mozart Oliveira e do autor. 
A maior diferença entre regiões ocorre entre o SE e o NO, o Sudeste apresentando um valor per capita $52 \%$ maior que a região NO. Na distribuição por Estados, encontra-se o maior valor no Estado de São Paulo (R $\$ 72,75$ PC) e o menor, no Estado do Amapá ( $R \$ 39,90$ PC). Entre São Paulo e Amapá há uma diferença de quase o dobro. São Paulo recebe, per capita, mais $82,33 \%$ que o Amapá.

\section{REPASSE AUTOMÁTICO DA UNIÃO - DOS RECURSOS DO ORÇAMENTO FISCAL E DA SEGURIDADE SOCIAL - PARA O FUNDO NACIONAL DE SAÚDE}

\subsection{O LEGAL}

Os órgãos arrecadadores de recursos federais destinados à saúde, não fazem parte do MS. Quem arrecada os recursos, referentes à Contribuição de Empregados e Empregadores sobre a folha de pagamento é o Ministério da Previdência e Assistência Social. As demais contribuições sociais, financiadoras da Seguridade Social são arrecadadas pelo Ministério da Fazenda.

Há que se identificar quanto, como e quando os recursos arrecadados por Ministérios outros, que não o da Saúde, devem ser repassados para manter a saúde.

O processo orçamentário é regulado pela CF, art. 165. Começa pela Lei do Plano Plurianual, feita a cada quatro anos para os três anos restantes de uma gestão e para o primeiro da gestão seguinte. A cada ano, faz-se a Lei de Diretrizes Orçamentárias, que traduz propostas referentes a cada ano. A LDO estabelecerá metas e prioridades de governo. Rotineiramente, os Ministérios são convocados a participarem na proposta do executivo que será submetida ao Congresso Nacional. A seguir, a proposta orçamentária, que já é o detalhamento, com valores da PPA e LDO, será elaborada integradamente entre Saúde, Previdência e Assistência.

$\mathrm{Na}$ CF, art. 195, §3, está escrito que: "a proposta de orçamento da seguridade social será elaborada de forma integrada pelos órgãos responsáveis pela saúde, previdência e assistência social, tendo em vista as metas e prioridades estabelecidas na lei de diretrizes orçamentárias, assegurada a cada área a geståo de seus recursos." 
Isto se repete no art.31, da 8080: "O orçamento da Seguridade Social destinará ao Sistema Único de Saúde - SUS, de acordo com a receita estimada, os recursos necessários à realização de suas finalidades, previstos em proposta elaborada pela sua direção nacional, com a participação dos órgãos de Previdência Social e da Assistência Social, tendo em vista as metas e prioridades estabelecidas na Lei de Diretrizes Orçamentárias."

A lei que regula a Seguridade Social, 8212, traz no Art. 19: "O Tesouro Nacional entregará os recursos destinados à execução do Orçamento da Seguridade Social aos respectivos órgãos e unidades gestoras nos mesmos prazos legais estabelecidos para a distribuição dos Fundos de Participação dos Estados, do Distrito Federal e dos Municípios. $\S 1^{\circ}$ Decorridos os prazos referidos no caput deste artigo, as dotações a serem repassadas sujeitar-se-ão a atualização monetária segundo os mesmos indices utilizados para efeito de correção dos tributos da União. $\S 2^{\circ}$ Os recursos oriundos da majoração das contribuições previstas nesta Lei ou da criação de novas contribuições destinadas à Seguridade Social somente poderão ser utilizados para atender as ações nas áreas de saúde, previdência e assistência social."

E os recursos da Seguridade Social, onde está previsto seu repasse para o MS? Esta determinação está contida na Lei 8080 , art. 34 , que responsabiliza as autoridades arrecadadoras (MPAS e MF), encarregadas pela distribuição da receita efetivamente arrecadada para a transferência automática dos recursos devidos, diretamente ao Fundo Nacional de Saúde. Sob que critério? O previsto no Orçamento da Seguridade Social.

O "quanto" está definido dentro de uma programação conjunta das três áreas que compõem a Seguridade Social com base na arrecadação das fontes próprias da Seguridade Social, já definidas e retratadas em capítulo anterior: COFINS, FOLHA, CSLL, CPMF, 50\% do DPVAT, percentual dos Concursos Prognósticos.

O "como" refere-se aos recursos fiscais e outros de contribuições sociais, procedentes do Tesouro Nacional e que, segundo a legislação supra citada, deverão ser entregues diretamente aos respectivos órgãos e unidades gestoras.

O "quando", está definido também, na Lei 8212, que estabelece que deverá ser nos mesmos prazos legais estabelecidos para a distribuição dos Fundos de Participação dos Estados, do Distrito Federal e dos Municipios. É mais: se não repassado nos prazos previstos e houver um processo inflacionário, "as dotações a serem repassadas sujeitar-se-ão a atualização monetária segundo os mesmos indices utilizados para efeito de correção dos tributos da União." 
Com a EC-20, de 15/12/1998, passou a ser constitucional uma medida adotada tomada em maio de 1993, que destina os recursos da Contribuição Social de Empregados e Empregadores exclusivamente ao Ministério da Previdência. CF,167, XI; "São vedados... a utilização de recursos provenientes das contribuições sociais de que trata o art.195,I, a e II, para a realização de despesas distintas do pagamento de benefícios do regime geral de previdência social de que trata o art.201."

Em função disso, o MPAS não passa mais nenhum recurso à saúde, ainda que se questione, juridicamente, o repasse de recursos que dizem respeito ao Acidente do Trabalho. Entretanto, os demais dispositivos legais, referentes à partição de receita dentro da Seguridade Social, permanecem em vigor, pois as demais receitas da Seguridade, ainda que não arrecadadas pelo MPAS, devem ser rateadas.

\subsection{O REAL}

O repasse, direto e automático, dos órgãos arrecadadores para a saúde não chegoua acontecer. O Ministério da Fazenda, na figura da Secretaria do Tesouro Nacional administra as receitas arrecadadas pela União, tanto as receitas fiscais, quanto as Contribuições Sociais, exceto a Contribuição sobre a Folha que é recolhida pelo Ministério da Previdência e Assistência Social.

O Ministério da Fazenda faz o fluxo de caixa, de acordo com as prioridades gerais do Governo Federal. Os recursos são liberados, em geral, por decêndios ou mediante a demonstração de necessidades.

As receitas fiscais, sem dúvida, devem ter uma maneira de serem tratadas de forma diferente das Contribuiçōes Sociais. Enquanto aquelas devem se submeter ao tratamento igual às demais receitas gerais do Governo, estas, as Contribuições Sociais, devem ser destinadas, exclusivamente, às áreas de Saúde, Previdência e Assistência Social, e a elas pertence.

Em épocas de inflação acelerada, como as enfrentadas nos anos 80 e início dos anos 90,0 Ministério da Fazenda, ao reter receitas específicas da Seguridade Social, subtraía recursos das áreas da Seguridade. A denominação desses recursos é de Disponibilidade da Receita. Estes tinham remuneração, e elevada, no periodo inflacionário e acabaram por ser apropriados pelo Ministério da Fazenda, e não entregues às áreas sociais, como devidos.

Outro aspecto grave foi que o Ministério da Previdência e Assistência Social, responsável pela arrecadação, utilizou-se dos mesmos critérios, repassando em prazos que lhe 
aprouvessem. Vale lembrar o relatado na primeira parte do Texto, que o Sr. Sérgio Cutolo, então Secretário Executivo do Ministério de Previdência e Assistência Social, disse, em audiência pública no Congresso Nacional, que iria repassar os recursos devidos à saúde, mas que não tinha prazo pois, segundo ele, a obrigação era repassar no ano, e isto seria feito no final do ano (78).

Todas essas perdas, durante anos, explicam, em parte, a defasagem com que os recursos da saúde chegaram ao Ministério da Saúde. Os órgãos arrecadadores Ministério da Previdência e Secretaria do Tesouro Nacional, durante anos, e a STN, até hoje, não têm pressa em fazer sistematicamente o repasse dos recursos, segundo a lei (nos mesmos prazos do FPM e FPE ou seja por decêndios dias 10-20-30 de cada mês). O arrecadado, de 1 a 10 , é transferido no dia 20 , o arrecadado, entre 11 e 20 , é transferido no dia 30 . O arrecadado, de 21 a 30, é transferido no dia 10 do mês seguinte. Com isto, o MS perdeu: a defasagem dos recursos pelo atraso no pagamento e a remuneração das disponibilidades dos recursos da Seguridade Social, arrecadados por um e outro.

São milhões e mais milhões de recursos de que ficou privada a saúde. O público, nas três esferas de governo, e os parceiros privados, lucrativos ou não.

\section{REPASSE AUTOMÁTICO DOS RECURSOS FEDERAIS DO MS - FUNDO NACIONAL DE SAÚDE - PARA ESTADOS E MUNICÍPIOS}

\subsection{O LEGAL}

Estabelecidos os critérios e quantitativos de repasses, cabiveis a cada esfera de governo, em relação aos recursos federais, o passo seguinte é definir como os recursos têm que ser repassados do Fundo Nacional de Saúde para os Fundos Estaduais e Municipais de Saúde.

Como condição de repasse a Lei 8142 no art. 4 determina que sejam cumpridos alguns prérequisitos; a existência de Fundo de Saúde, de Conselho de Saúde, Plano de Saúde, Relatório de Gestão, Contrapartida de Recursos, Comissão de Elaboração do Plano de Carreira, Cargos e Salários, previsto o prazo de dois anos para a sua aprovação. Esses condicionantes são colocados para que se possam passar os recursos. No parágrafo único, do mesmo artigo, dispõe-se que se Estados e Municípios não cumprirem com essas determinações, os recursos federais a eles devidos deverão ser administrados se Municípios, pelos Estados e, se Estados, pela União. 
A forma de passar os recursos da União para Estados e Municípios é, segundo o art. $3^{\circ}$ da mesma 8142 , de forma regular e automática.

Se os recursos federais para a saúde devem todos, segundo a própria CF, na EC-29 de $13 / 9 / 2000$, estarem dentro do Fundo Nacional de Saúde, logicamente só poderão sair dele para os repasses diretos e automáticos e virem a cair nos respectivos Fundos Estaduais e Municipais de saúde, caracterizando uma passagem de recursos, direta e automática, fundo a fundo.

O Decreto Federal 1232, de 30/8/94, reafirma que os repasses devam ser feitos de forma direta e automática.

\subsection{O REAL}

Em face do preceito legal de repasse, regular e automático, de recursos diretamente do Fundo Nacional de Saúde para os Fundos Estaduais e Municipais de saúde, há que se analisar o seu significado.

Há três questões que foram sempre tomadas como uma única. A primeira, é como devem ser repassados os recursos da esfera federal, MS, para as esferas estaduais e municipais. A resposta é que isto deva ser feito de maneira Fundo a Fundo. De um fundo para outro, sem nenhuma perda ou "pedágio", no meio do caminho. Nem no órgão transferidor, nem naquele que recebe os recursos: Estados e Municipios. A segunda, que esse repasse deva ser feito de forma direta (não permite intermediação, ágio, passagem pelas Secretarias de Fazenda etc. etc.), regular, obedecendo a prazos legais, mas dentro deles e a terceira, que essa transferência seja feita de forma automática. Independe de acordos, convênios, contratos de gestão etc.

A confusão é que, quando se desejou e lutou para a constituição dos Fundos de Saúde em cada esfera de Governo, o implícito nessa concepção é que seria a passagem direta, regular e automática de recursos, de acordo com as competências de cada esfera de Governo. Dai, a decepção diante da idéia usual, hoje, de que o repasse de recursos fundo a fundo esteja limitado à forma de transferência fundo a fundo. Assim, hoje, diz o Fundo Nacional de Saúde que tem crescido o repasse fundo a fundo de forma evidente. Só que, hoje, o repasse Fundo a Fundo foi generalizado a todo e qualquer recurso devido pelo MS a Estados e Municípios.

Guido Carvalho e Lenir Santos (85) demonstram juridicamente que os recursos não são posse do Ministério da Saúde, senão das três esferas de governo: MS, SES e SMS. Esses recursos deverão ser partilhados, segundo critérios técnicos. A concepção exata estava na 
NOB-93, em que o MS acolheu o cálculo feito dentro de cada Estado de qual seria o teto devido a determinado Municipio pleiteante à sua condição de gestão semi-plena. Como já foi dito anteriormente, esse cálculo ainda "pegava", por ser por série histórica de produção, mas a Gestão Plena da Nob-93 seria aquela em que os critérios seriam os da Lei 8080-35. Todos os recursos devidos eram repassados a esses municípios, que passaram a administrar seus recursos, de acordo com os Conselhos de Saúde e o Legislativo.

A transferência convenial acabou sendo hipertrofiada, a ponto de o Fundo Nacional de Saúde ter, em sua estrutura, todo um aparato para cuidar dos repasses financeiros, mediante convênios. Segundo o FNS, em 1999 11\% dos repasses eram feitos, mediante convênios e $47 \%$, através da sistemática Fundo a Fundo. Os quadros abaixo, montados pelo Fundo Nacional de Saúde, dão uma idéia do sistema totalmente inadequado, que está em vigor, para a transferência de recursos do MS para Estados e Municípios. 
CONVÊNIOS E TERMOS ADITIVOS FIRMADOS PELO MS - 2000

\begin{tabular}{|c|c|c|}
\hline AÇÃO & QTDE. & $\begin{array}{l}\text { Valor } \\
\text { (R\$) }\end{array}$ \\
\hline AIDS & 154 & $66.715 .057,48$ \\
\hline ALIMENTAÇĀO SAUDÁVEL & 15 & $1.424 .788,00$ \\
\hline ATENÇÃO À PESSOA PORTADORA DE DEFICIÊNCIA & 04 & $741.131,10$ \\
\hline CÂNCER & 30 & $12.312 .293,00$ \\
\hline CONTROLE DA HANSENIASE & 21 & $5.118 .999,50$ \\
\hline CONTROLE DA TUBERCULOSE & 22 & $2.494 .000,60$ \\
\hline EMENDAS PARLAMENTARES & 2.072 & $312.053 .508,68$ \\
\hline FARMÁCIA & 03 & $5.134 .622,00$ \\
\hline GESTÃO DE POLÍTICA DE SAÚDE & 11 & $2.140 .900,00$ \\
\hline MELHORIA HABITACIONAL PI CONTROLE DOENÇA CHAGAS & 01 & $156.713,50$ \\
\hline PREVENÇĀO E CONTROLE DE DOENÇAS DEGENERATIVAS & 25 & $4.340 .366,00$ \\
\hline QUALIDADE DO SANGUE E HEMODERIVADOS & 62 & $40.391 .144,54$ \\
\hline QUALIDADE E EFICIÊNCIA DO SUS & 538 & $76.650 .290,17$ \\
\hline SAÚDE DA CRIANÇA E ALEITAMENTO MATERNO & 11 & $2.188 .427,20$ \\
\hline SAÚDE DA FAMILIA & 43 & $11.297 .534,73$ \\
\hline SAÚDE DA MULHER & 09 & $943.592,40$ \\
\hline SAÚDE DO IDOSO & 01 & $22.440,00$ \\
\hline SAÚDE DO JOVEM & 11 & $459.437,00$ \\
\hline SAÚDE DO TRABALHADOR & 20 & $5.475 .498,01$ \\
\hline SAÚDE MENTAL & 10 & $533.819,80$ \\
\hline TOTAL & 3.063 & $550.594 .563,71$ \\
\hline
\end{tabular}

Fonte: Fundo Nacional de Saúde

Chama atenção a ação motivadora de se fazer um convênio ou termo aditivo. A presença maior é desencadeada por Emendas Parlamentares que, ainda que por autorização constitucional, acabaram por se tornar numa fonte de atos de corrupção. $\mathrm{Na}$ área da saúde, o que mais preocupa são que essas Emendas Parlamentares retaliam o orçamento do Ministério da Saúde, fazendo alocações de recursos, na maioria das vezes, totalmente fora dos planos de saúde. É de conhecimento comum que essas verbas de Emendas parlamentares, divididas e subdivididas, com recursos alocados, muitas vezes, como restos a pagar, anos depois, fugindo aos orçamentos iniciais, acabam por gerar inúmeras obras inacabadas. Alocação de consultórios dentários, sem infra-estrutura de instalações para sua localização e outros, constituem exemplos disso. 
CONVÊNIOS DO MS ACOMPANHADOS PELO FNS - OUT/99 A DEZ/00

\begin{tabular}{|c|c|c|c|c|c|c|}
\hline UF & $\begin{array}{l}\text { CONVÊNIOS } \\
\text { PROGRA- } \\
\text { MADOS }\end{array}$ & $\begin{array}{l}\text { CONVÊNIOS } \\
\text { ACOMPA- } \\
\text { NHADOS }\end{array}$ & $\%$ & $\begin{array}{c}\text { VALORES } \\
\text { PROGRAMADOS }\end{array}$ & $\begin{array}{c}\text { VALORES } \\
\text { ACOMPANHADOS }\end{array}$ & $\%$ \\
\hline$A C$ & 45 & 26 & 58 & $10.527 .864,39$ & $5.480 .980,54$ & 52 \\
\hline $\mathrm{AL}$ & 71 & 74 & 104 & $35.014 .158,00$ & $20.563 .123,69$ & 59 \\
\hline$A M$ & 56 & 45 & 80 & $14.353 .289,00$ & $9.654 .617,85$ & 67 \\
\hline $\mathrm{AP}$ & 69 & 62 & 90 & $11.651 .330,06$ & $12.992 .623,25$ & 112 \\
\hline $\mathrm{BA}$ & 97 & 56 & 58 & $71.405 .869,31$ & $54.286 .180,44$ & 76 \\
\hline CE & 63 & 85 & 135 & $30.804 .205,96$ & $24.406 .435,37$ & 79 \\
\hline DF & 13 & 08 & 62 & $40.925 .641,00$ & $29.605 .805,00$ & 72 \\
\hline ES & 61 & 72 & 118 & $22.189 .765,60$ & $26.090 .602,49$ & 118 \\
\hline GO & 112 & 151 & 135 & $20.563 .261,68$ & $36.279 .745,39$ & 176 \\
\hline MA & 58 & 91 & 157 & $15.900 .421,89$ & $16.364 .663,06$ & 103 \\
\hline MG & 117 & 69 & 59 & $66.460 .710,96$ & $45.380 .661,92$ & 68 \\
\hline MS & 63 & 81 & 129 & $31.400 .588,48$ & $42.144 .485,36$ & 134 \\
\hline MT & 75 & 59 & 79 & $16.465 .876,46$ & $16.405 .410,56$ & 100 \\
\hline PA & 70 & 73 & 104 & $37.584 .760,39$ & $29.419 .080,26$ & 78 \\
\hline PB & 82 & 73 & 89 & $37.093 .574,22$ & $16.113 .822,26$ & 43 \\
\hline $\mathrm{PE}$ & 108 & 71 & 66 & $52.718 .693,73$ & $45.994 .557,17$ & 87 \\
\hline PI & 46 & 30 & 65 & $26.020 .819,75$ & $7.619 .793,26$ & 29 \\
\hline PR & 121 & 135 & 112 & $31.904 .472,82$ & $28.831 .441,90$ & 90 \\
\hline RJ & 18 & 14 & 78 & $61.696 .505,85$ & $61.696 .505,85$ & 100 \\
\hline $\mathrm{RN}$ & 57 & 101 & 177 & $28.283 .809,94$ & $32.972 .107,77$ & 117 \\
\hline RO & 85 & 73 & 86 & $15.167 .060,35$ & $21.387 .656,49$ & 141 \\
\hline RR & 61 & 27 & 44 & $25.577 .221,85$ & $19.948 .029,02$ & 78 \\
\hline RS & 100 & 87 & 87 & $39.577 .269,86$ & $23.478 .385,98$ & 59 \\
\hline SC & 56 & 75 & 134 & $13.307 .309,95$ & $12.054 .584,62$ & 91 \\
\hline SE & 62 & 50 & 81 & $11.565 .206,56$ & $11.179 .803,85$ & 97 \\
\hline SP & 149 & 157 & 105 & $139.476 .515,99$ & $154.216 .864,59$ & 111 \\
\hline TO & 75 & 68 & 91 & $10.470 .896,98$ & $3.887 .472,36$ & 37 \\
\hline TOTAL & 1.990 & 1.913 & 96 & $918.107 .101,03$ & $808.455 .440,30$ & 88 \\
\hline
\end{tabular}

Fonte: Fundo Nacional de Saúde/CAAV 
CONVÊNIOS DO MS REGISTRADOS NO SIAFI - 1988-2000

\begin{tabular}{|l|c|c|c|}
\hline CONVÊNIOS & 1998 & 1999 & 2000 \\
\hline $\begin{array}{l}\text { Com PRESTAÇÃO DE CONTAS pendente de } \\
\text { análise }\end{array}$ & 1.940 & 1.780 & 2.888 \\
\hline Com PRESTAÇÃO DE CONTAS aprovadas & 562 & 277 & - \\
\hline $\begin{array}{l}\text { Com PRESTAÇÃO DE CONTAS } \\
\text { homologadas/aprovadas }\end{array}$ & 4.380 & 6.140 & 8.069 \\
\hline Com PRESTAÇÃO DE CONTAS inadimplentes & 322 & 960 & 614 \\
\hline Com recursos a liberar & 2.086 & 2.365 & 4.732 \\
\hline Com PRESTAÇÃO DE CONTAS a comprovar & 5.135 & 5.546 & 6.426 \\
\hline Com inadimplência suspensa & 433 & 682 & 842 \\
\hline TOTAL & 14.858 & 17.750 & 25.571 \\
\hline
\end{tabular}

Fonte: Fundo Nacional de Saúde

Diante dos dois quadros apresentados, a dúvida é sobre o tipo de acompanhamento possivel desses convênios pela esfera federal. Os processos a serem acompanhados, segundo o SIAFI, nos anos de 1998, 1999 e 2000, são, a cada dia, crescentes. Em 1998, são 14.858, em 1999, 17.750 e em 2000, 25.571. Fica registrado o crescimento de $72 \%$, entre 2000 e 1998. Toda a avaliação é feita na parte processualistica, inclusive a mais fácil de ser burlada. A questão fundamental que acaba não tendo condição de ser verificada é a propriedade daquele determinado objeto de convênio, para aquele local, naquela época. $E$ a seguir, se o objeto do convênio foi executado "in loco" e qual o impacto de sua efetivação sobre as condições de saúde daquela população.

7. ADMINISTRAÇÃO DOS RECURSOS FINANCEIROS FEDERAIS, ESTADUAIS E MUNICIPAIS DA SAÚDE EM FUNDOS DE SAÚDE

\subsection{O LEGAL}

Uma das boas novidades essenciais - agora no texto constitucional, embora nas ADCT, pela EC-29, de 13/9/2000 - foi a respeito da administração dos recursos do SUS, através de fundos. Tanto recursos próprios, como transferidos por outra esfera de governo, deverão ser administrados nos fundos de saúde (ADCT 77 § 3) (16). Na lei 8080 e na 8142 não ficou 
clara a questão da administração dos recursos através dos fundos de saúde. A primeira alusão que se faz é no art. 32 , em que se diz que as receitas geradas no âmbito do SUS (seriam as receitas próprias?) deverão ser creditadas diretamente em contas especiais e movimentadas pela sua direção na esfera de poder onde forem arrecadadas. Depois, no art. 33 , repete-se que os recursos do SUS (agora não mais com a limitação de serem apenas as geradas no âmbito do SUS!) serão depositados em conta especial, em cada esfera de sua atuação e movimentadas sob fiscalização dos Conselhos. A conta especial, mais à frente, recebe na 8142 , art. $4^{\circ}$, a denominação de Fundo de Saúde e este é colocado como exigência fundamental para se receberem os recursos de transferência federal.

Para a esfera federal, em que já existia o Fundo Nacional de Saúde, a determinação estava mais clara, pois o texto da $8080,33, \S$ determinava que os recursos de todos os orçamentos, o da Seguridade e o Fiscal seriam administrados pelo MS e no Fundo Nacional de Saúde. Recursos totais, de custeio e investimento $\left(8142-\right.$ art. $\left.2^{\circ}\right)$. No art. 34 , já existe a obrigação de que os recursos da Seguridade Social sejam transferidos, automaticamente, ao Fundo Nacional de Saúde. Os três elementos essenciais ficaram bem definidos: 1) trata-se de administração de todos os recursos, 2) o local dessa administração é o Fundo de Saúde e 3) a administração será do MS.

É de 30 de agosto de 1994 o Decreto Presidencial 1232, que trata do repasse de recursos do Fundo Nacional de Saúde para os Fundos Estaduais e Municipais de Saúde destinado à cobertura dos serviços e ações de saúde. Fica determinado que a transferência será feita, independente de convênios ou instrumentos congêneres, na dependência de critérios (art. $1^{\circ}$ ) e na dependência de existência de fundo de saúde em Estados e Municípios, plano de saúde e contrapartida de recursos.(art. $2^{\circ}$. (26)

\subsection{O REAL}

O Fundo Nacional de Saúde deveria administrar todos os recursos do Ministério da Saúde. Esses chegariam do Ministério da Fazenda e ingressariam no Fundo Nacional de Saúde, responsável por sua administração.

Após o preceito legal, até a extinção do INAMPS, houve uma grande separação da localização dos recursos. A parte mais substancial era administrada na autarquia INAMPS. 
Após a sua extinção, que se deu oficialmente em julho de 1993, pela Lei 8689 (33), até se completar o processo, continuou havendo esta dicotomia.

O que se esperava é que o órgão administrador dos recursos devesse ser aquele que estruturalmente faz a administração orçamentária e financeira. Evitar-se-ia a multiplicidade de órgãos e o excesso de níveis hierárquicos. O Ministério, entretanto, tem na sua estrutura, a meu ver, uma duplicidade de comando sobre a questão orçamentária-financeira.

Dentro da estruturação mais recente do MS, feita em junho de 2000, o FNS passou a ser uma Unidade Administrativa da Secretaria Executiva, saindo, assim, da Subsecretaria de Planejamento e Orçamento. Desta forma coexistem hoje, dentro da mesma Secretaria Executiva, a Sub-Secretaria de Planejamento e Orçamento e uma Diretoria Executiva do FNS. Ambos subordinados à linha de mando do Secretário Executivo, o Vice-Ministro, na estrutura ministerial.

Houve uma polêmica muito grande sobre a existência legal, ou năo, do Fundo Nacional de Saúde. A discussão partiu da premissa que todos os fundos foram extintos, a partir da CF de 1988. O entendimento de técnicos da saúde e alguns juristas é de que ele foi automaticamente criado na Lei 8080 , quando se fala de sua obrigatoriedade. A pressão foi tão grande, em 1995, que nem constou o Fundo Nacional de Saúde no orçamento 96 e foi preciso a LDO, 96-99, ratificar alguns fundos, entre eles o FNS, ainda que transitoriamente. A polêmica está finalizada, desde a EC-29, que sacramentou, de vez por todas, a obrigatoriedade de administrar os recursos da saúde, inclusive os próprios, e não apenas os de transferência, todos dentro do FNS e FES-FMS.

O ordenador de despesas do FNS é o Diretor Executivo do FNS, desde 2000.

Ao que consta dos relatórios do Fundo Nacional de Saúde, o FNS executa a totalidade de recursos, inclusive os recursos referentes ao pagamento de pessoal, ao pagamento da divida e às Fundações e Agências da estrutura do Ministério da Saúde.

\section{EXECUÇÃO ORÇAMENTÁRIA - FUNDO NACIONAL DE SAÚDE $\quad$ R\$ 1,00}

\begin{tabular}{|c|c|c|}
\hline ANO & INICIAL & TOTAL \\
\hline 1997 & 16.427 .879 .532 & 17.120 .238 .461 \\
\hline 1998 & 16.831 .673 .019 & 16.589 .298 .518 \\
\hline 1999 & 15.903 .341 .636 & 17.641 .705 .567 \\
\hline 2000 & 17.404 .567 .039 & 20.345 .610 .064 \\
\hline
\end{tabular}

Fonte: Fundo Nacional de Saúde 
Fica uma dúvida em relação à administração total dos recursos, quando relatórios do próprio FNS colocam, a seguir, a expressão: Valores Gastos com o SUS.

VALORES GASTOS COM O SUS - R\$1,00

\begin{tabular}{|c|c|}
\hline 1997 & $9.596 .770 .208,42$ \\
\hline 1998 & $9.676 .281 .904,25$ \\
\hline 1999 & $10.983 .724 .192,85$ \\
\hline 2000 & $13.287 .349 .181,18$ \\
\hline
\end{tabular}

Fonte: Fundo Nacional de Saúde

Qual seria a diferença? Todos os recursos são do SUS. A diferença aqui seria que os recursos referentes a determinadas despesas, como pessoal e outras, não são considerados como do SUS, ou não seriam administradas pelo FNS.

\section{FINANCIAMENTO DAS AÇÕES E SERVIÇOS COMPLEMENTARES DO SUS PRESTADOS PELO PRIVADO}

\subsection{O LEGAL}

A CF em seu artigo 197 diz que as ações e serviços de saúde são de relevância pública. Sua execução será feita diretamente, ou através de terceiros, e, também, por pessoa física ou jurídica de direito privado. É como se houvesse um Sistema Brasileiro de Saúde, com dois braços: o sub-sistema público de saúde e o sub-sistema privado. Aquele, denominado SUS e este, sem denominação, a não ser privado.

No art. 199 consagra-se a existência desse sub-sistema privado. Sua atividade é livre, evidentemente que submetido ao disposto no Art. 197, relativo ao caráter de relevância pública das ações e serviços de saúde, públicos e privadas, e à regulamentação, fiscalização e controle do poder público. Nesse artigo explicita-se melhor como as instituições privadas poderão participar, de forma complementar, do SUS, segundo suas diretrizes e sempre mediante contrato ou convênio. É dada a preferência para a relação com as entidades filantrópicas e as sem fins lucrativos. Terăo a remuneração contratual ou convenial, mas é vedada a destinação de recursos, como auxílios ou subvenções para o privado lucrativo. 
A Lei 8080 (27), no capítulo II, em três artigos, o 24, 25 e 26, explica como será a participação complementar do privado. A condição para recorrer ao privado é a insuficiência da cobertura assistencial do SUS em determinada área. A relação com o privado dar-se-á por contrato ou convênio, segundo o Direito Público, consolidando a preferência da filantrópica e as sem fins lucrativos. Como será o financiamento das ações? A Direção Nacional do SUS, MS, deverá estabelecer critérios e valores para a remuneração dos serviços e, também, os parâmetros de cobertura assistencial, aprovados pelo Conselho Nacional de Saúde (Lei 8080,26 (16)). Critérios, valores, reajustes têm que vir acompanhados de demonstrativo econômico-financeiro para que seja mantida a qualidade. Repete-se que tem que ser mantido o equilibrio econômico e financeiro do contrato.

\subsection{O REAL}

A realidade foi outra, durante muitos e muitos anos. O Ministério da Saúde não tinha nenhuma tradição em estabelecer parcerias com o setor privado. Muito excepcionalmente, eram feitas relativas a ações programáticas pontuais. Foi o INAMPS, sucedâneo do INPS, quem mais trabalhou com, e exagerou da parceria. É conhecida, e já citada aqui, a passagem em que o Ministro Delfim Neto, diante da opção de năo mais construir hospitais públicos previdenciários, criou o FAS para financiamento de hospitais privados que se propusessem a trabalhar contratados com o público. O pagamento do empréstimo estaria garantido, logo a seguir, pelo credenciamento automático para prestação de serviços de assistência à saúde aos previdenciários. Os contratos de parceria eram disputados entre os prestadores privados e só aconteciam através de muito tráfico de influência ou em situaçōes de necessidades emergenciais, ou de serviço único em determinada localidade. Os critérios políticos partidários levaram a muitos credenciamentos e descredenciamentos.

A realidade da parceria complementar do público, feita através do privado, apresenta alguns nós críticos, dos quais se destacam: os contratos e convênios, a defasagem de preços da tabela de pagamento, a defasagem de prazos de pagamento, o pagamento feito diretamente aos profissionais envolvidos nas instituiçőes.

A primeira questão refere-se a convênios e contratos. O MS, desde o advento do SUDS, em 1987, deixou de celebrar contratos e convênios com os prestadores, tendo transferido esta responsabilidade aos Estados. Com o SUS, abriu-se para que os Municípios fizessem contratos e convênios. (67) Depois de muita discussão, foi consensuado o texto entre representantes de todas as partes envolvidas, prestadores e gestores, resultando em uma portaria, que foi a grande conquista. Infelizmente mais uma vez se descumpriu a lei. Existem 
prestadores, há mais de uma década, sem nenhum termo oficial contratual. Problemas não resolvidos, nem pelo INAMPS, nem pelo MS, agora, cairam nas mãos dos Estados e Municípios. Existem Estados que, hoje, estão iniciando seus cadastros de prestadores para depois começarem o processo licitatório.

A segunda questão é a defasagem de preço da tabela de procedimentos. A tabela originária é de 1994 . Houve um abono de $25 \%$ nos idos de 1996. De lá para cá, a defasagem da tabela é gritante. De um lado, os procedimentos mais comuns e básicos encontram-se defasados em cerca de $100 \%$. Alguns procedimentos especiais, de maior complexidade, tiveram correção especial de até $300 \%$. É um grupo menor, mas de maior valor.

A lei 8080 , art. 26 (27), estabelece bem claramente que "na fixação dos critérios, valores, formas de reajuste e de pagamento da remuneração aludida neste artigo, a direção nacional do SUS deverá fundamentar seu ato em demonstrativo econômico-financeiro que garanta a efetiva qualidade de execução de serviços contratados". Nada disso ocorre na rotina, submetendo-se o MS às várias pressões recebidas para que os reajuste aconteçam. Como os procedimentos de maior complexidade sofrem mais pressão, estes são melhor aquinhoados, em detrimento dos de baixa complexidade e maior freqüência, em quantidade, e em pontos de prestação dos serviços. Enquanto, no período de 1998 a 2000 , os procedimentos básicos tiveram uma correção de $14,84 \%$, em média, os de média e alta complexidade tiveram um aumento de $30,35 \%$.

Uma das garantias de maior transparência e visibilidade dos procedimentos é a obrigatoriedade legal, prevista na Lei 8080 (27), que obriga a que os valores sejam aprovados pelo Conselho Nacional de Saúde. Essa prática aconteceu apenas nos anos de 1993 e 1994. Posteriormente, o cumprimento desse dispositivo legal foi abandonado até a presente data, início de 2002.

Como já foi citado acima na Lei 8212 (30) fala-se em correção de valores dentro do Governo, quando a STN deve corrigir valores repassados ao MS fora de seus prazos legais. Por que razão nunca houve correção desses valores, no mínimo, pela inflação?

A defasagem do prazo de pagamento é outra questão preocupante. Ao se estudarem séries históricas entre a competência dos serviços prestados e seu pagamento, imagina-se a impossibilidade de que se efetuassem os serviços. Emblematicamente, no quadro abaixo é apresentada essa defasagem percentual, num ano de grande inflação, como foi o de 1993. 


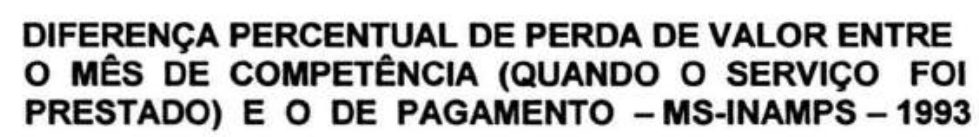

\begin{tabular}{|l|c|c|}
\hline MESES & AMBULATORIO & INTERNAÇÃO \\
\hline JANEIRO & 61,85 & 61,85 \\
\hline FEVEREIRO & 61,03 & 61,03 \\
\hline MARÇO & 45,11 & 50,65 \\
\hline ABRIL & 43,83 & 51,48 \\
\hline MAIO & 57,97 & 57,97 \\
\hline JUNHO & 75,78 & 74,96 \\
\hline JULHO & 74,89 & 65,03 \\
\hline AGOSTO & 54,02 & 67,42 \\
\hline SETEMBRO & 54,03 & 54,03 \\
\hline OUTUBRO & 53,60 & 53,60 \\
\hline NOVEMBRO & 55,15 & 67,59 \\
\hline DEZEMBRO & 52,14 & 58,52 \\
\hline MÉDIA TOTAL & 57,18 & 60,29 \\
\hline
\end{tabular}

Fonte: MS-DAF

Como fazer nessas circunstâncias inflacionárias? Como sobreviveram. Lembre-se de que nessa mesma tabela eram pagos os serviços prestados por entes públicos estaduais $\mathrm{e}$ municipais. Hoje, ainda, com menos inflação, a preocupação com a defasagem de prazos é grande. Não existe inflação, mas o custo do dinheiro para capital de giro está submetido aos juros escorchantes do sistema bancário. Pior que a inflação, quando a defasagem é grande.

Vale lembrar a questão dos indices de correção da tabela na conversão do Plano Real. Nesse periodo, a Saúde foi um dos setores mais prejudicados. Se, de um lado, os insumos se permitiram um aumento incontrolável, prevendo-se congelamentos futuros, o setor de prestação de serviços de saúde não conseguiu nem a correção para a tabela oficial, conforme foi apresentado na primeira parte deste trabalho.

A outra questão é que o pagamento aos profissionais médicos das instituições prestadoras de serviços de saúde eram feitas diretamente a eles, mediante simp!es credenciamento. $O$ mesmo acontecia com empresas da área de saúde, como Laboratório, Raio X, Banco de Sangue etc.. O absurdo dessas situações não era, como não é, aceita pelos juristas. É 
interessante que, quem inventou esta irregularidade, cristalizada há décadas, foi o INAMPS, um dos órgãos públicos responsáveis pela questão previdenciária, a que fica mais lesada. A autoridade do INAMPS, o caráter nacional e o interesse dos envolvidos fez com que isso fosse aceito e defendido como boa prática. Entretanto, ao passarem os contratos para Estados e, principalmente, municípios, a questão passou a não ser aceita pelas administrações públicas municipais, condenada pela procuradoria jurídica das prefeituras, levando ao medo plausível de possíveis ações trabalhistas. Se o contrato de prestação de serviços, mediante licitação, é feito com a instituição de saúde, Hospital, Santa Casa, como fazer qualquer pagamento direto aos seus fornecedores? Ou aos seus prestadores de serviços?

Hoje, o impasse está criado. De um lado, as entidades profissionais defendendo a permanência dessa maneira ilegal de pagamento. De outro, as entidades prestadoras com receio de assumirem esse pagamento e terem que arcar com os custos trabalhistas com valores totalmente defasados. Além disso, administradores públicos assumindo novos contratos e convênios, com receio de cometerem a ilegalidade anunciada pelos seus juristas.

A saída legal, já apontada no Ministério da Saúde, por juristas e técnicos da saúde, é que se faça o legal, passando-se às instituições contratadas a obrigatoriedade de pagar aqueles que prestam serviços, inclusos nos seus contratos. Como fazer isso com os mesmo valores irrisórios da tabela de serviços profissionais? Só existe a saída de se conceder uma correção nessa tabela no item serviços profissionais, em que se provisione o prestador com o diferencial de recursos necessários ao cumprimento das obrigações trabalhistas.

\section{A GRATUIDADE NO SUS}

\subsection{LEGAL}

Uma questão fundamental é a da gratuidade. Como isto se expressa na CF? A garantia está presente, quando se diz que saúde é um direito social $\left(C F-a r t .6^{\circ}\right)$ e, depois, que saúde é um direito do cidadão e dever do Estado (CF - art.196), assegurando acesso universal e igualitário às ações e serviços de caráter integral. Se é dever do Estado, e o acesso é para todos, sem distinção, está definida a gratuidade do acesso. Vale lembrar que a essência da gratuidade tem seu nascedouro no berço de toda a ação do Estado, que não oferece nada gratuito, senão com utilização dos recursos que provêm do próprio cidadão. A palavra 
gratuidade - talvez, por isso mesmo, não é explicita no texto constitucional. A lei 8080 , art. $2^{\circ}$ e $\S 1$ (27), repete os mesmos princípios, de forma mais explícita:

"A saúde é um direito fundamental do ser humano, devendo o estado prover as condições indispensáveis ao seu pleno exercício. O dever do estado de garantir a saúde consiste na formulação e execução de políticas econômicas e sociais que visem a redução do risco de doenças e de outros agravos e no estabelecimento de condições que assegurem acesso universal e igualitário às ações e aos serviços para sua promoção, proteção e recuperação."

Existe a interpretação de que a palavra gratuidade, que aparece no artigo 43 , refere-se a todas as ações e serviços de saúde: "A gratuidade das ações e serviços de saúde fica preservada nos serviços públicos contratados, reservando-se as cláusulas dos contratos ou convênios estabelecidos com entidades privadas". Entende-se que o texto seja "públicos contratados" numa expressão genérica, não jurídica, de que os contratados, ao se abrirem ao público universal, no objeto do contrato, aquela ação ou serviço seja público, claro que não a instituição em si, nem seus funcionários. Lenir Santos interpreta diferentemente e afirma:

"Outro entendimento não seria possível, uma vez que o artigo 43 garante a gratuidade dos serviços públicos e dos contratados e conveniados, e o artigo 196 da Constituição assegura ao cidadão acesso universal e igualitário. Assim, o serviço médicoassistencial prestado diretamente ao usuário não pode ser remunerado nem diferenciado. Há de ser gratuito. No SUS a gratuidade é um direito, infenso a qualquer construção administrativo-financeira tendente a contrariá-lo, por mais aparentemente lógica e convincente que possa ser a argumentação dos defensores da tese da "gratuidade contingente", equiparada, no caso do SUS, à "meia-gravidez"." (85).

Parece ser correta a interpretação acima; tem-se que aceitar, também, algo além do escrito, como uma conjunção "e" entre o público e o contratado. No texto legal, "público contratado". $\mathrm{Na}$ interpretação jurídica está faltando um "e" e o certo seria no público e contratado. Outra interpretação seria, onde se diz "contratados", subentenda-se "contratados e conveniados". Se assim não for, os conveniados podem cobrar por fora independentemente de cláusulas contratuais? Ou ainda, uma terceira interpretação é que esse artigo se refere ao "público contratado", no caso hipotético, com hospitais públicos universitários, militares e de assistência a servidores, o que não ocorre pois com estes a forma jurídica de "parceria" é mediante convênios. A questão é toda polêmica e tem-se que admitir que o artigo, em si, contém imperfeição em sua redação.

\subsection{REAL}

A dificuldade de se obterem recursos suficientes para a área de saúde (A EC-29 de 13/9/2000 garantiu apenas recursos definidos, mas não definitivos e insuficientes), tem 
levado a que sempre brotem saídas mágicas, muitas delas acabando por quebrar princípios constitucionais, incluindo-se o rompimento da gratuidade.

FHC, em sua proposta de reforma constitucional, incluía no direito universal à saúde o condicionante "nos termos da lei". O Ministro Adib Jatene defendeu a "cobrança por fora" em vários pronunciamentos. Albuquerque, que o sucedeu, também dizia, em suas falas, que em nenhum momento a federal afirmava que seja obrigação do Estado assumir integralmente a prestação ou o financiamento da saúde".

Em relação à situação global do financiamento da saúde, existem algumas alternativas em discussão, no momento, mas que são recorrentes: cobrança de fator moderador de uso, proposta da década de noventa do MF, Secretaria do Tesouro Nacional.

O Ipea, financiado pelo PNUD e CEPAL, publicou trabalho discutindo a gratuidade no SUS e a controvérsia do co-pagamento. (146)

A revisão da literatura nacional e internacional sobre recuperação de custos, um dos objetivos deste estudo, aponta que a divergência de opiniões resulta, pelo menos em parte, de as experiências com co-pagamento terem ocorrido em contextos bastante diversificados. O que pode ter dado errado em um lugar e sob determinadas circunstâncias pode ser exitoso em outro, e vice-versa. Além disso, de modo geral, as análises conhecidas referem-se ao uso generalizado dessa modalidade de cost sharing. Na verdade, muitas das restrições feitas à taxação do uso do serviço são menos ligadas ao instrumento em si do que à forma de sua implementação. Por exemplo: instituir o co-pagamento generalizado e estendê-lo a toda a população com a finalidade de moderar demandas supostamente abusivas não é o mesmo que o uso seletivo desse instrumento.

A seletividade, nesse caso, tem duplo significado. O primeiro é relativo à adoção do co - pagamento apenas nos municípios que o desejarem, ouvido sempre o conselho de saúde local. Impô-lo de cima para baixo e sem considerar a vontade e as possibilidades de cada comunidade local contraria o princípio da descentralização. Cobrar de quem, quanto, o que e em mais circunstâncias são decisões importantes demais para serem tomadas à distância do local de seus efeitos. Além disso, legislar nacionalmente sobre a gratuidade em um pais desigual, com faz a Lei $n^{\circ} 8080 / 90$, desatende às peculiaridades locais e impede que cada comunidade decida sobre o que Ihe pareça ser mais conveniente. A questão da saúde tem assumido tamanha importância na escala de valores da sociedade brasileira, como atestam as pesquisas de opinião, que não seria banal utilizar - se o plebiscito como instrumento de aferição da vontade popular, e adotá - lo nos municípios que venham a cogitar da implementação do co - pagamento.

O segundo significado da seletividade concerne à limitação do elenco de prestações do SUS passiveis de alguma contrapartida por parte de seus beneficiários diretos. Vale dizer que a participação no custeio não deve alcançar todos os serviços. Poderia ser limitada, por exemplo, aos não assistenciais. Seria um contra - senso se antepor barreira econômica ou algum outro tipo de dificuldade no acesso a serviços cujo uso deva ser estimulado em razão das externalidades positivas que geram, como acontece na vacinação contra poliomielite e o sarampo. 
Uma possibilidade a ser considerada em cada comunidade seria restringir a participação apenas ao uso de instalações privativas durante a internação e, eventualmente, a outros serviços médicos, particularmente aqueles nos quais a demanda reprimida tenha tamanho vulto que possa inviabilizar o seu custeio apenas com recursos orçamentánios ou, ainda, era que os procedimentos de cobrança tenham um custo aceitável e acarretem pouco ou nenhum transtorno para o paciente.

A institucionalização da participação no custeio inexoravelmente trará à tona a antiga questão da complementação dos honorários médicos. Conciliar os interesses das partes parece mais apropriado e menos difícil no município do que por norma nacional.

Evitar que na rede SUS, por exemplo, que o médico negocie seus honorários diretamente com o paciente tem claras vantagens: elimina o risco de mercantilização da medicina, protege o paciente na condição de consumidor, e ajuda a evitar a discriminação no acesso, além de eliminar a prática do pagamento por fora. Contudo, se impedido de cobrar, o profissional pode se desinteressar por pacientes privados de mudar esse atendimento para outro local de trabalho. Com isso, o hospital perde receita e as pessoas deixam de desfrutar do conforto que possam pagar. Usar os recursos arrecadados para melhorar a remuneração de todos os funcionários do hospital pode ser mais justo, democrático e eficiente para elevar o moral da equipe, mas provavelmente não será satisfatório para os médicos ideologicamente comprometidos com os postulados da medicina liberal clássica (Um desses postulados é o livre ajuste de honorários entre médico e paciente).

Uma possibilidade interessante para a proteção ao consumidor sem prejuízo do interesse legitimo do profissional seria a criação, em cada hospital, de tabela de preços acessivel ao usuário, combinada com a adoção dos chamados pacotes fechados, sobretudo no caso de internações. Essa medida tem as seguintes vantagens:

- protege o paciente, que saberá previamente quanto irá pagar pelo seu tratamento, independentemente dos dias que permanecer hospitalizado e dos medicamentos que consumir;

- cria competitividade entre hospitais;

- aumenta a cobertura da medicina privada, ao incorporar à demanda pacientes com alguma capacidade de pagamento mas que, por qualquer razão, não contam com proteção de plano de saúde;

- amplia o mercado de trabalho médico e assegura remuneração justa (fixa e/ou variável) ao profissional; e

- diminui a evasão fiscal, pois o paciente terá recebido e/ou nota fiscal sem ser constrangido a solicitá-la ao profissional.

A experiência internacional ensina que a participação no custeio, seja qual for seu objetivo, não está condicionada por fatores ideológicos. Cuba e China têm posições antagônicas nessa matéria. O mesmo acontece entre paises de economia de mercado. Os senviços médico - assistenciais são gratuitos no Reino Unido e no Canadá, mas não nos Estados Unidos."

Mais de uma vez, autoridades econômicas federais defenderam, em reuniões e publicamente, que se deva estabelecer um sistema de cobrança por uso, em que cada vez que o individuo utilizasse o serviço de saúde pagaria uma taxa, que teria duplo significado: moderar uso e contribuir no custo. Além de inconstitucional, diante da CF vigente, existe o seguinte: se são os pobres que estão usando e seria imoral cobrar deles, não acontecerá 
nem moderação no uso, nem ingresso de recursos novos. "Se os ricos usarem"... Usarão na ponta e pagarão preço vil pelos serviços de alto e altíssimo custo.

Outra proposta, prática em todo o Brasil é a da CPF, Cobrança Por Fora, uma prática inconstitucional, ilegal e...dita legitimada pela prática, pela tolerância e por posição de autoridades de saúde. É a "lei do cão", pela qual a mais valia prepondera e quem tem mais pode pagar por fora e consegue ser atendido nos serviços de saúde e os que menos têm, cada vez ficam mais alijados do acesso, pois ainda há repressão da demanda e as necessidades são maiores que as disponibilidades. Nesse momento, as disponibilidades serão seletivas para aqueles que pagam, como a história já mostra.

É a prática mais universal no Brasil, tolerada há décadas. Foi e continua sendo um dos empecilhos a que a saúde conseguisse outras saidas legais. A muitos profissionais interessa que o SUS continue sem recursos, pois isso permite a transformação da clientela SUS em "pagadores por fora", dentro de um critério individual onde predominam julgamentos subjetivos e injustos, muitas vezes, agravados pelo mau caratismo de só cobrar por fora para si, excluindo os companheiros que participaram como auxiliares no procedimento e a instituição!

Nesse particular o Ministro da Saúde, em 1995, manifestou sua posição a favor do pagamento de complementação, diretamente feita aos profissionais.

Uma outra questão maximizada, hoje, é a privatização de leitos públicos. Hospitais públicos, mantidos com recursos orçamentários públicos, com servidores públicos, com instalações e equipamentos públicos passam a destinar, por decisão interna corporis, um determinado percentual de leitos e serviços para serem "vendidos" aos cidadãos que têm planos e seguros de saúde ou que paguem diretamente ao hospital e/ou a profissionais. São segregadas partes dos hospitais: sala de espera, leitos, acomodações hoteleiras especiais, para serem utilizadas por essa clientela. $\mathrm{Na}$ instituição pública passa a existir uma dupla porta de entrada: uma para os cidadãos com direito ao atendimento público. Outra, com muito maiores facilidades de entrada e de recursos, destinada a cidadãos que, além do direito ao público, possuem algum tipo de plano e seguro de saúde, ou façam pagamento extra. O argumento utilizado é o da falta de recursos para manter a instituição. Deste modo, ao abrirem leitos e serviços segregados para uma minoria, que tem mais recursos, sofismase dizendo que esses recursos extras ajudarão a recuperar e manter os demais leitos e serviços para o restante da população. Os hospitais públicos federais, universitários, estão na busca de mais recursos, há já algum tempo. Eles recebem recursos orçamentários do Ministério da Educação, recursos de pagamento por produção, com tabela diferenciada de 
até setenta e cinco por cento a mais do Ministério da Saúde e possiveis convênios extras. Os recursos continuam insuficientes e a defesa de suas administrações é a privatização de leitos públicos. A grande investida é ver totalmente aprovada no Congresso Nacional (já o foi no Senado) uma Emenda Constitucional que permite, agora oficialmente, a separação de um percentual de leitos para serem vendidos no mercado com entrada privilegiada e acomodações especiais. Dentro do próprio público.

Entenda-se que a pretensão é oposta ao que se faz com o principio do ressarcimento a que estão submetidos, legalmente, planos e seguros de saúde. No ressarcimento existe uma porta única de entrada para todos os pacientes e quando estes têm direito a algum plano e seguro de saúde será cobrado destes o ressarcimento das despesas havidas para que não se tenha lucro sem matéria. Não há nenhum tratamento diferenciado, os administradores não sabem quem é, os profissionais igualmente desconhecem, ao contrário da privatização de leitos públicos, que contraria o princípio da igualdade e eqüidade do direito à saúde de todos os cidadãos à saúde.

\section{0 - CONTROLE PÚBLICO INSTITUCIONAL E SOCIAL DOS RECURSOS FINANCEIROS Do sus}

\subsection{LEGAL}

O controle público: é o controle sobre o público, a "res publica". O Controle público tem dois componentes: o controle institucional e o controle social. Controle social: é o controle exercido pelos cidadãos, individual ou coletivamente. Controle institucional: é o controle do público sobre o próprio público, intrainstitucional e interinstitucional, ou interno e externo.

Fundamento legal do controle institucional: " a administração pública, direta, indireta ou fundacional, de qualquer dos poderes da União, Estados e Municipios e DF, obedecerá aos principios da legalidade, impessoalidade, moralidade, publicidade." Cf art. 37. (16)

O fundamento legal do controle social está na CF art. $1^{\circ}$ "todo o poder emana do povo, que o exerce por meio de representantes eleitos ou diretamente, nos termos desta constituição". Os atores e mecanismos do controle público são de duas ordens, igualmente: atores do exercício do controle social: Individualmente, cada cidadão que ao fazer-se representar, institucionalmente ou não, não perde sua condição de exercer diretamente o poder. CF, art. $1^{\circ}$ : O cidadão, coletivamente, por intermédio de partidos políticos, associações de classes trabalhadoras, associações de moradores, movimentos de maiorias e minorias vários outros 
coletivos congregadores de cidadãos e vários conselhos existentes dentro da instituição pública geralmente ligados ao executivo como os conselhos de saúde e suas conferências.

Os atores do exercício do controle institucional: Intrainstitucional ou intra-poder por unidade, setor, órgão, esfera de governo como as ouvidorias, os sistemas e subsistemas de auditoria internos ou setoriais como a CISET, o Ministério Público, 127 a 130, os Tribunais de Conta (CF art.73,75). Interinstitucional ou inter-poderes, como o Legislativo, 70 a 75 , e Judiciário, 92 a 100 , sobre o executivo.

O controle institucional financeiro será feito segundo a legislação geral e a específica. Alguns artigos da lei 8080 referem-se a esses controles. Por exemplo, o art. 33, coloca que o MS acompanhará, através de seu sistema de auditoria, a conformidade à programação aprovada da aplicação de recursos repassados a Estados e Municípios. Constatada a malversação, desvio ou não aplicação dos recursos, caberá ao MS aplicar as medidas previstas em lei. No 35, §6 fala da atuação dos órgãos de controle interno e externo e da aplicação de penalidades previstas em lei em caso de irregularidades verificadas na gestão de recursos transferidos. Vários são os textos constitucionais e legais que determinam esse controle sobre a coisa pública. O financiamento é o principal objeto desse controle, já que ele é determinante das demais ações do estado. A primeira ferramenta para se fazer o controle é a informação: "todos têm direito a receber dos órgãos públicos informações de seu interesse particular ou de interesse coletivo ou geral que serão prestadas nos prazos da lei, sob pena de responsabilidade". Cf art. $5^{\circ}$, XXXIII

Outros textos constitucionais abrem a forma de participação do cidadão, como a CF, art.74,2, em que se afirma que qualquer cidadão pode denunciar o gestor público ao Tribunal de Contas da União, o que, por ilação, deve se aplicar aos Tribunais de Contas dos Estados. Os prefeitos têm que ouvir a comunidade ao planejar, (CF, 29, X). O executivo tem que publicar bimestralmente a execução orçamentária (CF art.165, III, $\S 3^{\circ}$ ) e deixar as contas municipais abertas, durante sessenta dias com a prestação de contas anuais, para que qualquer cidadão contribuinte possa ter acesso a ela. (CF art.31 $\S 3^{\circ}$ ). A divulgação dos dados de arrecadação é obrigatória às três esferas de governo: “A União, os Estados e os Municipios divulgarão, até o último dia do mês subseqüente ao da arrecadação, os montantes de cada um dos tributos arrecadados, os recursos recebidos, os valores de origem tributária entregues e a entregar e a expressão numérica dos critérios de rateio. Os dados divulgados pela União serão discriminados por Estado e por Municipio; os do Estado por Município" (CF, 162). 
Mais recentemente, em maio de 2000, a Lei de Responsabilidade Fiscal - Lei complementar 101, consagra a questão da transparência. Já na exposição de motivos "cabe notar que a experiência internacional sobre códigos de finanças públicas,bem como a literatura a este respeito indicam ser a transparência um dos instrumentos mais eficazes para a disciplina fiscal". Vários artigos desta Lei remetem à questão da transparência, como facilitador para o controle público, a ser feito pelo cidadão. No art. 64 fala da obrigação de divulgar amplamente, inclusive por meio eletrônico (internet) versões simplificadas, para maior entendimento, dos planos dos orçamentos (PPA, LDO, LOA), dos relatórios fiscais e dos pareceres sobre as contas, lembrando, ainda, que a União ficará com a responsabilidade de prestar assistência técnica e financeira para que os municípios assim possam fazer. Deverão ser feitas audiências públicas - ouvir a comunidade - quando for elaborar o plano plurianual, as diretrizes orçamentárias e o orçamento anual. (LC 101, art. 48 PU). O primeiro princípio constitucional era de que as contas devessem ficar à disposição do cidadão, por sessenta dias, após o fechamento do ano (CF, $31, \S 3^{\circ}$ ). Com a LC 101, a obrigatoriedade de deixar as contas abertas para consulta e apreciação do cidadão deve ser permanente e isto, nos municípios, deve ser feito na Câmara Municipal. Além da obrigatoriedade de audiência pública para elaborar o plano, também tem-se que fazer audiência pública para prestar contas do que

estava previsto na Lei de Diretrizes Orçamentárias. Isto deverá acontecer até o final de maio, setembro e fevereiro. Os municipios terão até o ano de 2006 para começar a fazer estas audiências, que serão a cada seis meses. Estes são dispositivos gerais de controle que servem para todas as áreas e, também, para a área de saúde.

Quanto ao Ministério Público que, constitucionalmente, recebeu novas funções como a de defesa do cidadão, estão expressas na CF 129, II “São funções institucionais do Ministério Público... II- zelar pelo efetivo respeito dos poderes públicos e dos serviços de relevância pública aos direitos assegurados nesta constituição, promovendo as medidas necessárias à sua garantia."

Especificamente na área de saúde e de seu financiamento, a questão do controle social está redigida de forma clara em textos constitucionais, como : "É assegurada a participação dos trabalhadores e empregadores nos colegiados dos órgãos públicos em que seus interesses profissionais ou previdenciários sejam objeto de discussão e deliberação"CF art. $10^{\circ}$. O mesmo se reafirma em relação à seguridade social: "Compete ao poder público organizar a seguridade social com base nos seguintes objetivos:....caráter democrático e descentralizado da gestão administrativa, com a participação da comunidade, em especial dos trabalhadores, 
empresários e aposentados" Cf 194,VII (16). Logo à frente, no art. 198, entre as diretrizes específicas da saúde está, no inciso III, a "participação da comunidade".

$\mathrm{Na} 8080$, art. 33: "Os recursos financeiros do SUS serão depositados em conta especial, em cada esfera de sua atuação e movimentadas sob fiscalização dos respectivos conselhos de saúde". Na lei 8142 , art. $1^{\circ}$, estão detalhados os instrumentos de controle do SUS: "O SUS contará em cada esfera de governo, sem prejuízo das funções do poder legislativo, com as seguintes instâncias colegiadas: conferência e conselho de saúde". E a missão encontra-se no $\S 2^{\circ}$ do mesmo artigo: “o Conselho de Saúde, em caráter permanente e deliberativo, órgão colegiado composto por representantes do governo, prestadores de serviço, profissionais de saúde e usuários, atua na formulação de estratégias e no controle da execução da política de saúde na instância correspondente, inclusive nos aspectos econômicos e financeiros".

Esse conselho tem que receber informações:

"O sistema único de saúde, em cada esfera de governo, apresentará, trimestralmente, ao conselho de saúde e em audiência pública nas câmaras de vereadores e assembléias legislativas respectivas, para análise e ampla divulgação, relatório detalhado contendo, dentre outros, dados sobre o montante e fonte de recursos aplicados, auditorias, serviços produzidos no próprio e contratado." Lei 8689 27-7-93 art.12 (33)

A segunda: surge constitucionalmente a figura do Conselho de Saúde como órgão de acompanhamento e fiscalização do fundo de saúde. Só se tem que rejubilar com essas conquistas - ainda que possam ser transitórias. Elas vêm consagrar um entendimento que não ficou absolutamente claro nas leis 8080 e 8142 . A participação da sociedade no Controle Social, principalmente, na área social, é preceito constitucional consagrado no Art 10 da CF "É assegurada a participação dos trabalhadores e empregadores nos colegiados de órgãos públicos em que seus interesses profissionais ou previdenciários sejam objeto de discussão e deliberação." O mesmo principio se repete no art. 194,VII da CF : " caráter democrático e descentralizado da administração, mediante gestão quadripartite, com participação dos trabalhadores, dos empregadores, dos aposentados e do Governo nos órgãos colegiados." (este inciso teve modificações pela EC-20 de 15/12/98).(16)

O Decreto Presidencial 1232, de 30 de agosto de 1994, trata em seu art. $3^{\circ}$ que os recursos transferidos pelo MS serão movimentados, sob a fiscalização do respectivo Conselho de Saúde, sem prejuizo da fiscalização exercida pelos órgãos do Sistema de Controle Interno do executivo e do Tribunal de Contas da União. 
A Lei 9452 , de 1997, obriga os gestores estaduais e municipais a informarem sindicatos, partidos, entidades empresariais sobre cada recurso federal recebido para a área da saúde, num prazo de 48 horas, após o recebimento.

\subsection{O REAL}

\section{O REAL DO CONTROLE PÚBLICO INSTITUCIONAL}

Os vários descumprimentos da legislação em relação ao financiamento federal para a saúde foram descritos anteriormente. $O$ grande nó da realidade é não se estabelecer claramente o que deve ser controlado e quem controla quem e o quê.

Concomitantemente, o velho problema é que os que controlam, os controladores, são escolhidos, eleitos ou preteridos e transferidos, pelo órgão que deve controlá-lo. Assim é o TCU, a CISET, o SNA.

Os órgãos de Controle Institucional Externo, como o MP, o TCU, a CISET, e os de controle interno, como o Componente Federal do Sistema Nacional de Auditoria, pouco ou nenhuma ação efetiva tiveram e têm para o controle de questões substantivas do financiamento da saúde como as citadas.

- A falta de controle sobre os Ministérios responsáveis, pelas repetidas crises da saúde, por não aporte de recursos legais pertencentes ao MS: os recursos, a menos, transferidos pela Previdência até chegar à apropriação ilegal e indébita da totalidade dos recursos da Contribuição Sobre a Folha, feita pelo Ministro Britto; recursos, a menos, da época Collor, da apropriação da Conversão do Real, efetivada pelo MF; da CPMF e, agora, da interpretação restritiva da EC-29, de 13/9/2000. (15)

- A falta de controle sobre o MS, por uso ilegal dos recursos que the caem nas mãos, desde o pré-constitucional, o pós imediato, às NOBs ilegais e inconstitucionais, à recentralização proposta e executada pela NOAS, o "campanhismo campanhista" inconstitucional e ilegal, o desrespeito ao Conselho Nacional de Saúde na sua função controladora do econômico e financeiro, o repasse convenial e casuístico dos recursos devidos a Estados e Municípios entre outras.

Uma tendência histórica, que se repete a cada ano e vez, é que, esses órgãos, muito mais se deliciam em investigar, punir as instâncias estaduais e municipais que os órgãos da esfera federal, à qual pertencem, como os Ministérios e, muito especialmente, o da Saúde. Esses órgãos têm se mostrado excelentes críticos e mordazes denunciadores das outras esferas de governo. E, coniventes por omissão, com as ilegalidades cometidas pelos vários Ministérios envolvidos na questão Saúde. Os Municipios brasileiros estão sofrendo um processo que bem poderia denominar-se de "a farra das auditorias". Estas se multiplicam, em número e temas, por órgãos federais, cada um com sua lógica, com suas exigências de documentos, com entradas de dados de diferentes formas. Em geral, não dão retorno aos 
auditados e não se estabelece nenhuma relação entre órgãos que as fazem. São auditorias cruzadas e descruzadas sobre as outras instâncias de governo e não sobre os órgãos federais.

Demonstrado está que o maior volume de desvios de recursos devidos, constitucional e legalmente à saúde, acontecem antes mesmo de chegarem ao próprio MS. Nunca se soube de que os Ministérios, responsáveis por esse desvio de recursos da saúde, tenham estado sob suspeição, investigação ou auditoria, devido a estes motivos.

O mesmo se diga a realidade em relação ao órgão de controle interno do MS, o Sistema Nacional de Auditoria, em seu componente federal. Não se tem notícia "das inúmeras e reiteradas declarações, relatórios e publicações do SNA sobre as ilegalidades (descumprimento de leis) dos vários dirigentes do Ministério da Saúde nas últimas décadas"!!!

\section{O REAL DO CONTROLE PÚBLICO SOCIAL}

O Controle Público Social no "controle da execução da política de saúde(....) inclusive nos aspectos econômicos e financeiros." Lei 8142 (28). É um espaço que se conquistou mas ainda muito tenuemente. O Conselho Nacional de Saúde tem sua Comissão de Orçamento e Finanças há já muitos anos.

Existem quatro grandes nós que poderão ser sintetizados aqui:

1)a insuficiente abrangência e profundidade de conhecimento sobre os recursos federais para a saúde; 2) o conhecimento dos Conselheiros e as instituiçōes as quais representam, sobre as questões orçamentárias e financeiras; 3) a desimportância total dada pelos Ministérios responsáveis pelo orçamento federal da saúde (F, MO, MPAS) à função do Conselho Nacional de Saúde; 4) a desimportância dada pelo MS e seus órgãos internos ao dever do Conselho Nacional de Saúde de controlar os aspectos econômicos e financeiros. Relatórios, pedidos de informação, acesso aos estudos pré-orçamentários, destino dos recursos, necessidade de passar pelo Conselho Nacional de Saúde alterações de forma de pagamento e repasse dos recursos a prestadores, estados e municipios. 
VI- CONCLUSÕES E RECOMENDAÇÕES 


\section{CONCLUSÕES E RECOMENDAÇÕES}

Para garantia da felicidade, da vida com qualidade, inúmeros são os insumos necessários. As condições de saúde e bem estar são altamente determinantes da qualidade de vida. Como conseguir essas condições? O Brasil tem esse desafio pela frente: garantir saúde, como direito de cidadania e dever do Estado em meio a inúmeras necessidades. O quanto é justo os governos despenderem com saúde? André-Pierre Contandriopoulos, um dos mentores do sistema público de saúde canadense, repetiu, em várias conversas aqui, no Brasil, e no Canadá, uma frase emblemática: "o limite do gasto em saúde se traduz pelo momento em que o mesmo investimento em outra área é capaz de gerar ou desencadear melhor qualidade de vida".

Sabe-se que de duas maneiras pode-se garantir mais recursos para determinada atividade humana. A saúde não foge à regra. O caminho passa pelo aumento da receita e/ou diminuição da despesa (por usar os recursos nas ações corretas - eficácia e/ou por usar os recursos corretamente nas ações - eficiência). (81)

Pode-se dizer que, no Brasil pós Constitucional, gasta-se pouco com saúde no âmbito do Governo Federal e se gasta indevidamente por uso incorreto ou mau uso. Erros esses, no mínimo, culposos, por desvios de finalidade e de processo no uso de recursos.

A conclusão essencial, aqui demonstrada o "quantum satis" é que: ESTÁ SENDO DESCUMPRIDO O BLOCO DE CONSTITUCIONALIDADE REFERENTE AO FINANCIAMENTO FEDERAL DA SAÚDE.

Como corolário: OS ÓRGÃOS FISCALIZADORES DAS AÇÕES GOVERNAMENTAIS NO ÂMBITO FEDERAL DESCUMPREM A LEI AO NÃO IMPEDIREM QUE ESTAS ILEGALIDADES DO EXECUTIVO CONTINUEM SE MANTENDO.

O que é necessário é a "ousadia de cumprir e fazer cumprir a lei". Em seguida, exigir que normas, portarias, instruções normativas, atuais e futuras, sigam a hierarquia das leis, respeitando a CF e a LOS. Buscar o debate juridico para a interpretação consensual daquilo que diz a lei cuja jurisprudência seja polêmica. Se necessário for iniciar o processo de mudança na legislação, acrescentando ou retirando determinações, mas cumprindo a atual até sua possivel mudança.

Três questōes prévias e gerais devem fazer parte dessas conclusões:

1. Os recursos aqui denominados de RECURSOS FEDERAIS, fazem parte do grupo de RECURSOS DA SEGURIDADE SOCIAL destinados ao cumprimento de competências constitucionais das três esferas de governo, Uniāo, Estados e 
Municípios) e, por conseguinte não deveriam, pelo espírito da lei, serem denominados como RECURSOS FEDERAIS, mas sim como RECURSOS NACIONAIS.

2. Os RECURSOS NACIONAIS destinados à saúde e denominados de RESTOS A PAGAR como, legalmente, significam recursos existentes e disponiveis, tanto que foram empenhados e só não se processou seu pagamento, deveriam estar fielmente depositados previamente no FUNDO NACIONAL DE SAÚDE.

3. Os RECURSOS NACIONAIS destinados vinculadamente à saúde pela Constituição Federal (EC-29) deveriam ser intocáveis não podendo sofrer nenhum tipo de contingenciamento por normas e dispositivos legais infraconstitucionais

As conseqüências dos desvios inconstitucionais são patentes. Às vezes com fácil estabelecimento de causa e efeito, outras impossíveis de se associar. Muitas delas são inquantificáveis e irrecuperáveis, como perdas de vida, seqüelas físicas, sofrimento humano, sabidamente, decorrentes da falta de financiamento da saúde. Outras conseqüências são perfeitamente quantificáveis como as perdas em estruturas, equipamentos, pessoal etc.

Dirão alguns que nada há a fazer em relação ao passado. A defesa é que a qualidade dos serviços atuais de saúde ainda pode ser recuperada com "pagamento" das dívidas históricas. O que se deixou de melhorar, de ser corrigido, de ser criado, pode e deve ser feito com a devolução desses recursos, diretamente destinados aos Fundos de Saúde. Recomenda-se que o Ministério Público Federal, a Procuradoria Geral da República, que tão prontamente autua os serviços e trabalhadores de saúde, por suas falhas na ação final do atendimento, umas justificáveis e outras injustificáveis, mova-se no sentido de buscar reparo para os desvios apontados que são determinantes de muitas delas.. Deverão eles se louvar de juristas, tributaristas e aqueles que trabalham com cálculos autuariais para que façam um amplo levantamento dessa divida e discutam uma maneira de que seja ressarcida a área de saúde. Este montante histórico pode ser uma reserva técnica do Fundo Nacional de Saúde a ser sacado programadamente em situações reparadoras bem definidas. É o minimo que se espera.

Isso vai servir tanto para o ressarcimento da divida histórica como para as compensações atuais de descumprimento da Emenda Constitucional 29 que podem ser feitas, como na educação, com reposição no orçamento subseqüente.

A seguir serão tiradas conclusões e recomendações com referência a cada um dos dez eixos acima descritos. 


\section{1 - RECURSOS DESTINADOS AO FINANCIAMENTO DA SAÚdE VEM FINANCIANDO AÇÕES NÃO TIPIFICADAS COMO SENDO DE SAÚDE.}

Recursos financeiros destinados à saúde financiaram no período pós constitucional, no âmbito federal, pagamento de inativos e pagamento de dívidas, não específicas da saúde ou assumidas diretamente pela área. Outras, como o pagamento de hospitais universitários, pessoal de saúde do GDF, ou já aconteceram ou estão em vias de acontecer, devido ao possivel aumento de recursos determinados pela EC-29, de 13/9/2000.

O efeito em cadeia nas instâncias estaduais e municipais é, após definido o montante legal obrigatório para a saúde (EC-29) desembarcar nas despesas de saúde, outras despesas que não Ihe sejam afetas. Inativos foi a primeira despesa agregada, por mimetismo, ao Ministério da Saúde, às despesas de saúde de alguns Estados e Municípios. Tem-se notícias, ainda que iniciais e sem possibilidade de comprovação, de que estejam sendo agregadas como despesas de saúde outras, sabidamente, de outras áreas. Citam-se algumas delas: sob o manto do saneamento: água, esgoto, limpeza urbana; sob o manto da nutrição: merenda escolar e restaurantes populares; sob o manto de saúde: hospitais universitários, militares e de servidores públicos, com clientela exclusiva; sob o manto do social: a integralidade das ações de assistência social. Quem conceituará esta questão de forma definitiva e quem fiscalizará para que todas as esferas de governo a cumpram, em especial o MS? Isto depende da regulamentação por lei. Por essa interpretação, ilegal, às vezes, e imoral outras, de expandir o conceito de saúde, foram financiadas com eles ações até mesmo interligadas, mas que devessem ser financiadas com outros recursos e não com os da saúde. Com a ampliação do conceito de saúde, perderam-se inúmeros recursos.

\section{RECOMENDAÇÃO:}

- Regulamentar, urgentemente, a EC-29, de 13/9/2000 (16). Que se defina, o mais explicitamente possivel, o conceito de ações e serviços de saúde, sob a ótica do financiamento, com recursos próprios alocados nos orçamentos, na função saúde.

- Fazer com que o Governo Federal reponha para o Ministério da Saúde os recursos perdidos em todos esses anos, principalmente com o pagamento da divida e inativos. 


\section{FONTES FEDERAIS DE FINANCIAMENTO DA SAÚDE NÃO SE APLICARAM EM SAÚDE}

Inúmeros recursos se perderam, sem chegar á área da saúde, como consequaência do desvio de fontes, totais ou parciais, de financiamento da saúde. Recursos criados ou de aliquotas aumentadas para financiar a saúde foram destinados a outras áreas: aumento da Contribuição dos Trabalhadores sobre a Folha, de 6\% para 8\%.; aumento do FINSOCIAL de 0,5\% para 2\%; criação do Fundo Social de Emergência (posterior Fundo de Estabilização Fiscal e atual Desvinculação das Receitas da União (DRU); criação da CPMF.

\section{RECOMENDAÇÃO:}

- Estabelecer cálculos atuariais dessas perdas.

- Fazer uma programação de desembolso desses recursos, para recuperação e ou expansão da rede e melhora da prática da eqüidade redistributiva entre Estados e cidades brasileiras, no que tange à saúde.

\section{AS COMPETÊNCIAS LEGAIS DE CADA ESFERA DE GOVERNO NÃO ESTÃO SENDO DECENTRALIZADAS E DEVIDAMENTE CUMPRIDAS PELO MINISTÉRIO DA SAÚDE, ESTADOS E MUNICIPIOS.}

O movimento recentralizatório, inconstitucional e ilegal, vem se dando nos últimos anos. É uma prática que não passa mais pelo legislativo, mas apenas o executivo federal, Ministério da Saúde, interpreta como quer, executa e manda Estados e Municipios repetirem ilegalidades. Essa interpretação ilegal das competências de cada esfera de governo tem, como conseqüência imediata, a transferência incorreta de recursos, em valores e em processo, para Estados e Municipios.

\section{RECOMENDAÇÃO:}

- Exigir que o Governo Federal cumpra as determinações legais, em relação às competências de cada esfera de governo.

- Exigir o redirecionamento do processo descentralizatório, de acordo com a legislação em vigor, que determina seja feito segundo as competências de cada esfera de governo CF.30,VII (15) 
- Rediscutir o processo de descentralização, a partir do entendimento das competências legais de cada esfera de governo sendo vedadas a manutenção ou a progressão de qualquer retrocesso que fira o bloco de constitucionalidade.

- Usar melhor o mecanismo da negociação entre as três esferas de governo fortalecendo e desatrelando a Comissão Intergestores Tripartite que, em outras épocas, já desempenhou importante papel na implantação e implementação do sus.

\section{A TRANSFERÊNCIA DE RECURSOS FEDERAIS PARA ESTADOS E MUNICÍPIOS VEM OCORRENDO EM OSTENSIVO DESCUMPRIMENTO DOS CRITÉRIOS LEGAIS DE RATEIO}

O MS, desde 1991, época da vigência da LOS, vem fazendo o rateio dos recursos entre União, Estados e Municipios, em desobediência à Lei 8080, art 35 (27) e à Lei 8142 (28).

\section{RECOMENDAÇÃO:}

- Exigir que o MS divida os recursos entre as três esferas de governo, segundo as competências legais e obedecendo os critérios da Lei 8080, 35 (27).

- Exigir urgente regulamentação do Art.35 da Lei 8080 (27) e melhora do sistema de informação em saúde para possibilitar a alocação de recursos de forma mais eqüitativa.

- Exigir o cumprimento da Lei 8142 (28), enquanto os critérios da 8080 não são regulamentados, repassando $100 \%$ dos recursos a Estados e Municípios pelo quociente populacional.

5. A TRANSFERÊNCIA DE RECURSOS ENTRE OS ÓRGÃOS ARRECADADORES FEDERAIS E O FUNDO NACIONAL DE SAÚDE DO MINISTÉRIO DA SAÚDE DEIXARAM DE OCORRER NO QUANTITATIVO E NA FORMA AUTOMÁTICA PREVISTOS NA LEI.

Recursos arrecadados e de transferência obrigatória, do MPAS e da STN deixaram de ser repassados ao MS, com conseqüências graves, principalmente, em periodo inflacionário, para a saúde da população. 
Os recursos arrecadados não foram transferidos automaticamente ao MS - preceito da Lei 8080 , art. 34. (27)

Os recursos arrecadados pelo MPAS e STN, e de direito do MS, ao não serem transferidos automaticamente ao MS, geraram rendimentos. É a denominada remuneração das disponibilidades financeiras (dinheiro em caixa não utilizado e aplicado na ciranda financeira) que não foram repassadas automaticamente ao MS, mas passaram a constar como receitas dos órgãos arrecadadores. De extrema gravidade, esse fato levou à privação de recursos da saúde, principalmente, em períodos em que a inflação chegou a mais de $50 \%$ ao mês.

Os recursos referentes ao Acidente do Trabalho, recolhidos pelo MPAS, não são devidamente repassados ao Ministério da Saúde há décadas.

RECOMENDAÇÃO:

- Estabelecer cálculos atuariais dessas perdas acima referidas: acidente do trabalho e remuneração das disponibilidades;

- Fazer uma programação de desembolso dos recursos para recuperação e ou expansão da rede e melhora da equidade redistributiva entre Estados e cidades brasileiras, no que tange à saúde.

\section{A TRANSFERÊNCIA FINANCEIRA DO MINISTÉRIO DA SAÚDE A ESTADOS E} MUNICÍPIOS AINDA TEM SIDO FEITA PELA FORMA CONVENIAL OU, MESMO QUE DENOMINADA COMO DE "FUNDO A FUNDO", TEM TODAS E MAIS ALGUMAS CARACTERISTICAS REGULAMENTADORAS CONVENIO-SIMILE.

O MS condiciona o repasse de recursos por outras formas que não a por competência, que é a maneira legal de se fazerem transferências, pois as três esferas de governo receberam competências legais próprias. Sendo próprias tais competências, não são transferíveis de uma a outra esfera por acordo de vontade, na dependência do querer e de condicionantes restritivos.

Inúmeras transferências a Estados e Municipios são feitas de forma convenial, como acordo de vontades. Transferências outras vêm sendo feitas, hoje, sob o título de transferências fundo a fundo, mas que, na realidade, escamoteiam as mesmas caracteristicas da transferência convenial: determinação do que fazer, como fazer e não remessa ou suspensão do repasse se não aderir às regras. Se o PAB, comemore-se, representou de um 
lado um avanço em cumprimento à Lei do critério per-capita, seu atrelamento a regras acordadas fere o princípio do repasse "fundo a fundo" com liberdade de uso conforme necessidades locais, expressas nos planos, aprovada no Conselho e no Legislativo de cada esfera de governo. Além disto continua existindo transferência convenial permitindo a transferência casuística a determinados Estados e Municípios, favorecendo uns, em desobediência aos princípios da igualdade e equidade. Lembre-se que o princípio convenial do acordo de vontades pode escamotear a imposição de vontade do mais forte sobre o mais fraco, do que faz a transferência de recursos sobre o que a recebe!

\section{RECOMENDAÇÃO:}

- O MS deverá fazer transferências de forma direta, regular e automática, baseada no desempenho de competências e não por outros critérios que incluam acordo de vontade ou decisão unilateral;

- Todos os recursos federais de saúde devem ser transferidos a Estados e Municipios, de forma direta e automática, através do mecanismo " Fundo a Fundo", e não mais através de convênios ou similares (grande parte do "fundo a fundo"atual) com características intrínsecas típicas de acordo de vontades.

- As transferências entre MS e Estados e Municipios devem ser feitas nos mesmos moldes das transferências do FPM e FPE. (Exclusivamente no que tange à maneira de repasse "fundo a fundo" e não à forma de cálculo.)

\section{A ADMINISTRAÇÃO DE RECURSOS FINANCEIROS DO MINISTÉRIO DA SAÚDE E DOS ESTADOS E MUNICÍPIOS NÃO É TOTALMENTE FEITA DENTRO DO FUNDO DE SAÚDE.}

Existe determinação legal (8080) que todos os recursos federais da Saúde devam estar depositados no Fundo Nacional de Saúde e administrados pelo Ministro da Saúde. O art.77 da ADCT (15) determina que os recursos devam ser totalmente administrados nos fundos estaduais e municipais de saúde sob acompanhamento e fiscalização do Conselho.

O Ministério da Saúde não administra seus recursos totalmente dentro do Fundo Nacional de Saúde fazendo-se uma diferença entre recursos do SUS e outros, como demonstrou-se nos quadros de dados do Fundo Nacional de Saúde.

Estados e Municípios, em sua grande maioria, não depositam seus recursos próprios nos Fundos de Saúde. Mesmo os recursos de transferências federais, não raro, passam primeiro 
pelas Secretarias de Fazenda (descaracterizando o fundo a fundo) ou ficam em suas contas e são administrados por elas.

\section{RECOMENDAÇÃO:}

- Exigir que todos os recursos federais para a saúde sejam administrados diretamente pelo Fundo Nacional de Saúde de onde serão utilizados para desempenho de suas competências e para transferências fundo a fundo a Estados e Municípios para cumprimento de suas competências.

- Exigir que todos os Estados e Municípios administrem os recursos federais transferidos fundo a fundo dentro dos fundos estaduais e municipais de saúde, bem como todos os seus recursos próprios.

\section{A RELAÇÃo PÚBlico-PRIVAdo NÃO OBEDECE OS CRITÉRIOS LEGAIS dE LICITAÇÃO, CONTRATOS E CONVÊNIOS, PREÇOS E PRAZOS}

A relação público-privado, doze anos após a determinação constitucional, ainda, em inúmeros casos, não vem sendo feita mediante processo licitatório de contratos administrativos ou convênios.

Os valores estabelecidos pelo MS para retribuição dos serviços comprados complementarmente, estão em frontal desobediência à Lei 8080, art. 26 (27): não existe fundamentação econômico-financeira, nem seu conseqüente equilibrio, critérios e valores de remuneração de serviços e parâmetros de cobertura nacional, não inclui todos os procedimentos e não estão passando pela aprovação do Conselho Nacional de Saúde.

\section{RECOMENDAÇÃO:}

- Realização de processo licitatório para todos os serviços de saúde complementares ao SUS;

- Celebração de contratos e convênios com os serviços complementares, em obediência à lei, com cadastro, alvará da Vigilância Sanitária, e outras exigências;

- Estabelecimento de critérios e valores de remuneração, obedecendo ao principio do equilibrio econômico e financeiro, para todos os procedimentos de saúde reincluindo os básicos que, ilegalmente, foram eliminados da tabela por vontade exclusiva do Ministério da Saúde; 
- Estabelecer prazos justos de pagamento de serviços comprados;

- Buscar, obrigatoriamente, a aprovação do Conselho Nacional de Saúde para o estabelecimento de critérios, valores e parâmetros;

- Buscar cálculos atuariais para remunerar, minimamente, as perdas com a defasagem de preços e prazos, principalmente aquelas decorrentes da adoção de URV diferenciada, a menor, para a saúde, no período da conversão do Real.

\section{EXISTEM INÚMERAS QUEBRAS DO PRINCÍPIO DA GRATUIDADE NO SUS: UMAS DESCONHECIDAS E OUTRAS CONHECIDAS E TOLERADAS PELO MINISTÉRIO DA SAÚDE E SEU SISTEMA NACIONAL DE AUDITORIA E PELOS ÓRGÃOS DE CONTROLE EXTERNO INCLUINDO-SE O MINISTÉRIO PÚBLICO}

Desobediência ou tolerância à desobediência histórica ao princípio da gratuidade, com a cobrança por fora, havida nos próprios públicos e nos hospitais conveniados e contratados pelo INAMPS-MS.

Quebra do princípio da gratuidade pela permissão tácita para que hospitais públicos, universitários e outros, vendam leitos públicos para convênios e pacientes privados, com remuneração extra para a instituição e profissionais já assalariados pelo público como funcionários, em detrimento do atendimento aos pacientes que só disponham do sistema público.

\section{RECOMENDAÇÃO:}

- Impedir, por todos os meios, que se quebre a gratuidade do Sistema Único de Saúde, em qualquer de suas formas explícitas e implícitas;

- Lutar com mais ênfase, neste momento, pela não aprovação do projeto no Legislativo de "Privatização de Leitos Públicos" dos Hospitais Públicos Universitários;

- Combater, denunciar e evitar as formas indiretas de quebra da gratuidade, mediante permissão da Cobrança Por Fora (CPF), desde a cobrança de pequenas taxas de material e medicamentos, até pagamentos institucionais de serviços hospitalares e serviços profissionais. 


\section{O CONTROLE PÚblico INSTItUCiONAL E SOCIAL DO SUS NO ÂMBito FEDERAL, PRINCIPALMENTE NA ÁREA FINANCEIRA, NÃO VEM ACONTECENDO OU É FEITO INSATISFATORIAMENTE.}

O controle público institucional do Governo Federal, em relação à saúde, incluindo o MS e os demais envolvidos, não vem ocorrendo de maneira alguma, em alguns casos, e apenas superficialmente em outros. Isto ocorre em relação ao Ministério Público Federal, ao TCU, à Secretaria Federal de Controle Interno e, obviamente, à auditoria interna do MS. Sem exceção, esses órgãos têm se dedicado com mais afinco a fazer o controle de Estados e Municípios, que o controle sobre as ilegalidades, antes citadas, do MS. O mesmo se diga, com mais ênfase, do órgão de auditoria do próprio MS, que nada audita do MS e nem as ilegalidades de sua própria estruturação e organização, como SNA.

O controle público social, exercido oficialmente pelos Conselhos de Seguridade e Saúde e pelas Conferências de Saúde, tem sido minimizado nas questões financeiras, o que se materializou, entre outras, pelo fechamento do Conselho de Seguridade Social e pelo desrespeito do MS em não ouvir o Conselho Nacional de Saúde nas questões financeiras, no estabelecimento de critérios, valores e parâmetros de assistência.

RECOMENDAÇÃO:

- Definir claramente os papéis e responsabilidades na ação controladora sobre o financiamento federal do SUS, nas várias instâncias do Controle Público Externo e Interno: Ministério Público Federal, Tribunal de Contas da União, Secretaria Federal de Controle Interno, Sistema Nacional de Auditoria do SUS, em seu componente Federal. Deixar aos Tribunais de Contas de Estados o controle sobre as contas estaduais e municipais, ficando com o TCU a fiscalização dos repasses dos recursos do Ministério da Saúde para os Estados e Municípios. Chega de controle federal sobre recursos apenas de arrecadação federal, cuja execução dos serviços é competência (dever) dos Estados e Municipios;

- Esclarecer todos os princípios e normas de regulação do financiamento no SUS para as três esferas de governo para que estas sejam conhecidas e perfeitamente entendidas pelos controlados.;

- Reafirmar o conceito de que as transferências federais dos recursos financeiros do SUS são transferências constitucionais, confirmadas pela EC-29, de 13/9/2000, (16) e entram nos respectivos orçamentos de Estados e Municipios e que deverão ser utilizados exclusivamente em saúde e de acordo com o Plano de Saúde, aprovado pelo Conselho de Saúde e constante nas Leis Orçamentárias 
(PPA-LDO-LOA) e controlados pelo Tribunal de Contas da respectiva esfera de governo;

- Exigir dos órgãos de controle público institucional, internos e externos, MPF, TCU, SFCI, SNA: controle permanente da arrecadação dos recursos financeiros federais do SUS, de sua transferência direta e automática pelos órgãos arrecadadores, sua utilização, distribuiçăo, transferências (forma e quantitativo de repasse) a Estados e Municípios para o cumprimento da legislação;

- Garantir o espaço do Conselho de Saúde na sua ação propositiva e controladora, garantindo condições para que os Conselhos possam realizar seu trabalho e suas decisões sejam acatadas;

- Exigir do MS respeito ao Conselho Nacional de Saúde, para sua efetiva participação na discussão e decisão de questões substantivas, relativas ao financiamento como quantitativo, critérios de rateio, forma de transferência, acompanhamento dos recursos dentro do Fundo Nacional de Saúde, para cumprimento do preceito legal de controle social da CF,194 (16) Lei 8080 (27) e Lei 8142 (28);

- Reativação do Conselho Nacional de Seguridade Social, previsto na CF e desativado pelo Governo Federal. Garantir mais espaço real e substantivo ao Conselho Nacional de Saúde, no que tange ao Controle Social dos recursos financeiros, previstos na EC-29, de 13/9/2000, e na 8080 e 8142;

- Adotar para a prestação de contas, de Estados e Municípios, dos recursos transferidos pelo MS, o mesmo principio do FPE e FPM, em que Estados e Municipios prestam contas diretamente aos seus respectivos Tribunais de Contas. (Ainda que técnicos do TCU afirmem que fiscalizam os recursos do FPM e FPE.) A responsabilidade do Ministério da Saúde, em sua prestação de contas, seria até o momento da transferência dos recursos, da mesma maneira que o Ministério da Fazenda em relação ao FPM e FPE. O Ministério da Saúde teria que explicitar os critérios utilizados para transferir tal montante de recursos para este ou aquele Estado ou Municipio, assim como a forma pela qual foram repassados esses recursos. Dai para frente, Estados e Municipios deverão prestar detalhadas contas a seus tribunais, de forma descentralizada, como fazem com todos os seus outros recursos orçamentários: FPM. 
- acionar, PROVOCAR, COBRAR de ORgãos, INSTITUIÇŌES E PESSOAS A OUSADIA DE CUMPRIR E FAZER CUMPRIR A LEI EM DEFESA DA VIDA E SAÚDE EM TODAS AS AREAS E ENTRE ELAS, NA DE GARANTIA DE RECURSOS FEDERAIS DEFINIDOS, DEFINITIVOS E SUFICIENTES PARA A SAÚDE.

- MOBILIZAR PARA ESTA TAREFA CIDADÃ: órgãos de Controle Público Institucional - Externo: Legislativo, como um todo, e a Comissão de Seguridade e Família, Comissão de Controle e Fiscalização Financeira (do Senado e da Câmara), Comissão de Assuntos Sociais do Senado, Ministério Público, TCU, CISET (Atual Secretaria Federal de Controle do MF); órgãos de Controle Público Institucional - Interno: SNA; Assessoria Juridica do MS; órgãos de Controle Público Social: Conselhos de Saúde; Conselhos de áreas afins (Criança e Adolescente, Idoso, Portadores de Deficiências, Assistência Social, Previdência); órgãos e entidades e movimentos afins à saúde; órgãos de defesa do Consumidor e todos os cidadãos individualmente.

Decisões como essas, devem ser partilhadas com a sociedade. É urgente seu envolvimento, para que se possa concretizar a garantia do direito à saúde, sob o controle social. São decisões que dizem respeito à sociedade, como um todo, e que, portanto, devem ser partilhadas com os cidadãos usuários, com os prestadores de serviço, com os trabalhadores de saúde, além dos órgãos de governo.

Governo democrático e justo é aquele que é do povo e para o povo. O Estado previsto na Constituição Federal de 1988, servidor, moderno, tem de conhecer junto seus problemas, analisar junto, priorizar junto, assumir junto e, principalmente colher frutos junto com sua gente. Um esforço coletivo em busca do objetivo maior de toda sociedade humana que deve ser a conquista da felicidade para todos os seus cidadãos tendo a saúde como um de seus maiores condicionantes e determinantes. 
VII - REFERÊNCIAS BIBLIOGRÁFICAS 
1. Afonso JRR. Dilemas da saúde: financiamento e descentralização. In: Fórum As novas políticas sociais - Financiamento e Gestão: os desafios do Sistema Único de Saúde; 1994 nov.18; Rio de Janeiro:IPEA; 1994.

2. Alvarenga AT. Departamento de Saúde Materno-Infantil. Apoio da Faculdade de Saúde Pública à descentralização. São Paulo.11 de novembro de 1994 . www.idisa.org.br. Acesso em 31.1.2002.

3. Amaral C. Britto não vê a hora de deixar a previdência. www.idisa.org.br. Acesso em 31.1.2002.

4. Anais da $3^{\mathbf{a}}$ Conferência Nacional de Saúde; 1963; Niterói: Fundação Municipal de Saúde; 1991.

5. Anais da $8^{\mathrm{a}}$ Conferência Nacional de Saúde; 1986; Brasília. Brasilia(DF): ministério da Saúde; 1987.

6. Associação Brasileira de Pós-Graduação em Saúde Pública - ABRASCO. A experiência SUDS e os desafios atuais da reforma sanitária. Rio de Janeiro: Europa; 1978-89.

7. Ataliba G. Jornal do Conselho Regional de Medicina do Estado de São Paulo CREMESP. Ano XV, n.94, fev./mar. 1995.

8. Barros MED. Implementação do SUS: recentralizar será o caminho? Ciência \& Saúde Coletiva, v.6, n.2, p.307-310. 2001.

9. Barros MED. Ministério da Saúde. Nota Técnica. Considerações sobre a proposta de especialização de fontes no âmbito do orçamento da seguridade social. 17/5/93. www.idisa.org.br. Acesso em 31.1.2002.

10. Boletim da Associação Brasileira de Pós-Graduação em Saúde Pública ABRASCO. Ano XIII, n.56, abr./jun. 1995.

11. Bob F. Jekyll e os monstros. Rev Carta Capital, $1^{\circ}$ de abril de 1998. p.28.

12. Brasil. Câmara dos Deputados. Farhat C. Proposta de emenda a constituição de 1993. www.idisa.org.br. Acesso em 31.1.2002.

13. Brasil. Câmara dos Deputados. Relatório. Comissão Parlamentar de Inquérito destinada a apurar as inúmeras irregularidades no Instituto Nacional de Assistência Médica da Previdência Social - INAMPS/SUS. Relator: Deputado Jackson Pereira. 7 de junho de 1994.

14. Brasil. Câmara dos Deputados-DETAQ. Comissão Especial - PEC 256-A/95-CPMF. Parecer Final da Comissão. Campos R., Jorge, E e outros. Reunião 0180/96. Fita 72-J, Quarto: 4/1.

15. Brasil. Congresso Nacional. Comissão especial - PEC 256-AV95 - CPMF. № 0147/96, Audiência pública. Congresso sobre CPMF. 21 de março de 1996. 80p.

16. Brasil. Constituição da República Federativa do Brasil de 5 de outubro de 1988. www.senado.gov.br/legislação. Acesso em 31-01-2002.

17. Brasil. Decreto 1651 de 28 de setembro de 1995. Regulamenta o Sistema Nacional de Auditoria no âmbito do Sistema Único de Saúde.www.senado.gov.br/legislação. Acesso em 31-01-2002.

18. Brasil. Decreto 94657 de 20 de julho de 1987. Dispõe sobre a criação do Programa de desenvolvimento de sistemas unificados e descentralizados de saúde nos Estados (SUDS) e dá outras providências. www.senado.gov.br/legislação. Acesso em 31-012002 
19. Brasil. Decreto 95861 de 22 de março de 1988. Dispõe sobre o programa de desenvolvimento de sistemas unificados e descentralizados de saúde nos estados SUDS na área de competência do Ministério da Previdência e assistência Social e dá outras providências. www.senado.gov.br/legislação. Acesso em 31-01-2002.

20. Brasil. Decreto 95892 de 4 de abril de 1988. Altera a redação do artigo 3 do Decreto 95861 de 22 de março de $1988 . \quad$ www.senado.gov.br/legislação. Acesso em 31-012002.

21. Brasil. Decreto 96303 de 12 de julho de 1988. Dá nova redação ao artigo 3 do Decreto 95861 que dispõe sobre o programa de desenvolvimento de sistemas unificados e descentralizados de saúde nos estados - SUDS www.senado.gov.br/legislação. Acesso em 31-01-2002 .

22. Brasil. Decreto $\mathbf{9 7 2 7 5}$ de 16 de dezembro de 1988. Altera dispositivos do Decreto 96186 de 21 de junho de 1988 que dispõe sobre o programa de desenvolvimento de sistemas unificados e descentralizados de saúde nos estados - SUDS na área de competência do Ministério da Saúde. www.senado.gov.br/legislação. Acesso em 31-01-2002.

23. Brasil. Decreto de 1 de julho de 1993. Declara estado de calamidade pública do setor hospitalar do Sistema Único de Saúde - SUS. www.senado.gov.br/legislação. Acesso em 31-01-2002.

24. Brasil. Decreto de 30 de Agosto de 1994. Institui comissão para propor medidas relativas a racionalização dos gastos com a saúde e melhoria do atendimento a população. www.senado.gov.br/legislação. Acesso em 31-01-2002.

25. Brasil. Decreto de 4 de maio de 1994. Dispõe sobre a constituição de grupo de trabalho interministerial voltado para a racionalização dos gastos com saúde e a melhoria do atendimento à população. www.senado.gov.br/legislação. Acesso em 31-01-2002.

26. Brasil. Decreto n. 1232, de 30 de agosto de 1994. Dispõe sobre as condições e a forma de repasse regular e automático de recursos do Fundo nacional de Saúde, para os fundos de saúde estaduais, municipais e do Distrito Federal, e dá outras providências. Diário Oficial da República Federativa do Brasil, Brasilia, 31 ago. 1994.

27. Brasil. Lei 8080 de 19 de setembro de 1990. Dispõe sobre as condições para a promoção, proteção e recuperação da saúde, a organização e o funcionamento dos serviços correspondentes e dá outras providências. www.senado.gov.br/legislação. Acesso em 31-01-2002 .

28. Brasil. Lei 8142 de 28 de dezembro de 1990. Dispõe sobre a participação da comunidade na gestão do Sistema Único de Saúde (SUS) e sobre as transferências intergovernamentais de recursos financeiros na área da saúde e dá outras providências. www.senado.gov.br/legislação. Acesso em 31-01-2002.

29. Brasil. Lei 8173 de 30 de janeiro de 1991. Dispõe sobre o plano plurianual para o qüinqüênio 1991/1995 e dá outras providências. Acesso em 31-01-2002.

30. Brasil. Lei $\mathbf{8 2 1 2}$ de 24 de julho de 1991. Dispõe sobre a organização da seguridade social, institui plano de custeio e dá outras providências. www.senado.gov.br/legislação. Acesso em 31-01-2002. 
31. Brasil. Lei 8446 de 21 de julho de 1992. Dispõe sobre a revisão do Plano Plurianual, para o triênio 1993-95 de que trata o artigo 5 da lei 8173 de 30 de janeiro de 1991 e dá outras providências. nuw.senado.gov.br/legislaçăo. Acesso em 31-01-2002.

32. Brasil. Lei $\mathbf{8 4 4 7}$ de 21 de julho de 1992. Dispõe sobre as diretrizes orçamentárias para o exercício de 1993 e dá outras providências. www.senado.gov.br/legislaçăo. Acesso em 31-01-2002.

33. Brasil. Lei 8689 de 27 de julho de 1993. Dispõe sobre a Extinção do Instituto Nacional de Assistência Médica da Previdência Social-INAMPS, e dá outras providências. uww.senado.gov.br/legislaçăo. Acesso em 31-01-2002.

34. Brasil. Lei 9311 de 25 de outubro de 1996. Institui a Contribuição Provisória sobre a Movimentação ou Transmissão de Valores e de Créditos e Direitos de Natureza Financeira CPMF e dá outras providências. www.senado.gov.br/legislação. Acesso em 31-01-2002.

35. Brasil. Lei 9434 de 4 de fevereiro de 1997. Dispõe sobre a remoção de órgãos, tecidos e partes do corpo humano para fins de transplante e tratamento e da outras providências.www.senado.gov.br/legislação. Acesso em 31-01-2002.

36. Brasil. Lei $\mathbf{9 7 8 2}$ de 26 de janeiro de 1999. Define o Sistema nacional de Vigilância Sanitária, cria a Agência Nacional de Vigilância Sanitária e dá outras providências. uww.senado.gov.br/legislação. Acesso em 31-01-2002.

37. Brasil. Lei 9797 de 6 de maio de 1999. Dispõe sobre a obrigatoriedade da cirurgia plástica de mama pela rede de unidades integrantes do Sistema Único de Saúde nos casos de mutilação decorrentes de tratamento de câncer. www.senado.gov.br/legislação. Acesso em 31-01-2002.

38. Brasil. Lei 9836 de 23 de setembro de 1999. Acrescenta dispositivos à Lei 8080 de 19 de setembro de 1990, que "dispõe sobre condições para a promoção, proteção e recuperação da Saúde, a organização e o funcionamento dos serviços correspondentes e dá outras providências", instituindo o Subsistema de Atenção à Saúde Indigena. uww.senado.gov.br/legislaçăo. Acesso em 31-01-2002.

39. Brasil. Lei 9961 de 28 de janeiro de 2000.Cria a Agência Nacional de Saúde Suplementar - ANS e dá outras providências. www.senado.gov.br/legislação. Acesso em 31-01-2002.

40. Brasil. Lei Complementar 77 de 13 de julho de 1993. Institui o Imposto Provisório sobre a Movimentação ou a Transmissão de valores e de créditos e direitos de natureza financeira - IPMF e dá outras providências. uww.senado.gov.br/legislação. Acesso em 31-01-2002.

41. Brasil. Medida provisória n 331. 30 de junho de 1993. www.idisa.org.br. Acesso em 31.1.2002.

42. Brasil. Ministério da Previdência e Assistência Social Informes da Previdência Social maio 93 a janeiro de 94 (excerta). Brasília, v.5, n.9, dez. 1993.Informes da previdência social. www.idisa.org.br. Acesso em 31.1.2002.

43. Brasil. Ministério da Previdência e Assistência Social. Reorientação da assistência à saúde no âmbito da Previdência Social. Brasilia(DF); 1983.

44. Brasil. Ministério da Previdência Social. Conselho Nacional da Seguridade Social. Resolução N.6 - Plenário. www.idisa.org.br. Acesso em 31.1.2002.

45. Brasil. Ministério da Saúde. Ministério da Previdência e Assistência Social. Programa Nacional de Serviços Básicos de Saúde - PREVSAÚDE: anteprojeto. Brasilia(DF): 1980 
46. Brasil. Ministério da Saúde. Agenda para o Ministério da Saúde em 1994. Descentralizando a gestão construindo o sistema único de saúde em cumprimento à Constituição. SOS Saúde: Descentralização já. unww.idisa.org.br. Acesso em 31.1.2002.

47. Brasil. Ministério da Saúde. Assessoria de Comunicação Social. Plano qüinqüenal de saúde 1990/95: a saúde do Brasil novo. Brasília(DF): Assessoria de Comunicação Social; 1991.

48. Brasil. Ministério da Saúde. Conferência Nacional de Saúde. Relatório Final da 10 Conferência Nacional de Saúde, Brasilia-DF, 2 a 6 de setembro de 1996. Brasília: Ministério da Saúde, 1998. p.48-51.

49. Brasil. Ministério da Saúde. Conselho Nacional de Saúde. Ata da Reunião Ordinária de Julho. 1994. www.idisa.org.br. Acesso em 7/1/2002.

50. Brasil. Ministério da Saúde. Conselho Nacional de Saúde. Regulamentação da EC 29. www.idisa.org.br. Acesso em 7/1/2002.

51. Brasil. Ministério da Saúde. Conselho Nacional de Saúde. Resolução $n^{2} 148$, de 15 de dezembro de 1994.

52. Brasil. Ministério da Saúde. Descentralizações das ações e serviços de saúde: a ousadia de cumprir e fazer cumprir a lei. Brasília: Biblioteca da ENSP/FIOCRUZ; 1993.

53. Brasil. Ministério da Saúde. Discurso do Ministro Adib Jatene na Solenidade de transmissão do Cargo de Ministro de Estado da Saúde. Brasília, 2 de janeiro de 1995.

54. Brasil. Ministério da Saúde. Fundação Serviços Especiais de Saúde Pública (FSESP). Brasília(DF); 1968.

55. Brasil. Ministério da Saúde. Gabinete do Ministro. Cerimonial. Fundo a Fundo. Cerimônia. 28/11/94. www.idisa.org.br. Acesso em 31.1.2002.

56. Brasil. Ministério da Saúde. Programa de Interiorização das Ações de Saúde e Saneamento (PIASS). Brasília(DF); 1976.

57. Brasil. Ministério da Saúde. SAS - Departamento de Desenvolvimento, controle e Avaliação dos Serviços de Saúde. Relatório das atividades. 1994.

58. Brasil. Ministério da Saúde. Secretaria de Assistência à Saúde. Conselho Nacional de Secretários Estaduais de Saúde - CONASS. Conselho Nacional de Secretários Municipais de Saúde - CONASEMS. Relatório Geral da Comissão Intergestores Tripartite. Dez. 1994.

59. Brasil. Ministério da Saúde. Secretaria de Assistência à Saúde. Resultado final da mesa de negociação (MS/MF/PRESTADORES). 21/6/1994.

60. Brasil. Ministério da Saúde. Subsídios à votação da CPMF. Brasília, junho de 1996.p37.

61. Brasil. Ministério da Saúde.Tabela financiamento semiplena - MS - 1994. www.idisa.org.br. Acesso em 31.1.2002.

62. Brasil. Ministério do Planejamento e Orçamento - Consultoria Jurídica. Memo/CONJUR/№ 020/98. 26 de fevereiro de 1998.

63. Brasil. Portaria - INAMPS - 227 de 27 de julho de 1990. Estabelece condições para que os Hospitais Públicos recebam recursos diretamente do MS-INAMPS. www.idisa.org.br. Acesso em 31.1.2002. 
64. Brasil. Portaria MS-GM - 1882 a 1923 de 28-12-1997. Regulamentam a implementaçăo da NOB-96. wnw.idisa.org.br. Acesso em 31.1.2002.

65. Brasil. Portaria MS-GM - 1827 de 1993. Transferências do Fundo Nacional de Saúde para os Fundos Estaduais e Municipais de Saúde. www.idisa.org.br. Acesso em 31.1.2002.

66. Brasil. Portaria MS-GM 132 - 2001 - Fundo de Ações Estratégicas e Compensação - FAEC. www.saúde.gov.br. Acesso em 31-01-2002.

67. Brasil. Portaria do MS-GM 1286 de 26 de outubro de 1993. Dispõe sobre a explicitação de cláusulas necessárias nos contratos de prestação de serviços entre o estado, o Distrito Federal e o Município e pessoas naturais e pessoas jurídicas de direito privado de fins lucrativos, sem fins lucrativos ou filantrópicas participantes completamente, do Sistema Único de Saúde. Diário Oficial da República Federativa do Brasil, Brasilia, 3 nov. 1993.

68. Brasil. Portaria do MS-GM 2203 de 9 setembro de 1996. Dispõe sobre a Norma Operacional Básica 96 que normalizará a operação do Sistema Único de Saúde. Diário Oficial da República Federativa do Brasil, Brasilia, 6 nov 1996.

69. Brasil. Portaria MS-GM - 1481 de 30 de dezembro de 1990. Norma Operacional Básica - NOB - 91. www.saúde.gov.br. Acesso em 31-01-2002.

70. Brasil. Portaria MS-GM - 3925 - 1999. Manual para organização da atenção básica. www.saúde.gov.br. Acesso em 31-01-2002.

71. Brasil. Portaria MS-GM - 95 - 2001. Norma Operacional da Assistência. NOAS. www.saúde.gov.br. Acesso em 31-01-2002.

72. Brasil. Portaria MS-GM 3046 de 20 de julho de 1982. Estabelece os parâmetros para credenciamentos, contratos e convênios na área de Assistência Médica da Previdência Social. Diário Oficial da República Federativa do Brasil, Brasília, 20 jul. 1982.

73. Brasil. Tribunal de Contas da União. Secretaria das Sessões. Grupo I - Classe I. TC-005.399/93-9. www.idisa.org.br. Acesso em 31.1.2002.

74. Brito A. Caros amigos. Brasilia, nov. 1991. www.idisa.org.br. Acesso em 31.1.2002.

75. Britto A. Despesas com Previdência Social e saúde em 1993. Jornal A Gazeta. Cuiabá. 10 de julho de 1993. p. $3^{A}$. www.idisa.org.br. Acesso em 31.1.2002.

76. Campos DLC., Raggio AMB. Ofício enviado ao Ministro da Saúde. Brasília, 1 de setembro de 1994. www.idisa.org.br. Acesso em 31.1.2002.

77. Campos GWS. Um balanço do processo de municipalização dos serviços de saúde do Brasil. Saúde em Debate 1990; 28: 24-27.

78. Carvalho G. A crise da saúde em 1993: "Previdência subtrai recursos da saúde". Pronunciamento na Comissão do Congresso Nacional em 22/06/93. www.idisa.org.br. Acesso em 31.1.2002.

79. Carvalho G. Algumas considerações sobre a proposta de acordo da CSSF, de 30/9/99, para substitutivo às PEC's 169/93 e 82 - A/95. www.idisa.org.br. Acesso em $7 / 1 / 2002$.

80. Carvalho G. Avanço da descentralização na área da saúde. www.idisa.org.br Acesso em 31.1.2002.

81. Carvalho $\mathrm{G}$. Financiamento para a saúde,em busca de saidas impossiveis... para se conquistar as saidas possiveis. www.idisa.org.br. Acesso em 31.1.2002. 
82. Carvalho G. Propostas a serem discutidas com a nova equipe do Ministério da Saúde. wuw.idisa.org.br. Acesso em 31.1.2002.

83. Carvalho G. Sus e você. www.idisa.org.br. Acesso em 31.1.2002

84. Carvalho G. Uma fórmula para o financiamento federal da saúde "pela igualdade conquistando - se a equidade". Brasília. Outubro de 1993. www.idisa.org.br. Acesso em 31.1.2002.

85. Carvalho GI de, Santos L. Comentários à lei orgânica da saúde (leis $8.080 / 90$ e 8.142/90): sistema único de saúde. Săo Paulo: Hucitec; 1995.

86. Chagas C. Um auto-de-fé para o Dr. Jatene. Rev Manchete. 22 de junho de 1996. p.75.

87. Chinaglia A. CPMF: Chantagem e um falso dilema. FSP - CPMF. Jan. 1997.

88. Circular SINDHOP $n^{2} 198 / 93$. Identificação de pagamento dos serviços prestados ao INAMPS/SUS. www.idisa.org.br. Acesso em 31.1.2002.

89. CNS-Confederação Nacional de Saúde-Hospitais, Estabelecimento e Serviços. FBHFederação Brasileira de Hospitais. CMB- Confederação das Misericórdias do Brasil. Comissão Tripartite - 002/94. Brasilia, 23 de agosto de 1994.

90. CNS-Confederação Nacional de Saúde-Hospitais, Estabelecimento e Serviços. FBHFederação Brasileira de Hospitais. CMB- Confederação das Misericórdias do Brasil. Ofício 002/94. Brasília, 18 de agosto de 1994.

91. CNS-Confederação Nacional de Saúde-Hospitais, Estabelecimento e Serviços. FBHFederação Brasileira de Hospitais. CMB- Confederação das Misericórdias do Brasil. Ofício. Brasília, 31 de agosto de 1994.

92. CNS-Confederação Nacional de Saúde-Hospitais, Estabelecimento e Serviços. FBHFederação Brasileira de Hospitais. CMB- Confederação das Misericórdias do Brasil. Ofício. Brasília, 6 de setembro de 1994.

93. CNS-Confederação Nacional de Saúde-Hospitais, Estabelecimento e Serviços. FBHFederação Brasileira de Hospitais. CMB- Confederação das Misericórdias do Brasil. Frente Parlamentar da Saúde. Ofício CNS/Comissão Tripartite 005/94. Brasília, 14 de setembro de 1994.

94. CNS-Confederação Nacional de Saúde-Hospitais, Estabelecimento e Serviços. FBHFederação Brasileira de Hospitais. CMB- Confederação das Misericórdias do Brasil Comissão Tripartite dos Prestadores Privados de Serviços de Saúde. Comunicado. 26 de julho de 1994.

95. Comitê Nacional em Defesa do Sistema Único de Saúde. Relatório. 19/06/1996.

96. Conselho Nacional de Secretários de Saúde - CONASS - Boletim Informativo Semanal $39-26.09 .01$. www.idisa.org.br. Acesso em 31.1.2002.

97. Conselho Nacional de Secretários de Saúde - CONASS. Informativo Semanal CONASS. Ano VII, n.36/2001. Set. 2001.

98. Conselho Nacional de Secretários de Saúde - CONASS. Solicitação de Parecer sobre EC - 29 - Resposta do Ministério da Saúde sobre Nova técnica - SIS - SPI . www.idisa.org.br. Acesso em 7/1/2002.

99. Conselho Nacional de Secretários Municipais de Saúde - CONASEMS. Emenda Aglutinativa substituta à PEC 82-A/95 - Proposta de 20/10/1999. www.idisa.org.br

100.Cordeiro H. Sistema único de saúde. Rio de Janeiro: Ayuri Editorial; 1991. 
101.Cordoni Jr L. Política de saúde nos anos 90 e a reforma sanitária - considerações sobre o artigo "Política de saúde nos anos 90: relações intergovernamentais e o papel das Normas Operacionais Básicas". Ciência \& Saúde Coletiva, v.6, n.2, p.306310. 2001.

102.Dallari SG. Municipalização dos serviços de saúde. São Paulo: Brasiliense; 1985.

103.Dellape FU. CNS convoca a categoria para tomar as medidas administrativas e judiciais cabiveis para a obtenção do pagamento dos $25 \%$. Saúde Hoje, ano VII, n.63, p.3, jun. 1996.

104.Federação Brasileira de Hospitais - FBH. Os hospitais aprovados não filantrópicos e a aprovação do CPMF. Audiência Pública. 21 de março de 1996.

105.Freitas S. Governo pede intervenção em hospitais de Alagoas. Jornal Folha de São Paulo. Cotidiano. p.3-4, 30 de agosto de 1994.

106.Giraldi R. Saúde ameaça paralisar plano de controle à AIDS. Jornal de Brasília, 6/9/1994.

107.Gomes C. Ofício enviado ao Ministro de Estado da Saúde. Aviso n. 1465. Brasília, 21 de setembro de 1994.

108.Goulart FAA. Municipalização: veredas caminhos do movimento municipalista de saúde no Brasil. Rio de Janeiro: Abrasco/Conasems; 1996.

109.Greenless A. Fleury dá prazo para união liberar verbas. Jornal Folha de São Paulo. p.1-9. 25 de junho de 1993. www.idisa.org.br. Acesso em 31.1.2002.

110.Grupo de Trabalho - Em defesa do SUS. Financiamento - 1995. www.idisa.org.br. Acesso em 31.1.2002.

111.Jaeger ML., Carvalho G. A questão do financiamento suficiente, definido e definitivo para a saúde : as PECs e o ano de 1998. www.idisa.org.br. Acesso em $7 / 1 / 2002$.

112.Jorge E. Projeto de lei complementar $n^{\circ} 153$, de 1993. www.idisa.org.br. Acesso em 31.1.2002.

113.Jornal da IX Conferência Nacional de Saúde. Financiamento e não implantação do sus, as duas grandes falhas. p.4-5, jul./ago. 1992. unw.idisa.org.br. Acesso em 31.1.2002.

114.Jornal Folha de São Paulo. Cem hospitais fecham por falta de dinheiro. Reportagem local. P.3-4 25 de junho de 1993. www.idisa.org.br. Acesso em 31.1.2002.

115.Jornal O Estado de São Paulo. Geral. P.14. 25 de junho de 1993. Começa hoje locaute de hospitais em todo o país. www.idisa.org.br. Acesso em 31.1.2002.

116.Jornal O Estado de São Paulo. Hospitais deixam de atender pacientes do SUS. 23 de junho de 1993. www.idisa.org.br. Acesso em 31.1.2002.

117.Jornal O Globo. Serra volta a reclamar de cortes e critica CPMF. Sexta-feira, 9 de outubro de 1998.

118. Marques RM., Mendes, A. Novas técnicas para operacionalização da Emenda Constitucional 29. www. idisa.org.br. Acesso em 7/1/2002.

119.Médici AC. Perfil da saúde no Brasil. Brasilia(DF):IPEA; 1997.

120.Melquiades Neto. CPMF: a única fonte com que o SUS pode contar no segundo semestre. Saúde Hoje, Ano VII, n.64, junho 1996. p.3. 
121.Ministro Carlos César Albuquerque. Jornal Conasems. Ano III, jan./fev. 1998.

122.Moraes A., Caleman G. Relatório Final. Comissão Interministerial nomeada pelo Decreto Presidencial de 30 de agosto de 1994. www.idisa.org.br. Acesso em 31.1.2002.

123.Muller AMC. Denúncia por crise de responsabilidade. www.idisa.org.br. Acesso em 31.1.2002.

124.Muller Neto JS. Políticas de saúde no Brasil: a descentralização e seus fatores. Rev Saúde em Debate. n31; mar 1991; p.54-66.

125.Nassif L. O ajuste fiscal e a saúde. Jornal Folha de São Paulo. 29.06.93. unw.idisa.org.br. Acesso em 31.1.2002.

126. Nassif L. O início oficial de federalismo. Jornal Folha de São Paulo, p.2-3, 14.1.94. www.idisa.org.br. Acesso em 31.1.2002.

127.Piola,SF, Reis,COO, Ribeiro JAC. Financiamento das Politicas Sociais anos 90: 0 caso Ministério da Saúde. Texto para Discussão. Ipea. 2000.

128.Pires W, Jorge E. Proposta de emenda à constituição n.169, de 1993. Câmara dos Deputados; 1995.

129.Portugal Filho M. et al. Conclusões do grupo de trabalho interministerial para racionalização dos gastos com saúde e melhoria do atendimento a população. SEPLAN-PR. Relatório Final. Decreto de 4 de maio de 1994. www.idisa.org.br. Acesso em 31.1.2002.

130.Previdência e saúde fazem a dança dos desesperados, afirma Britto. 1993. www.idisa.org.br. Acesso em 31.1.2002.

131.Proposta do CONASSEMS AO CNS. Propostas de intervenção para o momento atual do SUS. outubro de 1992. www.idisa.org.br. Acesso em 31.1.2002.

132.PSDB. Programa de Governo de FHC. www.idisa.org.br. Acesso em 7/1/2002.

133.Relatório Final da Oficina de Trabalho. O financiamento do SUS. 1995; maio 18 19; Maceió:OPAS/OMS; 1995.

134.Resultados da Comissão para propor medidas objetivas e emergenciais a serem implementadas para a solução do problema de assistência médica e hospitalar - 17 a 29/6/93. www.idisa.org.br. Acesso em 31.1.2002.

135.Santillo H. Nota ao Senhor Presidente da República. Descentralização das ações da saúde. № 047/GM. 1 de novembro de 1994. www.idisa.org.br. Acesso em 31.1.2002.

136.Seixas JC et al. Relatório Final. Comissão Interministerial nomeada pelo Decreto Presidencial de 30 de agosto de 1994 - Brasilia, 21 de dezembro de 1994. www.idisa.org.br. Acesso em 31.1.2002.

137.Seminário sobre Financiamento do Sistema Unificado e Descentralizado de Saúde - SUDS; 1988 ago. 8-11; São Paulo:Secretaria da Ciência, Tecnologia e Desenvolvimento Econômico.

138.Seminário da ABRASCO. Coordenador João Gilberto Lucas Coelho. Reforma Sanitária: estratégias politicas para a constituinte. Rev Saúde em Debate, n.20, p.18, abr.1988.

139.Silva SC., Sato S. CPMF é insuficiente para resolver crise da saúde. Jornal O Estado de São Paulo, p. A25, 12 de janeiro de 1997. 
140.Sobre o documento municipalização das ações e serviços de saúde: a ousadia de cumprir e fazer cumprir a lei - CONAM. Saúde em Debate 1993; 38: 27.

141.Tavares C. $O$ caráter progressivo da tributação sobre a circulação financeira. Documento interno. Versão revisada 10.09.1995.

142.União Internacional de fortalecimento do Poder Local. Declaração mundial sobre autonomia municipal. 1985; www.idisa.com.br. Acesso em 31 de janeiro de 2002.

143.Valadares AC. Emenda n¹-CCJ (Substitutivo) à proposta de emenda à Constituição nº $\mathbf{4 0}$ de 1995.

144. Vianna SM, Piola SF, Guerra AJ, Camargo SF et al. O financiamento da descentralização dos serviços de saúde. Brasília: OPS. Economia e Financiamento $1 ; 1990$.

145.Vianna SM, Piola SF, Mendes EV. O financiamento da Saúde no Brasil. Brasilia: OPAS; Economia e Financiamento 4; 1994.

146.Vianna SM, Piola SF, Reis COO. Gratuidade no SUS: controvérsia em torno do co-pagamento. [Texto para discussão n.587]. Brasília:IPEA; 1998. 